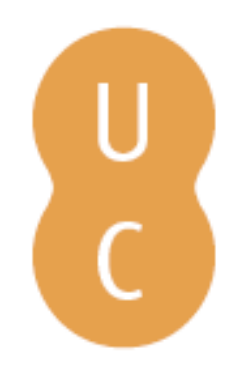

\title{
nommalina
}

\section{Política externa: as relações internacionais em mudança}

Publicado por: Imprensa da Universidade de Coimbra

URL persistente:

URI:http://hdl.handle.net/10316.2/2759

DOI:

DOI:http://dx.doi.org/10.14195/978-989-26-0086-4

Accessed : $\quad$ 19-May-2017 17:31:48

A navegação consulta e descarregamento dos títulos inseridos nas Bibliotecas Digitais UC Digitalis, UC Pombalina e UC Impactum, pressupõem a aceitação plena e sem reservas dos Termos e Condições de Uso destas Bibliotecas Digitais, disponíveis em https://digitalis.uc.pt/pt-pt/termos.

Conforme exposto nos referidos Termos e Condições de Uso, o descarregamento de títulos de acesso restrito requer uma licença válida de autorização devendo o utilizador aceder ao(s) documento(s) a partir de um endereço de IP da instituição detentora da supramencionada licença.

Ao utilizador é apenas permitido o descarregamento para uso pessoal, pelo que o emprego do(s) título(s) descarregado(s) para outro fim, designadamente comercial, carece de autorização do respetivo autor ou editor da obra.

Na medida em que todas as obras da UC Digitalis se encontram protegidas pelo Código do Direito de Autor e Direitos Conexos e demais legislação aplicável, toda a cópia, parcial ou total, deste documento, nos casos em que é legalmente admitida, deverá conter ou fazer-se acompanhar por este aviso.

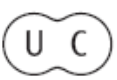


Política Externa As Relações Internacionais em Mudança

$\frac{\mathrm{I}}{\mathrm{U}}$ 
(Página deixada propositadamente em branco) 

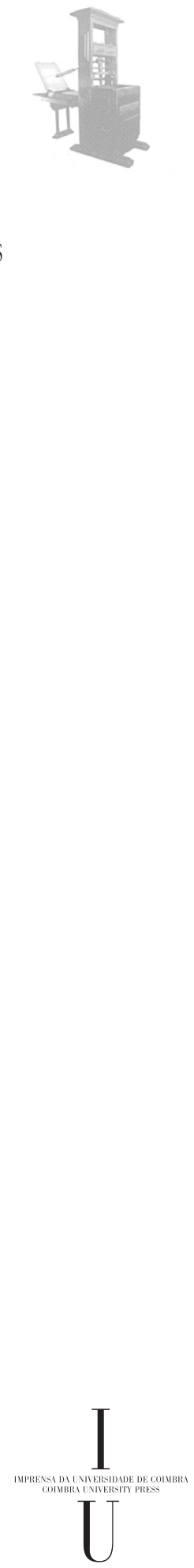


\title{
EDIÇÃO
}

Imprensa da Universidade de Coimbra

Email: imprensauc@ci.uc.pt

URL: http://www.uc.pt/imprensa_uc

Vendas online http://www.livrariadaimprensa.com

\section{CONCEPÇÃO GRÁFICA}

\author{
António Barros
}

INFOGRAFIA

Carlos Costa

Imprensa da Universidade de Coimbra

\section{EXECUÇÃO GRÁFICA}

Sereer, Soluções Editoriais

ISBN

978-989-26-0086-4

ISBN Digital

978-989-26-0935-5

DOI

978-989-26-0086-4

DEPÓSITO LEGAL

322732/11

Obra Publicada com o apoio:

FCT Fundação para a Ciência e a Tecnologia MINISTÉRIO DA CIÊNCIA, TECNOLOGIA E ENSINO SUPERIOR Portugal 
Maria Raquel Freire

Coordenação

\section{Política Externa \\ As Relações Internacionais \\ em Mudança}


(Página deixada propositadamente em branco) 


\section{SUMÁRIO}

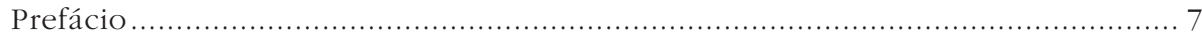

Introdução, Maria Raquel Freire ............................................................... 9

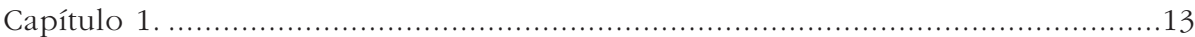

Política externa: modelos, actores e dinâmicas, Maria Raquel Freire e Luís da Vinha

Capítulo 2 .55

Alemanha, Patrícia Daehnhardt

Capítulo 3

Arábia Saudita, Ana Santos Pinto

Capítulo 4 .

Brasil, Carmen Fonseca

Capítulo 5.

125

Estados Unidos da América, Luís Tomé

Capítulo 6

Federação Russa, Maria Raquel Freire

Capítulo 7

França, Verónica Martins 
Capítulo 8.

.201

Grã-Bretanha, Carlos Gaspar

Capítulo 9.

Índia, Constantino Xavier

Capítulo 10. .253

Japão, Paula Marques dos Santos

Capítulo 11.

Portugal, Nuno Severiano Teixeira

Capítulo 12 . .287

República Federal da Nigéria, Paula Duarte Lopes e Daniela Nascimento

Capítulo 13. 313

República Islâmica do Irão, Licínia Simão

Capítulo 14 .

República Popular da China, Carmen Amado Mendes

Capítulo 15. 361

Turquia, André Barrinha

Notas Biográficas 387 


\section{PREFÁCIO}

Este volume resulta da necessidade sentida no âmbito das unidades curriculares de política externa que lecciono, de um trabalho inclusivo, combinando uma componente teórica com vários estudos de caso sobre política externa que constitua uma base sólida para a análise e discussão de tendências e dinâmicas que definem as variações e ajudam a compreender as modelações nos vários processos de decisão e implementação de política externa, em contextos diferenciados. Os textos que constituem este volume respondem a esta necessidade de uma forma não só abrangente, como profundamente informativa em termos da diversidade de modelos, processos e formas de implementação das políticas externas de diferentes Estados. A inclusão num mesmo volume de estudos sobre países tão distintos como a Alemanha, Arábia Saudita, Brasil, Estados Unidos da América, Federação Russa, França, Grã-Bretanha, Índia, Japão, Portugal, República Federal da Nigéria, República Islâmica do Irão, República Popular da China, e Turquia, é indicativa da riqueza que este volume constitui e um primeiro passo para discussões que permitam análises aprofundadas e, mesmo criativas, de dinâmicas associadas à política externa. Não poderia deixar de agradecer a todos/as quantos se envolveram neste projecto desde o seu início, e me acompanharam na construção deste volume, através da sua dedicação e empenho. De facto, o volume que temos em mãos não teria sido possível sem a colaboração incondicional de todos/as os autores. Agradeço ainda à Imprensa da Universidade de Coimbra o imediato interesse por este projecto, bem como o acompanhamento do mesmo, através do apoio necessário para a sua consecução, e que se revelou fundamental na concretização deste 
trabalho. E espero, que de facto este seja um contributo útil para todos/as aqueles que se interessam por estudos de política externa.

Coimbra, Novembro de 2010

Maria Raquel Freire 


\section{INTRODUÇÃO}

Este volume tem como temática central a análise de política externa, uma área vasta, onde o cruzamento de factores internos e externos se evidencia nos processos de definição, decisão e implementação de políticas. De facto, o volume explora os processos associados à formulação e implementação da política externa, como estruturas institucionais, definição da agenda, instrumentos, processo de decisão e prossecução de objectivos, permitindo um entendimento amplo, num enquadramento multi-nível, embora não exaustivo das principais dinâmicas associadas à política externa. No entanto, e dado tratar-se de uma área muito abrangente, o estudo aqui desenvolvido segue um enfoque de análise político, securitário e económico, em diferentes pesos e com abordagens distintas, contudo sem detalhar outras áreas de actuação que fazem parte de uma agenda alargada de política externa, como por exemplo questões ambientais ou de natureza cultural, cuja menção surge em alguns casos, embora não como foco de análise prioritário. Além do mais, apesar da política externa não ser actualmente um domínio exclusivo dos Estados, constitui ainda uma área de actuação por excelência destes, pelo que este volume apenas se foca na análise de política externa de Estados enquanto actores das relações internacionais.

Este exercício, explanado no capítulo teórico, visa fornecer os instrumentos conceptuais e analíticos de base para a compreensão dos vários estudos de caso que se seguem. Deste modo, o volume apresenta uma componente empírica muito forte, entendida como essencial para o entendimento dos processos diferenciados de formulação, implementação e objectivação da política externa de Estados distintos. Esta opção é ilustrativa da vontade 
de que este volume constitua um trabalho de referência inclusivo, onde se encontram casos díspares ilustrativos da grandeza diferencial dos processos em análise de acordo com uma série de factores quer de ordem interna, incluindo órgãos e procedimentos de decisão, recursos económicos e militares, entre outros, quer de ordem externa, nomeadamente o contexto de vizinhança, regional e mesmo internacional. Seguindo esta fórmula, os estudos de caso exploram os objectivos, actores e instrumentos na formulação e condução das políticas externas destes países, relacionando factores domésticos e externos fundamentais nesta articulação, e entendidos neste trabalho como co-constitutivos na definição e entendimento de política externa de qualquer Estado. São aqui analisados como estudos de caso, e por ordem alfabética, os seguintes países: Alemanha, Arábia Saudita, Brasil, Estados Unidos da América, Federação Russa, França, Grã-Bretanha, Índia, Japão, Portugal, República Federal da Nigéria, República Islâmica do Irão, República Popular da China, e Turquia.

A escolha dos estudos de caso prendeu-se com três factores essenciais: primeiro, o facto de se tratar de actores relevantes nas relações internacionais, constituindo por isso mesmo um conjunto de actores dinâmicos e com implicações claras na determinação e curso de transformação da ordem internacional; segundo, procurando exprimir, ainda que de forma limitada, equilíbrios geográficos através da identificação de actores diferenciados na estrutura mundial; e terceiro, e não menos importante, representatividade da diferença existente em termos dos processos de formulação e implementação das políticas externas, mesmo em áreas regionais próximas, como por exemplo ilustrarão os estudos de caso de países europeus, como a Alemanha, França, Grã-Bretanha ou Portugal. Estes elementos permitem assim uma combinação que julgamos da maior relevância para um trabalho desta natureza e que entendemos tratar-se de um contributo fundamental para os estudos de política externa.

Em termos da estrutura do Manual, este visa analisar a política externa dos países em questão num período temporal definido, embora não necessariamente determinístico, desde a Segunda Guerra Mundial até à actualidade, com maior destaque para o período pós-Guerra Fria. Os capítulos seguem uma estrutura similar ajustada de acordo com as particularidades de cada 
caso, que são variadas e evidentes, com o objectivo de garantir maior coesão no resultado final. Deste modo, em traços gerais, os capítulos empíricos identificam os principais actores, mecanismos e processos associados à formulação e decisão em política externa, e analisam a evolução desta, salientando as articulações das dinâmicas existentes com a actualidade. São apresentadas as diferentes perspectivas e opções subjacentes ao processo evolutivo de formulação e implementação de políticas, explorando relações de maior ou menor proximidade com terceiros (relações de vizinhança, inserção no quadro regional, posicionamento nas relações internacionais), políticas de envolvimento/isolacionismo, limites e possibilidades. Ou seja, prosseguindo a análise das políticas externas numa relação co-constitutiva, fazendo a interligação entre recursos, instrumentos e actores internos com o contexto externo, nas diferentes dimensões em que o Estado em análise se insere. O resultado é um volume rico, em termos teóricos e empíricos, que se pretende uma ferramenta de trabalho fundamental para todos os que se dedicam ao estudo da política externa. 
(Página deixada propositadamente em branco) 
Maria Raquel Freire

e Luís da Vinha

\section{CAPÍTULO 1}

\section{POLÍTICA EXTERNA: MODELOS, ACTORES E DINÂMICAS}

A política externa, tradicionalmente associada aos Estados, mas crescentemente associada a outros actores, como a União Europeia (UE), projecta interesses e objectivos domésticos/internos para o exterior. É assim entendida como uma ferramenta essencial no posicionamento dos actores no sistema internacional. No entanto, o desenho, formulação e implementação da política externa não é um processo simplista e linear, como analisado nos diferentes modelos teóricos e na necessidade de conjugação destes para um entendimento mais compreensivo do processo; e não tem lugar de forma isolada, revelando o carácter co-constitutivo das dimensões interna (doméstica) e externa (internacional) que acompanham todo o processo. A discussão agente/estrutura é, neste quadro, um referencial fundamental com alguma discordância relativamente à prevalência do agente sobre a estrutura ou, ao invés, da condicionalidade que a estrutura impõe ao agente. Neste contexto, a proposta avançada por James Rosenau (1966, 1969) de que a política externa implica uma relação bi-direccional entre as dimensões interna e externa, ultrapassando a convicção tradicional de que a política externa é dirigida por factores internacionais, foi generalizada nos estudos nesta área. Contudo, a discussão mantém-se relativamente ao peso relativo de cada uma destas dimensões no processo de formulação da política externa. Por um lado, há autores que argumentam que o contexto interno constitui a variável relevante na definição e prioritização da agenda de política externa (Neack et al., 1995; Saideman e Ayres, 2007: 191); por outro, 
as abordagens estruturalistas focam no papel da estrutura como informando os desenvolvimentos internos, e desse modo constituindo o elemento de referência fundamental (Keohane e Nye, 2000; Waltz, 1979).

Para além da tradução do debate agente/estrutura na teorização sobre política externa, outras dimensões de análise têm sido incorporadas em alguns estudos, nomeadamente questões mais subjectivas, mas não menos relevantes, como atitudes, crenças, valores e interesses subjacentes aos processos de formulação e decisão, e que têm contribuído essencialmente para a análise das motivações implicadas nos processos de política externa. Este debate implica a discussão do papel e características individuais do decisor, bem como a consideração dos quadros ideológicos em que as decisões são tomadas (Carlsnaes, 2003; Houghton, 2007; Jørgensen, 2006; Snyder et al., 1954). Como expressão deste desenvolvimento, estudos recentes introduziram novas metodologias na análise de política externa, como análise de discurso, estudando a linguagem da política externa (Campbell, 1993; Doty, 1997; Larsen, 1997; Sjöstedt, 2007). A análise de política externa tornou-se, assim, uma área de estudo complexa implicando múltiplas variáveis relativamente aos níveis de análise, actores, processos e resultados.

Este capítulo avança com algumas definições de política externa, apresenta os modelos teóricos de formulação e decisão em política externa, e explicita diferentes variáveis que devem ser tidas em conta em análises de política externa. Não pretendendo ser exaustivo, procura mapear as bases teóricas essenciais associadas à política externa, fornecendo os enquadramentos para uma análise mais detalhada e compreensiva de políticas externas diferenciadas.

\section{As origens da análise de política externa}

A análise de política externa enquanto abordagem teórica distinta teve a sua origem no período a seguir à Segunda Guerra Mundial. Segundo Hudson e Vore (1995) três trabalhos distintos estão na génese desta abordagem: Foreign Policy Decision-Making de Richard Snyder, Henry Bruck e Burton Sapin (1954); Man-Milieu Relationship Hypothesis in the Context of 
International Politics de Harold e Margaret Sprout (1956 e desenvolvido mais detalhadamente em 1965 no livro The Ecological Perspective on Human Affairs: With Special Reference to International Politics); e Pre-theories and Theories of Foreign Policy de James Rosenau (1966).

O estudo de Snyder, Bruck e Sapin foi inovador e importante, pois identificou o decisor humano como o principal determinante do comportamento do Estado. Desta forma, o foco da análise centrou-se no decisor e no seu entendimento da situação. Mais concretamente, "O objectivo analítico principal é a recriação do 'mundo' dos decisores conforme eles o vêem” (Snyder, Bruck e Sapin, 2002: 59). Igualmente significativo, o trabalho de Herman e Margaret Sprout foi fundamental para determinar a relação entre o psycho-milieu (o meio percepcionado pelos decisores e ao qual reage) e o operational milieu (o meio no qual as decisões são executadas). Relativamente à formulação e ao conteúdo das decisões políticas, o que importa é a forma como os decisores imaginam que o meio é, e não a forma como realmente é. Relativamente aos resultados operacionais das decisões, o que importa é como as coisas são, e não a forma como os decisores imaginam que são (Sprout e Sprout, 1957: 327-328). Por sua vez, o artigo de Rosenau, reforçando a necessidade de aplicar conhecimentos de outras ciências sociais nas explicações de política externa, contribuiu para uma análise multi-nível e multi-causal da complexidade associada à compreensão da mesma.

Embora os estudos de política externa tenham desenvolvido diferentes abordagens, os trabalhos acima referidos estabeleceram os pressupostos teóricos basilares da disciplina (Hudson e Vore, 1995), nomeadamente: o conhecimento das especificidades dos indivíduos envolvidos nas decisões de política externa é crucial para a compreensão das escolhas; a informação sobre estas especificidades deve ser incorporada na construção de teorias transnacionais e de médio-alcance; as teorias resultantes devem integrar múltiplos níveis de análise; e a compreensão do processo de formulação da política externa é tão importante, se não mais importante, do que a compreensão dos outputs da política externa.

Embora todos os trabalhos incorporassem estes pressupostos, cada um contribuiu de forma particular para o crescimento e consolidação de abordagens distintas na análise da política externa. Desta forma, o trabalho de 
Snyder, Bruck e Sapin catalisou os estudos dedicados à decisão de política externa, com especial enfoque nos processos de decisão e nas estruturas dos grupos responsáveis por essas mesmas decisões. Ao distinguir entre os diferentes milieu, os Sprout estiveram na génese dos trabalhos dedicados ao contexto da política externa, nomeadamente os que procuram compreender a dimensão cognitiva dos decisores (crenças, atitudes, valores, emoções, estilos, percepções). O enfoque teórico de Rosenau, por sua vez, estabeleceu os alicerces para os trabalhos de política externa comparada, com a sua ênfase na análise dos 'eventos' de política externa.

O sucesso destes diferentes trabalhos fez da análise de política externa uma componente central para a compreensão da política internacional. Porém, desde o fim da Guerra Fria os pressupostos subjacentes à análise de política externa adquiriram uma renovada importância e centralidade (Hagan, 2001). Devido à dificuldade das teorias tradicionais dominantes em explicar a complexidade da política contemporânea, o enfoque nos indivíduos e nos processos de decisão passou a assumir um lugar central na política internacional. Os novos desafios do pós-Guerra Fria cimentaram a convicção de que as teorias tinham de reconhecer que «com cada transformação sistémica... a vontade e imaginação humana são fundamentais ao influenciar a condução dos assuntos globais» (Hudson e Vore, 1995: 210). A natureza fluida do mundo pós-Guerra Fria amplificou a exigência de encontrar modelos capazes de lidar melhor com a complexidade da política internacional do que os modelos sistémicos tradicionais. De acordo com Hudson (2008), a análise de política externa contemporânea mantém os compromissos teóricos particulares que a demarcaram desde a sua concepção e que hoje se continuam a demonstrar relevantes para uma compreensão mais efectiva da complexidade da política internacional.

\section{Compreender a política externa}

Não existe uma definição absoluta e consensual de política externa, mas as várias definições avançadas contêm atributos e pressupostos semelhantes: 
«O sistema de actividades desenvolvido pelas comunidades para modificar o comportamento de outros Estados e para ajustar as suas próprias actividades ao ambiente internacional" (George Modelski apud Kegley e Wittkopf, 1995: 45);

"O esforço de uma sociedade nacional para controlar o seu ambiente externo pela preservação das situações favoráveis e a modificação das situações desfavoráveis» (James Rosenau apud Zorgbibe, 1990: 433);

"programa orientado para a resolução de objectivos ou de problemas elaborado pelos decisores políticos com autoridade (ou seus representantes), direccionado a entidades externas à jurisdição dos responsáveis pela formulação política» (Hermann, 1990: 5);

«O conjunto de objectivos, estratégias e instrumentos escolhidos pelos responsáveis governamentais pela formulação política para responder ao ambiente externo actual e futuro» (Rosati, 1994: 225).

Todas estas definições comungam de uma série de princípios e pressupostos, dos quais se destacam o papel dos governos estatais como actores privilegiados na formulação da política externa e a dimensão intencional da acção política. Nestas conceptualizações há dificuldade em compreender outros actores como agentes activos na política internacional, pois instituições não estatais não são consideradas. Assim, temos dificuldade em incluir entidades supra-estatais (como a ONU ou a UE) ou sub-estatais (como o Hezebollah e comunidades não-estatais) na análise da política internacional. Igualmente, estas definições não incluem os resultados não intencionais das decisões políticas, deixando uma lacuna conceptual por resolver. De facto, Kalevi Holsti (Gustavsson, 1999) já alertou para a distinção entre a política externa «intencional» e "actual», confirmando que os resultados das decisões políticas nem sempre são os inicialmente pretendidos. Por sua vez, Kjell Goldmann (Gustavsson, 1999) e Laura Neack (2008) têm salientado o facto de haver uma distinção a fazer entre a "política verbalizada" (acção que o actor declara que persegue) e a "política não-verbalizada" (acção de facto 
implementada). Vários autores defendem que as análises devem considerar a razão porque os actores declaram e seguem determinadas acções, pois a análise de política externa inclui o estudo dos processos, declarações e comportamentos (Neack, 2008: 10).

Tendo em consideração o exposto, este manual apresenta uma definição de política externa que procura ser o mais abrangente possível e que transponha algumas das lacunas conceptuais referidas. Assim, entende-se por política externa o conjunto de objectivos, estratégias e instrumentos que decisores dotados de autoridade escolhem e aplicam a entidades externas à sua jurisdição política, bem como os resultados não intencionais dessas mesmas acções.

Ao concentrar-se nos diferentes actores e nos diferentes processos e dinâmicas de decisão, a análise de política externa permite uma abordagem complementar que enriquece o nosso entendimento da política internacional. Mais concretamente, a análise de política externa centrada nos processos de decisão ajuda a "identificar padrões de decisão únicos e genéricos e gerar entendimentos sobre os estilos e personalidades de liderança que não podem ser revelados através de uma abordagem sistémica à política externa» (Mintz e DeRouen Jr., 2010: 5). Como referido, a política externa envolve dinâmicas complexas, como incerteza sobre o ambiente político, trade-offs diversos no momento da decisão, difusão da autoridade política, variabilidade nas estruturas de decisão (Hagan, 2001). Só uma abordagem assente na compreensão dos processos de decisão permite compreender estas complexidades. De facto, as teorias tradicionais das Relações Internacionais, sobretudo as teorias sistémicas, não explicam convenientemente muitos dos eventos da política internacional (Hagan, 2001), pois ao renunciar à análise dos processos de decisão e seus principais intervenientes, as teorias tradicionais acabam por não abordar factores fundamentais para uma compreensão mais completa dos acontecimentos internacionais, uma vez que qualquer Estado tem de decidir sobre uma agenda ampla que exige a tomada de decisões (Mintz e DeRouen Jr., 2010). Além do mais, a análise de política externa, ao focar nos diversos actores envolvidos nos processos de decisão, permite conhecer a forma como os indivíduos, grupos e organizações são condicionados pelos vários factores 
domésticos, nomeadamente os factores eleitorais, a opinião pública, os grupos de pressão e as preferências ideológicas (Holsti, 2006).

Em suma, a política externa é uma área abrangente cujo enfoque inclui questões diversas, como segurança, economia, ambiente, e cultura. A agenda é, por isso, densa, e as burocracias e grupos que apoiam o processo de formulação e decisão cruzam diferentes valências para poderem responder à multi-dimensionalidade associada à política externa. Paralelamente ao quadro institucional, variáveis objectivas como localização geoestratégica, população e recursos humanos, capacidade militar, económica e de inovação tecnológica, bem como factores de cariz subjectivo (incluindo motivações, identidade, valores, percepções) conjugam-se na formulação, decisão e implementação da política externa, com diferentes matrizes a caracterizarem diferentes actores. Além do mais, os objectivos de política externa, fundamentalmente assentes em interesses nacionais, são modelados de acordo com estes factores e com a interacção destas componentes com os arranjos do sistema internacional, exigindo ajustes variados e não permitindo uma projecção dos interesses e objectivos dos Estados sem limites. São estes múltiplos modelos, actores e dinâmicas que procuramos identificar, descrever e explicar nas páginas seguintes.

\section{Modelos teóricos}

Os assuntos de política externa são muitas vezes abordados de forma ligeira e informal, sem grandes considerações teóricas. Contudo, análises mais profundas dos eventos revelam um grau de complexidade que exige uma maior compreensão teórica. De facto, os estudos realizados pelos investigadores de política externa «evidenciam características regulares e previsíveis que reflectem pressupostos nem sempre reconhecidos sobre o carácter dos desafios, as categorias nas quais os problemas devem ser considerados, os tipos de provas relevantes e os determinantes das ocorrências» (Allison e Zelikow, 1999: 4). Consequentemente, estes pressupostos estão na base dos diferentes modelos teóricos que auxiliam os investigadores a melhor compreender os eventos políticos internacionais, nomeadamente 
identificando os factores determinantes mais relevantes das ocorrências, bem como as circunstâncias em que determinados factores conduziram a um determinado desfecho em vez de outro.

Esta secção identifica os principais modelos teóricos relativos aos processos de formulação e decisão em política externa. Note-se que apesar de apresentados em secções distintas, estes modelos não são necessariamente excludentes, havendo consenso na bibliografia relativamente à interacção destas diferentes abordagens numa explicação compreensiva dos processos. O quadro que se segue sintetiza as principais linhas caracterizadoras destes modelos para uma mais fácil leitura das secções seguintes.

\begin{tabular}{|c|c|c|c|c|}
\hline & Actor Racional & $\begin{array}{l}\text { Organizações } \\
\text { Burocráticas }\end{array}$ & $\begin{array}{c}\text { Pequenos } \\
\text { Grupos }\end{array}$ & Líderes \\
\hline $\begin{array}{c}\text { Actores } \\
\text { envolvidos } \\
\text { na decisão } \\
\text { de política } \\
\text { externa }\end{array}$ & $\begin{array}{l}\text { Estado age } \\
\text { como decisor } \\
\text { racional único }\end{array}$ & $\begin{array}{c}\text { Organizações } \\
\text { burocráticas } \\
\text { formais do } \\
\text { Estado }\end{array}$ & $\begin{array}{c}\text { Pequeno } \\
\text { número de } \\
\text { indivíduos } \\
\text { (variável) junto } \\
\text { da liderança }\end{array}$ & $\begin{array}{c}\text { Líderes } \\
\text { individuais }\end{array}$ \\
\hline $\begin{array}{l}\text { Dinâmicas } \\
\text { do modelo } \\
\text { de decisão }\end{array}$ & $\begin{array}{c}\text { Identificar } \\
\text { interesse } \\
\text { nacional; } \\
\text { Identificar } \\
\text { opções; } \\
\text { Análise custo/ } \\
\text { benefício das } \\
\text { opções; } \\
\text { Escolher } \\
\text { política que } \\
\text { melhor serve } \\
\text { o interesse } \\
\text { nacional }\end{array}$ & $\begin{array}{c}\text { Organizações } \\
\text { agem com base } \\
\text { em processos } \\
\text { estandardizados; } \\
\text { Interesses } \\
\text { determinados } \\
\text { para organização } \\
\text { a que se } \\
\text { pertence; } \\
\text { Negociações } \\
\text { para determinar } \\
\text { política }\end{array}$ & $\begin{array}{c}\text { Interacção } \\
\text { dinâmica entre } \\
\text { os diversos } \\
\text { membros do } \\
\text { grupo; } \\
\text { Group think; } \\
\text { Imposição de } \\
\text { solução; } \\
\text { Internalização; } \\
\text { Compromisso } \\
\text { negocial }\end{array}$ & $\begin{array}{c}\text { Decisão } \\
\text { resultante } \\
\text { da escolha } \\
\text { individual; } \\
\text { Apreciação } \\
\text { subjectiva da } \\
\text { situação; } \\
\text { Processos } \\
\text { cognitivos }\end{array}$ \\
\hline $\begin{array}{l}\text { Origens } \\
\text { e fontes } \\
\text { teóricas }\end{array}$ & $\begin{array}{l}\text { Teoria da } \\
\text { utilidade } \\
\text { esperada }\end{array}$ & $\begin{array}{c}\text { Teoria } \\
\text { organizacional; } \\
\text { Sociologia das } \\
\text { burocracias; } \\
\text { Política } \\
\text { burocrática }\end{array}$ & $\begin{array}{c}\text { Psicologia } \\
\text { social; } \\
\text { Sociologia } \\
\text { dos pequenos } \\
\text { grupos }\end{array}$ & $\begin{array}{l}\text { Psicologia } \\
\text { cognitiva; } \\
\text { Dissonância } \\
\text { cognitiva; } \\
\text { Dinâmica } \\
\text { psicológica }\end{array}$ \\
\hline
\end{tabular}

Quadro 1. Modelos de formulação e decisão em política externa 


\section{O Estado unitário e o processo de decisão racional}

A abordagem tradicional parte do princípio de que os Estados são agentes unitários e monolíticos na formulação e execução das suas políticas externas; e da existência de uma dicotomia entre a política externa e a política interna. Nesta perspectiva, a política interna é encarada como uma esfera distinta e independente da política externa, sendo o principal problema de análise a necessidade governamental de manter a autonomia e a integridade do Estado face à possibilidade de agressões exteriores (os factores externos são determinantes do comportamento dos Estados). A perspectiva tradicional assume, deste modo, que a política externa é formulada de forma homogénea e unitária, em conformidade com os elementos de poder e com base na definição do interesse nacional. Partindo desta perspectiva, os cálculos estratégicos sobre segurança nacional são os principais determinantes das escolhas dos decisores políticos; a política interna e o processo de formulação política são preocupações secundárias. De acordo com este mapa mental, os líderes que fazem a política externa, os tipos de governo que lideram, as características das suas sociedades, e as suas condições económicas e políticas internas não são relevantes.

Aqueles que estudam o processo de decisão e aconselham os decisores políticos sobre formas de melhorar as suas qualidades políticas, descrevem a racionalidade como uma sequência de actividades de decisão que envolvem os seguintes passos: 1) reconhecimento e definição do problema; 2) selecção de objectivos; 3) identificação de alternativas; 4) escolha a partir de um leque de várias opções; e 5) selecção racional da alternativa que melhor poderá levar ao objectivo pretendido. De acordo com a teoria da utilidade esperada de von Neumann, a racionalidade do actor (Estado) permite-lhe escolher entre as diferentes alternativas e calcular a melhor forma para atingir os seus objectivos. Aplicado à política externa, o modelo da racionalidade implica que o Estado aja intencionalmente, motivado por objectivos claramente definidos, demonstrando capacidade para ordenar as suas opções e preferências e maximizar a utilidade da sua escolha (Mintz e DeRouen Jr., 2010). A crise dos mísseis de Cuba de 
$1962^{1}$ ilustra o modo como as decisões dos EUA foram conformes a um processo racional. Uma vez descoberta a presença de mísseis soviéticos em Cuba, o Presidente John F. Kennedy pediu ao grupo de crise criado para proceder a um levantamento exaustivo relativo aos perigos e possíveis cursos de acção. Foram definidas seis opções: nada fazer; exercer pressão diplomática; fazer uma aproximação secreta ao líder cubano Fidel Castro; invadir Cuba; lançar um ataque aéreo cirúrgico contra os mísseis; e impor um bloqueio à ilha. Os objectivos tiveram de ser ordenados por ordem de preferência antes da escolha poder ser feita. Seria o objectivo de retirada dos mísseis soviéticos retaliação contra Castro ou pretensão de manutenção da balança de poder? Ou será que os mísseis significavam uma pequena ameaça aos interesses vitais dos EUA? Até que os mísseis fossem considerados como uma ameaça séria à segurança norte-americana, 'nada fazer' não podia ser eliminado como opção. Uma vez acordado que a remoção dos mísseis era o objectivo, a discussão dos conselheiros voltou-se para a avaliação das opções do ataque cirúrgico e do bloqueio. Esta última foi a escolhida devido às suas presumidas vantagens. Permitia aos EUA uma demonstração de firmeza, enquanto mantendo flexibilidade relativamente a novas opções de ambos os lados.

Apesar da aplicação aparente da racionalidade a esta crise, o modelo de decisão racional é mais um padrão idealizado segundo o qual se avaliam preferências, do que propriamente uma descrição precisa do comportamento no mundo real. Theodore Sorensen, que participou nas deliberações da crise de Cuba, escreveu não só sobre os passos da administração Kennedy seguindo o processo de escolha racional, como também sobre a facilidade com que o processo de decisão real se afasta dele: "não se pode dar cada passo segundo uma ordem. Os factos poderão ser duvidosos ou estar em contradição; várias políticas, todas boas, podem entrar em conflito. Vários meios, todos maus, podem ser tudo o que está em aberto. Os julgamentos de valor podem ser diferentes. Os objectivos definidos podem ser imprecisos.

\footnotetext{
1 Os exemplos da crise dos mísseis de Cuba que servem para ilustrar os diferentes modelos teóricos seguem a proposta de Kegley e Wittkopf (1995).
} 
Pode haver muitas interpretações sobre o que está certo, o que é possível, e o que é no interesse nacional» (Kegley e Wittkopf, 1995: 49).

Apesar das virtudes oferecidas pela escolha racional, os impedimentos à sua realização são substanciais. Alguns são humanos; derivam de deficiências nos serviços de informação, capacidade, e aspirações e necessidades psicológicas daqueles que tomam decisões de política externa sob condições de incerteza. Outros são organizacionais pois a maior parte das decisões são tomadas em grupo. Em resultado, a maior parte das decisões requerem assentimento do grupo quanto ao interesse nacional e ao curso de acção a seguir. Chegar a um acordo não é fácil, dada a discordância sobre objectivos ou preferências, e sobre os resultados prováveis de opções alternativas. Por exemplo, o reconhecimento do problema é muitas vezes adiado. Grandes quantidades de informação para trabalhar em tempo escasso ou informação insuficiente ou inadequada para definir problemas emergentes de forma cuidada, condicionam o processo de formulação política racional.

Uma vez que os decisores políticos trabalham constantemente com agendas sobrecarregadas e prazos curtos, a procura de opções políticas é raramente exaustiva. Como Kissinger afirmava, "há pouco tempo para os líderes reflectirem. Estão presos numa batalha sem fim onde o urgente se sobrepõe constantemente ao importante. A vida pública de cada figura política é uma luta contínua para salvar um elemento de escolha da pressão das circunstâncias» (Secretário de Estado norte-americano, 1979, em Kegley e Wittkopf, 1995: 50). Na fase da escolha, em vez de seleccionarem uma opção ou conjunto de opções com as melhores hipóteses de sucesso, os decisores geralmente decidem quando surge uma alternativa que parece melhor que as consideradas anteriormente. Em vez da optimização, dá-se apenas uma satisfação, através de uma escolha que satisfaça os requisitos mínimos, evitando opções mais arriscadas.

Ou seja, em certas circunstâncias, os governos tomam decisões como se estivessem a seguir a norma da racionalidade meios-fins e escolhem a alternativa que melhor lhes permite atingir os objectivos ou promover os valores dos decisores. A dicotomia entre os pressupostos da racionalidade e da irracionalidade no comportamento de indivíduos, grupos e governos constitui, assim, uma das dimensões mais persistentes e problemáticas. 
A «concepção sinóptica» da tomada de decisões que parte do princípio de que os políticos colocam perante si todas as alternativas possíveis avaliando, a partir da sua hierarquia de preferências, todas as consequências das mudanças sociais inerentes às diversas acções em consideração, não se adequa à realidade. Pressupõe uma omnisciência e uma espécie de análise abrangente demasiado dispendiosa e que a pressão do tempo normalmente não permite. Cada solução tem de estar limitada a uma série de factores, incluindo as capacidades individuais de resolução de problemas, a informação disponível, o custo da análise (em pessoal, recursos e tempo) e a impossibilidade prática de separar os factos dos valores.

Herbert Simon (1955: 13) foi um dos principais críticos do modelo clássico da tomada racional de decisões, postulando um mundo de «racionalidade limitada». Substituiu o conceito de maximização ou optimização do comportamento pelo de comportamento satisfatório. Este pressupõe que os políticos não elaboram uma matriz com todas as alternativas disponíveis, os prós e contras de cada uma delas e as avaliações de probabilidade das consequências esperadas. Em vez disso, as unidades de decisão examinam, de forma sequencial, as alternativas disponíveis até chegarem a uma que corresponda aos seus níveis mínimos de aceitabilidade. Por outras palavras, os indivíduos vão rejeitando as soluções que os não satisfazem até encontrarem uma solução suficiente e consensualmente satisfatória que lhes permita agir. Apesar de os decisores conseguirem absorver rapidamente grandes quantidades de informação sob grande pressão, e assumir riscos calculados com base num planeamento ponderado, muitas vezes o grau de racionalidade tem pouca relação com o mundo onde os oficiais conduzem as suas deliberações. Apesar da formulação racional da política externa ser mais um ideal do que uma descrição da realidade, parece útil aceitar a racionalidade como imagem do modo como o processo de decisão se deve processar e como uma descrição dos elementos chave de como pode funcionar.

O modelo do actor racional assume que os estados unitários são os intervenientes-chave e que agem de forma racional, calculando os custos e os benefícios inerentes às várias escolhas políticas, na procura da escolha que maximize a sua utilidade. Este modelo encontra laços estreitos com o realismo clássico e o neo-realismo ou realismo estruturalista. Apesar disso, 
institucionalistas liberais como Keohane, juntamente com teorizadores da paz democrática como Doyle, são vistos como comungando do essencial do modelo do actor racional. De qualquer modo, o campo liberal e pluralista tende a juntar ao modelo, quadros de referência centrados na máquina e políticas governativas: os processos organizacionais - segundo modelo de Allison, que consiste em identificar as organizações governamentais relevantes envolvidas numa crise, determinando depois os interesses e os procedimentos operacionais standard que influenciam o comportamento das organizações; e os processos burocráticos - que analisamos em seguida e que se prendem com as políticas internas, não tendo a ver tanto com escolhas ou com resultados, mas mais com os jogos negociais e de influência no seio da estrutura hierárquica governativa. Ou seja, enquanto o actor racional procura maximizar os objectivos estratégicos nacionais; as organizações comportam-se de acordo com os procedimentos operacionais estandardizados; e as burocracias envolvem-se em compromissos, negociações, coligações e competição.

As organizações burocráticas e os pequenos grupos no processo de decisão da política externa

No mundo de hoje, as relações extensivas em termos políticos, militares e económicos exigem dependência de grandes organizações especializadas que possam melhor recolher e tratar informação. Os líderes apoiam-se nelas perante escolhas críticas ao nível da política externa, sendo que se poderá afirmar que a maior parte das decisões de política externa são tomadas num contexto organizacional. Sem desvalorizar a noção de liderança, Max Weber escreveu que, "num estado moderno, o dirigente é necessária e inevitavelmente a burocracia, pois o poder não é exercido, nem por discursos parlamentares, nem por enunciados monárquicos, mas sim através da rotina administrativa» (Max Weber in Dougherty: 707). Embora sejam os dirigentes quem decide o que fazer, é a burocracia que decide como se deve proceder. Decidir como fazer pode, por sua vez, moldar o que fazer. Por isso, as burocracias são de importância vital no estudo da tomada de decisões. 
Aliás, segundo Vertzberger (2002) o que distingue as organizações burocráticas é exactamente a sua dependência em procedimentos que auxiliam na coordenação e na execução de tarefas específicas.

Os decisores dependem de conselheiros, chefes de departamentos e de agências governamentais e do seu pessoal burocrático para obterem informações fundamentais relativamente às decisões da política externa, o que não invalida que em muitos casos haja discordância na interpretação das informações e acontecimentos. As restrições orçamentais podem ser um factor determinante ao nível da recolha e qualidade da informação, levando mesmo a competição interna no seio das burocracias por mais recursos. Além do mais, as burocracias podem moldar as perspectivas dos dirigentes políticos e da opinião pública sobre assuntos de política externa, podendo mesmo influenciar o curso dos acontecimentos. A «unidade de decisão legítima» - unidade capaz de atribuir os recursos necessários e de produzir uma decisão investida de autoridade, pode assumir diferentes formatos: um dirigente dominante (como Castro), um único grupo onde os elementos se confrontam directamente (Politburo ou Conselho de Segurança Nacional) ou múltiplos actores autónomos (sistemas parlamentares).

As burocracias visam melhorar a eficiência e a racionalidade ao conferirem a responsabilidade de diferentes tarefas a diferentes pessoas, definindo regras e procedimentos operacionais que especificam o modo como as tarefas devem ser executadas, e a divisão de autoridade entre diferentes organizações para evitar a duplicação de esforços. Ainda permitem o planeamento avançado com o objectivo de determinar necessidades a longo prazo e os meios de as alcançar. Deste modo, a presença destas organizações poderá resultar numa multiplicidade de opções, melhorando as hipóteses de um maior número de alternativas ser considerado, bem como de adopção de procedimentos de resposta estandardizados. Por exemplo, quando a administração Kennedy optou pela imposição da quarentena naval a Cuba durante a crise dos mísseis para prevenir novos carregamentos de mísseis, a marinha norte-americana pôde pôr em prática a decisão presidencial de acordo com procedimentos anteriormente definidos. Contudo, estas rotinas limitam a opção de escolhas políticas viáveis a partir das quais os decisores políticos poderão seleccionar as suas opções. Mais do que expandir o número de 
alternativas em termos de políticas de forma consistente com a lógica da decisão racional, aquilo que as organizações estão preparadas para fazer molda o que é e o que não é considerado possível. Na crise de Cuba, o ataque aéreo cirúrgico com vista a destruir os mísseis soviéticos então em construção foi vista como alternativa possível ao bloqueio, mas quando a força aérea admitiu que não poderia garantir 100\% de sucesso na operação, essa alternativa foi posta de lado. Assim, as capacidades organizacionais moldaram claramente as opções da administração Kennedy para alcançar o seu objectivo de retirar os mísseis soviéticos de solo cubano.

Para além da influência que as organizações burocráticas exercem nas escolhas dos líderes políticos, podem afectar o ambiente de decisão, assumindo muitas vezes posições destinadas a aumentar a sua influência face a outras agências. Para proteger os seus interesses, as organizações burocráticas procuram reduzir a interferência dos líderes políticos a quem reportam, bem como a de outras agências governamentais, e chegam mesmo a não partilhar informação relativa a actividades internas. Adicionalmente, cada burocracia desenvolve uma forma dominante de olhar a realidade resultante da própria solidariedade e coesão que geralmente se gera no interior de pequenos grupos. Este tipo de perfilamento institucional acaba por reduzir a criatividade e o pensamento independente, encoraja o ancoramento em procedimentos operacionais padronizados e dá preferência a procedimentos já utilizados em vez de novas opções face a novos desafios.

Novamente recorrendo à crise dos mísseis de Cuba de 1962, enquanto o Presidente Kennedy procurou dirigir a acção e negociação, a sua burocracia em geral, e a marinha em particular, estavam de facto a controlar os acontecimentos. A marinha escolheu obedecer às ordens que quis e ignorar as outras. Assim, após discussão com a marinha, Kennedy ordenou que a linha do bloqueio se aproximasse de Cuba de tal modo que os soviéticos tivessem mais tempo para se retirarem. Tendo perdido na discussão com o presidente, a marinha simplesmente ignorou a sua ordem. Sem o conhecimento do presidente, a marinha estava envolvida na pressão aos submarinos soviéticos para que viessem à superfície, muito antes de Kennedy autorizar qualquer contacto com os navios soviéticos. E apesar da ordem presidencial para terminar com acções e informações provocadoras, um 
avião norte-americano entrou no espaço aéreo soviético no auge da crise. Quando Kennedy se apercebeu que não estava no controlo da situação, pediu ao secretário da defesa para averiguar o que se estava a passar. McNamara fez a sua primeira visita ao posto de comando da marinha no Pentágono. Num debate acalorado, o chefe das operações navais sugeriu a McNamara que regressasse ao seu posto de trabalho e deixasse a marinha gerir o bloqueio.

As organizações burocráticas não são as únicas estruturas a participar e auxiliar os líderes nos processos de decisão e implementação da sua política externa. Há muito que se reconheceu o papel dos pequenos grupos na formulação da política externa. Embora os grupos possam variar em tamanho, composição, importância e funções, eles dispõem de algumas características comuns (Vertzberger, 2002): partilham uma série de valores, atitudes e crenças elementares; a maioria dos membros partilha de uma ligação efectiva; e dividem os papéis formais e informais entre si. Estes atributos geram dinâmicas muito particulares que podem ter efeitos significativos no conteúdo e na qualidade das decisões em que participam (Holsti, 2006).

Os pequenos grupos são úteis para lidar com as complexidades da política internacional, contribuindo com uma pletora de perspectivas e com a possibilidade de um debate mais enriquecedor. Igualmente, a relação efectiva típica dos pequenos grupos oferece várias formas de apoio aos decisores, nomeadamente ao nível emocional. Todavia, há também a tendência para limitarem os processos de decisão através de dinâmicas propícias à conformidade. Uma das dinâmicas mais significativas é a do groupthink. Segundo Irving Janis (1971) este fenómeno refere-se à forma de pensar que ocorre quando a procura de concordância entre os indivíduos se torna tão dominante no seio de um grupo que tende a impor-se sobre as apreciações realistas de outras alternativas de acção. O groupthink é reforçado pelo desejo dos indivíduos em serem aceites no grupo, assim as perspectivas e interpretações que possam contrariar as percepções comuns do grupo acabam por ser relegadas para segundo plano ou abandonadas por completo. Em geral, o groupthink apresenta como características (Vertzberger, 2002): prosseguir uma avaliação racional de modo a ignorar informações contraditórias; alguns membros do grupo auto-nomeiam-se para proteger o grupo 
de informação dissonante; o grupo acredita profundamente na sua rectidão, censurando quaisquer dúvidas relativamente a esta; excesso de optimismo que predispõe acções com elevados riscos; os adversários são concebidos de forma estereotipada e considerados altamente perigosos ou ignaros; os membros desviantes são pressionados directamente permitindo consenso no grupo sobre a existência de uma percepção comum.

Contudo, por vezes podem ocorrer divergências no seio dos grupos, exigindo alternativas para resolver o impasse. Em primeira instância, os principais decisores no grupo podem impor a sua preferência, caso tenham poder para tal. Outra forma de resolução acontece quando existe uma maioria de elementos a favor de uma determinada interpretação, existindo uma tendência para os elementos minoritários aceitarem a decisão e em muitos caso internalizá-la. A internalização da decisão maioritária depende em grande parte dos atributos do grupo, designadamente a distribuição de poder, o papel que cada elemento desempenha no grupo, o estatuto de cada elemento e as ligações afectivas entre os indivíduos (Vertzberger, 2002). Por último, quando não existem elementos com poder suficiente para impor uma decisão e não existe uma maioria clara, as resoluções das incongruências derivam de um compromisso que se atinge através das premissas comuns existentes entre os diferentes elementos do grupo.

Não surpreendentemente, os vários participantes das deliberações que levam a escolhas políticas, muitas vezes definem temas e favorecem alternativas políticas que reflectem a sua afiliação organizacional ou grupo. Assim, os diplomatas profissionais tipicamente favorecem soluções diplomáticas para os problemas, enquanto os agentes militares favorecem a opção militar. Mais do que se tratar de uma escolha maximizante de valor, então, o processo de formulação política é em si mesmo intensamente político. Assim, face a uma decisão, mais do que pressupondo a existência de um actor unitário, é necessário identificar jogos e jogadores, e apresentar coligações, exigências e compromissos. Desta perspectiva, a decisão de impor um bloqueio a Cuba foi tanto produto de quem favoreceu a escolha como de qualquer lógica inerente que a possa ter recomendado. Quando Robert Kennedy (irmão do presidente e procurador geral), Theodore Sorensen (conselheiro presidencial) e o secretário da defesa Robert McNamara se uniram em de- 
fesa do bloqueio, formou-se uma coligação dos principais conselheiros do presidente e com os quais ele mais se compatibilizava.

Todavia, Alexander George defende que as decisões acertadas não têm de seguir obrigatoriamente processos racionais e consensuais (Renshon e Renshon, 2008). Embora não negando a importância dos grupos nos processos de decisão de política externa, George salienta que nem todas as decisões são tomadas em grupo e em muitos casos as decisões executivas não dependem dos consensos nos grupos. Este argumento reforça o papel determinante que a psicologia dos líderes tem nas dinâmicas de grupo e nos processos de decisão. Enquanto alguns líderes dependem dos grupos para informar e sustentar as suas decisões, outros conseguem determinar de forma autónoma as políticas a seguir. Desta forma, a necessidade de analisar o papel dos líderes no processo de decisão é indispensável.

\section{O papel dos líderes no processo de decisão da política externa}

Os líderes, e o tipo de liderança que exercem, moldam o modo como é feita a política externa e o consequente comportamento dos Estados na política internacional. Este modelo equaciona a acção nacional com as preferências e iniciativas dos mais altos oficiais dos governos nacionais, uma imagem clara quando rotineiramente ligamos os nomes de líderes a políticas (por exemplo, Doutrina Monroe ou Doutrina Brejnev), e quando atribuímos a maior parte dos sucessos e falhanços na política externa aos líderes no poder na altura da ocorrência. Há, no entanto, amplas divergências entre aquilo que os líderes muitas vezes fazem e aquilo que é esperado deles.

Podemos explicar esta divergência, em parte, ao distinguirmos entre racionalidade procedimental e racionalidade instrumental. A racionalidade procedimental sustenta a visão da política mundial no mesmo tipo de cálculos frios, baseados num balanceamento cuidado de todos os cursos de acção alternativos possíveis. A racionalidade instrumental, por outro lado, constitui uma visão mais limitada de racionalidade. Diz simplesmente que os indivíduos têm preferências, e quando são confrontados com duas ou mais alternativas, escolherão a que lhes parece conter o desenrolar prefe- 
rido. Em oposição à definição de racionalidade procedimental, a definição instrumentalista não oferece avaliações normativas das preferências de um actor, por muito repreensíveis ou mal-fundadas que sejam, baseando então a sua explicação na questão dos objectivos. As implicações destas diferenças aparentemente semânticas são importantes. Demonstram que a racionalidade tem limites, o que nem sempre é assumido quando o modelo de actor racional descrito acima é aplicado a situações reais. Também sugerem que os indivíduos podem actuar racionalmente (no sentido instrumentalista) ao mesmo tempo que o processo de decisão e o seu produto surgem de forma irracional.

Apesar da popularidade deste modelo, não devemos conferir demasiada importância aos líderes individuais. A sua influência é capaz de ser muito mais subtil do que as impressões populares nos têm feito crer. A maioria dos líderes age sob uma variedade de constrangimentos políticos, psicológicos e circunstanciais que limitam aquilo que podem alcançar e reduzem o seu controlo dos eventos. Nas palavras de Lincoln, «eu não controlei os acontecimentos, os acontecimentos é que me controlaram a mim» (1864). A questão passa pelo facto de os líderes não controlarem completamente uma situação, e a sua influência ser severamente circunscrita. Assim, a personalidade e as preferências políticas pessoais não determinam de forma directa a política externa. A questão relevante, então, não é se as características pessoais do líder fazem a diferença, mas sob que condições as suas características são determinantes. Em geral, o impacto das características pessoais de um líder na política externa aumenta quando a sua autoridade e legitimidade são amplamente aceites pela população ou, em regimes autoritários ou totalitários, quando os líderes são protegidos de amplas críticas públicas. Além do mais, alguns tipos de circunstâncias favorecem o potencial impacto dos indivíduos. Entre elas encontram-se novas situações que libertam os líderes das abordagens convencionais; situações complexas que envolvem um grande número de factores diferentes; e situações isentas de sanções sociais que permitem liberdade de escolha porque as normas que definem o leque de opções permissíveis não são claras.

A auto-imagem do líder - a crença de uma pessoa na sua capacidade para controlar os acontecimentos de forma política (conhecida como 
«eficácia política») - também influenciará o grau em que os valores pessoais e as necessidades psicológicas governam o processo de decisão. Por outro lado, quando o sentido de auto-importância ou eficácia está ausente, isto minará a capacidade do líder para lidar com e iniciar mudanças nas políticas. Contudo, esta ligação não é directa. O desejo das populações por uma liderança forte também a afecta. Quando a opinião pública produz uma preferência forte por um líder poderoso, e quando o chefe de Estado tem uma necessidade excepcional de admiração, por exemplo, a política externa irá mais certamente reflectir as necessidades próprias do líder. Por exemplo, a personalidade de Guilherme II foi ao encontro do desejo do povo alemão de um líder simbólico poderoso, e as preferências públicas alemãs influenciaram a política externa da Alemanha durante o seu reinado, que acabou com a Primeira Guerra Mundial.

A quantidade de informação disponível sobre situações particulares é também importante. Sem informação pertinente, as políticas poderão ser baseadas nos gostos e preferências dos líderes. Por outro lado, quanto mais informação um indivíduo tiver sobre os acontecimentos internacionais, menos provável será que o seu comportamento se baseie em influências pouco lógicas. De forma similar, o timing da chegada de um líder ao poder é importante. Quando um indivíduo assume pela primeira vez uma posição de liderança, os requisitos formais de tal posição são menos propensos a circunscrever aquilo que pode ou não fazer. Isto é especialmente verdade no período inicial do mandato, durante o qual estão livres de críticas e pressões excessivas. Além do mais, quando um líder assume governo após um acontecimento dramático (como o assassínio do seu antecessor), pode definir políticas quase sem impedimento pois nestes períodos o eleitorado geralmente abstém-se de críticas.

Uma crise nacional é uma circunstância especialmente propensa a aumentar o controlo do líder sobre a formulação da política externa. O processo de decisão durante uma crise é tipicamente centralizado e gerido exclusivamente no topo da liderança. Falta muitas vezes informação crucial e os líderes vêem-se como responsáveis pelos desenvolvimentos. De forma não surpreendente, então, os nomes de grandes líderes da história, como Napoleão Bonaparte, Winston Churchill, e Franklin D. Roosevelt, emergem facilmente em períodos de grande turbulência. Os líderes são heróis capazes 
de determinar os acontecimentos. O momento pode fazer a pessoa, mais do que a pessoa fazer o momento, no sentido em que a crise pode libertar o líder dos constrangimentos que normalmente iriam inibir a sua capacidade de controlar acontecimentos ou engendrar mudanças na política externa. Na história abundam exemplos de líderes políticos que surgem em diferentes momentos e lugares para tomarem papéis decisivos que mudam o rumo da história mundial (por exemplo, Gorbachov na União Soviética).

No entanto, o impacto pessoal do líder varia com o contexto, e muitas vezes o contexto é mais influente que o líder. A questão prende-se em saber se são os tempos que conduzem à emergência de grandes líderes, ou ao invés, se grandes pessoas seriam líderes determinantes independentemente de quando e onde vivessem. Este modelo parece simplista na sua explicação da forma como os Estados reagem, uma vez que a maior parte dos líderes mundiais seguem as regras do jogo da política internacional, que sugerem que a forma como os Estados lidam com os ambientes externos é muitas vezes menos influenciada pelas pessoas na liderança do que por outros factores. Deste modo, este modelo parece claramente complementar as abordagens anteriores, somando-lhes o ingrediente fundamental relativo ao papel da liderança na política externa.

\section{Determinantes e condicionantes do processo de decisão de política externa}

Como referido, a política externa envolve uma pletora de realidades complexas que dificultam a tomada de decisões. Nesta secção analisamos alguns dos principais determinantes e condicionantes do processo de decisão de forma a compreender as dinâmicas mais subtis que estão envolvidas na formulação de política externa dos diversos Estados. Porém, antes é necessário identificar os diversos tipos de decisões envolvidos em política externa (Mintz e DeRouen Jr., 2010):

- Decisões singulares - decisão isolada, sem estar contextualizada num processo mais amplo. Embora sejam raras em política internacional, algumas decisões são estudadas pelos investigadores e analistas políticos como actos isolados, como são o caso da decisão americana 
para não ratificar o Protocolo de Quioto ou a decisão americana para não auxiliar as tropas francesas em Dien Bien Phu em 1954;

- Decisões estratégicas interactivas - interacção entre pelo menos dois actores cujas decisões afectam e são afectadas reciprocamente. Neste caso, a decisão de um actor vai afectar a decisão do outro actor ou vice-versa. O modelo clássico do Dilema do Prisioneiro atesta este tipo de situações;

- Decisões sequenciais - envolvem uma sequência de decisões interrelacionadas, como por exemplo no caso americano de decidir invadir ou não o Iraque, ocupar ou não o país, aumentar ou diminuir a presença de forças militares, retirar ou comprometer mais activos, término da operação;

- Decisões sequenciais interactivas - sequência de decisões condicionadas pela interacção de pelo menos dois actores. Exemplos tradicionais deste tipo de decisões são as corridas armamentistas, nas quais os diferentes Estados respondem de forma recíproca às decisões dos seus adversários para aumentar a sua capacidade bélica.

Podem-se ainda destacar várias formas de decisão (Mintz e DeRouen Jr., 2010):

- Decisões unilaterais - tomadas pela iniciativa exclusiva de uma parte, sem considerar a vontade dos outros actores. A decisão da Líbia para abandonar o seu programa nuclear em 2003 ou a decisão dos EUA para não ratificar o Tratado de Quioto são exemplos ilustrativos;

- Decisões negociadas - resultam da interacção de pelo menos dois actores que chegam a um acordo sobre a forma de agir. Um exemplo elucidativo foi a decisão da Coreia do Norte de abandonar o seu programa nuclear em troca de ajuda externa depois de um longo processo negocial multilateral;

- Decisões forçadas - são determinadas pela pressão ou ameaça de coacção de um ou mais actores externos. Um exemplo característico foi a pressão política e económica exercida sobretudo pelos EUA e a Rússia para forçar a retirada das forças Britânicas, Francesas e Israelitas que ocuparam o Canal do Suez em 1956; 
- Decisões estruturadas - resultantes da repetição e rotinas formalmente estabelecidas. Estas decisões são típicas das organizações burocráticas e envolvem um elevado grau de certeza. A elaboração dos orçamentos de defesa dos diferentes Estados resulta, regra geral, de processos padronizados desenvolvidos pelas respectivas organizações e envolvem pouca inovação e incerteza;

- Decisões semi-estruturadas - envolvem um maior grau de risco, pois um ou mais factores não estão previstos nos processos estabelecidos;

- Decisões não-estruturadas - nestes casos, alguns factores estruturais como os objectivos e opções podem não estar suficientemente especificadas, impossibilitando a aplicação de soluções disponíveis ou de rotina. A decisão da intervenção militar americana no Afeganistão depois do 11 de Setembro enquadra-se neste perfil, pois a complexidade da situação não tinha sido convenientemente antecipada pelas organizações responsáveis e não havia planos preparados para responder de forma imediata à ameaça (Woodward, 2005).

Contudo, o processo de decisão de política externa não é um procedimento simples e linear. Pelo contrário, a complexidade é a característica dominante do processo de decisão (Renshon e Renshon, 2008). Para além da informação subjacente à decisão ser sempre imparcial e deficiente, a ambiguidade e incerteza são próprias do ambiente de decisão. Existem inúmeras variáveis no ambiente de decisão que agravam os obstáculos que os decisores enfrentam e dificultam a aplicação de estratégias decisórias optimizadas e das quais se destacam os constrangimentos temporais, contextos dinâmicos e interactivos, riscos envolvidos e stress sobre os decisores (Mintz e De Rouen, Jr., 2010; Renshon e Renshon, 2008). A complicar esta situação está o ambiente político internacional que é igualmente complexo devido a um conjunto de características particulares que o tornam opaco e incerto e dos quais se destacam (Vertzberger, 2002):

- Multiplicidade de actores - existem inúmeros actores activos no ambiente político internacional - por exemplo, Estados, organizações internacionais, actores não-estatais - que produzem uma quantidade considerável de estímulos que são difíceis de ser captados e desco- 
dificados eficientemente pelos diversos sistemas de processamento de informação;

- Assimetrias na acessibilidade tecnológica - embora as tecnologias de informação e comunicação tenham assistido a uma autêntica revolução nos últimos anos, nem todas as organizações de informação têm a mesma capacidade para analisar e interpretar a quantidade de informação recebida;

- Decepção - muitos actores utilizam a decepção como uma táctica para iludir ou manipular outros actores, dificultando a distinção entre estímulos e mensagens autênticas ou simuladas;

- Secretismo - muitos actores guardam muita informação em segredo impedindo o acesso de outros actores à informação necessária para proceder a uma avaliação correcta da situação;

- Inexistência de informação - há informação desejada e necessária que simplesmente não existe;

- Ambiguidade de conteúdo - a informação tende a ser susceptível de múltiplas interpretações, muitas contraditórias. A ambiguidade da informação pode resultar do seu próprio conteúdo ser pouco explícito ou o actor assumir que a decepção é uma regra do jogo político, criando a tendência para procurar significados alternativos na informação;

- Inconsistência de conteúdo - por vezes um actor pode apresentar mensagens diferentes e até contrárias conforme os públicos a que se dirige - i.e. público doméstico, elite doméstica, público opositor, elite opositora, elites noutros países, opinião pública mundial. Esta situação cria dificuldades em discernir qual a mensagem que representa as verdadeiras intenções do actor emissor;

- Ambiguidade da fonte - por vezes é difícil identificar a fonte de informação o que complica a relevância e importância da informação;

- Associação de vários assuntos - numa época onde a interdependência dos assuntos é cada vez maior, assiste-se a uma organização horizontal dos diferentes temas. Esta interdependência leva a que seja difícil distinguir quando é que as causas e consequências de um tema são afectadas ou influenciam outro; 
- Cinética - o ambiente político está em constante fluxo, obrigando a uma interpretação permanente das variáveis que se mantêm ou se alteram. Desta forma, a informação recebida tem de ser constantemente reinterpretada e avaliada;

- Modularidade - a informação pertinente às decisões de política externa tem de ser interpretada em conjunto. Todavia, não existe uma fórmula que determine qual a ordem e lógica subjacente à diferente informação recolhida para proceder à avaliação mais correcta. As diferentes organizações impõem sequências distintas nos dados avaliados resultando em interpretações e definições diferentes, se não mesmo contraditórias, das situações.

Porém, enquanto se reconhece que o ambiente no qual os decisores actuam é altamente complexo, outros factores contribuem de forma igualmente significativa para a complexidade do processo de decisão. Em seguida examinamos de forma heurística os factores mais determinantes no condicionamento das decisões de política externa. Sendo certo que não esgotamos os diversos factores que determinam e condicionam o processo de decisão de política externa de um Estado, identificamos os que prevalecem na bibliografia temática ${ }^{2}$ com enfoque nos grupos de interesse, comunidades epistémicas e opinião pública, e nos factores psicológicos, especialmente processos cognitivos e de representação.

\section{Grupos de interesse, comunidades epistémicas e opinião pública}

Os grupos de interesse, comunidades epistémicas e de peritos e a opinião pública são referidos na bibliografia como factores de análise fundamen-

2 Variáveis como localização geoestratégica, poder económico e militar, recursos naturais são referenciadas comummente como determinantes na formulação e decisão em política externa. Além do mais, a bibliografia identifica factores como as alianças, as corridas ao armamento, o nuclear ou o tipo de regime político como aspectos a ter em conta nas análises. Ver Doyle (1983), Foot (2006), Freedman (2004), Gray (2007), Ikenberry (2008), Levy (1981), Mintz e DeRouen Jr. (2010), Nye Jr. (2002), Saunders (2009), Wallace (1979). 
tais no estudo da política externa. Como referido na secção relativa aos modelos teóricos, estes factores podem ter um peso determinante nos processos de formulação e implementação de decisões, moldando, formatando e condicionando opções. De forma variada, estes influenciam, directa ou indirectamente, o processo de decisão de política externa.

Os grupos de interesse organizados representam variados interesses distintos. Um grupo muito influente representa os interesses económicos nacionais, onde organizações de trabalhadores e empresas dispõem de recursos importantes para influenciar os decisores políticos. Seja para proteger os seus postos de trabalho ou para consolidar e aumentar os seus negócios, estes grupos de interesse aplicam uma elevada pressão nos políticos e que se traduz na mobilização eleitoral e financeira dos seus constituintes (Jacobs e Page, 2005). Outros grupos organizados representam interesses mais específicos em termos de política externa. Os lobbies políticos associados a causas de outros Estados também condicionam os decisores políticos através dos inúmeros recursos de que dispõem. Um estudo recente testemunha o peso que o lobby israelita tem na formulação da política externa norte-americana (Mearsheimer e Walt, 2008). Composto por uma coligação informal de indivíduos e grupos, o lobby israelita tem mobilizado um nível assinalável de apoio material e diplomático para persuadir os decisores americanos a manterem uma política de apoio a Israel. Os autores argumentam que o poder do lobby assume proporções tão significativas que as políticas por si avançadas por vezes acabam por ser prejudiciais e contraproducentes para o próprio interesse nacional dos EUA (Mearsheimer e Walt, 2008).

Por sua vez, as comunidades epistémicas são compostas por uma «rede de profissionais com experiência e competência reconhecidas numa determinada área e uma autoridade reconhecida sobre um conhecimento de interesse político dentro dessa mesma temática» (Haas, 1992: 3). Embora as comunidades epistémicas compreendam geralmente grupos compostos por cientistas e académicos, também se referem a grupos constituídos por outros indivíduos que partilhem um conjunto de características comuns (Haas, 1992: 3), nomeadamente um conjunto de crenças normativas e princípios que fornecem uma base valorativa para a actividade social dos seus membros; a partilha de crenças sobre a causalidade central de um 
determinado problema e que estabelece a ligação entre as alternativas de acção política e os resultados desejados; noções partilhadas de validade, i.e. critérios intersubjectivos internamente definidos para avaliar e validar o conhecimento na sua área de especialização; e um projecto político comum que acreditam possa melhorar a situação em causa.

As comunidades epistémicas e os peritos influenciam a decisão política ao fornecer os decisores com reflexões e recomendações sobre as políticas a prosseguir, nomeadamente identificando causas, dinâmicas, objectivos e alternativas políticas inerentes aos eventos políticos internacionais. O Project for a New American Century (PNAC) reflecte estes preceitos. Fundado em 1997 por um pequeno conjunto de indivíduos de orientação conservadora, o PNAC foi moldando o debate de política externa no seio do Partido Republicano nos EUA. Inicialmente irradiado do palco principal do debate político, o PNAC conseguiu através da utilização de diversos recursos à sua disposição, principalmente a autoridade intelectual reconhecida dos seus membros em questões de política internacional, afirmar-se como um grupo de pressão altamente eficiente na influência do poder político. É hoje reconhecido que a afirmação contemporânea do poder militar americano e a sua orientação intervencionista e transformadora fruem de muitos dos princípios e orientações apontadas pelo PNAC (Chollet e Goldgeier, 2008).

Vários estudos demonstram que a opinião pública tem um impacto significativo no processo de decisão política. Os períodos de crise internacional são particularmente susceptíveis ao poder do sentimento popular. No seu estudo sobre a influência da opinião pública americana, Brulé e Mintz demonstram que os líderes moderam o uso da força quando há uma oposição popular generalizada, mas quando há uma maioria favorável os líderes geralmente optam por políticas mais agressivas (Mintz e DeRouen Jr., 2010). Contudo, a opinião pública é susceptível a alterações significativas. Se é certo que pode haver um inequívoco apoio público a uma qualquer política em determinado momento, tal não significa que essa mesma opinião não se altere de forma substancial em pouco tempo. Todavia, estudos aprofundados, abrangendo ciclos temporais relativamente longos, evidenciam uma maior estabilidade na opinião pública do que usualmente se pressupõe 
(Holsti, 2006; Jacobs e Page, 2005). De qualquer maneira, a sua influência não pode ser afastada, particularmente quando se considera a forma como os decisores percepcionam a vontade popular.

Estreitamente associado à opinião pública estão os meios de comunicação social. Em muitas situações os decisores aferem o apoio público através da cobertura que os meios de comunicação atribuem a determinado assunto (Breuning, 2007). Logicamente, o poder dos órgãos de comunicação é importante não só pela sua capacidade para direccionar a atenção do público, mas também dos decisores políticos. De facto, muitos estudos debruçam-se sobre o denominado «efeito CNN», procurando analisar a forma como os meios de comunicação têm influenciado as decisões políticas. Embora se mantenha um debate vivo sobre os modelos e metodologias mais apropriadas para averiguar o fenómeno, a importância efectiva dos meios de comunicação é hoje consensualmente aceite (Gilboa, 2005). O próprio Richard Nixon (1980: 116) confirma o poder dos media ao atribuir-lhes um papel determinante no desfecho da Guerra do Vietname: "A cobertura desonesta e dúbia da Guerra do Vietname não constituiu um dos mais belos momentos da comunicação social americana. Distorceu poderosamente a percepção pública, e isso reflectiu-se no Congresso".

O enquadramento legal doméstico também pode condicionar as decisões de política externa. A legislação nacional pode, em muitos casos, condicionar as opções disponíveis aos líderes. A Administração Clinton, por exemplo, viu-se limitada na sua perseguição a Bin Laden pela proibição consagrada na Ordem Executiva 12333 de Dezembro de 1981 e que impede as agências governamentais americanas de participar em assassinatos políticos (Woodward, 2005). Noutros Estados esta diversidade de condicionantes não é tão manifesta. No caso chinês, o Partido Comunista Chinês retém ainda um elevado controlo sobre o processo de política externa. Embora nos últimos anos se tenham verificado alterações significativas na participação de outros actores domésticos no processo de decisão política (Gilboy e Read, 2008), «O Partido mantém o seu direito de permanecer como o derradeiro actor político no país» (Lanteigne, 2009: 24). A abertura chinesa nas últimas décadas acabou por aumentar a capacidade reivindicativa de vários actores 
domésticos que tradicionalmente não tinham qualquer dinâmica política como são os casos da classe empresarial, das ONG, grupos de interesse organizados e think tanks (Lanteigne, 2009: 24).

A discrepância entre o número de factores domésticos que determinam e condicionam a política externa dos diferentes Estados é muitas vezes consequência de diferenças culturais. As culturas nacionais - conjunto unificado de ideias que são compartilhadas pelos membros de uma sociedade e que estabelecem um conjunto partilhado de premissas, valores, expectativas e predisposições entre os membros da nação como um todo - influenciam o processo de decisão de diversas formas (Vertzberger, 2002). Mais especificamente, a cultura actua sobre a forma como os indivíduos contextualizam e compreendem as diferentes situações, destacando determinados tipos de informações sobre outras, e as formas de lidar com elas. Vários estudos têm evidenciado como os factores culturais condicionam a política externa. Numa investigação recente, Yang, Geva e Chang demonstraram que os decisores americanos são mais propícios ao risco do que os decisores chineses. Os diferentes contextos culturais determinam que, perante a mesma escolha, os chineses têm expectativas de benefícios maiores do que os americanos (Mintz e DeRouen Jr., 2010). Desta forma, os vários estudos têm alegado que as diferenças culturais afectam tanto a escolha como o processo de decisão.

Todos estes factores contribuem para a complexidade do ambiente de decisão. Porém, é a dimensão psicológica que permite aos decisores compreender e avaliar os factores internacionais e domésticos, integrando-os no processo de decisão externa.

\section{Factores psicológicos}

Os factores psicológicos adquirem especial importância quando "as representações dos problemas são contestadas, quando os problemas não são rotineiros, quando há muito em jogo para os decisores e quando o ambiente oferece um grau suficientemente amplo de liberdade que permite um vasto leque de escolhas» (Stein, 2005). Porém, os factores psicológicos são determinantes em todas as situações. De acordo com Renshon e Renshon 
(2008: 511), «[a] enorme complexidade do mundo real, associada à nossa incapacidade para apreender e compreender todos os seus elementos, requer métodos de redução da complexidade». São os processos cognitivos dos indivíduos que permitem reduzir a complexidade do mundo político (Jervis, 1976). Mais concretamente, os processos cognitivos produzem determinadas crenças e construções psicológicas que possibilitam aos decisores impor ordem e sentido ao seu ambiente político.

Deste modo, uma abordagem dos factores psicológicos envolvidos na decisão de política externa procura conhecer «as estratégias cognitivas que os responsáveis políticos empregam para construir e manter as suas imagens simplificadas do ambiente» (Tetlock e McGuire Jr., 1999: 506). Contudo, existe uma soma infindável de factores cognitivos que influenciam os processos de decisão de política externa. Neste caso, somente analisamos os mais conhecidos e explorados na bibliografia temática. De forma a sintetizar a variedade de conceitos e métodos existentes nesta área temática, empregamos a classificação utilizada por Jerel Rosati (2001) para distinguir a forma como os factores cognitivos afectam a política internacional, designadamente através do conteúdo, organização e estrutura das crenças dos decisores; dos padrões comuns de percepção e erros de percepção; da rigidez e flexibilidade cognitiva; e do impacto na elaboração política.

O conhecimento do conteúdo das crenças é essencial, pois o que os decisores acreditam é determinante para informar as suas decisões. Existe uma profusão de abordagens cognitivas que permitem aferir os conteúdos das crenças dos decisores, desde as mais genéricas às mais particularizadas. Uma das abordagens mais utilizadas para identificar as imagens gerais dos decisores é através da análise dos seus "códigos operacionais». Estes compreendem um conjunto coerente de convicções sobre a natureza da vida política internacional (Alexander, 1969). As crenças subjacentes aos códigos operacionais são decompostas na sua dimensão "filosófica» (crenças que definem a situação) e «instrumental» (crenças que determinam o comportamento). Para poder desvendar os códigos operacionais dos decisores, Alexander propõe um conjunto de dez perguntas que têm de ser respondidas sobre as crenças filosóficas e instrumentais. A sua análise permite aos 
investigadores identificar a tendência ideológica e orientação de política externa geral dos decisores.

Os mapas cognitivos também são utilizados para aferir o conteúdo das crenças dos decisores. A ênfase dos mapas cognitivos é na determinação da forma como as crenças do decisor motivam determinados comportamentos. De forma a revelar a complexidade do processo de decisão, os mapas cognitivos evidenciam a relação causal entre as convicções pessoais e as opções políticas, nomeadamente através da aplicação de modelos matemáticos representados por esquemas ilustrados (Axelrod, 1976).

Outra forma de identificar o conteúdo das crenças dos decisores é através da análise das imagens que têm sobre o ambiente internacional. As imagens consistem em simplificações do mundo político e resultam da avaliação que os decisores fazem relativamente às capacidades, relação e cultura de outro Estado (Mintz e DeRouen Jr., 2010; Schafer, 1997). As imagens ajudam os decisores a enquadrar e perceber a informação complexa existente no ambiente político internacional, nomeadamente através da categorização dos diferentes eventos e actores. Desta forma, estas abordagens cognitivas diferenciadas possibilitam uma análise ampla das diversas crenças que os indivíduos têm sobre o ambiente político internacional, desde as mais genéricas às mais específicas.

A forma como o decisor organiza e estrutura as suas crenças é igualmente determinante para o processo de decisão de política externa. A sua compreensão facilita a análise da coerência do sistema de crenças dos responsáveis políticos. A questão central desta perspectiva assenta na consistência ou fragilidade do sistema de crenças e imagens dos políticos. A tese da consistência cognitiva defende que os indivíduos tendem a assimilar informação nova de forma a encaixá-la congruentemente nas suas crenças e imagens préexistentes (Jervis, 1976). Consequentemente, qualquer informação discordante é recusada durante o processo de decisão. O estudo de Holsti (2006) sobre o Secretário de Estado americano John Foster Dulles realça esta tendência para a manutenção da rigidez cognitiva. Dulles mantinha a sua imagem negativa dos soviéticos mesmo quando a informação que recebia contrastava essa ideia. O Secretário de Estado rejeitava as informações contrárias com base no argumento que os soviéticos estavam a aplicar estratagemas para iludir os americanos sobre os seus verdadeiros objectivos expansionistas. 
Desde a década de 1970 que se desenvolvem perspectivas que privilegiam processos cognitivos mais complexos. Em vez de inflexibilidade cognitiva, o decisor é encarado como um "avarento» cognitivo (cognitive miser) no sentido em que devido à sua limitada capacidade para processar informação ele é obrigado a recorrer a esquemas e atalhos mentais para simplificar a informação (Rosati, 2001). Desta forma, os esquemas encerram informação genérica sobre o mundo, pois são «estruturas cognitivas que representam conhecimento sobre um conceito ou tipo de estímulo, incluindo os seus atributos e as relações entre esses mesmos atributos»(Larson, 1994). Mais do que simples crenças, os esquemas incluem exemplos específicos e analogias derivados da experiência pessoal (Larson, 1994). Desta forma, as crenças pré-existentes ainda são consideradas importantes para interpretar informação nova, mas os sistemas de crenças são entendidos como mais fragmentados, com diferentes crenças ou esquemas invocados em diferentes situações para dar sentido à complexidade do ambiente político. Mediante este entendimento, a possibilidade dos decisores modificarem as suas crenças é mais facilmente abraçada.

Alguns estudos têm verificado que ambos os padrões são possíveis. Num estudo sobre as imagens que a Administração Truman tinha sobre a União Soviética, Larson testemunha que enquanto Acheson manteve uma imagem estável e coerente ao longo dos anos, outros elementos da Administração (por exemplo, Truman, Harriman, Brynes) demonstraram inconsistências em vários períodos (Rosati, 2001). Por sua vez, Rosati (1991) evidencia o mesmo padrão na Administração Carter. Todos os elementos responsáveis pela política externa revelaram alterar as suas imagens do sistema internacional ao longo dos anos, passando de uma visão mais optimista e cooperativa para uma mais negativa e hostil.

De acordo com Rosati (2001) três factores estão implícitos na definição das estruturas cognitivas e contribuem para a sua maior inflexibilidade ou fragmentação:

- O nível de conhecimento e experiência do decisor - a distinção entre decisores experientes e principiantes determina que quanto mais experiência e conhecimento efectivo um indivíduo tem, maior a coerência das suas imagens e crenças. Contrariamente, quanto menos 
experiência e conhecimento o indivíduo tem, maior a tendência para a inconsistência e fragmentação das crenças;

- O papel desempenhado pelo decisor - a função que cada indivíduo desempenha no processo de decisão também condiciona a sua estrutura cognitiva. No modelo apresentado por Steinbruner existem três formas comuns de pensar entre os decisores - 1) os burocratas que assentam as suas actividades em rotinas e na consistência processual; 2) os teóricos, que ocupam os lugares intermédios no processo de decisão e estão mais dispostos a considerações abstractas, embora revelando uma notável consistência ao longo do tempo; e 3) os descomprometidos, que ocupam os lugares cimeiros no processo de decisão e são alvo de uma vasta quantidade de informação, optando por soluções diferentes em situações análogas (Rosati, 2001);

- A situação e as expectativas mantidas pelo decisor em determinado momento - os decisores tendem a ser mais influenciados conforme preocupações imediatas que os ocupam. De acordo com Jervis (1976) as preocupações imediatas (evoked sets) dos decisores levam-nos a interpretar as informações recebidas de acordo com os assuntos que mais os consomem nesse momento. Assim, "para adivinhar as inferências que uma pessoa irá retirar de um determinado sinal necessitamos muitas vezes de saber quais os problemas que a preocupam e qual a informação que recebeu recentemente» (Jervis, 1976: 203).

A par com o conteúdo e estrutura cognitiva dos decisores é necessário analisar os padrões comuns de percepção e erros de percepção para compreender algumas das dinâmicas inerentes aos processos de decisão de política externa. Rosati (2001) identifica três padrões de percepção utilizados pelos decisores para organizarem e trazerem ordem à complexidade do ambiente político:

- Tendência para categorizar e estereotipar - para impor alguma ordem na quantidade de informação que adquirem do seu ambiente político, os indivíduos compartimentam e organizam a informação recebida. A simplificação envolvida neste processo leva normalmente à estere- 
otipagem dos eventos e actores. Neste processo há propensão para simplificar as situações de tal forma que se perdem muitos dos traços distintivos das mesmas, criando-se categorias antagónicas como nóseles, bons-maus, etc;

- Tendência para simplificar inferências causais - os indivíduos procuram sempre explicações para as diferentes ocorrências. Um erro de percepção comum é atribuir aos adversários maiores capacidades e responsabilidades do que efectivamente têm. Assim, assume-se que o comportamento dos Estados adversários é geralmente mais centralizado, melhor planeado e mais coordenado do que realmente é. Isto porque, como explica Jervis (1976: 319) «é uma manifestação do ímpeto para comprimir eventos complexos e não-relacionados num padrão coerente». Das diversas inferências causais associadas ao processo de decisão de política externa algumas revelam-se particularmente importantes (Rosati, 2001): tendência para sobrestimar ou subestimar as causas disposicionais e situacionais do comportamento; tendência para sobrestimar ou subestimar a própria importância; tendência para sobrestimar o planeamento e centralização das actividades de outros; tendência para ceder a pensamentos pessimistas ou demasiado optimistas; tendência para utilizar analogias históricas - na busca de soluções simples, os indivíduos têm propensão para utilizar as lições do passado para responder aos desafios do momento. Os eventos internacionais passados servem de repertório de opções à disposição dos decisores. Vertzberger (2002) esclarece que os decisores geralmente utilizam as analogias históricas para definir a situação, circunscrever funções, e determinar e justificar a estratégia.

A abordagem cognitiva também é útil para determinar a rigidez e flexibilidade cognitiva dos decisores de política externa. Segundo Rokeach as diferentes crenças dos indivíduos não têm todas a mesma importância (Rosati, 2001). Aliás, quanto mais central uma crença é para um indivíduo, mais resistente será à mudança. Se eventualmente ocorrer uma mudança numa crença central, maior será a implicação dessa transformação no restante sistema de crenças. Todavia, conforme foi exposto anteriormente, a teoria da consistência cognitiva e teoria dos esquemas diferem na probabilidade 
e na natureza das transformações das crenças. A primeira, subscrevendo a inflexibilidade cognitiva, ao salientar a interdependência das crenças assume que uma transformação a ocorrer repercutir-se-ia em todo o sistema de crenças (Jervis, 1976). Por sua vez, a teoria dos esquemas, apoiando-se nas teorias da cognição social, argumenta que as crenças são muito menos interdependentes, facilitando alterações de crenças singulares incrementadas ao longo do tempo. As implicações destas diferentes perspectivas para o processo de decisão são profundas. Em última instância, comprometem a capacidade dos mais variados decisores políticos (incluindo organizações) para aprender com as suas diversas experiências. Implicam, igualmente, a capacidade que os decisores possuem para se adaptar a novas situações e transformações no seu ambiente político (Rosati, 2001).

No que se refere ao impacto dos factores cognitivos na elaboração política, estes fazem-se sentir em duas etapas distintas: 1) na definição da agenda e 2) na formulação e decisão da política externa. No primeiro ponto, o estudo da definição das agendas tem ocupado um lugar periférico na análise de política externa (Rosati, 2001). Contudo, é de todo o interesse compreender como é que os factores cognitivos influenciam as percepções do ambiente de decisão dos decisores, pois «a forma como o problema é definido e representado é crucial à sua possível solução" (Sylvan, 1998: 3). Por sua vez, como anteriormente foi evidenciado, os factores cognitivos actuam no processo de decisão simplificando o processo, minimizando os custos psicológicos inerentes ao ambiente político. Mais especificamente, os processos cognitivos separam os valores e os objectivos, limitam a procura de informação, reduzem a consideração de alternativas, privilegiam a alternativa mais próxima dos objectivos escolhidos e constringem a capacidade de aprendizagem (Rosati, 2001).

\section{Propostas para melhorar o processo de decisão de politica externa}

As decisões de política externa serão sempre resultado de processos complexos e imperfeitos. Contudo, há formas de melhorar o desempenho das organizações, grupos e decisores de forma a reduzir a quantidade e 
dimensão das condicionantes. Neste sentido, vários modelos têm sido desenvolvidos que procuram melhorar a qualidade do processo de decisão, evitando algumas das tendências e vícios de forma acima referidos. No modelo desenvolvido por Alexander George (1980), este defende a necessidade de um sistema de advocacia múltipla (multiple advocacy), no qual são potenciados os conflitos e desacordos inerentes ao processo de decisão. O sistema compreende uma estrutura mista em que o poder executivo se conjuga com vários actores que representam perspectivas distintas. Desta forma, para garantir que se analisem as várias opções políticas, o líder promove a competição entre as diferentes organizações ou indivíduos de forma a evitar a omissão de alternativas. O modelo de advocacia múltipla impõe três condições: 1) os diferentes elementos devem exibir diversidade de perspectivas e deve haver uma distribuição equilibrada em termos de poder (influência), competência, informação, recursos analíticos e aptidões negociais ou de persuasão; 2) o poder executivo deve monitorizar e regular activamente o processo; 3) deve existir tempo suficiente para se debater e negociar as diferentes opções.

Por sua vez, o modelo do advogado do diabo (devil's advocate) é destinado a descrever o papel de um determinado indivíduo e não uma estrutura de decisão (como o modelo anterior). Na sua concepção teórica, o modelo implica que nas decisões de política externa mais importantes haja pelo menos um consultor sénior que tenha (ou tome) uma posição divergente e argumente em seu favor. O objectivo do advogado do diabo é contrariar a propensão excessiva para haver conformidade nos grupos, nomeadamente através de comportamentos que procuram consenso (George, 1980). Contudo, há vários obstáculos à sua aplicação efectiva. Logo à partida, pode não existir nenhum membro na estrutura de decisão que tenha uma opinião divergente. Embora se possa nomear um elemento para argumentar uma posição discordante, este pode ser encarado como somente desempenhando um papel, não evidenciando nenhuma convicção real a favor dessa perspectiva. O próprio advogado do diabo indicado pode também não estar totalmente comprometido com a abordagem dissidente e não desenvolver os esforços necessários para bloquear a posição maioritária ou até mesmo alterá-la. 
Yaacov Vertzberger (2002) propõe medidas mais vocacionadas para aumentar a capacidade técnica das organizações burocráticas. No seu entender deve haver mecanismos que evitem a politização das burocracias, permitindo a prossecução de propostas livres de caprichos políticos. Porém, nada garante que as avaliações e recomendações de política externa feitas pelos tecnocratas das burocracias estatais estejam livres de deficiências e não evidenciem perspectivas tendenciosas. Vertzberger insiste que é necessário estimular formas de pensamento criativas para evitar algumas das lacunas actuais, nomeadamente através da formação contínua dos burocratas e da monitorização dos processos de decisão. Essas propostas podem contribuir para de facto aperfeiçoar o processo de decisão. Contudo, acreditamos que a forma mais elementar para melhorar o processo de decisão passa pela consciencialização da sua existência e reconhecimento dos principais desafios que se lhe colocam.

\section{Conclusão}

Ao longo deste capítulo procurou-se demonstrar que a política externa é caracterizada por um elevado grau de complexidade. Os problemas que os decisores enfrentam são complicados e os processos de decisão envolvem dificuldades múltiplas. A própria definição de política externa não é consensual e a natureza fluida do ambiente político internacional contemporâneo impõe uma renovada reflexão sobre a sua conceptualização. Todavia, é possível identificar alguns modelos, dinâmicas e actores que ajudam a atenuar a complexidade e melhor compreender a política internacional. A formulação e decisão de política externa podem ser analisadas e compreendidas através de vários modelos que se focam em níveis de análise distintos. Ao tradicional modelo do actor racional, juntam-se-lhe os modelos das organizações burocráticas, dos pequenos grupos e dos líderes. Cada modelo encerra vantagens e inconvenientes na sua apreciação do processo de decisão de política externa. O processo de decisão é igualmente sujeito a enormes complexidades. Não só as decisões diferem no seu tipo e na sua forma, como o ambiente de decisão cria imperativos 
aos decisores que os obriga a decidir em condições que não são as mais adequadas. O ambiente político internacional também dificulta o processo, revelando-se opaco dada a multiplicidade de factores na identificação e avaliação da situação política. O processo de decisão de política externa é condicionado ainda por factores externos, domésticos e psicológicos. A maior parte destes factores são imperceptíveis ao olhar desatento. A análise de política externa centrada nos processos de decisão permite identificar e explicar muitos destes fenómenos. Acima de tudo, possibilita reconhecer esses factores e procurar, se não corrigi-los, evitar os seus efeitos perversos na formulação de política externa.

\section{Questões para análise}

Quais os pressupostos basilares dos estudos iniciais de análise de política externa e como é que se coadunam com a realidade da política internacional contemporânea?

Porque é que os modelos de análise de política externa adquiriram maior ênfase com o término da Guerra Fria?

Como é que o ambiente político internacional condiciona o processo de decisão de política externa?

Como é que os factores cognitivos influenciam a decisão de política externa?

Em que medida é que é possível corrigir algumas das deficiências do processo de decisão de política externa?

\section{Leituras recomendadas}

Allison, Graham e Zelikow, Philip (1999) Essence of Decision: Explaining the Cuban Missile Crisis. New York: Addison-Wesley Longman, Inc.

George, Alexander (1980) Presidential Decisionmaking in Foreign Policy: The Effective Use of Information and Advice. Boulder, Colorado: Westview Press.

Jervis, R. (1976) Perception and Misperception in International Politics. Princeton, New Jersey: Princeton University Press.

Mintz, Alex e DeRouen Jr., Karl (2010) Understanding Foreign Policy Decision 
Making. New York: Cambridge University Press.

Vertzberger, Yaacov (2002) The World in their Minds: Information Processing, Cognition and Perception in Foreign Policy Decisionmaking. Stanford, California: Stanford University Press.

\section{Bibliografia}

Allison, G. e Zelikow, P. (1999) Essence of Decision: Explaining the Cuban Missile Crisis. New York: Addison-Wesley Longman, Inc.

Axelrod, R. (1976) Structure of Decision: The Cognitive Maps of Political Elites. Princeton, New Jersey: Princeton University Press.

Breuning, M. (2007) Foreign Policy Analysis: A Comparative Introduction. New York: Palgrave Macmillan.

Campbell, D. (1993) Politics without Principle: Sovereignty, Ethics, and the Narratives of the Gulf War. Boulder: Lynne-Rienner.

Chollet, D. e Goldgeier, J. (2008) America between the Wars: From 11/9 to 9/11. The Misunderstood Years Between the Fall of the Berlin Wall and the Start of the War on Terror. New York: Public Affairs.

Doty, R. (1997) «Aporia: A Critical Examination of the Agent-Structure Problematique in International Relations Theory” European Journal of International Relations, 3: 365-392.

Doyle, M. (1983) «Kant, Liberal Legacies, and Foreign Affairs», Philosophy and Public Affairs, 12(3), 205-235.

Freedman, L. (2004) Deterrence. Cambridge: Polity Press.

Foot, R. (2006) "Chinese Strategies in a US-hegemonic Global Order: Accommodating and Hedging", International Affairs, 82(1), 77-94.

George, A. (1980) Presidential Decisionmaking in Foreign Policy: The Effective Use of Information and Advice. Boulder, Colorado: Westview Press.

George, A. (1969) «The 'Operational Code': A Neglected Approach to the Study of Political Leaders and Decision-Making, International Studies Quarterly, 13(2), 190-222.

Gilboa, E. (2005) «The CNN Effect: The Search for a Communication Theory of International Relations", Political Communications, 22(1), 27-44.

Gilboy, G. e Read, B. (2008) "Political and Social Reform in China: Alive and Walking», The Washington Quarterly, 31(3), 143-164.

Gray, C. (2007) War, Peace, and International Relations: An Introduction to Strategic History. New York: Routledge.

Gustavsson, J. (1999) «How Should We Study Foreign Policy Change?», Cooperation and Conflict, 34(1): 73-95.

Haas, P. (1992) «Introduction: Epistemic Communities and International Policy Coordination», International Organization, 46(1), 1-35.

Hagan, J. (2001) «Does Decision Making Matter? Systemic Assumptions vs. Historical Reality in International Relations Theory», International Studies Review, 3(2): 5-47. 
Hermann, C. (1990) "Changing Course: When Governments Choose to Redirect Foreign Policy», International Studies Quarterly, 34(1), 3-21.

Holsti, O. (2006) Making American Foreign Policy. New York: Routledge.

Hudson, V. (2008) "The History and Evolution of Foreign Policy Analysis», in Smith, S., Hadfield, A. e Dunne T. (org), Foreign Policy: Theories, Actors, Cases. Oxford: Oxford University Press, 11-30.

Hudson, V. e Vore, C. (1995) «Foreign Policy Analysis Yesterday, Today, and Tomorrow», Mershon International Studies Review, 39(2), 209-238.

Ikenberry, J. (2008) "The Rise of China and the Future of the West: Can the Liberal System Survive?», Foreign Affairs, 87(1), 23-37.

Jacobs, L e Page, B. (2005) «Who Influences Foreign Policy?», American Political Science Review, 99(1), 1-17.

Janis, I. (1971) "Groupthink», Psychology Today Magazine, 84-90.

Jervis, R. (1976) Perception and Misperception in International Politics. Princeton, New Jersey: Princeton University Press.

Jørgensen, K. E. (2006) "Theoretical perspectives on the role of values, images and principles in foreign policy", in Lucarelli, S. e Manners, I. (org), Values and Principles in European Union Foreign policy. London: Routledge, 42-58.

Keohane, R. e Nye, J. (2000) Power and Interdependence. $3^{\mathrm{a}}$ ed. New York: Longman.

Lanteigne, M. (2009) Chinese Foreign Policy: An Introduction. London: Routledge.

Larsen, H. (1997) Foreign Policy and Discourse Analysis: France, Britain and Europe. London: Routledge.

Larson, D. (1994) "The Role of Belief Systems and Schemas in Foreign Policy Decision-Making», Political Psychology, 15(1), 17-33.

Levy, J. (1981) "Alliance Formation and War Behavior: An Analysis of the Great Powers, 1495-1975", Journal of Conflict Resolution, 25(4), 581-613.

Lincoln, Abraham (1864) "Letter to Albert G. Hodges», Sumário da missiva. [http://showcase. netins.net/web/creative/lincoln/speeches/hodges.htm].

Mearsheimer, J. e Walt, S. (2008) The Israel Lobby and US Foreign Policy. New York: Farrar, Straus and Giroux.

Mintz, A. e DeRouen Jr., K. (2010) Understanding Foreign Policy Decision Making. New York: Cambridge University Press.

Neack, L. (2008) The New Foreign Policy: Power Seeking in a Globalized Era. New York: Rowman \& Littlefield Publishers, Inc.

Neack, L.; Hey, J. and Haney, P. (1995) "Generational Change in Foreign Policy Analysis», in Neack, L.; Hey, J. e Haney, P. (org), Foreign Policy Analysis: Continuity and Change in its Second Generation. Englewood Cliffs: Prentice Hall.

Nixon, Richard (1980) A Verdadeira Guerra. Lisboa: Portugália Editora.

Nye Jr., J. (2002) Compreender os Conflitos Internacionais: Uma Introdução à Teoria e à História. Lisboa: Gradiva Publicações, Lda.

Renshon, J. e Renshon, S. (2008) "The Theory and Practice of Foreign Policy Decision Making", Political Psychology, 29(4), 509-536.

Rosati, J. (2001) "The Power of Human Cognition in the Study of World Politics», International Studies Review, 2(3), 45-75. 
Rosati, J. (1994) «Cycles in Foreign Policy Restructuring: The Politics of Continuity and Change in US Foreign Policy", in Rosati, J; Hagan, J e Sampson III, M. (org), Foreign Policy Restructuring: How Governments Respond to Global Change. Columbia, South Carolina: University of South Carolina Press, 221-261.

Rosati, Jerel (1991) The Carter Administration's Quest for Global Community: Beliefs and Their Impact on Behavior. Columbia, South Carolina: University of South Carolina Press.

Rosenau, J. (1966) «Pre-theories and Theories of Foreign Policy», in Farrell, R. B. (org), Approaches to Comparative and International Politics. Evanston: Northwestern University Press, 27-92.

Rosenau, J. ed. (1969) Linkage Politics: Essays on the Convergence of the National and International Politics. New York: Free Press.

Saideman, S. e Ayres, R. W. (2007) «Pie Crust Promises and the Sources of Foreign Policy: The Limited Impact of Accession and the Priority of Domestic Constituencies", Foreign Policy Analysis, 3(3), 189-210.

Saunders, E. (2009) "Transformative Choices: Leaders and the Origin of Intervention Strategy», International Security, 34(2), 119-161.

Schafer, M. (1997) «Images and Policy Preferences», Political Psychology, 18(4), 813-829.

Simon, H. (1955) «A Behavioral Model of Rational Choice», The Quarterly Journal of Economics, 69(1), 99-118.

Sjöstedt, R. (2007) "The discursive origins of a doctrine: norms, identity, and securitization under Harry S. Truman and George W. Bush", Foreign Policy Analysis, 3(3): 233-254.

Snyder, R.; Bruck, H. e Sapin, B. (org) (2002) Foreign Policy Decision-Making (Revisited). New York: Palgrave-Macmillan.

Sprout, H. e Sprout, M. (1957) "Environmental Factors in the Study of International Politics», Journal of Conflict Resolution, 1(4), 309-328.

Sylvan, D. (1998) “Introduction», in Sylvan, D e Voss, J. (org), Problem Representation in Foreign Policy Decision Making. Cambridge: Cambridge University Press, 3-7.

Stein, J. (2005) «Psychological Explanations of International Conflict», in Carlsnaes, W; Risse, T. e Simmons, B. (org), Sage Handbook of International Relations. London: Sage, 292-308.

Tetlock, P. e McGuire Jr., C. (1999) "Cognitive Perspectives on Foreign Policy", in Ikenberry, G. J. (org), American Foreign Policy: Theoretical Essays. Massachusetts: Addison Wesley Longman, 504-521.

Vertzberger, Y. (2002) The World in their Minds: Information Processing, Cognition and Perception in Foreign Policy Decisionmaking. Stanford, California: Stanford University Press.

Wallace, M. (1979) "Arms Races and Escalation: Some New Evidence», Journal of Conflict Resolution, 23(3), 3-16.

Waltz, K. (1979) Theory of International Politics. Reading: Addison-Wesley.

Woodward, B. (2005) Bush at War. New York: Simon \& Schuster Paperbacks. 
(Página deixada propositadamente em branco) 
Patrícia Daehnhardt

\section{CAPÍtULO 2}

\section{ALEMANHA}

A particularidade da política externa alemã após o fim da Segunda Guerra Mundial foi o facto de tanto a República Federal da Alemanha como a República Democrática da Alemanha verem as suas margens de manobra política condicionadas pela presença política e militar das potências vencedoras da Segunda Guerra Mundial, e pela ordem bipolar emergente pós-1945 que dividiu o continente europeu entre a Europa ocidental, aliada aos Estados Unidos da América, e a Europa de leste, sob a hegemonia da União Soviética. A Segunda Guerra Mundial terminou, na Europa, em Maio de 1945, com a partilha do território alemão entre as potências vencedoras, os Estados Unidos, a União Soviética, a Grã-Bretanha e a França com a criação de quatro zonas de ocupação, cabendo à União Soviética o controlo sobre a parte oriental da Alemanha, e às restantes três potências aliadas o controlo sobre a parte ocidental do território. O início da Guerra Fria na Europa, assim como o crescente desentendimento sobre a forma de administração conjunta das zonas de ocupação, levaria, após o bloqueio soviético à cidade de Berlim, em 1948, à divisão efectiva e à criação, em 1949, de dois Estados alemães, a República Federal da Alemanha (RFA), apoiada pelas três potências ocidentais, e a República Democrática da Alemanha (RDA), inserida na zona de influência da União Soviética. A cidade de Berlim permaneceria, dividida, sob administração das quatro potências. Com a unificação, a 3 de Outubro de 1990, a Alemanha, potência no centro da Europa, recuperou a sua completa soberania 
política e iniciou um percurso de normalização da sua política externa e de afirmação do seu novo estatuto de poder.

Este capítulo visa analisar a evolução da política externa alemã, abordando a constituição das duas Alemanhas e o papel da RFA durante a Guerra Fria, e o período após a unificação. Apesar da especificidade do regime político da antiga RDA, a análise centra-se sobre as decisões políticas tomadas pela RFA, tendo em conta que a República Federal foi a principal representante da nação alemã e foi ela que liderou o processo de unificação. Na primeira parte, o capítulo incide sobre a política externa da RFA durante a Guerra Fria, sob as lideranças de Konrad Adenauer, Willy Brandt e Helmut Kohl. Na segunda parte, o capítulo articula as diferenças na condução da política externa alemã nos períodos de Helmut Kohl, Gerhard Schröder e Angela Merkel.

\section{A Alemanha no centro da Europa}

Historicamente, o território do que é hoje a Alemanha esteve dividido entre diferentes parcelas políticas e apenas se constituiu como unidade política em finais do século XIX. Isto prende-se com várias razões que explicam a especificidade da Alemanha na política europeia. O fim da Guerra dos Trinta Anos, em 1648, teve um desfecho paradoxal. Enquanto marcou o nascimento do sistema de Estados modernos, na Europa, através da constituição de estados soberanos, a mesma data representou, para os alemães, o adiamento, sine die, do seu próprio projecto de soberania política, já que da guerra resultou a permanência de várias pequenas entidades políticas alemãs que careciam de um centro unificador. Foi apenas dois séculos mais tarde, em 1871, que a Alemanha se unificou enquanto Estado, sob a liderança do Chanceler Otto von Bismarck, após guerras com a Dinamarca, a Áustria e a França. Para Bismarck, a Alemanha, com a Prússia como o seu centro unificador, era agora uma potência 'saturada', sem pretensões expansionistas sobre os territórios dos seus vizinhos e empenhada em manter o equilíbrio geopolítico europeu. Para tal, Bismarck definiu uma hábil política de alianças e isolou diplomaticamente a França. Com Guilherme II, a Alemanha seguiu, a partir de 1890, 
uma Weltpolitik (política mundial) e a pretensão de tornar a potência continental alemã uma potência naval, o que rivalizou com o tradicional papel marítimo da Grã-Bretanha, e contribuiu para o advento da Primeira Guerra Mundial. A forma como as potências vencedoras do conflito lidaram com a Alemanha, em 1919, aplicando-lhe elevadas reparações de guerra assim como impondo-lhe a ostracização momentânea do sistema internacional, viriam a acelerar a debilidade do recém criado regime democrático e facilitar a emergência de uma Alemanha revisionista, que, na década de 1930, seguiu uma política de preparação para a Segunda Guerra Mundial, com o objectivo de alterar o status quo fragilizado do período entre as duas guerras e prosseguir uma política expansionista de germanização da Europa.

O que estas diferentes políticas demonstram é que a complexidade da posição da Alemanha no centro da Europa e a forma como os Estados vizinhos responderam causou, historicamente, aquilo que se denomina de tradicional 'questão alemã': o dilema que resultava ou da excessiva fraqueza, ou da exagerada força do Estado alemão, e da dificuldade de se criar um sistema de equilíbrio que contivesse esta tensão constante. No primeiro caso, a fraqueza tornava o estado alemão vulnerável a pressões externas; no segundo, a Alemanha tornava-se demasiadamente forte para se manter uma potência europeia equilibrada, com fronteiras estáveis e uma política externa benigna.

Este dilema ajuda também a compreender porque é que, na Alemanha, a construção do estado e da nação ocorreram tardiamente e porque é que a nação alemã tem sido qualificada de 'nação tardia' (verspatete Nation, Helmut Plessner): uma industrialização tardia, uma emancipação incompleta da burguesia e uma democratização falhada da estrutura política constitucional foram as razões internas que se aliaram às condicionantes externas referidas.

\section{O início da Guerra Fria na Europa e a divisão alemã}

Se concebermos que a Guerra Fria foi um sistema internacional que ideologicamente, economicamente e geopoliticamente opôs os Estados Unidos e a União Soviética, que se combateram numa guerra de ideias, de territórios e de mercados à escala global, a Europa foi a região mais 
decisiva para as duas superpotências, e localizadas no seu centro, as duas Alemanhas, e principalmente a RFA, eram as peças mais cobiçadas no novo palco estratégico e político-militar da Guerra Fria. ${ }^{1}$ Nenhuma das duas superpotências iria voluntariamente desistir da 'sua' parte alemã e permitir que a outra superpotência obtivesse a vantagem de vir a incluir uma potencial Alemanha unificada no seu bloco. Para a RFA, isto significava que era simultaneamente o elemento mais vulnerável, com uma margem de manobra política limitada, e o jogador passivo mais importante porque excluía a hipótese do seu isolamento internacional.

\section{Interesse nacional: Reunificação ou Westbindung?}

Qual foi o interesse nacional da RFA nos anos imediatos depois da sua constituição? Perante os condicionalismos da bipolaridade, o primeiro Chanceler da República Federal, Konrad Adenauer, da União Democrata Cristã (CDU), definiu as duas opções da política externa da seguinte forma: prosseguir com o objectivo da reunificação das duas Alemanhas ou promover a integração da RFA nas estruturas institucionais ocidentais que se estavam a criar através de uma política de Westbindung (aliar-se ao Ocidente). A primeira opção sugeria uma alteração do status quo recém imposto pelas potências vencedoras, o que corria o risco de isolar a RFA diplomaticamente. A divisão alemã e a presença das quatro potências vencedoras da Guerra fazia com que qualquer tentativa de resolução deste problema teria de ser enquadrada num contexto mais amplo de confronto leste-oeste, e da Guerra Fria que se estava a iniciar. A segunda opção integraria a RFA nas estruturas institucionais da Europa ocidental, ancorando-a na Aliança Atlântica e nas Comunidades Económicas Europeias, ao mesmo tempo que reconhecia, implicitamente e a curto prazo, a efectiva divisão alemã, e corria

\footnotetext{
1 A cidade de Berlim era o centro nevrálgico desse conflito bipolar. Várias crises da Guerra Fria decorreram na Europa: a crise de Berlim, em 1948, que levou à partilha da Alemanha, e de Berlim, em dois, e a crise de 1958-1961, que terminaria com a construção do Muro de Berlim, em Agosto de 1961.
} 
o risco de impopularidade junto do eleitorado devido à artificialidade da divisão da nação alemã. ${ }^{2}$

A escolha entre estas duas opções foi fundamental, porque determinou a condução da diplomacia alemã durante a Guerra Fria. Konrad Adenauer optou pela política de Westbindung. O objectivo da reunificação era o objectivo primordial, mas teve de ser relegado para segundo plano. Impunha-se, em primeiro lugar, convencer os aliados, e principalmente a França e os Estados Unidos, de que a RFA pretendia ocupar um lugar sólido nas novas estruturas institucionais ocidentais, e que a nova classe política alemã se tornara uma elite em que o ocidente podia confiar, que não sucumbia às tentações de uma neutralidade política que poderia vir a desequilibrar o frágil equilíbrio assegurado pela dissuasão nuclear entre os dois blocos.

Para Adenauer, oriundo da Renânia, a opção externa pela Westbindung era uma questão existencial e passava por duas relações bilaterais indispensáveis: a França e os Estados Unidos. Face ao receio francês de um ressurgimento militar alemão, a RFA aceitou a criação de uma Agência de Controlo de Armamentos para que a França aceitasse o rearmamento alemão e a integração da RFA na Organização do Tratado do Atlântico Norte (OTAN). Isto levou a Alemanha a seguir uma política de reconciliação com a França, que se traduziu no início do processo de integração europeia na década de 1950. Quanto aos Estados Unidos, a administração Truman teve a visão estratégica de, para tornar a política de contenção do comunismo soviético eficaz, ser essencial incluir a RFA nas estruturas institucionais que os Estados Unidos estavam a promover no continente europeu, a partir de 1947.

O Chanceler Adenauer não sucumbiu à oferta do líder soviético Estaline, quando este propôs, em 1952, que a URSS aceitaria a reunificação das duas Alemanhas desde que uma Alemanha unificada fosse neutra e não integrasse nenhuma aliança militar. Tal situação teria colocado as forças ocidentais à esquerda do rio Reno, numa clara desvantagem estratégica face a Moscovo. Para além do mais, uma Alemanha unificada desligada de uma aliança

\footnotetext{
2 É por essa razão que não existiu, na RFA, uma Constituição, mas apenas uma 'Lei Básica' (Grundgesetz) como lei fundamental, elaborada por um 'período de transição' que seria terminado aquando da reunificação do povo alemão.
} 
levantaria, mais uma vez, o 'problema alemão': o de que uma Alemanha demasiado forte seria uma ameaça hegemónica para os seus vizinhos, e uma Alemanha demasiado fraca seria uma tentação para ambições dos mesmos. Uma Alemanha neutra e desarmada causaria o duplo problema de mantê-la desarmada e livre da dominação de outras potências; uma Alemanha neutra e armada levantaria o problema oposto de mantê-la neutra e de evitar uma nova hegemonia de poder. Neste sentido, e apesar da anormalidade da existência de dois Estados alemães na Europa, a RFA estava firmemente integrada numa rede de instituições o que evitava simultaneamente o isolamento do país e as tentações neutralistas, ao mesmo tempo que assegurava, voluntariamente, o constrangimento do poderio alemão. O constrangimento foi tal que levou alguns a falar da transição de uma 'obsessão pelo poder' (Machtbesessenheit) para um 'esquecimento do poder' (Machtvergessenheit) (Schwarz, 1994) por parte dos decisores políticos alemães.

É face a este conjunto de cenários que a administração de Dwight Eisenhower e Adenauer, conceberam a inclusão da RFA na OTAN para assegurar a política de contenção de expansionismo militar e ideológico da União Soviética. ${ }^{3}$ A integração na OTAN aconteceu através dos Acordos de Paris, de 23 Outubro de 1954, e depois de a França ter recebido garantias do Reino Unido e dos EUA de que estes manteriam uma presença militar substancial na RFA e na Europa (Paris Agreements, 1954). Os Acordos terminaram com o estatuto de ocupação da RFA, que recuperou a sua soberania e integrou consequentemente a OTAN e a União da Europa Ocidental (UEO). Pelos Acordos, a RFA podia ter forças militares próprias, comprometendo-se a integrá-las na totalidade nas estruturas da OTAN, e renunciava ao fabrico de armas nucleares, biológicas e químicas. Os Acordos incluíram ainda uma declaração de auto-limitação, onde a RFA se comprometeu a «nunca recorrer à força para obter a reunificação da Alemanha», e de "resolver por meios pacíficos» disputas com outros países. Integrar a RFA na OTAN serviria, as-

3 É preciso não esquecer o contexto internacional. Devido à constituição da República Popular da China, que se tornara comunista na sequência da vitória de Mao Tse-Tung, em 1949, e devido à Guerra da Coreia, entre 1950 e 1953, os Estados Unidos alargaram a sua doutrina de contenção, concebendo-a em termos globais, e reforçando a defesa da Europa ocidental. Uma consequência desse reforço foi o apoio norte-americano ao rearmamento alemão e à inclusão da RFA na OTAN. 
sim, também para assegurar o controlo militar ocidental sobre o país. Lord Ismay, o primeiro secretário-geral da OTAN, caracterizou bem a tripla função da Aliança ao afirmar que a OTAN serviria "to keep the Americans in, the Soviets out and the Germans down». A União Soviética, após as malogradas 'notas de Estaline', e após a integração da RFA na OTAN, criou o Pacto de Varsóvia, em 1955. Ou seja, da perspectiva de Moscovo, uma RFA na OTAN era mais decisivo do que a própria existência da OTAN. ${ }^{4}$

Face à República Democrática da Alemanha, a RFA prosseguia, desde 1955, a diplomacia da chamada doutrina Hallstein, segundo a qual Bona abstinha-se de celebrar relações diplomáticas ou cortaria relações existentes com Estados que reconhecessem diplomaticamente a RDA. Com esta política, a RFA pretendia ser a legítima representante do povo alemão, retirar legitimidade ao regime político da RDA e isolá-lo internacionalmente. Ao mesmo tempo, e consequência da política de Westbindung, isto deveria demonstrar a pertença da RFA ao mundo ocidental e revelar uma prova de confiança à França e aos Estados Unidos. A excepção a esta postura foi, contudo, a celebração de relações diplomáticas com a URSS, em 1955, revelando a importância da URSS como uma das chaves no futuro processo de unificação.

Economicamente, a Alemanha Federal também se integrou nas estruturas ocidentais. O apoio norte-americano através do plano Marshall à reconstrução económica da Europa, em 1947, permitiu à RFA desenvolver uma capacidade económica formidável e contribuiu para a estabilidade política na Europa ocidental (já que a URSS pressionou os países da Europa de leste a recusarem a ajuda) e a reconstrução dos países envolvidos na guerra. Internamente, o Ministro da Economia, Ludwig Erhard (CDU), iniciou uma política social de mercado (soziale Marktwirtschaft) para assegurar a revitalização da economia alemã, produzindo assim o 'milagre económico alemão'. Este rápido desenvolvimento económico fomentou a estabilização política interna e o fortalecimento das estruturas políticas democráticas.

\footnotetext{
${ }^{4}$ Não foi por acaso que, na sequência da queda do Muro de Berlim, em 9 de Novembro de 1989, a questão negocial mais controversa, e aquela que ainda hoje é debatida, foi a adesão da Alemanha unificada à OTAN, mais do que a própria continuidade institucional da OTAN. Ainda hoje em dia é assim, no que se refere à hipótese, de momento remota, da integração da Geórgia e da Ucrânia na OTAN.
} 
Por outro lado, iniciou-se o processo de integração económica na Europa ocidental. Através do chamado 'plano Schuman', que propunha a integração das indústrias europeias do carvão e do aço, a França e a RFA criaram a CECA, em 1951. A RFA e a França, a Itália e os três países do Benelux criaram, em 1957, a Comunidade Económica Europeia (CEE). Desde o início, a RFA e a França representaram o núcleo do processo de integração europeia, que foi ao mesmo tempo também catalizador na reconciliação entre os dois Estados.

Desde então a RFA desenvolveu uma política europeia assente na forte congruência entre as instituições e interesses entre a RFA e a CEE, o que fez com que muitos considerassem a Alemanha um 'Estado europeizado' (Bulmer et al., 2000). O compromisso da RFA com a integração europeia teve, desde a sua origem, uma dupla motivação adicional, diferente da dos restantes países europeus. Por um lado, para Adenauer, a participação no projecto de integração europeia era uma forma de a RFA recuperar soberania política. Assim, ao passo que o projecto visava, a longo prazo, delegar prerrogativas de soberania nacional para as instituições comunitárias, para Bona o objectivo era, em primeira instância, adquirir margem de manobra e consolidar a soberania política. Por outro lado, o papel da Alemanha e a memória histórica dos crimes do nacional socialismo condicionaram a política externa e moldaram a identidade internacional da RFA, na medida em que os próprios decisores políticos alemães concebiam a nação alemã como fortemente europeizada, assente numa identidade pós-nacional. Nesse sentido, a integração europeia não foi para os alemães apenas uma questão económica e de reconciliação entre povos europeus, mas também um instrumento para a gradual recuperação da identidade nacional. Num contexto onde palavras como 'patriotismo' eram tabu, o marco alemão tornou-se um substituto para a identidade debilitada, e o chamado Verfassungspatriotismus (patriotismo constitucional) (Sternberger, 1990) funcionou como substituto do patriotismo nacional (Sternberger, 1990).

Adenauer inverteu a lógica da integração ao não delegar elementos de soberania que a RFA não possuía, mas para recuperar esses mesmos elementos. É neste duplo sentido que se pode argumentar que a RFA, ao longo dos quarenta anos de Guerra Fria, se tornou uma potência domesticada, 
um «tamed power» (Katzenstein, 1997). Tratou-se de uma política de baixos custos e de elevadas compensações: num cenário de enfraquecida identidade nacional, a integração europeia correspondeu ao interesse nacional alemão e a melhor forma de alcançar a crescente integração foi através do multilateralismo político.

Nos 14 anos em que foi Chanceler da RFA, Adenauer prosseguiu uma política de aproximação ao ocidente, 'ancorou' a RFA nas estruturas institucionais da OTAN e da Comunidade Económica Europeia, e reconciliou o seu país com a França, o que levou à assinatura do Tratado dos Eliseus, em Janeiro de 1963, com o Presidente francês, Charles de Gaulle, institucionalizando a relação de parceria entre os dois países.

\section{Willy Brandt e a Ostpolitik}

A construção do Muro de Berlim, pela RDA, com apoio da URSS, em Agosto de 1961, para impedir a continua fuga de cidadãos da RDA para Berlim ocidental, levou ao reconhecimento de que a doutrina Hallstein limitava a margem de manobra diplomática da RFA, e impedia uma aproximação entre os dois Estados alemães que permitisse desenvolver contactos entre os cidadãos alemães de ambos os países. O novo governo de Willy Brandt, do Partido Social Democrata (SPD), a partir de 1969, alterou, por isso, a política relativamente aos países de leste, iniciando a Ostpolitik (política a leste). Para o Chanceler, não era a política de isolamento da RDA, mas antes uma aproximação à RDA e aos países da Europa de leste, que traria os maiores benefícios à diplomacia da RFA e ao povo alemão dividido. Sem negar os méritos da Westbindung, o governo de Brandt desenvolveu uma política de aproximação à Alemanha de leste, à União Soviética e aos restantes países do Pacto de Varsóvia.

Esta Ostpolitik, que revogou a doutrina de Hallstein, culminou na assinatura de uma série de acordos, da RFA com a União Soviética e a Polónia, e mais decisivamente, entre as duas Alemanhas através do Tratado Básico, de 21 de Dezembro de 1972, onde ambas as partes se reconhecem como entidades políticas autónomas (não como Estados soberanos), e concor- 
dam resolver disputas através de meios pacíficos (The Basic Treaty, 1972). A Ostpolitik desenvolveu-se num clima de desanuviamento entre os Estados Unidos e a União Soviética, e na Europa, que levou à assinatura da Acta Final de Helsínquia, na Conferência sobre Segurança e Cooperação na Europa, em 1975.

Foi contudo a década de 1980 que permitiu desenvolver uma gradual independência das duas Alemanhas em relação às superpotências, numa altura em que os EUA e a URSS entraram num novo período de Guerra Fria. A crise dos euromísseis e a política soviética de expansão multidireccional para países na América Central, África e a intervenção militar soviética no Afeganistão desafiaram os princípios da dissuasão entre as superpotências; contudo, esta nova tensão não se reproduziu no campo inter-alemão, onde a aproximação se reforçou entre os dois Estados, permitindo um maior contacto interpessoal entre cidadãos alemães.

\section{A unificação alemã}

A RFA chegou ao fim da Guerra Fria numa posição económica poderosa combinada com um papel reduzido na política internacional, e com uma fórmula militar limitada. Mas as circunstâncias em que ocorreu a unificação da Alemanha foram benéficas à política externa alemã. Primeiro, porque o objectivo foi alcançado de forma pacífica: atipicamente na transição de um sistema internacional para outro, a Guerra Fria terminou sem a ocorrência de uma guerra hegemónica (Gaspar, 2002). Segundo, porque pela primeira vez, uma Alemanha unificada, encontrava-se rodeada, no centro da Europa, por Estados amigos e vizinhos, e sem questões territoriais por resolver. Em terceiro lugar, porque os termos da diplomacia da unificação foram, em larga medida, determinados pelo Chanceler Kohl e pelo seu Ministro dos Negócios Estrangeiros, Hans-Dietrich Genscher, de uma forma inversa àquilo que durante décadas fora o possível cenário da unificação. Perante o acelerar dos acontecimentos que levaram à queda do Muro de Berlim, em 9 de Novembro de 1989, os líderes da RFA conduziram o processo diplomático «2+4» com rapidez e determinação. Depois de reconhecer a fronteira territorial com a Polónia, a Alemanha unificou-se, em 3 de Outubro de 
1990, através da integração da RDA na RFA, e através da permanência da Alemanha unificada na OTAN e na CEE. Por último, a ordem euro-atlântica do pós-Guerra Fria é uma ordem construída a partir das consequências da unificação alemã: o início do novo poder da Alemanha deu-se logo em 1989/90 e na forma como decorreram as negociações da unificação. Por isso, o processo de negociação internacional que antecedeu a unificação e moldou o fim da Guerra Fria foi crucial na construção da futura ordem de segurança pós-Guerra Fria na Europa (Daehnhardt, 2009).

A unificação levantou dúvidas quanto à futura política europeia da Alemanha: a simbiose entre a Alemanha e a Europa foi questionada, aumentando expectativas e responsabilidades de ambos os lados. O debate centrou-se entre aqueles que defendiam a inevitabilidade da afirmação da Alemanha como potência central europeia (Schwarz, 2005), e aqueles que argumentavam que a Alemanha não alteraria o seu curso, já que as instituições, os interesses e a identidade estavam firmemente consolidados (Bulmer et al., 2000).

Helmut Kohl: a continuidade como motor e o alargamento como estratégia

Em termos bilaterais, as prioridades do governo de coligação Kohl e Genscher foram a política de cooperação e aliança com a França, e com os Estados Unidos. Com a França, Kohl e Genscher aprofundaram a integração europeia, através da assinatura do Tratado de Maastricht, em 1991, instituindo a União Europeia, e elevando o grau de interligação institucional europeu. Com os Estados Unidos, reforçaram a relação bilateral. Em Maio de 1989, aquando de uma visita à RFA, o Presidente George Bush propôs uma parceria na liderança à Alemanha (partnership in leadership), demonstrando simultaneamente não recear outras grandes potências no sistema internacional ao reconhecer que, para Washington, a Alemanha era o Estado mais importante na Europa.

A estratégia do governo de Kohl traduziu-se na manutenção da continuidade do multilateralismo por duas razões. Primeiro, porque tinha sido uma política bem sucedida que evitava que a Alemanha tivesse que 
escolher entre a relação franco-alemã e americano-alemã, e jogasse uma contra a outra. Segundo, uma política de continuidade deveria tranquilizar as ansiedades e receios quanto a uma nova hegemonia alemã na Europa. A estratégia escolhida foi a Europeização das políticas alemãs através do alargamento institucional da União Europeia e da OTAN. O Ministro alemão da Defesa, Volker Rühe, CDU, foi dos primeiros políticos europeus a sugerir o alargamento da Aliança Atlântica para o leste europeu; simultaneamente, o alargamento das estruturas institucionais e da ordem constitucional para a Europa central e oriental foi a fórmula encontrada para exportar a estabilidade ocidental. Para Kohl não havia alternativas à Europeização da política externa alemã: a unificação alemã e a unificação europeia não eram apenas os dois lados da mesma medalha, eram uma questão de guerra ou paz na Europa. Logo, a característica mais determinante da sua liderança, perante a inevitabilidade das mudanças estruturais, foi manter a continuidade dos objectivos - aprofundar e alargar a União Europeia - e dos instrumentos - com a introdução do euro. Assim, o reforço da parceria franco-alemã e da aliança americano-alemã serviu para deliberadamente evitar a mudança dos parâmetros da política externa. Apesar da continuidade, a política europeia da Alemanha era progressista, federalista e idealista na defesa da ideia de unificação europeia.

Na política de segurança da Alemanha ocorreu, contudo, uma alteração importante, tanto pelas mudanças de conteúdo como pela forma como elas aconteceram: em 12 de Julho de 1994, o Tribunal Constitucional Federal autorizou a participação de tropas da Bundeswehr em missões militares out-of-area da OTAN, com o apoio das Nações Unidas, e quando aprovadas pelo Bundestag (parlamento alemão). Pela primeira vez, o espectro de acção da Bundeswehr foi para além da mera defesa territorial europeia, passando a Bundeswehr a participar, em coligação com outras forças militares da Aliança Atlântica, em operações em território extra-Aliança Atlântica. O facto de ter sido o órgão de soberania judicial que decidiu esta mudança política, demonstra a dificuldade de tomada de decisões quanto a questões militares. Esta mudança na política de segurança, significativa em termos de política interna, foi, no entanto, coerente com as alterações ocorridas nos objectivos estratégicos da OTAN do pós-Guerra 
Fria, e que se prendiam, precisamente, com um alargamento do campo de acção e da natureza das missões.

A mudança com Gerhard Schröder: a redefinição do estatuto de poder

A partir de Outubro de 1998, com a constituição do governo de coligação social-democrata e verdes (SPD/Die Grünen), a política externa assume novos contornos quando o Chanceler Gerhard Schröder inicia a mudança do tradicional europeísmo alemão, ao afirmar, perante o Bundestag, pouco depois de se ter tornado Chanceler, que «nós somos europeus não porque temos que sê-lo, mas porque queremos sê-lo» (Schröder, 1998). O Chanceler representava a primeira geração do pós-guerra que já não sentia os constrangimentos da história alemã da mesma forma que a geração Kohl. O europeísmo alemão tinha deixado de ser um pressuposto para uma política credível e passou a ser uma opção voluntária. Um novo sistema internacional pressupunha uma nova Alemanha: esta pretendia manter os laços europeus e transatlânticos, mas redefinir o estatuto da Alemanha no seio das mesmas estruturas institucionais.

Como é que Schröder e Fischer procederam à redefinição do estatuto da Alemanha? Em primeiro lugar, na Primavera de 1999, a Alemanha participou, sob comando da OTAN, pela primeira vez numa missão militar ofensiva contra um terceiro estado, a Sérvia, em defesa da minoria albanesa, na guerra do Kosovo. Fê-lo em concordância com os seus parceiros europeus e os Estados Unidos, mas sem o mandato internacional da ONU, e pôs em prática a alteração da política de segurança alemã. Decorria a presidência alemã da União Europeia, e o Conselho Europeu de Colónia decidiu, sob forte impulso alemão, adoptar o Pacto de Estabilidade para os Balcãs para a estabilização da região. Em segundo lugar, na sequência do ataque terrorista aos Estados Unidos, em 11 de Setembro de 2001, o Chanceler declarou, um dia depois, a "Solidariedade sem restrições» (uneingeschränkte Solidarität) aos EUA na luta contra o terrorismo internacional (Stenographischer Bericht 186, 2001). Sem reservas, a Alemanha participou militarmente na operação militar norte-americana no Afeganistão. Em Novembro de 2001, 
o Bundestag pronunciou-se sobre a participação alemã, que foi ao mesmo tempo um voto de confiança no próprio governo alemão, e que este ganhou apenas por uma pequena margem. ${ }^{5}$ Contudo, e em terceiro lugar, o desentendimento transatlântico provocado pelo debate, nas Nações Unidas, sobre o objectivo dos EUA de intervir militarmente no Iraque, em 2003, foi instrumentalizado por Schröder, por razões eleitorais, no verão de 2002, quando este defendeu que a Alemanha não participaria numa guerra contra o Iraque, mesmo com uma resolução do Conselho de Segurança da ONU. Pela primeira vez, a Alemanha confrontou politicamente os EUA e manteve a sua oposição, mesmo após a reeleição da coligação SPD-Verdes, em Setembro de 2002. Schröder justificou a postura ao afirmar que a Alemanha era uma nação auto-confiante e sem complexos, empenhada no 'caminho alemão' (deutscher Weg), que não estaria disposta a participar em «aventuras militares» (Schröder, 2002).

Esta posição inédita de unilateralismo alemão contribuiu significativamente para a pior crise transatlântica desde a criação da Aliança Atlântica: em primeiro lugar, porque a Alemanha desperdiçou valioso capital de confiança junto dos Estados Unidos, o que levantou dúvidas sobre a sua posição de aliado responsável e defensor do multilateralismo tradicional. Em segundo lugar, o governo alemão não impediu a consequente divisão europeia entre países transatlanticistas, como o Reino Unido, a Polónia, a Holanda, a Dinamarca e Portugal, entre outros, e europeus mais críticos da postura norte-americana, como a Alemanha, a França, a Bélgica e o Luxemburgo, e que se veio a reflectir na rejeição do Tratado Constitucional, em 2005, quanto ao futuro da integração europeia. Por último, a contestação alemã posicionou a Alemanha de novo ao lado da França, após desentendimentos iniciais, na Conferência Intergovernamental de Nice, em Dezembro de 2000, quanto à distribuição dos votos por Estado membro da UE. A revitalização da relação franco-alemã e a celebração mediática do quadragésimo aniversário do Tratado dos Eliseus, em Janeiro de 2003, sublinhou a contestação da

\footnotetext{
5 Schröder ligou a necessária votação do Bundestag quanto à participação de soldados alemães na luta contra o terrorismo no Afeganistão a uma moção de confiança à sua política. A moção foi aprovada por 336 dos 662 deputados.
} 
própria França à hiperpotência americana (byperpuissance) como afirmava o Ministro dos Negócios Estrangeiros francês, Hubert Védrine. Esta preferência alemã pela relação bilateral com a França em detrimento da relação com os Estados Unidos foi uma decisão consciente que todos os governos alemães desde 1949 tinham evitado, porque a melhor opção política era aquela que evitava ter que escolher entre os dois aliados mais importantes da Alemanha. O Chanceler Schröder, no entanto, quis inverter esta lógica, ao secundarizar o bilateralismo com os EUA e ao galvanizar o bilateralismo com a França.

Como foi referido, o tradicional europeísmo alemão alterou-se neste período. Em Maio de 2000, o Ministro dos Negócios Estrangeiros, Joschka Fischer, pronunciou um discurso sobre a União Europeia, na Universidade de Humboldt, em Berlim, onde advogou o federalismo europeu e a constituição de um núcleo duro de países que intensificariam a integração europeia (Fischer, 2000). Na realidade, foi a última vez que um político alemão falou publicamente desta forma da unificação europeia, e Fischer foi, ironicamente, o sucessor de Kohl nesta sua perspectiva federalista. Schröder, que fora ministro presidente da Baixa Saxónia, até 1998, tinha uma visão menos europeísta, mais defensor dos interesses dos Estados federados alemães (Länder), e concebia, por isso, a devolução de alguns poderes aos Estados membros.

Para Schröder, a normalização da política externa alemã passava, assim, pelo aumento da capacidade de projecção de poder da Alemanha no sistema internacional. Isto ocorreu, por exemplo, na revitalização da relação com a Rússia, com a qual Berlim tentou estabelecer uma relação bilateral forte, por vezes à custa dos países da Europa de leste e fora do quadro comunitário, e na aproximação à China, onde a Alemanha prosseguiu fortes interesses económicos. Por último, aumentar o estatuto de poder passou ainda por uma política activa de perseguir um lugar permanente para a Alemanha no Conselho de Segurança da ONU, objectivo insistentemente prosseguido, mas sem resultado.

Enquanto que para Kohl a estratégia preferida foi a estratégia da continuidade, aliada ao alargamento das instituições euro-atlânticas para o leste europeu, Schröder alterou essa estratégia ao privilegiar a relação bilateral 
com a França, e ao tornar a Alemanha mais assertiva na sua relação com os EUA. O multilateralismo alemão manteve-se, mas pode falar-se de um 'multilateralismo transformado'.

\section{Angela Merkel e o pragmatismo na política externa alemã}

Depois das divergências partidárias quanto à política para o Iraque entre 2002 e 2004, a política externa foi um tema relativamente consensual no governo da Grande Coligação (CDU e SPD), liderado por Angela Merkel, CDU, entre 2005 e 2009. Apesar da questão difícil do Afeganistão e do papel da Bundeswehr na operação ISAF, da OTAN, não existiram controvérsias semelhantes às de 2002, quando a possibilidade de uma guerra contra o Iraque colocou os dois principais partidos em campos opostos e a controvérsia desempenhou um papel chave no resultado eleitoral alemão.

O governo de Merkel afirmou, desde 2005, a indivisibilidade entre a segurança europeia e a segurança atlântica. Era do interesse alemão que a unificação europeia e a parceria atlântica não constituíssem pólos opostos, mas funcionassem como os dois pilares mais importantes da diplomacia alemã. Isto foi feito a partir de uma estratégia integrada, onde o multilateralismo europeu e o transatlantismo bilateral da política externa alemã não se anularam e onde a OTAN reafirmou-se como o instrumento central da política de segurança e defesa alemã.

A nova Chanceler criticou a dominância do eixo franco-alemão na política do anterior governo, e apesar de reconhecer a importância das relações bilaterais com Paris, Merkel voltou a ter em consideração a posição de outros (pequenos) países. À semelhança de Kohl, também Merkel, considerava que a vocação da Alemanha é a de mediadora no seio da União Europeia face a potenciais divisões intra-europeias. Assim, não descurando os interesses alemães, o discurso de Merkel foi um discurso pró-europeu e europeizante que defendia uma Europa auto-confiante (ao passo que Schröder defendia a auto-confiança da Alemanha). Foi durante a presidência alemã da UE, no

primeiro semestre de 2007, que o processo do Tratado de Lisboa foi desbloqueado, levando à sua entrada em vigor, em Dezembro de 2009. Com este 
tratado de reforma das estruturas institucionais, a Alemanha aumentou o seu poder já que a tomada de decisões passou a ser feita através de uma dupla maioria, composta pelos votos favoráveis de 50\% dos estados membros e 65\% da população dos estados membros, o que favorece a Alemanha, por ser, com 83 milhões, o Estado mais populoso da UE.

Quanto ao alargamento da União Europeia, Merkel afirmou que a União deve definir claramente quais as delimitações externas da mesma. Considerando que é na prática impossível prosseguir paralelamente com o alargamento a novos membros, por um lado, e com o aprofundamento institucional, por outro, Merkel defende uma definição clara das fronteiras; não há, na sua perspectiva, condições para que a UE num futuro próximo aceite integrar novos países, à excepção dos estados dos Balcãs ocidentais. Por outras palavras, a Alemanha sente o enlargement fatigue no que se refere aos potenciais alargamentos da OTAN, como à Geórgia e à Ucrânia, e da UE, por exemplo, à Turquia.

No relacionamento com a Rússia, o governo de Angela Merkel sublinhou a parceria estratégia entre a Alemanha e a Rússia, em termos económicos e na luta contra o terrorismo internacional, mas inseridos na lógica europeia para fortalecer uma parceria efectiva entre a UE e a Rússia.

O segundo governo liderado por Angela Merkel, desde Outubro de 2009, é um governo de coligação centro-direita entre a CDU e o Partido Liberal (FDP), e o Ministro dos Negócios Estrangeiros é Guido Westerwelle, do FDP. O programa do novo governo comprometeu-se com a continuidade na política europeia e externa, orientadas simultaneamente por interesses e valores. Na política europeia, o governo defende que as negociações de adesão à UE com países candidatos devem ser realizadas sem resultado predeterminado. Isto implica que as negociações de adesão com a Turquia serão 'open ended', e volta-se a falar na 'parceria privilegiada' como alternativa em caso de fracasso das negociações. Esta posição segue a linha tradicional da CDU, que sempre se mostrou crítica quanto à possível integração da Turquia, enquanto que a FDP não se tinha mostrado contrária a uma possível adesão.

Quanto à guerra no Afeganistão, a coligação mantém a sua participação militar, mas perante a hipótese de retirada gradual, defende que a segurança afegã deve ser cada vez mais transferida para as forças de segurança 
afegãs o que criará as condições para a saída da Bundeswebr. O novo governo, à semelhança dos anteriores, defende um lugar permanente para a Alemanha no Conselho de Segurança da ONU, e também não é contrário a que a União Europeia porventura venha a obter um lugar permanente no Conselho de Segurança.

Com a entrada em vigor do Tratado de Lisboa, em 1 de Dezembro de 2009, encerrou-se o capítulo de reformas e aprofundamento institucional da União Europeia que decorria há mais de uma década. A UE percorreu uma viragem intergovernamental, e entrou aparentemente numa fase de sobriedade pós-federalista. Muito por isso, a Alemanha, que decisivamente moldou esta transformação, tornou-se menos progressista e mais conservadora na prossecução dos seus interesses. A Chanceler Merkel é assim europeísta, mas não federalista, pragmática, sem seguir apenas a política europeia de Schröder ou de Kohl.

Contudo, a pretensão alemã de se afirmar como nova grande potência, desde 1998, levantou sérias questões quanto à capacidade efectiva da Alemanha quanto aos meios necessários, materiais e financeiros para custear tal transformação. O orçamento de defesa da Alemanha tem vindo a diminuir, e os gastos de defesa, entre 2006 e 2008, não ultrapassaram os 1.31\% do PIB. ${ }^{6}$ Por outro lado, os custos da unificação alemã ainda contraem o orçamento de Estado, e a recente crise financeira internacional, assim como a crise do euro, de 2010, condicionam a atribuição de verbas consideráveis à diplomacia alemã.

\section{Conclusão}

Durante a Guerra Fria, a Alemanha dividida foi um peão no tabuleiro de relacionamento entre as duas superpotências. Passo a passo, a RFA traçou uma política externa que lhe permitiu alargar o contexto de actuação. Após a unificação, a política externa correspondeu à diplomacia de um

\footnotetext{
${ }^{6}$ Military Balance 2010, p. 462. Os Estados Unidos, por exemplo, gastaram, no mesmo período, entre $4.53 \%$ e $4.88 \%$ do PIB.
} 
actor crescentemente auto-confiante e assertivo, tanto nas suas relações com membros da União Europeia como nas suas relações transatlânticas com os Estados Unidos.

Ao contrário do que se passou na primeira metade do século xx e de forma menos acentuada durante a Guerra Fria, uma Alemanha unificada no centro da Europa já não é hoje vista como ameaça à estabilidade do espaço euro-atlântico. Podem surgir novas questões, como a recente postura do governo de coligação centro-direita de Angela Merkel face à crise do euro e à situação destabilizante na Grécia, na Primavera de 2010, quando a Chanceler não demonstrou a liderança necessária e estratégica que se espera de uma potência central europeia. Mas a expressão 'a Questão Alemã', conotada historicamente com uma postura de política externa agressiva e destabilizadora já não caracteriza a política externa da Alemanha unificada. Esta Alemanha não apenas rejeitou um incremento unilateral de poder como prosseguiu o aprofundamento da integração europeia e o reforço das instituições ocidentais, e manteve ênfase na continuidade do multilateralismo como melhor estratégia da política externa alemã até hoje.

\section{Questões para análise}

Contextualize a importância da memória histórica recente na definição da política externa alemã.

Como é que a elite política alemã se adaptou às mudanças estruturais internas e internacionais ocorridas após a unificação alemã?

Que estratégia seguiram os diferentes governos alemães na articulação da posição da Alemanha na União Europeia e na Aliança Atlântica?

\section{Fontes na Internet}

Chanceler da Alemanha, http://www.bundeskanzlerin.de/Webs/BK/En/ Homepage/home.html

Ministério dos Negócios Estrangeiros, http://www.auswaertiges-amt.de/ diplo/en/Startseite.html

Deutsche-Aussenpolitik.De, http://www.deutsche-aussenpolitik.de/ 
Deutsche Gesellschaft für Auswärtige Politik, http://en.dgap.org/

Frankfurter Allgemeine Zeitung, http://www.faz.net/

\section{Leituras recomendadas}

Bulmer, S. C. Jeffery and W. Paterson (2000). Germany's European diplomacy: Shaping the regional milieu. Manchester: Manchester University Press. Hanrieder, Wolfgang (1989). America, Europe: Forty Years of German Foreign Policy. New Haven and London: Yale University Press.

Katzenstein, Peter, ed. (1997). Tamed Power. Germany in Europe, Ithaca and London: Cornell University Press.

Maull, Hanns, ed., (2006). Germany's Uncertain Power: Foreign Policy of the Berlin Republic. Basingstoke: Palgrave Macmillan.

Sarotte, Mary Elise (2009). 1989 and the Struggle to Create Post-War Europe, Princeton, N.J.: Princeton University Press.

\section{Bibliografia}

Aftendorn, H. (2006) Coming of Age: German Foreign Policy since 1945. Lanham, Md: Rowman \& Littlefield.

Ash, Timothy Garton (1994) In Europe's Name: Germany and the Divided Continent. New York: Random House.

Banchoff, T. (1999) The German Problem Transformed: Institutions, Politics, and Foreign Policy, 1945-1995. Ann Arbor: University of Michigan Press.

Daehnhardt, Patrícia (2007) «De Kohl a Merkel: A gradual afirmação da Alemanha como grande potência euro-atlântica», Relações Internacionais, 14, 27-45.

Daehnhardt, Patrícia (2009) «O fim da Guerra Fria e a Unificação Alemã», Relações Internacionais, 23, 39-51.

Fischer, Joschka (2000) «From Confederacy to Federation: Thoughts on the Finality of European Integration", Universidade de Humboldt, Berlim, 12 de Maio. [www.auswaertigesamt.de/ www/de/infoservice/download/pdf/reden/2000/r000512a.pdf].

Gaspar, Carlos (2003) "A Guerra Fria acabou duas vezes», Nação e Defesa, 105, 141-176.

Green, Simon and William E. Paterson (org) (2005) Governance in Contemporary Germany: The Semisovereign State Revisited. Cambridge: Cambridge University Press.

Harnisch, S. and H. Maull (org) (2001) Germany - Still A Civilian Power? The Foreign Policy of the Berlin Republic. Manchester: Manchester University Press.

Hyde-Price, A. (2000) Germany and European order. Manchester and New York: Manchester University Press. 
Longhurst, K. (2004) Germany and the use of force: the evolution of German security policy 1990-2003. Manchester: Manchester University Press.

Miskimmon, A. (2007) Germany and the common foreign and security policy of the European Union: between Europeanization and national adaptation. Basingstoke, New York: Palgrave Macmillan.

Paris Agreements (1954) Documents Relating to the Accession to the Treaty of the Federal Republic of Germany. [http://www.nato.int/docu/basictxt/b541023a.htm].

Schröder, G. (1998) Discurso perante o Bundestag, 10 Novembro 1998. [http://archiv.bundesregierung.de/bpaexport/regierungserklaerung/16/69116/multi.htm].

Schröder, G. (2002) Discurso eleitoral de Gerhard Schröder em 5 de Agosto de 2002 em Hannover. [http://www.spd.de].

Schwarz, Hans-Peter (2005) Republik obne Kompass: Anmerkungen zur deutschen Aussenpolitik. Berlin: Propylaen.

Stenographischer Bericht 186 (2001), Sitzung, 12 de Setembro. [http://www.bundestag.de/ plenargeschehen/pp/2001/index.htm].

Sternberger, Dolf (1990). Verfassungspatriotismus, Suhrkamp: Frankfurt am Main.

The Basic Treaty, 1972. [http://germanhistorydocs.ghi-dc.org/sub_document.cfm?document_ $\mathrm{id}=172]$. 
(Página deixada propositadamente em branco) 


\section{CAPÍtulo 3}

\section{ARÁbia SAUdita}

A Arábia Saudita tem vindo a afirmar-se, nas últimas décadas, como um dos actores mais activos da diplomacia do Médio Oriente. Fundador da Organização dos Países Exportadores de Petróleo (OPEP), único país árabe com representação no G-20 e membro respeitado da Liga Árabe, a monarquia saudita tem marcado presença em diversos esforços de mediação e promoção da paz na região, procurando demonstrar ser um parceiro credível da comunidade internacional. Porém, a natureza conservadora do regime, sustentado no apoio de clérigos wahabitas, e a permanente ausência de reformas políticas efectivas, aumentam a desconfiança face ao país de origem de Osama Bin Laden e de quinze dos suicidas que perpetraram os atentados terroristas de 11 de Setembro de 2001.

Analisando a acção do regime saudita, em particular a partir da segunda metade do século xx, é possível identificar três pilares fundamentais, com implicações na formulação da política externa: ser o guardião dos locais mais sagrados do Islão (Meca e Medina); deter uma das maiores reservas de petróleo do mundo; e contar com o apoio das sucessivas administrações norte-americanas. Este texto procurará analisar as principais orientações da política externa saudita à luz destes três pilares, numa dinâmica marcada pela natureza particular do regime vigente na Arábia Saudita. 
Tensão no regime: tradição versus modernidade

A Arábia Saudita assenta a sua narrativa de diferenciação face aos restantes Estados muçulmanos no facto de ser o guardião das cidades santas de Meca - local de nascimento de Maomé - e Medina - local onde o Profeta veio a falecer e onde se recolheu após a Hégira. ${ }^{1}$ Reconhecida como o lugar de nascimento do Islão, o significado simbólico da Arábia Saudita não pode ser subestimado, já que é não só o destino da Hajj (peregrinação anual a Meca e um dos cinco pilares do Islão) como o local para onde se orientam as orações diárias de todos os muçulmanos. Esta estreita ligação às origens do Islão promove um ambiente cultural conservador, sustentado numa interpretação estrita da Lei Islâmica (Sharia) (al-Rasheed 2002: 5).

É neste contexto que o regime saudita considera ter deveres islâmicos acrescidos e que, como tal, deve adaptar as necessidades de reforma, impostas pela modernidade, aos princípios religiosos mais conservadores. A este facto não é alheia a importante influência wahabita na formação do Estado e do regime na Arábia Saudita.

A origem do Estado saudita remonta a 1750, quando um líder local, Muhammad Bin Saud, uniu forças com um reformador islâmico, Muhammad Abd al-Wahhab, para a criação de uma nova entidade política. Abd al-Wahhab, fundador da doutrina wahabita, defendia uma interpretação particularmente puritana no Islão sunita que, adaptada à contemporaneidade, consiste na tentativa de purificação do Islão face a quaisquer inovações ou práticas que o desviam das interpretações do Profeta e dos seus companheiros (Commins, 2006). Ou seja, baseia-se nos princípios do Islão afirmados no séc. VII, rejeitando subsequentes acréscimos de crenças e costumes. Desde então, a família Saud mantém uma aliança com os wahabitas, com o objectivo de conservar um Estado dirigido de acordo com os princípios do Islão (Yamani, 2008).

Porém, a concretização do Estado saudita só surge já no século Xx. Após o período de domínio Otomano no Médio Oriente, o mentor e fundador da

${ }^{1}$ Hégira consiste no processo de migração de Maomé e dos seus seguidores de Meca para Medina, em 622 d. C, onde se constitui como a primeira cidade regida de acordo com os princípios definidos pelo Profeta. A Hégira é um acontecimento central na história do Islão, cuja importância se reflecte na sua consagração como a base do calendário religioso. 
Arábia Saudita, Abdul Aziz Al Saud (conhecido por Ibn Saud), aproveita o vazio de poder na Península Arábica e promove a unificação das diversas províncias através da conquista de territórios. Rapidamente, e apoiado numa coligação de tribos liderada pela família Saud, foram conquistados quatro quintos da Península Arábica, tendo o novo Estado sido proclamado, primeiro em 1926 - enquanto Reino de Hijaz - e, mais tarde, já como Reino da Arábia Saudita, em 1932.

Neste sentido, a manutenção do Estado saudita depende, também, de acordos ad hoc com líderes tribais, que mantêm a sua importância na estrutura da comunidade nacional (Commins 2006: 104). Isto, porque a Arábia Saudita assenta numa sociedade de estrutura tribal, que deriva da existência de diversas regiões com diferentes histórias de relação com o exterior. No interior do território mantêm-se fortes tradições tribais e uma interpretação mais estrita do Islão, enquanto nas zonas litorais e maiores aglomerados urbanos existe um crescente cosmopolitismo e uma maior diversidade social, económica e política da população (alRasheed 2002: 6).

Por estes motivos, a Arábia Saudita vive uma tensão entre duas perspectivas face à natureza e organização da sua sociedade: por um lado, uma perspectiva conservadora, que defende a existência de um país culturalmente uniforme, sustentado no wahabismo sunita e nos valores tribais da região de Najd (local de origem da família real Saud), e que, como tal, promove uma estratégia de homogeneização da comunidade nacional; por outro, uma perspectiva progressista, que reconhece a existência de uma comunidade diversificada - resultado de um país composto por diversas regiões, tribos e seitas -, e que, por isso, exige uma estratégia pluralista assente em reformas inclusivas. Ambas as estratégias reflectem-se em cisões no seio da família real saudita, bem como das elites nacionais e mesmo na classe religiosa, e na definição de diferentes posicionamentos face às expectativas e exigências de reformas internas, designadamente as tentativas de alargamento da representação política.

No seio da família real, que conta com mais de 22 mil membros, existe uma luta interna entre aqueles que são mais abertos à promoção de reformas económicas, políticas e sociais, e aqueles que defendem a manutenção do 
status quo. $^{2} \mathrm{O}$ actual monarca da Arábia Saudita, Rei Abdullah bin Abdulaziz, é considerado um pluralista moderado, procurando acomodar, com cautela, as exigências populares, e tendo já promovido um conjunto de reformas que conduziram, por exemplo, à realização de Diálogos Nacionais - que envolvem a participação de sunitas e xiitas, homens e mulheres -, bem como das primeiras eleições municipais, em 2005 (único acto eleitoral realizado no país até à data). Por seu lado, e em particular desde 2001, as elites sauditas têm procurado formar um lobby no sentido da concretização de reformas internas, que incluem a consagração de direitos civis e políticos, promoção da igualdade de género, responsabilidade governativa, promoção de medidas anti-corrupção, distribuição equitativa dos recursos do Estado, promoção de um poder judicial independente e regulação do poder da estrutura wahabita. Em resposta a estas exigências, a monarquia saudita tem procurado promover um conjunto de reformas políticas no sentido de responder, por um lado, às pressões internas das elites no sentido da modernização e, por outro, às pressões internacionais de aproximação aos princípios de organização dos Estados democráticos. Porém, encontra obstáculos nos princípios conservadores patentes na sociedade.

Os clérigos wahabitas procuram pressionar o regime para manter os seus privilégios e a pureza dos princípios islâmicos vigentes na Arábia Saudita. Ao contrário do que aconteceu com o império Otomano ou com o Egipto, por exemplo, onde a moderação do Estado resultou na marginalização dos ulemas, a profunda ligação histórica entre a família Saud e o wahabismo significa que a componente religiosa do Reino não poderia ser marginalizada. Assim, os clérigos wahabitas usam o seu controlo sobre a Lei, influenciam a educação e afirmam uma legitimidade moral para influenciar a população contra a modernidade ocidental. O wahabismo infiltrou-se, assim, no Estado e na Administração Pública, utilizando-os para difundir a sua mensagem (Commins 2006: 105). Os clérigos wahabitas controlam o poder judicial todos os Juízes do Reino são nomeados pelos ulemas -, defendem a ma-

\footnotetext{
2 Recorde-se que o Rei Faisal (1904-1975) foi assassinado por um sobrinho, por ser considerado progressista, já que tinha desenvolvido, entre 1965 e 1975, uma tentativa de alargamento da representação política, incluindo, no Governo, representantes de diversas tribos e grupos religiosos. (Yamani, 2008)
} 
nutenção de uma interpretação estrita do Corão e a aplicação da Sharia de acordo com uma interpretação exclusivamente wahabita. Para além disso, controlam importantes estruturas e políticas do Estado, como o Ministério dos Assuntos Islâmicos e das Finanças, ${ }^{3}$ a definição da política religiosa ( mutaw'a) e educativa, bem como controlam os órgãos de comunicação social e as Forças Armadas.

A estrutura institucional do Estado saudita assenta numa mistura entre tradições locais e modelos ocidentais, resultado da influência, mas não controlo directo, dos impérios ocidentais. Assim, Arábia Saudita é uma monarquia absoluta, onde o Rei é, simultaneamente, Chefe de Estado, Chefe de Governo, Guardião das Duas Mesquitas Sagradas do Islão e Comandante Supremo das Forças Armadas, sendo coadjuvado nas suas funções pelo Príncipe herdeiro, segundo na sucessão ao trono. Os poderes do Rei são limitados pela Sharia, não tendo o monarca competência para promulgar leis (apenas emite decretos reais, de acordo com a Lei islâmica), e não existindo separação entre a Igreja e o Estado. Neste sentido, o Corão e a Sunna ${ }^{4}$ compõem a Constituição do Estado, existindo ainda um conjunto de Leis Básicas de Governo, em vigor desde 1993. O poder executivo centra-se no Conselho de Ministros, composto actualmente por 22 ministérios. O Rei é, ainda, aconselhado por um Conselho Consultivo (Majlis Al-Shura), composto por 120 membros com um mandato de quatro anos, cuja composição é aprovada pelo Rei, não existindo partidos políticos ou eleições nacionais.

De acordo com as tradições sauditas, de natureza tribal, as decisões do Rei (obrigatoriamente membro da família Saud) devem obter o consenso da família real, dos líderes religiosos e de outros elementos de destaque da sociedade saudita. Neste sentido, as decisões em matéria de política externa seguem um princípio de consulta alargada, sendo o responsável pelo Ministério dos Negócios Estrangeiros um dos membros da família real saudita.

\footnotetext{
3 A componente de recolha de impostos tem, também, uma dimensão religiosa já que o Islão define a existência do Zakat (um dos pilares do Islão), um imposto obrigatório, que exige a todos os muçulmanos 2,5\% do seu rendimento. Uma das categorias de beneficiários do Zakat são os muçulmanos que lutam pela causa do Profeta, podendo incluir, ainda, a construção de mesquitas, hospitais, escolas, investimentos em obras de divulgação do Islão ou a defesa da comunidade muçulmana de agressões externas. (Cf. Esposito, 2003)

4 Síntese dos costumes e práticas do Islão, conforme a vida do Profeta Maomé.
} 


\section{A diplomacia dos 'petrodólares'}

A Arábia Saudita dispõe, na actualidade, de uma das maiores reservas de petróleo do mundo. Com a descoberta das jazidas, em 1930, deu-se uma rápida inserção da monarquia saudita na economia mundial, bem como um acelerado desenvolvimento económico e urbano, com a consequente sedentarização de uma população tradicionalmente nómada. Os elevados preços do petróleo, na última década, têm contribuído para que a Arábia Saudita disponha de importantes recursos financeiros e de uma economia forte, porém excessivamente dependente da produção e exportação petrolífera. Surge, então, um Estado de aparência liberal - tendo em conta que a modernização da economia e promoção do sector privado estão dependentes dos interesses da família real, detentora da empresa nacional petrolífera -, mas conservador face à devoção ao Islão wahabita, por convicção ou conveniência política dos seus líderes.

A expansão da doutrina wahabita constitui uma das prioridades de política externa da monarquia saudita, estando dependente dos recursos financeiros oriundos do petróleo (os designados 'petrodólares'). Por um lado, porque é através dos recursos do Estado que se mantém a estrutura clerical wahabita (o Estado controla todas as Mesquitas), bem como a sua influência nas mais diversas áreas da sociedade. Desta forma, a monarquia apoia os ulemas wahabitas na expansão da sua doutrina e, em troca, recebe o apoio da estrutura clerical às suas decisões políticas. Por outro lado, ao nível externo, porque a exportação da doutrina é feita, igualmente, através do recurso a financiamentos estatais. Em diversas áreas regionais onde o desenvolvimento económico é mais reduzido (como os Estados da Ásia Central, Balcãs ou antigas repúblicas soviéticas), grupos radicais que professam o wahabismo, financiados pela Arábia Saudita, estabelecem organizações de caridade - criando mesquitas, escolas, orfanatos e hospitais - e promovem redes de crédito à população. Através da criação destas estruturas, estas organizações e os seus financiadores granjeiam o apoio das populações locais, em troca da adesão à doutrina wahabita. Desta forma, a própria monarquia saudita adquire capacidade de influência nas mais variadas áreas regionais (Takeyhab \& Gvosdevc, 2002: 100-103). 
Já ao nível do Golfo Pérsico, uma das prioridades nacionais sauditas centra-se na definição de fronteiras - resultado da estrutura social tribal e de se tratar de uma área maioritariamente desértica - e no acesso aos recursos petrolíferos. Aquando da criação do Estado, na década de 1920, foi assinado um conjunto de Tratados entre a família Saud e os países vizinhos, com vista à definição de fronteiras e a criação de zonas neutras, face à partilha de recursos petrolíferos. Contudo, esta é uma questão que se mantém até à actualidade, em particular com o Sultanato de Oman. Ainda no período entre Guerras, em 1934, a monarquia saudita desencadeou um conflito com o único Estado independente à data, o Iémen, com o qual assinou um Tratado de Paz, em 1935, consagrando a vitória saudita e a incorporação no Reino de três províncias - Asir, Jizan e Najran -, até então consideradas parte do Iémen. Porém, esta questão ficou longe de estar resolvida e lançou as bases para um conflito entre a Arábia Saudita e o Iémen, que durou várias décadas. Só em Junho de 2000, numa Cimeira entre o Rei Abdullah e o Presidente al-Abdullah Salih, foi definido um acordo fronteiriço permanente.

Ainda ao nível regional, em 1960, eclodiu um conflito no Iémen que, para além da dimensão interna, opôs dois dos principais actores do Médio Oriente: a Arábia Saudita (apoiante do grupo monárquico iemenita) e o Egipto (em apoio aos republicanos). Este foi, apenas, um dos palcos da competição pela liderança regional entre sauditas e egípcios, que se alargou a vários fóruns, designadamente à Liga Árabe, onde a Arábia Saudita levou vantagem devido aos recursos financeiros provenientes do petróleo - dispondo, por isso, de capacidade de financiamento a diversas iniciativas - e à expulsão do Egipto, em 1979, após a assinatura do tratado de paz com Israel (al-Rasheed, 2002: 112-134).

Foi, precisamente, por dispor de uma capacidade financeira superior a outros Estados da região, que a Arábia Saudita se afirmou, ao longo da segunda metade do século xx, como um importante financiador do mundo árabe e muçulmano, designadamente através do apoio à Jordânia, Síria e grupos palestinianos. No quadro da Guerra Fria, e durante a década de 1980, a monarquia saudita apoiou a resistência afegã contra a ocupação soviética, tal como os Estados Unidos e o Paquistão. Este apoio concretizava-se através da disponibilização de recursos financeiros, em particular a grupos pastun, 
que demonstravam uma tendência pró-wahabita. Após a retirada soviética, esta tendência terá desvanecido, o que originou uma menor capacidade de influência saudita (Yamani, 2008). Porém, tal não impediu a monarquia de Riade de ser um dos poucos Estados do mundo a reconhecer, diplomaticamente o regime Taliban, no Afeganistão, dado que ambos defendem uma interpretação estrita do Islão. Um dos principais apoiantes do regime Taliban, Osama Bin Laden, é membro de uma importante família saudita, mas nem por isso um apoiante da monarquia Saud. Apesar de defender uma interpretação igualmente puritana do Islão, Bin Laden considera que a monarquia saudita é uma 'marioneta' do Ocidente, em particular dos Estados Unidos da América, e que por isso deverá ser deposta e substituída por um regime que garanta a pureza dos princípios islâmicos.

Enquanto Guardiã das Duas Mesquitas, locais sagrados do Islão, a Arábia Saudita declara-se como detentora de uma legitimidade de representação dos milhões de muçulmanos, em particular em matérias religiosas. Por isso, afirma como prioridade de política externa a promoção do Diálogo Inter-religioso, defendido pelo Rei Abdullah em 2008, e concretizado através da promoção de uma conferência em Meca, em Junho desse ano, e de uma outra em Madrid, no mês seguinte. Estas iniciativas, que tinham sido antecedidas por uma visita histórica, em 2007, ao Vaticano, granjearam o apoio de diversos líderes religiosos e políticos, tendo resultado na organização de uma Cimeira dedicada à "Cultura da Paz», promovida no quadro da Organização das Nações Unidas e patrocinada pela Arábia Saudita, e que contou com a participação, entre outros, do Presidente israelita Shimon Peres e do Presidente norte-americano, George W. Bush.

A existência de recursos financeiros decorrentes da exploração e produção de petróleo têm garantido à Arábia Saudita a inserção no sistema internacional. Não só através da presença em diversas áreas regionais, mas também pela participação em vários fóruns internacionais, como o G-20, a Organização Mundial do Comércio (OMC) ou o Conselho para a Cooperação no Golfo, do qual é fundador, e que consiste numa organização composta por seis Estados do Golfo Pérsico dedicada à promoção da cooperação económica regional e do desenvolvimento social pacífico. O objectivo saudita, definido desde a década de 1970, era mover-se da margem para o centro 
da política árabe e mundial, assumindo-se como um actor de relevo do Médio Oriente, para o que contou com o apoio das sucessivas administrações norte-americanas.

\section{Continuidades e mudanças: a aliança com os Estados Unidos}

A relação de proximidade entre a Arábia Saudita e os Estados Unidos da América constitui um pilar fundamental do regime e da política externa saudita. Ao nível interno, porque só o respaldo americano tornou possível ao regime sobreviver às pressões internacionais de aproximação aos parâmetros ocidentais de democratização e laicização do Estado. Ao nível externo, porque a Arábia Saudita foi o parceiro americano no Médio Oriente, na segunda metade do século xx, não só ao nível económico e político - através do apoio a intervenções americanas na região, como a Guerra do Golfo de 1991 -, mas também militar, através da presença de bases americanas em território saudita.

A década de 1980, e o contexto bipolar, demonstraram a importância da Arábia Saudita para os interesses americanos na região, face ao expansionismo soviético no Golfo Pérsico e no Oceano Índico. A sua localização estratégica (com a proximidade ao Iraque, Irão e Israel) bem como a garantia de acesso a recursos energéticos fundamentais, determinaram a parceria entre sauditas e norte-americanos. Uma estratégia de cooperação, em matéria de segurança entre a Arábia Saudita e os Estados Unidos era, por isso, vista por ambos como uma necessidade. Porém, esta relação demonstrava ser problemática já que expunha a tensão entre a visão islâmica do mundo, defendida pelo regime saudita, e a necessidade de apoio por parte de um parceiro ocidental, como os Estados Unidos, para fazer face aos desafios à segurança regional (Niblock, 2006: 85-87). A Guerra do Golfo, de 1991, é disso exemplo, constituindo um importante momento de viragem nas relações diplomáticas na região.

Perante a ameaça expansionista de Saddam Hussein, plasmada na invasão ao território do Kuwait, a Arábia Saudita solicitou auxílio aos Estados Unidos e à Comunidade Internacional para que, através de uma força in- 
ternacional, garantissem a segurança das fronteiras sauditas. Esta decisão conheceu, contudo, a oposição do Iémen (tradicional rival saudita no Golfo Pérsico), da Jordânia e da OLP (apoiantes do regime iraquiano). O então monarca saudita, Fahad bin Abdul Aziz Al Saud (1921-2005), destacou-se enquanto uma das principais vozes de mediação do conflito, orientando o tom da Comunidade Internacional para um esforço multilateral no sentido de restaurar a integridade territorial e soberana do Kuwait. Assumiu o papel de porta-voz da coligação internacional e utilizou a sua influência enquanto Guardião das Duas Mesquitas Sagradas do Islão para persuadir as nações árabes e muçulmanas a juntarem-se à coligação (al-Rasheed, 2002).

Existem, contudo, elementos na Guerra do Golfo de 1991 que vale a pena destacar. Em primeiro lugar, a reacção internacional. Os Estados Unidos da América reagiram, de forma rápida, à invasão por parte do Iraque - detentor da segunda maior reserva de petróleo mundial - a um território que lhe permitia alcançar uma posição reforçada no fornecimento energético mundial (já que as reservas petrolíferas do Kuwait equivaliam a cerca de 10\% das reservas mundiais). Isto, porque os Estados Unidos importavam cerca de 50\% das suas necessidades energéticas e não seria aceitável ficarem dependentes da disponibilidade de negociação do regime iraquiano. Em segundo lugar, a reacção regional. Pela primeira vez desde a criação da Liga Árabe, em 1945, regimes conservadores, como as monarquias do Golfo, assumiram uma causa comum com Estados mais radicais, como a Síria e a Líbia. A Jordânia, influenciada pelo apoio popular interno a Saddam Hussein, recusou-se a juntar-se à coligação internacional e opôs-se ao envolvimento americano e ocidental, apelando a uma solução exclusivamente árabe para o conflito. Esta tensão foi, aliás, objecto de duas reuniões de emergência da Liga Árabe, que resultaram na aprovação do envio de uma força de dissuasão para a Arábia Saudita, com o apoio de forças militares internacionais, primariamente americanas, com o objectivo de defender o território de um eventual ataque iraquiano (Milton-Eduards \& Hinchcliffe, 2004, 95-105). Finalmente, a reacção interna na Arábia Saudita. Os principais círculos da família real Saud estavam, aparentemente, divididos quanto à melhor acção a tomar: uns defendiam que seriam necessárias tropas americanas para defender o Reino; outros, como o Príncipe Abdullah (actual 
monarca), defendiam uma tentativa inicial de acordo negociado, no quadro da Liga Árabe. Esta segunda opção reflectia a preocupação face ao impacto da presença de forças militares americanas em solo saudita, quer na opinião pública saudita quer no mundo islâmico (Niblock, 2006: 87).

Como consequência da crise do Golfo, em 1991, o governo saudita decidiu convidar as forças americanas a instalarem-se na Arábia Saudita (cuja retirada só se verificou em 2003) e a reforçar os seus laços de cooperação militar, designadamente através da realização de exercícios conjuntos e aquisição de equipamentos. Esta decisão constituiu um ponto de ruptura nas relações entre a monarquia saudita e os militantes radicais, liderados por Osama Bin Laden, nos quais os serviços de intelligence e príncipes sauditas se tinham apoiado durante a década de 1980. Este foi, sem dúvida um ponto de viragem importante e que sustentou, uma década mais tarde, a retórica em torno dos atentados terroristas de 11 de Setembro de 2001 (Halliday, 2005: 151).

O conflito do Golfo gerou tensões sociais e políticas na Arábia Saudita. Os dissidentes, entre os quais alguns ulemas, começaram a questionar a liderança da família Saud e, em particular, as suas relações com o Ocidente. O governo saudita respondeu dando um ênfase renovado ao processo de reformas políticas económicas. Porém, estas iniciativas não se reflectiram em resultados visíveis para a população, mas a liderança saudita permanecia como um parceiro credível aos interesses americanos. O Príncipe Abdullah, então regente, sempre foi considerado, pelas sucessivas administrações norte-americanas, como um líder moderado da região, a par do Presidente egípcio, Hosni Mubarak, e do Rei Abdullah da Jordânia. Para os Estados Unidos, estes líderes representam o Médio Oriente (Yamani, 2008)

Contudo, a participação de cidadãos sauditas nos atentados terroristas de 2001 prejudicou, em grande medida, a relação entre a Arábia Saudita e os Estados Unidos da América. Ao mesmo tempo, crescia a oposição interna no regime à amizade com o Ocidente, e em particular com os americanos, como resultado da segunda Intifada palestiniana e da crescente retórica do extremismo islâmico na sociedade saudita. No plano da implementação de reformas internas, o regime saudita também não correspondia às expectativas norte-americanas, tendo respondido criticamente à iniciativa política do 
Grande Médio Oriente, que visava a democratização dos diversos regimes desta área regional. Os processos de reforma interna, na Arábia Saudita, tardavam em demonstrar resultados e a população permanecia distante das liberdades democráticas que os Estados Unidos consideravam ser o pilar de um Médio Oriente estável e próspero.

No plano económico, a monarquia saudita mostrava relutância em abrir a sua economia ao investimento americano. Por seu lado, os Estados Unidos concluíram acordos de livre-comércio com outros membros do Conselho para a Cooperação no Golfo, o que foi encarado internamente como uma tentativa de prejudicar a política económica saudita (Niblock, 2006: 167). A par de todas estas questões surgia o debate na sociedade norte-americana sobre o empenho saudita na luta contra o terrorismo. O Congresso dos Estados Unidos aprovou o Saudi Arabia Accountability Act, em 2003, que requeria ao Presidente americano que se certificasse que a Arábia Saudita estava a desenvolver os máximos esforços para combater o terrorismo. Esta iniciativa não foi, mais uma vez, bem acolhida pelo regime saudita, que tinha desenvolvido um programa de reabilitação de terroristas na prisão, através da re-educação religiosa e aconselhamento psicológico, que considerava ser de grande sucesso (Yamani, 2008).

Em 2003, os Estados Unidos e um conjunto de aliados decidem desencadear uma intervenção militar no Iraque, com o objectivo de depor o regime de Saddam Hussein. Porém, desta vez não contaram com o apoio saudita. Após o fim da intervenção militar, a relação dos Estados Unidos com a Arábia Saudita foi sujeita a novas pressões: a monarquia do Golfo foi acusada de não combater e limitar o fluxo de jovens sauditas que participavam nas acções insurgentes no Iraque. No mesmo ano, verificou-se uma alteração das forças americanas no Golfo Pérsico, tendo sido retiradas as bases militares do território saudita. Esta mudança resultou, por um lado, da preocupação do regime face à oposição islamista e às questões de soberania (Cordesman, 2003: 35) e, por outro, de uma renitência americana em entender a ênfase saudita em mecanismos de cooperação informal e actividades low-profile, em vez de acordos formais e de alto nível. Para o regime, a estabilidade interna e externa da Arábia Saudita dependia da manutenção de uma cooperação estratégica, tão discreta quanto possível, 
o que não coincidia com a vontade americana de firmar acordos públicos e formais.

Apesar das mudanças e continuidades, a Arábia Saudita mantém-se como parceiro privilegiado dos Estados Unidos no Médio Oriente, como demonstra, aliás, a escolha do Presidente Barack Obama por uma televisão satélite saudita (al-Arabyiya) para realizar a sua primeira grande entrevista sobre o mundo árabe e muçulmano. ${ }^{5}$ A relação entre ambos tenderá a manter-se enquanto os Estados Unidos considerarem que os seus interesses nacionais e de segurança estarão melhor salvaguardados pela monarquia saudita do que por um regime democrático naquele país. Porém, verificou-se uma nova mudança na estratégia americana: da promoção da democracia e da guerra contra o terrorismo, passou-se para a tradicional ênfase no apoio aos regimes moderados e na promoção da estabilidade. O que significa que a Arábia Saudita poderá reemergir como representante do mundo islâmico perante a administração americana. E, uma vez mais, a utilização de Meca como instrumento de política externa reforça este estatuto (Yamani, 2008).

\section{Principais desafios regionais}

A primeira década do século Xxi trouxe um conjunto de novos desafios, ao nível da política externa e de segurança, à Arábia Saudita. Por um lado, o regime de Riade tornou-se um alvo das redes terroristas, sustentadas pelo fundamentalismo islâmico. Tal pode resultar, em primeiro lugar, do regresso à Arábia Saudita de combatentes que estiveram no Afeganistão e que agora se baseiam numa nova dinâmica de radicalismo islâmico decorrente do conflito no Iraque. Em segundo lugar, existem novas características do terrorismo internacional: grupos radicais islâmicos que, antes, operavam de forma independente na arena internacional, agem agora sob o grande 'chapéu' da al-Qaida, mesmo que através de acções espontâneas, o que

\footnotetext{
5 Cf. «TRANSCRIPT of Obama's interview with Al Arabiya», 27 de Janeiro de 2009. [http://www. alarabiya.net/articles/2009/01/27/65096.html].
} 
condiciona, em grande medida, o combate e a limitação da acção por parte das estruturas estatais.

Por outro lado, a Arábia Saudita pretende-se afirmar enquanto actor central no Médio Oriente face a três importantes questões regionais: o processo de paz israelo-palestiniano; a estabilização no Iraque e a ascensão do Irão enquanto actor regional, com potencial capacidade nuclear.

Ao longo das cerca de cinco décadas de história do conflito israelo-palestiniano, a Arábia Saudita esteve presente enquanto promotor de relações diplomáticas, seja no seio do mundo árabe seja face ao exterior: perante a eclosão do conflito e, mais tarde, face à Guerra dos Seis Dias, em 1967, declarou neutralidade; em 1973, face à Guerra de Yom Kipur, decidiu não participar militarmente, apesar de ter aderido ao boicote ao fornecimento de petróleo aos países ocidentais; e, mais tarde, durante as iniciativas de paz desenvolvidas na década de 1980, designadamente o Plano da Liga Árabe de 1982 (Plano de Fez), foram utilizadas as propostas do Rei Fahad que originariam, mais tarde, o principio "terra por paz», que sustenta uma parte importante das negociações até ao presente. Mais recentemente, em Março de 2002, o Príncipe Abdallah submeteu à Liga Árabe um plano de paz - conhecido como Plano de Paz Árabe ${ }^{6}$ - que, ao contrário de documentos anteriores, visava um acordo segundo o qual todos os Estados regularizariam as suas relações com Israel. Desta forma, o compromisso não seria, apenas, o reconhecimento da soberania do Estado de Israel e a manutenção da paz, mas todo um conjunto de relações de cooperação económica, cultural e política entre Estados. Em troca, Israel teria de retirar dos territórios ocupados em 1967, tal como consta em todos os documentos árabes anteriores, designadamente no Plano de Fez.

A questão palestiniana e o conflito israelo-árabe foram determinantes para a definição das relações externas sauditas. A par da promoção de iniciativas de paz no quadro do mundo árabe, em particular da Liga Árabe, crescia na população saudita uma percepção de injustiça perante a questão palestiniana, que influenciou o desenvolvimento das atitudes populares face

\footnotetext{
6 Cf. «Arab Peace Initiative 2002 - King Abdullah's Peace Plan». Saudi-US Relations Information Service. [http://www.saudi-us-relations.org/fact-book/documents/2006/060609-arab-peace-plan.html].
} 
ao Ocidente (Niblock, 2006: 86). Da mesma forma, os desenvolvimentos do processo de paz frustraram os policy-makers sauditas, em particular porque cada momento de intensificação do conflito provocava um sentimento de decepção face aos esforços desenvolvidos e promovia o apoio à retórica de grupos extremistas. É neste contexto que surge Plano de Paz Árabe, que se constitui como um instrumento diplomático com o objectivo de reconstruir a posição externa da Arábia Saudita, pós-11 de Setembro de 2001, e reafirmar a sua pretensão a ser o representante do mundo árabe, granjeando assim o apreço dos Estados Unidos pela postura construtiva e reconciliadora face a Israel (Niblock, 2006: 169). Porém, esta iniciativa surge na mesma altura do Roteiro para a Paz - apresentado pelo Quarteto (composto pelos Estados Unidos, Rússia, União Europeia e Nações Unidas) - o que resultou na sua secundarização, não tendo sido feita justiça às potencialidades que o seu contributo poderia representar para o processo de paz.

Finalmente, os dois principais desafios estratégicos que se colocam à Arábia Saudita: Iraque e Irão.

Na década de 1980, a região do Golfo Pérsico ficou marcada pelo conflito entre o Irão e o Iraque (1980-1988). Na época, a Arábia Saudita apoiou o regime iraquiano, com base na premissa de que ambos constituíam uma ameaça ao Reino mas o Irão - xiita liderado pelo Ayatollah Khomeini - constituía um perigo maior. Desde logo porque o regime teocrático iraniano ambicionava a posição de representante do mundo muçulmano e da pureza do Islão, tendo mesmo tentado assumir a função de verdadeiro Guardião dos lugares sagrados de Meca e Medina. Após o conflito, o regime de Saddam Hussein deparou-se com importantes dificuldades financeiras, tendo contado com o apoio de diversos Estados do Golfo, entre os quais a Arábia Saudita.

Hoje, a monarquia saudita encontra-se perante um desafio semelhante: tanto o Iraque como o Irão constituem ameaças ao Reino, mas o Irão poderá constituir um perigo maior. No que diz respeito ao Iraque, a deposição do regime de Saddam Hussein e a permanente desestabilização do país resultam numa instabilidade que tem, naturalmente, consequências para o Reino. Desde logo, ao nível da segurança, existe uma maior mobilidade nos grupos extremistas que encontram na Arábia Saudita, enquanto tradicional 
parceiro dos Estados Unidos, um alvo privilegiado. Como tal, o regime de Riade poderá fortalecer os mecanismos de segurança interna, o que poderá representar um atraso significativo nos processos de reforma iniciados na década de 1990.

No que concerne ao Irão, este poderá representar o maior desafio externo à Arábia Saudita, não só por se pretender afirmar como Guardião da causa muçulmana, mas pelo risco que representa a promoção do designado 'arco xiita' no Médio Oriente. Esta designação decorre do facto de os xiitas - principais inimigos dos wahabitas no seio do Islão - constituírem a maioria dos crentes muçulmanos no Irão, Iraque e Líbano. Por outro lado, a comunidade xiita da Arábia Saudita, minoritária, reside em áreas de exploração petrolífera, o que poderá representar um desafio estratégico para as autoridades sauditas. Acresce que a situação política no Afeganistão, tal como no Iraque, no Líbano e nos territórios palestinianos, é propícia à intervenção iraniana.

É neste contexto que a partir de 2007, a Arábia Saudita tem desenvolvido uma acção diplomática particularmente activa: promoveu a formação de um Governo de unidade nacional da Autoridade Palestiniana e uma Cimeira para reactivação do processo de paz, procurando, por um lado, apresentar-se como parceiro credível no processo de negociação e, por outro, contribuir para a diminuição da influência iraniana face aos grupos palestinianos; e desencadeou uma acção diplomática dirigida ao Irão, através do convite ao Presidente Ahmadinejad para visitar Riade, bem como para o acompanhar na peregrinação anual a Meca, tal como exigido a todos os muçulmanos em condições de o realizarem. Esta dupla iniciativa face ao regime iraniano pretendeu demonstrar a importância que a Arábia Saudita atribui às relações com aquele país, possivelmente não como estratégia de aproximação, mas sim como um "estender de braços» a um vizinho perigoso.

No que concerne ao desenvolvimento de um programa nuclear pelo Irão, a preocupação saudita é evidente: por um lado, porque um dos principais rivais do regime saudita, e da doutrina wahabita, poderá adquirir capacidade nuclear; por outro, porque tal significaria o desencadear de um processo de proliferação nuclear em todo o Médio Oriente, algo a que a Arábia Saudita sempre se opôs. 


\section{Considerações finais}

A Arábia Saudita confronta-se, no final da primeira década do século XXI, com importantes desafios que poderão influenciar a sua imagem externa, a médio prazo. No plano interno, a manutenção do regime, por um lado com base na legitimidade religiosa e, por outro, nos recursos petrolíferos, levanta importantes questões de sustentabilidade. No plano religioso, o regime saudita procurará continuar a resistir às pressões de reforma - internas e externas - e às exigências de aproximação aos parâmetros democráticos e de laicização do Estado. No plano dos recursos petrolíferos, as variações do preço do petróleo poderão influenciar o nível de intervenção externa do regime, desde logo porque a maioria das acções externas sauditas tem como base os 'petrodólares'. Para além disso, e ainda o nível económico, a Arábia Saudita encontra-se perante o desafio de regeneração e reactivação do sector privado nacional, em áreas não ligadas ao petróleo, visando a diversificação do sector económico. Esta dimensão poderá abrir novas oportunidades de cooperação internacional, não só ao nível regional mas também internacional. Finalmente, ao nível social, a educação e o desenvolvimento dos recursos humanos constituem uma importante prioridade para o Reino, onde dois terços da população têm menos de 30 anos.

Já no que concerne aos principais desafios à política externa do regime saudita, mantêm-se as linhas definidas nas últimas décadas: a manutenção de uma aliança privilegiada com os Estados Unidos; a promoção do processo de paz israelo-palestiniano; a estabilização do Iraque e a contenção do Irão. As ambições da monarquia saudita também se mantêm: constituir-se como o representante legítimo do Islão, enquanto Guardião das Duas Mesquitas Sagradas (Meca e Medina) e afirmar-se enquanto líder do mundo árabe e muçulmano. Resta saber como é que as idiossincrasias do regime, bem como o desenvolvimento do contexto regional e internacional, contribuirão para este objectivo. 


\section{Questões para análise}

De que forma a ideologia wahabita está presente nas acções externas da Arábia Saudita?

Identifique as principais prioridades de política externa do regime saudita.

Analise a tensão entre os princípios tradicionais/conservadores e as pressões de modernidade, à luz dos processos de reforma do regime e das suas consequências para a imagem internacional da Arábia Saudita.

\section{Fontes na Internet}

Brookings Institution, http://www.brookings.edu/topics/saudi-arabia.aspx Embaixada do Reino da Arábia Saudita em Washington, http://www. saudiembassy.net/

Gulf Research Center, http://www.grc.ae/

Ministério dos Negócios Estrangeiros, http://www.mofa.gov.sa/

\section{Leituras recomendadas}

Al-Rasheed, M. (2002) A History of Saudi Arabia. Cambridge: Cambridge University Press.

Halliday F. (2005) The Middle East in International Relations. Cambridge: Cambridge University Press.

Lacey, R. (2010) Inside the Kingdom: Kings, Clerics, Modernists, Terrorists, and the Struggle for Saudi Arabia. Nova Iorque: Random House.

Niblock, T. (2006) Saudi Arabia: Power, Legitimacy and Survival. Oxford: Routledge.

\section{Bibliografia}

Al-Rasheed, M. (2002) A history of Saudi Arabia. Cambridge: Cambridge University Press.

Commins, D. (2006) The Wahbabi Mission and Saudi Arabia. Londres: I. B. Tauris.

Cordesman, Anthony H. (2003) Saudi Arabia enters the $21^{\text {st }}$ century. The military and international security dimensions. Center for Strategic and International Studies (CSIS).

Esposito, J. (2003) The Oxford Dictionary of Islam. Oxford: Oxford University Press. 
Halliday F. (2005) The Middle East in International Relations. Cambridge: Cambridge University Press.

Karsh E. \& Karsh I. (2003) Empires of the Sand. The struggle for mastery in the Middle East (1789-1923). $3^{\text {a }}$ ed. Harvard: Harvard University Press.

Milton-Eduards B. \& Hinchcliffle P. (2004) Conflicts in the Middle East since 1945. $2^{\mathrm{a}}$ ed. Oxford: Routledge.

Niblock, T. (2006) Saudi Arabia - Power, Legitimacy and Survival. Oxford:Routledge.

Takeyhab R. \& Gvosdevc N. (2002) "Do terrorist networks need a home?», The Washington Quarterly, 25(3), 97-108.

Yamani, M. (2008) "The Two Faces of Saudi Arabia», Survival, 50(1), 143-156. 
(Página deixada propositadamente em branco) 


\section{CAPÍtulO 4}

\section{BRASIL}

No Brasil, a transição para a democracia não marcou uma ruptura nas principais linhas da política externa brasileira. Os princípios de política externa são constantes e transversais à grande parte dos diferentes momentos políticos, embora, por vezes, sejam instrumentalizados de forma diferente. O próprio regime militar caracteriza-se por uma maior oscilação de preferências, do que alguns períodos políticos (anteriores e posteriores) e a própria democracia. Gradualmente, muitas das estratégias adoptadas, inclusivamente durante os anos do regime militar, foram recuperadas em momentos subsequentes. As principais alterações registam-se, como iremos ver de seguida, no que é definido como prioridade, e nas estratégias formuladas para a alcançar, que se ajustam em função das conjunturas internas e externas e, naturalmente, por influência dos próprios actores políticos.

A formulação e decisão da política externa: o Presidencialismo e autonomia do Itamaraty

O sistema político e partidário do Brasil é bastante complexo não obstante o seu enquadramento no perfil presidencialista. A Constituição de 1988 confere ao chefe do Executivo, o Presidente da República, amplos poderes 
sobre a administração pública ${ }^{1}$ o que, por um lado define a forma como se relaciona com o Congresso e, por outro, como lida com as forças políticas dos vários estados federados. Deste modo, os estudos especializados têm distinguido o presidencialismo brasileiro dos restantes, definindo-o como "presidencialismo de coligação". Esta categorização justifica-se pelos múltiplos arranjos de coligações partidárias necessárias para a obtenção de maiorias no Congresso. Verifica-se por isso uma grande heterogeneidade ideológica e fragmentação parlamentar, que atingiu com Lula a maior diversificação, «Lula foi o presidente que mais partidos trouxe para o primeiro escalão do governo federal, 9 (...). Trata-se do mais fragmentado ministério formado na história do presidencialismo latino-americano» (Neto, 2007: 132).

$\mathrm{Na}$ verdade, as instituições políticas brasileiras concentram o poder no Executivo. O papel do Chefe do Executivo é reforçado constitucionalmente através da faculdade de editar medidas provisórias, ${ }^{2}$ o que lhe permite controlar e, consequentemente, enfraquecer o Poder Legislativo. No quadro dos sistemas presidencialistas, no caso brasileiro «é natural que o poder executivo seja o centro de gravidade do regime político» (Neto, 2007: 131), mas tal como acrescenta Octavio Amorim Neto, isso não é condição necessária do sistema presidencial (por exemplo, nos Estados Unidos o Congresso é o órgão mais relevante na condução dos assuntos internos). No Brasil, «a centralidade do Poder Executivo deriva não apenas da estrutura constitucional do país, mas também de fatores históricos e do padrão de carreiras políticas» (Neto, 2007: 131), especialmente o tradicional papel do Estado na economia e no desenvolvimento do país que contribuiu para o fortalecimento do Executivo.

O que fica evidente é que, no sistema político brasileiro, o Poder Executivo tem o direito de iniciativa legislativa, e, consequentemente, influencia directamente a agenda legislativa. Ao nível da política externa esta

\footnotetext{
1 Pode nomear e demitir livremente os ministros de Estado.

2 As medidas provisórias são decretos que têm força de lei a partir do momento em que são publicados no Diário Oficial. Até 2001 o Congresso tinha 30 dias para votá-la, se nada fizesse, a medida expirava, o que acontecia na maioria dos casos. Em 1989 o Tribunal declarou que o Executivo poderia repetir o pedido, e assim fez. Em 2001, o prazo para apreciação pelo Congresso foi aumentado para 60 dias e as medidas só podem ser apresentadas uma vez (ver Neto, 2007).
} 
dinâmica é também uma prática comum. A intervenção do Congresso na formulação da política externa é muito reduzida, porque a competência que lhe é atribuída se cinge à ratificação de tratados e acordos internacionais (Art ${ }^{\circ} 49^{\circ}$ da Constituição do Brasil). Neste sentido, é comum o debate em torno da partilha do poder entre os órgãos Executivos e Legislativos, e o dilema sobre a delegação ou a abdicação das funções pelo órgão Legislativo. Embora à partida seja evidente a centralidade do Executivo, existem argumentos contraditórios. Maria Regina Soares de Lima e Fabiano Santos (1998) consideram que

As posições do Presidente, como iniciador político, e as do Congresso, meramente de ratificação ex-post, geram um cenário em que é extremamente difícil para o legislador intermédio rejeitar as políticas negociadas pelo Executivo em fóruns internacionais (Lima e Santos, 1998: 10)

e, por isso, verifica-se uma demissão do Congresso das suas funções legisladoras em matéria de política externa. Lima (2000) argumenta ainda que ao nível da política externa a delegação da autoridade de decidir é necessária quer seja para se obterem "políticas mais voltadas aos interesses da coletividade e não àqueles meramente eleitorais, seja em função do conhecimento especializado» (Lima, 2000: 282) exigido pela política externa «seja ainda para preservar as decisões em arenas internacionais» (Lima, 2000: 282). Por outro lado, Leany Lemos (2010) considera que não sendo a ratificação dos Tratados o único indicador da autoridade do Congresso, é insuficiente basear a argumentação apenas nesse elemento, sendo que a ausência do Congresso no processo de formulação e decisão da política externa não deve ser vista como uma abdicação, mas como uma delegação. Em contrapartida, a autora reforça que o sistema brasileiro é tendencialmente pró-executivo, pois "as prerrogativas constitucionais favorecem o presidente e o poder executivo em qualquer assunto, mas especialmente naqueles relacionados com os assuntos externos" (Lemos, 2010: 4). No mesmo sentido, João Augusto de Castro Neves (2003) também argumenta que o «poder legislativo não é alheio ou desinteressado sobre questões internacionais» (Neves, 2003: 106) e que só delega as suas responsabilidades quando existe 
consenso sobre os assuntos em questão, ${ }^{3}$ como foi no caso do debate da criação do Mercosul. No estudo que desenvolveu o autor acrescenta que, no Brasil "a ausência de um mecanismo claro de delegação de autoridade é a principal causa da percepção de que o poder Legislativo está alheio às questões internacionais» (Neves, 2003: 117), contrariamente ao que acontece no sistema presidencialista norte-americano.

Assim, no quadro do poder Executivo, o processo de formulação e decisão da política externa no Brasil era tradicionalmente associado, exclusivamente ao Ministério das Relações Exteriores. O Itamaraty é tido como a instituição de onde, desde os tempos do Barão do Rio Branco, e com brechas efémeras, emanam as estratégias da política externa do Brasil. A centralidade do Itamaraty no processo de formulação da política externa resulta, em certa medida, da legitimidade que lhe fora atribuída, quer pelas elites políticas, quer pela sociedade, tendo em conta a especialização e o elevado grau de competência do corpo de diplomatas brasileiro. E, por outro lado, os detentores de cargos políticos, ou os que os almejam, não tendem a reconhecer qualquer impacto das medidas de política externa no plano interno logo, não centram o discurso nos temas de política externa, nem sequer suscitam o seu debate.

Todavia, quer devido ao processo de democratização do Brasil, quer devido às transformações do sistema internacional, aceleradas com o fim da Guerra Fria e a globalização, a partir da década de 1990, este processo começou a ser partilhado com outros actores e, especialmente, com o Presidente da República, através da diplomacia presidencial. Mas esta divisão de tarefas «não é de todo uma tradição brasileira» (Cason \& Power, 2009: 121), o Itamaraty sempre se caracterizou pela autonomia e isolamento burocrático na formulação da política externa, pelo elevado grau de profissionalização da diplomacia, bem como pelo monopólio das responsabilidades políticas (Cason \& Power, 2009: 119-120). A autonomia do Itamaraty reflecte-se também na ausência de cunhos ideológicos e partidários no seio do corpo

3 O autor analisa o caso das negociações do Mercosul referindo que o distanciamento do Parlamento das negociações foi devido ao consenso entre o Executivo e o Legislativo, já no caso da ALCA não existindo posições semelhantes «aumenta a vontade dos parlamentares de institucionalizar a participação nas negociações de política externa” (Neves, 2003: 107). 
diplomático, ${ }^{4}$ como refere Lima (2000) «a política externa é assunto de Estado, insulada da política partidária» (Lima, 2000: 290). Tal ideia começou, contudo, a ser questionada com mais veemência desde a filiação ao Partido dos Trabalhadores (PT) em 2009, do Ministro das Relações Exteriores, Celso Amorim. Nesse contexto, o ex-ministro das Relações Exteriores, Celso Lafer, referiu que o consenso da política externa brasileira como política de Estado foi algo que marcou a democracia brasileira, desde Sarney a Fernando Henrique Cardoso (FHC), mas que o fim desse consenso «é fruto da inédita partidarização da política externa promovida pelo governo de Lula» (Lafer, 2009). Como indicadores dessa partidarização Lafer destacou a nomeação de Marco Aurélio Garcia (membro histórico do PT) como Assessor diplomático do Presidente bem como a, já referida, filiação de Amorim ao PT. Mas note-se por exemplo que em 2008 os únicos Embaixadores de nomeação política estavam em Cuba e na UNESCO, até mesmo nas organizações internacionais, como a OMC ou a UNCTAD, é comum encontrarem-se diplomatas de carreira, transversais aos vários governos.

Deste modo, o ponto de viragem, no que toca à redução da exclusividade da responsabilidade do processo de formulação e decisão da política externa, ocorre não só devido aos factores atrás mencionados, mas também à figura de FHC, que assume a presidência da República em 1995. Até então, os anteriores Presidentes nunca tinham demonstrado interesse pela formulação da política externa (quer por opção pessoal, ou por factores de política interna; como no caso de Itamar Franco que herdou três crises internas que exigiram que o Presidente se concentrasse na resolução dos problemas políticos, económicos e sociais internos e delegasse toda a matéria de política externa no Itamaraty). Pelo contrário, FHC (intelectual e académico), que já havia sido Ministro das Relações Exteriores de Itamar Franco, quando ocupa a Presidência, encarrega-se também da função diplomática para dar a conhecer ao mundo o Brasil democrático e restaurar a imagem do país. Inicia-se, assim, de forma empenhada, a chamada diplomacia presidencial,

\footnotetext{
4 Embora o PR possa nomear Embaixadores da sua confiança para assumirem os postos diplomáticos, em 2008 apenas se registavam dois casos de nomeações políticas: em Cuba e na Unesco, em todos os outros casos os Embaixadores foram nomeados a partir da estrutura diplomática (ver Mariano \& Mariano, 2008).
} 
que o Presidente Lula da Silva continua de forma intensa. Este mecanismo demonstra que o processo de definição da política externa já não está apenas no Itamaraty, embora este continue a ser o actor central. É esta autonomia, formação e especialização que caracterizam o corpo diplomático que, de certo modo, ajudam a explicar a permanência dos princípios tradicionais na política externa brasileira.

\section{Nacionalismo e Desenvolvimento, e a relação com os EUA}

O Brasil foi o único país da América do Sul a enviar tropas para a $2^{\text {a }}$ Guerra Mundial de apoio aos Aliados. Findo o conflito manteve-se um fiel parceiro dos Estados Unidos ${ }^{5}$ desempenhando um importante papel na criação da Organização dos Estados Americanos (em 1948) e na influência aos restantes países latino-americanos para a assinatura, em 1947, do Tratado Inter-americano de Assistência Recíproca (TIAAR). Esperava-se que, tal como havia acontecido em 1918, os Estados Unidos reconhecessem o contributo brasileiro durante o conflito e incluíssem o país nas negociações internacionais de paz, contudo, tais expectativas saíram frustradas, ao que se somou a intensificação das relações dos Estados Unidos com a Argentina. Deste modo, nos anos imediatamente após o final da $2^{\mathrm{a}}$ Guerra Mundial registou-se uma indefinição da política externa do Brasil, especialmente nas relações com os Estados Unidos, que oscilavam entre uma dependência passiva (e frustrada), e o desejo de quebrar esse alinhamento.

A Presidência de Getúlio Vargas - tinha estado no poder como Chefe do Governo Provisório e depois como Presidente da República, entre 1930 e $1945^{6}$ - demonstra essa ambiguidade nas relações com os Estados Unidos, ou como o historiador Paulo Vizentini refere uma "política de ziguezagues»,

5 Logo em 1949 o Presidente Gaspar Dutra visitou os Estados Unidos retribuindo a visita efectuada por Truman em 1947.

6 Após a Revolução de 1930, Getúlio Vargas foi nomeado Chefe do Governo Provisório, em 1933 foram realizadas eleições indirectas que o elegeram como Presidente da República, e em 1937 em vez das eleições previstas acabou por acontecer um golpe de estado que deu continuidade à permanência de Vargas no poder até 1945. 
que teve consequências no isolamento do próprio Presidente. As políticas norte-americanas centravam-se na contenção da eventual expansão do comunismo, e que nem sempre iam de encontro aos interesses brasileiros. Consequência destas políticas e dos acordos militares ${ }^{7}$ celebrados entre os Estados Unidos e o Brasil foi a intensificação de um discurso anti-americano (que visava diminuir a dependência em relação aos Estados Unidos) e a pressão sobre o Presidente que contribuiu para o enfraquecimento da sua base de apoio. A vontade de diminuir a dependência em relação aos Estados Unidos veio novamente à tona quando, em 1962, é promovida a Aliança para o Progresso, através da qual o Presidente Kennedy se comprometeu a ajudar economicamente a América Latina (com excepção de Cuba, que não subscreveu a adesão à Aliança).

O suicídio de Vargas, em 1954,põe na sua sucessão o vice-presidente Café Filho, e, com ele, um grupo mais adepto das políticas norte-americanas e menos adepto do projecto nacionalista. O desenvolvimento surgiu associado à segurança nacional, tendo sido criada a Escola Superior de Guerra, e promovida a ideia de que era necessário um alinhamento com o Ocidente, liderado pelos Estados Unidos. Na verdade, "O hiato representado pelo governo de Café Filho significou, em termos de política exterior, principalmente no que tange às relações com os Estados Unidos, um retorno ao período Dutra» (Cervo \& Bueno, 2008: 286). Deste modo, Vargas não conseguiu implementar o projecto nacional-desenvolvimentista que idealizara, mas continha as bases para a definição de uma nova política externa para o Brasil na década de 1960, com a Política Externa Independente.

Na segunda metade da década de 1950, o Presidente Juscelino Kubitschek implementou uma estratégia de desenvolvimento associada, num primeiro momento, a um bem sucedido plano económico (caracterizado pela industrialização e pela atracção do capital estrangeiro), e, depois, pela retoma da «barganha nacionalista» de Vargas. Com base na ideia da interdependência entre os Estados, e da importância da cooperação internacional, promoveu,

\footnotetext{
7 Em 1952 foi assinado o Tratado de Assistência Militar Brasil-EUA e, em 1953, o Acordo Militar Brasil-EUA que definia os termos para a venda de minerais aos EUA, sem quaisquer contrapartidas para o Brasil.
} 
em 1958, a Operação Pan-Americana, com vista a criar uma estrutura regional para apoiar financeiramente os países latino-americanos, e que culminou com a criação do Banco Internacional de Desenvolvimento (BIRD). A sua criação recebeu algumas críticas devido à ausência de medidas concretas, mas acima de tudo, a Operação Pan-Americana significou a instrumentalização da política externa em prol do desenvolvimento nacional, pois «nunca na história brasileira do século xx valorizara-se tanto o contexto externo no equacionamento dos problemas nacionais" (Cervo \& Bueno, 2008: 288). No quadro do debate da descolonização, que marcava o contexto internacional da altura, o Brasil não adoptou uma posição resoluta quanto à sua condenação, embora o seu discurso fosse nesse sentido ${ }^{8}$.

A primeira metade da década de 1960, com Jânio Quadros e João Goulart na Presidência, é marcada pela continuidade do projecto nacional-desenvolvimentista. De facto, apesar da instabilidade deste período tanto ao nível da Presidência como do Ministério das Relações Exteriores, tal não se reflectiu na formulação da política externa. Entre 1960 e 1964, o Ministério das Relações Exteriores teve 5 Ministros, e a Presidência foi dividida entre o Presidente Jânio Quadros9 e o seu vice-presidente, João Goulart, quando aquele renunciou ao cargo.

Ao nível da política externa destaca-se o papel do Ministro das Relações Exteriores, San Tiago Dantas (bem como Afonso Arinos e Araújo de Castro $^{10}$ ), que «dotou a Política Externa Independente de um corpo teórico consistente e colocou-a em prática, pois Quadros pouco ultrapassara o nível

\footnotetext{
8 Note-se por exemplo a aproximação intensa e positiva entre Kubitschek e Salazar. Dada a posição de colonizador de Portugal, Kubitshek tinha uma posição dúbia em relação ao colonialismo: por um lado, condenava tais acções e defendia a auto-determinação dos povos, mas por outro, não queria perturbar a relação com Portugal, e por isso não afirmava aquela posição com veemência.

9 Jânio Quadros é caracterizado pela sua ousadia, que se reflectiu na forma como abandonou a Presidência (logo em Agosto de 1961) - ao julgar que recusariam o seu pedido de renúncia, enganou-se e o mesmo foi aceite. Impedia-se uma primeira tentativa de golpe de estado, já que a direita desde meados da década de 1950 desejava assumir o poder. Leonel Brizola consegue que o vice-presidente de Quadros, João Goulart, assuma a presidência e a solução consensual residiu na implementação de um sistema parlamentarista, em que Tancredo Neves foi nomeado Primeiroministro. Contudo, o governo formado era frágil e o populismo aumentava em desfavor do governo, antecipando o golpe de estado que teria lugar em 1964.

10 Em 1963, nas Nações Unidas, o Ministro das Relações Exteriores, Araújo de Castro apresenta o discurso dos três 'D': descolonização, desenvolvimento e desarmamento.
} 
do discurso" (Vizentini, 2008: 26). Ao contrário de Kubitschek que concebia a política externa a partir de uma visão do hemisfério, a Política Externa Independente partia de uma concepção universal, assente no pragmatismo, na independência de acções, e no nacionalismo, traduzindo-se na multilateralização das relações internacionais do Brasil. Entendia-se também que a política externa promovia o desenvolvimento económico e era a base das reformas sociais, sendo, por vezes, entendida como típica de um país capitalista que reage à potência dominante (Vizentini, 2008). A Política Externa Independente visava a demarcação em relação aos Estados Unidos, ou a quaisquer outros países, não baseando as relações com os Estados em ideologias, e por isso «a busca de maior liberdade de movimentos no concerto internacional foi acompanhada de uma componente de frieza nas relações com os Estados Unidos»(Cervo \& Bueno, 2008: 311). A concepção de "Brasil potência», que se começava a desenhar, encaixava nesta estratégia já que o desenvolvimento e a industrialização seriam bem sucedidos «se o Brasil mantivesse certa autonomia diante dos Estados Unidos» (Vizentini, 2008: 31). Assim, paralelamente à relação pragmática com os Estados Unidos intensificaram-se as relações com a África e a Ásia, bem como com a Argentina, relacionamento entendido como uma forma de cooperação importante para os dois países aumentarem o seu grau de participação nos assuntos internacionais. No mesmo sentido, foram reatadas as relações diplomáticas com a URSS e, o Brasil não aprovou a expulsão ${ }^{11}$ de Cuba da OEA, em 1962. Todavia, relativamente à situação cubana, a crise dos mísseis de Cuba contrariou o argumento brasileiro, de que a situação era apenas um assunto interno, e deu mais credibilidade à posição norte-americana, do mesmo modo que, ao enfraquecer o governo, criou condições para o golpe militar que viria a acontecer.

Deste modo, as décadas de cinquenta e sessenta caracterizam-se pelas tentativas de demarcação em relação à dependência exclusiva dos Estados Unidos. Mas a influência norte-americana sentiu-se inclusivamente na queda do regime. O enfraquecimento interno do Governo de Goulart, e a

\footnotetext{
11 A expulsão de Cuba da OEA foi aprovada com as abstenções da Argentina, Bolívia, Brasil, Chile, Equador e México.
} 
falta de apoio dos Estados Unidos ao Governo, por um lado, e o apoio ao sector golpista, por outro, criaram as condições para o golpe militar em Março de 1964. Esta acção foi antecedida pela renovação do Acordo Militar com os Estados Unidos, negociado pelo Itamaraty sem o conhecimento do Presidente; bem como pela operação «Brother Sam» no Atlântico, articulada pelos Estados Unidos e que, em caso de necessidade, previa a ajuda militar aos golpistas.

\section{O regime militar brasileiro e a Guerra Fria}

O período do regime militar, entre 1964 e 1985, foi marcado por algumas intermitências, ou um governo mais conservador ou um governo mais nacionalista, em que o epicentro esteve, mais uma vez, na definição da relação com os Estados Unidos e, consequentemente, na forma como o Brasil se afirmava no sistema internacional.

Ao analisarmos o regime militar como um todo verificamos que apenas o governo de Castelo Branco (entre 1964 e 1967), tentou romper com a linha de política externa anterior ao golpe. Como previsto, começou por afirmar o projecto da Escola Superior de Guerra (com maior impacto a nível interno) instituindo a Constituição de 1967. A política externa previa o alinhamento com os Estados Unidos e o relacionamento entre os Estados com base nas ideologias. Nesse sentido, as relações com Cuba foram rompidas logo em 1964, assim como se enfraqueceram as relações comerciais com a URSS, a China e os continentes africano e asiático. Sob a alçada da OEA, o Brasil interveio no conflito da República Dominicana que, contrariamente ao esperado, contribuiu para denegrir a sua imagem na região. ${ }^{12}$ O regime brasileiro recebeu apoio económico dos Estados Unidos, do Fundo Monetário Internacional (FMI) e do Banco Mundial. Os parceiros norte-americanos apresentavam-se como a única alternativa face a uma conjuntura económica que tendia a agudizar-se, e o Ministro das Relações Exteriores

\footnotetext{
12 Na mesma lógica, o Brasil, sob influência dos Estados Unidos, tentou agregar parceiros para a criação de uma Força Interamericana de Defesa, mas tal não foi bem recebido.
} 
afirmou inclusivamente que «o que é bom para os Estados Unidos é bom para o Brasil» (Vizentini, 2008: 41). Esta cumplicidade não se restringiu ao âmbito económico, também a nível diplomático se registou um regresso ao "âmbito hemisférico e bilateral»13 das relações externas (Pecequillo, 2008). Mas, paralelamente, o Itamaraty conseguiu preservar um certo grau de autonomia em relação ao regime militar, e, gradualmente, foi reavivada a Política Externa Independente. É, certamente, neste quadro que se inclui o incremento das relações com os países africanos, pois a primeira missão comercial à África Ocidental teve lugar em 1965 lançando-se as bases da política africana do Brasil.

Em 1967, com a substituição de Castelo Branco por Costa e Silva, retomaram-se algumas ideias da Política Externa Independente, especialmente, no que se refere às questões económicas. Costa e Silva, da linha nacionalista do regime, inaugurou a chamada «Diplomacia da Prosperidade», associando o desenvolvimento à soberania e utilizando a diplomacia em prol do desenvolvimento económico. Contrariando rigorosamente as posições norte-americanas, foi quebrada a submissão inicial do Brasil aos Estados Unidos ${ }^{14}$ e foram definidas novas parcerias, especialmente entre os Países do Terceiro Mundo. Foi neste quadro que a política africana do Brasil também se redefiniu. No quadro regional foi assinado o Tratado da Bacia do Prata (Argentina, Bolívia, Brasil, Paraguai e Uruguai), com vista a promover a integração física daquela área.

No final da década de 1960, o discurso político era marcado pela concepção de "Brasil a potência» e pela "Diplomacia do interesse nacional». O Brasil não era auto-percepcionado como um país do Terceiro Mundo, nem se preconizavam essas alianças, recuperava-se novamente a ideia da necessi-

\footnotetext{
13 O paradigma hemisférico-bilateral foi dominante entre 1902 e 1961 e defendia a preservação de uma boa relação com os Estados Unidos que oscilou entre um alinhamento pragmático ou automático. Após 1961 esta concepção é substituída pelo paradigma global e multilateral, que se resume à Política Externa Independente e que pressupõe a quebra do alinhamento automático com os Estados Unidos e a procura de novas parcerias e alianças (o melhor exemplo é o Pragmatismo Responsável de Geisel). Collor de Melo, Itamar Franco e FHC representam o paradigma hemisférico-bilateral em que se preconizam as relações com os países mais desenvolvidos e há o desejo de pertencer ao Primeiro Mundo (Pecequillo, 2008).

14 Tal posição deve-se, em certa medida, a um desentendimento do Presidente brasileiro com o sub-secretário de Estado norte-americano para a América Latina.
} 
dade de uma relação cordial com os Estados Unidos. Ainda assim, em 1972, o Ministro das Relações Exteriores, Gibson Barboza, realizou uma missão a vários países africanos contribuindo para o fomento da política africana. ${ }^{15}$ Simultaneamente, Médici permitiu conjugar as boas relações com os Estados Unidos com o seu projecto de desenvolvimento nacional, o que foi facilitado também pela posição norte-americana em ter um aliado estável na região (quando os governos de esquerda e as guerras civis tendiam a proliferar).

O interesse nacional foi ainda favorecido pelo "milagre económico» que o Brasil conheceu entre 1970 e 1973, e que contribuiu para o aparecimento de uma classe média consumidora. Todavia, este período foi perturbado pelo choque petrolífero de 1973 que ditou, não só, a quebra da prosperidade, mas também o fracasso da aproximação aos países árabes, e com isso a falência do projecto de desenvolvimento do Brasil. Assim, quando Ernesto Geisel chegou ao poder, em 1974, começou por implementar o II Plano Nacional de Desenvolvimento que previa a diversificação das fontes de energia, a capacitação tecnológica e a definição do Estado como o maior agente produtivo, com o objectivo de controlar o elevado deficit comercial e contribuir para a estabilidade do país.

O início do processo de abertura política do regime registou um sinal importante com o Presidente Geisel que desde a sua tomada de posse definiu a abertura como a sua prioridade, começando por pôr fim à censura da imprensa (ver Spektor, 2004: 210-214). A própria política externa foi utilizada para reunir consenso interno e como moeda de troca com as facções militares rivais do regime. Mais concretamente, no que se refere à política externa, o Ministro das Relações Exteriores de Geisel, Azeredo da Silveira apresentou-se como um actor-chave, definindo juntamente com o Presidente, e com base na Política Externa Independente da década de 1960, o Pragmatismo Responsável. Esta concepção visava conciliar as necessidades económicas com as estratégias de política externa, direccionando-se

15 Alguns autores (Lechini, 2008) entendem que foi esta viagem, em 1972, que definiu a aproximação do Brasil a África, enquanto outros (Saraiva, 1996) entendem que tal só foi possível devido ao que começara a ser delineado na década de 1960, com a missão comercial em 1965. Todavia, nessa altura o contexto ainda não era favorável à cooperação com o continente africano, pois a falta de apoio explícito às colónias africanas nem sempre jogou a favor do Brasil. 
para os países árabes e com outras potências regionais asiáticas e africanas. Deste modo, recuperou-se a noção de autonomia da política externa, especialmente em relação às grandes potências, "Os anos Geisel situam-se confortavelmente na tendência geral a maior e mais veloz asserção da autonomia nacional face aos estritos limites impostos pelo sistema internacional da Guerra Fria» (Spektor, 2004: 196). Devido às transformações ocorridas no sistema internacional, e sob a retórica do início da década de "Brasil a Potência», Azeredo da Silveira pretendia projectar o Brasil na cena internacional, acreditando que os países em desenvolvimento poderiam ganhar espaço e influenciar a agenda internacional. Nesse sentido, foi definida claramente a posição do Brasil em relação ao colonialismo. E, apesar da amizade com Portugal, a diplomacia brasileira foi a primeira a reconhecer a independência de Angola, em 1975.

No que concerne às relações com os Estados Unidos, destaca-se a cessação do Acordo Militar ${ }^{16}$ entre os dois países em 1952, dadas as pressões norte-americanas para que o Brasil não celebrasse o Acordo Nuclear com a Alemanha. No entender de Spektor (2009) a tese da «rivalidade emergente» - que defende que o processo de modernização e industrialização do Brasil contribuiu para o aumento da rivalidade com os Estados Unidos não é suficiente para explicar o fracasso do relacionamento entre o Brasil e os Estados Unidos, na década de 1970, é necessário atentar também no empenho tanto de Azeredo da Silveira como de Richard Nixon. Mas, mesmo assim, apesar das suas tentativas "os planos de convergência conviveram com dúvidas profundas e recorrentes desconfianças de ambos os lados» (Spektor, 2009: 185). No mesmo sentido, Cervo \& Bueno (2008: 442) referem que «as relações entre os dois países permaneceram nos anos 1980, como nos anos 1970, à espera de propostas substantivas e igualitárias, desprovidas de egoísmos nacionais, para se alcançarem ao nível das necessidades e conveniências bilaterais».

\footnotetext{
16 Note-se que o Brasil e os Estados Unidos voltaram a assinar um novo Acordo Militar apenas em Abril de 2010.
} 
O processo de abertura político iniciado com Geise ${ }^{17}$ foi continuado pelo Presidente João Figueiredo, apelidado como o "Presidente da abertura", que implementou, logo em 1979, uma reforma partidária. O seu mandato foi influenciado, quer, pelo segundo choque petrolífero de 1979 (em termos económicos), quer pelo fim da détente. Por um lado, o choque petrolífero contribuiu para a deterioração da situação económica mundial que atingiu o Brasil (e a América Latina) através da "crise da dívida». Por outro lado, o fim da détente, e a agudização das relações entre o bloco americano e o bloco soviético contribuíram para que, em 1981, o Presidente Ronald Reagan instituísse uma alta taxa de juro aumentando a dívida externa de países em desenvolvimento, como o Brasil. Mas a par das dificuldades económicas, o Brasil continuava a tentar demarcar-se das propostas norte-americanas recusando, por exemplo, as propostas de militarização do Atlântico Sul, mas, em contrapartida, consolidando as relações com alguns Estados africanos, nomeadamente a Nigéria e outros Estados no Golfo da Guiné. A diversificação das relações visava não só suprir as necessidades energéticas do Brasil, assim como unir os países do «sul» de modo a pronunciarem-se a uma só voz nas organizações económicas multilaterais.

\section{A transição democrática: mudança de regime sem mudança de política}

No seguimento das reformas introduzidas por Geisel e Figueiredo criaram-se as condições mínimas necessárias para que, em 1984, sob o lema das "Diretas já", se realizassem eleições. Das eleições de 1984 saiu vencedor Tancredo Neves que acabou por não tomar posse dadas as suas condições de saúde. O seu lugar foi ocupado por José Sarney, eleito vice-presidente. Assim, a democracia re-instalou-se no Brasil de forma gradual não se verificando qualquer processo revolucionário e, por isso, também, ao nível da política externa não se verificou qualquer corte abrupto com o passado.

\footnotetext{
17 Geisel mostrou-se contrário a algumas das acções levadas a cabo, a partir de 1976, pelos órgãos de repressão, e que incluíam atentados, sequestros e assassinatos. O Presidente demitiu o Comandante do Exército, o Ministro do Exército e o Chefe de Gabinete Militar.
} 
Mas a linha de continuidade deriva também da componente institucional e burocrática encontrada no Itamaraty, o que "garante continuidade nas escolhas e relativa consistência nas orientações de política» (Lima, 2000: 289). Ao mesmo tempo que se reconhecia que o novo Governo deveria procurar um consenso mínimo com os actores sociais de modo a evitar qualquer ruptura institucional, o que culminou com a adopção da Constituição em 1988.

José Sarney chegou ao poder com um contexto interno que não era de todo favorável. À explosão simultânea de três crises, política, económica e social, somava-se a complexidade do país, que o próprio Presidente definiu como «um Brasil composto por diversos Brasis» (Sarney, 1986). As primeiras medidas do Governo prenderam-se com a estabilização do país, a convocação da Assembleia Constituinte, a promoção do crescimento económico e o investimento no bem-estar social. A recuperação económica exigiu também que a nível externo se adoptasse uma política firme para reduzir a dívida externa, resultado do esgotamento do modelo económico iniciado na década de 1930 (quando o Estado era o actor central). De modo a estabilizar a economia através da redução dos valores da inflação, Sarney implementou em 1986, com êxito, o Plano Cruzado.

A conjuntura económica também se repercutiu na actuação externa. No seguimento da "crise da dívida", adoptou-se uma moratória aos Estados Unidos. O discurso do Presidente era bastante crítico da atitude norte-americana, que no seu entender, tratava o Brasil, um país rico e com um grande potencial, como um "país de segunda". A incompatibilidade de posições entre o Brasil e os Estados Unidos foi evidente, quer nas questões da organização do comércio continental e internacional, quer nas tentativas de integração da região. O segundo Ministro das Relações Exteriores de Sarney, Abreu Sodré (antecedido por Olavo Setúbal), além de reatar relações com Cuba, reconheceu a necessidade de diversificar as parcerias não se alinhando, exclusivamente, aos Estados Unidos. Por conseguinte, este período é marcado por um fortalecimento da cooperação entre o Brasil e a Argentina ${ }^{18}$ (assim como com o Uruguai). Os dois

\footnotetext{
18 O Brasil e a Argentina assinaram a Acta para a Integração e Cooperação Económica, em 1981, e o Tratado de Integração, Cooperação e Desenvolvimento Brasil-Argentina, em 1988.
} 
países associaram-se ainda ao Grupo de Apoio a Contadora, como forma de manifestarem o seu desagrado pelas políticas norte-americanas para a América Latina. Em retaliação, os Estados Unidos aplicaram sanções comerciais ao Brasil, o que comprova o desacordo norte-americano quanto às tentativas de integração entre as duas principais potências da América do Sul. Por conseguinte, o Brasil procurou novos parceiros noutras áreas regionais, como a República Popular da China e a URSS, ao mesmo tempo que desenvolveu e aprofundou as suas relações com os países africanos e do Médio Oriente.

O governo de José Sarney foi, essencialmente, um período de transição, em que as dificuldades económicas do país e as condições políticas e sociais internas, bem como as incompatibilidades com os Estados Unidos, ainda num contexto de Guerra Fria, ditaram muitas das opções que se fizeram.

Os dois governos seguintes, de Collor de Mello e de Itamar Franco, encaixam-se ainda num período de indefinição e ajustes. Na verdade, as transformações na política internacional, com o fim da Guerra Fria, tiveram consequências também para o Brasil, nomeadamente com a importância crescente das dinâmicas de regionalização, que criavam novas condições para a consolidação de grandes potências regionais, bem como para a autonomia da América do Sul, e forçaram o início de uma revisão das prioridades da política externa brasileira. No Brasil, gerou-se um grande debate entre os que defendiam a revitalização da relação com os Estados Unidos, reformando a política interna de acordo com as suas orientações, e os que defendiam uma correcção da postura global do país, de modo a adaptar-se às mudanças internacionais. Collor de Mello, eleito em 1989, optou pela primeira concepção, pois, no seu entender, "a proposta de modernização econômica pela privatização e abertura é a esperança de completar a liberdade política, reconquistada com a transição democrática» (Mello, 1990). Collor de Mello optou pelo alinhamento com os Estados Unidos e adoptou as medidas neoliberais propostas pelo "Consenso de Washington", e "a chegada de Collor de Mello à presidência trouxe à arena do processo decisório de política externa uma corrente liberal, minoritária no Itamaraty, mas seu impeachment reduziu suas influências até os dias 
atuais» $^{19}$ (Saraiva, 2010: 2). Contrariamente ao Governo anterior, a política externa teve como ponto de atracção a relação com os Estados Unidos, entendida por alguns autores como a «ilusão norte-americana de Collor» (Vizentini, 2003: 61) Se o jovem Presidente começou por defender a inevitabilidade da aproximação aos Estados Unidos para modernizar o país, cedo reconheceu as desvantagens desse alinhamento. O insucesso das políticas económicas e a deterioração da situação política, levaram-no a chamar para o Itamaraty o Embaixador Celso Lafer que introduziu novos padrões de referência para o Brasil, diminuindo a excessiva centralidade dos Estados Unidos. Lafer entendia que a "autoridade do Itamaraty" (Vigevani \& Cepaluni, 2009: 42) era necessária para uma política externa efectiva, e os seus discursos destacavam a "adaptação criativa» da política externa e a "visão de futuro».

No plano regional, destaca-se a articulação entre o Brasil e a Argentina que culminou com a criação do Mercosul, em 1991, entendido acima de tudo como um mecanismo para acelerar a liberalização da economia do Brasil, uma das prioridades de Collor de Mello (a importância estratégica da estrutura regional só viria a ser reconhecida com Itamar Franco).

Itamar Franco assumiu a presidência num contexto de crise - não muito diferente daquele deixado por Sarney, no final do seu mandato. Deparando-se com a necessidade de responder à crise económica interna, o Presidente Itamar concentra todos os seus esforços nesse campo, transferindo as tarefas de política externa, na sua totalidade, para o Itamaraty, que tinha como Ministro das Relações Exteriores, Fernando Henrique Cardoso.

O curto mandato de Itamar Franco foi, em parte, distinto do anterior: em vez de fragilizar a condição do país conseguiu definir algumas estratégias para a política externa e económica, que nem sempre seguiram as directrizes dos Estados Unidos. Embora a percepção internacional inicial fosse de que o país iria adoptar uma actuação mais nacionalista para se

19 No Itamaraty têm existido duas correntes de pensamento da política externa, que Miriam Gomes Saraiva (2010) define como os «autonomistas" ("desenvolvimentismo» económico, autonomia, universalismo, inserção internacional, reforma da ordem internacional) e os «institucionalistas-pragmáticos» (liberalização económica, apoio crítico aos regimes internacionais, defesa da autonomia e soberania, prioridade da região sul-americana). Vide, entre outros, Saraiva 2010. 
diferenciar de Collor, tal não aconteceu, «O que se percebeu foi a manutenção das políticas iniciadas anteriormente, paralelamente à adoção de um posicionamento marcado pela condição de país em desenvolvimento" (Hirst \& Pinheiro, 1995: 11). Tanto no quadro da política externa como da recuperação económica, FHC teve um papel fulcral. Ao nível da política externa começou por reorganizar o Itamaraty, e reconheceu a necessidade de «adicionar uma base sólida à nossa própria região, se não for por outra razão, pelo menos para aumentar a nossa capacidade de negociação. (...)» (Fernando Henrique Cardoso apud Vigevani \& Cepaluni, 2009: 47), embora isso não significasse uma ruptura das relações com os Estados Unidos. O desenvolvimento do Mercosul é aprofundado através da assinatura, em 1994, do Protocolo do Ouro Preto que institucionalizou a sua estrutura intergovernamental e implementou o consenso como processo de tomada de decisão. O Mercosul era, então, entendido como fundamental para o comércio da região, mas também como forma de compensar a dependência em relação aos Estados Unidos.

Em 1992, a substituição de FHC por Celso Amorim não significou uma mudança no rumo da política externa. Contudo, à estratégia de valorização da região somou-se a definição de uma estratégia de inserção internacional para afirmar a posição do país, que fora abalada com Collor. No entender de Amorim, tal inserção internacional poderia ser feita através da reforma do Conselho de Segurança das Nações Unidas, ${ }^{20}$ ambição que o Brasil tem há vários anos. Começavam então a ser delineadas e implementadas algumas estratégias de acção externa, ao mesmo tempo que o lançamento do Plano Real aliviou a crise económica do país.

O Plano Real, implementado em 1994 pelo Ministro da Fazenda, Fernando Henrique Cardoso, permitiu controlar a inflação, contribuindo para o aumento do consumo ${ }^{21}$ e a recuperação da economia brasileira, e serviu

20 Neste período, o Brasil foi eleito por dois anos membro do Conselho de Segurança das Nações Unidas, participou em sete operações de paz, apresentou a proposta de uma agenda de desenvolvimento, e incrementou o relacionamento com os países vizinhos.

21 A euforia provada pelo consumo, e que contribui para os anos de ouro da economia, ocultava os deficits do comércio externo e da balança de pagamentos, que só se revelariam no segundo mandato do Presidente Fernando Henrique Cardoso. 
para melhorar a posição do Brasil no contexto internacional. Noutro domínio criou, ainda, as condições para a vitória de FHC nas eleições presidenciais de 1994.

Fruto das transformações do sistema internacional, no início da década de 1990, Collor de Melo "pôs em xeque os princípios da política externa adotada até então, mas que não foi capaz de consolidar um novo conjunto de princípios» (Saraiva, 2007: 45), embora a tentativa de modernização seja recuperada posteriormente. Deste modo, o período intercalar (após o fim do regime militar e a consolidação da democracia) é uma «crise de transição", ou uma "dança de paradigmas» (Cervo \& Bueno, 2008: 455), em que todas as novas orientações se começam a esboçar - o Mercosul, a reforma monetária, a diversificação de relações, a candidatura ao Conselho de Segurança - sem se forjar contudo um (novo) modelo e persistindo um balouçar entre os «autonomistas» e os «liberais».

\section{A revelação internacional do Brasil}

Fernando Henrique Cardoso, em 1995, introduziu uma nova atitude nas estratégias da política externa do Brasil preconizando uma intervenção mais activa do Brasil na política internacional, demonstrada através da vontade de «influenciar o desenho da nova ordem» internacional (Oliveira, 2010: 14). O discurso do novo Ministro das Relações Exteriores, Luiz Felipe Lampreia expressava também essa ideia, "nem a maior autonomia, nem o aumento da nossa capacidade de influência poderão ser alcançados por meio do isolamento ou da pretensa autosuficiência” (Lampreia, 1998: 9).

Por um lado, a administração de FHC demonstrou-se empenhada na política externa e na área económica, e por outro, habilmente separou estes dois domínios, reformando as atribuições do Itamaraty e as do Ministério da Fazenda, e concentrando uma parte importante da política externa nas mãos do Presidente da República. No que se refere à política externa, os dois mandatos de FHC foram marcados pela "diplomacia presidencial»; pela aposta na região Sul-americana através da integração regional e da revalorização do Mercosul; pela adopção das regras e dos regimes internacionais, 
e num segundo momento, pela intensificação das relações com o Sul. A "diplomacia presidencial» valorizou a inserção internacional do país, através das visitas oficiais realizadas pelo Presidente, mas não diminuiu a importância da afirmação regional do Brasil. FHC quis conciliar uma dimensão global com uma outra mais centrada na América do Sul, espelhada na postura de participação e de integração do Brasil - integração não só em termos regionais, como também integração do Brasil no que se refere às normas e aos regimes internacionais. Como referiu Lampreia, "a política externa do Presidente FHC busca a autonomia pela integração, ou seja, ao invés de uma autonomia isolacionista, uma autonomia articulada com o meio internacional» (Lampreia, 1998:11). Nesse sentido, foi possível registar também uma coincidência entre a definição da identidade do Brasil e os valores universais, ao que Luiz Felipe Lampreia denominou de "convergência crítica».

As relações Sul-Sul começaram a ser desenhadas no final do governo de FHC, motivadas pela conjuntura internacional que se traduziu no cepticismo de FHC quanto à associação automática com as normas do neo-liberalismo, que se mostraram negativas nos países em desenvolvimento (como o Brasil, ou a Argentina). Na verdade, FHC começou por recuperar, no início do seu mandato, o modelo neo-liberal, que fracassou com Collor de Mello, embora reclamasse simultânea e paradoxalmente, a reforma do sistema internacional. Mas a verdade é que, no final do segundo mandato, FHC reconheceu as fragilidades do modelo neo-liberal: a conjuntura internacional, associada à crise financeira e cambial de 1999 desmoronou o projecto brasileiro, pois «todo o cenário mundial em que o governo baseara a sua inserção internacional veio abaixo» (Vizentini, 2008: 98). Em 2001, a Argentina passou por uma grave crise económica que anunciou o colapso do neoliberalismo e das políticas recomendadas pelo FMI e pelo Banco Mundial no país e na região. Por conseguinte, no discurso que, em 2001, FHC fez na abertura da Assembleia Geral das Nações Unidas refere que "nosso lema há-de ser o da 'globalização solidária', em contraposição à atual globalização assimétrica” (Folha Online, 2001).

$\mathrm{Na}$ verdade, o relacionamento com o Norte (símbolo dos países ricos) foi uma prioridade da política externa de FHC, que se aproximou não só dos Estados Unidos, mas também da Europa e do Japão, colocando em se- 
gundo plano as relações com os países menos desenvolvidos, e os países africanos em particular. Aliás, a aproximação do Brasil a África durante os mandatos de Cardoso é normalmente apelidada de "opções selectivas» por existir uma grande precisão nas parcerias estabelecidas.

Nesse sentido, a relação com os Estados Unidos manteve-se estável. As incompatibilidades registaram-se no respeitante às políticas comerciais e aos objectivos de integração, especialmente à proposta norte-americana para a criação de uma Área de Livre Comércio das Américas (ALCA). Em todo o caso, verificou-se, também, uma aparente alteração da postura brasileira, pelo menos em termos retóricos, quanto ao projecto da ALCA, mas que, na prática, não surtiu grandes efeitos. A inconsistência da posição brasileira visava apenas evitar qualquer possibilidade de isolamento do Brasil, caso o projecto de criação da ALCA se viesse a concretizar. O final do mandato de Cardoso registou, contudo, um enfraquecimento do relacionamento com os Estados Unidos, que se deveu, sobretudo, à alteração da estratégia internacional dos Estados Unidos, esboçada após os ataques do 11 de Setembro, que passou a privilegiar as questões de segurança e a dar menos importância ao sul do continente. Ora, o fortalecimento da postura unilateral norte-americana, levou FHC a incrementar a vertente multilateral, diversificando as relações e aproximando-se das potências regionais. ${ }^{22}$

Concomitantemente, a realização da Cimeira da América do Sul, em Brasília em 2000, representou um marco importante na política externa brasileira ao propor a Iniciativa para a Integração da Infra-estrutura Regional Sul-Americana 23 (IIRSA) e dando ao discurso diplomático brasileiro um carácter autonomista, que de certo modo, chocava com o projecto da ALCA. A realização da Cimeira simbolizou a redefinição da identidade regional do Brasil, que, gradualmente, deixou de se referir à América Latina, considerada uma construção artificial e imprecisa, para utilizar o conceito

\footnotetext{
22 Momento que coincide também com a apresentação, pela Goldman Sachs do acrónimo BRIC, destacando o potencial de crescimento das economias destes países (Brasil, Rússia, Índia e China).

23 A IIRSA corresponde a uma iniciativa dos 12 países sul-americanos, tendo sido institucionalizada em 2000, na Cimeira dos Presidentes da América do Sul. Pressupõe a realização de acções conjuntas para promover o processo de integração política, económica e social da América do Sul, estimular a integração e o desenvolvimento de sub-regiões isoladas. Ver: http://www.mp.gov.br/ secretaria. asp?cat $=156 \&$ sub $=302 \&$ sec $=10$.
} 
de América do Sul, uma construção política onde mais facilmente o Brasil pode fazer valer os seus interesses. A definição da área regional da América do Sul era algo que já vinha sendo conceptualizado desde os tempos do Barão do Rio Branco, mas foi com Fernando Henrique Cardoso que se consolidou, consequência dos processos de regionalização e globalização que ocorreram, e à tomada de consciência de que «a América do Sul constitui uma unidade física contígua, que favorece as oportunidades de cooperação económica» (Lafer, 2002: 67).

Verificamos, portanto, que os anos de FHC permitiram consolidar a democracia brasileira e projectar a imagem do Brasil no exterior - democrático, adepto das normas e valores universais, com uma conduta pacífica - embora alguns autores considerem que não se tenha incrementado, simultaneamente, um desenvolvimento sólido (Vigevani \& Oliveira \& Cintra, 2003: 58). A passagem de FHC para Lula da Silva, em 2003, permitiu que se continuassem as políticas económicas iniciadas, contribuindo para o crescimento e estabilidade económica do país, e simultaneamente, para o aumento do protagonismo internacional do Brasil.

Ao nível dos princípios históricos ${ }^{24}$ da política externa brasileira, o Governo de Lula pode ser visto como um contínuo dos anos de FHC, pese embora os ajustes efectuados, pois "ao exercerem juntos dezasseis anos de mandato, são determinantes para a evolução do modelo brasileiro de inserção internacional na passagem do século xx para o XxI» (Cervo \& Bueno, 2008: 491). Em 2003, o discurso de tomada de posse do Presidente Lula da Silva acentuava a ideia de mudança porém, tal não se concretizou, pelos menos nos eixos que definem a política externa brasileira. Muitas das parcerias consolidadas por Lula tiveram a sua génese ainda durante a administração de Cardoso, "mas Lula deu uma nova ênfase a este aspecto da agenda internacional do Brasil» (Vigevani \& Cepaluni, 2009: 81), ou como afirmou o Ministro das Relações Exteriores, Celso Amorim,

${ }^{24}$ Como por exemplo o pacifismo, a não-intervenção, a auto-determinação e a segurança colectiva. 
os princípios básicos são os mesmos. Mudaram as ênfases e as intensidades com que certos temas são tratados. Quando eu era embaixador na ONU, o Brasil sempre teve proximidade com os africanos. Não se pode dizer, portanto, que a boa relação com a África é uma invenção do governo atual. Agora, vá comparar a intensidade dessa relação antes e depois. (Amorim, 2008)

A política externa desenvolvida nos dois mandatos de Lula reflecte não só os constrangimentos e oportunidades do ambiente internacional e interno, como o aproveitamento das oportunidades criadas pelo anterior Governo. Os temas e relacionamentos privilegiados são, na sua maioria, reavivados, e não uma novidade. É possível registar também a recuperação da instrumentalização da política externa em prol do desenvolvimento nacional, "no meu Governo, a ação diplomática do Brasil estará orientada por uma perspectiva humanista e será, antes de tudo, um instrumento do desenvolvimento nacional» (Silva, 2003).

Lula da Silva define o multilateralismo como um instrumento prioritário da sua estratégia externa, bem como as relações Sul-Sul. A demarcação da dependência exclusiva das grandes potências é concretizada através da participação em organizações internacionais, da definição de uma agenda externa própria e da prioridade dada à diversificação de parcerias. Tal é representado, por exemplo na posição firme (e por vezes intransigente) do Brasil nas negociações da Organização Mundial do Comércio, que em 2003 reúne um conjunto de países em desenvolvimento e com posições comuns em torno do que ficou conhecido com o Grupo dos 20, ${ }^{25}$ funcionando como um mecanismo para contrabalançar o poder de influência dos países ricos relativamente às questões agrícolas e comerciais. A estratégia foi expressa também no discurso de tomada de posse do Presidente afirmando que «a democratização das relações internacionais sem hegemonias de qualquer

25 O Brasil faz parte também do G20 que é um fórum de diálogo e cooperação das maiores economias, criado em 1999 como resposta às crises económicas dos anos 1990. O Brasil acolheu a cimeira do G20 em 2008. 
espécie é tão importante para o futuro da humanidade quanto a consolidação e o desenvolvimento da democracia no interior de cada Estado» (Silva, 2003).

É, neste sentido, que se assinala a "autonomia pela diversificação» (Viegavi \& Cepaluni, 2009) na política externa de Lula, estratégia que pela variedade de parcerias visa aumentar a capacidade de influência do Brasil na região e no mundo. Durante o mandato de FHC, essa dinâmica foi desenvolvida de forma mais moderada. As jogadas brasileiras em arenas diplomáticas, ora complementares ora alternativas, visam, justamente, a diversificação de parcerias e a emancipação face aos actores dominantes do sistema internacional. Note-se, por exemplo, a recuperação da política africana, desenvolvida por Lula, aproveitando os espaços deixados em aberto pelas grandes potências. Todavia, não foi descurado o relacionamento com o Norte, tanto com os Estados Unidos como com a União Europeia (UE). A parceria estratégica institucionalizada com a UE, em 2007, é disso exemplo, simbolizando o reconhecimento europeu do papel regional e internacional do Brasil. Gradualmente, Lula da Silva contribuiu para a definição de uma postura assertiva do Brasil, que muito se parece com o Pragmatismo Responsável de Geisel, da década de 1970, não interessando os vínculos ideológicos para o relacionamento entre os países. E, por isso mesmo, algumas estratégias são marcadas por uma certa inconstância que deriva dos interesses temporais do Brasil.

No que toca à região, em 2003, o Ministro das Relações Exteriores afirmava que «a América do Sul será nossa prioridade» (Amorim, 2003). Registou-se a proliferação de mecanismos de integração e diálogo, como a UNASUL e o Conselho sul-americano de Defesa, a par do diálogo com a Venezuela ou a Bolívia, e a missão no Haiti. O Mercosul é percepcionado como um instrumento político que agiliza negociações internacionais a diversos níveis (inclusivamente, como alternativa à ALCA), conduzindo a vantagens económicas e comerciais. As relações comerciais do Brasil, no quadro do Mercosul, são bastante significativas, e especialmente as trocas com a Argentina conheceram um aumento durante o mandato de Lula.

Mas, como evidenciámos, as relações extra-regionais juntaram-se a esta opção, devido às vantagens que apresentavam para a afirmação internacional do Brasil e para a multipolaridade das relações internacionais, defendida 
por Lula. Na verdade, o Brasil rentabilizou os vários tabuleiros de actuação internacional, através da participação nos fora multilaterais (quer seja nas organizações internacionais, como a Organização Mundial do Comércio, quer seja no fomento de fóruns multilaterais de diálogo, como o IBSA, as cimeiras BRIC, ou o G20), do incremento do diálogo bilateral com diversos países (note-se por exemplo as relações com alguns países da União Europeia, como a França ou a Alemanha, e Portugal), assim como aumentando a sua expressão diplomática no continente africano e asiático.

E daqui deriva um dos debates actuais sobre a política externa do Brasil: liderança regional ou liderança internacional? Na verdade, para o Brasil permanece o dilema entre a conciliação da sua atitude e reconhecimento internacional (a UE, e países como os EUA e alguns estados-membros da UE reconhecem o Brasil como o interlocutor privilegiado da região, do mesmo modo que em fora internacionais a opinião do Brasil passou a ser relevante) e a aceitação, pelos países vizinhos, do seu status internacional, devido à existência de preconceitos históricos, ou à concorrência, que impedem os países da região de reconhecer a relevância internacional do Brasil (como a Argentina e o Paraguai, ou também a Venezuela) (ver, entre outros, Burges, 2009).

\section{Nota final}

A análise permite-nos constatar uma evidente dinâmica entre o contexto internacional e interno e a formulação da política externa do Brasil. É evidente o reflexo da conjuntura internacional da Guerra Fria na criação de constrangimentos e possibilidades aos actores brasileiros, assim como as condições económicas e políticas internas, especialmente nos momentos de crise, tiveram um impacto nas opções de política externa.

A necessidade de definir a relação com os Estados Unidos, assente durante muito tempo na "aliança não escrita» do princípio do século xx, tem sido uma das marcas da política externa brasileira, especialmente durante e após o período de Guerra Fria. Esta exigência deve-se não apenas aos constrangimentos internacionais, dado o papel hegemónico dos Estados 
Unidos; mas também à própria posição de vizinhança entre os dois países, partilhando áreas de influência comuns; e com isso o tradicional desejo brasileiro em obter um lugar importante no sistema internacional, o que em alguns momentos choca com os interesses americanos.

A política externa do Brasil tem reflectido as tentativas de definição da sua identidade internacional, que deriva das múltiplas identidades que ao longo dos tempos o país foi agregando. A dicotomia entre o contexto interno (pobreza e desigualdade), o crescimento económico e o reconhecimento internacional tem dificultado, inclusivamente, a definição do lugar do Brasil no sistema internacional, o que não deixa de ser característico das potências médias. Contudo, cada vez mais se torna evidente, pelo menos no plano externo, a coincidência entre as ambições e as capacidades do Brasil.

\section{Questões para análise}

De que forma o sistema política brasileiro determina a formulação da política externa do país?

A política externa brasileira é marcada por um paradoxo de mudanças na continuidade. Comente esta ideia tendo por base os principais eixos da política externa do Brasil desde a década de 1960.

O discurso oficial brasileiro enuncia a pertença do Brasil a um espaço regional restrito à América do Sul. Analise a evolução da política externa brasileira para esta área, tendo em conta as influências norte-americanas no continente.

As tentativas de integração regional são uma constante na América do Sul. Identifique os principais processos e analise o papel do Brasil.

\section{Fontes na internet}

Ministério das Relações Exteriores, http://www.itamaraty.gov.br/

O Estado de São Paulo,http://www.estadao.com.br/

Presidência da República Federativa do Brasil, http://www.presidencia.gov.br/

Revista Brasileira de Politica Internacional, http://www.scielo.br/scielo. php?script=sci_serial\&pid=0034-7329\&lng=pt

Revista Contexto Internacional, http://publique.rdc.puc-rio.br/ contextointernacional/cgi/cgilua.exe/sys/start.htm?tpl=home 


\section{Leituras recomendadas}

Brainard, L. \& Martinez-Dias, L. (2009) Brazil as an economic superpower? Washington: Brookings Institution Press.

Burges, S. (2009) Brazilian Foreign Policy after the Cold War. Florida: University Press of Florida.

Cervo, A. L. \& Bueno, C. (2008) História da Política Exterior do Brasil. $3^{\mathrm{a}}$ ed. Brasília: Ed. Universidade de Brasília.

Vigevani, T. \& Cepaluni, G. (2009) Brazilian Foreign Policy in changing times. The quest for autonomy from Sarney to Lula. Nova Iorque: Lexington Books. Vizentini, P. (2004) A politica externa do regime militar brasileiro. $2^{\mathrm{a}}$ ed. Porto Alegre: Editora da UFRGS.

\section{Bibliografia}

Amorim, C. (2008) Entrevista ao jornal O Estado de São Paulo, 16/03/2008. [http://www.mre. gov.br/portugues/politica_externa/discursos/discurso_detalhe3.asp?ID_DISCURSO=3267].

Burges, S. (2009) Brazilian Foreign Policy after the Cold War. Florida: University Press of Florida.

Cason, J. \& Power, T. J. (2009) «Presidentialization, Pluralization and the rollback of Itamaraty: Explianig change in Brazilian Foreign Policy Making in the Cardoso-Lula Eran, International Political Science Review, 116(4), 611-636.

Cervo, A. L. \& Bueno, C. (2008) História da Política Exterior do Brasil, $3^{a}$ ed. Brasília: Ed. Universidade de Brasília.

Constituição da República Federativa do Brasil (1988). Texto consolidado até a Emenda Constitucional no 64 de 04 de Fevereiro de 2010. [http://www.senado.gov.br/legislacao/const/ con1988/CON1988_04.02.2010/CON1988.pdf].

Folha Online (2001) «FHC cobra na reunião da ONU ordem internacional mais solidária», 10 de Novembro. [http://www1.folha.uol.com.br/folha/brasil/ult96u26573.shtml].

Hirst, M. \& Pinheiro, L. (1995) "A política externa do Brasil em dois tempos», Revista Brasileira de Política Internacional, 38(1), 5-23.

Hirst, M. (2006) "Los desafios de la política sudamericana de Brasil». Revista Nueva Sociedade, $n .^{\circ} 205,131-140$.

Lafer, C. (2002) La identidad internacional de Brasil. Buenos Aires: Fondo de Cultura Economica.

Lafer, C. (2009) «Partidarização da política externa», Jornal O Estado de São Paulo, 20 de Dezembro.

Lampreia, L. F. (1998) «A política externa do governo FHC: continuidade e renovação», Revista Brasileira de Politica Internacional, 42(2), 5-17.

Lechini, G. (2008) «O Brasil na África ou a África no Brasil? A construção da política africana pelo Itamaraty", Nueva Sociedad, Outubro.

Lemos, L. (2010) Brazilian Congress and Foreign Affairs: Abdication or Delegation?. Global Economic Governance Programme. [http://www.globaleconomicgovernance.org/wp-content/ uploads/GEG-Working-Paper-Lemos.pdf]. 
Lima, M. R. S. de \& Santos, F. (1998, Setembro) Brazilian Congress and Foreign Trade Policy. Comunicação apresentada na conferência da Latin American Studies Association. Chicago, Illinois. [http://lasa.international.pitt.edu/LASA98/Soares-Santos.pdf].

124 22(2), 265-303.

Lima, M. R. S. de (2007) "Brasil en América Latina. Liderazgo regional en América del Sur». Revista Foreign Affairs en Español, 7(4), 10-12.

Mariano, K. \& Mariano, M. (2008) "A Formulação da política externa brasileira e as novas lideranças políticas regionais», Perspectivas, 33, 99-135.

Mello, C. (1990) [http://www.collor.com/discursos1990_001.asp].

Neves, J. A. de C. (2003) "O Papel do Legislativo nas Negociações do Mercosul e da ALCA", Contexto Internacional, 25(1), 103-138.

Neto, O. A. (2007) "O poder executivo, centro de gravidade do sistema político brasileiro», in Avelar, L. \& Cintra, A. O. (org), Sistema politica brasileiro: uma introdução. Rio de Janeiro: Fundação Konrad Adenauer, 131-141.

Oliveira, M. D. de (org) (2010) Discursos selecionados do Presidente Fernando Henrique Cardoso. Brasília: Fundação Alexandre de Gusmão.

Pecequillo, C. (2008, Março) Brazil's Foreign Policy in the 21st Century: The Combining Axis of Horizontal and Vertical Multilateral Cooperation. Comunicação apresentada na $49^{\text {a }}$ Convenção Anual da ISA, São Francisco, EUA [http://www.allacademic.com/meta/p254209_index.html].

Saraiva, J. F. S. (1996) O lugar da África. A dimensão atlântica da política externa brasileira. Brasília: Editora Universidade de Brasília.

Saraiva, M. G. (2007) "As estratégias de cooperação Sul-Sul nos marcos da política externa brasileira de 1993 a 2007», Revista Brasileira de Política Internacional, 50(2), 42-59.

Saraiva, M. G. (2010, Março) "A diplomacia brasileira e as visões sobre a inserção externa do Brasil: institucionalismo pragmático x autonomistas», Real Instituto Elcano. [http://www. realinstitutoelcano.org/wps/wcm/connect/0bf4ae0041b8c1ee9e81fee151fccd56/ARI462010_gomes_saraiva_diplomacia_brasileira_institucionalismo_pragmatico_autonomista.pd $\mathrm{f}$ ?MOD=AJPERES\&CACHEID=0bf4ae0041b8c1ee9e81fee $151 \mathrm{fccd} 56$ ].

Silva, L. (2003) Discurso de tomada de posse de Lula da Silva, 1 de Janeiro. [http://www.mre. gov.br/portugues/politica_externa/discursos/discurso_detalhe3.asp?ID_DISCURSO=2029].

Vigevani, T. \& Oliveira, M. F. de \& Cintra, R. (2003) "Política externa no período FHC: a busca de autonomia pela integração", Tempo Social, 15(2), 31-61.

Vigevani, T. \& Cepaluni, G. (2009) Brazilian Foreign Policy in changing times. The quest for autonomy from Sarney to Lula. Nova Iorque: Lexington Books.

Vizentini, P. (2003) "A política externa brasileira em transição: do desenvolvimento ao neoliberalismo", in Martins, E. C. de R. (org), Relações Internacionais. Visões do Brasil e da América Latina. Brasília: Instituto Brasileiro de Relações Internacionais, 63-105.

Vizentini, P. (2008) Relações Internacionais do Brasil. De Vargas a Lula. $3^{\text {a }}$ Edição. São Paulo: Ed. Fundação Perseu Abramo. 


\section{CAPÍtULO 5}

\section{ESTADOS UNIDOS DA AMÉRICA}

Este capítulo analisa as grandes matrizes que vêm orientando a política externa dos Estados Unidos da América (EUA), centrando-se nos períodos de Guerra Fria e da chamada «Nova Ordem Mundial» que se lhe seguiu. O texto faz o levantamento das principais políticas e estratégias dos EUA, frequentemente associadas ao nome dos Presidentes em exercício, situando-as nos respectivos contextos, procurando identificar objectivos, prioridades e aspectos definidores, e caracterizando ainda a política externa americana na actualidade.

\section{Objectivos e elaboração da política externa americana}

Enquanto os outros actores se focalizam primeiramente nas regiões onde 'residem', os Estados Unidos, potência proeminente desde o final do século XIX e única superpotência desde o fim da Guerra Fria, encaram a política externa à luz das suas aspirações globais e dos seus objectivos: liderança/hegemonia mundial; segurança dos EUA e dos seus aliados e parceiros; prosperidade e desenvolvimento com base na inovação e num sistema económico e comercial internacional livre e aberto; expansão da democracia, das liberdades e dos direitos humanos; e ordem internacional estável. Conceber e implementar uma política externa coerente e consistente na promoção destes objectivos tem demonstrado ser, porém, um exercício 
complexo e delicado para Washington, com oscilações e reajustamentos constantes em resultado, por um lado, das evoluções, transformações e circunstâncias específicas dos contextos interno e internacional e, por outro, do carácter específico e democrático do sistema político americano e, portanto, do cruzamento da visão das sucessivas Administrações no poder, da relação de forças entre os Partidos Democrata e Republicano nas duas Câmaras do Congresso e dos necessários compromissos entre a Administração e o Congresso, bem como dos muitos e variados grupos de interesse e de pressão e, naturalmente, dos calendários eleitorais.

Como é evidente, independentemente das suas percepções e tendências de base, «todos os Presidentes Americanos têm de proteger os interesses particulares, e por vezes egoístas, de eleitorados particulares; (...) têm de dar resposta às reivindicações de vários eleitorados dentro dos Estados Unidos» (Fukuyama, 2006: 97), tal como têm todos de defender, afirmar e promover os interesses e valores dos EUA nos palcos regionais e mundial. Simplesmente, apesar da sua supremacia, os Estados Unidos defrontam-se com um mundo sempre complexo e em constante transformação onde não só não estão em posição de determinar o comportamento de todos os outros actores como também se deparam com interesses distintos, autónomos e, frequentemente, contraditórios dos seus aliados e parceiros regionais, o que exige da Casa Branca uma gestão muito delicada da agenda internacional americana e dos compromissos internos com o Congresso. Alguns exemplos são paradigmáticos disto mesmo. Ao findar a I Guerra Mundial, o Presidente Wilson propôs e envolveu-se na criação da inovadora Sociedade das Nações (SDN) em que os EUA tomariam parte como membro-permanente do Conselho; porém, o Congresso não ratificou a adesão dos EUA à SDN. Mais recentemente, a Administração Clinton (Democrata) empenhou-se na celebração e assinatura do Protocolo de Kyoto e do Comprehensive Test Ban Treaty (CTBT) que o Congresso (então, maioritariamente Republicano) não ratificou e que a Administração W. Bush que se lhe seguiu abandonaria expressamente. Em Maio de 2008, a Administração Republicana de W. Bush assinou com a Federação Russa um Acordo de Cooperação em matéria de energia nuclear para fins civis (um dos denominados "Tratados 123» americanos) que o Congresso, já maioritariamente Democrata, recusou 
ratificar. Também o Presidente Obama tem enfrentado os constrangimentos provocados pelo Congresso mesmo sendo este também maioritariamente Democrata, como evidenciam os processos em torno das putativas soluções para a crise económica americana e internacional, da reforma do sistema de saúde americano, do encerramento do presídio de Guantanamo e o destino dos respectivos prisioneiros, ou das estratégias e dos financiamentos para os conflitos no Iraque e no Afeganistão.

$\mathrm{Na}$ realidade, apesar de todas as Administrações considerarem os objectivos Americanos em política externa «mutuamente reforçadores», estes nem sempre são conciliáveis, ou são-no muito dificilmente e ambiguamente: nos últimos anos, por exemplo, a sustentação da primazia/liderança dos EUA, o incremento dos laços económicos e a expansão da democracia e dos direitos humanos têm demonstrado ser difíceis de conciliar e de implementar coerentemente na política Asiática dos EUA e, em particular, na relação com a República Popular da China.

A política externa Americana é, por conseguinte, elaborada em função do ambiente internacional e das prioridades da Administração em exercício mas é igualmente o produto da competição e dos equilíbrios entre as várias tendências que concorrem para a influenciar e determinar, dos wilsonianistas aos neoconservadores, dos isolacionistas aos internacionalistas e aos intervencionistas: «Esta batalha entre multilateralistas e unilateralistas, muitas vezes jogada como luta entre o Presidente e o Congresso, levou a uma política externa americana de algum modo esquizofrénica» (Nye, 2002: 156).

\section{Na era de Guerra Fria}

No final da II Guerra Mundial, os Estados Unidos eram a potência hegemónica cabendo-lhes, por isso, o papel principal na reorganização do sistema internacional para onde transpuseram os seus interesses e valores. Vencida a guerra, reduziram drasticamente o seu orçamento de defesa e iniciaram uma rápida e extensa desmobilização militar sem, todavia, cometerem os mesmos 'erros' que tinham cometido após a I GM: não retiraram completamente nem da Europa nem da Ásia-Pacífico e tornaram-se mem- 
bros fundadores da nova Organização das Nações Unidas (ONU) e um dos cinco membros permanentes do respectivo Conselho de Segurança. Por esta altura, aquele que parecia vir a ser o principal factor de fricção na política internacional era o direito de autodeterminação, colocando lado a lado Washington e Moscovo ante os colonizadores europeus. No entanto, as profundas divergências e a competição entre os EUA e a URSS rapidamente transformaram o espírito cooperativo em confrontação.

No teatro europeu, a Guerra culminara com o avanço simultâneo dos exércitos Aliados a partir do Ocidente (Americano, fundamentalmente) e do Leste (Soviético, essencialmente), funcionando como uma autêntica tenaz sobre a Alemanha mas que também deixava a Europa automaticamente dividida por uma "cortina de ferro". Logo depois, as manobras de Estaline destinadas a "Sovietizar» toda a Europa Central e Oriental levaram os EUA, em 1947, a enunciar a chamada "Doutrina Truman», a propor a todos os países europeus um programa de recuperação económica ( Plano Marshall») e a avançar com a política de containment, isto é, "uma política de firme contenção, delineada para confrontar os russos com um constante contra-poder relativamente a todos os sinais de invasão dos interesses do mundo Livre» (Kennan, 1947: 575) criando, neste quadro e em plena primeira crise de Berlim, em Abril de 1949, a Aliança Atlântica/OTAN. Por seu lado, os soviéticos proclamaram a "Doutrina Jdanov», criaram o Kominform, recusaram e obrigaram os seus Estados satélite a recusar o Plano Marshall e estabeleceram depois o Pacto de Varsóvia (1955). A Guerra Fria começava, assim, na Europa, epicentro da disputa entre as duas superpotências que rapidamente se alastrou a todo o globo.

Em relação à Ásia-Pacífico, só com a vitória comunista na China (1949), a Guerra da Coreia (1950-1953) e o agravar da Primeira Guerra da Indochina (1947-1954) é que o perímetro de segurança americano se começou a expandir. ${ }^{1}$ Desde logo, a pressão comunista tornava imprescindível e urgente substituir a política de ocupação do Japão pela sua ancoragem ao

\footnotetext{
${ }^{1}$ Logo em 1950, os EUA disponibilizavam ajuda significativa aos franceses na Indochina, assinavam um Tratado de Assistência Mútua com a Tailândia e, dois dias após a invasão Norte-Coreana do Sul, o Presidente Truman levava os EUA a entrarem na Guerra da Coreia, ao mesmo tempo que dava ordens para a $7^{\mathrm{a}}$ Esquadra Americana proteger Taiwan da China comunista.
} 
«mundo livre»: em 8 de Setembro de 1951, os EUA promoveram o Tratado de Paz entre as Potências Aliadas e o Japão e assinaram com Tóquio um Tratado de Segurança bilateral, ambos em São Francisco. Começava, então, a ser implementado o "Sistema de São Francisco", conjunto de alianças dos EUA na Ásia-Pacífico para conter o comunismo: cerca de uma semana antes da assinatura daqueles Tratados com o Japão, os EUA firmaram com as Filipinas um Tratado de Defesa Mútua e com a Austrália e a Nova Zelândia um Tratado de Segurança tripartido (ANZUS); dois anos mais tarde, e já depois de assinado o Armistício de Panmunjon que pôs fim à Guerra da Coreia, os EUA celebraram com a Coreia do Sul um Tratado de Defesa Mútua; em 1954, após os Acordos de Genebra sobre a Indochina, os EUA assinaram o Tratado de Defesa Colectiva para o Sudeste Asiático ou Pacto de Manila com a Austrália, Nova Zelândia, Reino Unido, França, Filipinas, Tailândia e Paquistão, Pacto que no ano seguinte passaria a ter uma estrutura político-militar com a criação da Organização do Tratado do Sudeste Asiático (OTASE/SEATO). A última unidade a integrar esta rede de alianças foi a República da China/Taiwan, com quem os EUA assinaram um Tratado de Defesa Mútua, em 2 de Dezembro de 1954. A política de "contenção" anti-comunista aplicava-se verdadeiramente na Ásia-Pacífico, mas a política dos EUA em relação à Península Coreana e ao Estreito de Taiwan definia-se pela manutenção do status quo - na prática, duas Coreias e duas Chinas.

Evidentemente, quer os pactos do Sistema de São Francisco quer a OTAN estavam ligados ao sistema global de containment montado pelos EUA e que incluiria também o Pacto de Bagdade $^{2}$ (1955) e ainda muitos outros países e movimentos igualmente em África e na América Latina. Enquanto durou a Guerra Fria, o containment anti-URSS foi o conceito orientador de toda a política externa e de segurança dos Estados Unidos.

\footnotetext{
2 Baseado no modelo da OTAN, o Pacto de Bagdade foi firmado, em 1955, entre o Iraque, Irão, Turquia, Paquistão e Reino Unido a fim de promover a cooperação mútua e conter a influência soviética no Médio Oriente e na Ásia Meridional. Apesar de a instigarem, promoverem e financiarem, os EUA somente aderiram ao Comité Militar desta aliança, em Julho de 1958. Inicialmente designada Middle East Treaty Organization (METO), a organização renomeou-se Central Treaty Organization (CENTO), em 1959, por ocasião da retirada da aliança do Iraque operada pelo novo regime republicano iraquiano. Verdadeira aliança fracassada, foi dissolvida, em 1979, após a Revolução Islâmica no Irão e a consequente saída da CENTO.
} 
Entretanto, desde o final dos anos 1950, início dos anos 1960, emergiu uma "outra guerra fria» entre as duas grandes potências comunistas, a URSS e a China. Paralelamente, os EUA enterraram-se no 'pântano do Vietname' ou Segunda Guerra da Indochina. A Guerra do Vietname rapidamente começou a concentrar os recursos americanos, mas a confrontação sino-soviética também não podia deixar de interessar aos EUA: contudo, as Administrações Eisenhower, Kennedy e Johnson não a exploraram e só com o advento da Administração Nixon, no final de 1968, é que os EUA começaram a tirar partido da cisão entre as grandes potências comunistas, conectando-a à disputa bipolar e à guerra no Vietname.

A Guerra Fria e a política de containment tinham empurrado os EUA para um envolvimento universal em nome do anti-comunismo e era esta política que precisava de ser reconsiderada à luz do trauma do Vietname. Por isso, o novo Presidente Americano apressou-se a enunciar, em Julho de 1969, na base naval de Guam, no Pacífico, os novos critérios que pautariam o envolvimento americano. ${ }^{3}$ Sem abandonar o containment mas recusando o espírito de cruzada anti-comunista e baseando-se na mais pura realpolitik, a Administração Nixon assumiu o «interesse nacional» como preceito orientador da política externa e de segurança dos EUA e também como principal critério para julgar os adversários desenvolvendo, consequentemente, a política de "articulação» (linkage) na direcção da URSS: "A ideia era enfatizar as áreas em que a cooperação era possível e usar essa cooperação como alavanca para modificar o comportamento soviético em áreas em que os dois países se encontrassem em conflito» (Kissinger, 1996: 622). Na visão do Presidente Nixon e do seu Conselheiro Kissinger seria crucial arranjar um

\footnotetext{
3 Reflectindo sobre os envolvimentos militares dos EUA desde o fim da II Guerra Mundial e a situação no Vietname, Nixon (1969) estipulou «três princípios orientadores para a futura política americana na Ásia: 1) os EUA manteriam todos os compromissos assumidos; 2) providenciaremos um escudo se uma potência nuclear ameaçar a liberdade de uma nação nossa aliada ou de uma nação cuja sobrevivência considerarmos vital para a nossa segurança; 3) nos casos envolvendo outros tipos de agressão, nós forneceremos a assistência militar e económica quando solicitada de acordo com os nossos compromissos nos tratados. Mas esperamos que seja a nação directamente ameaçada a assumir a responsabilidade primordial de dar os meios humanos para a sua defesan. Evidentemente, à luz deste terceiro critério, a ideia de substituir no Vietname os militares americanos pelos muito frágeis 'meios humanos' vietnamitas, ficando os EUA na retaguarda, só poderia conduzir à retirada americana da Indochina e, consequentemente, à queda do Vietname do Sul, do Laos e do Camboja para o 'campo' comunista.
} 
incentivo forte para a moderação soviética e o funcionamento da articulação, gizado na aproximação à China: «Excluir das opções diplomáticas da América um país com a dimensão da China significava que a América estava a agir internacionalmente com uma mão presa atrás das costas. Estávamos convencidos de que o aumento das opções da política externa da América abrandaria, em vez de endurecer, a posição de Moscovo» (Kissinger, 1996: 629). O desanuviamento com Moscovo e a abertura a Pequim ${ }^{4}$ eram, portanto, as duas faces da mesma moeda, fazendo Washington explicitamente um convite a cada uma das grandes potências comunistas para se moderarem e melhorarem as suas relações com os Estados Unidos.

Assim, num curto espaço de tempo, as relações entre Washington e Pequim evoluíram da hostilidade para uma frente comum na contenção da ameaça soviética. É certo que a «doutrina Nixon» não livrou os EUA de uma saída humilhante do Vietname e conduziu a um relativo "recuo» americano na Ásia Oriental: ao longo dos anos 1970, as sucessivas Administrações Americanas (Nixon, Ford e Carter) iriam retirar da Indochina, pôr fim ao relacionamento oficial e à aliança com Taiwan, dissolver a SEATO (em 30 de Junho de 1977), retirar o dispositivo nuclear estratégico da Coreia do Sul e reduzir os seus contingentes militares na Coreia, no Japão, nas Filipinas e na Tailândia. Porém, confortados pelo sucesso da "cartada chinesa", os EUA puderam retirar do Vietname sem deixar a Indochina simplesmente à mercê do domínio soviético, uma vez que a China Popular tinha todo o interesse e estava, mais do que nunca, empenhada em conter a URSS nesta sua região vizinha, como se veria logo a seguir na Terceira Guerra da Indochina - opondo, essencialmente, o Vietname, aliado da URSS e o Camboja dos Khmers Vermelhos, apoiados pela China. Foi, aliás, em plena crise na Indochina, em 1 de Janeiro de 1979, que os EUA e a China oficializaram relações diplomáticas.

\footnotetext{
4 A aproximação à RPC implicava, necessariamente, começar a abrir mão de Taiwan e, em 25 de Outubro de 1971, a AGNU aprovava a Resolução 2758 pela qual a China se tornava na "única representante legal da China na ONU». O epílogo desta aproximação ocorreu com a viagem que o próprio Presidente Nixon efectuou à Mainland China, de 21 a 27 de Fevereiro de 1972, no que se pode considerar como o reconhecimento de facto da RPC pelos EUA: no final desta visita histórica, a primeira de um Presidente Americano à China, Mao e Nixon assinaram o famoso "Comunicado de Xangai" que se destinava a orientar as relações sino-americanas no futuro.
} 
Por seu lado, se os EUA e a URSS continuavam adversários irredutíveis, a "destruição mútua garantida" provocada pelas armas nucleares dissuadia o conflito militar directo, pelo que ambos tinham de ir além da simples confrontação e construir uma ordem mundial que, na medida do possível, estipulasse regras acordadas entre as superpotências e impostas a todos os outros. Esta foi, sem dúvida, uma das grandes motivações para que Moscovo e Washington se empenhassem no desanuviamento, embora cada uma das superpotências tivesse outras motivações suplementares para o condominium. ${ }^{5}$ Paralelamente, parece inquestionável que a aproximação dos EUA à China fez acelerar o processo de détente Leste-Oeste. Efectivamente, do final dos anos 1960 a 1979, regista-se uma vaga de desanuviamento Leste-Oeste que abriria a porta a toda uma série de iniciativas da maior importância: a implementação da ostpolitik pela RFA (a partir de 1969), o fim da Guerra do Vietname (1973-75), o início do processo de paz israelo-árabe (1973 e 1978), o lançamento da Conferência sobre Segurança e Cooperação na Europa (CSCE) e os Acordos de Helsínquia (1975) ou ainda os múltiplos e fundamentais acordos e convenções sobre "controlo de armamentos» - do TNP (1968/70) aos chamados SALT 1 (1972) e SALT 2 (1979), passando pelo Tratado ABM (1972), a BTWC/BWC (1972), as MBFR (1973) ou o Acordo Sovieto-Americano Sobre a Prevenção da Guerra Nuclear (1973). Mas tal como a Guerra Fria não era um conflito normal, a détente também não era uma paz verdadeira: nenhuma das superpotências abandonou os seus propósitos hegemónicos, continuando a competir e a confrontar-se "por procuração", da América Latina (Chile e Nicarágua, por exemplo) a África

5 Os EUA precisavam de espaço para respirar, a fim de se libertarem do trauma do Vietname, a que se somavam outros problemas: a crise política interna na sequência do escândalo de Watergate que levaria à resignação do Presidente Nixon, em 1974; a subida vertiginosa dos défices orçamental e comercial americanos; e a primeira grande crise económica internacional pós-II Guerra Mundial despoletada pela conjugação da desvalorização do dólar e a suspensão da sua convertibilidade em ouro, fazendo ruir o edifício das paridades fixas que vinha desde os Acordos de Bretton Woods, e do choque petrolífero na sequência da guerra Israelo-Árabe do Yom Kippour, em Outubro de 1973. Por seu lado, a URSS tinha também motivos fortes para procurar uma trégua devido ao conflito sino-soviético e às tensões e dissidências no seio do seu bloco (que levara, por exemplo, à proclamação da Doutrina Brejnev e à intervenção do Pacto da Varsóvia contra um dos seus membros, a Checoslováquia, em 1968), mas também porque a sua economia se revelava cada vez menos eficiente comparativamente às economias capitalistas, efeito agravado pela corrida aos armamentos. No fundo, ambas as superpotências pareciam querer 'recuperar fôlego' para uma decisiva etapa de confrontação. 
(incluindo as ex-colónias portuguesas), passando pela Europa, pelo Médio Oriente ou pela Ásia-Pacífico (incluindo a "aceitação" americana da invasão de Timor-Leste pela Indonésia), com a pressão comunista a acentuar-se.

Essas ambições hegemónicas conduziriam a um novo período de grande tensão EUA-URSS. Em 1979, três acontecimentos foram particularmente decisivos para o fim da détente: a invasão vietnamita do Camboja, a invasão soviética do Afeganistão e a chamada "crise dos Euromísseis». 6 Entrava-se, assim, na fase de "guerra fresca" Leste-Oeste, clima que foi decisivo para a eleição Presidencial de Ronald Reagan, em 1980, com uma retórica invulgarmente agressiva contra a União Soviética que apelidou de "Império do Mal». No essencial, a "Doutrina Reagan» recuperou a estratégia de roll-back de Foster Dulles segundo a qual os EUA deviam activamente forçar o recuo soviético de onde já estava instalado, admitindo todo o tipo de acções e em apoio de todo o tipo de "forças da liberdade» anti-comunistas, do Solidariedade na Polónia aos Contras anti-Sandinistas na Nicarágua ou aos mujahadeen no Afeganistão: afinal, "apoio a freedom fighters é auto-defesa» (Reagan, 1985). Além disso, a Administração Reagan lançou um espectacular desafio aos soviéticos com a sua Iniciativa de Defesa Estratégica (IDE), vulgo "guerra das estrelas»: a URSS bem invocou o Tratado ABM de 1972, mas via-se confrontada com a iminência de uma nova competição tecnológica e militar que, de facto, já não tinha condições para acompanhar.

A par da pressão americana, a retórica conciliatória do novo líder soviético, M. Gorbatchov, a partir de 1985, e a "ofensiva da paz» soviética ${ }^{7}$ puseram termo à confrontação EUA-URSS. As cimeiras entre Gorby e os líderes Ocidentais sucederam-se a um ritmo sem precedentes, nomeadamente, com os Presidentes Americanos Ronald Reagan e George Bush (eleito no final

\footnotetext{
6 A "crise dos Euromísseis" resultou da instalação, na Europa de Leste, dos mísseis nucleares soviéticos SS 20 de curto e médio alcance e a que a OTAN respondeu, em Dezembro de 1979, com a famosa "dupla decisão": a instalação de mísseis americanos idênticos (Pershing) na Europa Ocidental se, entretanto, os soviéticos não desmantelassem todos os seus.

7 A União Soviética reduz, drasticamente, o seu orçamento e panóplia militar; recua no Terceiro Mundo, fardo impossível de suportar, suprimindo ou reduzindo sensivelmente o auxílio aos movimentos e regimes aliados, por exemplo, em Angola, Moçambique, Etiópia, Nicarágua, Coreia do Norte, Śria, Cuba ou Vietname; retira os seus militares do Afeganistão e leva o Vietname a retirar do Camboja; estabelece, significativamente, relações diplomáticas com o Vaticano (1990) e Israel (1991).
} 
de 1988), sendo uma das mais significativas a de Malta, em Dezembro de 1989, onde Gorbatchov e Bush declararam solenemente o "fim da Guerra Fria». As transformações operaram-se de forma alucinante, a começar pela Europa: em Novembro de 1989, o Muro de Berlim era desfeito por uma população eufórica, abrindo caminho à reunificação alemã concretizada menos de um ano depois; num curtíssimo espaço de tempo, os regimes comunistas desaparecem na Europa; em 1991, o COMECOM e o Pacto de Varsóvia eram oficialmente desmantelados e a URSS desfazia-se para dar lugar a 15 novos Estados independentes. Sem os constrangimentos inerentes à disputa bipolar, a ONU ganha um novo dinamismo e a Guerra do Golfo confirmava a emergência de uma Nova Ordem Mundial em que soviéticos e americanos, finalmente, 'desbloqueavam' o Conselho de Segurança permitindo aos EUA liderar a comunidade internacional na punição do Iraque que tinha invadido o Kuwait.

Entretanto, o massacre de Tiannanmen, em Junho de 1989, prejudicou gravemente as relações EUA-China: ao terminar a Guerra Fria, a imagem da China como um país que empreendia reformas e servia de contrapeso à URSS era subitamente substituída pela de um regime altamente repressivo, hostil à democracia e violador dos direitos humanos, contrariando o espírito e as expectativas da "nova ordem mundial». A reacção dos EUA, pela mão da Administração Bush, foi especialmente dura mas também extraordinariamente ambivalente: por um lado, liderou a campanha internacional contra o regime de Pequim e a imposição imediata de sanções contra a China, apoiou os «dissidentes» chineses, suspendeu a cooperação militar com Pequim e aumentou o volume de armamentos entregues a Taiwan; por outro, promoveu uma imediata "diplomacia secreta" mantendo aberto o diálogo bilateral, preservou os laços económicos (incluindo o estatuto de Nação Mais Favorecida à China, não sem um aceso debate no Congresso) fazendo com que o intercâmbio comercial rapidamente voltasse a uma certa normalidade e manteve a China envolvida na cooperação económica regional (incluindo o apoio à adesão chinesa na APEC, em 1991) e na resolução de certos problemas regionais e internacionais (como o processo de paz Cambojano e a Guerra do Golfo). De qualquer forma, no momento em que o eixo Washington-Moscovo-Pequim se dissolvia, as relações entre 
as duas grandes potências vencedoras da "dupla guerra fria» entravam, de facto, numa nova fase.

\section{Política externa dos EUA no período pós-Guerra Fria}

Coube à Administração George Bush (1989-1993) a tarefa de começar a reinventar a política externa dos EUA no fim da Guerra Fria. Em 1990, na Assembleia-Geral da ONU, o Presidente Americano expunha a sua visão sobre a "Nova Ordem Mundial», baseada numa "nova parceria de nações» (Bush, 1990). No ano seguinte, na ressaca da Guerra do Golfo, novamente perante a AGNU, Bush (1991) assegurava que "os EUA não têm intenção de lutar por uma Pax Americana... procuramos uma Pax Universalis construída sobre responsabilidades e aspirações partilhadas». Um documento do Pentágono enunciava, contudo, outra ambição: "O nosso principal objectivo é prevenir a emergência de um novo rival (...) A nossa estratégia deve agora recentrar-se em evitar a emergência de qualquer potencial competidor global futuro" (The New York Times, 1992), naquilo que passaria a ser conhecido por "Doutrina Cheney-Wolfowitz". 8

Num contexto de profunda transformação, os EUA optam imediatamente por manter o sistema de alianças herdado da confrontação bipolar, embora redimensionando o seu dispositivo no estrangeiro, com uma nova região e uma nova potência a emergirem nas prioridades e preocupações de Washington por razões económicas e de segurança: a Ásia-Pacífico e a China. Paralelamente, ganhava ênfase o impulso americano para usar o seu enorme hard power em missões de soft power, ${ }^{9}$ bem como para o intervencionismo humanitário: em Dezembro de 1992, o Presidente Bush autorizava as forças

\footnotetext{
8 Concebido pelos Secretário da Defesa Dick Cheney e Sub-Secretário Paul Wolfowitz, o documento em causa era um draft interno do Pentágono de Fevereiro de 1992 preparatório do Defense Planning Guidance 1994-1999. Perante a polémica e as duras críticas do Congresso, a versão definitiva acabaria por ser revista e "suavizada".

9 Por exemplo, na Operation Sea Angel, em 1991, soldados americanos assistiram os esforços internacionais no Bangladesh na recuperação de um desastroso ciclone; no mesmo ano, durante a Operation Provide Comfort, soldados das forças especiais americanas salvaram cerca de 400.000 curdos da fome iminente nas montanhas do Norte do Iraque e do Sudeste da Turquia.
} 
americanas a darem início à Operation Restore Hope na Somália, liderando a missão das Nações Unidas (UNITAF).

Criticando a Administração Bush por ter uma «mentalidade de Guerra Fria», o Presidente Bill Clinton (1993-2001) procurou desenvolver uma política externa mais adequada ao que chamou New World, articulando uma nova National Security Strategy of Engagement and Enlargement (The White House, NSS, 1996 e 1999) tendo por objectivos estratégicos "promover a nossa segurança com forças armadas preparadas para lutar e com uma representação efectiva além fronteiras; promover a democracia além fronteiras» (NSS, 1996: Preface), e promovendo o internacionalismo dos EUA enquanto "nação indispensável" e peacemaker. ${ }^{10}$ Por outro lado, para esta Administração Democrata eleita pela ênfase no vector económico, a Ásia Oriental assumia uma importância acrescida - só os défices comerciais americanos face ao Japão e à China representavam mais de dois terços do total do défice comercial dos EUA no ano em que Clinton tomou posse.

Baseada nas noções de engagement e enlargement, destacam-se cinco vectores fundamentais da política externa e de segurança da Administração Clinton: 1) a manutenção do sistema de alianças (ou mesmo a sua expansão, como revelam a transformação e o alargamento da OTAN e da omnipresença militar dos EUA englobadas, todavia, numa abordagem mais abrangente ou presence plus; 2) o envolvimento nos assuntos e nas organizações regionais e internacionais e o desenvolvimento de novos quadros multilaterais sem, contudo, avançar na segurança multilateral institucionalizada na Ásia-Pacífico temendo que isso diluísse a importância das alianças bilaterais dos EUA na região; 3) a prioridade aos laços económicos e a expansão do liberalismo

10 Daí, por exemplo, a liderança na elaboração do Comprehensive Test Ban Treaty (CTBT), tendo sido os EUA o primeiro país a assiná-lo, em Setembro de 1996; o activismo do Vice-Presidente Al Gore na protecção ambiental e em prol do Protocolo de Quioto de 1997 que o Presidente Clinton assinou nesse mesmo ano (e que, tal como o CTBT, o Congresso se recusou ratificar); o apoio americano aos Objectivos do Milénio adoptados pela ONU, em 2000, reconhecendo a íntima associação entre Segurança e Desenvolvimento; ou o desenvolvimento da ideia de "ingerência humanitária» quando em causa estão violações massivas dos direitos humanos e/ou valores universais, retórica que seria exercitada na Somália (onde os EUA se mantiveram até retirarem sob o manto do fiasco, em 1994) e, sobretudo, no Haiti (1994), na Bósnia (1995) e no Kosovo (1999), as duas últimas com a OTAN, se bem que no Kosovo sem o consentimento do CSNU, mas não, por exemplo, aquando do genocídio no Ruanda, em 1994-1995. 
económico e comercial; 4) a promoção e expansão dos direitos humanos e universais, incluindo pela consagração do "direito de ingerência humanitária», expresso na liderança da intervenção da OTAN na Bósnia e, sobretudo, no Kosovo; e 5) a procura de engagement com todos os actores regionais, incluindo antigos ou novos virtuais rivais como o Vietname, a Coreia do Norte, a Rússia e, em particular, a China. Foi neste quadro que Clinton fez, em 1998, uma longa e sem precedentes visita de 9 dias à China, sem passar antes pelo Japão ou pela Coreia do Sul, manifestando o desejo de desenvolver com Pequim uma "parceria estratégia construtiva». Todavia, a ressurgente China continuou a ser encarada pelo Congresso e pelos americanos em geral mais como um rival estratégico do que um parceiro cooperativo: em Janeiro de 1999, o Congresso fez publicar a versão não classificada do polémico U.S. National Security and Military/Commercial Concerns with the People's Republic of China; ${ }^{11}$ no ano seguinte, o Congresso solicitava em forma de lei que o Pentágono passasse a elaborar e a submeter-lhe um relatório anual sobre «O Poder Militar da China».

A verdade é que a estratégia Clintoniana se revelou extraordinariamente ambivalente, contemplando aspectos similares às Administrações Republicanas: a aspiração de "primeiro, e acima de tudo, devemos exercer liderança global»; o envolvimento selectivo, "focando nas ameaças e oportunidades mais relevantes aos nossos interesses e aplicando os nossos recursos onde podemos fazer a maior diferença»; a noção de que muitos dos interesses dos EUA «são melhor alcançados como líder de uma coligação ad hoc formada em torno de um objectivo específico... através da formação de coligações com nações que partilham os nossos princípios»; ou ainda a predisposição para «agir sozinhos quando esse é o curso mais vantajoso, ou não há alternativa» (referências do NSS, 1996: Cap. II). Além disso, mesmo atribuindo uma maior importância à relação segurança-desenvolvimento-direitos humanos e às «ameaças transnacionais», Clinton assumiria que «a mais provável

\footnotetext{
11 Este documento, também conhecido por Cox Report, descreve as actividades chinesas em busca de tecnologia de ponta e acusa Pequim de se envolver em actividades proliferantes e espionagem industrial.
} 
ameaça futura à nossa existência é... o recurso a armas de destruição em massa por um estado pária ou grupos terroristas» (1999).

Emergindo em contraposição à política Clintoniana, a Administração George W. Bush (2001-2009) sobrevaloriza o interesse nacional e a liderança mundial dos Estados Unidos como princípios orientadores, muito influenciada por 'políticos pensadores' que reapareceram em postos destacados ${ }^{12}$ e think tanks 'inspiradores' como o Project for the New American Century (PNAC). Por conseguinte, o Presidente W. Bush começou por cultivar mais as relações com os aliados regionais dos EUA do que o engagement com virtuais adversários. Por outro lado, inicialmente, o ímpeto desta Administração apontava para um certo "isolacionismo», perfilhando um envolvimento dos EUA nos assuntos mundiais e regionais muito selectivo e somente quando estivessem directamente em causa interesses americanos.

Os atentados terroristas do 11 de Setembro, contudo, ocorridos menos de oito meses depois de W. Bush ter tomado posse, levaram esta Administração Republicana a declarar a "Global War on Terror» (GWOT) (Bush, 2001) e a aprovar uma nova estratégia de segurança que, embora fosse abrangente, multidimensional e multi-instrumental, incluía vectores particularmente controversos: a possibilidade dos EUA efectuarem acções preemptivas (actos militares antecipatórios) "mesmo se a incerteza permanecer relativamente ao tempo e lugar do ataque inimigo» (The White House, NSS, 2002: Cap. V) consagrando, assim, a inovadora doutrina que muitos consideram de «guerra preventiva»; a intenção de montar coligações de vontade; e a predisposição para, se necessário, os EUA actuarem sozinhos.

Em nome da "guerra contra o terror», a Administração Bush remilitarizou a política externa americana, como demonstram o aumento das despesas militares dos EUA, ultrapassando os 4\% do PIB; as intervenções militares no Afeganistão (Outubro de 2001) e no Iraque (Abril de 2003); o abandono unilateral do Tratado ABM (2002); a pressão coerciva contra os Estados pária

12 De que se destacam, entre outros, o Vice-Presidente Dick Cheney, o Secretário da Defesa Donald Rumsfeld, o Secretário de Estado Collin Powell, o Deputy Defense Secretary Paul Wolfowitz, o Deputy Secretary of State Richard Armitage, a National Security Advisor e depois Secretária de Estado Condoleezza Rice, o Assistant Secretary of State for East Asia James Kelly ou o US Trade Representative Robert Zoellick. 
e regimes tiranos (sobretudo, Iraque, Irão e Coreia do Norte e, também, Sudão e Myanmar); a intensificação da cooperação militar, anti-terrorista e contra-proliferação de ADM com aliados e parceiros; a criação de novos diálogos e parcerias estratégicas; etc.. Paralelamente, todavia, também montou uma vasta série de novas "coligações de vontade»; 13 expandiu os laços económicos e comerciais bilaterais dos EUA através da celebração de múltiplos acordos, incluindo Trade and Investment Framework Agreements (TIFAs), Bilateral Investment Treaties (BITs), Free Trade Agreements (FTAs) e Generalized System of Preferences (GSP) para países considerados elegíveis; instigou 'revoluções coloridas' pro-democráticas; estabeleceu climate partnerships bilaterais (com 15 países e organizações, entre 2001 e 2008); e aumentou significativamente a Ajuda Pública ao Desenvolvimento (APD) de menos de 10 mil milhões USD, em 2000 para quase 27 mil milhões USD, em 2008, voltando a colocar os EUA na posição de maior doador mundial de APD desde 2001 - embora numa percentagem do PIB inferior a outros doadores e muito abaixo dos compromissos para os Objectivos do Milénio de $0.7 \%$ do PIB.

No contexto pós-11/09, a Ásia assumiu uma nova centralidade estratégica, para os EUA, propondo-se a Administração Bush manter "parcerias robustas apoiadas por uma postura de defesa avançada que apoia integração económica através da expansão do comércio e investimento e da promoção da democracia e direitos humanos» (NSS, 2006: Cap. VIII). Essa centralidade seria, aliás, visível, por exemplo, na reforma que a Administração iniciou no sentido de aumentar a coordenação na política asiática entre os Departamentos de Estado e da Defesa ou de reforçar as respectivas unidades asiáticas ou, e sobretudo, no apreciável reinvestimento americano na Ásia:

\footnotetext{
13 De que constituem exemplos as coligações montadas para as intervenções no Afeganistão e no Iraque e outras, muito mais amplas, para as subsequentes fases de estabilização; o Quarteto para o Médio Oriente (EUA, Rússia, UE e ONU), estabelecido em 2002; a Container Security Initiative (CSI), lançada em 2002; a Middle East Partnership Initiative (MEPI), no final de 2002; a Proliferation Security Initiative (PSI), em 2003; as Conversações a 6 sobre a Coreia, em 2003; a Global Initiative To Combat Nuclear Terrorism, em Julho de 2006; a Merida Initiative, em 2007, juntando EUA, México e países da América Central com vista a combater o narcotráfico, o crime transnacional e o terrorismo; a coligação para resolver a crise em torno do programa nuclear do Irão envolvendo, fundamentalmente, os EUA, o G3/UE (Reino Unido, França e Alemanha), a Rússia, a AIEA e a ONU (CS e Secretário-Geral).
} 
além do reforço da presença militar dos EUA em virtude das intervenções no Afeganistão e no Iraque, de envolver os aliados regionais nas suas iniciativas e coligações de vontade ou de tornar o Japão, a Coreia do Sul, as Filipinas, a Tailândia e a Austrália parceiros de contacto da OTAN, desenvolveu novas parcerias estratégicas, por exemplo, com a Mongólia (que contribuiu com mais de 1000 militares para as coligações no Iraque e no Afeganistão) ou com a Indonésia (maior país muçulmano do mundo e a quem Bush levantou totalmente as restrições à venda de armamentos, em 2005, que haviam sido impostas por Clinton, em 1999, para pressionar Jacarta a aceitar a autodeterminação timorense); aumentou a pressão contra os 'regimes tiranos' da Coreia do Norte e do Myanmar; promoveu, em 2003, as Conversações a 6 (EUA, China, Japão, Rússia, Coreia do Norte e Coreia do Sul) para gerir a crise em torno do programa nuclear norte-coreano); firmou novas áreas de comércio livre com Singapura e a Coreia do Sul - iniciando negociações para o mesmo fim com a Tailândia e a Malásia - e Trade and Investment Framework Agreements (TIFAs) com o Brunei, a Tailândia, a Malásia, o Camboja, a ASEAN e o Vietname; estabeleceu climate partnerships com o Japão, a Austrália, a China, a Coreia do Sul, a Índia e a Rússia; e reorientou o sentido da APD Americana, fazendo da Ásia a principal região destinatária acolhendo mais de metade do total - em vez de África.

Por outro lado, ainda que preservando como objectivos dos EUA «manter a força militar acima de qualquer desafio" e "moldar as escolhas de países atravessando momentos cruciais» (Bush, 2002), a Administração W. Bush mostrou-se particularmente activa no "desenvolvimento de agendas para acção cooperativa com outros centros fulcrais do poder global» com o propósito declarado de "promover um equilíbrio de poder favorável à liberdade» (NSS, 2002: Caps. I e VIII), incluindo a Rússia, a Índia e, sobretudo, a China em relação à qual abandonou a retórica inicial de rival estratégico para a incentivar a ser uma parte responsável nos assuntos mundiais.

Eleito numa lógica de ruptura com a política de W. Bush e num contexto profundamente marcado pela crise económica, as guerras assimétricas no Afeganistão e no Iraque e uma imagem desgastada dos EUA internacionalmente, o Presidente Barak Obama (desde Janeiro de 2009) já fez História ao tornar-se o primeiro negro a desempenhar o cargo e provocando uma onda 
de empatia e expectativas no mundo sem precedentes nos recém-empossados Presidentes dos EUA, juntando no seu Gabinete 'transpartidário' o que pode ser descrito como uma dream team mas também uma team of rivals. ${ }^{14}$

Os objectivos gerais e interesses definidos pela Administração Obama, conforme enunciados no mais importante documento publicado por esta Administração até agora, incluem

The security of the United States, its citizens, and U.S. allies and partners; A strong, innovative, and growing U.S. economy in an open international economic system that promotes opportunity and prosperity; Respect for universal values at home and around the world; and An international order advanced by U.S. leadership that promotes peace, security, and opportunity through stronger cooperation to meet global challenges (NSS, 2010: 6).

A fim de se demarcar da Administração predecessora, e fortemente influenciada por outros 'políticos pensadores' como Joseph Nye ou Richard Armitage, esta Administração proclama pautar-se pela conjugação de todos os instrumentos do poder americano, hard e soft, usando o chamado smart power: «temos de ter o que tem sido chamado smart power, o conjunto de todos os instrumentos à nossa disposição», nas palavras da Secretária de Estado Hilary Clinton (2009) na sua audição de confirmação no Congresso.

Paralelamente, baseado na convicção de que "O mundo partilha uma humanidade e segurança comuns», na recusa "da falsa dicotomia entre os nossos valores e a nossa segurança» e na predisposição «de ouvir e conversar com os nossos adversários de modo a promover os nossos interesses» (Obama/The White House-Foreign Policy), este Presidente proclama A New Strategy for a New World em que «O ponto de partida para essa acção colectiva será o nosso envolvimento com outros países» (The White House, NSS, 2010: 3). Mais, na nova estratégia, "Os EUA devem renovar a sua liderança mundial através da

${ }^{14}$ Efectivamente, o Executivo Obama inclui personalidades reputadas e influentes como Joe Biden, Vice-Presidente e seu antigo concorrente político; Hillary Clinton, Secretária de Estado e sua principal rival nas primárias do Partido Democrata; Robert Gates, que transitou da Administração Bush como Secretário da Defesa; Timothy F. Geithner, Secretário do Tesouro e antigo Presidente do Federal Reserve Bank of New York; ou Steven Chu, Secretário da Energia e galardoado Nobel da Física. 
construção e promoção de bases que nos fortaleçam e aumentem a nossa influência. A nossa segurança nacional depende da capacidade da América para usar os atributos nacionais únicos, tal como a segurança global depende de uma liderança Americana forte e responsável» (The White House, NSS, 2010: 6). O uso do smart power, o envolvimento alargado e a liderança mundial dos EUA, são, assim, pedras basilares da política externa de Obama: a ordem para encerrar a prisão de Guantanamo Bay, a retirada gradual do Iraque, a abertura para dialogar e estabelecer entendimentos com adversários tradicionais como Cuba, Venezuela, Myanmar ou Irão, a tentativa de colocar os EUA na liderança global da protecção ambiental e das energias renováveis, o empenho na concretização dos Objectivos do Milénio ou a surpreendente predisposição para os EUA liderarem um processo conducente a um «mundo livre de armas nucleares» (objectivo que muito contribuiu para que Obama fosse galardoado com o Prémio Nobel da Paz 2009) demonstram, na prática, essa tentativa de liderar pelo exemplo e a ruptura face à Administração americana anterior.

Em certos aspectos, porém, parece haver mais continuidade do que ruptura. Desde logo, ainda que expressando uma concepção de segurança abrangente e completa, Obama sublinha a importância da presença militar e das alianças dos EUA quer como factor de estabilidade nas várias regiões e no mundo quer como instrumento crucial na promoção dos interesses e valores americanos e, por outro lado, também enfatiza que «não há maior ameaça ao povo americano do que armas de destruição massiva, particularmente o perigo da procura deste armamento por extremistas violentos e a sua proliferação noutros Estados» (NSS, 2010: 4). Além disso, embora destacando "que o poder, num mundo interdependente, já não é um jogo de soma nula" (NSS, 2010: 3), esta Administração mantém-se empenhada no reforço de laços com o que denomina "outros centros primordiais de influência - incluindo a China, Índia e Rússia, bem como nações crescentemente influentes, como o Brasil, África do Sul, e Indonésia - de modo que podemos cooperar em temas de preocupação bilateral e global» (NSS, 2010: 3).

Relativamente à Europa, onde goza de grande empatia, esta Administração afirma que «a nossa relação com os nossos aliados europeus permanece central ao envolvimento dos EUA no mundo, e um catalisador de acção internacional» (NSS, 2010: 41), mantendo a Aliança Atlântica como principal 
quadro referenciador das relações transatlânticas, mas mostrando igualmente uma certa decepção que vinha de trás com os Aliados europeus por não contribuírem como os EUA desejam com efectivos para o Afeganistão. Obama mantém também a linha de apoio americano ao processo integrador da UE, incluindo o desenvolvimento da Política Comum de Segurança e Defesa (PCSD), bem como ao desenvolvimento dos laços OTAN-UE, ainda que em 2010 só tenha aceitado participar numa Cimeira EUA-UE fazendo-a coincidir com a Cimeira da OTAN a realizar em Lisboa, em Novembro. Por seu turno, esta Administração confirma a percepção de crescente centralidade da Ásia-Pacífico para os EUA: o primeiro líder estrangeiro recebido por Obama na Casa Branca foi o Primeiro-Ministro do Japão, Taro Aso; pela primeira vez em quase 50 anos, a primeira viagem oficial ao estrangeiro de um/a Secretário/a de Estado Americano, Hillary Clinton, foi à Ásia Oriental; e autodenominando-se "O primeiro Presidente do Pacífico» - recordando o facto de ter nascido no Hawai e de ter vivido na Indonésia quando criança -, Obama sublinhou na sua primeira visita oficial à região que os EUA são uma "nação do Pacífico" e que «temos interesse no futuro desta região, porque o que acontece aqui tem efeito directo nas nossas vidas» (Obama, 2009b).

Também no que concerne à China, esta Administração dá mostras de a continuar a encarar como central na política externa: o papel atribuído à China na recuperação da crise económica global ou na protecção ambiental faz as reuniões do G-20 parecerem antes um «G2+18»; na sua primeira viagem oficial à Ásia Oriental, em 2009, Obama passou três dias na China e apenas um no Japão, um na Coreia do Sul e outro em Singapura (na Cimeira da APEC). Aliás, mais claro não podia ter sido o Presidente Americano quando, na abertura do primeiro encontro U.S.-China Strategic and Economic Dialogue, em 27 de Julho de 2009, se referiu à relação EUA-China como «tão importante como qualquer outra relação bilateral no mundo» (Obama, 2009a). Similarmente, todavia, a Administração mantém a tradicional prática americana de ambivalência em relação às questões de Taiwan e do Tibete: poucos meses depois de reafirmar, em Pequim, que "Os EUA respeitam, a soberania e integridade territorial da China (...) e reafirmam o compromisso para com a política de "uma China'» (Obama, 2009a), Obama anunciou, no final de Janeiro de 2010, a venda de armamentos a Taiwan no valor de 6 
mil milhões USD e, no mês seguinte, recebeu o Dalai Lama na Casa Branca, satisfazendo pressões internas, mas irritando Pequim.

\section{Uma política «cocktail»}

É famosa a observação atribuída a Lord Salisbury segundo a qual «O mais comum erro político é manter-se preso a carcaças de políticas mortas». Esta tendência parece evidenciar-se na estratégia dos Estados Unidos na nova ordem uma vez que, apesar das diferenças entre as sucessivas Administrações, todas preservaram uma robusta presença militar americana no estrangeiro (incluindo a OTAN na área euro-atlântica e o Sistema de São Francisco na Ásia-Pacífico) como primeira fonte da proeminência americana e da segurança e estabilidade internacional e, por outro lado, reorientaram até certo ponto o containment para a China. Neste sentido, os EUA comportam-se como uma potência status quo.

Estes vectores representam, contudo, apenas parte de uma estratégia global americana muito mais vasta e diversificada. Efectivamente, a fim de promoverem os seus objectivos e de maneira a ultrapassarem os seus dilemas, internos e externos, os EUA vêm implementando uma autêntica estratégia cocktail que consiste, genericamente, numa amálgama de várias políticas e estratégias:

a) hub and spokes - posicionando-se no centro do sistema coordenando as actividades e interacções dos outros actores e surgindo como a nação indispensável e líder na gestão dos assuntos locais, regionais e globais;

b) primacy - empregando todos os instrumentos do seu poder, hard e soft, no sentido de garantir a hegemonia e a liderança global;

c) containment - contendo a ascensão, o poder e a influência de outras potências para um nível que possa representar uma ameaça à supremacia americana e, sobretudo, opondo-se à reemergência de uma potência virtualmente rival (em particular, a China) e/ou à criação de um eixo estratégico hostil (eventualmente, envolvendo a China, Rússia e Índia mais o Irão, Myanmar e Coreia do Norte);

d) engagement - mantendo-se sempre envolvidos na generalidade dos assuntos e organismos regionais e cultivando laços quer com aliados e 
parceiros, quer com virtuais rivais. Ainda, variantes desta como o selective engagement, seguindo uma ordem de prioridades estabelecida com base nos interesses nacionais americanos e nos desafios e oportunidades mais relevantes, e o comprehensive engagement, pretendendo que esse envolvimento seja abrangente, completo, multi-instrumental e multi-dimensional;

e) balancing - procurando manter os equilíbrios geopolíticos regionais balanceando, em particular, a Rússia pós-soviética e, sobretudo, a rápida e poderosa ressurgência da China, com base nas parcerias e capacidades tanto americanas como dos seus aliados e parceiros e promovendo o estatuto e o papel de actores 'contra-peso' como a UE (Reino Unido, Alemanha, Itália, Polónia, Países Bálticos, Ucrânia, Geórgia, etc.), o Japão, a ASEAN, a Coreia do Sul, a Índia e a Austrália. Ciclicamente, praticando a variante off-shore balancing, aceitando a ascensão de outras potências e mantendo um relativo distanciamento que torne possível limitar a sua intervenção apenas a situações em que os interesses vitais americanos estejam directamente postos em causa;

f) enlargement - promovendo a expansão do liberalismo económico, democracia e estado de direito, comércio livre, direitos humanos, segurança humana, enfim, valores universais confundidos, frequentemente, com valores americanos;

g) carrot and stick - recompensando ou punindo determinadas condutas de outros Governos, através de incentivos às boas práticas com reconhecimento político e ajuda económica segundo critérios prévios de elegibilidade, ou impondo/ameaçando impor sanções e medidas restritivas e até dispondo-se à intervenção militar; e

b) grand facilitator - arbitrando e mediando as relações regionais mais sensíveis, gerindo disputas, crises e conflitos e promovendo interdependências e cooperações regionais e inter-regionais.

\section{Considerações finais}

Os EUA recorrem a todos os elementos dos seus hard power e soft power, combinando o enunciado smart power, desde as capacidades e om- 
nipresença militares à ajuda ao desenvolvimento, passando pela influência política, diplomática e económica, o auto-proclamado 'exemplo moral' ou ainda utilizando o seu dispositivo militar em missões de soft power - auxílio humanitário e ajuda de emergência em resposta a catástrofes naturais, por exemplo. Utilizam também todos os canais possíveis, procurando que se complementem o unilateralismo, o bilateralismo, o trilateralismo e o multilateralismo, tanto institucionalizado como ad hoc e quer intergovernamental quer não-governamental ou track 2, apoiando ainda os esforços tendentes à construção das comunidades Americana, Transatlântica e do Pacífico desde que, naturalmente, englobem os próprios EUA. Onde todas as Administrações Americanas se têm mostrado mais reticentes é, ao contrário do que fazem no teatro europeu, na institucionalização da segurança multilateral tanto no Continente Americano como, sobretudo, na Ásia-Pacífico, receando que isso possa reduzir a centralidade do sistema americano de alianças e parcerias bilaterais e, logo, o papel e o estatuto regional dos EUA.

A 'estratégia cocktail' Americana é ainda o resultado do chamado hedging, baseado numa postura que além de ser cautelosa, difusa, omni-direccional e multi-instrumental contempla ainda outras duas características essenciais, a flexibilidade e o pragmatismo, presentes em todas as Administrações Americanas na nova ordem. A Rússia e, em particular, a China são, naturalmente, os objectos centrais do hedging americano.

Finalmente, o idealismo/messianismo e a realpolitik são dois traços que se combinam na política externa dos EUA, exemplarmente expressos numa alocução do então Conselheiro para a Segurança Nacional da Administração Clinton, Anthony Lake (1993): «temos de promover liberdade no mundo (...) porque esta reflecte valores que são Americanos e universais (...) apenas um factor fundamental pode determinar se os EUA devem actuar de modo multilateral ou unilateral, e esse são os interesses americanos (...) A questão simples em cada momento é: o que funciona melhor?». 


\section{Questões para análise}

De que forma o sistema político Americano condiciona a política externa Americana?

Explique em que consistiu e como foi implementada a política de containment dos EUA durante a Guerra Fria.

Analise as principais diferenças e similitudes em matéria de política externa entre as várias Administrações Americanas nas duas últimas décadas.

Enuncie as razões que justificam a aparente crescente centralidade da Ásia- Pacífico na política internacional dos EUA.

\section{Fontes na internet}

Casa Branca, www.whitehouse.gov

Departamento de Estado, www.state.gov

Missão EUA na ONU, http://www.usunnewyork.usmission.gov/

Departamento de Defesa, www.defenselink.mil

The American Presidency Project, University of California, http://www. presidency.ucsb.edu/index.php

The National Security Archive, http://www.gwu.edu/ nsarchiv

\section{Leituras recomendadas}

Fukuyama, Francis (2006) Depois dos Neoconservadores. A América na Encruzilhada. Lisboa: Gradiva.

Jentleson, Bruce W. (2010) American Foreign Policy: The Dynamics of Choice in the 21st Century ( $4^{\mathrm{a}}$ ed). Nova Iorque: W. W. Norton \& Company.

Kissinger, Henry (2003) Precisará a América de uma Politica Externa? Uma Diplomacia para o Século XXI. Lisboa: Gradiva.

Nye, Joseph S. (2002) The Paradox of American Power: Why the World's Only Superpower Can't go It Alone. New York: Oxford University Press.

Rochester, J. Martin (2007) US Foreign Policy in the Twenty-First Century: Gulliver's Travails (Dilemmas in World Politics). Boulder: Westview Press. Tomé, Luís (2004) Novo Recorte Geopolítico Mundial. Lisboa: EdiUAL, Quid Juris. 


\section{Bibliografia}

Bush, George (1990) "Address Before the 45th Session of the United Nations General Assembly in New York", in Wooley, John e Peters, Gerhard (org) The American Presidency Project. Santa Barbara: University of California.

Bush, George (1991) "Address to the 46th Session of the United Nations General Assembly in New York City", in Wooley, John e Peters, Gerhard (org) The American Presidency Project. Santa Barbara: University of California.

Bus, George W. (2001) "Address before a Joint Session of the Congress on the United States Response to the Terrorist Attacks of September 11", in Wooley, John e Peters, Gerhard (org) The American Presidency Project. Santa Barbara: University of California.

Bush, George W. (2002) «Commencement Address at the United States Military Academy in West Point, New York", in Wooley, John e Peters, Gerhard (org) The American Presidency Project. Santa Barbara: University of California.

Clinton, Hillary (2009) Statement of Senator Hillary Rodham Clinton Nominee for Secretary of State. Foreign Relations Committee, Washington: US Senate Committee on Foreign Relations, 13 Janeiro. [http://foreign.senate.gov/testimony/2009/ClintonTestimony090113a.pdf].Clinton, William J. (1999) "Remarks to the 54th Session of the United Nations General Assembly in New York City", in Wooley, John e Peters, Gerhard (org) The American Presidency Project. Santa Barbara: University of California.

Fukuyama, Francis (2006) Depois dos Neoconservadores. A América na Encruzilhada. Lisboa: Gradiva. Kennan, George F. («») (1947) "The Sources of Soviet Conduct», Foreign Affairs, 25(4), 566-582.

Kissinger, Henry (1996) Diplomacia. Lisboa: Gradiva.

Lake, Anthony (1993) "From Containment to Enlargement", Remarks at the Johns Hopkins University, School of Advanced International Studies, Washington D.C., 21 Setembro. [http://www.mtholyoke. edu/acad/intrel/lakedoc.html].

Nixon, Richard (1969) "Address to the Nation on the War in Vietnam", Washington D.C., 3 Novembro. [http://www.presidency.ucsb.edu/ws/index.php?pid=2303].

Nye, Joseph S. (2002) The Paradox of American Power: Why the World's Only Superpower Can't go It Alone. New York: Oxford University Press.

Obama, Barak (2009a) "Remarks at the United States-China Strategic and Economic Dialogue», in Wooley, John e Peters, Gerhard (org) The American Presidency Project. Santa Barbara: University of California.

Obama, Barak (2009b) "Remarks in Tokyo, Japan, November 14», in Wooley, John e Peters, Gerhard (org) The American Presidency Project. Santa Barbara: University of California.

Obama, Barak / The White House (s/d) "Issues - Foreign Policy». [http://www.whitehouse.gov/ issues/foreign-policy].

Reagan, Ronald (1985) "Address before a Joint Session of the Congress on the State of the Union", in Wooley, John e Peters, Gerhard (org) The American Presidency Project. Santa Barbara: University of California.

The New York Times (1992) «Excerpts from Pentagon's Plan: Prevent the Re-Emergence of a New Rival", The New York Times, 8 Março.

The White House (1991) «National Security Strategy of the United States», Washington, D.C.

The White House (1996) «A National Security Strategy of Engagement and Enlargement, Washington, D.C..

The White House (1999) "A National Security Strategy for a New Century», Washington, D.C..

The White House (2002) «The National Security Strategy of the United States of America», Washington, D.C..

The White House (2006) "National Strategy for Combating Terrorism», Washington, D.C..

The White House (2006) "The National Security Strategy of the United States of America», Washington, D.C..

The White House (2010) «The National Security Strategy of the United States of America», Washington, D.C.. 


\section{CAPÍtuLO 6}

\section{FEDERAÇÃO RUSSA}

Este capítulo traça as principais linhas de política externa da União das Repúblicas Socialistas Soviéticas (URSS) e depois da Federação Russa, identificando linhas de decisão e actuação em contextos diferenciados que se revelam fundamentais para a compreensão das suas dinâmicas de política externa. O texto segue um alinhamento histórico dado o processo de transição que a desagregação da URSS pressupôs e as implicações em matéria de política externa que o final da Guerra Fria e a redefinição geográfica, política e socioeconómica da Rússia exigiram.

\section{Processo de formulação e decisão em política externa: centralismo} e autoridade

Na URSS o processo de formulação e decisão de política externa estava concentrado nos líderes do Partido Comunista, sendo que o governo apenas ratificava as decisões aí tomadas, conferindo-lhes legitimidade. O papel dos líderes foi sempre fundamental na União Soviética e na Rússia pós-soviética dado o carácter dirigista do sistema, como analisado. O contexto de Guerra Fria e o modelo ideológico de base à política Marxista-Leninista condicionavam fortemente a política externa, bem como as políticas domésticas, assentes em princípios de centralismo e autoridade. O centralismo dirigista inerente ao modelo permitia um processo de decisão e implementação 
unificado, prosseguindo o interesse da União num cenário de nenhuma abertura a críticas ou pressões anti-linha do Partido. A militarização da Guerra Fria constituiu um factor determinante na orientação das políticas do país no contexto bipolar. Com o final da Guerra Fria a política externa altera-se radicalmente dada a alteração profunda quer a nível interno, com a desagregação do bloco soviético e a redimensionação da área pós-soviética, quer externo, com o final da bipolaridade que havia caracterizado a ordem internacional por mais de cinco décadas. A nova Constituição da Federação Russa institucionaliza as principais competências em matéria de política externa no presidente, apoiado por uma estrutura burocrática, onde as elites vão alcançar influência substancial.

A política externa russa é essencialmente da responsabilidade do presidente, incumbido da definição das linhas de actuação de base subjacentes ao posicionamento da Federação Russa nos assuntos internacionais (The Constitution of the Russian Federation, 1993, art.80). O executivo está encarregue da implementação da política externa (ibid, art.114), sob supervisão presidencial, especialmente no contexto de governação centralizada existente. De facto, este é um dos elementos de continuidade mais vincado, a par do peso histórico da 'grande Rússia', como factor determinante na orientação das suas políticas.

A institucionalização do ruling vertical (autoridade vertical), termo cunhado pelas elites russas para designar um sistema de governo hierárquico assente em princípios de subordinação e num papel de domínio do ramo executivo (Shevtsova, 2005: 7), com apoio da elite política próxima do Presidente, tem assegurado controlo político e social na Rússia pós-soviética. Os lobbies económicos e na área da segurança e defesa, essencialmente, têm-se confundido nos meandros dos grandes grupos económicos estatizados ou quasi-estatizados. Quanto a grupos de pressão e opinião, estes têm tido expressão limitada num contexto de governação centralizada, onde o activismo cívico se mantém sob escrutínio apertado das autoridades. De facto, o controlo de actividades e vozes dissidentes, práticas comuns nos tempos dos czares e sob o regime Soviético, são nos dias de hoje comuns na Rússia. "A Rússia é ainda melhor explicada por uma rede de relações clientelistas e patrimonialistas. Esta é uma das razões pelas quais a Rússia 
pós-Soviética tem tanta dificuldade em gerar o seu próprio sentido de comunidade cívica» (Hosking, 2003: 10).

O processo de construção identitária ainda em curso na Rússia, e cujas influências europeias e asiáticas são historicamente conhecidas, tem marcado a própria delineação da política externa, onde a tensão entre as dimensões ocidental e oriental tem sido visível, em particular no período pós-Guerra Fria. A consubstanciação da identidade russa pós-soviética passa não só pela linhagem sociológica europeia ou asiática, mas também pela identificação ideológica já não soviética de orientação comunista, mas também não democrática no entendimento ocidental, o que tem implicado o desenho de uma identidade muito própria - uma nova identidade num contexto diferenciado. As divisões internas na Rússia, com os Euro-Atlantistas a favorecer ligações mais próximas aos Estados Unidos da América e Europa, os Eurasianistas a olharem o cenário a leste para alianças estratégicas, incluindo a China e Índia, e a estratégia nacionalista a centrar-se no quadro interno, procurando a afirmação do poder russo com base no legado imperial do país, na sua força política, influência e recursos económicos, mostram, de forma simplificada, a multi-dimensionalidade do discurso de política externa (ver Porter, 1996: 121; Lowenhardt, 2000: 167-174).

Deste modo, a política externa, bem como as políticas internas, conjugam-se numa lógica de articulação multi-nível, com heranças importantes e padrões de formulação e decisão de política externa que se vão ajustando quer a contextos quer a momentos, como analisado nas próximas secções.

\section{O período soviético}

Os primeiros anos da Guerra Fria foram marcados por uma crescente desconfiança entre os dois blocos, prosseguindo políticas de desenvolvimento assentes em pressupostos antagónicos: o capitalismo ocidental versus o comunismo soviético. Além do mais, eram notórios os esforços de salvaguarda de influências externas de áreas de interesse, em particular no que toca a Europa Central e de Leste, definida como central na estratégia hegemónica soviética, que entendia a presença dos EUA na Europa como uma ameaça às 
suas ambições. O factor ideológico tornou-se um elemento fundamental nas políticas soviéticas, expresso em políticas sociais, económicas e de segurança, revelando o carácter co-constitutivo das dimensões doméstica e externa. As acções de Estaline contra movimentos comunistas alternativos, como na China e Jugoslávia, constituem sinal da ameaça que a instabilidade externa podia causar, bem como um reconhecimento das fragilidades do bloco soviético, incluindo em termos económicos. Isto resultou na redução de contactos com o mundo ocidental, e proporcionou uma postura fechada e introspectiva, melhor capaz, de acordo com Estaline, de responder à necessidade de projecção de uma imagem de força da União Soviética, independentemente dos seus problemas internos. E, neste contexto, o desenvolvimento de capacidades militares e o redireccionamento de recursos económicos para o esforço de militarização eram ilustrativos da estratégia de afirmação no contexto bipolar. Além do mais, em finais dos anos 1940, as acções soviéticas manifestavam já a sua vontade de manter controlo sobre uma área alargada, bem para além dos estados satélite. A Guerra da Coreia (1950-1953) é disso exemplo, com a máquina ideológica soviética a fornecer incentivos para a ofensiva de Ho Chi Minh na Indochina contra os franceses. Estas acções faziam parte de um entendimento mais lato de que a angariação de apoios para a causa ideológica conferiria poder e estatuto adicional à URSS na sua lógica de afirmação e expansão global. Estaline apoiou o líder da Coreia do Norte Kim Il Sung nos seus esforços de fortalecer o controlo da República Democrática da Coreia e eventualmente alargar o seu poder à República da Coreia (sul), deste modo fazendo pressão sobre a área de influência norte-americana. O resultado deste envolvimento não foi bem sucedido, e as lições aprendidas desta experiência demonstraram a verdadeira possibilidade de confrontação armada entre dois grandes poderes nucleares, mas também que os seus líderes podiam optar pela contenção (Gaddis, 2005: 61).

O mandato de Khrushchev, que se sucede a Estaline, com o prosseguimento da 'des-Estalinização' vai marcar um novo curso na política soviética, com início em 1956, contra o 'culto da personalidade' e os procedimentos internos de colectivização forçada. Isto significou uma nova direcção nas políticas soviéticas que implicou não só a definição de novos objectivos económicos, mas também uma abordagem política diferenciada resultante 
também do posicionamento pós-Coreia. Esta nova abordagem definiu a "Coexistência pacífica» como o reconhecimento da capacidade de destruição nuclear mútua (Sakwa, 1998), e o entendimento de que o conflito violento entre capitalismo e comunismo deveria ser substituído por confrontação económica e ideológica. O objectivo soviético era alcançar e ultrapassar o poderio económico norte-americano nos anos 1980, o que lhe permitiria prosseguir o objectivo ideológico de expansão comunista.

Procurando contrapor o poder e influência do bloco ocidental, em Maio de 1955 foi criada a Organização do Pacto de Varsóvia como contrapeso à Aliança Atlântica (OTAN). Esta estrutura militar centrada na União Soviética, incluía estados satélite como a Albânia, Bulgária, Checoslováquia, Hungria, Polónia e Roménia. Seguia uma estrutura de comando unificada sob controlo de Moscovo, e tornou-se uma extensão das forças militares soviéticas na sua área de influência de modo a desempenhar funções várias, incluindo o monopólio incontestado sobre as forças do Pacto, competição relativa quanto à representatividade militar dos estados membros, e legitimação da presença de tropas soviéticas nos territórios dos estados membros do Pacto. A criação desta estrutura também pretendeu enviar um sinal ao bloco ocidental relativo às capacidades militares soviéticas, enquanto simultaneamente procurando uma resposta estrutural aos receios da URSS relativamente a perda de controlo face a dinâmicas de contestação internas, incluindo centralização económica, comando militar e estratégias de controlo. Esta tensão sublinha as dificuldades enfrentadas no seio do bloco, mas é também reveladora da forma como os líderes soviéticos entendiam estas como limitando a sua capacidade para actuar globalmente.

Contudo, a década de 1950 foi marcante em termos científicos e tecnológicos. Neste período é registado o desenvolvimento da primeira bomba termo-nuclear, de mísseis balísticos inter-continentais, e de tecnologia espacial avançada com o lançamento do Sputnik, o primeiro satélite artificial. Estes avanços tecnológicos, apesar dos vários falhanços das experiências de colectivização e da excessiva concentração na produção industrial pesada, conferiram à liderança soviética confiança para prosseguir um papel activo dentro e fora da sua área de influência. O sucessor de Khrushchev, Leonid Brejnev, cunhou a denominada Doutrina Brejnev, espelhando esta realidade 
de um envolvimento mais activo. A União Soviética actuaria face a qualquer tentativa de minar o poder central de Moscovo, fosse através de tentativas de mudança revolucionária do regime ou quaisquer esforços para abandonar o bloco (Checoslováquia, Hungria e Polónia, ver d'Encausse, 1983: 159-218). Deste modo, e apesar do registo de autonomia constante dos estatutos da União, os estados do bloco não poderiam desafiar a liderança em termos ideológicos ou materiais, nem a abordagem soviética centralizada à governação das diferentes regiões. A doutrina foi alargada para além dos estados satélite, como demonstrado na intervenção soviética no Afeganistão em 1979. Contudo, Moscovo confrontou-se com uma China desconfortável com a leitura ideológica soviética, resultando em interpretações diferenciadas da via para o comunismo, e no diferendo ideológico sino-soviético de finais da década de 1950, inícios dos anos 1960.

A União Soviética procurou reposicionar o seu estatuto de grande potência na década de 1970 após problemas no seio do bloco e a tensão que marcou a década de 1960, com a construção do Muro de Berlim, e em particular a crise dos mísseis de Cuba (1962). A elevada tensão resultante da crise chamou a atenção para a necessidade de uma nova estratégia face ao reconhecimento da destruição mútua assegurada, e a insegurança associada a esta capacidade militar deu lugar ao diálogo, que por seu turno permitiu passos concretos na negociação de acordos de limitação de armamento. Exemplos incluem o Tratado de Interdição Parcial de Testes Nucleares (1963), o Tratado de Não-Proliferação de Armas Nucleares (1968), e o Acordo de Limitação de Armas Estratégicas (1972), que iniciou as conversações SALT (Strategic Arms Limitation Talks). Estes desenvolvimentos são ilustrativos de dois aspectos fundamentais: por um lado, a necessidade de condições domésticas favoráveis para avançar os objectivos de política externa, sublinhando o reconhecimento da parte dos líderes soviéticos da existência de constrangimentos internos; e por outro, o entendimento de que para manter o reconhecimento internacional desejado, a URSS precisava abrir-se e demonstrar capacidade de diálogo face ao exterior, de modo a alterar a sua imagem de poder iliberal.

Neste contexto de détente, em 1975 foi assinada a Acta Final de Helsínquia que estabeleceu a Conferência sobre Segurança e Cooperação na Europa (CSCE) 
(HFA, 1975). O objectivo deste organismo político era fomentar o diálogo entre os dois blocos, com contactos diplomáticos a alcançar um nível substancial na altura, e permitindo um fórum de contacto que apesar da sua estrutura informal e das suas reuniões com periodicidade indeterminada, fazia a ponte entre o leste e o ocidente. Mas rapidamente o contexto se deteriorou e na década de 1980 não houve cimeiras bilaterais URSS-EUA, estes últimos não participaram nos Jogos Olímpicos de Moscovo de 1980 e, em 1984, foi a vez dos soviéticos boicotarem a sua participação nos Jogos de Los Angeles. Em meados da década de 1980, não só os conflitos políticos se adensavam, mas também a situação da economia soviética se tornava insustentável. A guerra no Afeganistão, desfavorável aos soviéticos, ainda pressionou mais recursos parcos: «entre 1986 e 1990 o défice enquanto parte do PIB da União Soviética oscilava entre $5.7 \%$ e 9.1\%, atingindo 12-14\% em 1991" (Kaufman e Hardt, 1993: 47). A conjugação de vários factores apontava para a necessidade de reformas estruturais, que Gorbachev encabeça e cujo desfecho, para além do esperado, leva à desagregação da URSS e ao fim da rivalidade bipolar.

\section{A política externa em transição e a delineação da nova Rússia}

Mikhail Gorbachev foi um político central na transformação da União Soviética após o desencanto dos anos de Leonid Brezhnev, e das curtas lideranças de Yury Andropov e de Konstantin Chernenko (1982-1985). Gorbachev concentrou-se no processo de mudança que entendia como necessário à modernização e crescimento da URSS (Sakwa, 1998: 72, 7576). Contudo, as políticas da reestruturação (perestroika) da economia, de aceleração (uskorenie) e de abertura (glasnost), indicando um curso reformista que visava a transformação política e o desenvolvimento económico, quer a nível interno quer na política externa, não foram capazes de alterar práticas profundamente enraizadas, afastando-se dos seus objectivos iniciais.

A política externa de Gorbachev reflectia o seu curso reformista a nível interno, acompanhado pela vontade de aproximação ao ocidente, em termos externos. Esta política de aproximação ao ocidente foi expressa em medidas concretas, como a assinatura em Dezembro de 1987 com os EUA do Tra- 
tado sobre Forças Nucleares de Alcance Intermédio; o anúncio da retirada soviética do Afeganistão em 1988; e uma política de abertura e proximidade ao leste. Internamente, qualificou o sistema económico socialista e o papel de gestão política operado pelo Partido Comunista como desadequados à nova realidade que a União experimentava.

Pôs assim em marcha os princípios da dimensão humana contidos na Declaração de Helsínquia de 1975 (incluindo, por exemplo, a promoção de liberdades civis e discussão pública), encontrando no entanto oposição do aparelho burocrático que claramente entendia estas medidas como ameaça à sua autoridade e poder, agravado pelos movimentos nacionalistas que por todo o espaço pós-soviético exigiam independência. Contudo, revelou-se tarefa difícil operacionalizar as reformas estruturais profundas a nível político e económico necessárias à consolidação do crescimento no seio da União. Como acelerador deste processo, Gorbachev procurou consolidar o seu poder, para que a sua capacidade de decisão e implementação fosse reforçada, mas foi incapaz de desenvolver a maior parte dos seus projectos reformistas face à crescente resistência com que se deparava - o aparelho do partido permaneceu um forte desafiador da perestroika.

No entanto, e apesar destes obstáculos, Gorbachev conseguiu levar a cabo reformas político-administrativas fundamentais, como o estabelecimento do Congresso dos Deputados do Povo em 1989, sob a sua liderança, e com maior poder de decisão que o Soviete Supremo. De facto, foi eleito um novo Soviete Supremo pelo novo Parlamento e Gorbachev conseguiu aqui reunir amplo poder, permitindo terminar com o monopólio do Partido Comunista da União Soviética enquanto única organização política legal. Gorbachev permitiu uma política externa diferente, mais democrática para com o leste - especialmente os estados-satélite desde a Segunda Guerra Mundial -, bem como mais flexível relativamente às repúblicas constituintes da URSS. Estas mudanças profundas permitiram o fim da Guerra Fria e conduziram à queda da URSS. "Foi Gorbachev que simbolizou a transcendência das revoluções progressistas e que assim permitiu à Rússia o regresso às políticas 'normais', um tipo de políticas que não incluía uma fronteira emancipatória. O sujeito da emancipação acabou por não ser o povo no sentido dos sujeitos soberanos da democracia, mas uma elite 
transformadora guiada pelos princípios de liderança e modernização das elites para as populações»(Sakwa, 2005: 272).

A queda da URSS teve implicações várias no reordenamento a diferentes níveis que se seguiu. Tratou-se do fim de uma ideologia unificada sustentada em princípios Marxistas-Leninistas que permitiam coesão social; implicou a perda de identidade, agregada durante décadas sob a planificação e governação centralizada do Partido Comunista; pôs em marcha um processo de transição para um modelo de governação que a Rússia nunca antes havia experimentado; alterou fronteiras e exigiu redefinição de relações com uma vizinhança instável, lado a lado com a redefinição do papel e lugar da Rússia na Europa e no mundo. Este foi um processo de mudança complexo com impacto claro na definição de uma política externa diferenciada no contexto pós-Guerra Fria. A Federação Russa assumiu muitas das responsabilidades da extinta URSS, incluindo o controlo do arsenal nuclear soviético, bem como representações em fora internacionais, como as Nações Unidas, incluindo um lugar permanente no Conselho de Segurança.

Na Rússia da transição, a política externa reflectiu os constrangimentos que as políticas russas enfrentavam internamente. Muitas das dinâmicas até então reprimidas surgem agora de forma desarticulada, revelando os limites inerentes ao processo burocrático centralizado que havia vigorado durante décadas. O pluralismo associado ao modelo democrático em experimentação revelou-se sinónimo de pressão e desordem. A incapacidade de estruturação de princípios delineadores assentes em processos discutidos e plurais, acabou por levar à tendência de centralização dos processos de decisão e implementação de políticas, incluindo a política externa, e a um crescente autoritarismo, claramente visíveis na Rússia de hoje.

\section{A primeira década pós-Guerra Fria: Boris Ieltsin}

Boris Ieltsin chegou à política sob anuência de Gorbachev na altura em que o último se tornou presidente da URSS (1985). Apesar de uma trajectória sinuosa, em 1989 foi eleito para o Congresso dos Deputados do Povo e tornou-se mais tarde Presidente do Parlamento russo. Nesta altura, 
Ieltsin e Gorbachev prosseguiam objectivos incompatíveis, com o primeiro a enfrentar hostilidade interna para com medidas que se revelaram difíceis e não recompensadoras, e o último a criticar duramente Gorbachev por actuar lentamente na reforma do sistema, exigindo um ritmo mais acelerado e medidas mais resolutas. Face à situação de tensão vivida, agravada pela sucessão de declarações de independência de antigas repúblicas, foi convocado um referendo para aferir sobre o futuro da União enquanto federação de repúblicas soberanas igualitárias, cujo resultado foi favorável à preservação da URSS enquanto entidade agregadora, mas não aglutinadora, das diferentes repúblicas. Na Rússia uma outra questão foi colocada a escrutínio: se a eleição Presidencial se devia manter como processo selectivo e fechado, ou ao invés, decorrer a nível nacional com participação alargada das populações.

O referendo da União de Março de 1991 foi favorável a eleições presidenciais directas, que culminaram na vitória de Boris Ieltsin, marcando claramente o descontentamento generalizado com o processo de transição iniciado por Gorbachev. A tentativa falhada de golpe de estado em Agosto de 1991, criticando os falhanços da perestroika e glasnost, sinalizava então uma União Soviética fragmentada que oficialmente cessou a sua existência a 25 de Dezembro.

Dias antes, a 8 de Dezembro de 1991, foi criada a Comunidade de Estados Independentes (CEI) por um acordo assinado entre a Rússia, Bielorrússia e Ucrânia, com base no princípio da igualdade soberana dos seus estados membros. O objectivo era constituir um mecanismo agregador que permitisse continuidade nas unidades constituintes da União Soviética, agora sob uma nova designação. Contudo, a criação da CEI não evitou que as repúblicas seguissem o seu próprio curso, independentemente da sua adesão à nova organização. Actualmente, a CEI, bastante fragilizada no que toca o nível de coesão interna, é essencialmente um fórum de diálogo.

Eleito como a nova face da reforma, Ieltsin não foi bem sucedido no processo de transição democrática, tornando-se progressivamente dependente e ávido de poder, centralizando autoridade e deixando pouco espaço de manobra para visões alternativas em formação na nova Rússia. Apesar de acordo quanto ao pacote alargado de reformas necessárias, quer a nível institucional quer económico e social, a transição de um modelo de organização e desenvolvi- 
mento socialista, planificado e centralizado, não foi simples. A privatização de empresas russas, entendida como forma de invalidar o regresso a um sistema comunista, beneficiou essencialmente a elite próxima de Ieltsin. "Os velhos oficiais soviéticos apoiavam enfaticamente [Ieltsin] enquanto tomavam conta de bens públicos - desde o pequeno comércio à indústria petrolífera -, e se transformavam em capitalistas ao mesmo tempo que a inflação dizimava os rendimentos da população comum» (Daniels, 2008: 33). A nível externo, os críticos da postura europeísta promovida por Gorbachev apelaram a um enfoque da política externa na Eurásia, enquanto os nacionalistas pressionaram para a concentração das decisões políticas nas questões internas, para que a Rússia pudesse reunir condições económico-sociais e políticas essenciais à sua projecção externa de forma sustentada no que era definido como o seu «estrangeiro próximo», leia-se espaço pós-soviético.

Os primeiros anos de governação são conhecidos como período romântico quando boas relações com o ocidente são privilegiadas e é prosseguida uma política de não-ingerência no espaço pós-Soviético. A Doutrina Sinatra - «I'll do it my way» - permitiu às antigas repúblicas consolidarem o seu curso de independência, muitas das quais pela primeira vez, dado que apesar da autonomia que formalmente gozavam no quadro da União, esta equivalia na realidade a uma relação de submissão face ao poder central do Partido Comunista em Moscovo. A definição da Rússia como aliado natural da Europa será evidenciada na procura de integração em instituições ocidentais, solicitando a adesão ao Conselho da Europa (concretizada em Fevereiro de 2006), aderindo à Parceria para a Paz no contexto da OTAN (Junho de 1995), e aprofundando relações com a Comunidade Europeia, com base na assinatura do Acordo de Parceria e Cooperação (APC) de 1994 (apenas ratificado em 1997), a par do estreitamento de relações com Washington. No entanto, a esperada ajuda financeira internacional chegou tardiamente e revelou-se insuficiente, sendo que a condicionalidade associada acabou por gerar sentimentos anti-ocidentais e uma exigência interna de mudança, essencialmente promovida pelos grupos nacionalistas e comunistas. As críticas sobre a ingerência ocidental nos assuntos russos, em particular no que toca o tratamento das minorias russas fora do país (leia-se espaço pós-soviético), aumentaram o descontentamento e levaram as autoridades de 
Moscovo a adoptarem uma política mais interventiva. Note-se, no entanto, o cariz reactivo desta opção.

Na sequência destes desenvolvimentos, Ieltsin aprovou um novo conceito de política externa em Abril de 1993, reflectindo já o tom reactivo ao crescente desencanto com a opção ocidental e aos baixos benefícios resultantes dessa, levando à equação de democracia com caos, oportunismo e corrupção. A vizinhança próxima tornou-se foco de atenção de Moscovo, tendência esta que se manteve até aos nossos dias. Referências ao ex-espaço Soviético incluem o uso de expressões como «interesses vitalmente importantes», constituindo uma "primeira prioridade» e tornando-se de «importância fundamental», e reflectindo também uma política mais equilibrada entre ocidente e oriente.

... A Federação Russa, apesar da crise que atravessa, permanece uma grande potência em termos do seu potencial, da sua influência no curso dos acontecimentos mundiais e da responsabilidade que assume como resultado disso. É responsável não só pela nova ordem mundial que emergiu após o colapso do campo socialista, mas especialmente pela criação de um novo sistema de relações positivas entre os estados que faziam parte da União Soviética, oferecendo a garantia de estabilidade nestas relações (Foreign Policy Concept, 1993).

Mais tarde, em Novembro, Ieltsin anunciou o documento plasmando a nova doutrina militar russa, identificando as principais linhas de política militar, o cariz não ameaçador dos meios militares russos (nucleares e não nucleares), e a identificação de fontes de instabilidade existentes ou potenciais, bem como de eventuais ameaças. A doutrina afirma que os «interesses vitais da Federação Russa de modo algum colidem com a segurança de outros estados e são assegurados no quadro de relações interestaduais equitativas e mutuamente benéficas» (Russian Military Doctrine, 1993). O novo conceito de política externa e a doutrina militar reforçam o interesse nacional, a interconexão próxima entre a política e os militares, e a vontade de posicionar a Rússia enquanto actor fundamental nas relações internacionais.

A partir de 1993, e apesar das dificuldades associadas, o curso de reafirmação tornou-se claro na orientação política do Kremlin: reafirmar o papel 
da Rússia como actor influente, em particular em termos regionais. Este objectivo foi prosseguido através de influência e poder político, pressão político-económica e presença militar dissuasora no espaço pós-Soviético, para descontentamento de algumas destas repúblicas. Como garante da estabilidade na sua área de vizinhança, a Rússia assumiu-a como de interesse estratégico nacional onde ingerências externas não eram bem acolhidas. Desde 1995 esta abordagem consolidou-se, com a definição inicial de uma política externa multi-vectorial pelo Kremlin. Em meados dos anos 1990, a política externa russa encontrava-se traçada em torno de dois círculos principais: um círculo mais restrito revestido de primazia que incluía as repúblicas ex-soviéticas, e outro mais alargado, envolvendo o ocidente (Europa e EUA) e a Ásia, embora inicialmente não enquanto dimensões de relevância paralela, com a primeira a dominar a agenda. Até ao final da década pós-Guerra Fria esta tendência foi reforçada.

Após as eleições de 1995, Yevgeni Primakov, um líder pragmático, assumiu o Ministério dos Negócios Estrangeiros. Conhecido como o "Eurasianista», recalibrou a dimensão oriental como peça fundamental nos interesses de política externa russos. Procurou marcar também o descontentamento russo face a algumas políticas ocidentais, em particular a questão da OTAN. As relações tortuosas de maior ou menor proximidade ao ocidente, o relacionamento nem sempre fácil com as novas repúblicas independentes, e a prossecução do objectivo de reconhecimento da Rússia enquanto potência internacional marcaram os anos de Ieltsin, não pela sua capacidade de gestão de interesses e oportunidades, mas antes pela sua incapacidade de formulação e implementação de políticas coesas e claramente orientadas para os objectivos máximos da política externa russa, nomeadamente a promoção do interesse nacional.

\section{A política externa de Vladimir Putin e Dmitry Medvedev}

Enquanto presidente da Rússia entre 2000 e 2008, Putin definiu a política externa do país como multi-vectorial e multipolar. Os principais documentos adoptados no início do seu primeiro mandato sublinham o potencial desta- 
bilizador de uma «estrutura unipolar do mundo com o domínio económico e poder dos Estados Unidos», a CEI como área de importância estratégica e a dimensão leste (Ásia-Pacífico) como uma região relevante na política externa de Moscovo (National Security Concept 2000; Russian Military Doctrine 2000; Foreign Policy Concept 2000). Assim, a Rússia procura uma política externa equilibrada onde a procura de pólos múltiplos tem por objectivo diversificar aliados e permitir a alteração de relações privilegiadas numa procura constante de contra-peso e primazia. A fórmula multi-vectorial ganha nova dimensão com Putin.

O 11 de Setembro adicionou um novo elemento a este desenho da política externa: uma nova ordem internacional sob primazia dos Estados Unidos. Putin ofereceu o seu apoio à luta global contra o terrorismo, e as vozes críticas ocidentais face ao desrespeito pelos direitos humanos e liberdades fundamentais na Rússia, e em particular na República da Chechénia, foram quase silenciadas. Além do mais, a realização concreta de que a Rússia não podia fazer muito face a desenvolvimentos inevitáveis, como o alargamento da UE e da OTAN, levaram a que a Rússia alterasse o seu discurso. "As mudanças na política externa russa desde 11 de Setembro, assim, baseiam-se em cálculos de prioridade e interesse, onde o risco se distingue da ameaça e as necessidades reais estão separadas de falsas ambições» (Lynch, 2003: 29-30).

Com um olhar realista sobre o interesse nacional e as prioridades de política externa, o chamado "pragmatismo nacionalista" (Light, 2003: 48), a projecção de poder e curso afirmativo de Vladimir Putin assentam numa ordem interna estável e em crescimento económico derivado essencialmente das receitas do petróleo e gás natural. Como o Ministro dos Negócios Estrangeiros Sergei Lavrov afirmou, "a política externa russa hoje é tal que pela primeira vez na sua história, a Rússia está a começar a proteger o seu interesse nacional usando as suas vantagens competitivas» [geopolítica da energia] (RFE/RL, 2007). Contudo, o crescimento da Rússia entre 2000 e 2008 não escondeu as fragilidades que o país enfrenta face a um sistema económico demasiadamente dependente dos recursos energéticos, visíveis na crise do Outono de 2008. No entanto, um contexto interno favorável permitiu a Putin uma política externa assertiva no espaço CEI e para além deste, demonstrando o seu des- 
contentamento face a uma série de acontecimentos, como o alargamento da OTAN, o projecto de instalação de equipamentos relacionados com o escudo de defesa anti-míssil em território polaco e checo, ou as pressões da União Europeia para assinatura da Carta Energética, entendida como não coincidente com os interesses russos. A não renovação do APC no quadro das relações com a UE, e a retirada unilateral do Tratado sobre Forças Convencionais na Europa (Tratado CFE), são exemplo da demonstração de desagrado face a um conjunto de desenvolvimentos entendidos como hostis à projecção de poder e influência russos. Paralelamente, a consubstanciação da cooperação no âmbito da Organização de Cooperação de Xangai, com especial relevância para a China, incluindo a realização de vários exercícios militares, surge como factor de contenção da primazia norte-americana, não escondendo o mesmo tipo de exercício face à China. Formas várias de a Rússia prosseguir o seu curso de afirmação internacional, contestando de forma mais activa acções que entende como contrárias aos seus interesses. Uma postura mais assertiva a que Dmitry Medvedev vai dar continuidade.

A eleição de Dmitry Medvedev como presidente da Rússia (Março 2008), implicou linhas de continuidade aos alinhamentos de política externa definidos por Putin. Medvedev apresentou em Setembro de 2008 o que definiu como os cinco pressupostos de base que informam a política externa. Estes incluem o primado do direito internacional; uma ordem internacional multipolar, novamente sublinhando os limites da unipolaridade e o contra-peso à primazia norte-americana; uma política não confrontacionista e o não isolamento da Rússia através do prosseguimento de relações de amizade na Europa, EUA e com outros estados (note-se o contexto pós-guerra na Geórgia); a protecção dos cidadãos russos independentemente da localização das diásporas, mantendo o discurso nacionalista; e o reconhecimento de áreas de influência, nomeadamente as áreas de fronteira descritas como "regiões prioritárias» (Reynolds, 2008). Estes princípios estão expressos no documento de política externa de 2008, bem como têm tradução, num tom mais acutilante, na nova doutrina militar aprovada em Fevereiro de 2010 (Russian Military Doctrine, 2010; Foreign Policy Concept, 2008).

Medvedev trouxe ainda uma nova abordagem aos temas económicos. Uma mudança muito necessária, expressa numa política de diversificação 
de investimentos, e no desenvolvimento de outras áreas sectoriais (não-energéticas) de forma a ultrapassar uma excessiva concentração nos recursos energéticos. Esta excessiva dependência de um sector económico tornou a economia russa extremamente vulnerável, demonstrando a necessidade de ajustes estruturais para evitar flutuações inesperadas nos preços do petróleo e do gás, com consequências directas no desempenho e resultados da economia russa. Aliás, a política de investigação, inovação e desenvolvimento tecnológico tem sido referida como um novo vector na política externa russa, ao permitir não só a consolidação de desenvolvimentos internos, como também a promoção de cooperação com parceiros externos, em diferentes áreas sectoriais.

Estes princípios sintetizam as linhas fundamentais de política externa que se foram consolidando na Rússia pós-soviética, sublinhando no entanto questões fundamentais relativamente à guerra na Geórgia de Agosto de 2008, e em particular às leituras desta. A intervenção russa na Geórgia teve lugar num contexto internacional com contornos de dissensão claros, como referido. A Rússia aproveitou a oportunidade para demonstrar o seu descontentamento face a um conjunto de acções que descreveu como provocadoras, não só da parte da república da Geórgia, mas também e em grande medida, dos seus aliados ocidentais. Estas incluem, por um lado, um alinhamento de política externa na Geórgia pro-ocidental, reforçado após a revolução rosa, e cuja determinação sempre desagradou a Moscovo. Por outro lado, a possibilidade em discussão de alargamento da OTAN a países como a Geórgia e Ucrânia, os avanços do projecto de defesa anti-míssil e o bloqueio nas conversações para a renegociação do APC, com as discussões a seguirem um curso que a Rússia entende como contrário aos seus interesses, entre outros, pesaram na decisão. Com a intervenção armada na Geórgia, Moscovo demarcou as linhas relativas a áreas de influência e interferência, enfraquecendo uma Geórgia cujo curso pro-soviético de desalinhamento era há muito entendido como provocador; reforçando a sua política de contenção dos EUA na Eurásia; e sublinhando o seu reposicionamento no sistema internacional como grande potência. De facto, em 26 de Agosto de 2008, por decreto presidencial, Medvedev reconhece a independência das duas repúblicas, a Ossétia do Sul e a 
Abcázia, formalizando um status quo entendido como consonante com os interesses russos.

Apesar da radicalização da tensão nas relações com a Europa e os EUA após a intervenção armada na Geórgia, rapidamente as relações foram normalizadas quer nos contextos bilaterais quer no âmbito multilateral, com a retomada de conversações no quadro da UE relativamente a um novo documento refundador da parceria, quer no quadro da OTAN com a retomada das sessões do Conselho OTAN-Rússia. Esta normalização progressiva, enquadrada também na reset policy promovida pelo presidente Obama, tem dado lugar a um contexto mais favorável. A assinatura em Abril de 2010 do novo Tratado START, que vem substituir o Tratado de 1991, sobre redução de armas estratégicas, é demonstrativa de progresso. Os EUA e a Rússia combinados detêm cerca de $90 \%$ do arsenal nuclear mundial, pelo que o acordo relativo a uma redução nos arsenais nucleares, inspecções conjuntas e troca de informação, constitui um momento fundamental na construção de confiança. Apesar de pender ratificação, este é um primeiro passo de um longo caminho. A adicionar à dimensão nuclear, note-se que a anterior proposta de instalação de um escudo de defesa anti-míssil na Europa (Polónia e República Checa), como referido, foi revista pelo presidente Obama, que propõe a instalação de sistemas interceptores em navios de guerra norte-americanos no Mediterrâneo, com bases terrestres móveis eventualmente após 2015. Este será um tema debatido na Cimeira da OTAN em Lisboa, em Novembro de 2010, tendo sido a Rússia formalmente convidada a participar nas discussões. De novo, este tipo de entendimento e a presença do presidente russo na Cimeira da OTAN em Lisboa, constituem sinais de que a cooperação é possível, e de que certamente os discursos inflamados sobre uma nova guerra fria, acabaram mesmo por se revelar desajustados. No Outono de 2010, a política externa russa para com o ocidente segue linhas de cooperação, apesar de animosidade em temas difíceis, como mencionado, com espaço de diálogo aberto, sendo no entanto muito necessário assegurar que paralelamente a este aja também espaço para a transformação de percepções, pois só desse modo a consolidação das chamadas parcerias poderá assumir verdadeira substância. 


\section{Considerações finais}

A Rússia tem lutado internamente com ambiguidade, tentando lidar com uma evolução nas atitudes e um contexto doméstico e internacional mudado, enquanto procurando lidar com o seu passado histórico e as heranças de séculos de governação autocrática e estatuto imperial. Uma mistura de tendências que se revela nas actuações da Rússia, demonstrando as dificuldades que o estado tem enfrentado na definição da sua própria identidade, fundamental para justificar tendências, opções e atitudes. Estas dificuldades internas têm expressão a nível internacional. O curso afirmativo no cenário internacional é como o espelho da imagem doméstica da Rússia, de consolidação e afirmação de poder. As linhas de orientação de base da política externa russa pós-Guerra Fria têm-se pautado pela multi-vectorialidade, com a identificação de áreas prioritárias de actuação, e multipolaridade, na defesa de um sistema internacional multipolar onde a primazia dos EUA seja constrangida. O desejo de reconhecimento do seu estatuto enquanto grande potência tem estado na agenda, demonstrando a relevância e peso da história não só naquilo que a Rússia é hoje, mas também naquilo a que a Rússia aspira, quer em termos de consolidação doméstica, quer relativamente à sua projecção a nível internacional.

\section{Questões para análise}

De que forma o papel dos líderes tem condicionado/projectado a política externa soviética/russa?

Analise o binómio ideologia/pragmatismo na política externa soviética e russa.

Face a um espaço pós-soviético heterogéneo onde se jogam políticas muito diferenciadas, argumente quanto ao poder e influência russos actuais no espaço da Comunidade de Estados Independentes (CEI).

Rússia entre leste e oeste: gestão comprometida de interesses? Comente a política externa russa de Putin para com a União Europeia e os Estados Unidos/Aliança Atlântica (OTAN). 


\section{Fontes na internet}

Carnegie Moscow Center, http://www.carnegie.ru/?lang=en

Ministério da Defesa, http://www.mil.ru/eng/

Ministério dos Negócios Estrangeiros da Federação Russa, http://www. mid.ru/brp_4.nsf/main_eng

Presidente da Rússia, http://eng.kremlin.ru/

The Moscow Times, http://www.themoscowtimes.com/index.php

\section{Leituras recomendadas}

Brown, Archie (2001) (org), Contemporary Russian Politics: A Reader. Oxford: Oxford University Press.

Freire, Maria Raquel; Kanet, Roger E. (2010) Key Players and Regional Dynamics in Eurasia: The Return of the 'Great Game'. Basingstoke: Palgrave MacMillan.

Levgold, Robert (2007) (org) Russian Foreign policy in the $21^{\text {st }}$ Century and the Shadow of the Past. New York: Columbia University Press.

Sakwa, Richard (1998) Soviet Politics in Perspective. $2^{\mathrm{a}}$ ed. London: Routledge.

Shevtsova, Lilia (2007) Russia Lost in Transition: The Yeltsin and Putin Legacies. Washington, D. C.: Carnegie Endowment for International Peace.

Tinguy, Anne (2008) (org) Moscou et le Monde - L'Ambition de la grandeur: Une Illusion?. Paris: Éditions Autrement.

\section{Bibliografia}

Blagov, S. (2004) "Putin Aims for Higher Russian Profile», PINR-Power and Interest News Report. [www.pinr.com/report.php?ac=view_report\&report_id=139\&language_id=1].

Daniels, Robert (2008) "From Gorbachev to Putin», The Nation, 20 de Outubro.

D'Encausse, Helene Carrere (1983) Le grand frere: l'Union Sovietique et l'Europe sovietisee. Paris: Flammarion.

Foglesong, D. and Hahn, G. (2002) «Ten Myths about Russia: Understanding and Dealing with Russia's Complexity and Ambiguity", Problems of Post-Communism, 6, 5-16. 
Foreign Policy Concept (2000) Foreign Policy Concept of the Russian Federation, Approved by the President of the Russian Federation V. Putin, 28 de Junho.

Foreign Policy Concept (2008) Foreign Policy Concept of the Russian Federation, Approved by the President of the Russian Federation Dmitry Medvedev, The Foreign Policy Concept of the Russian Federation, President of Russia Official Web Portal, 12 de Julho.

Freire, Maria Raquel (2007) «Triangulating Power: Russia, Europe and the United States Security Policies and Interests Projection in a Globalizing World", in Ioannis Stivachtis (org.), International Order in a Globalizing World. Aldershot: Ashgate.

Gaddis, J. L. (2005) The Cold War: A New History. New York: The Penguin Press.

Haas, Marcel de (2006) "Russia-China security cooperation", PINR-Power and Interest News Report, 27 de Novembro.

HFA (1975) Helsinki Final Act, Conference on Security and Co-operation in Europe Final Act. [http://www.osce.org/documents/mcs/1975/08/4044_en.pdf].

Hosking, Geoffrey (2003) Russia and the Russians: A History. Harvard: Belknap Press.

Ivanov, Aleksandr (2006) «Russia's Asian Face», International Affairs, A Russian Journal of World Politics, Diplomacy and International Relations, 52(2), 54-59.

Ivanov, Igor (2003) Minister for Foreign Affairs of the Russian Federation, "A New Foreign Policy Year for Russia and the World", International Affairs, A Russian Journal of World Politics, Diplomacy and International Relations, 49(6), 33-38.

Kapila, Subhash (2006) "Russia's Foreign Policy in a Resurgent Mode: An Analysis», Paper 1682, South Asia Analysis Group, 19 de Janeiro.

Katz, Mark N. (2006) "Primakov Redux? Putin's Pursuit of 'Multipolarism' in Asia», Demokratizatsiya, 14(1), 144-152.

Kaufman, Richard F. e Hardt, John P. (org) (1993) The Former Soviet Union in Transition. Ney York: M.E.Sharpe.

Light, Margot (2003) "In search of an identity: Russian foreign policy and the end of ideology", Communist Studies and Transition Politics, 19(3), 42-59.

Lowenhardt, John (2000) "Russia and Europe: Growing Apart Together», The Brown Journal of World Affairs, VII(1), 167-174.

Lynch, Dov (2003) «Russia Faces Europe», Chaillot Papers, 60. Paris: Institute for Security Studies.

Margelov, M. (2006) "Russia and the US: Priorities Real and Artificial", International Affairs, A Russian Journal of World Politics, Diplomacy and International Relations, 52(1), 23-30.

Page, Jeremy (2007) "Giants meet to counter US power», Times Online, 15 de Fevereiro. [www. timesonline.co.uk/tol/news/world/us_and_americas/article1386812.ece].

Pant, Harsh V. (2004) "The Moscow-Beijing-Delhi 'Strategic Triangle': An Idea whose Time May Never Come», Security Dialogue, 35(3), 311-328.

Porter, Bruce (1996) "Russia and Europe after the Cold War: The Interaction of Domestic and Foreign Policies", in Celeste Wallander (org.), The Sources of Russian Foreign Policy after the Cold War. The John M. Olin Critical Issues Series. Boulder, Colorado: Westview Press.

Reynolds, Paul (2008) "New Russian world order: the five principles», BBC News, 1 de Setembro.

"Russia: Kremlin sees its foreign policy star on rise», Radio Free Europe/Radio Liberty (RFE/ RL), 21 de Março de 2007. [www.rferl.org/featuresarticle/2007/03/2e6ae5fc-18c5-4150-85a291dde1e4e823.html]. 
Russian Military Doctrine (1993) The Basic Provisions of the Military Doctrine of the Russian Federation, Edict 1833 of the President of the Russian Federation, 2 de Novembro. [http:// www.fas.org/nuke/guide/russia/doctrine/russia-mil-doc.html]

Russian Military Doctrine (2010) Approved by Presidential Decree, 5 de Fevereiro.

Sakwa, Richard (1998) Soviet Politics in Perspective, $2^{\mathrm{a}}$ ed. London: Routledge.

Sakwa, Richard (2005) "Perestroika and the Challenge for Democracy in Russia" Demokratizatsiya, 13(2), 173-191.

Shevtsova, Lilia (2005) Putin's Russia. Washington, D. C.: Carnegie Endowment for International Peace.

Schöpplin, George (2007) «Russia's Reinvented Empire», Open Democracy, 3 de Maio.

Slezneva, Ludmilla (2003) "Post-Soviet Russian Foreign Policy: Between Doctrine and Pragmatism», in Rick Fawn (org.), Realignments in Russian Foreign Policy. London: Frank Cass, 10-28.

The Constitution of the Russian Federation (1993) com as emendas de 9 de Janeiro de 1996, 10 de Fevereiro de 1996 e 9 de Junho de 2001, 25 de Dezembro. [http://www.constitution.ru/]. 
(Página deixada propositadamente em branco) 
Verónica Martins ${ }^{1}$

\section{CAPÍTULO 7}

\section{FRANÇA}

\section{Introdução}

A França atingiu o estatuto de potência média depois da Segunda Guerra Mundial (Bozo, 1997: 3), estatuto que parece ter criado algum embaraço junto dos Franceses para situar a França no mundo actual, como referiu o antigo Ministro dos Negócios Estrangeiros Hubert Védrine: «Observai as nossas contorções quanto às noções de 'grande potência' ou de 'potência média'. Para mim, a França é, logo atrás dos Estados Unidos, uma das seis potências de influência mundiais» (Védrine, 1998: 2).

A saída da Segunda Guerra Mundial originou, sem dúvida, grandes mudanças nas linhas adoptadas pela França na condução da sua política externa sem, contudo, pôr em causa a sua história cuja interpretação gerou a ambição de desempenhar um papel mundial. O peso da história é, de facto, decisivo na compreensão da política externa da França e, como refere o historiador Bertrand Gallet, é difícil poder falar-se de doutrina da política externa forjada por políticos e ensinada a diplomatas, é mais correcto falar-se em herança, atitudes, comportamentos e leis não escritas

${ }^{1}$ A autora agradece o financiamento do seu projecto de doutoramento, no qual a temática deste capítulo se insere parcialmente, pela Fundação para a Ciência e a Tecnologia no âmbito do QREN POPH - Tipologia 4.1 - Formação Avançada, comparticipado pelo Fundo Social Europeu e por fundos nacionais do MCTES. 
(Gallet, 1996: 86). Nesse contexto, os objectivos diplomáticos promovidos pela França fundam-se numa análise do «lugar da França no mundo» e do balanço das forças presentes e podem resumir-se à busca de um estatuto de grande potência e a garantia dos seus interesses nacionais e à necessidade de preservar valores fundamentais como a sua independência nacional e a defesa do seu território (Kessler, 1999: 143-144). Estes preceitos gaullistas irão manter-se na política francesa.

O contexto internacional do fim da Segunda Guerra Mundial constitui a base para o contexto do fim da Quarta República e criação da Quinta República pelo General de Gaulle, pois esta fixou o quadro institucional actualmente em vigor em França. Da mesma forma, veremos quais são as relações entre a França e as regiões que marcam o seu passado colonial, o Mediterrâneo e a África negra francófona, mas também com a República Federal Alemã (RFA e depois a Alemanha reunificada) no quadro da integração europeia, com os Estados Unidos da América (EUA) e com a União Soviética(URSS)/Rússia.

Num segundo tempo, num contexto pós-bipolar, focalizaremos brevemente a nossa atenção, sobre a acção de François Mitterrand e, atentaremos com mais pormenor, sobre a política externa dos Presidentes Chirac e Sarkozy, considerando os instrumentos e recursos disponíveis à luz do novo contexto internacional $^{2}$ e, finalmente, concluiremos a nossa reflexão.

A passagem da Quarta para a Quinta República: a busca de um estatuto para a França

Logo a seguir ao armistício da Segunda Guerra Mundial, o General De Gaulle esteve a dirigir o Governo provisório francês da República (Agosto 1944-Janeiro 1946) com a ambição de restabelecer o estatuto internacional

${ }^{2}$ A autora teve de fazer escolhas quanto às regiões/países e presidentes tratados neste capítulo devido à limitação de espaço. Desta forma, os mandatos dos presidentes Pompidou e Giscard d'Estaing (período entre 1969 e 1981) não foram abordados; com base na bibliografia generalista sobre a política externa francesa, e com uma preocupação de comparabilidade entre os presidentes, a autora seguiu a selecção das regiões e temas mais utilizados, com destaque para Dalloz (2004), Gallet (1996), De La Gorce \& Moschetto (1996) e Bozo (1997). 
da França junto dos três grandes vencedores da Guerra, os EUA, o Reino Unido e a URSS e afirmar a independência do Estado (Bozo, 1997: 6). Apesar de um sucesso parcial através do reconhecimento por aqueles Estados, a França é excluída das conferências que marcaram o pós-guerra, Yalta e Postdam, e De Gaulle demitiu-se em Janeiro de 1946 (Bozo, 1997: 7). No entanto, mesmo depois da ausência provisória do General De Gaulle, a França procurou, por um lado, desenvolver uma acção independente tentando manter um certo equilíbrio entre as duas potências que emergiram no fim da guerra e, por outro, manter o seu império colonial (Dalloz, 2004: 32). Contudo, desde o início da IV República, estes dois objectivos ficaram comprometidos com o início da Guerra Fria e a onda de descolonização dos ex-territórios franceses (Dalloz, 2004: 32).

Após a adopção de uma nova Constituição em Outubro de 1946 e a eleição do primeiro Presidente da Quarta República, Vincent Auriol em Janeiro de 1947, o General De Gaulle 3 decidiu criar o partido Rassemblement $d u$ Peuple Français (RPF) em Abril de 1947 como instrumento para regressar ao poder (Dalloz, 2004: 35). A fragilidade que caracterizou a Quarta República (1947-1958) impediu a França de desenvolver uma política independente, pois o Estado sofria de uma instabilidade ministerial crónica causada pelo sistema de escrutínio proporcional que impedia que um partido tivesse a maioria na Assembleia e, institucionalmente, estabeleceu um processo de decisão difuso em matéria de política externa. ${ }^{4}$

Perante essa paralisia institucional, a diplomacia francesa alinhou-se com a dos EUA, inclusive com a adesão à Organização do Tratado do Atlântico Norte (OTAN), cuja ajuda financeira através do Plano Marshall se tornou

3 Visto o presidente De Gaulle ter sido o fundador da V República e, por isso, o primeiro a pôr em prática os seus princípios, é usual encontrar a divisão «era De Gaulle» e "pós De Gaulle» ou ainda "legado" ou "herança" para designar os mandatos dos seus sucessores. Contudo, deve ser feita uma ressalva para o facto da «era pós De Gaulle» designar para a maioria dos autores os mandatos de Pompidou e de Giscard D'Estaing (Bozo, 1997; Chevallier, Carcassonne e Duhamel, 2009; outros, como Dalloz (2004), incluem o período que vai até ao fim da Guerra Fria. No entanto, sem ignorar as consequências geopolíticas e geoestratégicas do fim da bipolaridade, a autora segue esta divisão para os presidentes que sucederam a De Gaulle visto que os preceitos gaullistas irão manter-se apesar da mudança de estilo inerente a diferentes personalidades e outros factores internos e externos.

4 As principais responsabilidades foram atribuídas ao MNE e ao Presidente do Conselho, enquanto o Presidente da República pode influenciar a política e o Parlamento decide as suas grandes orientações (Bozo, 1997: 9). 
indispensável para a reconstrução e modernização da economia (Bozo, 1997: 10-13; Dalloz, 2004: 42-48). Ademais, o endividamento que resultou das guerras coloniais em África e na Ásia também contribuiu para aumentar essa dependência, especialmente a Guerra na Argélia que foi longa e desgastante (CRDP Champagne-Ardenne, s.d.). Contudo, pela primeira vez, a França apareceu como líder da política europeia através da iniciativa de Jean Monnet (CECA) marcada pelo famoso discurso de Robert Schumann de 9 de Maio de 1950 e, em vez de submeter-se, ela apontou o caminho (Bozo, 1997: 15) que conduziria à assinatura do Tratado de Roma em 1957.

\section{O estabelecimento da Quinta República e o legado do General De Gaulle}

No sentido de compreender de que maneira a França dispõe de diversos instrumentos para levar a cabo a sua política externa, é necessário, em primeiro lugar, compreender o funcionamento da Quinta República resultante da Constituição de 4 de Outubro $1958 .{ }^{5}$ Esta Constituição assenta nos princípios de separação e equilíbrio dos poderes e, contrariamente à sua antecessora, conferiu um lugar privilegiado à Presidência da República no processo de decisão da política externa, poderes que fazem desta um domaine réservé do Presidente da República (Kessler, 1999: 23). ${ }^{6}$ Contudo, a primazia presidencial tem dependido, em larga medida, da personalidade dos presidentes que se sucederam. São numerosos os actores que intervêm no processo de decisão, mas de acordo com os poderes particulares conferidos pelas normas constitucionais e legislativas, Marie-Christine Kessler identificou um núcleo decisório que, para além do Presidente, é constituído pelo Primeiro Ministro, o Ministro e o Ministério dos Negócios Estrangeiros e o Parlamento (Kessler, 1999: 20). Contudo, como é observado por alguns autores, durante mais de dez anos, a política externa foi "obra pessoal» de De Gaulle que escolheu conservar o mesmo Ministro dos Negócios Estran-

\footnotetext{
5 Para um aprofundamento da temática da Quinta República, consultar Chantebout (2004), Chevallier, Carcassonne e Duhamel (2009).

6 O estatuto do Presidente saiu reforçado com a revisão constitucional que ocorreu em $1962 \mathrm{e}$ que instituiu a eleição do Presidente por sufrágio universal directo.
} 
geiros, Maurice Couve de Murville, durante todo o seu mandato (De La Gorce e Moschetto, 1996: 26).

Veremos adiante que o Ministério dos Negócios Estrangeiros e o Governo ganharão mais peso (neste último caso especialmente durante os períodos de coabitação), cenário que não se verificará realmente com o Parlamento, pois este não tem poder de iniciativa e o Presidente não responde perante essa instituição em matéria de política externa (Kessler, 1999: 52), apesar da reforma constitucional de 2008. Assim, o poder do Parlamento é essencialmente consultivo e orçamental, pois a lei de finanças em matéria de defesa e de política externa é analisada por várias comissões ${ }^{7}$ e exerce um poder de controlo a posteriori dos compromissos assumidos ao nível europeu e/ou internacional para ratificação, nomeadamente os que implicam as finanças do Estado e as cessões/transferências de território (Constitution de la République Française: article 53).

Apesar de a descolonização ter ocorrido até 1962 e a economia francesa ter-se aberto à Europa, os laços com as antigas colónias mantiveram-se, nomeadamente em termos culturais e linguísticos, devido à diplomacia cultural promovida pelo Ministério dos Negócios Estrangeiros e ao movimento da Francofonia, apoio importante da diplomacia bilateral, mas que se multilateralizou a partir dos anos 1960 (Kessler, 1999: 411). De facto, já em 1962 um líder africano tinha referido a ideia de uma "commonwealth à francesa", e mesmo se o General De Gaulle, que organizou a descolonização em África, teve o receio que a institucionalização de um sistema de francofonia fosse rotulado de neocolonialismo, este tornou-se um instrumento incontornável da diplomacia cultural (Kessler, 1999: 412-413).

Contudo, a França tinha outros recursos para se impor no mundo do pós-guerra. Na verdade, o estatuto da França foi igualmente reconhecido na altura da criação da ONU em 1945, pois foi designada como um dos cinco membros permanentes do Conselho de Segurança, embora o poder de negociação decorrente desse estatuto tenha sido hipotecado nos anos de

\footnotetext{
7 Relativamente à Assembleia: Comissão da Defesa e das Forças Armadas, Comissão dos Negócios Estrangeiros e Comissão das Finanças. Quanto ao Senado, Comissão dos Negócios Estrangeiros da Defesa e das Forças Armadas e, para um parecer, a das Finanças (Gallet, 1996: 33).
} 
Guerra Fria pelos vetos sucessivos da URSS e dos EUA. Além disso, a França também se tornou uma potência nuclear (primeiros testes realizados em Fevereiro de 1960), integrando assim "um clube exclusivo» que lhe permitiu ser encarado como um "actor sério» no plano diplomático durante a Guerra Fria (Howorth, 1996: 383). Se na Constituição a repartição das responsabilidades em termos de defesa entre o Primeiro Ministro e o Presidente não era clara, dois decretos (18 Julho 1962 e 14 de Janeiro 1964) promulgados sobre as forças militares clássicas e sobre as forças nucleares atribuem os poderes ao Presidente (Kessler, 1999: 166).

À excepção da Argélia, os outros Estados do Magrebe e os Estados de África já tinham adquirido a sua independência, apesar de as relações estarem integradas num esquema de cooperação quase neocolonial (Bozo, 1997: 33). O conflito na Argélia estava a pesar no papel que a França podia desempenhar em termos internacionais já que em 1960, a ONU tinha votado uma resolução proclamando o direito à independência para o povo argelino (Bozo, 1997: 33). A França estava sem opções e depois de um primeiro referendo a 8 de Janeiro 1961, um segundo referendo ocorreu no dia 8 de Abril 1962 para aprovar os Acordos de Evian, assinados em 18 de Março 1962 (Chevallier, Carcassonne e Duhamel, 2009: 68-76).

Depois do "problema argeiino" resolvido e da descolonização terminada, o General pôde concentrar a sua atenção em termos de política externa noutras prioridades. O seu desejo de afirmar a independência da França levou ao desenvolvimento de uma política de defesa forte assente na força nacional de dissuasão e numa doutrina estratégica (De La Gorce e Moschetto, 1996: 27-28) que se caracterizou por uma dimensão anti-americana, anti-hegemónica, cuja origem não era ideológica, mas sim derivada de uma avaliação clássica das relações de poder (Mireur, 2006-2007: 93). Apesar de procurar uma certa independência em relação aos dois blocos que se tinham formado nessa época, o desejo de reforma da OTAN contido num memorando elaborado pelo General De Gaulle em Setembro de 1958 que reivindicava a tomada de decisões políticas e estratégicas mundiais pela França, Reino Unido e Estados Unidos, inclusive na aplicação de planos de acção estratégica que necessitassem a utilização de armas nucleares, tornou-se condição para a participação futura da França nos desenvolvimentos da 
Aliança (Dalloz, 2004: 166-167). Perante as resistências a essas ideias, com o desenvolvimento da détente, a ruptura sino-soviética que enfraqueceu a posição soviética e a constituição da força nuclear francesa, De Gaulle distanciou-se progressivamente da OTAN até à retirada em Março de $1966 .{ }^{8}$

Relativamente à construção europeia, o General De Gaulle propôs o lançamento de uma Europa autónoma no domínio político e militar (plano Fouchet I, 1961) e a resistência dos seus parceiros europeus causou um endurecimento da sua posição (Plano Fouchet II, 1962), reafirmando o carácter intergovernamental da construção europeia e o afastamento da OTAN, mas os dois planos foram rejeitados pelo Benelux que reivindicava a adesão do Reino Unido (Gallet, 1996: 115). No entanto, a França recusou várias vezes esta adesão, pois receava o potencial controlo americano que se poderia instalar se aquela aderisse à Comunidade (Dalloz, 2004: 158-160). Entretanto, no seio da construção europeia, a França e a RFA aproximaram-se, e apesar de o Presidente Adenauer não aprovar a política que De Gaulle estava a desenvolver relativamente às relações transatlânticas e ao seu desejo de independência, os dois Estados assinaram o Tratado do Eliseu a 22 de Janeiro de 1963 (Bozo, 1997: 44). Com cooperação prevista em termos militares, o Presidente francês pretendia, de certa forma, obrigar a RFA a «escolher» entre Washington (e o seu projecto de força nuclear multilateral) e Paris (Bozo, 1997: 44).

Relativamente ao bloco comunista verificou-se uma tentativa de aproximação à URSS com a realização de uma viagem em 1966 por parte do Presidente francês, no sentido de promover uma "Alemanha Unificada" tendo levado à instalação de um "telefone vermelho» entre as duas capitais e uma busca por parte da França de uma aproximação aos países de Leste em termos bilaterais, nomeadamente com a Roménia, primeiro país sob tutela soviética a ter respondido ao pedido de diálogo francês (Dalloz, 2004: 168-169). Não obstante essa aproximação, não se tratava de inverter alianças, mas de aproveitar o movimento de independência criado pelo General para ganhar influência na cena internacional e para acabar com

\footnotetext{
8 Em 1963, o General retirou a frota francesa do comando integrado (Dalloz, 2004: 167). Para mais informações sobre a política de De Gaulle em relação à OTAN, consultar também Bozo (1996).
} 
o monopólio americano do diálogo com os Soviéticos, beneficiando do período de détente (Dalloz, 2004: 168).

Finalmente, devemos ainda referir as linhas da política externa do fundador da Quinta República para duas regiões que permanecerão componentes estruturantes das relações externas, ${ }^{9}$ África Negra e os países árabes, junto dos quais a França procurará obter apoio para a independência da sua política. O Ministério da Cooperação foi criado oficialmente em 1961, em plena descolonização da África subsaariana, com um campo geográfico limitado aos países francófonos, tendo por objectivo gerir as relações de cooperação franco-africanas, pelo menos provisoriamente, mas acabou por prolongar-se e tornar-se um instrumento essencial nas relações bilaterais. De facto, os países africanos recém independentes são colocados entre os principais beneficiários da política de cooperação construindo assim o pré carré francês em África (Gallet, 1996: 93), onde os presidentes da Quinta República procurarão continuar a exercer a sua influência de forma directa e pessoal, o que contribuiu para o "apagamento" dos Primeiros Ministros apesar de estes continuarem a desempenhar um papel institucional e oficial (Kessler, 1999: 308).

No que respeita ao Magrebe, como vimos, o principal ponto de preocupação para a França foi a violenta guerra de descolonização na Argélia. Os Acordos de Evian instituíram a livre circulação de pessoas entre os dois Estados, visando regular fluxos migratórios, mas o que se verificou foi a deslocação dos Pieds-noirs e dos Argelinos em direcção à Metropole (Gourevitch, 2000: 107). No que concerne os dois vizinhos da Argélia, Marrocos e Tunísia, ambos procuraram também desenvolver uma relação privilegiada com a França. Não obstante uma melhoria da imagem na cena internacional, tendo em conta a oposição francesa à liderança americana na região, foi necessário esperar por 1967 para assistir a uma viragem decisiva nas relações franco-árabes (Boniface, 2004: 211). De facto, o General desejou ocupar de novo um lugar de destaque no mundo árabe, opondo-se inclusive

\footnotetext{
9 Bertrand Gallet considera as políticas para essas duas regiões e a do eixo franco-alemão como sendo "políticas particulares da França” (Gallet, 1996: 92).
} 
a Israel. ${ }^{10}$ Esta mudança na política do Próximo Oriente vai ser perpetuada e sistematizada numa verdadeira política árabe, até mesmo pro-árabe (Bozo, 1997: 53; Chérigui, 1996: 298-300).

A política externa francesa do pós-Guerra Fria: a gestão do legado do General De Gaulle e os desafios de um mundo multipolar

$\mathrm{Na}$ primeira parte desta análise, olhamos para as linhas e o funcionamento da política externa tal como foi concebida pelo General De Gaulle, que lançou as bases da política que seria praticada pela França em várias regiões do mundo. Não podemos deixar de referir que os sucessores do General tiveram estilos diferentes que poderão ter contribuido para alguns reajustes, além de considerar as mudanças geradas pelo fim da bipolaridade, mas no essencial as grandes linhas gaullistas foram conservadas. Mesmo no caso de François Mitterrand, primeiro Presidente socialista da Quinta República, a continuidade das principais linhas da política externa acabou por impôr-se pois, apesar de se considerar opositor do Gaullismo na altura do regresso do General ao poder, o Presidente Mitterrand afirmou contudo querer «assumir a herança, mas fazê-la evoluir suavemente» (Védrine, 1996: 89).

Não é aqui nosso objectivo fazer uma análise dos dois mandatos de Mitterrand, mas vamos delinear o panorama da política externa no fim da bipolaridade. Para o seu segundo mandato, o partido socialista não obteve maioria absoluta na Assembleia dificultando a acção do governo nos assuntos internos e externos, mas já no Verão de 1989, François Mitterrand conseguiu estabelecer um maior controlo sobre as questões de segurança e de política externa (Howorth, 1992: 49). o Presidente tinha antes decidido colocar homens capazes e seguros em postos chave para dispôr de informações fiáveis e para garantir lealdade, mas Mitterrand foi o coração do sistema e mesmo se o Primeiro Ministro não teve um papel negligenciável na política externa, o Presidente procurou monopolizar todas as grandes

\footnotetext{
10 Sendo um dos principais fornecedores de equipamentos militares para Israel, a França decretou um embargo sobre as exportações de armas para o Médio Oriente (Gallet, 1996: 92).
} 
questões do pós-Guerra Fria (Védrine, 1996: 43, 51). Por outras palavras, se com o fim da bipolaridade a estratégia mudou, os objectivos permaneceram os mesmos (Boniface, 1998: 158).

A verdade é que, no segundo mandato de Mitterrand, a França reconheceu a sua incapacidade em manter um impacto mundial por e para ela mesma, e rompeu a ligação entre a sua independência e a sua influência (Salamé, 1998: 228). Para poder levar a cabo a sua política de forma independente, a França procurou desenvolver uma terceira via (nem capitalista, nem comunista), mas o desaparecimento da URSS tornou caduca essa estratégia. O desenvolvimento de uma Europa forte já não aparecia como uma terceira opção, mas como uma forma de fortalecer diplomaticamente a França num mundo multipolar (Guyomarch, 1998: 121). Assim, nas negociações do Tratado de Maastricht, a posição francesa evoluiu de apoio a um papel mais importante da política externa da UE para apoio ao desenvolvimento de uma política europeia de defesa, sob os auspícios da UEO, permitindo assim à UE manter a sua independência em relação à OTAN e aos EUA (Guyomarch, 1998: 121).

A França deixou de seguir uma lógica regional, à excepção do espaço ao qual ela pertence, e para confirmar essa tendência, Hubert Védrine (1996: 238) apresentou, entre outras justificações para a intervenção da França no Koweit, a necessidade de evitar que ela fosse moral, diplomatica e militarmente desacreditada no terreno europeu e euro-atlântico. Contudo, a Guerra do Golfo acelerou o reconhecimento da caducidade da política árabe francesa que começou a perder a sua especificidade com o fim da bipolaridade. ${ }^{11}$ Apesar de Mitterrand ter tentado manter as melhores relações possíveis em simultâneo com os três Estados do Magrebe, devemos assinalar a situação de guerra civil na Argélia desde 1992 (e) que perturbou a relação com a França (Védrine, 1998: 11).

Finalmente, que tipo de relações foram mantidas com a África francófona nos primeiros anos do pós-Guerra Fria? As diversas publicações sobre a

\footnotetext{
11 Na verdade, já nos anos 1980 François Mitterrand tinha promovido a iniciativa diplomática que viria a dar origem ao Diálogo 5+5. Depois, em 1994, juntamente com o Egipto, promoveu a iniciativa do Fórum do Mediterrâneo (Chérigui, 1996: 300).
} 
temática sublinham que, em relação à política dos seus antecessores, houve algumas pequenas rupturas e grandes continuidades (Marchesin, 1995: 3). Mantiveram-se algumas características como a primazia das relações personalizadas com os dirigentes africanos, já que a África permaneceu um domaine réservé da presidência, a manutenção dos acordos de defesa concluídos antes de 1981 e uma recusa de renovação dos mesmos no início dos anos 1990 (Marchesin, 1995: 3). No entanto, podemos afirmar que Mitterrand tentou ir mais longe quanto às regras que deveriam reger a ajuda francesa aos países africanos com o seu discurso de La Baule, em Junho de 1990 (Mitterrand, 1990), mas cujas propostas não foram bem acolhidas, pois assemelhavam-se a uma ingerência nos assuntos internos (Gallet, 1996: 102-103). Apesar da falta de iniciativas francesas, a política africana da França aparece como uma das heranças melhor conservadas desde o General De Gaulle (Marchesin, 1995: 3).

\section{Jacques Chirac: afirmação e adaptação do legado do General De Gaulle}

Jacques Chirac, líder do partido Rassemblement pour la République, foi eleito para o seu primeiro mandato presidencial a 7 de Maio de 1995 e no seu primeiro discurso ao corpo dos Embaixadores, confirmou a aspiração gaullista (Lombart, 2007: 379) de procurar manter a França na sua posição de potência mundial através «de um esforço constante de vontade, adaptação, imaginação, a partir de uma visão lúcida e de uma abordagem pragmática das grandes evoluções do nosso mundo» (Chirac, 1995).

Quando assumiu o poder, fê-lo ainda por sete anos, já que no seguimento do referendo de 24 de Setembro 2000, foi decidido que o mandato presidencial iria passar a ser um quinquénio. O Presidente Chirac tinha um programa ambicioso e estava decidido a implementar rapidamente as reformas prometidas, mas o país estava a braços com graves perturbações causadas por uma acumulação de problemas domésticos do ponto de vista social, político e económico. Jacques Chirac estava contudo decidido a lançar uma política de influência apoiada na apologia do multilateralismo e na promoção do direito internacional (Howorth, 2001: 159). 
Para apoiar estes objectivos, devemos aqui referir um instrumento importante para a credibilidade da acção internacional da França: a política de ajuda ao desenvolvimento, política que adquiriu uma dimensão cada vez mais transversal incluindo a governação democrática, o desenvolvimento sustentável ou ainda a igualdade de género (MAEE, 2007: 9-10). Apesar de uma estrutura institucional governamental complexa, devemos destacar o Comité Interministerial da Cooperação Internacional (CICID) sob presidência do Primeiro Ministro, o papel do Ministério dos Negócios Estrangeiros e Europeus e do Ministério da Economia e das Finanças, sendo este último o maior contribuidor, e a Agência Francesa de Desenvolvimento (Kessler, capítulo 8). O seu campo geográfico tradicional estava centrado na África francófona, mas ao longo dos anos foi progressivamente alargado aos Estados do Oceano Índico e às antigas colónias inglesas, portuguesas ou espanholas, assim como a Estados das Caraíbas (Kessler, 1999: 312-313). A grande reforma da política de desenvolvimento ocorreu em 1998 quando o Conselho de Ministros formalizou a decisão de suprimir o Ministério da Cooperação e as suas competências foram absorvidas pelo Ministério dos Negócios Estrangeiros (Tavernier, 1999). Com essa reforma, foi igualmente criada uma Zona de Solidariedade Prioritária que inclui todos os Estados beneficiários cuja extensão foi definida em 2002. ${ }^{12}$ Desde 2000, a França aumentou regularmente o PNB dedicado à ajuda ao desenvolvimento, passando de $0,30 \%$ a $0,41 \%$ em 2004 e 0,47\% em 2005 e 2006 (8,5 mil milhões em 2006) (MAEE, s.d.d), mas esse aumento não se manteve em 2007 como foi globalmente o caso da ajuda pública mundial (MAEE, 2007: 17) e voltou a caír para 0,39\% em 2008 (MAEE, s.d.c). Conforme ao compromisso europeu, a França tem como ambição atingir o objectivo de 0,7\% de ajuda pública ao desenvolvimento em 2015 e o aumento da ajuda tem beneficiado principalmente o aumento da ajuda europeia (cerca de 20\% da APD francesa tramita pelo dispositivo comunitário) e multilateral (MAEE, 2007: 17).

\footnotetext{
12 Em 1998, foi criada a Zona de Solidariedade Prioritária (ZSP) para uma maior concentração e selecção da ajuda. Os países beneficiários são dos menos desenvolvidos em termos de rendimentos e de acesso aos mercados de capitais e com os quais a França pretendia desenvolver uma relação de parceria. Em 2002, eram 55 Estados, a grande maioria pertence ao continente africano (MAEE, 2007).
} 
As ambições mundiais da França são, por conseguinte, apoiadas pelo esforço de ajuda ao desenvolvimento em várias zonas do globo e, apesar das dificuldades financeiras generalizadas, o esforço passou de 7,56 mil milhões de euros em 2008, ou seja, o quarto doador mundial em volume e o segundo no G8, para 8,92 mil milhões de euros em 2009 (0,46\% do PNB) (MAEE, s.d.d).

Apesar dos protestos de muitos Estados, o primeiro acto forte do Presidente para testemunhar a "grandeza" da França foi o anúncio do retomar dos testes nucleares a 13 de Junho de 1995, depois de estes terem sido abandonados pelo seu antecessor (Lombart, 2007: 380).

No início do primeiro mandato de Jacques Chirac, poderia ter-se acreditado numa nova divisão de tarefas entre o Eliseu e Matignon (Howorth, 2001: 159). Com efeito, Alain Juppé, que no governo de Edouard Balladur (1993-1995) ocupou o posto de Ministro dos Negócios Estrangeiros, tinha sido nomeado Primeiro Ministro e exerceu uma certa influência nos momentos de mudança de questões importantes como as relações com a OTAN (Howorth, 2001: 162). ${ }^{13}$ Houve um terceiro período de coabitação ${ }^{14}$ entre o governo socialista de Lionel Jospin e Jacques Chirac que durou até ao fim do primeiro mandato (1997-2002). O Primeiro Ministro procurou não penetrar nas áreas do Presidente e este não contestou o direito do Governo em pronunciar-se sobre a orientação dos assuntos externos e militares que ele próprio tinha reivindicado em 1986 (Cohen, 2003: 350-351). No entanto, esse acordo não impediu que algumas decisões fossem tomadas pelo Presidente sem concertação prévia com o Primeiro Ministro (participação discreta deste último durante a crise do Kosovo) ou que este tenha tido algumas «derrapagens» mediáticas ${ }^{15}$ (Cohen, 2003: 352-353). Disto resultou

13 Esse segundo período de coabitação foi menos conflituoso e a novidade reside na aceitação de uma co-gestão serena, no respeito das prerrogativas constitucionais do Chefe de Estado e do Chefe do Governo para evitar choques (Cohen, 2003: 348).

14 O primeiro período de coabitação ocorreu entre 1986 e 1988, tendo sido Jacques Chirac o chefe do Governo; o segundo entre 1993 e 1995.

15 Devemos referir o facto de ter havido algumas divergências de política, nomeadamente durante a viagem oficial a Israel de Lionel Jospin em Fevereiro de 2000 durante a qual qualificou o Hezbollah libanês de grupo terrorista, rompendo assim com a neutralidade da política árabe de Jacques Chirac (De Chalvron, 2000). 
uma monopolização pelo executivo (Presidente/Primeiro Ministro) do tratamento das questões de política externa em detrimento do Parlamento e do debate público, executivo que se empenha em afirmar que a França «fala a uma só voz» (Cohen, 2003: 354).

No que diz respeito à dimensão europeia, podemos afirmar que Jacques Chirac teve uma atitude por vezes divergente face à posição gaullista. Pode-se considerar que o Presidente chegou à conclusão que era inevitável que a Europa caminhasse para algo mais federal enquanto prosseguisse a integração europeia (Zuqian, 2002: 118), nomeadamente através do apoio firme em favor da União Económica e Monetária no Outono de 1995 e da consequente política do Governo Juppé em matéria de redução do défice público (Bozo, 1997: 106). Mais recentemente, podemos também referir o apoio do Chefe de Estado à campanha para a adopção do Tratado Constitucional em 2005 (Lequesne, 2007a: 5), apesar da sua rejeição com quase $55 \%$ de votos contra (AFP e Reuters, 2005).

Devemos ainda referir um aspecto intimamente ligado ao desejo de Jaques Chirac de voltar a conquistar um lugar de destaque na Europa ocidental (Bozo, 1997: 106), nomeadamente uma tentativa de ruptura em relação à política militar com uma eventual reintegração da França na OTAN, frustrada contudo devido à oposição do governo socialista de 1997 a 2002 (Apathie e Ottenheimer, 1997).

Quanto à reaproximação da França à OTAN, deu-se num contexto de degradação da situação no Kosovo já a partir de 1998 e com a tentativa falhada de paz com a conferência de Rambouillet (Fevereiro 1999), que conduziu ao lançamento da campanha de bombardeamento da OTAN no Kosovo a 19 de Março de 1999, à qual Jacques Chirac associou a força aérea francesa, apesar da presença dominante dos EUA (Lequesne, 2007a: 6). Contudo, essa decisão não foi despropositada pois, tendo sido um dos protagonistas da Cimeira bilateral de Saint-Malo com o Reino Unido em 1998, encontro fundamental para o projecto de uma defesa europeia com vocação autónoma, Jacques Chirac via nessa intervenção a possibilidade de contribuir para a autonomização do pilar europeu no seio da Aliança Atlântica (Lequesne, 2007a: 6). Esta constitui uma das excepções em termos de iniciativas de política externa, pois como sublinhou Frédéric Charillon, 
os sucessivos períodos de coabitação tiveram um certo efeito de paralisia pois, por um lado, era necessário evitar que a política externa se tornasse um assunto importante da política interna e, por outro, devia evitar-se projetar as dimensões internas para a cena internacional (Charillon, 2002: 925).

Outro aspecto intimamente ligado à política europeia da França é o da relação franco-alemã que foi positivamente incentivada pelo apoio de Jacques Chirac aos alargamentos da UE para Leste, ${ }^{16}$ já que, como afirmou este último em 1998, "a França deseja que possa ocorrer, logo que possível, a adesão de todos os países candidatos que preencherão as condições fixadas pelos tratados. O alargamento é um dever moral e constitui também uma oportunidade para a Europa» (Chirac, 1998). No entanto, desde o início do mandato, as relações do eixo franco-alemão mostraram-se complicadas, pois as divergências e os mal-entendidos multiplicaram-se, nomeadamente no que diz respeito às reformas institucionais da União, não conseguindo restabelecer a harmonia da dupla Mitterrand-Kohl (Lequesne, 2007a: 7-8). A situação não melhorou com o chumbo do Tratado Constitucional no referendo de 29 de Maio de 2005, condicionando igualmente o papel da França no seio da UE até ao final do mandato de Chirac que não dipôs nem do tempo, nem dos recursos políticos necessários para poder saír da crise com propostas originais (Lequesne, 2007b: 1).

No que diz respeito às relações com a Rússia, Jacques Chirac mostrou desde o início do mandato o desejo de não isolar esse Estado na cena internacional, o que se tornou patente, nomeadamente na reforma da OTAN para a qual preconisava uma parceria com a Rússia (Chirac, 1996a) e cuja importância não podia ser negada no fim da década de 1990 dada a situação na antiga Jugoslávia. Contudo, os dois Estados procuraram dar um novo impulso às relações bilaterais em 2000, aproveitando a cimeira UE-Rússia que se realizou sob os auspícios da presidência francesa, através

\footnotetext{
16 Sem descurar a dimensão mediterrânica, já que foi em parte sob o impulso da presidência francesa de 1995 que foi lançado o Processo de Barcelona.
} 
do relançar dos encontros bilaterais a todos os níveis. ${ }^{17}$ Assim, no campo diplomático, gerou-se uma relação privilegiada entre Vladimir Putin e Chirac que solidificou certas posições e terá contribuido para resolver algumas tensões e encetar dinâmicas que ultrapassam o quadro estritamente bilateral (Gomart, 2007: 128) como foi mencionado em relação aos «campos» criados na Guerra do Iraque (Gomart, 2007: 130). Tendo em conta que Paris não tem real capacidade de influência sobre a situação na Rússia, a França teria vantagens em "desbilateralizar» a relação para estabelecer uma articulação mais sistemática com o diálogo UE-Rússia (Gomart, 2007: 134), intenção que foi expressa em 2005 pelo Presidente no que diz respeito à implementação dos quatros espaços comuns com a UE (Chirac, 2005).

Vamos agora atentar na política externa desenvolvida na África e na região do Mediterrâneo com os Estados árabes. Nenhum outro Presidente alimentou tantos laços pessoais com alguns dirigentes africanos e mereceu tanto o qualificativo de o "Africano" (Claude, 2007: 906). Além disso, no seu discurso aos Embaixadores em 1998, o Presidente afirmou todo o seu empenho em manter a ajuda pública ao continente para apoiar os esforços de alguns Estados em fase de reformas democráticas, assumindo até um tom moralizador quanto à obrigação de integrar os países mais pobres na economia mundial (Chirac, 1998). Não esqueçamos que a política francesa de APD teve sempre como principal fonte de inspiração a manutenção e a progressão da francofonia, e esta constitui a regra principal de repartição geográfica dos créditos (Kessler, 1999: 336).

Houve contudo algumas mudanças, nomeadamente no âmbito militar, pois mesmo com um interesse renovado do Presidente francês pela África, ${ }^{18}$

17 O primeiro de uma série de encontros realizou-se ao nível dos Primeiros Ministros a 19 de Dezembro de 2000. Vários eixos foram estabelecidos nessa cooperação renovada: altas tecnologias, apoio às reformas encetadas na Rússia, a multiplicação de intercâmbios entre jovens, as relações culturais, assim como cooperação comercial que tomou logo forma com a conclusão de um contrato de equipamento de três satélites da Alcatel (s.a., 2000).

18 Devemos aqui sublinhar que a política africana passou por duas transformações importantes que tinham fragilizado a relação entre a França e os países africanos do pré carré, a saber, a depreciação do Franco CFA por causa da apreciação do Franco e da depreciação do Dólar em Janeiro de 1994 e um segundo acontecimento, a crise do Ruanda (Marchesin, 1998: 92-93). 
houve também um certo desinvestimento no pré carrée, ${ }^{19}$ pois o número de militares franceses baseados no continente diminuiram e mais nenhuma intervenção armada ocorreu desde Junho 1996 (Dalloz, 2004: 222) o que é interpretado como a última etapa da política de retirada do continente, pois a França não teria mais nada a defender em África (Marchesin, 1998: 199). Contudo, a França manteve o seu apoio à criação de forças interafricanas de interposição (Dalloz, 2004: 222).

Durante a Cimeira dos Chefes de Estado França-África organizada em Cannes entre 15 e 17 de Fevereiro 2007, o balanço foi muito negativo e, para vários observadores, a cimeira marcou uma viragem na história das relações entre a França e, em particular, a África subsaariana francófona: há menos nacionais franceses a viverem em África, várias empresas perderam a sua influência e a APD, contrariamente ao pretendido por Chirac, diminuiu passando de 0,63\% do PNB em 1995 para atingir no fim do segundo mandato 0,46\% (Soppelsa, 2007: 216). Para alguns especialistas, a África permanece uma componente da soberania francesa (Dozon citado em Claude, 2007: 917). Por outras palavras, a acção de Jacques Chirac não corrigiu as grandes orientações da política marcada pelo intervencionismo, o apoio aos regimes "amigos", mas também houve mudanças externas nos últimos anos com a emergência dos EUA ou ainda da China como novas potências na África e a confiança ficou enfraquecida entre a França e alguns estados africanos francófonos o que a levou a aproximar-se de Estados africanos anglófonos e lusófonos (Claude, 2007: 917-918).

Quanto à política árabe da França, ganhou novamente toda a sua importância em termos bilaterais, pois já em Julho de 1996, o Presidente tinha efectuado duas viagens pelo Próximo e Médio Oriente. O discurso pronunciado no Cairo no dia 8 de Abril de 1996 marcou o lançamento da sua política (Chirac, 1996b). Como o seu antecessor, reconheceu o direito do povo palestiniano em dispor de um Estado, opondo-se à política pro-israelita dos americanos. Foi igualmente em 1996 que ocorreu a crise israelo-libanesa e a França soube tirar proveito do alinhamento incondicional e tradicional

\footnotetext{
19 Os países que compõem o pré carré são os do Magrebe mais o Gabão, o Senegal e a Costa do Marfim (Claude, 2007: 908).
} 
dos americanos junto de Israel para facilitar a conclusão de um cessar-fogo no Líbano, pois este manteve-se uma porta de entrada privilegiada para o Médio Oriente (Gallet, 1996: 113). Ao continuar a apoiar os Palestinianos depois do início da segunda Intifada em 2000, a França aumentou a sua popularidade junto dos países árabes, mas foi a sua posição relativa à guerra do Iraque que lhe valeu a sua grande popularidade, não somente junto dos Estados árabes e muçulmanos em geral, mas também no resto do mundo, precisamente pelo facto de ter encarnado uma resistência a uma política americana agressiva considerada injusta e perigosa (Boniface, 2007b).

Assim, a acção diplomática do Presidente Chirac inscreveu-se contra a tese do choque das civilizações, procurando manter uma certa coerência entre as suas acções e o seu discurso, decidido a não deixar os EUA agirem sós (Boniface, 2007b). A política externa de Jacques Chirac foi marcada afinal por mais elementos de continuidade do que de ruptura com o Gaullismo (Lequesne, 2007a: 11). Não obstante, foi-lhe várias vezes apontado o facto de ter exercido uma política externa demasiado pessoal e comportando poucas iniciativas (Suleiman, 2007).

\section{Nicolas Sarkozy: ruptura no estilo mas incerta no seu conteúdo}

A 6 de Maio de 2007, sucedeu ao fundador da UMP, Nicolas Sarkozy, que tinha assumido a presidência desse partido em 28 de Novembro de 2004. Os três primeiros anos de mandato demonstraram a extrema energia e implicação do Presidente na política interna, contrariamente ao último mandato do seu predecessor, mas também um forte desejo de açambarcar a exclusividade da acção externa. Na altura em que assumiu as suas funções, eram grandes e contraditórias as expectativas em termos de política externa, nomeadamente quanto a uma eventual ruptura com a diplomacia tradicional da V República que consistiria em adoptar uma visão da construção europeia doravante próxima da britânica, uma viragem estratégica pro-americana, o fim de uma política activa dentro e com o mundo árabe a favor de uma reafirmação prioritária de uma aliança com Israel (Boniface, 2007a). Mas terá realmente seguido essas directivas e terá havido uma ruptura? 
Alguns meses depois do início do seu mandato, Nicolas Sarkozy lançou três iniciativas para uma reforma profunda que mereceram um certo destaque, a primeira sendo o lançamento em Agosto de 2007 de uma reflexão sobre um Livro Branco sobre a segurança e a defesa nacional. ${ }^{20}$ Como afirmou o Presidente Sarkozy:

Os livros brancos traduzem a ambição do Estado sobre o essencial, ou seja, a sobrevivência da Nação. E nesse contexto faço minhas as palavras do General De Gaulle: «A Defesa! É a primeira razão de ser do Estado. Não pode falhar esse objectivo sem destruir-se a si próprio». (Sarkozy 2007b)

A política seguida pelo Chefe de Estado em matéria de defesa, até agora, não entrou realmente em ruptura em relação ao seu predecessor. Com efeito, reafirmou a justeza da posição da França quanto à sua oposição à guerra do Iraque (e manteve o compromisso em relação ao Afeganistão) (Boniface, 2007a), prosseguiu e finalizou a linha reformadora encetada por Jacques Chirac no sentido de reintegrar a França na OTAN, decisão oficializada em Março de 2009, assumindo nesse sentido uma ruptura com a política gaullista. Para o Presidente Sarkozy, a política de defesa da UE e a OTAN são complementares e a reintegração da França na Aliança Atlântica visou também o reposicionamento da França num mundo multipolar junto dos seus aliados "na sua família ocidental» (Sarkozy, 2008). Na verdade, o novo Presidente nunca escondeu as suas afinidades com os Estados Unidos, tendo-lhe sido mesmo atribuído o nome de «O Americano» (s.a., 2007). Contudo, "amizade não é submissão" (Reuters, 2007) e o Chefe de Estado afirmou sentir-se "perfeitamente livre para exprimir os acordos e os desacordos, sem complacência nem tabus» (Sarkozy, 2007a).

A segunda iniciativa é inédita, pois tratou-se de lançar uma reflexão para um Livro Branco sobre a política externa em Outubro de 2007, ou seja, «identificar de forma operacional as missões prioritárias incumbentes ao aparelho diplomático num contexto mundial em plena evolução, restructu-

20 A terceira reflexão desde a criação da V República, ou seja, a primeira foi lançada em 1972 e depois em 1994. 
rar o Ministério para que possa concentrar-se nas suas missões..." (MAEE, 2008). Devemos ainda referir a terceira iniciativa promovida pelo Presidente, a reforma constitucional, consagrada na lei constitucional de 23 de Julho de 2008, tendo entre outros, o objectivo de re-equilibrar os poderes das instituições da República, nomeadamente a favor do parlamento (Balladur, 2008: 30). No campo da política externa, o Parlamento viu os seus poderes reforçados no que diz respeito às operações militares externas e quanto ao dever de informação do executivo relativo às negociações diplomáticas (Balladur, 2008: 62-63) apesar de, no final, os poderes do Presidente não terem sido em nada reduzidos ou questionados.

Se, no fundo, a questão que vimos mais acima sobre a OTAN e a defesa europeia está incluída na primeira prioridade que consiste em garantir a segurança da França e dos Franceses, a defesa e promoção dos interesses, a segunda prioridade consiste em construir uma Europa forte e eficaz com os seus parceiros. Como tinha anunciado aos Embaixadores, "a construção da Europa permanecerá a prioridade absoluta» da política externa francesa (Sarkozy, 2007a). Com efeito:

Não existe uma França forte sem Europa, como não existe uma Europa forte sem França. Faço parte daqueles que pensam que a emergência de uma Europa forte, actor importante na cena internacional, pode contribuir de uma forma decisiva para a reconstrução dessa ordem mundial mais eficaz, mais justa, mais harmoniosa, que reclamam os nossos povos. (Sarkozy, 2007a)

Neste contexto, o Presidente Sarkozy afirmou pretender um novo relacionamento entre os Estados e as instituições europeias, como é o caso da Comissão e do Parlamento Europeu (Sarkozy, 2008). Apesar da imagem enfraquecida da França devido ao chumbo do Tratado Constitucional, Sarkozy procurou aproveitar a proximidade entre a França e a Alemanha para apresentar um plano de resgate do Tratado sob a forma de um «mini-tratado» que retomava as inovações institucionais do texto de origem (Tardieu, 2007). Com efeito, Nicolas Sarkozy viu assim uma nova oportunidade de implicar a França no debate europeu e de relançar o debate sobre a construção europeia e as questões institucionais na cena política francesa (Tardieu, 2007). 
Outro facto que merece ser sublinhado foi a presidência da França no segundo semestre de 2008 durante a qual o Presidente Sarkozy procurou promover um programa ambicioso e se destacou, nomeadamente na gestão da crise gerada pela guerra da Geórgia permitindo à UE responder «de uma só Voz»e na intervenção relativa à crise financeira através da reunião do Eurogrupo ao nível dos Chefes de Estado e de Governo para elaborar um plano de apoio aos bancos europeus. Além da Presidência, a França tem apresentado múltiplas iniciativas no seio da Europa, em todos os domínios, o que reflete bem o dinamismo que caracteriza a condução da política externa de Nicolas Sarkozy.

Referindo a crise da Geórgia de Agosto 2008, não podemos deixar de mencionar a política desenvolvida por Sarkozy para a Rússia. Se o Presidente mostrou desde logo o seu interesse por uma aproximação aos EUA, o mesmo não aconteceu com a Rússia pelo menos no seu primeiro ano de mandato. Com efeito, durante o seu discurso aos embaixadores em 2007, o Chefe de Estado fez declarações muito firmes em relação ao regime de Vladimir Putin e à sua acção na cena internacional (Sarkozy, 2007a). Por outras palavras, parece que o Eliseu decidiu destacar-se da política externa dos anos Chirac pondo fim ao que era considerado como uma forma de complacência (Vaulerin, 2007). Contudo, durante a sua primeira visita à Rússia, em Outubro de 2007, a firmeza da linguagem anunciada não se verificou e o Presidente francês declarou que «A Rússia é um país forte que tem responsabilidades internacionais e quer assumi-las. (...) Tenho a convicção que as nossas posições mostram uma certa convergência» (Sarkozy e Poutine, 2007).

Os jornais russos notaram contudo o pragmatismo do Presidente francês, "preocupado em mostrar que a 'amizade franco-russa' não chegou ao fim com a partida de Jacques Chirac» (LCI, 2007). Ademais, a partir de 2009, verificou-se uma melhoria nas relações entre os dois Estados e o bom entendimento existente entre os presidentes Medvedev e Sarkozy tem conotações essencialmente económicas e comerciais já que desde 2009, vários contratos importantes foram assinados, contribuindo para a aproximação franco-russa (Rocco, 2010).

Nicolas Sarkozy anunciou ainda uma ruptura relativa à política do Próximo Oriente (Sarkozy, 2007a). Por inclinação pessoal, também podemos 
dizer que ele está mais próximo de Israel (Cogan, 2010: 90); enquanto já se deslocou várias vezes ao território hebraico, a primeira visita aos territórios palestinianos ocorreu apenas em 23 e 24 de Junho de 2008. No entanto, se esse interesse por Israel poderia ter sido interpretado como uma ruptura com a política gaullista, como nos primeiros anos de Mitterrand, na verdade, todos os países ribeirinhos do Mediterrâneo foram alvo de atenção particular, e disso testemunha a ideia de uma «União mediterrânica» anunciada em Fevereiro de 2007 (Sarkozy, 2007c) e que evoluiu, principalmente fruto de negociações bilaterais com a Alemanha, ${ }^{21}$ até ao lançamento formal da «União para o Mediterrâneo» em Julho de 2008 (s.a., 2008b). Uma das principais razões subjacentes ao seu lançamento repousa no enquadramento das relações entre a UE e a Turquia. Com efeito, enquanto Jacques Chirac se mostrou sempre a favor da adesão da Turquia, Nicolas Sarkozy, ao contrário, manifestou a sua firme oposição à integração desse país no espaço europeu, mas com a abertura das negociações em Outubro 2005, as relações euro-turcas acabaram por inscrever-se numa clara path dependency da qual só poderá sair com uma alternativa credível. Contudo, durante a cimeira de lançamento, o Presidente francês aproveitou para 'relaxar' as relações com a Turquia e afirmar ao Primeiro Ministro turco que não bloquearia a progressão das negociações de adesão (s.a., 2008b). Para alguns observadores, as viagens que Nicolas Sarkozy efectuou no Próximo Oriente e no Golfo tiveram como propósito reforçar o papel regional da França para além da sua esfera de influência constituída pelo Magrebe, aproveitando a imagem algo degradada dos EUA (Klein, 2008: 10).

Foram também numerosas as viagens efectuadas na África negra pelo Presidente Sarkozy que durante a sua campanha tinha prometido renovar, procurando «limpar» a relação dos mal-entendidos do passado (Thiam, 2008: 873). Com efeito, em Novembro de 2006, ainda antes da sua eleição, os

21 Com efeito, devido às reticências da Alemanha, Reino Unido e outros Estados da UE que tinham receio de ser excluídos do projecto tal como tinha sido formulado no início. Em Março de 2008, Nicolas Sarkozy e Angela Merkel chegaram a um entendimento que modificou consideravelmente a proposta francesa já que todos os membros do Processo de Barcelona poderiam participar, e a União para o Mediterrâneo não pretendia substituir-se à Parceria. Além disso, a proposta teria de assumir uma conotação europeia, ou seja, não deveria ser apresentada como uma iniciativa francesa (s.a., 2008a). 
países africanos tinham um certo receio da política que o 'candidato' Sarkozy promovia e poderia desenvolver após a sua eleição, nomeadamente em termos de imigração, tema de grande relevância nas relações bilaterais (Thiam, 2008: 874). Foi aliás por essa ocasião que, em Cotonou, o futuro Presidente apresentou o seu conceito de «imigração escolhida», tanto para o país de destino como para o país de origem (Thiam, 2008: 874). Além disso, o próprio tinha declarado que muitos Africanos se alegravam de ouvir um novo discurso global sobre a política africana da França (Soudan e Yahmed, 2006: 22). O Presidente pretendia uma nova «visão da parceria» anunciando um eventual aumento da APD ao qual estaria associada condicionalidade democrática, já preconizada pelo Presidente Miterrand em 1990 (D’après agence, 2007).

Contudo, durante a sua primeira deslocação ao continente africano, ao Senegal, em Julho de 2007, o Presidente tinha proferido um discurso que suscitou grande polémica à volta da afirmação que o «Homem africano ainda não tinha entrado na História» (AFP, 2009), discurso que não convidava francamente ao diálogo (Mbembe, 2007; Sarkozy, 2008). No entanto, na cimeira UE-África que se realizou em Dezembro de 2007, Nicolas Sarkozy procurou lançar as bases do «início da normalização» de relações com a Costa do Marfim e o Ruanda, dois Estados com os quais as relações se tinham deteriorado durante a presidência de Chirac (Bernard e Nougayrède, 2007). Da mesma forma, no que concerne a Líbia, aproveitando o início da normalização de relações na viagem de Jacques Chirac em 2004 (Samson, 2004), e no seguimento da libertação bem sucedida das enfermeiras búlgaras e de um médico palestiniano a 24 de Julho de 2007, criaram-se novos incentivos, nomeadamente económicos, nas relações franco-líbias. A grande actividade internacional do Presidente conduziu-o em várias viagens pelo continente das quais devemos destacar a tournée realizada em Março de 2009. ${ }^{22} \mathrm{Na}$ verdade, apesar de o Presidente desejar «limpar as relações da Françafrique» de todo o paternalismo e da personalização das relações entre chefes de Estado e das «redes opacas» (Thiam, 2008: 875),

\footnotetext{
22 Em 36 horas o Presidente visitou a República Democrática do Congo, o Congo-Brazzaville e o Niger (Boisbouvier, 2009: 36).
} 
a África não consegue fazer abstracção do facto da França tentar explorar os recursos do pré carré (Thiam, 2008: 876).

Além disso, a Cimeira África-França que decorreu em Nice nos dias 31 de Maio e 1 de Junho pretendeu precisamente privilegiar a parceria com todos os Estados africanos (pelo menos os presentes), e pôr o acento no aspecto económico - relevo para o papel dos empresários - mostrando que as suas afirmações quando ainda era candidato, «a França, economicamente, não precisa da África» (Sarkozy citado em Bernard, 2010) já não são actuais (Bernard, 2010). Além disso, em termos políticos, a França comprometeu-se em apoiar os Estados africanos nas suas reivindicações para uma melhor representação nas instâncias internacionais (Bernard, 2010).

Assim, em três anos, pudemos constatar algumas mudanças nas linhas da política de Sarkozy pois, finalmente, reintegrou a França na OTAN concretizando o que era apenas uma intenção de Jacques Chirac, demonstrou uma grande pro-actividade no seio da UE com o intuito de reconquistar um lugar de destaque e, junto dos países africanos, manifestou durante a última cimeira África-França, o desejo de reformar as bases da relação que caracterizou até agora a Françafrique, apesar de nenhuma mudança ser ainda realmente visível.

\section{Conclusão}

Como afirma o especialista Pascal Boniface, a história, as tradições e, em particular os interesses, são factores poderosos que não podem simplesmente ser postos de lado na condução da política externa (Boniface, 2007a). No desenvolvimento deste capítulo foi assim possível constatar que os princípios de base lançados pelo General De Gaulle - a busca de um estatuto de grande potência, a garantia dos seus interesses nacionais, a preservação de valores fundamentais como a sua independência nacional e a defesa do seu território (Kessler, 1999: 143-144) - mantiveram-se ao longo das décadas seguintes mas tiveram de adaptar-se às grandes mudanças geradas pelo fim da bipolaridade. 
Na verdade, apesar da recuperação conseguida durante o mandato de De Gaulle e dos recursos diversos, a aspiração gaullista a um estatuto de «grande potência» foi, de forma realista, reformulada por Valéry Giscard d'Estaing que forjou o termo "potência média", apercebendo-se que era necessário atenuar as pretensões algo excessivas da França, guiadas essencialmente pela ideia do universalismo da sua mensagem (Védrine, 2002: 8). Contudo, conforme indicou Hubert Védrine pouco depois de ter assumido funções e no seguimento da observação das mudanças operadas após o fim da Guerra Fria, a França é uma das "potências de influência mundial» (Védrine, 1998: 2 e 8). Vimos igualmente que, pelas disposições constitucionais da Quinta República e uma certa «dependência do caminho», a continuidade dos principais eixos da política externa francesa foi mais forte que as mudanças, mesmo se essas não podem ser ignoradas e decorrem em grande parte das mudanças no sistema internacional e nas regiões com as quais a França tem tradicionalmente exercido a sua influência. Além disso, devemos ainda referir uma evidência: a multiplicação da concorrência e das ameaças que afectam os interesses franceses e o facto de esta continuar a preconizar uma política externa universal. $^{23}$ Por outras palavras, considerando que os recursos nacionais não são ilimitados, poderemos igualmente concluir que a participação no projecto de integração europeu tem evoluído de forma estratégica mas sempre prioritária, pois a França acredita que uma Europa forte poderá contribuir para um melhor equilíbrio mundial e uma acção mais ambiciosa da França.

\section{Questões para análise}

O pragmatismo que caracteriza a acção do Presidente Sarkozy e a evolução das relações internacionais obrigarão a França a rever as suas alianças internacionais?

Perante uma personalização por vezes excessiva da política externa francesa pelos Presidentes, em que medida um reequilíbrio institucional poderia

\footnotetext{
23 «Eu sou dos que pensam que a França permanece portadora de uma mensagem e de valores que ressoam pelo mundo fora, os da Declaração dos Direitos do Homem e do Cidadão, do humanismo, mas também, mais recentemente, do humanitário (...)»(Sarkozy, 2007a).
} 
contribuir para um maior controlo democrático sem prejudicar (e até melhorar) a eficácia dessa política?

Que futuro tem a dupla franco-alemã num contexto de integração europeia em que as divergências entre as partes tendem a tornar-se mais evidentes?

Analise quais podem ser as consequências da reintegração da França na OTAN para o desenvolvimento da política de defesa europeia e a afirmação da França nesse domínio.

À luz da emergência de novas potências, fortes concorrentes da França no continente africano e da 'renovação' de muitos dos líderes africanos, argumente quanto à capacidade actual de influência da França nesse continente.

\section{Fontes na internet}

Presidência da República francesa, http://www.elysee.fr/president/accueil.1.html Ministério dos Negócios Estrangeiros, http://www.diplomatie.gouv.fr Organisation Internationale de la Francophonie, http://www.francophonie.org/ Institut Français des Relations Internationales, http://www.ifri.org Institut de Relations Internationales et Stratégiques, http://www.iris-france.org

\section{Leituras recomendadas}

Bozo, F. (1997) La Politique étrangère de la France depuis 1945. Paris: La Découverte e Syros.

Chevallier, J-J.; Carcassonne, G. e Duhamel, O. (2009) Histoire de la Vè République 1958-2009. (13è Ed). Paris: Dalloz.

Dalloz, J. (2004) La France et le Monde depuis 1945. Paris: Armand Colin.

De La Gorce, P.-M. e Moschetto, B. (1996).La Vè République. (7ª ed). Paris: Presses Universitaires de France.

Gallet, B. (1996) Précis de politique étrangère française. Paris: Ellipses.

Kessler, M-C. (1999) La politique étrangère de la France. Acteurs et processus. Paris: Presses de Sciences-Po. 


\section{Bibliografia}

AFP (2009) "Au Sénégal, Segolène Royal demande 'pardon' pour le 'discours de Dakar'», $L i$ bération, 7 Abril.

AFP e Reuters (2005) "La France rejette nettement le traité constitutionnel", Le Monde, 30 Maio. Apathie, J-M e Ottenheimer, G. (1997) «Entre Chirac et Jospin: la paix armée», L'Express, 10 Julho.

Balladur, E. (2007) Une Vè République plus démocratique: Comité de réflexion et de proposition sur la modernisation et le rééquilibrage des institutions de la $V$ épublique. France: Présidence de la République.

Bernard, P. (2010) "Le 25è sommet Afrique-France s'ouvre à Nice sous le signe du 'renouveau'", Le Monde, 31 Maio.

Bernard, P. e Nougayrède, N. (2007) "La Diplomatie africaine controversée de Nicolas Sarkozy», Le Monde, 10 Dezembro.

Boisbouvier, C. (2009) "France - Afrique. Sarkozy, l'homme pressé», Jeune Afrique, 2511, 2228 Fevereiro.

Boniface, P. (1998) "Révolution stratégique mondiale, continuité et inflexions de la politique française de sécurité», in Cohen, S. (org), Mitterrand et la sortie de la Guerre Froide. Paris: Presses Universitaires de France.

Boniface, P. (2004) "La France et le monde arabe», in Boniface P. e Billion, D. (org), Les défis du monde arabe. Paris: Presses Universitaires de France.

Boniface, P. (2007a) "La Politique arabe de Sarkozy», Réalités, 16 Maio.

Boniface, P. (2007b) "Le bilan diplomatique de Jacques Chirac", L'essentiel des relations internationales, Maio-Junho. [http://www.iris-france.org/Tribunes-2007-05-16a.php3].

Bozo, F. (1996) Deux stratégies pour l'Europe. De Gaulle, les Etats-Unis et l'Alliance atlantique (1958-1969). Paris: Plon.

Bozo, F. (1997) La Politique étrangère de la France depuis 1945. Paris: La Découverte e Syros.

Chantebout B. (2004) Brève histoire politique et institutionnelle de la Vè République. Paris: A. Colin.

Charillon, F. (2002) "Peut-il y avoir encore une politique étrangère française», Politique étrangère, 4, 915-930.

Chérigui, H. (1996) "La politique arabe de la France: de la centralité à l'effacement du Maghreb", Annuaire de l'Afrique du Nord, 35, 295-326.

Chevallier, J-J.; Carcassonne, G. e Duhamel, O. (2009) Histoire de la Vè République 1958-2009 $\left(13^{\mathrm{a}}\right.$ ed). Paris: Dalloz.

Chirac J. (1995) Discours de M. Jacques Chirac, Président de République, à l'occasion de la réunion des Ambassadeurs. Palais de l'Elysée, Paris, 31 Agosto. [http://www. elysee.fr/elysee/elysee.fr/francais/interventions/discours_et_declarations/1995/aout/ discours_de_m_jacques_chirac_president_de_la_republique_a_l_occasion_de_la_reunion_ des_ambassadeurs-palais_de_1_elysee.315.html].

Chirac J. (1996a) Discours de Monsieur Jacques Chirac, Président de la république à l'occasion de la réception des ambassadeurs (Palais de l'Elysée). 29 Agosto. [http://www. elysee.fr/elysee/elysee.fr/francais/interventions/discours_et_declarations/1996/aout/ discours_de_monsieur_jacques_chirac_president_de_la_republique_a_l_occasion_de_la_reception_des_ambassadeurs-palais_de_l_elysee.27729.html].

Chirac, J. (1996b) Discours de M. Jacques Chirac, Président de la République, à l'Université du Caire, 8 Abril. [http://www.elysee.fr/elysee/francais/interventions/discours_et_declarations/1996/ 
avril/discours_de_m_jacques_chirac_president_de_la_republique_a_l_universite_du_caire. $952 . \mathrm{html}]$.

Chirac J. (1998) Discours de M. Jacques Chirac Président de la République à l'occasion de la réception des Ambassadeurs Palais de l'Elysée, 26 Agosto. [http://www.elysee.fr/elysee/ 198 elysee.fr/francais/interventions/discours_et_declarations/1998/aout/discours_du_president_de_ la_republique_a_l_occasion_de_la_reception_des_ambassadeurs-palais_de_l_elysee.1594.html].

Chirac J. (2005) Discours de M. Jacques Chirac, Président de la République, lors de l'ouverture de la XIIIème Conférence des Ambassadeurs. Palais de l'Elysée - Paris, 29 Agosto. [http:// www.elysee.fr/elysee/elysee.fr/francais_archives/interventions/discours_et_declarations/2005/ aout/discours_du_president_de_la_republique_lors_de_1_ouverture_de_la_xiiieme_conference_des_ambassadeurs.31002.html].

Claude G. (2007) “Chirac 'l'africain'. Dix ans de politique africaine de la France, 1996-2006", Politique étrangère, 4, 905-918.

Cogan, C. (2010) “Les grands axes de la présidence Sarkozy à l'international», Revue internationale et stratégique, 77, 87-92.

Cohen, Samy (2003) "Cohabiter en Diplomatie: atout ou handicap?», Annuaire français des relations internationales, 344-358.

CRDP Champagne-Ardenne (s.d.) «La France face à la décolonisation de 1945 à 1962». [http:// www.crdp-reims.fr/cinquieme/decolonisation.htm].

Dalloz, J. (2004) La France et le Monde depuis 1945. Paris: Armand Colin.

D’après agence (2007) «Sarkozy à Dakar pour exposer sa vision de l'Afrique», TF1 News, 26 Julho.

De Chalvron, A. (2000) «Israël/Visite de Lionel Jospin», France 2, 25 Fevereiro.

De La Gorce, P.-M. e Moschetto, B. (1996) La Vè République (7ª ed). Paris: Presses Universitaires de France.

Gallet, B. (1996) Précis de politique étrangère française. Paris: Ellipses.

Gourevitch, J-P. (2000) La France africaine. Islam, Intégration, Insécurité: Infos et Intox. Paris: Le Pré aux Clercs.

Guyomarch, A. (1998) France in the European Union. New York: Saint Martin's Press.

Howorth, J. (1992) «François Mitterrand and the 'Domaine Réservé': From cohabitation to the Gulf War", French Politics \& Society, 10(1), 43-58.

Howorth, J. (1996) "A Testing Time for the Pursuit of grandeur», in Keller, J. e Schainm M. (org), Chirac's Challenge: Liberalization, Europeanization and Malaise in France. New York: Saint Martin's Press, 383-400.

Howorth, J. (2001) «Foreign and Security Policy in the post-Cold War World», in Hall P. (org), Developments in French Politics, $2^{\mathrm{a}}$ ed. London: Macmillan, 156-171.

Kessler, M-C. (1999) La politique étrangère de la France. Acteurs et processus. Paris: Presses de Sciences-Po.

Klein, M. (2008) «Un Moyen-Orient bleu-blanc-rouge», Courrier international, 938, 23-29 Outubro.

Lci (2007) «France/Russie - Sarkozy moqué par la presse russe», 11 Outubro. [http://tf1.lci.fr/ infos/monde/europe/0,,3570238,00-sarkozy-moque-par-presse-russe-.html].

Lequesne, C. (2007a) "La politique étrangère de Jacques Chirac ou la France sans surprise», DGAP Analyse Frankreich, 2. Berlin: Forschungsinstitut der Deutschen Gesellschaft für Auswärtige Politik.

Lequesne, C. (2007b) «Sarkozy et l'Europe», Les essais de Telos. Telos-agence intellectuelle. [http://www.telos-eu.com/]. 
Lombart, L. (2007) "La politique extérieure du Président Jacques Chirac dans un monde americano-centré», AFRI 2007, VIII. [http://www.afri-ct.org/La-politique-exterieure-du].

MAEE (2007) Ministère des Affaires étrangères et européennes, Mémorandum de la France sur ses politiques et programmes en matière d'aide publique au développement. [http://www.diplomatie.gouv.fr/fr/ministere_817/publications_827/cooperation-internationale-developpement_3030/ serie-reperes_3035/memorandum-france-sur-ses-politiques-programmes-matiere-aidepublique-au-developpement_19123/index.html].

MAEE (2008) Ministère des affaires étrangères et européennes, "Remise du livre blanc sur la politique étrangère et européenne de la France», 11 Julho. [http://www.diplomatie.gouv. $\mathrm{fr} / \mathrm{fr} /$ ministere_817/modernisation_12824/livre-blanc-sur-politique-etrangere-europeennefrance_18407/remise-du-livre-blanc-m.-bernard-kouchner-11.07.08_64433.html].

MAEE (s.d.a) Ministère des Affaires étrangères et européennes. "Sommets Afrique-France». [http:// www.diplomatie.gouv.fr/fr/pays-zones-geo_833/afrique_1063/sommets-afrique-france_326/ index.html [consultado em 14 de Maio 2010].

MAEE (s.d.b) Ministère des affaires étrangères et européennes, "L'évolution du réseau». [http:// www.diplomatie.gouv.fr/fr/ministere_817/modernisation_12824/les-enjeux-les-chantiers_12763/ evolution-du-reseau_19452/index.html].

MAEE (s.d.c) Ministère des affaires étrangères et européennes, "Aide au développement - Zone de Solidarité prioritaire». [http://www.diplomatie.gouv.fr/fr/actions-france_830/aide-audeveloppement_1060/zone-solidarite-prioritaire_6119.html].

MAEE (s.d.d) Ministère des Affaires étrangères et européennes, "L'aide Publique au Développement». [http://www.diplomatie.gouv.fr/fr/actions-france_830/aide-au-developpement_1060/ aide-publique-au-developpement-apd_19762/index.html\#sommaire_3].

Marchesin, P. (1995) "Avant-propos: la politique africaine de F. Mitterrand», Politique Africaine, 58, 85-100.

Marchesin P. (1998) "La politique africaine de la France en transition», Politique africaine, 71, 91-106.

Mbembe, A. (2007) "Sarko, Hegel et les nègres - Le Messager (extrait)», Courrier International, 878, 30 Agosto.

Mireur, Y. (2006-2007) «En finir avec l'anti-américanisme», Géoéconomie, 40, 93-111.

Reuters (2007) «Sarkozy: sa politique étrangère», L'Express, 28 Fevereiro.

Rocco, A-M. (2010) "La Russie et la France fraternisent», Challenges, 8 Abril.

Salamé, G. (1998) «Stratégies régionales et perspectives globales. Globalisme et régionalisme dans la politique miterrandienne de l'après-guerre froide», in Cohen, S. (org), Mitterrand et la sortie de la Guerre Froide. Paris: Presses Universitaires de France.

Samson, D. (2004) "Chirac rend visite à Khadafi», RFI, 24 Novembro.

Sarkozy, N. (2007a) Allocution de M. Nicolas Sarkozy, Président de la République, à l'occasion de la conférence des Ambassadeurs. Palais de l'Elysée, Paris, 27 Agosto. [http://www.elysee. fr/elysee/elysee.fr/francais/interventions/2007/aout/allocution_a_l_occasion_de_la_conference_des_ambassadeurs.79272.html].

Sarkozy, N. (2007b) Allocution de M. le Président de la République, Commission du Livre Blanc sur la Défense et la Sécurité nationale. Paris, 23 Agosto. [http://www.elysee.fr/president/ les-actualites/discours/2007/installation-de-la-commission-du-livre-blanc-sur.8276.html].

Sarkozy, N. (2007c) Discours de Toulon. 7 Fevereiro. [http://www.u-m-p.org/site/index.php/s_informer/discours/nicolas_sarkozy_a_toulon]. 
Sarkozy, N. (2007d) «Extraits je ne suis pas venu vous faire la morale». Extrait du discours que Nicolas Sarkozy a prononcé le 26 juillet 2007 à l'Université Cheikh Anta Diop, Courrier International, 911, 17-23 Abril 2008.

Sarkozy N. (2008) XVlè conférence des ambassadeurs. Palais de l'Elysée, 27 Agosto. [http://www. elysee.fr/president/les-actualites/discours/2008/xvie-conference-des-ambassadeurs.2078.html].

Sarkozy N. e Poutine V. (2007) Conférence de presse conjointe du président de la République, M. Nicolas Sarkozy, et du président de la Fédération de Russie, M. Vladimir Putin. Moscou, 10 Outubro. [http://www.slavika.com/spip.php?article999].

s.a. (2000) "Chirac-Poutine: l'heure du réchauffement, nouvelObs.com, 2 Novembro. [http:// tempsreel.nouvelobs.com/actualite/monde/20001031.OBS8660/chirac-poutine-l-heure-durechauffement.html].

s.a. (2007) “Nicolas Sarkozy s'emporte à la télévision américaine», Le Figaro, 28 Outubro. [http://www.lefigaro.fr/politique/20071028.WWW000000131_nicolas_sarkozy_semporte_ en_direct_a_la_television_americaine.html].

s.a. (2008a) «Sarkozy et Merkel trouvent un compromis sur l'Union pour la Méditerranée», EurActiv, 4 Março. [http://www.euractiv.fr/presidence-francaise-ue/article/sarkozy-merkeltrouvent-compromis-union-mediterranee-00715].

s.a. (2008b) «Le Sommet de Paris inaugure 'l’Union pour la Méditerranée'», EuroActiv, 14 Julho. [http://www.euractiv.com/fr/est-mediterranee/sommet-paris-inaugure-union-mditerrane/ article-174220].

Soppelsa, J. (2007) "De la politique étrangère de la France», Revue Politique et Parlementaire, 109(1042), 211-217.

Soudan, F. e Yahmed, M. Ben (2006) “Nicolas Sarkozy: Si j’étais président...», Jeune Afrique, 2391, 5 a 11 Novembro.

Suleiman, E. (2007) «Pour inventer une nouvelle politique étrangère, Nicolas Sarkozy doit d'abord faire un inventaire», Le Figaro, 5 Julho.

Tardieu, P. (2007) «Présidentielles: Nicolas Sarkozy, un mini-traité à la taille de ses ambitions?», Eurosduvillage.eu, 14 Março.

Tavernier, Y. (1999) La coopération française au développement: bilan, analyses et perspectives. Paris: Ministère des affaires étrangères.

Thiam, A. (2008) "La politique africaine: rupture ou continuité?», Politique étrangère, 4, 873-884.

Vaulerin, A. (2007) «Sarkozy veut mettre fin à une certaine forme de complaisance avec la Russie», Libération, 9 Outubro.

Védrine, H. (1996) Les mondes de François Mitterrand à l'Elysée: 1981-1995. Paris: Fayard.

Védrine, H. (1998) Entretien du Ministre des affaires étrangères, M. Hubert Védrine, avec la revue Politique internationale, Paris, 5 Fevereiro. [http://basedoc.diplomatie.gouv.fr/exl$\mathrm{php/cadcgp.php].}$

Védrine, H. (2002) Ouverture de la deuxième session de l'institut diplomatique, discours du Ministre des affaires étrangères, M. Hubert Védrine. Paris, 19 Março. [http://basedoc.diplomatie.gouv.fr/exl-php/cadcgp.php].

Zuqian, Z. (2002) «La politique étrangère de la France entre continuité et ajustements postguerre froide», La Revue internationale et stratégique, 45, 114-120. 


\section{CAPÍtULO 8}

\section{GRÃ-BRETANHA}

Nos últimos sessenta e cinco anos, a política externa britânica ficou marcada por três transições que corresponderam a mudanças sucessivas da sua posição internacional. Durante a primeira transição, acelerada pela II Guerra Mundial, a Grã-Bretanha procurou orientar um processo de transferência gradual das suas responsabilidades como primeira potência ocidental para os Estados Unidos. Na segunda transição, quando a estabilidade da divisão bipolar e o fim do império confirmaram a tendência de declínio, os responsáveis políticos concentraram-se na valorização da posição específica da Grã-Bretanha no centro das relações entre os Estados Unidos e a Europa Ocidental. A terceira transição, depois do fim da Guerra Fria, realizou-se sob o signo de uma crescente, embora relutante, «europeização» do velho império.

Em 1945, a Grã-Bretanha era uma das três grandes potências vencedoras que definiram uma nova ordem internacional assente na institucionalização das Nações Unidas. Mas o reconhecimento desse estatuto não podia esconder que a Grã-Bretanha já não tinha um poder comparável ao dos Estados Unidos ou da União Soviética, como dizia Sir Alexander Cadogan, os «três grandes» eram «2 1/2 !» (Dilks, 1972: 778). Nesse contexto, para garantir a continuidade do seu lugar na primeira linha da política internacional, era necessário encontrar uma forma de assegurar que os Estados Unidos estavam em posição de preencher os vazios estratégicos criados pelo retraimento gradual do império britânico. Em 1973, a transferência de poder entre os 
dois aliados ocidentais estava feita, quando, finalmente, a Grã-Bretanha entrou nas Comunidades Europeias e reconheceu a centralidade da política europeia e ocidental. Depois da descolonização, o velho império quis definir uma posição alternativa onde a sua «relação especial» com os Estados Unidos e o seu lugar na Aliança Atlântica se articulassem positivamente com uma maior intervenção na construção europeia. Na altura, a détente bipolar consolidou a preponderância dual dos Estados Unidos e da União Soviética, ao mesmo tempo que se iniciava uma viragem na política internacional. Em 1991, o fim da Guerra Fria e a vitória ocidental acentuaram ainda mais a preponderância singular dos Estados Unidos, que não precisou de aliados para definir o sentido da evolução das suas políticas externas, mas também confirmaram uma tendência de regionalização internacional, onde se tornou mais saliente a identidade da Grã-Bretanha como uma potência regional europeia.

Entre o fim da II Guerra Mundial e o princípio do pós-Guerra Fria, a Grã-Bretanha, não obstante ter sido membro proeminente das coligações vencedoras em todas as guerras hegemónicas do século Xx, deixou de ser uma das três principais potências internacionais, ao lado dos Estados Unidos e da União Soviética, e tornou-se uma das três potências relevantes da União Europeia, a par da Alemanha e da França, sem nunca se resignar inteiramente às consequências dessa mudança no seu estatuto internacional.

\section{A terceira superpotência}

A vitória da Grã-Bretanha contra a Alemanha na II Guerra Mundial foi um feito excepcional. A expansão alemã e japonesa, nos primeiros anos da guerra, parecia irresistível e, depois da rendição da França, o império britânico enfrentou sozinho as potências do Eixo. A vulnerabilidade da Inglaterra ficou demonstrada durante o blitz, enquanto a ofensiva japonesa e a queda de Singapura, onde se renderam mais de cem mil soldados britânicos, confirmou a vulnerabilidade de um império fragmentado. A invasão alemã da União Soviética e a entrada dos Estados Unidos na guerra garantiram o lugar da Grã-Bretanha entre as potências vencedoras. Em Teerão, na Crimeia e em Potsdam, o Primeiro Ministro britânico, Winston Churchill, 
esteve ao lado do Presidente Franklin Roosevelt e do Marechal Stalin para participar nas decisões cruciais sobre a estratégia aliada e a nova ordem das Nações Unidas.

A Grã-Bretanha foi o único Estado da Europa Ocidental que pôde preservar o seu estatuto como potência no fim da "guerra civil europeia». A fúria totalitária do nazismo destruiu a Alemanha e a derrota de 1940 comprometeu duradouramente o prestígio da França. Em 1944, quando inventou o conceito de "superpotência», William T.R. Fox incluiu, naturalmente, a Grã-Bretanha ao lado dos Estados Unidos e da União Soviética como um dos três Estados que mereciam essa classificação. Porém, o peso crescente das duas grandes potências de escala continental revelou os limites do poder britânico, num contexto em que as ilusões sobre a cooperação internacional eram substituídas pela competição entre as potências vencedoras.

Em Novembro de 1945, Ernest Bevin, Secretário do Foreign Office, considerava que "we are rapidly drifting into spheres of influence or what it can be described as three great Monroes» (Warner, 1994: 106). Nesse quadro, Bevin entendia que, para manter a posição da Grã-Bretanha como um dos "três grandes» era urgente consolidar o seu estatuto como a principal potência europeia: "Provided we can organize a Western European system it should be possible to develop our own power equal to that of the United States of America and the USSR» (Reynolds, 2000: 175).

Os responsáveis britânicos tinham preparado as condições para garantir a estabilidade europeia no pós-guerra. Na cimeira de Yalta, Churchill e Anthony Eden, Secretário do Foreign Office, obtiveram, não sem dificuldade, o reconhecimento formal da França como membro permanente do Conselho de Segurança das Nações Unidas e como potência ocupante da Alemanha. Para Churchill, a restauração da França era indispensável para conter a ressurgência alemã. A vitória do Partido Trabalhista, nas eleições de Julho de 1945, confirmou essa estratégia, partilhada pelo novo Primeiro Ministro, Clement Attlee. Para Bevin, a aliança entre as duas democracias era a chave para consolidar a Europa Ocidental como uma «Terceira Força» entre os Estados Unidos e a União Soviética.

Esse processo, porém, foi travado pela crise financeira britânica, pela resistência do general de Gaulle à aliança britânica e, sobretudo, pela 
força da ameaça soviética. O Governo trabalhista acabou por reconhecer que a Grã-Bretanha, para poder continuar a ser uma grande potência internacional, não podia, simultaneamente, sustentar um império colossal, conter a pressão soviética e assegurar a reconstrução de uma Europa física e moralmente arruinada. O preço da vitória na II Guerra Mundial foi uma dependência crescente em relação aos Estados Unidos. Quando a sobrevivência da Grã-Bretanha estava em causa, a aliança americana era a única alternativa, que justificava a cedência de bases militares aos Estados Unidos nas possessões britânicas no hemisfério ocidental, um endividamento maciço e a transferência do programa nuclear para território norte-americano, bem como o reconhecimento da supremacia financeira da nova grande potência nos acordos de Bretton Woods. A força das coisas legitimou a estratégia pela qual o velho império transferiu, gradualmente, as posições de poder que não podia continuar a manter para o seu principal aliado, procurando influenciar as políticas externas norte-americanas. A troca de lugares entre as duas principais potências ocidentais na hierarquia internacional representou um processo sem precedentes históricos, que limitou as consequências do declínio da Grã-Bretanha e consolidou a preponderância dos Estados Unidos.

O momento crítico ocorreu no início de 1947, quando o Governo tomou decisões cruciais sobre o seu programa nuclear, o futuro da Índia e da Palestina e a situação na Grécia e na Turquia, num contexto de crise económica interna. Em Janeiro, a incerteza sobre as intenções dos Estados Unidos para cumprirem os acordos bilaterais de cooperação nuclear forçou as autoridades britânicas a decidir, secretamente, desenvolver a sua capacidade autónoma de produção de armas nucleares, sem a qual o seu estatuto como grande potência ficaria comprometido. No mês seguinte, Bevin anunciou a decisão de devolver a questão da Palestina, que mobilizava mais de cem mil soldados britânicos, às Nações Unidas, enquanto Attlee, depois das revoltas que causaram centenas de milhares de mortos em confrontos entre as comunidades hindu e muçulmana, fixava a data da independência da Índia, marcada para Junho de 1948. Esses recuos não eram uma retirada e deviam abrir caminho à consolidação da Commonwealth e reforçar as restantes posições britânicas na Ásia e no Médio Oriente. Finalmente, em 21 de Fevereiro, Bevin comunicou ao Secretário de Estado 
norte-americano, George Marshall, que o seu Governo decidira cessar o apoio à Grécia e à Turquia, ambas sob forte pressão soviética, a partir de 31 de Março. Nos termos da nota oficial, as autoridades britânicas esperavam que os Estados Unidos pudessem assumir esse fardo, avaliado em cerca de quatrocentos mil dólares por ano, o que representava 1\% do orçamento federal norte-americano para esse ano. Quando, em 5 de Março, Bevin e o seu homólogo francês, Georges Bidault, assinaram, em Dunkerk, o tratado de aliança bilateral entre a Grã-Bretanha e a França, era tarde demais para o transformar no instrumento de construção de uma "terceira potência» europeia assente na entente das duas democracias.

A transferência de responsabilidades na Grécia e na Turquia foi um sinal dramático do declínio britânico. O Presidente Harry Truman respondeu, em 12 de Março, com a "doutrina Truman», que garantia o apoio dos Estados Unidos às nações dispostas a defender a sua independência. Em 5 de Junho, o "Plano Marshall» foi apresentado e a Grã-Bretanha e a França assumiram, em conjunto, a resposta europeia às propostas norte-americanas, que provocaram a primeira divisão formal da Europa, quando a União Soviética se recusou a participar e proibiu a Checoslováquia e a Polónia de aderir ao Programa de Recuperação Europeia.

A «cortina de ferro", anunciada por Churchill em Fulton, desfez as ilusões sobre a paz europeia e provocou uma escalada das tensões no eixo LesteOeste. Numa continuidade sem falhas - os diplomatas do Foreign Office diziam que a política de Bevin era a de Eden "without the haches» -, a estratégia britânica concentrou-se em assegurar a permanência das forças militares norte-americanas na Alemanha e em institucionalizar a posição dos Estados Unidos como uma potência europeia.

O Plano Marshall e a fusão das zonas de ocupação britânica e norte-americana na Alemanha foram passos importantes nesse sentido, tal como a definição de uma estratégia comum para a criação da nova moeda e de um banco central alemão, concertada entre Marshall, Bevin e Bidault na Conferência de Londres, em Dezembro de 1947. A resposta de Stalin foi, primeiro, o golpe de Praga e, depois, o corte das vias de comunicação de superfície com os sectores ocidentais de Berlim que atravessavam a zona de ocupação soviética da Alemanha. Bevin foi crucial na decisão de resistir 
ao bloqueio de Berlim e de criar uma ponte aérea permanente para manter os abastecimentos indispensáveis à sobrevivência dos habitantes, o que exigiu uma mobilização maciça dos meios aéreos americanos e britânicos durante meses sucessivos.

O erro de Stalin precipitou a formação da aliança ocidental. Em Janeiro de 1948, Bevin propusera a Marshall a criação de um Atlantic Approaches Pact, reunindo os países nas duas margens do Atlântico Norte. Mas os Estados Unidos queriam uma demonstração prévia da determinação europeia em garantir a sua defesa e a Grã-Bretanha, em conjunto com a França, a Holanda, a Bélgica e o Luxemburgo, criou, em Março, a União Ocidental - "a sprat to catch the mackerel», na fórmula prosaica atribuída a Bevin (Shlaim, 1977: 48). Nos meses seguintes os Estados Unidos, o Canadá e os cinco membros da União Ocidental definiram os termos do Pacto do Atlântico Norte, para o qual convidaram também a Noruega, a Dinamarca, a Islândia, a Itália e Portugal. Os doze fundadores assinaram o tratado de Washington em 4 de Abril de 1949, nas vésperas do fim da crise de Berlim e da fundação da República Federal, o novo Estado alemão constituído no território das três zonas de ocupação ocidentais.

A Aliança Atlântica era o instrumento perfeito para consolidar a «relação especial» entre os Estados Unidos e a Grã-Bretanha, que garantia não só a segurança europeia perante a ameaça da União Soviética, como a contenção dos riscos da ressurgência alemã, ao mesmo tempo que reforçava a posição britânica como a principal potência europeia - para Bevin, como para Churchill, a Grã-Bretanha era um arco entre os Estados Unidos e a Europa. Mas a garantia norte-americana tornou também possível uma convergência entre a França e a República Federal, que se concretizou na formação da Comunidade Europeia do Carvão e do Aço, com o apoio empenhado dos Estados Unidos.

O Ministro dos Negócios Estrangeiros francês, Robert Schuman não informou Bevin da sua iniciativa de 8 de Maio de 1950, da qual só tinham conhecimento o Chanceler alemão, Konrad Adenauer e o Secretário de Estado norte-americano, Dean Acheson. Na altura, o Secretário do Foreign Office não escondeu a sua fúria contra Acheson e Schumann, mas a sua reacção significava o reconhecimento de um problema que prejudicava 
a estratégia britânica e não uma vontade de estar presente na criação do projecto federal europeu.

A Grã-Bretanha não queria ser parte do processo comunitário. Na frase de Churchill, os britânicos "are with, but not of Europe» (White, 1992: 14). No pós-guerra, os britânicos não partilhavam com os outros europeus a profunda desilusão com o Estado nacional em que assentou o projecto de unificação da Europa. Ao contrário dos outros Estados europeus, a Grã-Bretanha demonstrou a sua capacidade de sobreviver, mesmo depois da Europa continental se ter unido contra o velho império. Nesse sentido, os britânicos tinham razões válidas para continuar a confiar no Estado e o cepticismo perante a integração europeia era partilhado tanto pelos conservadores, como pelos trabalhistas. Bevin justificava a sua oposição ao federalismo invocando os clássicos gregos: "if you open Pandora's box you never know what Trojan horses will jump out» (Bullock, 1983: 659).

Essa divergência política fundamental sustentou uma estratégia que procurava definir a posição britânica como o lugar geométrico em que, na fórmula de Churchill, se uniam «três círculos» - o círculo imperial, o círculo atlântico e o círculo europeu. Só a Grã-Bretanha era uma grande potência em cada um desses três círculos e, nesse sentido, tinha uma capacidade única para os articular. O círculo imperial garantia à Grã-Bretanha uma presença efectiva em todos os continentes: a Commonwealth of Nations prefigurava um «império informal», onde a Índia ou o Paquistão se encontravam ao lado dos velhos dominions brancos, como o Canadá, a Austrália, a Nova Zelândia ou a União da África do Sul, enquanto as autoridades coloniais britânicas se empenhavam em federar os territórios dependentes na Ásia do Sudeste, na África Central e na África Oriental. Os Estados Unidos e a Grã-Bretanha (e o Canadá) eram membros da Organização do Tratado do Atlântico Norte (OTAN), a "relação especial» incluía uma dimensão nuclear única, reforçada pela presença de uma parte significativa dos bombardeiros nucleares norte-americanos em Inglaterra desde a crise de Berlim e os britânicos eram o único aliado internacional dos Estados Unidos, com uma presença estratégica na Ásia do Sudeste, na Ásia do Sul e no Médio Oriente. A Grã-Bretanha ligava a Europa aos Estados Unidos através da 
Aliança Atlântica e o seu estatuto como potência nuclear reforçava a sua superioridade militar na relação com os parceiros europeus.

A vitória do Partido Conservador nas eleições de Outubro de 1951 trouxe Churchill e Eden de regresso aos seus respectivos lugares como Primeiro Ministro e Secretário do Foreign Office, sem alteração significativa das políticas externas. Churchill defendeu o regresso às cimeiras entre os Estados Unidos, a União Soviética, a Grã-Bretanha e a França, que valorizava a sua posição internacional. Eden teve uma intervenção decisiva para impedir que a débâcle da Comunidade Europeia de Defesa (CED) prejudicasse a arquitectura de segurança europeia e garantiu a entrada da Alemanha na Aliança Atlântica, depois da revisão do tratado de Bruxelas e do alargamento da União da Europa Ocidental (UEO). O Governo conservador manteve intacta a oposição à adesão britânica ao processo comunitário - «something which we know, in our bones, that we cannot do" (Carlton, 1981: 311), segundo o Secretário do Foreign Office - antes e depois de Eden ter substituído Churchill como Primeiro Ministro e ganho as eleições gerais, em Maio de 1955.

A posição internacional da principal potência europeia, consolidada pela formação da Aliança Atlântica, pelo sucesso do seu programa nuclear e pela estabilização da segurança europeia, foi posta à prova no Médio Oriente. A Grã-Bretanha, em Fevereiro de 1955, formou o Pacto de Bagdad, com a Turquia, membro da Aliança Atlântica, e o Iraque, o seu melhor aliado regional, aos quais se juntaram o Irão e o Paquistão. Eden queria integrar o Egipto nesse pacto ocidental, mas o Coronel Nasser resistiu às pressões britânicas e norte-americanas e pôde desenvolver as suas relações com a União Soviética para modernizar o exército e a força aérea egípcia, cujos bombardeiros se tornaram uma ameaça séria contra Israel.

Em 26 de Julho de 1956, os britânicos foram surpreendidos pela nacionalização do Canal do Suez, que dividiu os aliados ocidentais. Para os europeus, nomeadamente para Eden, aceitar a provocação de Nasser seria repetir os erros dos anos trinta, com cedências sucessivas perante as potências revisionistas, mas, para os norte-americanos, a Companhia do Suez não passava de uma relíquia colonial. A Grã-Bretanha e a França, em conjunto com Israel, decidiram intervir contra o Egipto, para provocar a mudança do regime de Nasser. As forças israelitas avançaram até ao Suez e 
a invasão franco-britânica iniciou-se em 5 de Novembro. Porém, Eden não tinha concertado a intervenção com os Estados Unidos e não antecipou a oposição do Presidente Dwight Eisenhower, o qual, nas vésperas da reeleição, decidiu demarcar-se do seu principal aliado e condenar a invasão nas Nações Unidas, ao lado da União Soviética, cujos exércitos estavam a invadir a Hungria nesse momento. Nesse contexto inédito, Eden decidiu recuar, ordenar a retirada das suas forças e demitir-se.

É difícil subestimar a importância da crise do Suez. Por certo, o recuo britânico (e francês) não fez mais do que confirmar a sua perda de poder e o novo Primeiro Ministro conservador, Harold Macmillan, pôde restaurar rapidamente a "relação especial", numa cimeira com o General Eisenhower, em Março de 1957, que confirmou a aliança nuclear bilateral. Não obstante, a crise do Suez foi uma demonstração clara da preponderância das superpotências - os Estados Unidos não admitiam uma intervenção dos seus aliados que não tinham autorizado, mas não fizeram nada contra a invasão soviética da Hungria. Por outro lado, marcou o declínio definitivo dos impérios ultramarinos europeus, como o reconheceu Macmillan no seu discurso célebre sobre os "ventos da mudança», que acelerou a descolonização africana. Finalmente, em plena crise, perante a condenação norte-americana e o recuo britânico, o Primeiro Ministro francês, Guy Mollet, e o Chanceler alemão, Konrad Adenauer, decidiram dar um passo crucial no processo de integração, que levou à assinatura dos tratados de Roma e à formação da Comunidade Económica Europeia (CEE), em Março de 1957.

A Grã-Bretanha não podia continuar à margem do processo comunitário e, no ano seguinte, respondeu à criação da "Little Europe» com uma proposta para formar uma área de livre comércio entre todos os países da Europa Ocidental, prontamente vetada pelo General de Gaulle. Nesse contexto, em 1959, a Grã-Bretanha decidiu formar a Associação Europeia de Livre Comércio (EFTA), em conjunto com a Suécia, a Noruega, a Dinamarca, a Irlanda, a Suíça, a Áustria e Portugal, numa tentativa de opor uma «Europa dos Sete» à "Europa dos Seis», que não resistiu ao sucesso das Comunidades Europeias. A integração comunitária não só fortalecia a posição relativa da França e da Alemanha no contexto europeu, como tinha o apoio dos Estados Unidos. O Presidente Eisenhower tomou posição a favor da CEE 
contra a EFTA e o Presidente John Kennedy era um defensor dos Estados Unidos da Europa e de uma nova "Parceria Transatlântica».

Em Julho de 1961, Macmillan admitiu na Câmara dos Comuns a necessidade de conhecer os termos de uma possível adesão às Comunidades Europeias, depois de lhe ter sido confirmado, em Washington, que as relações com os Estados Unidos seriam reforçadas, e não enfraquecidas, pela entrada da Grã-Bretanha na 'Europa dos Seis'. Paralelamente, para neutralizar a vontade francesa (e alemã) de desenvolver um programa nuclear europeu, os Estados Unidos propuseram a criação de uma Força Multilateral (MLF) que garantiria um controlo conjunto das armas nucleares no quadro da OTAN e admitiram rever a sua relação com a Grã-Bretanha, cuja força nuclear era considerada supérflua.

Na cimeira anglo-americana de Nassau, em Dezembro de 1962, Macmillan conseguiu preservar a posição da Grã-Bretanha como potência nuclear, embora dependente dos Estados Unidos na escolha dos vectores de lançamento. No final de um processo confuso, que prejudicou a posição de Macmillan, Kennedy acabou por impor a entrega, em condições razoáveis, dos mísseis Polaris à força nuclear britânica, que estava integrada no dispositivo militar da OTAN, embora o Governo pudesse actuar independentemente quando estivessem em causa os «supremos interesses nacionais». Em resposta, no dia 14 de Janeiro de 1963, o General de Gaulle anunciou o seu veto à entrada da Grã-Bretanha nas Comunidades Europeias, que significaria a formação de uma "colossal comunidade atlântica dependente dos Estados Unidos que rapidamente absorveria a comunidade europeia» (Reynolds, 2000: 207). O General considerava a Grã-Bretanha como um "cavalo de Tróia» norte-americano, cuja entrada nas Comunidades Europeias podia abrir a caixa de Pandora e destruir o projecto europeu.

Dean Acheson concluiu que a Grã-Bretanha "had lost an Empire and has not yet found a role» (Horne, 1989: 429). O veredicto do Macmillan, no seu diário, não era menos severo, "All our policies at home and abroad are in ruins» (Horne, 1989: 447). Em Outubro, o Primeiro Ministro demitiuse, mas a sua linha de consolidação da «relação especial» com os Estados Unidos inserindo a Grã-Bretanha nas Comunidades Europeias para manter o seu estatuto internacional manteve-se nos dez anos seguintes e assegurou 
o consenso entre o Partido Conservador e o Partido Trabalhista sobre a necessidade de entrar nas Comunidades Europeias.

\section{O parceiro indispensável}

Depois da demissão do General de Gaulle, em 1969, o Presidente Georges Pompidou e o Chanceler Willy Brandt empenharam-se ambos, ao lado do Primeiro Ministro Edward Heath, em acelerar a adesão britânica e, em 1 de Janeiro de 1973, a Grã-Bretanha, em conjunto com a Dinamarca e a Irlanda, tornou-se membro das Comunidades Europeias. Os acordos negociados pelo Governo conservador foram contestados pelo Partido Trabalhista, que ganhou as eleições em Fevereiro de 1974, mas o novo Primeiro Ministro, Harold Wilson, pôde renegociar os termos da adesão e, em Junho de 1975 , num referendum sem precedentes, mais de dois terços dos eleitores britânicos pronunciaram-se a favor da entrada nas Comunidades Europeias.

A entrada da Grã-Bretanha nas Comunidades Europeias representou uma mudança profunda na sua política externa. No fim da década de sessenta, a descolonização estava concluída - faltava resolver a questão da declaração unilateral de independência da Rodésia para encerrar a última etapa africana. O Governo tinha decidido retirar de todas as bases no Médio Oriente e na Ásia - East of Suez, na fórmula canónica da doutrina imperial britânica -, com excepção de Hong Kong, até 1971. A doutrina militar oficial deixou de admitir a possibilidade de intervir militarmente numa crise externa sem os Estados Unidos, enquanto o Governo trabalhista se recusava, invocando razões internas, a participar na Guerra do Vietname ao lado do seu principal aliado. Essa redução drástica das responsabilidades internacionais da Grã-Bretanha correspondia a uma concentração dos recursos estratégicos, incluindo o dissuasor nuclear independente, das dimensões europeia e transatlântica da sua política externa.

Na viragem da Guerra Fria, entre a détente bipolar e a Ostpolitik alemã, parecia ser possível restaurar a posição internacional da Europa. O Livro Branco sobre a Grã-Bretanha e a Europa, publicado em Julho de 1971, considerava que «num mundo mais multipolar, uma Europa unida teria os meios 
para recuperar a posição internacional perdida por uma Europa dividida». Nesse contexto, a adesão tornava-se imperativa: se a Grã-Bretanha voltasse a recusar a entrada nas Comunidades, teria "na mesma geração, renunciado ao império e rejeitado um futuro europeu» (Reynolds, 2000: 228).

Porém, por força dos sucessivos adiamentos, a Grã-Bretanha acabou por se integrar na Europa comunitária no pior momento possível, no fim do longo período de crescimento europeu e nas vésperas da crise energética. O «euro-pessimismo" paralisante dos anos seguintes foi acentuado pela percepção do declínio dos Estados Unidos, manifesto na passividade perante a intervenção cubana em Angola ou no Ogaden e na ausência de uma resposta à instalação dos novos mísseis SS-20 no teatro europeu.

A finalidade da estratégia britânica de adesão era restaurar um círculo virtuoso em que a sua "relação especial» com os Estados Unidos e a sua posição nas Comunidades Europeias se fortalecessem reciprocamente. A retirada da França dos comandos militares integrados da OTAN e a adesão britânica às Comunidades Europeias reforçaram o estatuto da Grã-Bretanha como o parceiro indispensável dos Estados Unidos. Mas a visão britânica permaneceu imune ao charme do federalismo e céptica acerca dos méritos do "método comunitário», enquanto a sua estratégia pragmática defendia uma concertação ao mais alto nível entre as três principais potências europeias no Conselho Europeu. Essa posição podia contar, pelo menos conjunturalmente, com o apoio dos gaullistas franceses e dos sociais-democratas alemães e o Conselho Europeu passou a ter uma nova centralidade nas Comunidades Europeias.

Numa fase inicial, com Heath, Pompidou e Brandt, o "trilateralismo» garantiu à Grã-Bretanha uma posição relevante no centro da decisão comunitária, que, de resto, se traduziu em posições comuns contra a política norte-americana. Nos meses seguintes à adesão, o entusiasmo europeísta de Edward Heath ficou demonstrado quando a Grã-Bretanha se juntou à França para rejeitar as propostas do Secretário de Estado norte-americano, Henry Kissinger, sobre uma nova Carta do Atlântico. No mesmo sentido, em Outubro de 1973, os aliados europeus, com excepção da Holanda e de Portugal e incluindo a Grã-Bretanha, rejeitaram o pedido dos Estados Unidos para usar as suas bases na ponte aérea para Israel, durante a Guerra do 
Yom Kippur. Esse breve intervalo não sobreviveu à restauração do «eixo» franco-alemão, com o Presidente Giscard d'Estaing e o Chanceler Helmut Schmidt. Em 1974, a Grã-Bretanha deixou de ter lugar no centro das decisões comunitárias sem que a sua diplomacia conseguisse compensar essa perda com uma maior intervenção internacional. No ano seguinte, a formação do G7 - uma cimeira ao mais alto nível com os Estados Unidos, a França, a Alemanha, o Japão, a Grã-Bretanha, a Itália e o Canadá - resultou de uma iniciativa do Presidente francês. Em Março de 1979, a Grã-Bretanha foi o único membro das Comunidades Europeias a não aderir ao Mecanismo de Taxas de Câmbio (ERM) do Sistema Monetário Europeu, confirmando os limites da sua integração. A "dupla decisão» da OTAN, que abriu caminho à instalação dos Pershing II na Europa Ocidental para contrabalançar os SS-20 soviéticos, foi imposta pela intervenção do Chanceler alemão.

Nos primeiros anos da adesão, acumularam-se os sinais de crise económica e social na Grã-Bretanha. Em 1976, o Primeiro Ministro James Callaghan teve de pedir um empréstimo ao Fundo Monetário Internacional para travar a queda da Libra estrelina. Entre 1973 e 1979, a inflação média foi de 15\% e o produto interno bruto cresceu somente $1.3 \%$ por ano, os piores números das Comunidades Europeias. As greves sucediam-se com aumentos salariais constantes. Em Maio de 1979, o Partido Conservador regressou ao poder com um programa de reformas radical, determinado a travar a inflação e a conter a força dos sindicatos. Mas as novas políticas precisaram de tempo antes de produzir efeitos e, nos anos seguintes, a inflação continuou demasiado elevada, o produto interno bruto diminuiu, o desemprego ultrapassou 10\% e persistiu a instabilidade social. Em finais de 1981, Margaret Thatcher era o Primeiro Ministro mais impopular desde Neville Chamberlain.

Thatcher foi salva pela Junta militar argentina que, no dia 2 de Abril de 1982, decidiu invadir as ilhas Falkland - um minúsculo arquipélago com pouco mais de mil habitantes, isolado nos confins do Atlântico Sul. A crise das Falkland inverteu o paradigma da crise do Suez. A Grã-Bretanha tinha a obrigação de defender a sua colónia e a Argentina foi condenada pelo Conselho de Segurança, no dia seguinte à invasão. Dois dias depois, Thatcher enviou uma força de intervenção para o Atlântico Sul que expulsou as forças da Junta militar da capital das Falkland no dia 14 de Junho. Os 
Estados Unidos prestaram um apoio decisivo à intervenção britânica no Atlântico Sul e as Comunidades Europeias decretaram sanções contra a Argentina. No fim do conflito, as sondagens indicavam que mais de $80 \%$ dos britânicos apoiavam o modo como o Governo tinha resolvido a crise. O Partido Conservador venceu as duas eleições gerais seguintes, em 1983 e em 1987.

No momento da vitória, o Primeiro Ministro proclamou: «We have ceased to be a nation in retreat» (Reynolds, 2000: 245). Mas a crise das Falkland não alterou a posição internacional, nem a politica externa britânica. O Governo conservador mostrara o seu pragmatismo desde o princípio do seu mandato, em 1980, com os acordos de Lancaster House, quando Peter Carrington, Secretário do Foreign Office, resolveu a crise rodesiana e assegurou a independência do Zimbabwe. Em 1983, quando a República Popular da China impôs a realização de negociações sobre a colónia de Hong Kong, a parte chinesa, perante a resistência inicial da parte britânica às propostas sobre o processo de transferência de poderes, limitou-se a sublinhar que «a China não era a Argentina e Hong Kong não era as Falkland». Em 1985, Margaret Thatcher e Zhao Ziyang, o seu homólogo chinês, assinaram, em Pequim, a Declaração Conjunta sino-britânica sobre o futuro de Hong Kong, que confirmou a transferência de soberania para a China em Julho de 1997. A flexibilidade britânica voltou a ser comprovada em 1985, nos acordos com a Irlanda sobre a segurança no Ulster, uma viragem crucial no processo de paz.

A prioridade atribuída à «relação especial» era dogmática para Thatcher, não obstante o fortalecimento da linha europeísta no partido conservador. A eleição do Presidente Ronald Reagan foi importante para consolidar a aliança anglo-americana. O Governo conservador esteve na primeira linha de defesa da instalação dos Euromísseis da OTAN, incluindo a sua instalação em território britânico, não obstante ter de enfrentar uma forte campanha pacifista, que radicalizou as posições do Partido Trabalhista. Em 1982, a aliança nuclear foi confirmada pela decisão britânica de substituir os mísseis Polaris pelos novos Trident. No momento crucial, a administração republicana apoiou a intervenção nas Falkland e, em 1986, échange de bons procédés, Thatcher, contra a posição dos seus parceiros europeus, apoiou 
a intervenção norte-americana na Líbia, a partir de bases na Grã-Bretanha. No intervalo, em 1983, Thatcher não protestou quando os Estados Unidos invadiram Grenada, um Estado membro da Commonwealth, sem ter previamente avisado o seu melhor aliado europeu.

O Primeiro Ministro britânico foi importante na definição da resposta americana à sucessão interna na União Soviética, em 1985. Thatcher defendeu uma posição de abertura quando Mikhail Gorbachev foi nomeado Secretário-Geral do Partido Comunista. Contra o cepticismo ocidental sobre o sentido da perestroika, Thatcher, que os soviéticos tinham baptizado como a "Iron Lady», deu a sua bênção a Gorbachev - "We can do business together» (Young, 1991: 393) - e contribuiu para uma posição convergente de Reagan e para uma segunda détente nas relações Leste-Oeste. A diplomacia britânica voltou a ter uma projecção relevante na política internacional, bem como na política europeia.

Desde a adesão, a política comunitária britânica ficou marcada pelo problema da sua contribuição excessiva e desproporcionada - a Grã-Bretanha pagava perto de mil milhões de libras anualmente para o orçamento das Comunidades Europeias - que, de resto, tinha sido o objecto principal da renegociação reclamada pelo Governo trabalhista, em 1974. Thatcher decidiu transformar esse tema numa questão política para mobilizar a opinião pública contra as Comunidades Europeias - «We want our money» era a sua palavra de ordem -, e para se demarcar do projecto federalista, mesmo à custa de um isolamento crescente no Conselho Europeu, resumida na frase deselegante de Giscard d'Estaing que se referia ao Primeiro Ministro britânico como «la fille d'épicier» (Young, 1991: 187).

A linha de Thatcher era um "gaullismo liberal», uma contradição de termos que combinava um nacionalismo anti-federalista com uma posição anti-estatista: "We have not rolled back the fortress of the state in Britain only to see it re-imposed at a European level with a European super-state» (Reynolds, 2000: 255). Todavia, essa linguagem, que contrastava com a ideologia europeia, não se traduziu numa estratégia de ruptura, como a "Cadeira vazia» do General de Gaulle, confirmando a interpretação de Lord Soames sobre a sua política: «On Europe, she is an agnostic who continues to go church» (Young, 1991: 185). 
O Conselho Europeu de Fontainebleau, em Junho de 1984, resolveu a questão da contribuição britânica, com o reembolso de 66\% da sua contribuição anual em imposto de valor acrescentado. Esse acordo tornou possível aprovar o Acto Único Europeu, em Dezembro de 1985, bem como completar o alargamento das Comunidades europeias às novas democracias em Portugal e em Espanha. Por uma vez ao lado do Presidente da Comissão Europeia, Jacques Delors, Thatcher empenhou-se na defesa do Acto Único e aceitou o voto por maioria qualificada para a execução do programa de liberalização da economia europeia. No mesmo sentido, o Governo conservador era a favor da Cooperação Política Europeia (CPE) e de uma maior articulação das políticas externas, nomeadamente entre a Grã-Bretanha, a França e a Alemanha. A estabilização da posição britânica nas Comunidades Europeias não só contribuiu para a uma política externa mais equilibrada, como se revelou decisiva para a recuperação económica da Grã-Bretanha. Mas a revolução europeia de 1989, que abriu caminho à unificação da Alemanha, provocou mais uma crise grave.

Em coerência com o seu apoio a Gorbachev, Thatcher empenhou-se em apoiar a linha reformista na Europa de Leste. O Primeiro Ministro teve um encontro com a direcção do Solidarnosc em Gdansk, durante a sua visita oficial à Polónia, que contribuiu para o início do processo da "mesa redonda», onde o regime comunista e a oposição definiram o processo de transição que esteve na origem da mudança que levou à queda do Muro de Berlim e à deposição sucessiva dos regimes comunistas na Europa de Leste. Mas o entusiasmo da "Iron Lady" sobre o fim do comunismo não incluía a unificação da Alemanha. Para Thatcher, a "questão alemã» persistia intacta no final do século Xx: "Germany is by its very nature more of a destabilizing than a stabilizing force in Europe» (Thatcher, 1993: 791). Na melhor tradição, o Primeiro-Ministro queria contra-balançar o regresso do perturbador europeu com uma aliança entre a Grã-Bretanha e a França. Num primeiro momento, Thatcher e o Presidente François Mitterrand uniram esforços para travar a estratégia de unificação acelerada do Chanceler Helmut Kohl, apoiada pelo Presidente George Bush. Mas o Presidente francês acabou por preferir um compromisso com o Chanceler alemão sobre uma nova etapa da unificação europeia e deixou o Primeiro Ministro britânico isolado. 
Depois do seu fracasso, a oposição radical de Thatcher às propostas franco-alemãs sobre a unificação monetária e a reforma das instituições europeias subiu de tom, quando declarou na Câmara dos Comuns que a Comissão Europeia queria «extinguir a democracia» e impor o federalismo "pela porta das traseiras» (Reynolds, 2000: 271). Essa radicalização esteve na origem da demissão do seu Vice-Primeiro Ministro, Geoffrey Howe, que desencadeou o processo interno de substituição de Margaret Thatcher pelo Ministro das Finanças, John Major, escolhido para dirigir o Partido Conservador em 28 de Novembro de 1990.

\section{Os dilemas da política externa britânica}

O fim da Guerra Fria não resolveu os dilemas da política externa britânica. Mais uma vez, a Grã-Bretanha tinha uma posição destacada na coligação vencedora, como o principal aliado dos Estados Unidos. O Governo britânico antecipou a viragem soviética e apoiou a linha reformista na Europa de Leste, mas resistiu à estratégia norte-americana de unificação da Alemanha, mesmo depois de a França ter mudado de campo. De certa maneira, tanto a nova preponderância internacional dos Estados Unidos, como o peso crescente da Alemanha, tornavam mais difícil a posição da Grã-Bretanha, dividida, como sempre, entre a sua vocação internacional e a sua vinculação europeia.

A «relação especial" passou a ser menos relevante para os aliados americanos e os alemães eram candidatos alternativos ao lugar de principal parceiro europeu, enquanto a integração europeia se tornou mais importante para todos os Estados europeus e os britânicos corriam o risco de ser secundarizados pelo eixo franco-alemão na formação da União Europeia. As prioridades britânicas não tinham mudado, mas as circunstâncias do pós-Guerra Fria pareciam exigir uma alteração dos equilíbrios entre a dimensão internacional, a dimensão atlântica e a dimensão europeia da sua política externa.

Foi nesse contexto que John Major iniciou o seu primeiro mandato como Primeiro Ministro. A «relação especial» estava em declínio. O Presidente 
George Bush tinha conduzido as conversações sobre a unificação da Alemanha com a União Soviética e a Alemanha sem contar com os seus aliados britânicos. A Grã-Bretanha e a França participaram ambas nas conferências 2+4, entre a República Federal e a RDA e as quatro potências ocupantes, e assinaram os acordos finais que restauraram a soberania da Alemanha, mas não tiveram uma intervenção decisiva na diplomacia da unificação. Thatcher foi intransigente sobre a necessidade da Alemanha unificada permanecer na OTAN como membro de parte inteira, quando o Secretário de Estado, James Baker, e o Ministro dos Negócios Estrangeiros alemão, Hans-Dietrich Genscher, se comprometiam a limitar a expansão oriental da Aliança Atlântica. Na mesma linha, opôs-se às propostas norte-americanas e alemãs de revisão da doutrina nuclear da OTAN no comunicado final da cimeira do Conselho do Atlântico Norte, realizada em Julho de 1990, nas vésperas do encontro crucial entre Gorbachev e Kohl. Em Agosto, o Primeiro Ministro encontrou-se com Bush logo nos dias seguintes à invasão do Koweit, quando uma parte importante dos responsáveis da administração republicana, incluindo o Secretário da Defesa, Richard Cheyney, admitiam reconhecer a anexação como um facto consumado. Thatcher defendeu que os Estados Unidos deviam intervir sozinhos para expulsar o Iraque, como ela própria tinha feito nas Falklands. O Presidente norte-americano fez o contrário e reuniu uma vasta coligação internacional, sob a égide das $\mathrm{Na-}$ ções Unidas, antes de iniciar as hostilidades contra o Iraque para restaurar a independência do Koweit.

Na fase final da crise iraquiana, John Major, o novo Primeiro Ministro, seguiu a linha americana e mobilizou 35 mil soldados - o maior contingente aliado - para apoiar a intervenção militar dos Estados Unidos, em Fevereiro de 1991. Mas os factores de crise da «relação especial» eram mais fundos e o estatuto excepcional da única superpotência sobrevivente implicava uma distância crescente dos Estados Unidos em relação à Grã-Bretanha e à comunidade transatlântica. Paralelamente, a política comunitária britânica também estava em crise. Major, um defensor da estratégia de integração que assegurou a adesão britânica ao Mecanismo de Taxas de Câmbio (ERM), entendia bem que o lugar da Grã-Bretanha nas Comunidades Europeias devia ser no centro da decisão, nas suas palavras, "within the charmed circle» 
(Reynolds, 2000: 280), ao lado da França e da Alemanha. Mas o sucessor de Thatcher não tinha condições políticas para pagar o preço de entrada nesse círculo e a sua posição foi sempre defensiva perante as propostas francesas e alemãs apresentadas nas conferências inter-governamentais durante a negociação do Tratado da União Europeia.

Nesse processo crucial, a Grã-Bretanha era a favor da institucionalização da Política Externa e de Segurança Comum (PESC), mas contra as tentativas francesas de criar um quadro autónomo para a defesa europeia e recusou-se a discutir sequer a possibilidade de integrar a UEO na União Europeia, ou a admitir qualquer iniciativa que pudesse prejudicar a OTAN, num momento crítico em que os próprios Estados Unidos podiam querer deixar cair a aliança transatlântica. No mesmo sentido, os britânicos continuavam a defender a união europeia como uma associação entre Estados soberanos e não aceitaram incluir no novo tratado a definição do sentido federal do projecto comunitário. O Governo conservador não queria aceitar as reformas sociais e era contra a moeda única, pelo que negociou duas cláusulas de opting-out que excluíram a Grã-Bretanha do "capítulo social» do tratado e das fases finais da União Económica e Monetária (UEM). Major, como muitos outros, previa o fracasso do longo processo previsto para a criação da moeda única europeia, que selava o compromisso crucial do eixo franco-alemão sobre a unificação, resumido na fórmula irónica citada por Timothy Garton-Ash, "Half the Deutsche Mark for Mitterrand, the whole of Germany to Kohl».

A Grã-Bretanha assinou o Tratado da União Europeia mas, com as suas reservas quanto ao "capítulo social» e a moeda única, era uma «minoria de um» entre os doze fundadores, o que confirmava a sua posição como um parceiro relutante na integração europeia. Nesse contexto, parecia igualmente excessivo concluir que Maastricht tinha sido um novo «Waterloo», como queria Major, ou que era um novo "Munique», na versão de Thatcher e dos seus apoiantes.

A crescente força da Alemanha ficou demonstrada, logo em Dezembro de 1991, quando impôs aos parceiros comunitários o reconhecimento da independência da Eslovénia e da Croácia e, mais tarde, da Bósnia-Herzegovina, que marcaram o regresso da guerra à Europa, no início do processo de 
secessão da Jugoslávia. No Conselho Europeu de Maastricht, o voto favorável do Governo conservador foi uma clara contrapartida do apoio alemão às cláusulas de opting out do Tratado de União Europeia, mas, a posteriori, a posição britânica tornou-se mais cautelosa. As sucessivas tentativas de mediação europeia entre as partes, dirigidas primeiro por Lord Carrington e, depois, por David Owen, dois antigos Secretários do Foreign Office, bem como a participação de tropas britânicas, ao lado dos franceses e dos holandeses, nas forças de interposição das Nações Unidas, eram consistentes com uma estratégia de contenção cuja finalidade principal era impedir a realização da profecia de Mitterrand, quando o Presidente francês anunciava que a unificação da Alemanha seria o "regresso a 1913» (Bozo, 2005), e impedir que a questão jugoslava voltasse a dividir as potências europeias. O fracasso das tentativas de mediação e a brutalidade da guerra civil na Bósnia-Herzegovina demonstraram os limites da capacidade estratégica da União Europeia e tornaram necessária a intervenção norte-americana. Nesse quadro, formou-se, em 1994, um "Grupo de Contacto", ao qual os Estados Unidos, a Alemanha, a Grã-Bretanha e a França associaram a Rússia, antes da diplomacia norte-americana impor, em 1995, os acordos de Dayton, que puseram fim às hostilidades e garantiram a constituição da Força de Intervenção (IFOR), pela qual a OTAN assegurou a ocupação da Bósnia-Herzegovina.

Tal como Macmillan se enganara no seu cálculo inicial sobre a Comunidade Económica Europeia, também Major falhou na previsão sobre o fracasso da União Económica e Monetária. Em Maio de 1997, quando o Partido Trabalhista ganhou as eleições, era claro que a criação da moeda europeia ia para a frente, deixando para trás a Grã-Bretanha, a Dinamarca e a Suécia, os países que tinham decidido ficar de fora, bem como a Grécia, que não reunia as condições mínimas para poder entrar.

O novo Primeiro Ministro, Tony Blair, representava uma nova geração política na esquerda democrática, cujas orientações foram apresentadas no manifesto do "Third Way", e era o mais europeísta de todos os chefes de governo britânicos desde Edward Heath. A sua posição foi enunciada durante a campanha eleitoral: «I want Britain to be one of the leading countries in Europe» (Wall, 2008: 162). Todavia, as escolhas do Governo do "New 
Labour» estavam condicionadas pelas decisões do seu predecessor e pelo compromisso de realizar um referendum antes de aderir à moeda única. Em Outubro, o Ministro das Finanças, Gordon Bown, confirmou que a GrãBretanha não entraria no Euro durante o mandato do novo parlamento. Para contrabalançar essa decisão, Blair inverteu a posição da Grã-Bretanha sobre a defesa europeia e, na cimeira bilateral de Saint Malo, em Dezembro de 1998, o Primeiro Ministro e o Presidente Jacques Chirac aprovaram uma declaração onde se definiram os termos em que a União Europeia passaria a ter, pela primeira vez, capacidades militares próprias para se responsabilizar pela resolução de crises, nomeadamente nos casos em que os Estados Unidos e a OTAN entendessem não dever intervir.

A iniciativa de Blair, que esteve na origem da Política Europeia de Segurança e Defesa (PESD), foi crucial para demonstrar que o seu Governo estava determinado a ocupar uma posição central na União Europeia apesar de não pertencer à União Económica e Monetária. A nova dimensão de segurança equilibrava a posição da Grã-Bretanha e da França, os dois Estados europeus membros permanentes do Conselho de Segurança, em relação à Alemanha, sem pôr em causa a União Europeia e, simultaneamente, as novas responsabilidades estratégicas moderavam os riscos de uma excessiva dependência dos aliados europeus em relação aos Estados Unidos, sem pôr em causa a OTAN. Pelo contrário, a PESD fortalecia a centralidade da União Europeia e uma partilha de responsabilidades mais equilibrada podia fortalecer a Aliança Atlântica.

No mesmo sentido, o Primeiro Ministro empenhou-se no duplo alargamento da Aliança Atlântica e da União Europeia para consolidar os dois pilares da comunidade ocidental e integrar as democracias pós-comunistas na Europa Central e Oriental numa Europa livre e unida. Para Blair, o alargamento da União Europeia era a prioridade crucial, muito mais importante do que a moeda única. Em Outubro de 2000, em Varsóvia, o Primeiro Ministro quis intervir no debate sobre o futuro constitucional da União Europeia para contrapor à posição dos federalistas a visão de uma Europa alargada, que devia ser "a superpower, but not a superstate», uma concepção que tinha não só o mérito da ambiguidade, como o de valorizar as dimensões políticas, estratégicas e de segurança da União Europeia. 
Nesse quadro, o "pólo ocidental» voltaria a ter duas superpotências, tal como tinha previsto William T.R. Fox, com a diferença de que os Estados Unidos deixariam de estar acompanhados só pela Grã-Bretanha, como na versão original, e passariam a ter a toda a União Europeia como parceiro. Em conjunto, as democracias ocidentais deviam poder consolidar o modelo multilateralista que estava no centro da «doutrina da comunidade internacional» (Seldon, 2005: 398) apresentada por Blair em Chicago, em Abril de 1999. Essa visão cosmopolita do internacionalismo liberal era partilhada pelo Primeiro Ministro britânico e pelo Presidente Bill Clinton e fundamentava a «relação especial» anglo-americana numa versão aggiornata da defesa comum dos valores da democracia e num esforço conjunto para definir as normas da ordem internacional do pós-Guerra Fria.

A intervenção da OTAN no Kosovo, em nome da doutrina da intervenção humanitária, serviu para pôr à prova a Aliança Atlântica e concretizar a nova visão cosmopolita. A guerra preventiva contra a Sérvia, sem mandato do Conselho de Segurança das Nações Unidas, era legitimada pela necessidade de punir um regime autoritário que não cumpria os seus deveres de protecção e ameaçava expulsar a minoria albanesa concentrada no Kosovo, parte integrante do que restava do Estado jugoslavo. Embora com limitações importantes - os norte-americanos não queriam ter baixas e opuseram-se à intervenção de forças terrestres, proposta pelos britânicos -, a intervenção da Aliança Atlântica, a instituição multilateral de defesa colectiva das democracias ocidentais, devia garantir a segurança dos kosovares e, sobretudo, a deposição de Slobodan Milosevic. O dirigente comunista resistiu, mas o Kosovo foi ocupado pelas tropas da OTAN no quadro da Força do Kosovo (KFOR).

Nas vésperas dos ataques terroristas de 11 de Setembro, Blair tinha acabado de ganhar, pela segunda vez, as eleições gerais, depois de ter conseguido restaurar a posição internacional da Grã-Bretanha. A intervenção das suas forças especiais para restabelecer a missão das Nações Unidas na Serra Leoa, a importância decisiva da decisão britânica para a intervenção da OTAN na guerra do Kosovo, ou a constante pressão anglo-americana sobre o Iraque mostravam que a Grã-Bretanha voltara a ter uma posição única entre as potências europeias como garante da segurança internacional. No 
mesmo sentido, o Governo trabalhista tinha demonstrado a sua relevância no quadro da União Europeia, com a PESD e o processo de alargamento. A eleição do Presidente George W. Bush não prejudicou a linha de continuidade da "relação especial», não obstante ser evidente os dois dirigentes não partilharem as afinidades políticas e ideológicas que aproximavam Clinton e Blair. Os atentados contra Nova Iorque e Washington coincidiram com a conferência anual do Partido Trabalhista, onde Blair substituiu o seu discurso por uma declaração de solidariedade contra o terrorismo, que definiu logo como a nova ameaça internacional: "This mass terrorism is the new evil in our world today» (Seldon, 2007: 5).

Num primeira fase, a solidariedade internacional prevaleceu e os Estados Unidos puderam intervir no Afeganistão no exercício do seu direito de legítima defesa para neutralizar os santuários da Al Qaida e derrubar o regime dos Talibã. A OTAN invocou, por iniciativa do Secretário-Geral, o princípio da defesa colectiva, mas os Estados Unidos dispensaram os seus aliados, cuja intervenção se limitou à acção das forças especiais britânicas, francesas, alemãs e australianas na campanha afegã.

Numa segunda fase, a administração republicana decidiu alargar a "guerra global contra o terrorismo» aos três Estados renegados suspeitos de terem armas de destruição maciça, incluindo o Iraque, o Irão e a Coreia do Norte. Depois de George W. Bush ter denunciado o "Eixo do Mal», a unidade ocidental foi posta em causa e, não obstante os esforços de Tony Blair para evitar uma divisão entre os aliados e obter uma autorização do Conselho de Segurança das Nações Unidas para legitimar uma intervenção militar contra o Iraque, a ruptura tornou-se inevitável.

Em Janeiro de 2003, nas comemorações do tratado do Eliseu (e do veto do General de Gaulle à entrada da Grã-Bretanha), Chirac e o Chanceler Gerhard Schroeder confirmaram a sua oposição à intervenção militar contra o regime de Saddam Hussein. Em resposta, o Secretário da Defesa, Donald Rumsfeld, quis desvalorizar essa tomada de posição, dizendo que os Estados Unidos, quando se referiam à Europa, falavam da «nova Europa» e não da «velha Europa» - o «Eixo da Paz» franco-alemão. Paralelamente, Blair mobilizou os aliados europeus dos Estados Unidos, que publicaram uma "Carta dos Oito", na qual o Presidente da República Checa e os chefes de Gover- 
no da Grã-Bretanha, da Espanha, da Itália, da Dinamarca, de Portugal, da Polónia e da Hungria manifestavam o seu apoio à política norte-americana.

A Grã-Bretanha foi o único aliado cujas forças militares acompanharam as tropas dos Estados Unidos na invasão do Iraque, em Março. Mais de 40 mil soldados britânicos participaram na guerra e na ocupação do Iraque, depois da deposição de Saddam Hussein. No momento decisivo, Blair não hesitou quando teve de escolher entre a «relação especial» e a "velha Europa». Mas os custos da sua decisão, entre a demissão de Robin Cook, Secretário do Foreign Office, as divisões internas no Partido Trabalhista e a onda de anti-americanismo na opinião pública britânica e europeia, foram elevados. De certa maneira, foi essa decisão que definiu os seus mandatos como Primeiro Ministro e condicionou a sua carreira política.

No dia seguinte, Blair voltou a empenhar-se na restauração da aliança atlântica e da sua política europeia. Embora as tropas francesas e alemãs não participassem na ocupação do Iraque, as suas forças integraram a missão da OTAN que se tornou responsável pela ocupação do Afeganistão, no quadro da Força Internacional de Assistência e Segurança (ISAF), em Agosto de 2003. Nos meses seguintes, os trabalhos da Convenção Europeia puderam contar com uma rara convergência das três principais potências europeias na feitura do Tratado Constitucional da União Europeia. Por iniciativa de Chirac, que quis assegurar a participação de Blair na definição do quadro da defesa europeia, o trilateralismo esteve presente na negociação do novo tratado, que consolidou o consenso de Saint Malo sobre as responsabilidades de segurança da União Europeia. Essa convergência era tanto mais necessária, quando o alargamento da União Europeia tornava indispensável o reforço da posição política e institucional da Alemanha, da França e da Grã-Bretanha. Mas também era, por definição, limitada, embora o Governo trabalhista tenha aceitado a definição do novo tratado como um "Tratado Constitucional", enquanto Blair defendia a criação de um Presidente do Conselho Europeu mais forte e independente do que Chirac e Schroeder podiam aceitar. Não obstante, as posições britânicas na política externa e na defesa marcaram o novo Tratado Constitucional e o peso crescente da Grã-Bretanha ficou demonstrado, na fase final, pela capacidade de Blair impedir a nomeação do candidato franco-alemão e 
impor, em Junho de 2004, o seu candidato português como o novo Presidente da Comissão Europeia.

A crise transatlântica prejudicou a posição internacional da Grã-Bretanha, enquanto a crise europeia, aberta pela rejeição francesa e holandesa do Tratado Constitucional em Junho de 2005, não só confirmou a necessidade política de ultrapassar as ilusões federalistas, como criou condições para não realizar um novo referendum europeu na Grã-Bretanha, que podia comprometer a ratificação do Tratado de Lisboa, tendo em conta a radicalização das posições do Partido Conservador. No entanto, a crise europeia também prejudicou a concertação entre a Grã-Bretanha, a Alemanha e a França na política externa ou um maior empenho da União Europeia na política de defesa e segurança, não obstante a formação da EUFOR, que substituiu as forças da OTAN na ocupação da Bósnia-Herzegovina. As divisões europeias eram, sobretudo, manifestas na relação com a Rússia e, mais tarde, a oposição conjunta da Chanceler alemã, Angela Merkel, e do Presidente francês, Nicolas Sarkozy à entrada da Turquia na União Europeia deixou o Primeiro Ministro britânico isolado. Do mesmo modo, na Aliança Atlântica, persistiam as divisões internas quer quanto ao alargamento da comunidade transatlântica à Ucrânia e Geórgia, quer em relação ao Afeganistão, onde a Grã-Bretanha estava na primeira linha dos combates ao lado dos Estados Unidos, enquanto a Alemanha e a França punham em causa a prioridade atribuída à missão da ISAF, mesmo depois da eleição do Presidente Barack Obama ter criado as condições para recuperar uma maior coesão transatlântica.

A crise financeira de Setembro de 2008, pouco depois de Gordon Brown ter substituído Tony Blair como chefe do Governo trabalhista, confirmou essas divisões e a paralisia europeia. A União Europeia não soube definir uma resposta conjunta à crise, ou sequer unir-se para propor um quadro de resposta. O Presidente francês, em nome da União Europeia, quis que Bush convocasse de urgência a cimeira do G8, enquanto o Primeiro Ministro britânico sugeria uma reunião inédita do G20 ao nível de Chefes de Estado e de Governo, como veio a acontecer em Novembro.

Nesse contexto, os dilemas que marcaram a política externa britânica desde o fim da II Guerra Mundial permanecem intactos. Obviamente, o fim do império prejudicou a prioridade atribuída à dimensão internacio- 
nal, embora a Grã-Bretanha tenha continuado a assumir responsabilidades políticas e de segurança a esse nível, como membro permanente do Conselho de Segurança, como potência nuclear e pela sua participação em todas as principais missões militares internacionais das Nações Unidas, da OTAN e da União Europeia. No fim da Guerra Fria, a «relação especial» anglo-americana, que representa o essencial da dimensão transatlântica, perdeu relevância estratégica, no sentido em que a última superpotência sobrevivente se distanciou dos seus aliados, mas ganhou saliência, quando a Grã-Bretanha foi a única potência com que os Estados Unidos puderam contar na Guerra do Iraque. A tendência de regionalização internacional fez com que a dimensão europeia tivesse uma importância cada vez maior para a definição da posição da Grã-Bretanha, que se tornou, no essencial, uma potência regional, embora o legado político e institucional da II Guerra Mundial e a persistência da "relação especial» continuem a contrabalançar esse estatuto mais reduzido.

Em 1947, Ernest Bevin declarou no Parlamento que «His Majesty's Government do not accept the view that we have ceased to be a Great Power» (Reynolds, 2000: 309). A política externa britânica nunca desistiu de demonstrar que a Grã-Bretanha não está preparada para desistir dessa qualidade gloriosa.

\section{Fontes na internet}

BBC News, http://www.bbc.co.uk/news/

British Foreign and Commonwealth Office, http://www.fco.gov.uk/en/

Chatham House, http://www.chathamhouse.org.uk/

Ministério da Defesa, http://www.mod.uk/DefenceInternet/Home/

The International Institute for Strategic Studies, http://www.iiss.org/

\section{Leituras recomendadas}

Hitchcock, William (2002) The Struggle for Europe. Nova York: Random House. Dumbrell, John (2001) A Special Relationship: Anglo-American Relations in the Cold War and After. Basingstoke: Palgrave MacMillan. 
Self, Robert (2010) British Foreign and Defence Policy Since 1945: Challenges and Dilemmas in a Changing World. Basingstoke: Palgrave MacMillan.

Wall, Stephen (2008) A Stranger in Europe. Oxford: Oxford University Press.

White, Brian (1992) «British Foreign Policy. Tradition and Change», in Macridis, Roy (org), Foreign Policy in World Politics. Londres: Prentice-Hall, 7-31.

\section{Bibliografia}

Bozo, Frédéric (2005) Mitterrand, la fin de la division européenne et l'unification allemande. Paris: Odile Jacob.

Bullock, Alan (1983) Ernest Bevin. Foreign Secretary (1945-1951). Nova York: Oxford University Press.

Carlton, David (1983) Anthony Eden. A Biography. London: Allen Lane.

Dilks, David (org) (1972) The Diaries of Sir Alexander Cadogan, OM (1938-1945). Nova York: G. P. Putnam's Sons.

Fox, William T.R. (1944) The Superpowers. The United States, Britain, and the Soviet UnionTheir Responsibility for Peace. Nova York: Harcourt, Brace and Company.

Hitchcock, William (2002) The Struggle for Europe. Nova York: Random House.

Horne, Alistair (1989) Macmillan (1957-1986). Londres: Macmillan.

Northedge, Frederick S. (1974) Descent from Power. British Foreign Policy (1945-73). Londres: Allen \& Unwin.

Reynolds, David (2000) Britannia Overruled. Harlow: Longman.

Seldom, Anthony (2005). Blair. Londres: Free Press.

Seldom, Anthony (2007) Blair Unbound. Londres: Simon\&Schuter.

Shlaim, Avi (1977) «Ernest Bevin», in Shlaim, Avi; Sainsbury, Keith e Jones, Peter (org), British Foreign Secretaries Since 1945. Newton Abbot.

Thatcher, Margaret (1993) The Downing Street Years. Londres: HarperCollins.

Wall, Stephen (2008) A Stranger in Europe. Oxford: Oxford University Press.

Warner, Geoffrey (1994) «Bevin and British Foreign Policy», in Craig, Gordon e Loewenheim, Francis (org), The Diplomats (1939-1979). Princeton: Princeton University Press, 103-134.

White, Brian (1992) «British Foreign Policy. Tradition and Change», in Macridis, Roy (org), Foreign Policy in World Politics. Londres: Prentice-Hall, 7-31.

Young, Hugo (1989, 1991) One of Us. A Biography of Margaret Thatcher. Londres: Macmillan. 
(Página deixada propositadamente em branco) 


\section{CAPÍtulo 9}

\section{ÍNDIA}

\section{O grande mito da evolução}

A emergência da Índia como um actor preponderante na política internacional tem sido objecto de diversas interpretações. Há quem aponte como factores explicativos o seu tamanho e peso económico, a sua cultura estratégica milenar, o seu relativo isolamento geopolítico, ou mesmo o seu regime democrático e o sucesso da sua transição pós-colonial. As várias explicações são, no entanto, todas influenciadas por uma narrativa central que apresenta a política externa indiana como tendo sofrido uma profunda evolução, "do idealismo para o realismo» (Mohan, 2003). Esta ideia baseia-se num grande mito que urge desconstruir para avaliar a real dimensão da transformação indiana.

O mito apresenta a política externa indiana como objecto de um período de 'amadurecimento' desde 1947, progressivamente abandonando a sua 'despropositada' vertente idealista e retórica moralista pós-colonial, a favor de uma crescente vertente realista e pragmática baseada em objectivos e interesses materiais. Nas palavras de Sumit Ganguly:

As características estruturais da ordem global conduziram, por fim, os decisores indianos a abandonarem a sua agenda transformativa (idealista) e a adoptar políticas adequadas a alcançar os interesses estratégicos e de segurança da Índia. (Ganguly, 2010: 2) 
Neste entendimento, as bases da política externa da Índia sofreram uma profunda mutação ao longo das últimas seis décadas, o país sendo inicialmente punido pelo excessivo idealismo de Nehru e depois obrigado a reajustar as suas prioridades, abraçando só em 1991 os princípios da Realpolitik pura e dura. Esta tese linear e quasi-biológica, que apresenta a Índia como uma nação adolescente que só recentemente atingiu a maioridade, encontra forte acolhimento entre os próprios académicos, diplomatas e estrategas indianos, ecoando na percepção de que a Índia foi, por demasiado tempo, desrespeitada internacionalmente por ser um soft state com boas intenções, mas capacidades materiais insuficientes.

Não há dúvida de que Nehru, Primeiro Ministro e titular da pasta dos Negócios Estrangeiros até 1964, partilhava de uma Weltanschauung idealista fortemente influenciada pela sua experiência pessoal no movimento anti-colonial. O sucesso da independência da Índia apresentava-se como um caso inédito na primeira metade do século xx, em que o Império Britânico tinha sido derrotado por via da não-violência e dos ideais pacifistas, e tudo indicava que a Índia iria perseguir os mesmos ideais na sua política externa independente, a começar pelo facto de, a partir de 1959, acolher o Dalai Lama e o seu governo tibetano no exílio. De facto, a retórica oficial iria adoptar esses valores até aos anos 1990, e ainda hoje o faz pontualmente, mas na prática cedo emergiu uma política externa extremamente calculista e pragmática, colocando os interesses nacionais acima de qualquer ideal.

Assim, o caso mais exemplar deste "pragmatismo prático» é o da posição ambígua de Nehru, em 1947, sobre a possibilidade de a Índia pacifista vir a desenvolver o seu embrionário programa de armamento nuclear, uma hipótese que sempre se recusou a descartar, declarando que o país não hesitaria a recorrer a "todos os meios disponíveis» para se defender. As políticas para Caxemira e o Tibete, a gestão do contencioso fronteiriço com a China (que viria culminar na guerra sino-indiana de 1962), ou a invasão militar do Estado da Índia Portuguesa, em 1961, são exemplos adicionais do pragmatismo de Nehru, ciente em consolidar a Índia como uma potência regional e delimitar a sua zona de influência e autonomia. O período pós-Nehru é igualmente fértil em exemplos, especialmente com a sua filha Indira Gandhi, considerada por muitos como um dos expoentes máximos 
do realismo indiano, incluindo as suas decisões de intervir na guerra de independência do Bangladesh em 1971, activar o programa nuclear indiano em 1974, e apoiar a invasão soviética do Afeganistão em 1979.

O papel da Índia nestes vários cenários, longe de qualquer ingénua motivação idealista, denota uma cultura estratégica extremamente sofisticada e pragmática, dedicada a evitar que o país caísse na dependência de uma das esferas de influência do sistema bipolar da Guerra Fria. Nesse sentido, tendo em conta que o interesse máximo era o de preservar a autonomia estratégica a todo o custo, a retórica idealista e a prática não-alinhada serviam a estratégia de criar um espaço de manobra mínimo e assim garantir a sua autonomia para além dos dois blocos.

É difícil imaginar uma política externa mais realista do que esta. Assim, o que realmente mudou no período pós-Guerra Fria não foi a política externa indiana, mas o contexto internacional em que esta se inseria, bem como as relativas capacidades indianas para materializar as suas prioridades. É por isso que a transição de 1989-1991 merece um olhar aprofundado para descortinar as linhas de continuidade e mudança no pensamento estratégico indiano.

\section{O trauma da transição}

O abrupto colapso da União Soviética, o consequente fim da Guerra Fria e a emergência de um sistema unipolar liderado pelos Estados Unidos emergiram, de forma adversa, no preciso momento em que a Índia beneficiava de níveis inéditos de estabilidade, crescimento económico e autonomia.

Os anos 1980 tinham visto a Índia iniciar o seu processo de reformas liderado por Rajiv Gandhi, o seu mais jovem e empreendedor Primeiro Ministro de sempre, o lançamento do seu programa de mísseis balísticos, um período de paz nas relações com o Paquistão e a normalização das relações com a China. Ao nível doméstico, tinha sido também controlada a insurreição separatista sique no Panjabe, bem como outros movimentos armados tribais no Nordeste do país. Mais importante ainda, perante a normalização das relações sino-americanas em 1972, a relação privilegiada de Nova Deli 
com a União Soviética tinha-se cristalizado numa semi-aliança, Moscovo passando a representar os interesses indianos no Conselho de Segurança das Nações Unidas (ONU) e a ser o principal fornecedor militar da Índia.

É neste contexto estrutural relativamente favorável que o fim do sistema bipolar, e em particular o colapso da parceria indo-soviética, representou um rude choque para as ambições indianas, deixando a sua política externa mais isolada do que nunca. Com a sua autonomia seriamente ameaçada, a transição sistémica assumiu um carácter traumático na perspectiva indiana, agravado por quatro factores adicionais.

Primeiro, o colapso financeiro e a crise económica. Em 1991, a Índia chegou a ter uma balança de pagamentos extremamente deficitária e reservas externas para cobrir menos de duas semanas de importações. O Governo foi assim obrigado a recorrer a um inédito empréstimo do Fundo Monetário Internacional (FMI), o que foi visto como uma violação da soberania financeira do país e como uma submissão a interesses externos potencialmente hostis.

Segundo, o país atravessava um grave período de instabilidade política, com uma fragmentação inédita no parlamento. O histórico Partido do Congresso estava reduzido à oposição entre 1989 e 1991, o que em quarenta anos de independência só por uma vez tinha acontecido, em finais dos anos setenta.

Terceiro, as aspirações de a Índia se afirmar como uma potência regional tinham sofrido um duro revés com a intervenção militar no Sri Lanka (1987-1990), que se saldou numa derrota militar com elevados custos humanos, numa retirada precipitada, e no assassinato de Rajiv Gandhi durante a campanha eleitoral em que se preparava para ser reeleito Primeiro Ministro.

E, por quarto, o sentimento de vulnerabilidade foi amplificado pela violenta insurreição que assolou a região de Jamu e Caxemira em 1989, marcando o início da radicalização do movimento separatista e de um crescente apoio tácito do Paquistão, assim agudizando o sentimento de insegurança indiano.

É neste contexto de vulnerabilidade que Nova Deli foi obrigada a reequacionar todas as suas prioridades estratégicas. Compreende-se que, desaparecido o "guarda-chuva de segurança» soviético e exposto o anacronismo da retórica do não-alinhamento, a preservação da autonomia se apresentasse como prioridade absoluta indiana no pós-Guerra Fria. 
É precisamente esta a principal linha de continuidade que atravessa os vários períodos históricos do posicionamento externo indiano e que nos permite entender as suas actuais prioridades.

Duas linhas de continuidade: ambição e autonomia

A quasi-obsessão em assegurar a maior autonomia possível deve ser vista como fundamentada num profundo desconforto com o sistema internacional pós-1945 e a posição marginal que a Índia nele mantém. Neste sentido, a Índia alimenta, desde a sua independência, um agudo descontentamento com o processo 'exclusivo' que esteve na origem da arquitectura internacional pós-Segunda Guerra Mundial e com a sua relativa irrelevância, pelo menos a nível formal, em termos de representatividade - em especial, em comparação com a China, a sua ausência como membro permanente do Conselho de Segurança da ONU.

Ao contrário do que hoje começa a ser reconhecido (o anacronismo da actual arquitectura institucional), para a Índia esta questão não se colocou só agora, subsequente à sua emergência internacional nos anos 1990. Para a Índia, o desconforto tem raízes históricas e culturais bem mais profundas, o que se deixa explicar por uma certa ansiedade pós-colonial que, por vezes, assume contornos retóricos vingativos. Estas percepções baseiam-se num entendimento profundamente negativo do passado histórico, em particular do domínio externo do subcontinente durante o último milénio, a Índia sendo sucessivamente dominada, primeiro pelas dinastias islâmicas e depois pelas potências coloniais europeias. É neste prisma que deve ser entendida a contínua prioridade indiana em preservar a autonomia estratégica e recusar entrar nos jogos de poder da Guerra Fria - o objectivo era (e é ainda) profundamente conservador, determinado a sobreviver as actuais circunstâncias hierárquicas consideradas injustas, se não hostis, e aguardar um contexto mais oportuno para realizar o ímpeto revisionista e actualizar o seu ambicionado estatuto.

No que consiste esta histórica ambição indiana que motiva, por sua vez, a sua orientação 'autonomista'? Acima de tudo, na ideia de que a Índia, por 
natureza e por defeito, é uma grande potência extra-regional e que deve ser reconhecida como tal. Quando os diplomatas indianos advogam um mundo "mais multipolar» não defendem necessariamente um mundo mais "democrático", "pacífico», ou «justo», ideias geralmente subentendidas na definição europeia de multipolaridade. Em vez disso, entendem o conceito como um simples estágio no desenvolvimento das relações internacionais, ou seja, um 'trampolim' para voos maiores. No plano concreto, a ambição indiana de se afirmar como grande potência baseia-se em diversas 'premissas' que são frequentemente invocadas por diplomatas indianos quando se discute a legitimidade de o seu país aspirar a uma posição mais relevante. Incluem-se frequentemente indicadores de dimensão (território, população, economia), materiais (capacidades militares, em particular a nuclear), mas também normativos (regime democrático, credenciais pacifistas) e históricos (civilização e cultura milenar).

Este último factor é particularmente importante para compreender as posições da política externa indiana. Assumindo o papel de herdeira de uma grande civilização, a Índia reveste as suas principais visões do mundo com um tom universalista, tal como é aliás reflectido na sua expressão védica vasudhaiva katumbakam (o mundo é a minha família). Deste modo, os destinos da Índia e do mundo são vistos como estando intimamente ligados, um sentimento expresso no histórico discurso de Nehru perante a Assembleia Constituinte, no qual afirmou que "os sonhos da Índia são também os sonhos do mundo", equiparando ainda o país a "uma nova estrela de liberdade no Oriente» (Nehru 1947). A ideia encontra-se também subtilmente representada na forma normativa como a Constituição descreve as tarefas indianas a nível internacional (ênfase adicionada):

51. Promoção da paz e segurança internacional. O Estado deverá:

(a) promover a paz e segurança internacionais;

(b) manter relações justas e honradas entre as nações;

(c) incentivar ao respeito pelo direito internacional e às obrigações dos tratados nas relações entre os povos organizados;

e (c) encorajar a resolução de diferendos internacionais por via da arbitragem (Indiacode, 2010). 
Assim, é possível constatar que a diplomacia indiana identificou, desde cedo, a política internacional como uma área privilegiada para sublinhar e promover a sua superioridade moral, assumindo um carácter pedagógico, legitimado pelo sucesso precoce do seu movimento independentista. Embora seja pouco claro qual o preciso conceito de "grande potência" que os estrategas indianos ambicionam para o seu país, é incontestável que estes argumentos originam todos no desconforto com a actual ordem internacional e que procuram legitimar, muitas vezes de forma contraditória, a sua ambição (Xavier, 2006).

Analisada a principal linha de continuidade da política externa indiana torna-se mais simples contextualizar a segunda linha de continuidade, nomeadamente a eterna preocupação em preservar e maximizar a autonomia estratégica do país na arena internacional. Para os estrategas indianos, desde 1947 até hoje, este objectivo sagrado decorre precisamente da centralidade da ambição de grande potência. Na perspectiva indiana, preservar a autonomia dos centros de decisão, a agenda e o ritmo de transformação em várias áreas-chave (economia, defesa, sociedade etc.), é entendido como uma estratégia obrigatória para um país que aspira ao estatuto de grande potência, mas enfrenta um contexto adverso e capacidades insuficientes para o poder materializar imediatamente.

Vários exemplos recentes demonstram que é precisamente perante a progressiva abertura e interdependência de vários sectores do país à economia global e a influências externas que os debates sobre a autonomia (self-reliance) se têm agudizado e, por vezes, conduzido a decisões radicais. É o caso das celebrações com que foram recebidos os testes nucleares em 1998 (simbolizando assim a autonomia estratégica do país ao mais alto nível das capacidades militares); do intenso debate acerca da contrapartida imposta pelos Estados Unidos no acordo bilateral de cooperação civil nuclear (2005) de colocar vários reactores sob tutela dos inspectores da Agência Internacional de Energia Atómica (IAEA); da recusa em aceitar qualquer apoio humanitário internacional a seguir ao tsunami de 2004; e a hostilidade com que são recebidas todas as ofertas de mediação, incluindo as norte-americanas, para o conflito indo-paquistanês da Caxemira.

Esta hiper-sensibilidade indiana no que concerne a autonomia do país e os riscos de dependência externa não se restringe só ao sector 
estratégico, mas influencia também importantes decisões económicas e culturais - é o caso das medidas proteccionistas impostas a investimentos e importações chinesas, invocando "razões de segurança», bem como do debate sobre o impacto cultural das reformas económicas e o associado 'perigo' de submissão a valores ocidentais (em 1998, os nacionalistas do BJP adoptaram com sucesso o slogan eleitoral «import electronic chips, not potato chips»).

\section{Três dimensões de mudança}

Ambição e autonomia caracterizam assim as duas linhas de continuidade que marcam a política externa indiana e que, em certa medida, têm reforçado a sua influência no contexto da abertura do país nas últimas duas décadas. Coexistem no entanto importantes dimensões de mudança, indicando uma progressiva transformação das prioridades desde 1991.

O primeiro elemento de mudança deixa-se caracterizar pelo desenvolvimento de uma diplomacia crescentemente económica. Embora o modelo indiano, ao contrário do caso chinês, nunca tivesse dependido das exportações para acelerar as taxas de crescimento, os interesses indianos inseriram-se rapidamente na nova economia global. Entre 1991 e 2007, o volume de comércio internacional cresceu sete vezes, de 46 para 320 mil milhões de dólares norte-americanos (MUSD), e o volume total de investimento directo estrangeiro acumulado na Índia de 540 milhões para 56 mil MUSD. No que concerne as reservas externas, em menos de dez anos, passaram de 28 mil para 316 mil MUSD em 2008 (Kowalski e Dihel, 2009).

Também as crescentes necessidades energéticas obrigaram a novas prioridades no plano externo. O consumo energético tem crescido anualmente entre 5 e 7 p.c. e espelha o rápido aceleramento da sua economia que, mesmo com a crise financeira, deverá crescer entre 7 e 9 p.c., podendo em 2010 vir mesmo a ultrapassar, pela primeira vez, a taxa chinesa. O carvão representa uma parte substancial (55 p.c.) do mix energético indiano, seguindo-se o petróleo (31 p.c.), o gás natural (8 p.c.), as energias renováveis (5 p.c.) e o nuclear (1p.c.) (Madan, 2006). 
A Índia já é o terceiro maior consumidor de petróleo na Ásia, e distingue-a, neste sector em particular, não só a sua imensa dependência em termos de importações (perto de dois terços), mas também uma dependência concentrada em termos geográficos: mais de dois terços das importações petrolíferas originam no Médio Oriente, e mais de metade em só quatro países daquela região: 25 p.c. da Arábia Saudita, 12 p.c. do Kuwait, 10 p.c. do Iraque, e 7 p.c. do Irão (Xavier, 2009). Estima-se aliás que a dependência de hidrocarbonetos irá aumentar significativamente nas próximas décadas, possivelmente para 90 p.c. em 2030, e compreendem-se assim os esforços indianos em apostar no desenvolvimento da energia nuclear (depois do acordo com os Estados Unidos), nas energias renováveis (nas eólicas é já um dos líderes mundiais), e também na diversificação regional das importações petrolíferas, nomeadamente para África e a América Latina.

Estas novas prioridades económicas tiveram um impacto profundo na política externa indiana, obrigada a diversificar o leque das suas relações estratégicas. Primeiro, logo nos anos 1990, conduziu a uma aproximação ao Japão e ao Sudeste Asiático, bem como aos Estados Unidos, à União Europeia (UE) e à China, vistos como fontes de investimento e mercados de exportação. Segundo, acelerou o processo de penetração institucional, a Índia passando a membro da OMC em 1995 e a participar de forma mais regular no FMI, Banco Mundial e outros fóruns económicos, incluindo quadros alternativos como os eixos BRIC ou IBSA. Por fim, no campo dos recursos energéticos, obrigou a diplomacia indiana a investir fortemente no Médio Oriente e, já mais recentemente, em África e na América Latina, e a adicionar uma política Look West à congénere Look East iniciada nos anos 1990 para o Japão e a Ásia do Sudeste (Jaffrelot, 2003).

O grau de profundidade desta viragem económica é revelado pelo papel da diáspora indiana. Até aos anos oitenta, os mais de vinte milhões de indianos residentes no estrangeiro eram ignorados e por vezes mesmo hostilizados por Nova Deli, com as reformas de 1991 e as novas prioridades económicas nacionais, esta abordagem mudou de forma abrupta. Os governos indianos, concentrados em maximizar potenciais fontes de investimento, remessas, depósitos, e know-how para modernizar sectores-chave emergentes (caso das tecnologias de informação), viram-se obrigados a redesenhar por completo 
o relacionamento com a diáspora, instituindo uma política especial para os emigrantes (incluindo os estrangeiros de origem indiana) que passou pela criação do Ministry of Overseas Indian Affairs e pela revisão da lei de nacionalidade (Lal, 2006).

A segunda dimensão de mudança diz respeito a uma nova posição perante um outro indicador fundamental de capacidades materiais - as capacidades militares, estratégicas e, em particular, nucleares. Obrigada pelas novas circunstâncias pós-Guerra Fria, e capacitada pelo crescimento da sua economia, a Índia iniciou um vasto processo de modernização das suas Forças Armadas. Os testes nucleares de Maio de 1998, duas semanas depois dos nacionalistas do BJP terem chegado ao poder, assumem uma importância crucial, marcando um ponto de ruptura com a ambiguidade que até então envolvia o estatuto nuclear do país. Nova Deli tem, desde então, efectuado elevados investimentos no seu programa de mísseis balísticos, indústria de defesa convencional, programa espacial, e tropas especializadas (counterterrorism, urban, jungle e bigh-altitude warfare, entre outras), chegando a ultrapassar a China e a assumir-se como maior importador de armamento convencional entre os países em desenvolvimento.

Ao mesmo tempo, indicando também uma maior extroversão estratégica, o país tem apostado na projecção de poder militar. Destacam-se o crescente número de exercícios bilaterais ou multilaterais, a expansão da actividade da sua Marinha de Guerra no Oceano Índico, a participação maciça em missões de paz internacionais da ONU (é um dos três maiores contribuintes em termos de forças) e a aposta na formação de oficiais estrangeiros nas suas academias militares.

A terceira dimensão de mudança aplica-se à estratégia de alianças e parcerias da política externa indiana. Até ao fim da Guerra Fria, a Índia teve na União Soviética o seu aliado mais próximo, mas, para além de Moscovo, os seus relacionamentos bilaterais eram, no melhor dos casos, cordiais e inócuos. O Movimento dos Não-Alinhados nunca se cristalizou num efectivo bloco diplomático e, com as restantes grandes potências (Estados Unidos, Reino Unido, França, Alemanha, China e Japão) as relações eram geralmente superficiais. 
Nas últimas duas décadas, a estratégia tem sido, no entanto, profundamente alterada, Nova Deli abraçando o que Kanti Bajpai apelidou de «Omni-alinhamento» (Bajpai, 2005). Este comportamento é indicado pelo facto de Nova Deli ser hoje das capitais mundiais que acolhe o maior número de missões diplomáticas. Motivado em boa parte pela primeira dimensão de mudança (a necessidade de acelerar a diplomacia económica) os Governos indianos têm, desde 1991, procurado aprofundar as relações bilaterais com praticamente todos os principais actores no xadrez internacional. A Índia conseguiu assim estabelecer parcerias estratégicas com um conjunto extremamente diverso de actores, não só com os Estados Unidos, a UE e as principais potências europeias, o Japão e a Austrália, mas também com a Rússia, o Irão e a China. Esta polivalência (ou mesmo "poligamia estratégica») é mais um indicador da sua preocupação em alargar a sua autonomia no pós-Guerra Fria. Contudo, em contraste com o passado, estas parcerias envolvem agora trocas e entendimentos muito mais substanciais nos capítulos económico e estratégico.

Já no plano multilateral, esta mudança espelha-se também no crescimento exponencial do número de fóruns institucionais de que a Índia é membro ou observador, incluindo a ASEAN, APEC, ARF, Organização de Cooperação de Xangai (OSC), IBSA e BRIC. Esta dimensão de mudança espelha assim uma Índia proactiva em termos bilaterais e multilaterais, empenhada em institucionalizar parcerias, maximizar o número de alternativas e assim alargar a sua autonomia.

É porém interessante observar que a sustentabilidade deste omni-alinhamento estratégico começa a ser posta em causa nos círculos estratégicos indianos, especialmente perante a crescente ameaça que a China apresenta para os interesses indianos. Depois de várias décadas em que era tabu falar sobre, ou mesmo estudar o vizinho chinês em Nova Deli, a Índia acordou repentinamente para o novo equilíbrio de forças, estando a reformular todas as suas prioridades perante o novo poderio da China. Assim, coloca-se a possibilidade de a ascensão da China estar já a despoletar uma nova dimensão de mudança na política externa indiana - designadamente a necessidade de o país se reequilibrar no contexto regional, possivelmente com recurso aos Estados Unidos, mas também à Europa, ao Irão e o Japão. No entendimento 
indiano, para preservar a autonomia do país, vale tudo, incluindo cultivar um leque de relações profundamente antagónicas que resultam, por exemplo, em parcerias estratégicas simultâneas com Israel e o Irão.

\section{A agenda diplomática indiana}

A agenda diária dos diplomatas indianos no South Block, em Nova Deli, e nas mais de uma centena de representações externas no estrangeiro, é um imenso masala de prioridades tão diversas como a nova ordem nuclear, a nova cidadania para os indianos da diáspora e a defesa dos interesses de Nova Deli em relação às questões climáticas. No total, é possível identificar 25 questões que, de acordo com a sua importância relativa, são classificadas de forma resumida em quatro categorias diferentes, desde as de prioridade absoluta até às que são consideradas indesejáveis, se não mesmo um tabu.

Num primeiro nível, encontramos um conjunto de cinco questões que são de prioridade absoluta para Nova Deli. Primeiro, tendo em conta um passado de três guerras e o estatuto nuclear deste vizinho e rival, encontra-se o Paquistão e, por associação, a situação no Afeganistão. O futuro desta frente Af-Pak é de importância vital para os interesses de Nova Deli, que nela identifica várias ameaças de segurança, em especial no que concerne a disputada região de Caxemira. Uma segunda prioridade absoluta relaciona-se com a China que surge de forma crescentemente ameaçadora no horizonte estratégico, muitas vezes ressuscitando o trauma da derrota na guerra de 1962. Embora as relações bilaterais se tenham intensificado de forma impressionante nos últimos dez anos, com grandes vantagens comerciais, subsistem vários focos de tensão (como a disputa fronteiriça ou a presença do Dalai Lama na Índia) e ganha terreno a posição de que é preciso desenvolver opções militares para enfrentar a crescente expansão da China na Ásia do Sul.

Uma outra prioridade de primeira categoria relaciona-se com a necessidade de garantir externamente os recursos energéticos necessários para sustentar as altas taxas de crescimento económico, o que tem conduzido a uma intensificação de relações com vários países no Médio Oriente (Arábia 
Saudita, Irão) e em África (Sudão, Nigéria, Angola). Uma quarta prioridade absoluta relaciona-se com a necessidade de desenvolver uma nova diplomacia económica, não só promovendo a Índia como mercado de capitais e destino atractivo para investimentos estrangeiros, mas também assistindo as novas multinacionais indianas (TATA, Essar, Reliance, Bharti, etc.) a operarem no plano global. Finalmente, a quinta prioridade absoluta de Nova Deli é afirmar-se como a grande potência residente no Oceano Índico, procurando dotar a sua Marinha de capacidades de projecção de poder oceânico ao mesmo tempo que desenvolve novas iniciativas multilaterais como o Indian Ocean Naval Symposium e reavivar a Indian Ocean Rim-Association for Regional Cooperation (IOR-ARC).

Num segundo nível de prioridade externa, encontramos um conjunto de nove questões importantes, mas não vitais. Primeiro, as relações com os Estados Unidos que, principalmente desde a administração Bush e em paralelo à ascensão da China, têm testemunhado uma melhoria sem precedentes, culminando no acordo de cooperação nuclear civil de 2008 e no apoio de Obama, em 2010, a um lugar permanente para a Índia no Conselho de Segurança da ONU. Segundo, a região da Ásia do Sul, considerada como o espaço estratégico 'natural' da Índia, onde iniciativas políticas multilaterais de integração regional como a South Asian Association for Regional Cooperation (SAARC) têm dado lugar a relações mais pragmáticas, de cariz bilateral, económico e militar, principalmente com o Nepal, Bangladesh e Sri Lanka. Terceiro, surge a política Look East iniciada na década de noventa, com o objectivo de reforçar os laços económicos e políticos com o Sudeste asiático e a Ásia Oriental, em particular com o Japão. Esta aproximação assume presentemente importância acrescida no sentido de contra-balançar a China.

Em quarto lugar, surge o objectivo de colocar a Índia no seio das novas potências económicas não-ocidentais e emergentes, tal como cristalizadas nas cimeiras BRIC (Brasil, Rússia, Índia e China) ou na trilateral IBSA (Índia, Brasil, África do Sul). Associada a esta prioridade encontra-se a reivindicação indiana de reforma das principais instituições internacionais incluindo, em particular, o Conselho de Segurança da ONU. Esta quinta prioridade inclui também a actualização do peso relativo da Índia, por exemplo em termos de voto, em organizações como o Banco Mundial ou o FMI. Uma 
sexta prioridade inclui a nova diplomacia indiana para África, vista como uma fonte importante de recursos energéticos e como mercado apetecível para investimentos indianos. Embora consciente dos seus limitados recursos em comparação com a China, Nova Deli tem vindo a explorar a ideia de se demarcar positivamente de Pequim, procurando oferecer um modelo de cooperação mais sustentável para os interesses africanos. Uma sétima prioridade de Nova Deli relaciona-se com a necessidade de desenhar uma nova ordem nuclear para além do Tratado de Não-Proliferação Nuclear (NPT) que os indianos vêem como arcaico e discriminatório, especialmente no seguimento do acordo com os Estados Unidos, que confere ao seu país um reconhecimento nuclear de facto, mas não de jure.

A oitava prioridade inclui os esforços indianos de condenação ao terrorismo internacional, visto como uma das maiores ameaças para a sua segurança doméstica. Enquanto que em público isto se tem reflectido mais na retórica diplomática, no terreno menos visível da cooperação na área das informações ou do treino em práticas anti-terroristas, esta temática tem tido uma importância crescente na agenda externa da Índia. Finalmente, uma última questão prioritária diz respeito à necessidade de desenvolver o imenso soft power indiano, ou seja, a imagem e capacidade de atracção internacional da Índia no plano cultural, educacional e económico. A criação, em 2006, de uma divisão de diplomacia pública no Ministério dos Negócios Estrangeiros indiano, é um importante passo nesse sentido.

Num terceiro nível de prioridade externa, encontra-se um conjunto de nove questões de importância menor, ou seja, de terceira categoria. É o caso da UE que, embora como bloco conjunto seja o maior parceiro comercial da Índia, continua a ter uma relevância reduzida na óptica indiana, Nova Deli preferindo sempre o plano bilateral ao contacto directo com Bruxelas, especialmente depois do falhanço de um acordo de comércio livre, em 2008. Segundo, em relação ao Médio Oriente, a Índia tem vindo a assumir uma posição crescentemente pragmática, aproximando-se de Israel (agora um dos seus principais fornecedores de equipamento militar) e mostra-se muito menos interessada em assumir um papel de liderança na resolução do contencioso israelo-árabe à volta da Palestina. Os recursos energéticos e militares em jogo, bem como a sua vasta diáspora residente na região, 
têm-se sobreposto ao prisma político-ideológico com que Nova Deli tradicionalmente abordava o Médio Oriente.

Terceiro, a Rússia mantém-se como um dos mais importantes parceiros na área da defesa, mas a sua importância tem vindo a decrescer significativamente desde os anos 1990, especialmente no plano comercial. Uma quarta prioridade 'menor' reside na Ásia Central, onde a Índia tem procurado novos recursos energéticos, conter a presença da China e, ao mesmo tempo, alcançar profundidade estratégica de forma a contrabalançar a influência paquistanesa no Afeganistão. A ambição de se ver na liderança de um ressuscitado bloco afro-asiático de países em desenvolvimento surge como uma outra prioridade indiana. Aqui, a diplomacia indiana procura distinguir-se de uma China «superpotência do Norte» e posicionar-se como voz representativa do "Sul Global», um eufemismo moderno para o que outrora se designava por Movimento dos Não-Alinhados. Uma sexta prioridade é a antiga questão do desarmamento mundial, tal como defendida no plano de acção de Rajiv Gandhi em 1988, nas Nações Unidas: embora de forma hesitante, os diplomatas indianos do South Block continuam a afirmar esta como uma das suas grandes bandeiras. Já a possibilidade de um novo acordo comercial global, no seguimento do falhanço da ronda de negociações de Doha, é visto como uma questão importante, mas já não prioritária na óptica externa indiana, que desde então tem preferido apostar em acordos ou parcerias de comércio livre bilaterais (por exemplo com a Coreia do Sul ou os países da ASEAN). Finalmente, uma última questão de importância relaciona-se com a nova diplomacia para a imensa diáspora indiana, vista como um recurso económico e diplomático para os interesses externos da Índia, tal como já discutido mais acima.

Finalmente, num quarto nível e tudo menos prioritárias, encontram-se três questões 'intocáveis' que, na perspectiva diplomática indiana, equivalem praticamente a tabus. Uma primeira questão relaciona-se com as grandes questões ambientais como as alterações climáticas e a agenda internacional para a redução de emissões de carbono. Neste capítulo Nova Deli tem assumido muitas vezes posições defensivas e mesmo obstrucionistas, bloqueando propostas de consenso nas cimeiras de Copenhaga e Bali e insistindo no seu "direito à poluição» derivado da sua necessidade de crescimento industrial 
equivalente ao que diz ter sido gozado pelos países ocidentais desde o século XIX. Uma segunda questão-tabu diz respeito aos regimes autoritários e às violações de direitos humanos, onde Nova Deli recusa radicalmente a imposição de sanções, votando também muitas vezes contra a adopção de resoluções de condenação nas Nações Unidas. Embora a diplomacia indiana seja uma histórica advogada do princípio soberanista e do princípio da não-ingerência, esta vertente tem-se intensificado nos últimos anos, fruto das novas prioridades económicas e estratégicas que nem sempre são compatíveis com posições mais normativas.

Finalmente, e por estas mesmas razões, a terceira temática 'intocável' na agenda externa indiana diz respeito aos rogue states com pretensões nucleares ou ligações terroristas (como o Irão, o Sudão, a Síria ou a Coreia do Norte) e as iniciativas internacionais, principalmente sob liderança norte-americana, que visam o seu isolamento ou punição. Receosa de ver o seu espaço de manobra reduzido, Nova Deli procura, em vez disso, preservar os seus privilegiados contactos bilaterais com estes párias da comunidade internacional, por vezes mesmo defendendo-os.

\begin{tabular}{|rl|}
\hline A agenda diplomática indiana \\
\hline Prioridades absolutas \\
\hline 1. & Afeganistão-Paquistão \\
2. & China \\
3. & Recursos energéticos \\
4. & Diplomacia económica \\
5. & Oceano Índico \\
\hline Prioridades de segunda categoria \\
\hline 6. & Estados Unidos \\
7. & Vizinhança regional/Ásia do Sul \\
9. & Ásia oriental e do Sudeste \\
10. & Reforma ordem económica (BRICs) \\
11. & África \\
12. & Nova ordem nuclear pós-NPT \\
13. & Combate ao terrorismo internacionais (ONU) \\
14. & Diplomacia pública (soft power) \\
\hline Prioridades de terceira categoria \\
\hline 15. & União Europeia \\
16. & Médio Oriente \\
\hline
\end{tabular}


17. Rússia

18. Ásia Central

19. Liderança Global South / G77

20. Desarmamento internacional

21. Comércio livre / Doha

22. Diáspora indiana

Tabus

23. Combate às alterações climáticas

24. Regimes autoritários e direitos humanos

25. Estados-pária

\section{Limitações infra-estruturais}

Será o país capaz de gerir esta complexa agenda diplomática e os variadíssimos obstáculos que enfrenta no plano externo? Que infra-estrutura institucional suporta a ambição indiana? No plano doméstico, identificam-se limitações a três níveis.

Primeiro, no plano institucional, é questionável até que ponto o pequeno e arcaico Ministério dos Negócios Estrangeiros indiano (o Ministry of External Affairs) será capaz de dar conta do imenso recado que é representar os interesses do país ao nível global. O ministério sofre de uma falta crónica de diplomatas: por cada indiano, há quatro congéneres brasileiros e sete chineses. Acresce uma rede de representações externas manifestamente insuficiente, muitas vezes na dependência de um ou dois diplomatas de carreira. A qualidade dos novos diplomatas também tem vindo a decrescer ao longo dos últimos anos, os jovens indianos agora preferindo uma carreira no lucrativo sector privado à estabilidade e prestígio anteriormente associados ao funcionalismo público. Mesmo entre os que procuram fazer uma carreira no Indian Administrative Services (IAS, ao qual concorrem anualmente cerca de duzentos mil candidatos para cerca de quinhentas vagas) a preferência é maior para os serviços domésticos (polícia, magistratura, etc.) do que para o diplomático que oferece menos regalias financeiras e obriga a ausências prolongadas do país (Markey, 2009; Rana, 2000).

Uma segunda limitação decorre do regime democrático, tamanho e diversidade da população indiana. É certo que a aparência coerente e centralizada da política externa de um país autoritário como a China é muitas 
vezes uma mera ilusão, mas não deixa de ser igualmente verdade que os processos de tomada de decisão numa democracia são bem mais complexos. No caso concreto da Índia há uma multiplicidade extrema de actores que influenciam ou determinam a política externa em várias dimensões. São exemplos os partidos comunistas que no parlamento se opuseram a um acordo nuclear com os Estados Unidos (2005); os governos estaduais do Querala e Maharastra no caso de acordos de comércio livre que afectam os seus interesses agrícolas ou industriais; a imensa minoria muçulmana no caso da oposição a um eventual apoio indiano nas duas guerras do Golfo; ou o caso em que a pressão de grupos nacionalistas hindus obrigou Nova Deli a abordar os direitos civis e culturais da sua diáspora ao nível bilateral. Ao mesmo tempo, a comunicação social, livre e extremamente activista, consegue também transmitir e mobilizar a opinião pública de uma forma ímpar na Ásia, obrigando muitas vezes o Governo a importantes compromissos na sua política externa. Se há quem explique o relativo imobilismo da política externa indiana com recurso a esta imensa diversidade e complexidade de actores intervenientes, é também verdade que, quando atingido um consenso, a representatividade associada garante aos diplomatas indianos uma maior celeridade e capacidade negocial (Kapur et al., 2009).

Finalmente, em contraste com esta vibrante comunidade política indiana, surge uma terceira limitação que diz respeito ao relativo desinteresse da maioria dos indianos pelas questões internacionais. A política externa tem uma comissão parlamentar própria na Lok Sabha (a Standing Committe on External Relations), mas esta é das menos concorridas. O grande debate à volta da aprovação do acordo de cooperação nuclear com os Estados Unidos, no Verão de 2008, terá sido talvez a única vez durante a última década em que uma questão de política externa foi fracturante, obrigando o Governo a submeter-se a uma moção de confiança. Em geral, no entanto, a política externa é uma ausente constante nos programas eleitorais de quase todos os partidos e das suas respectivas campanhas. É possível interpretar este desinteresse como resultado de várias décadas de introversão estratégica, em especial desde os anos 1970, quando a Índia se começou a isolar no plano internacional, com repercussões graves no próprio ensino e investigação em Relações Internacionais e estudos de área (Alagappa et al., 2009). No 
entanto, o animado debate que se trava actualmente em Nova Deli sobre a possibilidade de a Índia se vir a desenvolver num bridging power, bem como a emergência de uma nova geração de jovens liberais, por exemplo à volta do projecto The National Interest, promete uma mudança positiva.

\section{Quatro desafios para as próximas décadas}

Tendo em conta a trajectória da política externa indiana desde 1947, as suas principais linhas de continuidade, o "trauma estratégico» do pós-Guerra Fria, as principais dimensões de mudança, e a sua agenda diplomática e respectivas limitações infra-estruturais, é possível traçar um conjunto de quatro desafios.

Primeiro, a ambição indiana de alcançar o estatuto de grande potência depende, em grande medida, da sustentabilidade do seu modelo de crescimento (económico e estratégico) e da condição de os seus recursos domésticos poderem ser gradualmente transferidos para o plano externo. A questão não é meramente económica e estratégica - apresentam-se como desafios fundamentais questões tão diversas como a estabilidade e a coesão do seu sistema político federal, a pacificação da Caxemira, a radicalização da imensa minoria muçulmana (mais de 150 milhões), as tensões inter-religiosas e inter-étnicas, a sustentabilidade do já desgastado ecossistema subcontinental, bem como todos os principais indicadores do que convencionalmente se entende por segurança humana e que afectam uma população de mais de mil milhões de pessoas. É por esta razão que, tal como a China, a Índia (ainda) concentra a esmagadora parte dos seus recursos no nível interno, assumindo uma posição relativamente conservadora no plano externo.

Segundo, contrastando com o passado em que Nova Deli procurava constantemente transcender a região da Ásia do Sul e soltar-se do conflito bilateral com o Paquistão, de forma a assumir-se como uma grande potência global, os estrategas indianos têm vindo a recentrar as suas prioridades no plano regional, invertendo as prioridades - nesta perspectiva, a Índia só poderá aspirar a um papel preponderante a nível global depois de consolidar a sua posição como potência regional. Perante a crescente presença chinesa neste 
espaço de segurança tradicionalmente indocêntrico (do Afeganistão e do Nepal à Birmânia e ao Sri Lanka), este desafio assume uma urgência ainda

maior, a Índia estando a apostar na interdependência e integração regional económica com os seus principais vizinhos, mas também na projecção de poder (razão principal que levou ao seu envolvimento no Afeganistão). É este o objectivo da Gujral Doctrine, que desde os anos 1990 procura integrar os países vizinhos por via de medidas de confiança político-económicas.

Terceiro, como referido anteriormente, perante a inevitável emergência da China como segundo pólo num sistema crescentemente bipolar, Nova Deli terá que reequacionar a sua estratégia omni-alinhada e considerar uma ainda maior aproximação aos Estados Unidos (ou outros pólos alternativos, como o Japão ou o Médio Oriente). Tendo em conta as linhas de continuidade fundamentais que marcam a política externa indiana, este é certamente um desafio monumental, passível de despoletar grandes debates e tensões internas no campo da cultura estratégica indiana. O objectivo central será preservar a autonomia (via não- ou omni-alinhamento) e, ao mesmo tempo, não deixar que o ambicionado estatuto de grande potência sucumba perante as novas realidades geoestratégicas. Na prática, isto implica alcançar um equilíbrio extremamente difícil: conter a China de forma pacífica sem, no entanto, entrar numa relação de dependência perante os Estados Unidos.

Quarto, perante a comunidade internacional, Nova Deli será, a médio prazo, obrigada a abandonar as suas reticências em relação a um maior comprometimento, envolvimento e responsabilidade perante as principais questões de global governance. Até ao momento, a Índia tem aproveitado o estatuto de free rider, assumindo por vezes mesmo posições divergentes, bloqueando importantes consensos. Como reagirá a Índia à crescente pressão para transferir o seu peso em termos de capacidades materiais brutas para o plano da liderança e influência normativa no plano global, por exemplo em relação à ordem liberal ou ao regime político democrático? Aceitará abraçar um discurso mais intervencionista, por exemplo em relação aos rogue states e regimes autocráticos com que mantém parcerias económicas importantes? E, mais do que capacidade, terá Nova Deli interesse em assumir esse papel de responsible stakeholder, ou seja, de accionista empenhado, especialmente 
em contraste com uma China igualmente relutante, mas menos interessada e mais suspeita aos olhos da comunidade internacional?

É do conjunto destes quatro desafios que emergirá a nova política externa indiana nas próximas décadas. Para os interesses europeus, esta transição assume uma importância vital - o papel da Índia terá um impacto profundo não só na mutação da ordem regional da Ásia, mas também na estabilidade ou no conflito com que se desenrolará o processo de mutação do sistema internacional. Nesse contexto de transição de uma ordem essencialmente unipolar para um ainda incerto cenário pós-unipolar há uma certeza específica que sublinha a importância da Índia: o país encontra-se no epicentro de um novo espaço geopolítico que é fulcral para a política internacional das próximas décadas, no cruzamento entre as várias Ásias (Central, do Sul, Sudeste e Oriental, via China) e como uma "península" estratégica no Oceano Índico, entre o Atlântico e o Pacífico. É nesse âmbito que a Índia deve ser vista como uma potência-pivô, ou seja, uma peça-chave para compreender a nova ordem mundial.

\section{Questões para análise}

Faz sentido analisar a política externa indiana desde 1947 como uma evolução de idealismo para realismo?

O não-alinhamento não morreu em 1990. Comente.

Que obstáculos externos e limitações domésticas poderão dificultar a emergência da Índia como grande potência?

De que forma poderá a ascensão da China alterar as prioridades externas da Índia?

\section{Fontes na internet}

Institute for Defence Studies \& Analyses, http://www.idsa.in

Live Fist (Defesa), http://livefist.blogspot.com

Ministério dos Negócios Estrangeiros da Índia, http://www.mea.gov.in

The Hindu, http://www.hindu.com

The Takshashila Foundation, http://www.takshashila.org.in 


\section{Leituras recomendadas}

Cohen, Stephen (2001) India: Emerging Power. New Delhi: Oxford University Press.

Ganguly, S. (2010) (org) India's Foreign Policy: Retrospect and Prospect. Oxford: Oxford University Press.

Kapur, D. (2009) (org) "Future issues in India's foreign policy: ideas, interests and values", Special issue, India Review, 8(3).

Mallavarapu, S. \& Bajpai, K. (2005) (org) International Relations in India: Theorising the Region and Nation. New Delhi: Orient Longman.

Mohan, C. R. (2003) Crossing the Rubicon: The Shaping of India's New Foreign Policy. New Delhi: Viking Press.

Rana, K. S. (2000) Inside Diplomacy. New Delhi: Manas Publishers. 


\section{Bibliografia}

Alagappa, M. (2009) (org) International studies in India, in International Studies, 46(1-2).

Bajpai, K. (2005) "Indian strategic culture and the problem of Pakistan», in S. Mallavarapu \& K. Bajpai (org), International Relations in India: Theorising the Region and Nation. New Delhi: Orient Longman.

Ganguly, S. (2010) "Structure and agency in the making of Indian foreign policy», ISAS Working Papers 116, Novembro.

Indiacode (2010) Versão original no sítio do Ministry of Law and Justice. [http://indiacode.nic. in/coiweb/welcome.html].

Jaffrelot, C. (2003). «India's look east policy: an asianist strategy in perspective», India Review, 2(2): $35-68$.

Kapur, D. (2009) (org) "Future issues in India's foreign policy: ideas, interests and values», Special issue, India Review, 8(3).

Lal, B. V. (2006) (org) The Encyclopedia of the Indian Diaspora. Singapore: Editions Didier Millet.

Kowalski, P. \& Dihel, N. (2009) “India's trade integration, realising the potential», OECD Trade Policy Working Papers 88, OECD Trade Directorate.

Madan, T. (2006) Brookings foreign policy studies energy security series: India. [http://www. brookings.edu/reports/2006/11india.aspx].

Markey, D. (2009) "Developing India's foreign policy 'software'», Asia Policy, Julho, 73-96.

Mohan, C. R. (2003) Crossing the Rubicon: The Shaping of India's New Foreign Policy. New Delhi: Viking Press.

Nehru (1947) Discurso "Tryst with destiny" proferido a 14 de Agosto de 1947. [http://www. fordham.edu/halsall/mod/1947nehru1.html].

Rana, K. S. (2000) Inside Diplomacy. New Delhi: Manas Publishers.

Xavier, C. (2006) "O conceito de grande potência na política externa indiana», Relações Internacionais, 15: 7-20.

Xavier, C. (2009) "Ligando os extremos no Médio Oriente: um potencial papel transatlântico para a Índia", Relações Internacionais, 22: 47-62. 
(Página deixada propositadamente em branco) 
Paula Marques dos Santos

\section{CAPÍTULO 10}

\section{JAPÃO}

Este capítulo traça as principais linhas de política externa do Japão, procurando delinear as principais áreas de actuação e de decisão, essencialmente a partir do pós-Segunda Guerra Mundial, procurando contribuir para uma compreensão das dinâmicas japonesas de política externa enquanto actor no sistema internacional. Serão analisadas as principais vertentes do seu posicionamento, de acordo com um alinhamento histórico e cronológico para a compreensão da evolução de políticas nessas mesmas vertentes.

\section{A política externa do Japão: actores e dinâmicas}

O Japão tem sido genericamente retratado como um Estado reactivo, passivo na sua política de segurança, vivendo sob o guarda-chuva securitário dos Estados Unidos da América (EUA), devido às restrições associadas ao artigo $9^{\circ}$ da sua Constituição, que procura apaziguar os vizinhos asiáticos por causa das lembranças da sua agressão imperialista na altura da Segunda Grande guerra (Hughes et al., 2007). De facto, após a Segunda Guerra Mundial, o país inicia uma postura internacional completamente diferente da que havia seguido até 1941. Como potência derrotada e ocupada, adopta um posicionamento internacional centrado numa imagem pacifista e num país preocupado em reconstruir-se social e economicamente, tornando-se rapidamente numa das maiores economias mundiais. 
A sua aposta num reposicionamento de low profile e centrado ao nível das low politics (economia, saúde, etc.) não foi, no entanto, acompanhada ao longo da segunda metade do século xx pela reformulação da sua posição enquanto actor político e militar proeminente, permanecendo como um actor secundário a estes níveis, não só pelas limitações presentes na sua Constituição e pelos grandes princípios definidos por Yoshida Shigeru (pacifismo e reconstrução económica) e por Nobosuke Kishi (princípios anti-nucleares), mas também pela própria vontade da sua população, mais preocupada com a recuperação económica do que com o reforço da imagem político-militar do seu país no sistema internacional.

Além disso, outras das razões que levaram o país a manter este posicionamento advêm das próprias pressões regionais, onde muitos países (como por exemplo, a China ou a Coreia) continuam a demonstrar a sua cautela quanto a qualquer ressurgimento nipónico, depois de terem sido alvo do expansionismo do Japão em diversos momentos. Qualquer tentativa para mudança desta postura tem sido, de facto, vista com grande desconfiança e, mesmo numa região onde a China surge como uma potência de grande relevância, o Japão continua a ser considerado com preocupação. Destas características advém a postura nipónica de um relativo alheamento face à conjuntura asiática, não só em termos político-militares, mas também ao nível da cooperação regional (postura que só apenas nos últimos anos se tem vindo a alterar, como analisaremos adiante).

Assim, perante estas condicionantes, a política externa do Japão revela algumas constantes que influenciaram todo o período após a Segunda Guerra Mundial: a renúncia à guerra e a postura anti-nuclear; a doutrina Yoshida e o desenvolvimento de uma postura de low profile no sistema internacional; a aposta no desenvolvimento económico/tecnológico e a participação em acções de peacekeeping e humanitárias, como alicerces para a sua consolidação enquanto potência asiática e mundial; e a relação privilegiada com os EUA.

Perante estas constantes, aliadas a fragilidades endémicas, verificadas e comprovadas pelas recentes crises financeiras (finais da década de 1990 e início do século XXI), e à própria mudança do sistema internacional, identificam-se alguns desafios aos quais o Japão terá de responder, se 
deseja um papel mais evidente e de peso nas relações internacionais, reformulando a sua postura e permanecendo como uma potência relevante no sistema internacional: (a) repensar a organização interna, ao nível político, económico e financeiro, definindo uma relação diferente entre as forças que influenciam a tomada de decisão política; (b) promover a defesa dos direitos humanos e das questões ambientais a par da sustentabilidade do seu desenvolvimento económico; (c) repensar a sua estratégia de segurança, com as necessárias reformulações do art. $9^{\circ}$ e do relacionamento com os EUA; (d) repensar o relacionamento intra-regional; (e) reformular as bases da sua política externa e o seu posicionamento no sistema internacional.

A nível interno, o Japão atravessa também um momento de transformação. Após quatro décadas de domínio do Partido Liberal Democrático (Liberal Democratic Party - LDP), quer por eleição directa, quer por meio de coligações, o governo foi assumido por Hatoyama em Setembro de 2009, líder do Partido Democrático do Japão (Democratic Party of Japan - DPJ). Tal situação demonstra uma sociedade em transformação, que procura sair de uma situação de crise e desemprego, após duas graves crises financeiras (1997 e 2008) que reconfirmaram as fragilidades do crescimento económico, a deficiente regulamentação financeira interna e os problemas ambientais e sociais que resultam do modelo económico desenvolvido desde o final da Segunda Guerra Mundial, além da reformulação da estrutura ao nível da decisão política.

\section{O Japão após a II Guerra Mundial até ao presente: principais marcos e decisores políticos}

Após a assinatura da capitulação japonesa no navio de guerra Missouri, o general Douglas MacArthur desembarca as tropas de ocupação americanas em solo japonês. Os japoneses - tal como a zona de ocupação alemã - são reeducados no american way of life, ocupação que se prolonga desde 1945 até 1952. Os grandes trusts concorrentes dos americanos são destruídos e dissolvidos; o Direito e a Constituição são refeitos segundo o modelo americano e o Imperador assume um papel meramente simbólico, num 
quadro onde o governo é democratizado (parlamentarismo). A 3 de Maio de 1947 entra em vigor uma nova Constituição, segundo a qual o poder supremo passa a residir no povo. A Câmara Baixa tem doravante bastante mais competências do que a Câmara Alta e o Imperador. E esta Câmara Baixa recém-eleita, ainda totalmente sob o choque da derrota no conflito mundial, renuncia solenemente à guerra ou ao uso da violência na prossecução da política externa, princípio expresso no artigo $9^{\circ}$ da Constituição:

Aspirando à paz internacional baseada na justiça e na ordem, o povo japonês renuncia para sempre à guerra como direito soberano da nação e à ameaça ou uso da força como meio de resolver disputas internacionais. A fim de cumprir o objectivo do parágrafo anterior, o potencial de guerra terrestre, marítimo e aéreo, entre outros, não será mantido. O direito de beligerância do Estado não será reconhecido (Constituição Japonesa).

Face ao repatriamento de milhões de soldados e civis, o governo liderado por Yoshida Shigeru (1946-1954), ${ }^{1}$ trabalha no sentido de reformar o país e promover a recuperação económica, orientação que ficará conhecida pela Doutrina Yoshida e que influenciará a postura nipónica durante toda a segunda metade do século xx:

A doutrina Yoshida (...) subjaz a política externa do Japão subsequente: confiar nos EUA em primeiro lugar em termos de defesa e concentração num crescimento económico célere para reintegrar o Japão na família das nações da Ásia Oriental (Hughes et al., 2007: 157).

Com efeito, nos anos do pós-guerra, os operários e empresários japoneses produziram o milagre de reconstruir as suas cidades e fábricas destruídas, e mesmo de o fazer da forma mais moderna e melhor do que tudo o que existira antes. O valor, a capacidade de aprender e a diligência

\footnotetext{
${ }^{1}$ Apesar das datas indicadas, Yoshida Shigeru realizou dois mandatos: de Maio de 1946 a Maio de 1947 e de Outubro de 1948 a Dezembro de 1954. Durante o interregno passaram pelo cargo de Primeiro-Ministro Katayama Tetsu e Ashida Hitoshi.
} 
acompanhada de modéstia, dão origem a uma expansão extraordinária da indústria e do comércio.

A Guerra da Coreia (1950-1953) ajudou nessa recuperação ao permitir um incremento nas exportações japonesas. Também apressou os EUA a procurarem a conclusão de um tratado de paz com os japoneses e levou à assinatura do Tratado de Segurança (que será renegociado em Janeiro de 1960). Assim, a 8 de Setembro de 1951 é assinado em São Francisco o Tratado de Paz com os EUA, bem como um Tratado de Defesa Mútua, a que se associam também o Reino Unido e mais 46 Estados. Segundo este Tratado, o Japão perde 45\% do seu território e é confinado às suas quatro ilhas principais. ${ }^{2}$ Recupera a sua soberania total em 28 de Fevereiro de 1952, quando as tropas de ocupação norte-americanas abandonam as grandes ilhas do Japão, embora permaneça sob protecção norte-americana. Esta normalização permitiria a entrada do Japão como membro de pleno direito na ONU, em Dezembro de 1956.

Em 1951, como reacção ao contexto de Guerra Fria e à guerra da Coreia, os EUA autorizam o rearmamento nipónico, embora limitado pelos constrangimentos do art. $9^{\circ}$. A Força de Auto-Defesa (Self Defense Force - a SDF, nome oficial do exército japonês) limitava-se, por isso, a um armamento defensivo - excluindo certo tipo de armas estratégicas e, claro, o armamento nuclear (princípios anti-nucleares reafirmados por Kishi). O país comprometeu-se a não consagrar mais de $1 \%$ do PIB às despesas militares. ${ }^{3}$

Entre 1954 e 1972, a economia japonesa expandiu-se rapidamente. Partindo da sua base industrial anterior à guerra, o Japão importou tecnologia e maquinaria modernas, e tornou o desenvolvimento económico o cerne da política nacional e do seu posicionamento no sistema internacional. O planeamento económico centralizado permitiu ao governo controlar a es-

2 O Japão renunciou a todos os seus direitos sobre a Coreia, Formosa, ilhas Curilhas, Sakalina e as ilhas que eram antigos mandatos, abandonando igualmente qualquer reivindicação sobre a China; reconheceu o direito de se defender e de negociar acordos de segurança colectivos e aceitou a validade das reparações de guerra.

3 Apesar de estarem limitados a 1\% do PIB, este valor bastava para o colocar, na altura, no terceiro lugar mundial na área do armamento militar. De resto, o Japão passaria a viver sob o ónus da existência de bases permanentes de tropas norte-americanas no seu território, para as quais o Governo japonês contribui com o bost nation support, através do pagamento dos custos com funcionários japoneses nas bases norte-americanas. 
trutura económica, colocando os recursos, capital e força de trabalho onde o seu potencial de crescimento era maior. O "Estado desenvolvimentista», herdeiro dos Meiji, orquestrou uma política industrial, distinta do liberalismo anglo-saxónico pelo papel central desempenhado pelo Estado na definição dos grandes objectivos económicos e por uma política comercial mercantilista, conduzindo o Japão a um lugar cimeiro na economia mundial desde finais dos anos setenta. Em 1972, a entrega oficial ao Japão da base de Okinawa, ocupada pelos americanos desde 1945, assinalou o fim da subordinação nipónica aos EUA, embora se mantivesse a sua presença permanente em diversas bases no seu território, como é o caso de Futenma.

Durante os sete anos de ocupação efectiva, os japoneses e os americanos conheceram-se mais de perto, tendo os americanos contribuído para a reconstrução do país através de organizações de auxílio e de ajuda industrial. Apesar disso, não se tinha conseguido fundar uma verdadeira amizade nacional entre duas nações e culturas tão diferentes. Os acompanhantes inevitáveis de qualquer exército de ocupação (a corrupção, a prostituição, a droga, o alcoolismo e as numerosas manifestações de falta de tacto dos vencedores em relação aos vencidos), criaram um clima anti-americano junto da população.

Os movimentos socialistas, orientados quer para a Rússia quer para a China de Mao, atingem também o Japão. Face à sua própria decisão de renunciar para sempre à presença militar, o Japão necessita, neste mundo convulsionado, de uma garantia de segurança. Em Julho de 1957, os «princípios fundamentais da defesa nacional», aprovados pelo governo Kishi incluem princípios como: (a) a segurança nacional do Japão baseia-se na cooperação internacional, no entendimento com os EUA e na procura de independência económica; (b) as forças de autodefesa japonesas (SDF) serão progressivamente aumentadas, mas até ao limite do estritamente necessário, e Tóquio afasta-se da opção nuclear; (c) e a presença efectiva de forças americanas é entendida como tornando mais credível o "guarda-chuva" nuclear dos EUA como factor de dissuasão de um possível agressor, ao nível regional.

Um dos principais objectivos do mandato de Kishi foi a revisão do tratado de 1952, melhorando os termos previstos para o seu país. Assim, em 1960, o primeiro-ministro Kishi (que se demite pouco depois) assina um 
tratado revisto com os EUA, que concede a estes o direito de estacionar permanentemente tropas no Japão. Pelo Tratado bilateral de segurança (de 19 de Janeiro), ${ }^{4}$ vigente por dez anos, os EUA comprometiam-se a ajudar na defesa do Japão em caso de ataque, em troca de bases e portos para as forças armadas norte-americanas em território japonês. Este tratado

perdurou por meio século de mudanças dramáticas na política mundial a Guerra do Vietname, o colapso da União Soviética, a proliferação de armas nucleares até à Coreia do Norte, a ascensão da China - e, apesar das ferozes disputas comerciais, trocas de insultos e profundas diferenças culturais e históricas entre os EUA e no Japão (...) manteve seguro Japão e os EUA fortes na Ásia Oriental (Packard, 2010).

Mas como tanto a juventude nacional, como sobretudo os movimentos socialistas e a oposição, se voltam contra esta ligação semi-militar aos EUA, Kishi apresenta a sua resignação do cargo no mesmo dia em que o Tratado é ratificado (23 de Junho), o que demonstra ao Partido Liberal Democrata (conservadores) que não poderia impor permanentemente a sua vontade à oposição e população, em matéria de paz e de guerra. O Primeiro Ministro Ikeda Hayato consegue em 1972 a renegociação do Tratado que prevê a devolução gradual das bases americanas aos japoneses (especialmente Okinawa). Com prudência, o Japão retoma também relações comerciais e económicas com a China (essencialmente a partir de 1972, após a normalização das relações EUA-China em 1971).

$\mathrm{Na}$ esteira da política dos EUA, o Japão exportador e comerciante volta a virar a face para o seu parceiro natural, o gigantesco Império do meio que, na sua poderosa marcha para o futuro, necessita de ajuda industrial. Para a China, o principal objectivo desta normalização seria obter assistência do Japão para o seu desenvolvimento e modernização (Inoguchi, 2008: 6), ou seja, o início da assistência ao desenvolvimento no exterior (ODA - Overseas Development Assistance) do Japão à China.

\footnotetext{
${ }^{4}$ Este tratado seria o resultado da reformulação do Tratado de 1952, revendo a dependência total do Japão e procurando conceder bases mais equitativas na relação bilateral.
} 
Acima de tudo, o sistema internacional modifica-se profundamente: ainda que o seu crescimento económico haja restituído ao Japão a confiança em si próprio que perdera em 1945, o sentimento de extrema vulnerabilidade do arquipélago vai aprofundar-se com a crise energética de 1973, as difíceis negociações comerciais com os EUA e a, então, Comunidade Europeia - mas, sobretudo, com a omnipresença da marinha soviética, a derrocada das posições ocidentais no Vietname e o relançamento das tensões na península coreana. Um horizonte internacional subitamente obscurecido, agravado por vezes pela postura do próprio aliado norte-americano, que sem avisar, procura reencetar relações com outras potências da região, especialmente com a China, sem pré-aviso ao governo nipónico.

Num contexto mundial de Guerra Fria, relativamente a questões militares, podemos falar em momentos distintos no relacionamento EUA-Japão: (a) num primeiro momento, os anos 1950-1960 são de dependência total dos EUA; (b) de 1961 a 1965, esboça-se uma dependência parcial com o Japão a começar a produzir o seu próprio armamento e a combinar com os EUA a sua própria estratégia de defesa; (c) entre 1966 e 1968, afirma-se a noção de dependência selectiva, considerando-se possível uma réplica autónoma do Japão a uma agressão aérea ou naval; (d) e a partir de 1969 abre-se a era da "desamericanização", reforçando-se uma possível aproximação à vizinha China, marcadamente em contraste com o afastamento do ocidente.

Em Novembro de 1982, Nakasone Yasuhiro assume a liderança do Governo do Japão. Como grandes objectivos da sua governação define essencialmente duas ideias. Em primeiro lugar, o desejo de rejeitar os últimos tabus e partilhar com os EUA as competências e responsabilidades em matéria de segurança e defesa, procurando assim um novo curso nas relações americano-nipónicas, ou seja, eliminar a sua menoridade ao nível militar. Em segundo lugar, defende a integração nipónica no sistema internacional liberal ocidental, mediante concessões comerciais essencialmente aos EUA e à União Europeia. Em termos regionais, assume um compromisso de estratégia regional pacífica, que se traduz, na prática, na reconciliação com a Coreia do Sul. 
Este governo procurava o reforço das capacidades defensivas do Japão, proporcionalmente ao seu poderio económico. Esta ruptura com a ordem anterior, simboliza a exigência de maturidade diplomática e militar. Em Janeiro de 1989, a morte do Imperador Hirohito marcou também o fim de uma era, sucedendo-lhe o seu filho Akihito, que inicia o período Heisei. A década de 1980 marca, por isso, um ponto de viragem, onde o Japão inicia uma presença mais visível na cena mundial, tornando-se o maior fornecedor de ajuda externa ao desenvolvimento (em 1988). ${ }^{5}$ Em 1985 liderava o mercado mundial das exportações e permanecia proximamente ligado aos EUA e à Europa ocidental. Devido ao Japão ser grandemente dependente de importações petrolíferas do Médio Oriente, foi criticado pela sua modesta contribuição financeira para o esforço aliado na Guerra do Golfo de 1991.

O Japão tornou-se, por isso, num grande poder económico, embora a sua recuperação pós-guerra não tenha sido acompanhada por um crescimento comparável ao seu peso em termos de política e estratégia internacional, devido, como já indicámos, à Doutrina Yoshida. Miyazawa (1992) procurou retirar o Japão do seu tradicional isolacionismo nas relações internacionais, promovendo um maior intervencionismo na região asiática, através de um aumento da despesa com a defesa e fomentando um esforço permanente para a consolidação das relações de vizinhança. ${ }^{6}$ Apesar de não gastar mais do que 1\% do seu PIB em defesa e permanecer fiel à Constituição do pós-guerra, a força japonesa era em 1994 impressionante, com 250 mil soldados e a maior frota marítima do Pacífico (Yamauchi, 2006: 7). Este poderio constitui uma preocupação para os seus vizinhos, que recordam bem o seu passado agressivo. O pacifismo japonês, com estas características militares,

\footnotetext{
5 Todavia, esta pro-actividade resume-se a acções de apoio ao desenvolvimento, a acções humanitárias (com grande pendor no continente africano) e à participação em acções de manutenção da paz das Nações Unidas, nunca com a participação enquanto forças militarizadas.

6 Continuando as ideias do seu antecessor, as políticas de Kiichi Miyazawa (Primeiro Ministro desde 1992) assinalam firmemente a nova direcção da política externa nipónica. De facto, Miyazawa conseguiu a aprovação de legislação relativa à presença de forças japonesas em acções de manutenção da paz da ONU (forças não combatentes), sendo o Cambodja o primeiro caso de presença de forças japonesas fora do seu território desde a Segunda Guerra Mundial.
} 
poderia levar ao ressurgimento de um militarismo destinado a lidar com as disputas territoriais que mantém com a China e a Rússia.

No final da década de 1990, o Japão deparava-se com a primeira crise económico-financeira, que vem demonstrar as fragilidades endémicas do seu crescimento económico: o sobre-investimento, a falta de regulamentação relativamente ao sector financeiro e a extrema dependência do exterior ao nível energético e das matérias-primas, entre outras, e que demonstram o esgotamento do modelo adoptado no pós-II Guerra Mundial e a necessidade de uma reorganização política, económica e social do Japão. Perante as fragilidades evidenciadas pela crise, Junichiro Koizumi (2001-2006) estabelece como prioridade a revisão constitucional, ao nível da capacidade de segurança. Além disso, tendo assumido o governo no início do século XXI, propôs-se também desenvolver uma reforma profunda a nível interno, incluindo modificar a Constituição para regularizar a existência das Forças Armadas; e resistir às exigências de alguns Estados asiáticos (especialmente a China e a Coreia do Sul) de que o país alterasse o enfoque dado à Segunda Guerra Mundial nos manuais escolares. Todavia, as pressões e as dificuldades para a sua implementação foram inúmeras.

Shinzo Abe continuou este trabalho reformista através de três pilares fundamentais: a reforma educacional, a inovação tecnológica e a revisão constitucional. Para isso, apostava em cinco alvos políticos: a construção de uma economia aberta e cheia de vitalidade; a reforma educacional; a transição para uma diplomacia mais pró-activa; a reestruturação das medidas de assistência social (que incluía a expansão da aplicação dos benefícios do seguro social aos que não trabalham a tempo integral); e a redução de gastos, almejando diminuir a carga financeira dos contribuintes. Em termos de segurança, defendia que as funções do Primeiro Ministro teriam de ser reorganizadas e fortalecidas, acoplando-as da capacidade de reunir informações de inteligência.

Embora a liderança de Shinzo Abe tenha durado apenas um ano, esta reafirmou as principais questões (que já Koizumi havia levantado) e que têm marcado os últimos governos. A mudança do partido no poder em 2009, com Hatoyama Yukio (DPJ), não alterou a necessidade de reformas profundas no processo de formulação política, no controlo da influência lobbyista e/ou burocrática nesse mesmo processo, bem como a regulamen- 
tação das áreas financeira e económica, para que o Japão possa efectivar a sua capacidade enquanto actor internacional, de acordo com o "arco de liberdade e prosperidade» defendido por Taro Aso. ${ }^{7}$

A reformulação da organização interna, a nível político, económico e financeiro

A política japonesa está assente num sistema parlamentar, com uma forte tendência burocrática, de acordo com os parâmetros da teoria weberiana, onde a necessidade de consenso entre o Governo, Partidos maioritários, Dieta e Câmara dos Representantes (ou Câmara Baixa) são os alicerces para a estabilidade governativa, já que o Imperador detém apenas uma representação simbólica da soberania nacional.

Pela Constituição de 1947, procurou-se evitar a situação prevalecente na constituição Meiji, onde a autoridade e responsabilidade estavam difusas por entre os diversos detentores do poder, situação que havia conduzido ao reforço das oligarquias não eleitas. Com a Constituição do pós-guerra, pretendeu-se entregar o poder aos eleitos pelo povo. O poder executivo recai, assim, no Governo, constituído pelo Primeiro Ministro e pelos Ministros de Estado, os quais têm responsabilidade colectiva perante a Dieta. O Primeiro Ministro assume a liderança do Governo, tendo como funções autoridade sobre a sua administração, homologar propostas de lei, elaborar relatórios sobre assuntos nacionais e de relações externas (para a Dieta), bem como exercer o controlo e fiscalização sobre todos os departamentos administrativos. O Governo, por seu lado, tem como funções conduzir os assuntos de Estado, gerir a política externa, concluir tratados, preparar o orçamento, e proceder de acordo com as instruções recebidas do Gabinete do Primeiro Ministro.

\footnotetext{
7 Taro Aso defendia que o Japão deveria apoiar os Estados dentro do «arco da liberdade e da prosperidade» que se estende do Nordeste Asiático à Ásia Central e ao Cáucaso, à Turquia, à Europa Central e Oriental e aos Países Bálticos, o Japão teria de conseguir oferecer o seu apoio. A título de exemplo, no Verão de 1989, o Japão declarou-se pronto para fornecer assistência financeira em larga escala à Polónia e Hungria. Na Bósnia-Herzegovina, no final do conflito em 1995, o Japão prometeu 500 milhões de dólares em assistência financeira.
} 
Todavia, apesar destas pretensões constitucionais, o défice de liderança política tem minado a capacidade do Governo de agir rapidamente, essencialmente em momentos de crise, ou de exercer uma liderança internacional nas trocas comerciais ou mesmo na política externa. Esta incapacidade decorre, não só de factores históricos e culturais, mas essencialmente de factores institucionais. De facto, a existência de lideranças fortes por parte dos Primeiros Ministros nipónicos tem sido uma excepção e não uma regra (Mulgan, 200: 183). Esta situação deve-se essencialmente a duas questões - o poder excessivo dos burocratas e a existência de grupos internos em cada Partido. A fragmentação interna inerente aos grande partidos, essencialmente do LPD, contribui para o enfraquecimento do próprio Governo, uma vez que, embora detenham a maioria dos assentos na Dieta, as lutas entre esses diferentes grupos fazem esquecer, muitas vezes, a solidariedade política para com os Ministros e o Primeiro Ministro, enfraquecendo a sua governabilidade.

O poder dos burocratas tem também influenciado consideravelmente a capacidade de governação de vários Primeiros Ministros, já que a sua influência nos bastidores políticos consegue manipular e influenciar o desfecho de muitas negociações e tomadas de decisão, levando mesmo à queda de alguns líderes do executivo (Curtis, 2002: 6), como podemos verificar na rotatividade de governos desde 2006 até ao presente. A relação entre estas duas classes durante o longo período de domínio de governação do LDP 8 não pode, no entanto, ser considerada como um jogo de soma zero onde os burocratas detinham todo o poder e os políticos nenhum, pois foram os líderes políticos, não os burocratas, a definir o enquadramento da política externa e doméstica japonesa do pós-guerra.

A crise económica de 1997, e a sua reedição em 2008, comprova que ainda há muito a fazer ao nível de regulamentação económico-financeira, onde o Estado teria de conceder um maior espaço à iniciativa privada, ficando apenas com o papel regulador, bem como ao nível político-militar. E neste aspecto, a definição dos poderes do Governo e o reforço dos po-

\footnotetext{
8 O LDP apenas perde o poder em 2009, com a vitória de Hatoyama Yukio do Partido Democrático do Japão, substituído por Kan Naoto, um ano depois (Junho de 2010) do mesmo partido.
} 
deres legislativos da Dieta têm de ser realizados simultaneamente a uma aposta na regulamentação de sectores cruciais, como a economia e as finanças, concedendo maior segurança a estes sectores, para fazer face a novos ataques especulativos e permitindo que o investimento privado (nacional e estrangeiro) possa tornar-se numa realidade e num vector de desenvolvimento do país. Esta tem sido, com efeito, uma preocupação governamental desde 1997 e reforçada nos programas governativos desde 2001, a par da luta pela reforma constitucional e da libertação do estigma da menoridade ao nível da segurança nacional.

\section{Uma nova estratégia de segurança e a segurança estratégica}

Se é verdade que o Tratado de Segurança de 1960 durou mais que qualquer outra aliança entre duas potências, desde a paz de Vestefália de 1648, trazendo benefícios evidentes para ambas as partes, também é verdade que o Japão necessita repensar a sua agenda na área da segurança, reformulando as limitações constitucionais e consolidando uma posição distinta nas suas relações intra-regionais, bem como adquirindo um novo posicionamento no sistema internacional.

A alteração da visão da segurança constitui ainda um imperativo de estabilidade nacional: as grandes indústrias japonesas que fabricam material militar de primeira linha necessitam de se tornar rentáveis. E, evidentemente, a máquina militar japonesa tem problemas enormes: muitas tropas têm que treinar em território norte-americano; e não tem como projectar poder nas costas asiáticas nem como controlar as vias marítimas de longa distância, dependendo do apoio dos EUA. Ainda, as restrições legais (que impedem os soldados japoneses de participarem fora do Japão a não ser em missões de paz da ONU) e de mentalidade (herança do passado) impedem que essas forças sejam usadas de forma efectiva. A China, que procura afirmar-se como a grande potência regional, teria que se defrontar com um rival histórico extremamente poderoso. A Rússia veria o seu peso no tabuleiro de xadrez do Oriente ainda mais reduzido, e a Coreia do Sul sentir-se-ia ameaçada face a uma presença japonesa mais extensiva. 
Em qualquer caso, terá de haver mudanças. Aliás, algumas começaram a acontecer em 1991, procurando responder às restrições existentes ao emprego de forças armadas no exterior e que obrigaram o Japão, por exemplo, a limitar a sua contribuição para a resolução da crise levantada pela invasão do Kuwait pelas forças de Saddam Hussein a uma ajuda económica. Um ano depois, uma nova lei passou a permitir a participação das Forças de Auto-Defesa em operações de manutenção da paz no exterior, desde que sob mandato da ONU. Desde aí, a presença de militares japoneses passou a ser efectiva em países como o Camboja (1992), Moçambique (1993), Ruanda (1994), Montes Golã (desde 1996, como observadores da ONU) e, posteriormente, em Timor-Leste (1999 e 2002) e Iraque (2003-2004). Em 1995, com o lançamento da Iniciativa Nye, ${ }^{9}$ encetaram-se negociações para a revisão do Pacto de Defesa Mútua EUA-Japão, onde se apontavam quatro possíveis opções para o Japão: (a) tornar-se uma superpotência através de um processo de remilitarização; (b) continuar com a sua política economicista do pós-guerra; (c) dar ênfase ao contexto regional; (e) desempenhar um papel político global em decorrência e em conjunto com o seu poder económico global.

O Japão sofreu, na altura, três choques de segurança: os testes chineses de mísseis sobre o Estreito de Taiwan em 1995 e 1996; o teste de lançamento do míssil norte-coreano Taepodong-1, em 1998; e um conjunto de eventos que erodiu a confiança nos fundamentos do regime existente de não proliferação: os teste nucleares da Índia e Paquistão em 1998 e a decisão dos EUA de não ratificarem o Tratado de Proibição de Testes. O plano de reestruturação das Forças de Auto-Defesa previa a melhoria nas tecnologias de defesa e equipamento militar, enquanto visava redução de pessoal e o alargamento dos parâmetros operacionais das Forças de Auto-Defesa.

A Dieta japonesa tomou a decisão, em Julho de 1999, de constituir grupos especiais para a revisão do artigo $9^{\circ}$ da Constituição. O maior impacto foi causado pelas declarações, em Outubro desse ano, do Vice-Ministro da agora extinta Agência de Defesa do Japão, Nishimura Shingo, de que o Japão

\footnotetext{
9 Joseph Nye desempenhava, nessa altura, as funções de secretário assistente da defesa para os assuntos de segurança nacional dos EUA.
} 
poderia considerar a possibilidade de adquirir armas nucleares. A China opôs-se de imediato ao sistema de defesa de mísseis japonês - Theater Missile Defense (TMD), devido a cinco motivos: o possível envolvimento de Taiwan; a possibilidade de que a capacidade de dissuasão chinesa fosse minada; a ameaça da remilitarização do Japão; o reforço da aliança EUA-Japão; e o impacto negativo que poderia ter no processo global de controlo de armas.

A partir de 1997-1998 são adoptadas, no entanto, novas directivas sobre a cooperação em defesa, especificando detalhes sobre o acesso dos EUA à área de apoio do Japão, ao abastecimento e aos aeroportos em caso de emergência. Depois dos testes de um míssil balístico pela Coreia do Norte (1998), Tóquio concordou em cooperar com Washington e compartilhar tecnologia de anti-mísseis balísticos de defesa. Mais tarde, em 2001, uma nova lei permitiu que as forças navais japonesas colaborassem com as forças armadas norte-americanas no Índico, em missões de reabastecimento e apoio logístico, por ocasião da invasão do Afeganistão.

Em 2005, Condoleezza Rice e Donald Rumsfeld, em reunião com os representantes do Machimura (MNE) e do Obno (Ministério da Defesa), assinaram um documento intitulado US-Japan Alliance: Transformation and Realighment for the Future. Pode ler-se neste documento que a Aliança EUA-Japão continuava a ser o pilar indispensável da segurança do Japão e da paz e estabilidade da região Ásia-Pacífico. O Japão deveria, por isso, evoluir gradualmente a fim de assumir maior responsabilidade na segurança do Extremo Oriente, em aliança com os EUA e os seus aliados. A aliança entre o Japão e EUA representa a relação de segurança bilateral mais importante para ambos os governos. Quer em termos de poder estrutural, quer em termos de identidade democrática, o mundo desvia-se cada vez mais para a Ásia e, por isso, o Japão é um exemplo paradigmático: é um grande poder e, simultaneamente, possui uma identidade democrática.

Quando Shinzo Abe assumiu a liderança governativa (2006), enfrentou desafios profundos acerca da necessidade de repensar a estratégia do país no novo cenário internacional. O período da sua governação foi efémero, pois, não conseguindo responder à pressão conjuntural, resigna ao cargo, sendo substituído por Yasuo Fukuda, que toma posse em Setembro de 2007. A resignação de Abe esteve directamente ligada ao debate sobre a altera- 
ção do art. $9^{\circ}$ da Constituição japonesa, mas constituiu também o reflexo da própria instabilidade económica, financeira e mesmo social instalada no país, apesar de todas as tentativas de retoma que foram desenvolvidas após a recessão de $1997 .{ }^{10}$

Shinzo Abe considerava que, tendo em conta as mudanças da situação internacional como a proliferação de mísseis, armas de destruição em massa e luta contra o terrorismo, bem como os avanços tecnológicos militares e a crescente expectativa em relação à contribuição internacional do Japão, deveriam ser estudados casos específicos para identificar que tipo de situação se enquadraria no exercício do direito à autodefesa colectiva, tornando mais eficazes as funções da aliança Japão-EUA e promovendo a manutenção da paz. Perante este desafio, apontam-se nos nossos dias, para a revisão da Constituição, dois objectivos principais: legitimar a actual existência das Forças de Auto-Defesa, criadas em 1954, que alguns pensam não estar claramente enquadradas pela Constituição; e clarificar a questão da participação em iniciativas de autodefesa colectivas. ${ }^{11}$ Por uma questão de prestígio nacional e de necessidade estratégica, o Japão terá de se preparar para alterar o artigo $9^{\circ}$.

A vitória do Partido Democrata Japonês em Agosto de 2009, liderado por Hatoyama Yukio, levantou novas questões em relação aos benefícios do Tratado de Segurança, questionando se estes continuam a ser superiores aos custos. De facto, podemos apontar diversos benefícios para ambos os países. Se para o Japão este Tratado trouxe benefícios evidentes, permitindo-lhe o robustecimento económico e a consolidação democrática, ${ }^{12}$ para os EUA também foi favorável: possibilidade de prosseguir com a sua estra-

10 De facto, e apesar de todos os esforços de retoma económica no Japão, em Novembro de 2008 é anunciado um novo estado de recessão técnica no país, após a crise do sub-prime nos EUA.

11 Neste debate, existem 3 correntes essenciais: a) os nacionalistas (visão conservadora) entendem que a política de segurança deve centrar-se no Tratado de Segurança com os EUA, cujo âmbito deve ser expandido, quer a nível regional quer a nível global; b) os internacionalistas (visão moderada) pretendem que tudo se baseie numa maior cooperação com as Nações Unidas ou outros possíveis quadros multinacionais ou regionais; e c) os neo-nacionalistas (visão progressista) defendem a criação de capacidades de defesa autónomas.

12 O Tratado permitiu ao Japão permanecer sob o guarda-chuva nuclear dos EUA, prosseguindo com a Doutrina Yoshida e focalizar-se no crescimento económico, sem a necessidade de adquirir armas nucleares. Além disso, permitiu-lhe ainda o acesso ao mercado norte-americano e, dessa forma, ter a possibilidade de robustecer as raízes frágeis da democracia parlamentar. 
tégia no sudeste asiático, concedendo-lhe uma vantagem estratégica para observação das manobras soviéticas e possibilidade de ter tropas estacionadas permanentemente na região a baixo custo. Como definiu o Primeiro Ministro Yasuhiro Nakasone (1982-1987), o tratado concedeu aos EUA um "porta-aviões inafundável» (Packard, 2010).

Perante isto, se durante todos estes anos, Tóquio se escudou nos três princípios anti-nucleares de Eisaku Sato, constitucionalmente alicerçados - Tóquio não produzirá, possuirá ou introduzirá armas nucleares no território para se dirimir de uma participação pró-activa no sistema internacional e na região, o governo liderado por Yukio Hatoyama, e os seus sucessores, terão de conseguir consolidar uma nova estratégia de defesa, promovendo um debate nacional que consiga finalizar o processo encetado no início do século Xxi, essencialmente com Koizumi e Shinzo Abe, para a reformulação do art. $9^{\circ}$ e para uma nova política externa e estratégia de segurança. Esta deve ser mais preocupada e envolvida com a conjuntura regional asiática, e responder à necessidade de esbater a "pegada" norte-americana no Japão, incluindo a renegociação das condições de permanência no território, de forma a tornar este relacionamento mais equitativo.

Perante tal situação, a nova agenda de segurança do Japão terá de repensar o seu posicionamento regional, sem, contudo, eliminar a cooperação com os EUA no reforço da comunidade no sudeste asiático, ideia já lançada por Hatoyama.

\section{As relações intra-regionais}

Podemos considerar que a normalização definitiva dos relacionamentos ao nível regional será uma das grandes prioridades para o Japão, procurando eliminar definitivamente os traumas do conflito mundial e demonstrando uma postura assertiva e empenhada no desenvolvimento de toda a região. A base da política externa japonesa passará, então, pelo fortalecimento da aliança com os EUA e das relações com países vizinhos como a China, Coreia do Sul e Rússia, além do sudeste asiático. Ou seja, tal como Taro Aso (2008-2009) defendeu durante o seu governo, além das linhas de orientação tradicionais, 
o Japão deveria acrescentar um novo eixo em torno do qual deveria girar a política externa japonesa, alicerçada numa diplomacia de valores, prioritizando «valores universais» como democracia, liberdade, direitos humanos, Estado de direito e economia de mercado. Neste sentido, este Primeiro Ministro definiu ainda um conjunto de novas democracias ao longo dos limites externos da Eurásia, onde o Japão deveria desenhar o arco da liberdade e prosperidade, demonstrando uma liderança eficiente, como referido.

O fim da Guerra Fria permitiu ao Japão a oportunidade de desenvolver uma política independente relativamente à China. Após a assinatura do Tratado de Paz e Amizade em 1978, os laços entre os dois países desenvolveram-se consideravelmente: os japoneses alargaram substancialmente a sua assistência económica aos chineses com vários projectos de modernização (participação na ODA), florescendo uma forte relação económica e comercial. O intercâmbio bilateral comercial e cultural expandiu-se e, na década de 1990, a China tinha-se já tornado no segundo parceiro económico, ultrapassada apenas pelos EUA. Apesar de diferendos ocasionais (Segunda Guerra Mundial ou condenações nipónicas sobre a repressão chinesa de 1989), a visita do imperador Akihito à China em 1992, que incluiu um pedido de desculpas tácito pelo sofrimento severo que o Japão infligiu à população chinesa durante a guerra, demonstrou que o Japão está determinado não só em construir laços económicos bilaterais fortes, mas também em ultrapassar o fosso desde a guerra e restabelecer os laços culturais. Todavia, o relacionamento político mantém-se muito difícil.

Apesar das relações formais com Taiwan estarem suspensas desde 1978, o território continua a desempenhar um papel importante para o Japão, particularmente desde a década de 1980, quando o governo nipónico procurou reforçar os seus laços com os novos países industrializados asiáticos da altura (Coreia do Sul, Taiwan, Singapura e ainda Hong Kong). Estas regiões eram vistas como áreas capazes de fornecer produtos de alta qualidade ao mercado japonês e, consequentemente, como territórios para investimento directo das empresas nipónicas, criando uma região económica altamente dinâmica.

Os esforços para consolidar as relações com o sudeste asiático aprofundaram-se essencialmente a partir do final do século xx (os sentimentos 
de ressentimento e de exploração contra os japoneses mantiveram-se até à década de 1980). As nações do sudeste asiático, particularmente a Indonésia, tornaram-se destinos de ajuda japonesa ao desenvolvimento. Além disso, o Japão desenvolveu esforços ainda com o Vietname e o Cambodja. No caso do Vietname existiam grandes interesses económicos, enquanto no Cambodja o Japão participou amplamente no plano de paz do Conselho de Segurança das Nações Unidas e ajudou à sua implementação no ano de 1992, através da participação das Forças de Auto-Defesa na operação de manutenção da paz da ONU (a primeira desde a Segunda Guerra Mundial).

O Governo nipónico procurou ainda aligeirar as animosidades com a península coreana. Foram formalizados pedidos de desculpa relativos à acção colonial japonesa (desde 1995 pelo Primeiro Ministro Murayama Tomiichi), desenvolveram-se visitas mútuas pelos líderes políticos a ambos os territórios (Coreia do Sul e Japão) e foram negociados acordos de comércio bilateral. Todavia, estes passos positivos tendem a desvanecer-se por eventos que não agradam às autoridades da Coreia do Sul: declarações do governo japonês em defesa das acções coloniais e de guerra do Japão (incluindo a prostituição forçada de mulheres coreanas durante a guerra), ou revelações acerca de manuais escolares que exaltam o período colonial, além do estatuto diferenciado dado a coreanos em território japonês, muitos dos quais de terceira e quarta geração. Apesar destas diferenças, em 2002 os dois países organizaram conjuntamente o mundial de futebol, a primeira vez que tal evento se realizou no continente asiático, bem como têm colaborado na busca da resolução do problema norte-coreano. Com a Coreia do Norte as relações são muito mais precárias devido ao regime no poder vigente naquele país - o seu projecto de nuclearização tem levado a contactos frequentes entre o Japão, os EUA e a Coreia do Sul. De facto, as relações entre o Japão e a Coreia do Norte não poderão ser normalizadas a menos que o problema dos sequestros seja resolvido e o regime norte-coreano aceite uma abertura e fiscalização internacional ao seu território, em termos de armamento.

Quanto à Rússia, este relacionamento bilateral permanece distante. O problema das Curilhas mantém-se como obstáculo, evitando a assinatura de um tratado de paz formalmente terminando com as hostilidades da Segunda Grande Guerra. De facto, o Japão encarou a devolução das quatro ilhas das 
Curilhas como uma ameaça ao seu território e, por isso, continuam relutantes em garantir à Rússia ajuda ao desenvolvimento deste território. Contudo, e apesar deste impasse, a maioria dos japoneses não sente problemas na relação com a Rússia.

Além destes contactos bilaterais, uma série de movimentos e iniciativas recentes indicam também que o Japão está a procurar um posicionamento diferente da sua postura anterior e que pode propiciar o desenho de um papel mais cooperativo ou de liderança na região asiática:

- iniciativas com ênfase na dimensão inter-regional, visando ampliar a integração da região asiática com outros espaços, principalmente com a União Europeia, através do ASEM (Asia Europe Meeting) e com a América Latina, por intermédio da EALAF (East Asia Latin America Forum);

- projectos intra-regionais com o objectivo explícito de reforçar novas modalidades de integração, sem a presença norte-americana, como a retoma da proposta de um Fundo Monetário Asiático e a recente configuração da ASEAN (Association of Southeast Asian Nations) em ASEAN+3, com a inclusão da China, Coreia do Sul e Japão. Nesta perspectiva, pode-se ainda arrolar a disposição japonesa de assinatura de tratados comerciais bilaterais, especificamente com Singapura, Coreia do Sul e Chile;

- uma maior participação nas questões de segurança estratégica regional, ampliando o seu papel na sua defesa e na defesa regional. Esta ponderação apresenta-se de forma mais complexa em decorrência da manutenção da aliança militar com os EUA, inclusive com a sua participação no desenvolvimento do Theater Missile Defense (TMD).

Todos estes elementos demonstram que o Japão, após um longo período de aparente inércia, pretende assegurar um papel de maior proeminência na região asiática e ser um actor regional/internacional com maior peso. A reunião informal da ASEAN, em Novembro de 1999, ressuscitou a ideia defendida em 1990 pelo Primeiro Ministro da Malásia, Mahathir Mohamad, de 
institucionalização de um bloco regional, com características essencialmente asiáticas. Tanto a proposta inicial do East Asia Economic Group (EAEG), como a proposta mais suavizada do East Asia Economic Caucus (EAEC), dentro do fórum da APEC, foram fortemente rechaçadas pelos EUA por terem sido deixados de fora, forçando o Japão a não apoiar a iniciativa ou a instrumentalizar uma liderança dentro deste bloco asiático. No entanto, a ASEAN constitui ainda uma força regional e a adesão dos três líderes do nordeste asiático - Japão, China e Coreia do Sul - reflecte a tendência para uma crescente cooperação, especialmente económica. A ênfase no reforço da cooperação económica indica igualmente o cuidado em evitar eventuais discussões sobre questões políticas e de segurança.

Além do interesse de estreitamento de cooperação económica, o Japão demonstra igualmente dúvidas em relação ao controlo sobre fluxos de capitais e investimentos das economias ocidentais que dominam o FMI. Assim, na região da ASEAN, o Japão ganhou o endosso da região na indicação de Eisuke Sakakibara, antigo Ministro das Finanças do Japão, para a presidência do FMI. E igualmente procurou apoio para a retoma do processo de criação do Fundo Monetário Asiático (FMA), o qual se materializou a 5 de Maio de 2007.

Neste sentido, podemos concluir que o Japão está a promover um forte processo de abertura externa em três níveis: (a) abertura unilateral, representada pela reestruturação bancária; (b) abertura multilateral, decorrente dos esforços de inserção internacional através de instituições internacionais, em especial a OMC e a APEC; e, (c) abertura bilateral, em reconhecimento da eficácia de arranjos bilaterais, mas centrados em novas modalidades, principalmente as que se referem a informações tecnológicas e produção de conhecimento.

No início da década, a maioria das análises apontavam o Japão ou como uma superpotência económica ou como um poder incompleto em decorrência da sua renúncia ao uso da força como instrumento da política externa ou ao facto de não possuir recursos militares ofensivos, principalmente nucleares. Mas as suas decisões têm comprovado que o país procura uma forma de consolidar o seu posicionamento, não só ao nível internacional, mas também perante a realidade regional asiática. 


\section{Considerações finais}

Ao longo deste capítulo verificamos que o Japão se encontra num cruce de caminos, onde tem procurado redesenhar o seu posicionamento ao nível regional e mundial, reformulando, ou pelo menos procurando redefinir, os paradigmas nacionais ao nível da formulação e decisão política que lhe permitam esse mesmo reposicionamento.

Tal como Chin Wah (1997: 108-130) demonstra, o Japão deve encarar algumas questões para se apresentar como um grande poder regional. Primeiro, a retórica do retorno à Ásia não é um substituto para o relacionamento com os EUA. Consequentemente, deve procurar uma forma de manter equilíbrio entre ser parte do mundo desenvolvido e um líder na Ásia. Segundo, a China será um ponto crítico de referência num envolvimento triangular com vista à estrutura de estabilidade na Ásia-Pacífico. Mais do que visar uma política de contenção remodelada com os EUA, seria necessário envolver positivamente a China num processo de construção de confiança. Terceiro, com a emergência chinesa como uma força económica, inevitavelmente comparações serão feitas sobre quem desempenhará um papel crítico no desenvolvimento regional - o Japão, por um lado, tem a vantagem de ser a base do investimento e da regionalização dos processos de manufacturação, enquanto a China, por outro lado, deverá continuar a oferecer um mercado em expansão e oportunidade de investimento para as economias regionais. E, finalmente, o Japão continuará a ter que escolher entre estar atento às sensibilidades norte-americanas ou apoiar as iniciativas regionais, como por exemplo a EAEC.

A preferência e orientação pelo low profile e pela doutrina Yoshida, apesar das tentativas de reformulação encetadas a partir dos anos de 1980, constituem ainda um dos grandes desafios à política japonesa. Contudo, o novo contexto internacional tem questionado o valor desta postura tradicional, em particular face à nova distribuição de poder pós-Guerra Fria, pós-11 de Setembro e face a uma China emergente. Apesar do fim da Guerra Fria e da desagregação da URSS terem feito desaparecer a ameaça hipotética que pairava sobre o Japão (ainda que o contencioso territorial entre Tóquio e Pequim sobre as ilhas Curilhas continue por resolver), novas ameaças 
parecem cada vez mais claras. O aumento do poderio da China, potência nuclear, faz parte agora das preocupações de política externa nipónicas.

Independentemente do uso futuro do seu poderio militar, o Japão enfrenta um conjunto alargado de preocupações de segurança, que se podem intensificar caso a situação na Ásia se agrave, principalmente em relação à Coreia do Norte, ou face a um eventual afastamento norte-americano radical da área, que de momento não parece provável. Estes receios poderão, no entanto, incentivar a participação japonesa na corrida ao armamento que se tem verificado na região asiática. Ainda mais problemático, com os seus vizinhos bem equipados em termos militares, o Japão tem colocado questões sobre uma possível capacidade nuclear futura. Caso se venha a concretizar, significará uma mudança profunda na doutrina japonesa, iniciando uma nova postura do país relativamente ao seu papel militar no mundo.

O papel de liderança japonesa em política externa apresenta-se também dependente de um novo equilíbrio na sua política doméstica, com instabilidades contínuas desde início dos anos 1990, ou seja, o estatuto de grande poder não corresponde só ao direito mas também a responsabilidades na manutenção da ordem e estabilidade regional. No caso do Japão, a aceitação deste papel pelos outros dependerá também de como solucionará a sua bagagem histórica negativa.

Por fim, o Japão tem também procurado ganhar um novo fôlego enquanto actor mundial, em conjunto com a crescente procura de participação em arranjos e fora multilaterais sob a égide da ONU. De facto, o Japão tem também aumentado a sua capacidade e influência no seio das Nações Unidas, lançando uma candidatura na década de 1990 a um lugar permanente no Conselho de Segurança, ${ }^{13}$ além de procurar uma cooperação estreita com a UE e a NATO. Todavia, um papel mais activo na política externa

13 O Japão celebrou, no dia 18 de Dezembro de 2006, o $50^{\circ}$ aniversário da sua admissão nas Nações Unidas. O Japão foi admitido nos Nações Unidas em 1956, tornando-se o seu octogésimo membro e já foi membro não permanente do Conselho de Segurança por nove vezes. Em 2005, para ganhar um assento permanente no Conselho de Segurança, o Japão propôs um esboço de resolução visando a ampliação do número de assentos permanentes juntamente com os outros integrantes do G4 (Brasil, Alemanha e Índia), mas tal proposta foi rejeitada, parcialmente devido à oposição da China. A administração de Shinzo Abe retomou esta questão e conseguiu que em finais de 2006 os EUA expressassem o seu apoio à obtenção de um assento permanente. 
não é defendido por toda a população nipónica, razão pela qual o envio de tropas por Junichiro Koizumi em 2003 para apoiar os EUA no Iraque foi criticada por muitos. Actualmente, a contribuição financeira do Japão é a segunda maior de todas, representando 19,5\% do orçamento da ONU, perdendo somente para os 22\% dos EUA, tendo já disponibilizado 5.700 pessoas para operações para manutenção da paz em 18 ocasiões (Tanaka, 2006; Yamauchi, 2006: 6-7).

Neste momento, repensar o reposicionamento japonês no sistema internacional passa pela capacidade de moderar a influência directa dos EUA sem perder essa ligação privilegiada; promover uma melhor e maior aceitação ao nível regional, demonstrando à vizinhança a não vontade de todo de voltar a ter políticas imperialistas e expansionistas; promover a cooperação regional, adquirindo uma posição de liderança em organizações de cooperação; e aceitando o seu papel e responsabilidade perante os conflitos regionais e internacionais, alargando o seu envolvimento além da ajuda humanitária.

A sua posição no sistema internacional limita, por isso, a sua margem de manobra. A inserção do arquipélago na economia e na rede militar americanas da Guerra Fria teceu importantes laços de dependência política que perduraram quase imutáveis até aos nossos dias. Os EUA moldaram o sistema político e estimularam a emergência de elites pró-americanas, bem como do LDP. Durante a Guerra Fria, esta subordinação político-militar era compensada pela abertura quase incondicional do mercado norte-americano aos produtos nipónicos e pela tolerância americana face ao dirigismo japonês. No pós-Guerra Fria, os japoneses tiveram de se acomodar à manutenção desta subordinação política, ao mesmo tempo que se sujeitavam a um questionamento do seu modelo económico.

Sob fortes pressões externas, nos anos 1980-1990 o Estado desobrigou-se da economia, privatizou o sector público e desregulamentou os mercados financeiros. Nos finais da década de 1990, após anos de fraco crescimento e mesmo recessão, o Japão tem de enfrentar a crise de sobre-investimento, que se voltou a agravar em 2008. Enfraquecendo o Estado desenvolvimentista, a globalização teve um efeito profundamente corrosivo sobre o modelo económico nacional japonês. No século Xxi o Japão enfrenta uma crise multidimensional que afecta o próprio centro do seu sistema econó- 
mico e político. Além disso, é certo que o Japão continua a ser a potência dominante na Ásia oriental, mas enfrenta a concorrência da China, novo pólo de integração regional. O Japão está doravante colocado perante o desafio de reinventar o seu modelo e de se dotar de uma autonomia política à medida do seu peso económico, procurando paralelamente responder à instabilidade económica mundial que se tem reflectido negativamente na sua capacidade de retoma interna.

\section{Questões para análise}

Identifique e analise as principais forças que têm influenciado o processo de decisão política no Japão.

De que forma o relacionamento estreito com os EUA, tem condicionado o posicionamento ao nível do sistema internacional do Japão?

Perante um sistema internacional onde os EUA pretendem partilhar com as restantes potências a responsabilidade da estabilidade político-militar, analise a necessidade da redefinição da estratégia de segurança do Japão.

Identifique os principais desafios com que o Japão se depara ao nível regional, para consolidar e ver reconhecida a sua liderança e importância enquanto potência.

\section{Fontes na internet}

Constituição Japonesa (versão on-line, língua inglesa), http://www.kantei. go.jp/foreign/constitution_and_government_of_japan/constitution_e.html

Site oficial do Governo do Japão, http://www.kantei.go.jp/foreign/index-e.html Site oficial do Ministério dos Negócios Estrangeiros do Japão, http://www. mofa.go.jp/index.html

Site sobre o Japão, http://www.japan-guide.com/e/e2136.html

\section{Leituras recomendadas}

Miyashita, Akitoshi e Sato, Yoichiro (org) (2001) Japanese Foreign Policy in Asia and the Pacific: Domestic Interests, American Pressure, and Regional Integration. Basingstoke: Palgrave. 
Hughes, C. e Krauss, E. (2007) «Japan's new Security Agenda», Survival, 49(2), 157-176.

Mulgan, A. G. (2009) "Why Japan can’t lead», World Policy Journal, World Policy Institute.

Rooney, K. (2007) Japan's Foreign Policy since 1945. London: M.E. Sharpe.

Tanaka, Hitoshi (2006) «Strategic Challenges for Japanese Diplomacy in the Twenty-First Century", Gaiko Forum. Journal of Japanese Perspectives on Foreign Affairs, 5(4), 3-38.

\section{Bibliografia}

Constituição Japonesa, The Constitution of Japan, Prime Minister of Japan and His Cabinet. [http://www.kantei.go.jp/foreign/constitution_and_government_of_japan/constitution_e.html].

Curtis, G. (2002) «Politicians and Bureaucrats: What's Wrong and What's to Be Done», in Curtis, G. (org) Policymaking in Japan: Defining the Role of Politicians. Tokyo: Japan Center for International Exchange, pp. 1-17.

Hughes, C. e Krauss, E. (2007) «Japan's new Security Agenda», Survival, 49(2), 157-158.

Packard, G. (2010) “The United States - Japan Security Treaty at 50", Foreign Affairs, 89(2), 92-103.

Tanaka, Hitoshi (2006) «Strategic Challenges for Japanese Diplomacy in the Twenty-First Century», Gaiko Forum. Journal of Japanese Perspectives on Foreign Affairs, 5(4), 3-38,

Yamauchi, Masayuki (2006) «Japan and the UN», in Hanzawa, A and Yamaguchi, J, (org), Japan and the UN in International Politics - Historical Perspectives. Sapporo: Hokkaido University.

Wah, Chin Kin (1997) "Japan as a Great Power, in Chee, Chan Heng (org), The New Asia-Pacific Order. Singapura: Institute of Southeast Asian Studies, 108-130. 
Nuno Severiano Teixeira

\section{CAPÍTULO 11}

\section{PORTUGAL}

País europeu, Portugal é também um país atlântico. Potência pequena, semi-periférica e com uma só fronteira terrestre, Portugal viveu, sempre, um equilíbrio instável, entre a pressão continental e a procura de uma alternativa marítima. Dessas condicionantes geopolíticas e desta contínua tentativa de equilíbrio, decorrem movimentos de longa duração que foram definindo permanências nas opções estratégicas e nas características históricas da política externa portuguesa que podemos definir como estruturas ou modelos de inserção internacional.

E, historicamente, Portugal conheceu três modelos de inserção internacional, a que correspondem, também, três momentos históricos diferentes.

\section{O primeiro modelo}

O primeiro modelo é o do Portugal medieval. Até ao século XV as relações externas de Portugal fazem-se no quadro da Península Ibérica, entre cinco unidades políticas, todas elas mais ou menos da mesma dimensão e potencial: os reinos peninsulares - Castela, Leão, Navarra, Aragão e Portugal.

A luta contra o Islão no interior da Península e as limitações científico-tecnológicas inviabilizavam, de resto, quaisquer relações sustentadas extra-peninsulares. 
Durante a Idade Média as relações externas de Portugal desenvolvem-se, pois, no quadro intra-peninsular e num ambiente internacional de equilíbrio quase natural.

\section{O modelo clássico}

O segundo modelo começa a desenhar-se a partir do século XV, estende-se ao longo de cinco longos séculos e só termina entre 1974 e 1986 com o processo de democratização e a integração europeia. É o modelo histórico, ou tradicional de inserção internacional do País.

O que muda, então, relativamente ao modelo medieval? Praticamente, tudo, a começar pela condicionante geopolítica. Primeiro, a vitória sobre o Islão e a unificação de Espanha pelos Reis Católicos convertem a Península Ibérica em duas unidades de desigual dimensão e potencial - Portugal e Espanha. Segundo, a evolução científica e tecnológica vem possibilitar o desenvolvimento sustentado de relações internacionais extra-peninsulares.

O equilíbrio medieval converte-se num desequilíbrio geopolítico, o que obriga Portugal a procurar uma compensação para esse desequilíbrio. A costa atlântica e a capacidade de sustentação de relações extra-peninsulares vão possibilitar a construção de um vector de compensação: o vector marítimo. A partir de então, Portugal passa a viver sob a tentativa constante de equilíbrio entre a pressão continental de Espanha e a procura de uma compensação marítima do Atlântico.

Daqui decorrem os invariantes históricos que caracterizam o segundo modelo de inserção internacional. Primeiro, uma percepção contraditória entre o continente e o mar, entre a Europa e o Atlântico. Segundo, o afastamento estratégico em relação à Europa (percepcionada como ameaça espanhola) e a afirmação do vector marítimo e da opção atlântica de Portugal. Terceiro, no quadro da opção atlântica, dois movimentos de longa duração histórica na orientação externa do Estado: em primeiro lugar, a aliança privilegiada com a potência marítima (a Aliança Inglesa, os Estados Unidos da América, a NATO); em segundo lugar, o projecto imperial (nos seus vários ciclos: a Índia, o Brasil, a África). Quarto, a diversificação das 
alianças extra-peninsulares relativamente a Espanha e uma diplomacia, fundamentalmente, bilateral, assente no triângulo Lisboa, Madrid e Londres e, depois de 1945, Lisboa, Madrid e Washington.

É este modelo que preside às relações internacionais de Portugal durante cinco séculos e são, ainda, estas linhas de orientação estratégica que dão forma à política externa portuguesa até ao fim do Estado Novo.

São essas opções de afastamento das questões europeias, de afirmação de um Portugal atlântico e colonial e do equilíbrio triangular entre Lisboa, Londres e Madrid que estão presentes na posição portuguesa perante a Guerra Civil de Espanha e na neutralidade durante a Segunda Guerra Mundial. E são essas mesmas opções que continuam a presidir à posição portuguesa na ordem internacional da guerra fria: a integração no sistema de segurança atlântico e a entrada de Portugal na NATO; a reticência e o pragmatismo face ao processo de construção europeia; e a recusa da descolonização e a defesa intransigente do Império.

Opções estas que correspondem com uma clareza meridiana ao segundo modelo histórico de inserção internacional de Portugal.

Em primeiro lugar, a percepção contraditória, entre a Europa e o Atlântico, que atinge o "paroxismo" no final do Estado Novo, precisamente, no debate político entre as duas opções estratégicas para o País: os africanistas e os europeístas.

Em segundo lugar, o afastamento da Europa e o predomínio da opção atlântica e colonial. Predomínio, no plano político e na esfera económica. No plano político, com um dispositivo diplomático e estratégico totalmente assente no vector atlântico: integração na NATO e alianças privilegiadas com Washington e Londres. Na esfera económica, com um dispositivo geoeconómico, basicamente, ultramarino e colonial. E que, mesmo, quando o pragmatismo obrigava o País a uma aproximação às instituições económicas europeias, essa aproximação continuava a fazer-se num quadro estratégico atlântico e nunca continental. A entrada de Portugal na EFTA é disso o exemplo mais acabado.

Em terceiro lugar, a diversificação constante das alianças extra-peninsulares. No quadro atlântico, Portugal entra na NATO, a Espanha não. No quadro europeu, Portugal entra na EFTA, a Espanha não. Dito de outro modo, Portugal estará sempre onde a Espanha não está. 
Finalmente, a persistência da diplomacia bilateral, assente no triângulo Lisboa, Madrid e potência marítima.

A democratização em Portugal trouxe consigo a alteração de todo este quadro da política externa. Mas, trouxe mais do que isso. A transição à democracia e a consolidação democrática em Portugal e Espanha e a própria evolução internacional conduziram, em apenas doze anos (1974-1986), ao desaparecimento deste modelo histórico de inserção internacional de Portugal, velho de cinco séculos.

\section{A formação do modelo democrático}

O fim do regime autoritário e o processo de transição à democracia que se inicia em 25 de Abril de 1974 vêm determinar uma redefinição da política externa portuguesa de acordo com o espírito do programa do Movimento das Forças Armadas (MFA), que se traduzia, sinteticamente, pela fórmula «democratização; descolonização; desenvolvimento». Apesar de o programa do MFA assegurar o cumprimento de todos os compromissos internacionais de Portugal, tornava-se claro que esses dois simples princípios - democratizar e descolonizar - implicariam uma reinterpretação política desses mesmos compromissos e uma alteração de fundo na orientação externa do Estado Português.

A descolonização constitui o primeiro grande desafio da política externa do regime democrático. Mas, ao mesmo tempo que decorre o processo de descolonização, Portugal ultrapassa o isolamento internacional do fim do Estado Novo e estabelece relações diplomáticas com os países do bloco soviético e do terceiro mundo.

Todavia, a descolonização e a abertura ao mundo não bastavam, por si só, para definir as novas orientações externas da democracia portuguesa. Muito pelo contrário. Sob as lutas ruidosas do processo de democratização interna, trava-se uma outra luta, esta silenciosa, sobre os objectivos e as opções estratégicas da política externa portuguesa. Entre Abril de 1974 e Janeiro de 1986, a política externa portuguesa oscilou entre duas orientações de fundo, que marcaram, igualmente, duas fases distintas: a da transição à democracia, correspondente ao período pré-constitucional, dominado pelo 
processo revolucionário; e a da consolidação democrática, correspondente ao período constitucional, marcado pela institucionalização e pela estabilização do regime democrático.

O período pré-constitucional (1974-1976) caracterizou-se pela luta em torno das opções externas do País, pelo exercício de diplomacias paralelas e, consequentemente, pela indefinição da política externa. Apesar das lutas, das hesitações e da indefinição, durante os governos provisórios e em particular aqueles de maior preponderância militar, a orientação global da política externa portuguesa tende para uma opção terceiro-mundista e para o desenvolvimento de relações privilegiadas com os novos países saídos da descolonização portuguesa. Era o último avatar, agora socializante, da tese da «vocação africana» de Portugal.

O período constitucional (a partir de 1976), que se inicia, precisamente, com o primeiro governo constitucional, liderado por Mário Soares e tendo Medeiros Ferreira como ministro dos negócios estrangeiros, caracterizou-se pela clarificação da política externa portuguesa e pela definição unívoca e rigorosa do posicionamento externo do Estado. Portugal que assume, inteiramente, a sua condição de país ocidental, simultaneamente, europeu e atlântico. Serão estes, pois, os dois vectores fundamentais e as verdadeiras opções estratégicas do Portugal democrático.

O vector atlântico significou para Portugal a permanência das características históricas da sua política externa e jogou um papel importante não só ao nível da orientação externa como também da estabilização interna do País. O reforço das relações bilaterais com os Estados Unidos e o reempenhamento nos compromissos militares com a Organização do Tratado do Atlântico Norte (OTAN) constituíram a sua tradução mais visível.

A "opção europeia», porém, é a grande novidade da política externa do regime democrático. Ultrapassadas as resistências anti-europeias, primeiro da opção africana do regime autoritário, depois da tentação terceiro-mundista do período revolucionário, Portugal assume claramente, a partir de 1976, a «opção europeia». Agora, não mais com uma perspectiva estritamente económica e pragmática, como o Estado Novo, mas enquanto opção estratégica e projecto político. Em 1976, Portugal entra no Conselho da Europa. Em 1977 pede, formalmente, a adesão à Comunidade Europeia. E em 1985 assina 
o Tratado de Adesão. A partir de 1 de Janeiro de 1986, Portugal torna-se membro de pleno direito da Comunidade Europeia.

Se à opção europeia e ao vector atlântico acrescentarmos o estabelecimento de relações de amizade e cooperação com os novos países africanos de língua oficial portuguesa (PALOP) e com o Brasil, encontraremos aquelas que são as linhas de orientação estratégica da política externa da democracia.

A partir da década de noventa, a estes três eixos vem juntar-se um quarto: a participação portuguesa na produção de segurança internacional, com a presença dos militares portugueses nas operações de paz da Aliança Atlântica, da União Europeia e das Nações Unidas. As Forças Armadas tornam-se instrumento da política externa.

\section{O novo modelo democrático}

As mudanças introduzidas pelo regime democrático não são, porém, de curto prazo, nem se limitam às prioridades da política externa. Parecem de longa duração e tudo indica que estão a conduzir Portugal a um novo modelo de inserção internacional.

Mas o que caracteriza, então, este novo modelo? Quais as permanências e quais as mudanças?

Primeiro, as permanências. Decorrem dos factores estruturais e geopolíticos que não se alteram e respeitam, fundamentalmente, às áreas de interesse estratégico de Portugal que se mantêm: a Europa, o Atlântico e as relações pós-coloniais.

Segundo, as mudanças. Decorrem dos factores históricos e alteram as quatro características do modelo anterior, a que deve juntar-se uma quinta, inteiramente, nova.

Em primeiro lugar, muda a percepção e a lógica contraditória entre o continente e o mar. Hoje, a Europa e o Atlântico não só não são termos contraditórios como são complementares. Para a política externa portuguesa ser atlântica pode significar valor acrescentado na Europa, tal como ser europeu pode ter valor acrescentado no Atlântico e em particular o Atlântico Sul, onde se desenvolvem as relações pós-coloniais. 
Em segundo lugar, no binómio Europa-Atlântico mantém-se a equação geopolítica mas invertem-se as prioridades estratégicas: tradicionalmente Portugal pensava-se como um país atlântico e colonial e, quando o peso do vector marítimo era excessivo, procurava compensações continentais. Hoje, pelo contrário, pensa-se como país europeu e é como membro da União Europeia que procura valorizar e potenciar a posição atlântica e as relações pós-coloniais.

Em terceiro lugar e como resultado da democratização em Portugal e Espanha, os dois estados peninsulares aproximaram as suas posições internacionais. Significa isto que não só o dispositivo geoeconómico português se continentalizou com a entrada na Comunidade Europeia mas também que os dispositivos diplomáticos e estratégicos de Portugal e Espanha se aproximam, progressivamente, até coincidir. Pela primeira vez na sua história, Portugal e Espanha partilham, hoje, as mesmas alianças extra-peninsulares: a UE e a NATO.

Em quarto lugar, como resultado da globalização, da interdependência das relações internacionais e da valorização dos quadros diplomáticos multilaterais, ao velho triângulo bilateral Lisboa, Madrid e potência marítima junta-se, hoje, um novo triângulo multilateral, correspondente à presença de Portugal nas organizações internacionais das suas áreas de interesse estratégico: a UE na Europa, a NATO no Atlântico e a CPLP para as relações pós-coloniais.

Finalmente, um elemento novo, quinta característica do modelo democrático de inserção internacional: uma política externa de valores. Teve a sua origem, ainda no Estado Novo, no debate entre africanistas e europeístas. Para os primeiros, a manutenção do Império implicava a continuação da guerra e a guerra implicava a continuação do regime autoritário. Para os segundos, a integração europeia implicava a descolonização e a descolonização implicava a democratização. Os valores da democracia e do estado de direito estão, pois na matriz genética da política externa do regime democrático. E nas suas opções estratégicas, a Democracia acabará por concretizá-los. Na União Europeia como na Aliança Atlântica, todos os parceiros e aliados de Portugal são democracias. E a presença das forças armadas portuguesas nas missões de paz, sob a égide das Nações Unidas, 
confirma essa diplomacia de valores que teve na independência de Timor um dos seus maiores sucessos. A política externa parte da formulação dos interesses. Mas no modelo democrático não só não ignora como assume o seu quadro de valores. Que são os da democracia e do estado de direito.

Será, pois, no quadro deste modelo de inserção internacional que Portugal terá que pensar os seus desafios de futuro.

\section{Questões para análise}

Em que consiste um modelo de inserção internacional.

Quais os modelos históricos de inserção internacional de Portugal.

O que diferencia o modelo clássico, do modelo democrático de inserção internacional de Portugal?

\section{Fontes na internet}

Instituto de Defesa Nacional, http://www.idn.gov.pt/index.php

Instituto de Estudos Estratégicos e Internacionais, http://www.ieei.pt/

Instituto Português de Relações Internacionais, http://www.ipri.pt/home/ home.php

Ministério da Defesa, http://www.mdn.gov.pt/mdn/pt/

Ministério dos Negócios Estrangeiros, http://www.mne.gov.pt/mne/pt/

\section{Leituras recomendadas}

AAVV (2005) Visões da Política Externa Portuguesa. Lisboa: Instituto Diplomático.

Brito, Nuno Filipe (2005) «Política Externa Portuguesa. O Futuro do Passado», Relações Internacionais, 5, 147-161.

Ferreira, José Medeiros (2006) Cinco Regimes na Política Externa. Lisboa: Editorial Presença.

Macedo Jorge Borges de (2008) História Diplomática de Portugal. Constantes e Linhas de Força. Estudo de Geopolítica. Lisboa: Tribuna da História, edição/reimpressão.

Teixeira, Nuno Severiano (2004) «Entre África e a Europa. A política Externa Portuguesa 1890-2000», in António Costa Pinto (org), Portugal Contemporâneo. Lisboa: Dom Quixote, 87-116. 
Paula Duarte Lopes

e Daniela Nascimento

\section{CAPÍTULO 12}

\section{REPÚBLICA FEDERAL DA NIGÉRIA}

Desde a independência da Nigéria (1960) que o seu potencial para liderar o continente africano tem sido reconhecido e discutido internacionalmente. Os sucessivos governantes do país sempre incorporaram nas suas políticas externas a ideia da Nigéria como a 'líder natural' do continente africano. Este potencial tem-lhe valido inclusivamente a designação de 'Gigante de África'. O objectivo de liderança regional e continental tem marcado a estratégia de formulação da política externa nigeriana nas suas cinco décadas de existência, ainda que nem sempre de forma coerente ou eficaz.

A política externa de qualquer país é condicionada pelo seu processo de tomada de decisão, pela natureza do sistema político, pela personalidade dos seus governantes, pelos recursos disponíveis e pela natureza do sistema internacional. ${ }^{1}$ No caso da Nigéria, a evolução da sua política externa tem sido particularmente marcada pela personalidade dos seus sucessivos líderes, inclusivamente como uma extensão das suas ambições pessoais. Em teoria, os factores que condicionam a formulação da política externa de um país podem ser analisados segundo uma lógica de 'círculos concêntricos': interno, regional e internacional, sendo que estes se interligam e influenciam mutuamente. Esta grelha é particularmente útil para discutir a evolução da política externa nigeriana (Adebajo e Mustapha, 2008) desde a

\footnotetext{
1 Ver capítulo teórico neste Manual, secção 'Compreender a política externa'.
} 
sua independência. No círculo interno, destaca-se a estabilidade económica e política como factores de sustentação de uma política externa vigorosa e empenhada. Ao nível regional, distinguem-se as relações no âmbito de uma vizinhança mais próxima (Chade, Camarões, Níger e Benim) e de uma vizinhança alargada (Angola ou África do Sul), tendo esta um impacto directo na projecção internacional do continente africano. Salienta-se ainda o papel das organizações regionais na afirmação da política externa nigeriana. O círculo internacional inclui as dinâmicas de participação em organizações internacionais, nomeadamente de natureza multilateral, bem como as relações com outros países, nomeadamente com potências internacionais e regionais. é importante referir que a intensidade da influência de cada um destes círculos na formulação da política externa se foi alterando ao longo dos anos e de acordo com as linhas de actuação externa de cada regime.

A ideia de que a Nigéria está destinada a ser o líder da África negra baseia-se no facto de este ser o país mais populoso do continente africano, com cerca de 150 milhões de habitantes, a terceira maior economia africana, o maior produtor de petróleo de África e um dos dez maiores exportadores de petróleo do mundo. ${ }^{2}$ Acresce ainda, que em 1960, a Nigéria encontrava-se numa posição privilegiada para assumir esta liderança: país independente, rico e com uma posição claramente definida a favor dos movimentos de libertação nacional. Esta luta contra o domínio colonial em África, bem como conta o apartheid na África do Sul, domina a política externa nigeriana até à década de 1980 (círculo regional). A exploração da sua riqueza petrolífera permitiu, principalmente na década de 1970, uma política externa assertiva, nomeadamente no plano regional (círculos interno e regional). Este percurso de afirmação da liderança regional perdeu fôlego na primeira metade da década de 1980, devido à alteração do regime interno, à queda do preço do petróleo e às pressões da dívida externa. No final da década de 1980, assiste-se a uma reafir-

\footnotetext{
2 Informações facultadas pelo Banco Mundial [siteresources.worldbank.org/DATASTATISTICS/ Resources/GDP_PPP.pdf] e pela US Energy Information Administration [tonto.eia.doe.gov/country/ index.cfm].
} 
mação da imagem externa nigeriana no continente africano, permitindo projectar-se internacionalmente. Esta projecção internacional, por sua vez, consolidou a sua posição regional. Este período caracterizou-se assim por uma interdependência entre a liderança regional e o papel internacional da Nigéria (ć́rculos regional e internacional).

A política externa nigeriana da década de 1990 ficou marcada pelo regime militar violento de Abacha (1993-1998), influenciando de forma devastadora a imagem externa da Nigéria (ćrculo interno). Com a transição democrática, a Nigéria ganha uma nova oportunidade para retomar o seu 'destino' de líder africano negro. No entanto, as mudanças profundas nas conjunturas regional e internacional limitaram de forma estrutural a capacidade da Nigéria concretizar o seu papel de liderança. Além disso, internamente, a qualidade da democracia tem-se revelado frágil e marcada pela corrupção e clientelismo generalizados (ćŕrculo interno). A Nigéria não abandona o seu sentido de responsabilidade regional, mas passa a privilegiar canais multilaterais para cumprir esse objectivo, nomeadamente através de missões de paz das Nações Unidas (círculo internacional). Regionalmente, a política externa nigeriana tem-se pautado por iniciativas de soft power, incluindo mediação de conflitos e promoção da integração económica regional (círculo regional).

\section{Dimensão interna}

Internamente, a Nigéria desde cedo se deparou com os inúmeros desafios colocados pela imensa e indiscutível diversidade étnica: cerca de 250 grupos étnicos com predominância de Hausa e Fulani (29\%), Yoruba (21\%) e Igbo (18\%); e religiosa: população maioritariamente muçulmana (50\%) e cristã (40\%). ${ }^{3}$ Esta diversidade interna foi-se interligando com outros elementos, nomeadamente com os recursos naturais, sobretudo o petróleo, reflectindo-se em problemas de distribuição dos recursos e dos rendimentos geradores de tensões constantes entre o sul produtor e o norte mais populoso. Todas

\footnotetext{
3 Informação disponível na página da Freedom House, no relatório sobre Freedom of the Press, Nigeria (2006) [www.freedomhouse.org/template.cfm?page=251\&country=7030\&year=2006].
} 
estas questões acabaram por se reflectir naquela que foi sendo a evolução, nem sempre linear, da política externa nigeriana.

A este nível interno, e ainda que com estratégias e capacidades variáveis e distintas, a Nigéria pautou sempre a sua política externa pela ideia de que um país económica e politicamente estável e com uma qualidade de vida satisfatória está melhor posicionado para desenvolver uma política externa assertiva. Os princípios orientadores da política externa nigeriana, finalmente plasmados na Constituição de 1979, passavam, em grande medida, pela "defesa da integridade territorial e da independência do país», pela promoção do desenvolvimento económico nacional autónomo e sustentável, pela "promoção da igualdade e auto-subsistência em África, respeitando a dignidade humana, especialmente para a população negra, bem como [pel] a promoção e defesa da paz mundial» (Ajibewa, 1998: 86).

Imediatamente após a independência (1960), a política externa nigeriana durante a primeira república liderada por Balewa (1960-1966) foi caracterizada como "conservadora e tímida" (Abegunrin, 2001: 105) e "sem visão" (Garuba, 2008: 2). Na verdade, o legado colonial, a relativa pobreza do país, a personalidade conservadora de Balewa e a falta de experiência no plano internacional ajudam a explicar esta falta de autonomia e iniciativa em assuntos internacionais. Por exemplo, alguns autores referem que no que diz respeito a questões centrais para África, Balewa parecia estar sempre à espera da tomada de posição de outros países antes de afirmar a posição nigeriana (Garuba, 2008: 2).

Acresce ainda que a estrutura federal colonial do país criou a possibilidade, neste período, de cada estado-federado abrir a sua própria representação diplomática no estrangeiro, o que ilustra o carácter limitado da política externa nigeriana (Abegunrin, 2001: 105-106). Ainda assim, Balewa criou uma estrutura de tomada de decisão em matéria de política externa com vários ministérios e gabinetes ao nível federal. No entanto, a sua postura centralizadora, aliada a uma incapacidade de coordenação das distintas instituições, determinou não só a centralidade do cargo de chefe de estado, que neste caso, chegou a acumular a pasta de Ministro dos Negócios Estrangeiros (Inamete, 2001: 33), mas também a incapacidade das instituições criadas exercerem as suas funções de forma autónoma e activa. 
Apesar de a Nigéria ter sido governada predominantemente por regimes militares entre 1966 e 1999, é importante distinguir a fase pré e pós 1979, por dois motivos. O primeiro prende-se com a proclamação da segunda república constitucional entre 1979 e 1983 que criou as condições para uma maior abertura política, que só foi posta em causa com o regime de Abacha (1993-1998). O segundo está relacionado com a riqueza resultante de recursos petrolíferos que permitiu à Nigéria concretizar os seus objectivos de política externa de forma assertiva e autónoma até 1979. A partir desta data, esta capacidade de concretização da política externa nigeriana diminuiu significativamente, devido à crise petrolífera, à crise da dívida e à corrupção interna e desvio de fundos. Convém ainda referir, que dentro destas duas fases existem também diferenças marcantes entre os vários regimes.

Em 1966, dão-se os primeiros de vários golpes militares que marcam estruturalmente a vida política da Nigéria, influenciando directamente a sua política externa. O regime militar de Gowon (1966-1975), assim como a sua política externa, são profundamente marcados pela guerra civil no Biafra (região secessionista). Internamente, o regime teve dificuldade em reagir de forma rápida e eficaz aos sinais que despoletaram a violência e as estruturas do Ministério dos Negócios Estrangeiros mostraram-se desadequadas para lidar com a magnitude da crise. Gowon viu-se mesmo obrigado a enviar equipas especiais para explicar internacionalmente a posição do governo federal nesta matéria (Garuba, 2008). A guerra civil ditou uma viragem na definição da política externa nigeriana, passando-se de uma abordagem conservadora e tímida para uma abordagem assertiva, defendendo a sua integridade territorial. A Nigéria ganhou assim uma imagem pública de uma nação africana activa e rica em petróleo.

Um novo golpe militar em 1975 coloca no poder Mohammed/Obasanjo (1975-1979). Contrariamente aos anteriores, este período é caracterizado por uma política externa robusta, assertiva, dinâmica e, muitas vezes, denominada de radical. Os 'anos de ouro' da política externa nigeriana foram maioritariamente financiados pelos rendimentos provenientes do petróleo, permitindo uma abordagem autónoma e pró-activa. A formulação e implementação desta nova abordagem foram ainda potenciadas pela reforma das 
estruturas internas de tomada de decisão de política externa que passaram a incluir actores da sociedade civil ${ }^{4}$ (Abegunrin, 2001: 110).

Simultaneamente, quer Mohammed, quer Obasanjo mostraram-se empenhados em utilizar os militares na persecução dos objectivos nigerianos de política externa (Inamete, 2001: 88). Esta posição é particularmente visível na decisão de enviar delegações militares a Angola, reconhecendo o governo do Movimento Popular de Libertação de Angola (MPLA), sem o aval desse Ministério (Inamete, 2001: 88). A nacionalização da British Petrol e do Barcklays Bank, transformando-os em African Petrol e em Union Bank of Nigeria (Garuba, 2008: 7), respectivamente, ilustram igualmente a determinação nigeriana em se afirmar como uma potência autónoma e independente.

A segunda república nigeriana debateu-se com a diminuição da riqueza disponível para continuar a financiar a linha de política externa interventiva e autónoma dos regimes anteriores. Apesar da aprovação de uma constituição e da possibilidade de realização de eleições, com o fim dos dividendos das crises petrolíferas, o governo Shagari (1979-1983) viu-se obrigado a adoptar uma postura mais moderada e pró-ocidental. A situação económica degradada e a crescente dívida externa do país justificaram o golpe de estado que coloca Buhari (1983-1985) no poder. A sua política externa foi caracterizada como agressiva e nacionalista, mas menos ambiciosa e com menos apoio interno que a do regime anterior. Identificando a corrupção generalizada no país como um problema estrutural, Buhari decretou 'Guerra Contra a Indisciplina' e a corrupção, apesar de estes esforços não terem sido suficientes para resolver os problemas internos (Abegunrin, 2003: 131). Os métodos aplicados por este regime, bem como o aprofundar da crise económica, criaram um descontentamento crescente no seio da população, o que propiciou as condições para um novo golpe de estado em 1985, que coloca Babangida (1985-1993) no poder.

A política externa de Babangida reflectiu a confusão e turbulência política interna, tendo o Ministro dos Negócios Estrangeiros sido substituído cinco vezes ao longo deste regime (Abegunrin, 2001: 120). No sentido de

\footnotetext{
4 Nomeadamente através da criação do Instituto Nigeriano de Relações Internacionais e do Instituto Nacional para Política e Estudos Estratégicos (Abegunrin, 2001: 110).
} 
dar consistência aos compromissos assumidos internacionalmente, Babangida criou o Corpo de Assistência Técnica no âmbito do Ministério dos Negócios Estrangeiros para dar apoio aos países africanos, das Caraíbas e do Pacífico. O descontentamento interno identificado durante o regime Buhari manteve-se, acrescido pela percepção de que os recursos utilizados para concretizar a política externa nigeriana - missões de paz, apoios financeiros a países vizinhos, fundos de desenvolvimento regional, entre outros - estavam a ser desperdiçados e/ou indevidamente apropriados. Babangida tentou responder a estas críticas, lançando um debate nacional sobre a posição nigeriana relativamente à dívida externa e à relação com o Fundo Monetário Internacional e realizando uma conferência pública sobre política externa, numa tentativa de demonstrar abertura e transparência nesta matéria (Garuba, 2008: 9). A crise económica, no entanto, dificultou estruturalmente a capacidade da Nigéria assumir as suas responsabilidades internas e externas (Garuba, 2008: 9).

O ano de 1993, apesar de marcado por vários acontecimentos importantes - anulação das eleições para a terceira república, nomeação de um novo chefe de estado (Shonekan) e novo golpe de estado - não permitiu qualquer revisão da política externa nigeriana. O regime subsequente, liderado por Abacha (1993-1998), tomou o poder disposto a controlar a situação económica e o descontentamento interno por qualquer meio ao seu dispor. Assim, este revela-se o regime mais agressivo e opressivo da história da Nigéria, contendo grupos da oposição interna com 'mão de ferro', como ilustra a condenação a prisão perpétua em 1994 de Obasanjo e Yar'Adua (Abegunrin, 2001: 126-127) e a execução em 1995 de nove activistas Ogoni. Neste seguimento, a Nigéria foi suspensa da Commonwealth of Nations e condenada pela Assembleia Geral das Nações Unidas por alegadas violações de direitos humanos. Na verdade, durante o regime de Abacha, a sua política externa foi essencialmente condicionada pelas reacções internacionais à situação interna.

Em 1998, Abacha morre e Abubakar (1998-1999) sobe ao poder, abrindo um novo capítulo na história política do país. De facto, a morte de Abacha foi vista como uma oportunidade para «intensificar as pressões para o regime libertar todos os prisioneiros políticos, desmilitarizar a política 
nigeriana, e transferir o poder para um governo civil eleito» (Abegunrin, 2003: 163), procurando contrariar a imagem negativa deixada pelo regime anterior. Num gesto claro de concretização do plano estabelecido, Abubakar liberta os prisioneiros políticos, incluindo Obasanjo, o que «constituiu um passo importante para o recuperar da credibilidade internacional da Nigéria depois de anos de isolacionismo diplomático» (Abegunrin, 2003: 163). Em 1999, Abubakar passa o poder para um governo civil eleito liderado por Obasanjo (1999-2003 e 2003-2007), acabando com 15 anos de regime militar. "Com esta acção, Abubakar salvou os militares nigerianos de si próprios e restaurou o direito democrático do povo nigeriano de escolher o seu próprio governo" (Abegunrin, 2003: 164).

A eleição de Obasanjo em 1999 inaugura a quarta república nigeriana que se caracterizou por um compromisso com a consolidação da democracia, respeito pelos direitos humanos, reformas económicas liberais, bem como boa governação e transparência. Este compromisso espelha a ambição da Nigéria em se consolidar internamente e em se integrar de forma estável no sistema internacional. Após dois mandatos, Obasanjo é substituído por Yar'Adua (2007-2010), cujo objectivo principal era transformar a Nigéria numa das vinte maiores economias do mundo até 2020 (Garuba, 2008: 17). Uma das características essenciais da sua política externa foi o fomento da participação interna na sua formulação e definição - 'diplomacia de cidadania' - procurando contrariar a imagem de um país corrupto.

Do ponto de vista da estabilidade e qualidade democráticas da Nigéria, apesar da última década ter sido caracterizada por transições de poder civis e com recurso a eleições, estas têm sido consideradas como "um circo» (Obasanjo em 1999), como irregulares e manipuladas (Obsanjo em 2003), e como uma "fraude» e fantochada (Yar'Adua em 2007) (Taylor, 2007). De referir ainda que a morte de Yar'Adua levou a uma transição pacífica do poder para o Vice-Presidente, Goodluck Jonathan (2010-). A política externa do novo governo enfrenta como principais desafios de política interna: a corrupção e a gestão dos conflitos internos violentos, nomeadamente nas zonas de exploração petrolífera. As relações clientelares, patrimonialistas e corruptas sustentam a economia política nigeriana, envolvendo os actores de investimento directo estrangeiro nesta dinâmica e criando uma elite cada vez 
mais rica e poderosa ao nível das decisões estratégicas do país. A criação de 'economias enclave' em torno do petróleo agrava os desequilíbrios internos, alimentando dinâmicas de greed and grievance. Estas dinâmicas têm gerado focos de violência e instabilidade que minam não só a relação da Nigéria com os seus parceiros na exploração petrolífera (como por exemplo no Delta do Níger), como a sua própria estabilidade interna, enfraquecendo a sua capacidade de projecção internacional.

\section{Dimensão regional}

A ideia de liderança do continente africano que sempre esteve na base da definição do papel da Nigéria no sistema internacional é mais saliente a nível regional. Não só a população nigeriana acredita "que o seu país é uma superpotência (...) [e] que com uma melhor liderança, a Nigéria rapidamente se tornará o farol para África», 5 como internacionalmente a Nigéria foi sendo reconhecida como o «equivalente para África do Brasil, Índia, ou Indonésia» (Maier, 2000). Neste sentido, a Nigéria desenvolveu esforços em diferentes planos, ao longo do tempo, e com resultados distintos. A sua política externa regional tem sido pautada pela promoção do desenvolvimento e estabilidade regionais, com o intuito de consolidar uma arquitectura de paz africana, a qual tem sido denominada de Pax Nigeriana (Adebajo and Mustapha, 2008; Nuamah, 2003; Pham, 2007: 14). Esta abordagem tem incluído projectos de integração e afirmação económica, como a Economic Community of West African States (ECOWAS) ou a New Economic Partnership for Africa's Development (NEPAD); apoio político e financeiro aos movimentos de descolonização em África e contra o apartheid, por exemplo denominando-se membro honorário dos 'Estados da Linha da Frente'; 6 e através do apoio

\footnotetext{
5 Informação constante do Suplemento Especial do The Economist, "Here's Hoping: A Survey of Nigeria” de 15 de Janeiro de 2000.

6 Os 'Estados da Linha Frente' são um grupo regional de estados do sul de África que se organizaram contra o regime do apartheid e a favor da democracia. O grupo foi criado em 1970, contando com Angola, Botswana, Lesotho, Moçambique, Suazilândia, Tânzania, Zâmbia, e desde 1980, Zimbabué.
} 
e promoção de estruturas no seio de organizações africanas e missões de paz, como na Libéria e Serra Leoa.

O papel de líder regional tão ambicionado pela Nigéria, durante o governo Balewa (1960-1966), ficou limitado pela ausência de iniciativa própria e pelo conservadorismo que caracterizava a política externa nigeriana nestes primeiros anos de independência. Ainda assim, Balewa considerou essencial que a Nigéria adoptasse e respeitasse os princípios de direito internacional - não-interferência, integridade territorial e boa vizinhança - como se esperava de um jovem país independente. E, para este efeito, contribuiu para a criação da Organização de Unidade Africana (OUA) e desenvolveu «estruturas institucionais para a exploração de recursos naturais transnacionais para desenvolvimento económico» ${ }^{7}$ (Nuamah, 2003: 11).

Durante a primeira fase dos regimes militares (1966-1979), a dimensão regional da política externa nigeriana sofreu «transformações dramáticas» (Abegunrin, 2001: 109), não tanto por passar a haver uma coerência ou estratégia deliberada, mas antes por existirem meios disponíveis, devido à exploração petrolífera, para ir apoiando determinadas posições. Os dividendos petrolíferos permitiram uma política mais assertiva no que diz respeito à luta contra o apartheid na África do Sul e à concessão de assistência bilateral a movimentos de libertação nacional (na Rodésia e em Angola) - 'diplomacia spray'. Esta estratégia material foi sendo acompanhada por uma posição política firme. Por exemplo, durante o curto governo de Ironsi (1966), o espaço aéreo nigeriano foi fechado aos vôos de e para a África do Sul, como forma de fazer pressão sobre o regime de apartheid, e a Embaixada Portuguesa em Lagos foi encerrada, como forma de protesto contra o domínio colonial português em África. Através destas medidas, a Nigéria assumiu o seu papel como «líder negro e africano» (Abegunrin, 2001: 109).

A política externa do regime de Gowon (1966-1975) foi marcada pela guerra civil, opondo-o aos secessionistas no Biafra. A guerra civil levou o governo nigeriano a adoptar uma postura mais activa e envolvida com os seus vizinhos (Nuamah, 2003), nomeadamente no que diz respeito ao apoio concedido aos

\footnotetext{
7 Como é ilustrado pela criação da Comissão da Bacia do Rio Níger (1973) e as subsequentes comissões bilaterais Nigéria-Benin e Nigéria-Níger (Nuamah, 2003: 11).
} 
secessionistas por alguns destes. Este maior envolvimento regional ganhou fôlego com os meios disponíveis devido ao boom petrolífero, permitindo uma política regional e africana vigorosa. Esta estratégia culminou com a criação da ECOWAS em 1975, promovendo a integração e cooperação regionais.

O regime de Mohammed/Obasanjo (1975-1979) foi o que mais utilizou os meios económicos, resultantes da riqueza petrolífera para a concretização de políticas radicais e assertivas em matéria de política externa. Nesse sentido, apostou no apoio financeiro, material e técnico bilateral a vários países africanos: assistência a países recém-independentes (Moçambique, Cabo Verde e Zimbabwe); apoio humanitário a países assolados por catástrofes naturais (seca na Etiópia); assistência técnica a diferentes países (Argélia e Gâmbia); concessão de bolsas a estudantes africanos; e venda de petróleo a preços reduzidos a alguns países africanos mais necessitados (e não a outros). Estes apoios não eram inéditos, mas adquiriram uma dimensão pujante durante este regime. A assistência financeira passou a fazer parte integral da política externa nigeriana, sendo inclusivamente institucionalizada com a criação do Fundo Nigeriano no âmbito do Banco Africano para o Desenvolvimento. Esta lógica de apoio económico bilateral e regional baseia-se na convicção que a estabilidade e desenvolvimento económico dos países africanos contribuem para a estabilidade e desenvolvimento da Nigéria; e, desta forma, uma Nigéria estável e rica deve apoiar os países vizinhos nesse sentido. Assim, a Nigéria empenhou-se em "criar, promover e acelerar a integração económica entre os países africanos da África Ocidental, nomeadamente através da ECOWAS» (Inamete, 2001: 89-90).

Estes esforços económicos foram acompanhados por uma estratégia política de envolvimento e liderança no continente africano. O reconhecimento do governo angolano do MPLA constituiu um elemento fundamental de mudança na imagem da Nigéria, enquanto líder regional e continental. Com esta decisão, não só tomou uma posição contrária à dos Estados Unidos da América (EUA); como se empenhou na mobilização de países africanos para que estes também reconhecessem o novo governo angolano. Desta forma, a Nigéria passou a ser reconhecida como um «membro de facto dos 'Estados da Linha da Frente', insistindo no direito de ser consultada como tal»(Abegunrin, 2001: 114, itálico no original). 
Estes esforços continuaram durante o regime militar de Mohammed/ Obasanjo (1975-1979), mantendo, de forma robusta, o lugar central que o continente africano tinha na política externa nigeriana. No entanto, o governo seguinte liderado por Shagari (1979-1983) protagonizou um revés na estratégia de afirmação da Nigéria em África. Três acontecimentos em particular marcaram esta mudança drástica: os confrontos com os Camarões, a situação no Chade e a política interna de imigração. A Nigéria não conseguiu conter os conflitos violentos na fronteira com os Camarões (Península de Bakassi), acabando por ter de pedir ajuda à então OUA para intervir (Ajibewa, 1998). No caso do Chade, considerado o "pior reverso diplomático da Nigéria» (Ajibewa, 1998), Shagari «foi acusado de servir como uma nação mercenária 'para proteger os interesses dos EUA'» (Ajibewa, 1998: 89). O envio de forças armadas nigerianas para participar na missão da OUA no Chade foi interpretado por vários como um apoio à «intervenção imperialista americana» (Ajibewa, 1998: 89). Finalmente, em 1983, Shagari expulsou milhões de trabalhadores migrantes do Gana, Chade e Benim, contrariando os princípios da ECOWAS e fechando as fronteiras com o Benim e o Níger. Todas estas decisões contribuíram para um denegrir da imagem de liderança da Nigéria em África, transmitindo uma imagem pouco assertiva, sem iniciativa própria e sem capacidade de afirmação.

Entre 1984 e 1998, a Nigéria entra na segunda fase dos regimes militares. Os regimes de Buhari (1984-1985) e Babangida (1985-1993) desenvolveram esforços no sentido de recuperar a imagem de liderança da Nigéria e de reafirmar a centralidade africana na sua política externa. Apesar do seu curto mandato, Buhari (1984-1985) realizou um périplo pelos 'Estados da Linha da Frente' - 'diplomacia vai-e-vem' -, reafirmando o compromisso da Nigéria com os movimentos de libertação; reconheceu a Frente Polisario como governo legítimo do Sahara Ocidental; e fez uma demonstração de força ao colocar as forças armadas nas fronteiras com o Chade e os Camarões.

O regime de Babangida (1985-1993) tomou o poder empenhado em desenvolver uma política externa dinâmica e coerente, ancorada no papel central das organizações regionais (OUA e ECOWAS) e no princípio de boa vizinhança. Um dos reflexos desta vontade política foi a Doutrina 
Akinyemi ${ }^{8}$ onde se afirmava que "para obter o apoio político, diplomático ou outro da Nigéria, a Nigéria [devia] ser primeiro consultada por outros estados africanos antes dos mesmos tomarem alguma acção significativa de política externa» (Ihonvbere, 1994: 50). Ao nível das organizações regionais, Babangida encetou esforços para reactivar a ECOWAS, garantindo o seu financiamento e secretariado, organizando três cimeiras de chefes de estado e de governo e presidindo à organização quando nenhum outro membro se mostrou interessado. Estas medidas mostram claramente como o objectivo de estabilização da região através da ECOWAS se manteve central para a afirmação política e económica da Nigéria a nível regional.

Em 1993, no âmbito da ECOWAS, a criação do Economic Community of West African States Monitoring Group (ECOMOG) para a Libéria (1990-1998), constituiu uma das iniciativas mais assertivas da política externa nigeriana no pós-Guerra Fria. O envolvimento militar da Nigéria no ECOMOG resultou em parte da existência de relações privilegiadas entre os chefes de estado dos dois países e da preocupação em zelar pela estabilidade regional em resposta a um alegado plano de desestabilização líbio (Abegunrin, 2001: 121). A OUA manteve-se igualmente o fórum privilegiado de actuação regional da Nigéria, tendo Babangida presidido à organização em 1991, mediando vários conflitos armados, nomeadamente no Uganda e em Angola, e criando um Departamento de Prevenção, Gestão e Resolução de Conflitos. Durante este período, a Nigéria manteve também o seu estatuto de membro honorário dos 'Estados da Linha da Frente', continuando a apoiar os movimentos de libertação na África do Sul e na Namíbia (Abegunrin, 2001; Ihonvbere, 1994). Um outro acontecimento que marcou a política externa nigeriana de Babangida foi a visita do seu homólogo sul-africano, De Klerk, em 1992. Esta visita tem sido entendida, por alguns, como uma contradição da política nigeriana de luta contra o apartheid (Garuba, 2008: 10); enquanto para outros, a visita constituiu um reconhecimento do prestígio da Nigéria, ao ser incluída no périplo de De Klerk (Abegunrin, 2001: 122).

\footnotetext{
8 Akinyemi foi um dos Ministros dos Negócios Estrangeiros do regime do Babangida.
} 
O regime violento de Abacha (1993-1998) procurou manter o seu envolvimento na procura da estabilidade regional e na defesa da sua integridade territorial. No primeiro caso, mantendo a sua participação no ECOMOG na Libéria e iniciando uma nova missão na Serra Leoa (1997-2000). No segundo caso, a Nigéria envolveu-se em confrontos fronteiriços, opondo o seu exército ao dos Camarões, devido ainda à disputa sobre a Península de Bakassi, mostrando a sua determinação em fazer valer a sua posição de forma assertiva (Abegunrin, 2001: 126). No entanto, a violência e agressividade do regime em conter as actividades da oposição interna afectaram de forma determinante as relações da Nigéria com os países africanos. Em particular com a África do Sul, a qual manteve «uma política de porta aberta relativamente aos opositores do regime de Abacha, especialmente aos grupos pró-democráticos» (Abegunrin, 2001: 126-127). As relações entre os dois países atingiram o seu nível mais baixo, após a morte dos nove activistas Ogoni em 1995, o que "Mandela considerou um golpe pessoal, pois tinha recebido garantias que estes activistas não seriam mortos» (Abegunrin, 2001: 127).

Com o governo de Abubakar (1998-1999), o processo de recuperação da imagem externa da Nigéria, após o isolamento diplomático a que tinha sido remetida durante o regime de Abacha, ganha novo ímpeto. No entanto, contrariando a lógica até agora subjacente ao seu papel regional, Abubakar recusou participar no ECOMOG para a Guiné-Bissau e iniciou a retirada das forças armadas nigerianas destacadas na Serra Leoa (Pham, 2007: 13). O falhanço da missão da ECOWAS na Guiné-Bissau levou a que vários analistas considerassem a Nigéria como um elemento indispensável para qualquer esforço de paz na região (Nuamah, 2003).

Com a eleição dos dois governos consecutivos de Obasanjo (1999-2007), assistiu-se a um reforço da diminuição do envolvimento militar nigeriano nos esforços regionais de paz, ${ }^{9}$ com a continuação da retirada do ECOMOG da Serra Leoa. O regime de Obasanjo passou a privilegiar regionalmente o soft power através da mediação de conflitos armados, por exemplo no Sudão, no Togo ou no Senegal, e da criação de mecanismos institucionais

\footnotetext{
9 O envolvimento internacional nos esforços de paz regional será abordado na secção seguinte.
} 
para responder a situações de crise, como o Mecanismo para Prevenção, Gestão, Resolução de Conflitos, Peacekeeping e Segurança, criado em 1999 no âmbito da ECOWAS. No que diz respeito aos seus vizinhos, a disputa com os Camarões sobre a Península de Bakassi fica marcada pela decisão do Tribunal Internacional de Justiça (2002) favorável aos Camarões. Do ponto de vista do objectivo de integração económica, durante os mandatos de Obasanjo, destaca-se ainda o Projecto do Gasoduto da África Ocidental que integra o Benim, o Gana e o Togo. ${ }^{10}$

Na sua dimensão regional é clara a centralidade da ECOWAS para a política externa nigeriana. A Nigéria esteve envolvida na sua criação, manutenção, funcionamento, alargamento de funções, quer com recursos financeiros, quer humanos. No entanto, a estabilidade com base no desenvolvimento económico ambicionada pela Nigéria para si e para os seus vizinhos não tem sido alcançada. Por exemplo, os esforços da Nigéria em prol da integração regional têm sido, paradoxalmente, postos em causa pelo seu papel dominante no aumento do comércio informal transfronteiriço (Nuamah, 2003: 12). A ECOWAS, no entanto, tem funcionado como um fórum político importante onde é valorizado o consenso regional (Pham, 2007: 11-12), no âmbito da qual a Nigéria tem tido um papel fundamental. Do ponto de vista dos esforços regionais de paz no âmbito da ECOWAS, alguns analistas avançam um papel de 'polícia regional' para caracterizar o envolvimento da Nigéria. No entanto, o facto de em anos recentes a Nigéria ter retirado forças armadas do ECOMOG da Serra Leoa e ter recusado participar no da Guiné-Bissau contraria esta ideia. A Nigéria, na verdade, parece ter optado por activar regionalmente o seu soft power em detrimento de uma política assertiva mais militarizada, a qual passa a ser assegurada na região através de canais multilaterais. Independentemente dos meios utilizados, a sua presença é reconhecida como indispensável para o sucesso de quaisquer iniciativas de paz regional (Adebajo, 2002).

Nos últimos anos, o potencial de liderança regional da Nigéria tem diminuído face à afirmação de uma África do Sul multi-racial, democrática e

10 O projecto tem sofrido atrasados devido à crise no Delta do Níger. 
com uma economia emergente, a qual surge em melhor posição para reclamar a liderança africana do que uma Nigéria caracterizada por conflitos violentos internos e minada pela corrupção. Ainda assim, as relações com a África do Sul melhoraram substancialmente durante o regime de Obasanjo, falando-se mesmo de «uma aliança estratégica em evolução» (Nuamah, 2003: 13), a qual se reflectiu, nomeadamente, nos esforços de consolidação da União Africana (UA) e de criação do NEPAD, como resposta à crise de desenvolvimento do continente africano. Esta colaboração manifestou-se também na posição conjunta contra a criação de um comando militar dos EUA em África (AFRICOM). De referir que Yar'Adua (2007-2010) conseguiu inclusivamente o perdão de cerca de 30\% da dívida externa liberiana para com a Nigéria, como recompensa por esta se ter negado a acolher a sede do AFRICOM (Garuba, 2008).

A construção de uma Pax Nigeriana tem, como demonstrado, sido pautada por uma afirmação ora económica, ora político-militar, nem sempre conseguida. De facto, a predominância regional natural da Nigéria tem contribuído para criar um contexto propício a uma política externa influente e, por vezes, assertiva, mas também tem sido frequentemente caracterizada por avanços e recuos estruturais acompanhando claramente as mudanças de regime interno. Assim, o 'destino' nigeriano mantém-se um potencial reconhecido, mas ainda por concretizar. E, actualmente, "tendo em conta a realidade dos actuais equilíbrios de poder [em África], a liderança nigeriana tem de ser articulada com outras potências económicas e políticas da região, incluindo a África do Sul» (Pham, 2007: 16).

\section{Dimensão internacional}

A dimensão internacional da política externa nigeriana, apesar de ter tido momentos de assertividade unilateral, tem-se pautado por uma ênfase nos princípios de direito internacional. Assim, a Nigéria recém-independente rapidamente se tornou membro da Organização das Nações Unidas, do Movimento dos Não Alinhados e do Grupo dos 77, bem como da Commonwealth of Nations. Apesar de Balewa (1960-1966) ser criticado pela 
sua tendência pro-ocidental e o seu conservadorismo demasiado colado à herança colonial britânica, o seu governo procurou passar a imagem de um país preocupado em aumentar o poder dos países em desenvolvimento no sistema internacional. Para esse efeito, a Nigéria, por exemplo, participou, entre outras, na criação da Associação de Produtores de Chocolate, no sentido de aumentar o poder negocial internacional desses produtores, com o objectivo de obter uma melhoria dos termos de troca.

A era dos regimes militares (1966-1998) manteve esta ênfase na participação em organizações internacionais, com a entrada da Nigéria na Organização de Produtores e Exportadores de Petróleo (OPEP), no Fundo Monetário Internacional (FMI), no Banco Mundial e ainda com a sua assinatura do General Agreement on Trade and Tariffs (GATT). De referir, que a Nigéria também se envolveu nas negociações das Convenções de Lomé com a então Comunidade Económica Europeia (CEE), chegando mesmo a liderar algumas das negociações em nome do continente africano. Durante a primeira fase dos regimes militares, com Gowon (1966-1975) e Mohammed/Obasanjo (1975-1979), a participação da Nigéria nestas organizações foi marcada pelos seus esforços na luta contra o domínio colonial em África e contra o apartheid na África do Sul.

Na segunda fase da época militar (1979-1998), a Nigéria conseguiu uma maior visibilidade para o seu país no palco institucional internacional. O reconhecimento da Nigéria como um líder regional ao nível internacional foi conseguido durante os primeiros governos desta fase com Shagari (1979-1983) e Buhari (1984-1985), mas, essencialmente, com Babangida (1985-1993). A Nigéria ocupou vários cargos em diferentes organizações durante este período que lhe valeram uma visibilidade positiva, de respeito e confiança: Presidente do Comité Anti-Apartheid da ONU, Presidente da $44^{a}$ Sessão da Assembleia Geral das Nações Unidas e Secretário-Geral da Commonwealth of Nations (1990-2000). A Nigéria desenvolveu ainda esforços para que o General Osabanjo fosse eleito Secretário-Geral das Nações Unidas, no entanto, sem sucesso. Durante este período, a Nigéria conseguiu ainda que a $13^{\text {a }}$ Sessão Especial da Assembleia Geral das Nações Unidas fosse dedicada à situação económica crítica em África. E, finalmente, para além de ter assumido um papel de responsabilidade re- 
gional ao participar nos esforços regionais de paz da ECOWAS na Libéria e Serra Leoa, quando as Nações Unidas enfrentavam problemas de recursos, a Nigéria ainda participou nas missões de paz da ONU na Somália, ex-Jugoslávia e Bosnia-Herzegovina. Esta foi a época áurea da Nigéria no sistema internacional demonstrando um compromisso e empenho claros em seguir e defender as regras de direito internacional e em contribuir para os esforços colectivos nesse sentido.

Com o regime de Abacha (1993-1998), a imagem internacional da Nigéria sofreu uma deterioração drástica. A violência interna do regime militar levou à suspensão da Nigéria da Commonwealth of Nations, em 1995, após a execução de activistas opositores ao regime, bem como a uma condenação veemente por parte da Comissão Social, Humanitária e Cultural da Assembleia das Nações Unidas. Ainda assim, a Nigéria ocupou o cargo de Secretário-Geral da OPEP durante este período. A transição para um regime democrático foi assegurada por Abubakar (1998-1999), o qual encetou esforços para recuperar a imagem anterior do seu país no sistema internacional, recebendo mesmo o Secretário-Geral das Nações Unidas, Kofi Annan, em 1998, como um gesto de abertura da Nigéria a uma mudança estrutural do seu regime de governação. Já com Obasanjo (1999-2007), presidente eleito por dois mandatos, a Nigéria retoma um pouco da imagem passada ao presidir o G77, em 2000, e assim assumir um papel de liderança nas relações entre os países em vias de desenvolvimento e o G8. Salienta-se particularmente a sua participação em várias missões de paz das Nações Unidas no continente africano: UNAMSIL (1999-2004, Serra Leoa), UNMIL (2003, Libéria), UNOCI (2004, Costa do Marfim), UNMIS (2005, Sudão), MONUC (2007, República Democrática do Congo), UNAMID (2007, Darfur), MINURSO (2010, Sahara Ocidental) e MINURCAT (2010, Chade e República Centro-Africana). Esta estratégia revela uma mudança e uma preocupação em assumir a sua responsabilidade ao nível de hard power nos esforços de paz regionais mas, ao contrário do passado, privilegiando os mecanismos multilaterais. Acresce ainda que, com o fim do apartheid na África do Sul e o aproximar de posições, regional e internacionalmente, entre os dois países, a Nigéria tem vindo a reivindicar dois lugares permanentes no Conselho de Segurança das Nações Unidas, assumindo assim o papel de 
liderança que a África do Sul tem vindo a desenvolver quer regional, quer internacionalmente.

Nas suas relações bilaterais fora do continente africano, a Grã-Bretanha naturalmente assume uma posição de destaque. Logo após a independência, Balewa (1960-1966) foi duramente criticado pela manutenção da dependência relativamente à ex-metrópole, tendo mesmo sido assinado um Pacto de Assistência Mútua entre os dois países. Mas, ainda na década de 1960, com a Guerra Civil no Biafra, a Grã-Bretanha recusou financiar a compra de armas ao governo nigeriano na sua luta armada contra o movimento secessionista no leste do país. Ainda assim, as relações com a Grã-Bretanha mantiveram-se estratégicas e amistosas, tendo-se apenas tornado turbulentas com Mohammed e Obasanjo (1975-1979). Esta mudança deve-se, em parte, ao facto dos dois países se terem tornado concorrentes internacionais no mercado petrolífero, mas mais importante porque a política externa nigeriana entrou em rota de colisão com a britânica no que dizia respeito à sua política externa para com a África do Sul, sem uma condenação veemente do apartheid. Na segunda metade dos regimes militares, a situação foi-se agudizando episódio a episódio. Com Buhari (1984-1985) e a sua política de 'olho-por-olho e dente-por-dente', em 1985, a Nigéria responde à detenção de um avião nigeriano em Londres com a detenção de um avião britânico em Lagos. Acresce ainda que nos seus esforços para recuperar o dinheiro desviado pelos seus antecessores, Buhari depara-se com a posição intransigente da Grã-Bretanha, entre outros países, no sentido de extraditar os alegados 'corruptos e ladrões' que se tinham instalado em terras de sua majestade. Babangida (1985-1993) chega mesmo a boicotar os jogos da Commonwealth of Nations em 1989 como protesto pelo facto de a Grã-Bretanha continuar a não tomar uma posição contra ao apartheid. Convém referir que estas tensões nunca afectaram as relações comerciais entre os dois países ao longo das décadas. As demonstrações de força referidas ilustram apenas tomadas de posição simbólicas de parte a parte. Com a eleição de Obasanjo (1999-2003 e 2003-2007) e o fim do apartheid na África do Sul, as relações entre a Nigéria e a Grã-Bretanha deixaram de ter focos de tensão recorrentes. Obviamente que o facto da Grã-Bretanha, conjuntamente com a Suíça, os EUA e a Alemanha, terem garantido a Obasanjo a recuperação 
do dinheiro desviado por governantes anteriores, constituiu um elemento crucial na consolidação de uma aliança estratégica entre os dois países.

As relações da Nigéria com os EUA e a União Soviética/Rússia foram e têm sido marcadas pelas dinâmicas globais da Guerra Fria e do pós-Guerra Fria. A Nigéria é membro do Movimento dos Não Alinhados, tendo, no entanto, ao longo do período da Guerra Fria, tomado posições mais proocidentais ou pro-bloco de leste, conforme os temas e os governos. Balewa (1960-1966) nunca escondeu a sua postura pro-ocidental e de quase hostilidade para com a ex-União Soviética e o bloco de leste. Com a recusa dos países ocidentais financiarem os esforços de guerra nigerianos no Biafra e o facto da União Soviética ter vindo em auxílio da Nigéria, as relações com os países do bloco de leste desenvolveram-se de forma sólida, passando-se a assistir a um «desafio vigoroso à hegemonia ocidental global» (Abegunrin, 2001: 109), na última metade da década de 1960. Esta posição anti-ocidental mantém-se com Mohammed/Obasanjo (1975-1979). A Nigéria chega mesmo a cancelar a visita de Henry Kissinger ao país, aquando da realização de um périplo africano no sentido de persuadir os Chefes de Estado a não aderirem ao comunismo e a não seguirem a liderança da Nigéria no reconhecimento do governo angolano do MPLA (Abegunrin, 2003: 66).

A segunda metade da época dos regimes militares engloba o final da Guerra Fria, com uma posição pró-ocidental entusiasta por parte de Babangida (1985-1993): apoio tácito à Guerra do Golfo e acolhimento da Convenção de Lomé IV (Garuba, 2008). No entanto, com o regime violento de Abacha (1993-1998), a Nigéria volta a assumir uma posição anti-ocidental hostil (Abegunrin, 2001: 127). Este anti-ocidentalismo era privilegiadamente canalizado contra os EUA que desenvolviam esforços para aplicar sanções e um embargo petrolífero à Nigéria, despoletados pela execução de nove activistas em 1995. Abacha acusava os países ocidentais de «encorajarem activamente grupos de oposição [na Nigéria] bem como no estrangeiro» contra o seu governo (Abegunrin, 2001: 127).

Com as eleições democráticas em 1999, as relações com o Ocidente e, em especial, com os EUA alteraram-se drasticamente. Em 1999, a Nigéria e os EUA assinaram um acordo que levantou finalmente as restrições de vôos directos entre os dois países (restrições aplicadas desde Abacha) 
(Garuba, 2008). Apesar desta alteração, continuam a existir momentos de tensão sobre um ou outro tema. Recentemente, a posição nigeriana contra o estabelecimento de um comando militar americano em África (AFRICOM) constituiu um desses momentos (Garuba, 2008). O período pós-2001 proporcionou, no entanto, um novo ímpeto para as relações Nigéria-EUA, nomeadamente na área da cooperação para o desenvolvimento associada ao combate ao Síndrome da Imuno-Deficiência Adquirida (SIDA) e na luta contra o terrorismo. A Nigéria é um dos quinze países classificados como prioritários para o Plano de Emergência para o SIDA do Presidente dos Estados Unidos da América (PEPFAR) criado em 2004. Este Plano baseia-se na ideia que para além da tragédia humana per se, o impacto do SIDA na Nigéria cria condições para a existência de uma base de recrutamento mais fácil para movimentos extremistas, devido ao elevado número de jovens órfãos. Apesar de esta teoria não ser consensual, o facto é que a Nigéria é um dos países que mais apoio recebe dos EUA através deste Plano (cerca de 1,5 mil milhões de dólares americanos). Acresce ainda, que a Nigéria tem sido considerada uma fonte de ameaças à segurança regional na África Ocidental, devido às redes de actividades criminosas e à proliferação de armas e grupos armados, facilitadas por uma estrutura política corrupta e muitas vezes omissa. Desde 2005, a Nigéria confirmou-se como um dos aliados dos EUA no continente africano na luta contra o terrorismo, recebendo ajuda no âmbito da Iniciativa Contra o Terrorismo do Trans-Sahara e da Operação Liberdade Duradoura no Trans-Sahara, ambas enquadradas nas actividades do AFRICOM.

Obviamente que a Nigéria mantém relações diplomáticas e comerciais com vários outros países, mas para além dos países acima referidos, talvez o que mais se destaca actualmente seja a China. A relação entre estes dois países passou de inexistente, com a recusa de Balewa (1960-1966) em reconhecer diplomaticamente o então governo da República Popular da China, a uma relação bastante forte no início do século xxi. Em 2007, a Nigéria constituía praticamente o segundo maior parceiro comercial da China, tendo quadruplicado as suas exportações, que não petróleo, entre 1998 e 2001 (Taylor, 2007). De assinalar também que, em 2006, a Nigéria tornou-se o primeiro país africano a assinar, com Pequim, um Memorando 
de Entendimento sobre a Criação de uma Parceria Estratégica entres os dois países (Taylor, 2007). A China tem apostado numa política de longo prazo na Nigéria, investindo em infra-estruturas e canalizando uma percentagem significativa do seu investimento directo estrangeiro para a economia nigeriana. O impacto estrutural que esta estratégia possa vir a ter na política externa nigeriana não é ainda claro. Por um lado, a relação com a China tem criado alguma tensão interna devido às práticas chinesas de gestão fabril. Por outro, a Nigéria não tem sido um parceiro submisso nesta relação, pois, não só tem apostado na diversificação das suas fontes de recursos na área da ajuda pública ao desenvolvimento, como tem defendido de forma assertiva os interesses nacionais em matéria de direitos e benefícios associados à exploração petrolífera. ${ }^{11}$

A riqueza petrolífera nigeriana tem constituído um elemento estruturante da sua política externa a nível internacional. Por um lado, tem proporcionado meios para concretizar as suas decisões. O financiamento de senadores e líderes afro-americanos dos EUA, durante o regime Abacha (1993-1998), no sentido de estes fazerem pressão contra a proposta de aplicação de sanções comerciais e de um embargo petrolífero à Nigéria (Abegunrin, 2003: 154), é um exemplo claro da capacidade que os rendimentos do petróleo proporcionaram. Por outro lado, as dinâmicas associadas às crises petrolíferas da década de 1970 também afectaram negativamente a situação económica nigeriana. Esta é uma situação particular, pois a Nigéria é um país da OPEP. Neste caso, as dinâmicas internas nigerianas tiveram um impacto directo na sua capacidade para enfrentar a crise financeira internacional. Regimes corruptos (Babangida, 1985-1993 e Abacha, 1993-1998), com desvio de fundos para o estrangeiro e conflitos violentos internos, afectando a estabilidade da produção petrolífera, diminuíram de forma estrutural a capacidade dos governos lidarem com a crise económica e financeira. Ainda assim, a Nigéria tentou manter sempre a sua independência, por exemplo, fazendo frente ao FMI, ao não aceitar as condições para o reescalonamento da sua dívida externa no início da década de 1980. O regime Babangida (1985-1993), no

\footnotetext{
11 Para uma análise do tipo de contratos desenvolvidos pela Nigéria para a exploração petrolífera com empresas estrangeiras, ver (Taylor, 2007).
} 
entanto, acabou por adoptar medidas económicas que, na verdade, eram coerentes com os Programas de Ajustamento Estrutural do FMI (Garuba, 2008). Em 2005, o Clube de Paris finalmente decidiu perdoar cerca de $80 \%$ da dívida externa nigeriana (Pham, 2007), aliviando de forma estrutural as pressões económicas externas com que o país se debatia desde o final da década de 1970.

\section{Considerações finais}

A Nigéria tem sido recorrentemente referida como um 'gigante com pés de barro', caracterizada por uma estrutura económica, política e social frágil que não tem permitido a concretização do seu destino de líder da África negra. Esta fragilidade tem sido acompanhada pela ausência de uma estratégia coerente de política externa e reforçada pelo surgimento e afirmação de outras potências regionais africanas e internacionais. Na verdade, um dos traços mais marcantes da política externa nigeriana desde a independência, e que é transversal às três dimensões analisadas, tem sido a incoerência da mesma. Nesse sentido, e uma vez que a política externa nigeriana foi sempre dependente das dinâmicas de estabilidade e instabilidade que têm caracterizado o país, a Nigéria continua a enfrentar desafios de natureza essencialmente interna: a consolidação da sua democracia e dos princípios de boa governação, a distribuição equitativa da riqueza nacional, o combate à corrupção, a gestão pacífica dos conflitos internos violentos, e o combate ao HIV-SIDA. O Conselho de Assessoria ao Presidente sobre Relações Internacionais criado por Yar'Adua, em 2009, constitui um reconhecimento da necessidade sentida de criar uma política externa mais coerente e estável que apoie uma estratégia de recuperação e consolidação de um papel para a Nigéria como membro respeitável da comunidade internacional, como líder do continente africano e como exemplo na promoção dos interesses Sul-Sul. 
Cronologia dos regimes políticos

\begin{tabular}{|c|c|c|c|}
\hline Datas & Tipo de regime & Datas & Chefe de estado \\
\hline - & 一 & \multirow{2}{*}{ 1960-1966 } & \multirow{2}{*}{ Balewa (não eleito) } \\
\hline 1963-1966 & $1^{\text {a }}$ República & & \\
\hline \multirow{4}{*}{$1966-1979$} & \multirow{4}{*}{ Militar } & 1966 & Ironsi \\
\hline & & $1966-1975$ & Gowon \\
\hline & & $1975-1976$ & Mohammed \\
\hline & & 1976-1979 & Obasanjo \\
\hline $1979-1983$ & $2^{\text {a }}$ República & $1979-1983$ & Shagari (não eleito) \\
\hline \multirow{5}{*}{$\begin{array}{c}\text { 1983-1999 } \\
\text { [1993] }\end{array}$} & \multirow{5}{*}{$\begin{array}{c}\text { Militar } \\
{\left[3^{a} \text { República }\right.} \\
\text { (abortada)] }\end{array}$} & $1983-1985$ & Buhari \\
\hline & & $1985-1993$ & Babangida \\
\hline & & 1993 & Shonekan \\
\hline & & $1993-1998$ & Abacha \\
\hline & & 1998-1999 & Abubakar \\
\hline \multirow{4}{*}{ 1999- } & \multirow{4}{*}{$4^{\mathrm{a}}$ República } & 1999-2003 & Obasanjo \\
\hline & & $2003-2007$ & Obasanjo \\
\hline & & $2007-2010$ & Yar'Adua \\
\hline & & 2010 & Jonathan \\
\hline
\end{tabular}

\section{Questões para análise}

A riqueza petrolífera pode ser considerada uma 'maldição' para a política externa nigeriana?

Analise criticamente a analogia da Nigéria a um 'gigante com pés de barro'. Considera que a Nigéria se pode considerar uma 'nova polícia' em África'? Concorda que a política externa da Nigéria tem sido demasiado centrada em África?

\section{Fontes na internet}

The Nigerian Economic Summit Group, http://www.nesgroup.org/

The National Think Thank Project, http://www.nationalthinktank.org/ index.php

Página oficial do Governo da República Federal da Nigéria, http://www. nigeria.gov.ng/ 
Ministério dos Negócios Estrangeiros da República Federal da Nigéria, http://www.mfa.gov.ng/index2.php

Presidente da Nigéria, http://www.nigeriafirst.org/president.shtml

The Nigerian Tribune, http://www.tribune.com.ng/index.php

\section{Leituras recomendadas}

Bach, Daniel (2007) «Nigeria's 'manifest destiny' in West Africa: dominance without power", Afrika spectrum, 2, 301-321.

King, Mae C. (1996) Currents of Nigerian Foreign Policy. Washington D.C.: Howard University Press

Morgan, Denny and Webber, Mark (2002) "Sub-Saharan Africa: Nigeria and South Africa», in Webber, Mark; Smith, Michael, com David Allen, Alan Collins, Denny Morgan e Anoushiravan Ehteshami (org), Foreign Policy in a transformed world. Essex: Prentice-Hall.

Oby, Cyril I. (2008) «Nigeria's foreign policy and transnational security challenges in West Africa», Journal of Contemporary African Studies, 26(2), 183-196.

Osaghae, Eghosa E. (1998) The Crippled Giant: Nigeria since Independence. Bloomington: Indiana University Press.

Rotberg, Robert I. (2004) «Trouble Nigeria: Great Opportunities, Tough Challenges", in Rotberg, Robert I. (org) Crafting the New Nigeria: Confronting the Challenges. Boulder: Lynne Rienner Publishers Inc., 1-15.

\section{Bibliografia}

Abegunrin, Olayiwola (2001) "A Survey of Nigerian Foreign Policy: 1960-1998», in Ojo, Bamidele A. (org) Problems and Prospects of Sustaining Democracy in Nigeria: Voices of a Generation. New York: Nova Science Publishers, Inc., 105-.

Abegunrin, Olayiwola (2003) Nigerian Foreign Policy under Military Rule, 1966-1999. Westport: Praeger Publishers.

Adebajo, Adekeye (2002) Building Peace in West Africa: Liberia, Sierra Leone and GuineaBissau. Boulder: Lynne Rienner Publishers.

Adebajo, Adekeye and Mustapha, Abdul Raufu (org) (2008) Gulliver's Troubles: Nigeria's Foreign Policy after the Cold War. Durban: University of KwaZulu-Natal Press. 
Ajibewa, Aderemi (1998) "The Third Republic and Nigeria's Foreign Policy Options", in Ojo, Bamidele A. (org) Nigeria's Third Republic: The Problems and Prospects of Political Transition to Civil Rule. Cornmack: Nova Science Publishers, Inc., 83-100.

Garuba, Dauda (2008) CIDOB International Yearbook 2008: Keys to Facilitate the Monitoring of the Spanish Foreign Policy and the International Relations in 2007 - Country Profile: Nigeria and its regional context. Barcelona: Fundación CIDOB.

Ihonvbere, Julius Omozuanvbo (1994) Nigeria: the politics of adjustment and democracy. New Brunswick: Transaction Publishers.

Inamete, Ufot Bassey (2001) Foreign Policy Decision-Making in Nigeria. Cranbury, N.J.: Rosemont Publishing \& Printing Corp.

Maier, Karl (2000) The House Has Fallen. Midnight in Nigeria. Lagos: Public Affairs.

Nuamah, Rosemary (2003) Nigeria's Foreign Policy after the Cold War: Domestic, Regional and External Influences. Oxford: International Peace Academy, University of Oxford.

Pham, Peter J. (2007) «Nigeria's Foreign Policy: An Inquiry into Sources and Prospects». Paper presented at V FLAD-IPRI International Conference: "The EU and Africa: Looking for Strategic Partnershipm. Lisboa, Portugal, 8-9 de Novembro.

Taylor, Ian (2007) "China's Relations with Nigeria», The Round Table, 96(392), 631-645. 
Licínia Simão

\section{CAPÍTULO 13}

\section{REPÚBLICA ISLÂMICA DO IRÃO}

\section{Principais linhas da política externa iraniana: pragmatismo e ideologia}

O Irão ${ }^{1}$ apresenta um conjunto de princípios basilares na sua política externa que se mantiveram inalterados, durante a sua longa história (Frye, 1996): um profundo pragmatismo, que visa assegurar os interesses geoestratégicos do país e a sua segurança; e uma dimensão ideológica, que permanece parte integrante da identidade, história e cultura iranianas (Ramazani, 2004). Assim, a política externa iraniana apresenta-se como sendo "caleidoscópica» (Ramazani, 1989: 211), ilustrando a constante fluidez dos arranjos políticos e das posições defendidas pelos líderes políticos e religiosos. A defesa primordial do interesse nacional iraniano, que historicamente inclui independência e segurança num contexto regional desfavorável, é, pois, o principal motor da definição de uma política externa flexível e pragmática. Tendo em conta a natureza estratégica e disputada da região do Golfo Pérsico e a presença de potências externas, os diferentes regimes em Teerão procuraram implementar uma política de equilíbrio (imparcialidade e não-alinhamento), que exigia equidistância. A decisão, em 1951, do Primeiro-ministro Muhammad Mosaddeq de nacionalizar a industria petrolífera iraniana, então dominada

\footnotetext{
${ }^{1}$ Até 1935, a actual República Islâmica do Irão (RII) era conhecida pelo nome oficial de Pérsia. Por decisão do Xá Muhammad Reza, nesse ano, o país mudou a designação oficial para Irão e, depois de Revolução Islâmica de 1979, adoptou o actual nome. Ao longo deste capítulo serão utilizadas as designações Irão e RII de forma aleatória.
} 
pelos ingleses, e, mais tarde, o mote promovido pelo primeiro Líder Supremo, Aiatola Khomeini, ${ }^{2}$ "Nem Oriente, nem Ocidente, mas a República Islâmica», são boas ilustrações desta abordagem.

Um outro aspecto central é a política de alianças e acomodação (Barzegar, 2010: 181). Esta combinação de escolhas tácticas, aliando-se a actores estratégicos e procurado encontrar formas de acomodar, quer os seus interesses, quer os dos seus aliados, reforça a ideia de flexibilidade e fluidez na política externa iraniana. Embora as relações com os vizinhos sejam permanentemente tensas, depois da guerra Irão-Iraque e sob a liderança de Rafsanjani, foi visível uma aproximação às monarquias árabes do Golfo Pérsico, incluindo à Arábia Saudita, ilustrando a escolha pela acomodação de interesses regionais. Os líderes iranianos reconheceram que, sendo um estado Shi'ita motivado pela exportação da sua revolução religiosa, as relações regionais seriam inevitavelmente marcadas pela suspeição, mas reconheceram também, que a falta de apoio que o Irão sentiu durante a guerra com o Iraque se deveu, em parte, à dimensão ideológica e poderia ser alterada, se esta fosse revista (Takeyh, 2009: 130-139). De forma semelhante, durante a presidência de Khatami, foram visíveis esforços para reconfigurar as relações, quer com os vizinhos, quer com os Estados Unidos da América (EUA) (Barzegar, 2010: 181; Takeyh, 2009: 196-204).

A organização política e a distribuição de poder entre diferentes elites é outro factor central na definição de políticas externas. A estrutura governativa iraniana, criada pela Constituição de 1979, estabelece a par das estruturas seculares eleitas, como o Presidente da República ou o Parlamento nacional, estruturas religiosas não eleitas com vastos poderes de supervisão e decisão (ver gráfico em baixo). As responsabilidades pela política externa estão concentradas, oficialmente, na figura do Líder Supremo. É ele quem comanda as Forças Armadas (incluindo o Exército dos Guardiães da Revolução Islâmica) e o seu gabinete tem amplos poderes em matéria de segurança, defesa e política externa. O Conselho Supremo de Segurança Nacional foi estabelecido aquando da revisão constitucional de 1989 e funciona como

\footnotetext{
2 O Irão teve até hoje apenas dois Líderes Supremos: o Aiatola Ruhollah Khomeini (1979-1989) e o Aiatola Ali Khamenei (1989- ).
} 
o órgão decisório onde a política externa é efectivamente desenhada por consenso e sob supervisão do Líder Supremo. O Presidente mantém também poderes na formulação da política externa, devido à sua posição como chefe de governo. A par do Ministro dos Negócios Estrangeiros, cada Presidente procura imprimir um cunho pessoal nas opções de política externa, mas em última análise, as decisões finais devem reflectir o equilíbrio de forças existente na sociedade e entre as elites políticas e religiosas do país.

As relações com os EUA são um tema central e permanente da política externa iraniana, como são também as relações no contexto regional do Médio Oriente. A preocupação em manter um equilíbrio de forças que garanta a segurança da nação Shi'ita, num contexto maioritariamente Sunita é outro factor central, definidor das suas opções estratégicas, nomeadamente nas suas relações com movimentos como o Hezbollah no Líbano ou as minorias Shi'itas no Iraque e no Afeganistão. Assim, tendo em conta os pilares e opções estratégicas da política externa iraniana, a análise que se segue procura ilustrar estas dinâmicas, colocando-as no contexto político doméstico e externo e identificando eventos centrais que marcaram a forma como o Irão se apresentou ao mundo ao longo do século xx e no início do século XXI.

Gráfico 1. Estrutura Governativa do Irão.

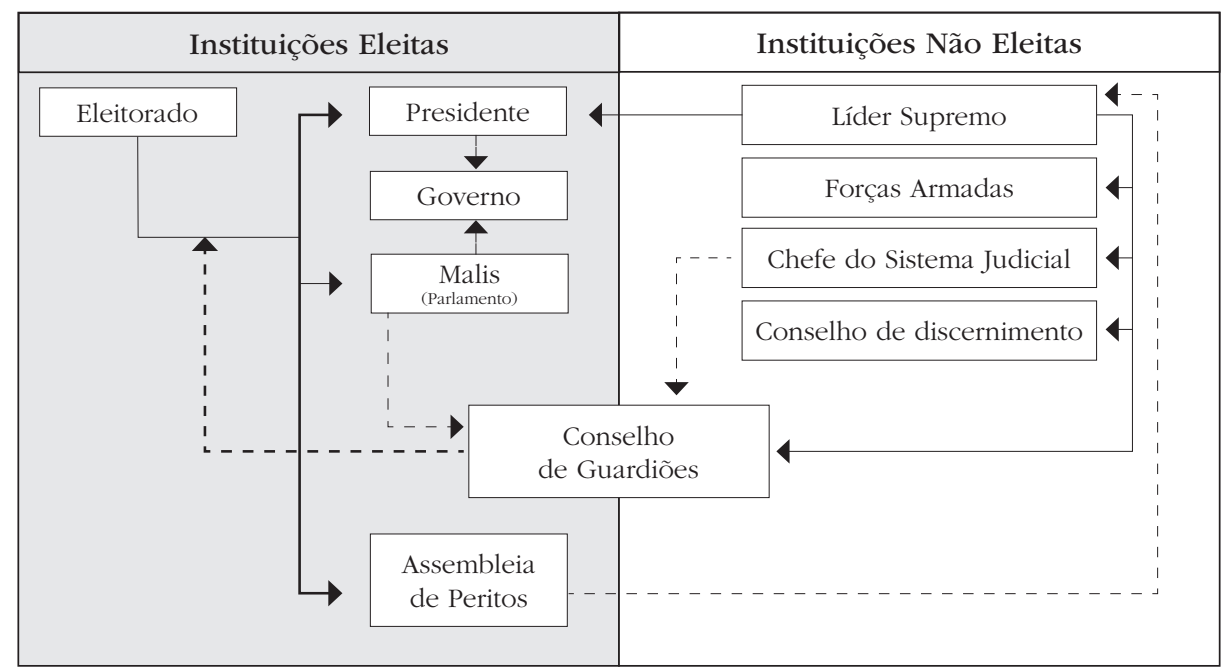

Legenda:

Eleição Directa - - - $\rightarrow$ Veta Candidatos 


\section{Política externa na dinastia Pahlavi}

A revolução islâmica de 1979, que levou à deposição do Xá Muhammad Reza Pahlavi, foi motivada pelo descontentamento geral com as políticas autoritárias do Xá, nomeadamente a actuação da polícia secreta SAVAK, mas principalmente por um profundo sentimento nacionalista que via o país refém de interesses estrangeiros, liderados pelos EUA. O Golpe de Estado que levou ao poder o Xá Reza Pahlavi e deu início à dinastia Pahlavi, em 1921, foi não só em parte facilitado pelo envolvimento britânico, como permitiu a criação e desenvolvimento formal de um modelo de estado ocidental (Chehabi, 1998: 495). Os interesses britânicos no Irão remontam ao início do século xx, com a criação da Companhia Petrolífera Anglo-Persa ${ }^{3}$, que viria a ser um laço fundamental nas relações do Irão com o ocidente. Mais tarde, a 25 de Agosto de 1941 e em plena Segunda Guerra Mundial, receando que a forte presença alemã no Irão se transformasse numa ameaça aos interesses ingleses e soviéticos na região, os dois países invadem o Irão, numa manobra militar e política que culminou na prisão e expulsão para o exílio do Xá Reza Pahlavi e a sua substituição pelo seu filho Muhammad Reza Pahlavi. Os motivos desta decisão britânico-soviética prenderam-se, oficialmente, com a necessidade de assegurar direitos de trânsito para as tropas aliadas, que procuravam derrotar os alemães na frente russa, mas reflectiram também a vontade de proteger interesses britânicos, nomeadamente na exploração dos campos petrolíferos (Eshraghi, 1984: 37-38). Entre 1941 e o fim da Segunda Guerra Mundial, a presença de tropas estrangeiras no Irão foi uma realidade. Embora os Aliados tenham procurado assegurar ao Xá o respeito pela integridade territorial do país e a sua intenção de retirar completamente do seu território, depois de terminada a guerra, os primeiros ecos da Guerra Fria fizeram-se já anunciar com a recusa soviética de retirar de território iraniano nas datas acordadas pelo Tratado de Teerão (Lenczowski, 1972: 47-50).

\footnotetext{
3 A Anglo-Persian Oil Company foi estabelecida em 1908, para explorar as reservas petroliferas descobertas na então Pérsia. Em 1935 foi redenominada Anglo-Iranian Oil Company e em 1953 tornou-se na British Petroleum Company (BP).
} 
Os anos que se seguiram tornaram a competição entre as duas potências da Guerra Fria, em território iraniano, mais visível. Em 1951, após a nacionalização da indústria petrolífera iraniana pelo Primeiro-ministro Mohammad Mosaddeq, os serviços secretos norte-americanos, instigados pelos parceiros britânicos, organizaram a "operação Ajax», que levou à deposição do governo. Embora os EUA tenham mantido confiança política no Xá, tornava-se claro que este se tinha tornado numa figura distante e cada vez mais desligada da realidade do país. Durante as décadas que se seguiram, o Xá, tal como outros líderes no Médio Oriente, usou a ameaça comunista como um meio para conseguir assistência política, económica, financeira e militar dos EUA, usada principalmente contra os oponentes internos ao regime (Summitt, 2004: 562).

Durante o regime do Xá Muhammad Reza, o Irão estabeleceu uma aliança estratégica com os EUA e tornou-se o maior comprador de armas norte-americanas (Ramazani, 2004: 554). O apoio de Washington ao regime repressivo do Xá constituiu um forte incentivo para a deterioração da percepção popular sobre os EUA no Irão e, depois da revolução islâmica, foi um vector central da política externa e doméstica iraniana. A história das relações entre os EUA e o Irão, até 1979, mostram a construção de uma aliança de necessidade, tendo em conta a convulsão das relações internacionais durante a Primeira e Segunda Guerras Mundiais e a consolidação de relações de clientelismo entre os dois estados durante a Guerra Fria (Gasiorowski, 1991; Ghaneabassiri, 2002: 170).

\section{A revolução islâmica: o período ideológico liderado por Khomeini}

Com a transição do poder político para as mãos dos clérigos Shi'itas e principalmente do fundador da República Islâmica, o Grande Aiatola Ruhollah Khomeini, deu-se início a uma profunda revolução que alteraria a face do Irão nas três décadas seguintes, com implicações profundas nas dinâmicas do Médio Oriente. Um dos legados mais duradouros do Imã Khomeini foi a estrutura institucional iraniana que emergiu do processo revolucionário. O estabelecimento de estruturas dominadas por clérigos, a par de estrutu- 
ras de governo seculares e da posição de Líder Supremo, acima de todos, instituiu não só a legitimação de um governo religioso, como centralizou todas as decisões nas mãos do Imã. Arjomand (2009: 6) refere a "rotinização do carisma” do Líder Khomeini como um elemento central na construção da nova ordem constitucional iraniana, ao passo que Takeyh (2009: 2) sublinha a longevidade da sua visão na construção do futuro da República Islâmica do Irão (RII).

Khomeini estabeleceu-se como um jovem clérigo na cidade de Qom e, especialmente a partir da década de 1960, mostrou interesse pelo debate de questões públicas, apresentando uma visão política muito influenciada pelos grandes movimentos anti-colonialistas e nacionalistas (Takeyh, 2009: 11-14). ${ }^{4}$ Khomeini revelou-se um clérigo influente, determinado a recuperar um lugar central para o Islão na vida pública iraniana. Para isso, denunciou a "submissão» do regime do Xá aos interesses norte-americanos e o abandono das práticas religiosas, que tinham até então formado parte integrante da vida pública iraniana. A mobilização conseguida por Khomeini, durante a década de 1960 e 1970, reflectiu um desejo de mudança que seria canalizado para a consolidação do poder religioso, em detrimento do poder da monarquia. Esta tensão entre as duas bases da estrutura de poder iraniano (o Shi'ismo e a Monarquia) foi radicalmente alterada em favor da primeira. Daí que Khomeini estivesse profundamente comprometido com o estabelecimento de uma república islâmica, baseada numa forma teocrática de poder. A centralidade do governo religioso na visão do Imã ficou imortalizada no estabelecimento de um modelo político de jurisprudência religiosa (velayat-e faqib) que viria a ser aceite, não só pela comunidade religiosa no Irão, mas também pela população iraniana. Os seus discursos públicos e as suas estratégias de mobilização da classe religiosa eventualmente levaram a que o Xá ordenasse primeiro a sua prisão e, em 1964, a sua deportação para o exílio, na Turquia. No ano seguinte, Khomeini estabeleceu-se em Najaf, no Iraque, onde desenvolveu o seu pensamento sobre a jurisprudência religiosa, que viria a ser divulgado de forma clandestina no Irão (Algar,

\footnotetext{
4 Para uma análise detalhada da visão ideológica de Khomeini ver Rajacc (1983). Ver também Arjomand (2009: 16-35).
} 
2010; Takeyh, 2009: 15-17). Conseguiu também consolidar um movimento de oposição nacional ao Xá, albergando diferentes forças políticas e religiosas sob a bandeira da revolução.

A resposta violenta do Xá ao descontentamento crescente na sociedade iraniana e as sucessivas e inconsequentes reformas revelaram os limites da monarquia em acomodar as reivindicações sociais e políticas iranianas (Bill, 1978: 324-329; Pollack, 2004: 137-140). Por sua vez, Khomeini consolidou a sua visão de uma república islâmica como alternativa à corrupção do regime vigente. No final de 1978 e até 16 de Janeiro de 1979, quando o Xá abandonou o país, verificaram-se manifestações populares desafiando a lei marcial, greves gerais e mesmo dentro das forças armadas emergiram profundas divisões entre a geração mais velha, leal ao Xá, e as gerações mais novas fascinadas pela ideia de um governo religioso (Algar, 2010). Com efeito, o objectivo comum e imediato de remover o Xá foi a força maior que juntou elementos de todas as classes sociais, de todos os quadrantes intelectuais, movimentos religiosos e seculares (Katouzian, 2009: 21). O regresso do Imã, a Teerão, a 1 de Fevereiro de 1979, simbolizou o culminar da revolução e inaugurou o novo período de acomodação política e social, com profundas implicações na forma como a política externa do país passou a ser conduzida.

Com a adopção, no final de 1979, de uma nova Constituição instituindo um governo religioso, a RII tornou-se o primeiro estado a ter um governo islâmico. Será, pois, Khomeini quem irá definir as grandes linhas da política externa iraniana no período pós-revolucionário, quer com uma visão ideológica da nova missão da república islâmica, quer fazendo sentir o seu poder sobre os outros elementos do novo governo. Segundo o Líder Supremo, a revolução iraniana simbolizava apenas o começo do que deveria ser um movimento maior, comum a toda a humanidade, mas em especial a todos os muçulmanos. ${ }^{5}$ Subjacente a este princípio estão portanto três ideias cen-

5 "The Iranian Revolution is not exclusively that of Iran, because Islam does not belong to any particular people. Islam is revealed for mankind and the Muslims, not for Iran... An Islamic movement, therefore, cannot limit itself to any particular country, not even to the Islamic countries; it is the continuation of the revolution by the prophets». Sermão proferido por Khomeini, a 2 de Novembro de 1979, citado em Rajacc (1983: 82). 
trais: a RII deveria ter um papel de charneira na exportação da revolução islâmica, principalmente no contexto do Médio Oriente; deveria procurar consolidar a unidade islâmica (principalmente entre Sunitas e Shi'itas) (Rajacc, 1983: 85); e seria necessário reconhecer que a falta de unidade entre muçulmanos se devia principalmente à presença de potências imperialistas no Médio Oriente, cujo objectivo era, não só explorar as riquezas da região, como evitar que o Islão se tornasse uma força relevante. Assim, emerge como parte crucial do discurso revolucionário e ideológico de Khomeini a criação de um arqui-inimigo da revolução, simbolizado pelos EUA e por Israel (Takeyh, 2009: 18-22).

A prevalência de um contexto ideológico e de grande conturbação durante o período revolucionário facilitou em grande medida a consolidação de uma imagem paranóica dos EUA. A crise dos reféns da embaixada norte-americana em Teerão ilustrou esse receio profundo de que Washington interferisse na revolução iraniana (Pollack, 2004: 153-159; Takeyh, 2009: 36-46). Este episódio acabou por marcar a imagem que as duas nações têm de si próprias e do outro. A 4 de Novembro de 1979, iniciaram-se 444 dias de ocupação da embaixada norte-americana em Teerão por um grupo de estudantes, reivindicando o fim dos planos norte-americanos de subversão da revolução sagrada. Embora a tomada da embaixada tivesse como objectivo a humilhação do "Grande Satã» e a afirmação de uma nova relação de poder, esta crise ilustrou também as dinâmicas internas de luta pelo poder. No imediato contexto pós-revolucionário, uma aliança de partidos de esquerda e liberais estabeleceu um novo governo liderado por Mehdi Bazargan, com o apoio dos clérigos. A par do governo, foi estabelecido o Conselho Revolucionário, sendo composto por clérigos próximos de Khomeini, por líderes políticos próximos de Bazargan e elementos das forças armadas. As decisões políticas que guiaram a RII no período pós-revolucionário viriam a ser o resultado do confronto entre uma visão conciliadora de Bazargan, nomeadamente no que toca ao relacionamento com os EUA, e a visão radical que o Conselho Revolucionário e Khomeini viriam a promover, incluindo o seu apoio implícito às acções dos estudantes.

Com efeito Bazargan mostrou-se favorável à manutenção de relações com os EUA, embora o seu objectivo imediato fosse fazer regressar a RII a uma 
política de equilíbrio, pondo fim à aliança com os EUA. Para esse efeito, a RII retirou-se da Organização do Tratado do Médio Oriente, que havia sido criada em 1955, e cancelou os acordos de defesa que o Xá tinha estabelecido com Washington (Ramazani, 1989: 204-205). Apesar destas decisões, o desejo de acomodação com os EUA foi visto pelos clérigos como um sinal de fraqueza e que contrariava o objectivo maior de Khomeini de estabelecer uma ordem mundial islâmica. Para além disso, o facto de a administração Carter ter admitido que o Xá entrasse nos EUA para tratamento médico, apenas reforçou a ideia de que a revolução estava em perigo. Segundo Ramazani (1989: 206-210), este período viu a política externa iraniana ser dividida em dois blocos centrais: por um lado os nacionalistas realistas, como Bazargan, viam a independência do Irão como um aspecto central, mas que deveria ser conseguida mantendo relações de equilíbrio com as duas super-potências e com os seus vizinhos; por outro lado, os idealistas revolucionários viam o Islão como a razão maior para a política externa do país e, como tal, todos os outros objectivos deveriam ser subjugados ao princípio da exportação da revolução e da criação de um Golfo Pérsico sem influência norte-americana.

Os reféns foram libertados, já em 1981, numa altura em que o poder de Khomeini e dos clérigos estava consolidado através de uma nova ordem constitucional. No entanto, em 1980, teve início um dos principais acontecimentos na vida pós-revolucionária do Irão: a guerra com o Iraque, que durou até 1988 e terminou com um armistício negociado pelas Nações Unidas. As razões que levaram Saddam Hussein a invadir o Irão a 22 de Setembro de 1980 são multifacetadas, incluindo disputas territoriais, políticas e religiosas (Gregory Gause III, 2002). Foi uma combinação de oportunidade e receio que levou Saddam Hussein a iniciar a guerra: oportunidade de enfraquecer ainda mais o seu inimigo histórico e conquistar parte do seu território, numa altura em que o seu governo se encontrava fragilizado; e receio de que a nova ideologia, protagonizada por Khomeini, tivesse um impacto visível na minoria Shi'ita no Iraque, destabilizando o regime secular Bah'ista (Takeyh, 2009: 82-87). Embora, no início da guerra, o Irão se apresentasse numa situação de aparente desvantagem, os novos líderes transformaram o conflito numa ferramenta de consolidação do seu poder. 
A guerra ganhou contornos de uma cruzada, representando uma oportunidade para o povo iraniano demonstrar «não só o ardor nacionalista, mas também a sua devoção religiosa» (Takeyh, 2009: 89).

A guerra entre o Irão e o Iraque foi uma dais mais longas e violentas da história do Médio Oriente. Foi uma guerra total, em que ambos os lados usaram todo o seu poderio militar, humano e financeiro (Hooglund, 1987: 13). Para além das implicações domésticas, a guerra teve um impacto profundo nas relações do Médio Oriente e acabou por se internacionalizar no contexto da Guerra Fria (Takeyh, 2009: 101-107). O Irão viu-se isolado e marginalizado pelo conflito, após a decisão dos estados do Conselho de Cooperação do Golfo (CCG), todos árabes, e dos EUA, Alemanha, França e Reino Unido de apoiarem o Iraque (Taremi, 2003: 386). Com efeito as políticas expansionistas da RII no Médio Oriente, através da criação de movimentos armados como o Hezbollah no Líbano ou o Hamas na Palestina criaram uma suspeita profunda, não só entre os seus vizinhos, como a nível internacional. No contexto da guerra com o Iraque, estes ressentimentos foram um motivo forte para isolar o regime islâmico.

A RII manteve, nessa altura, relações próximas com Moscovo e com Pequim (Hickey, 1990), bem como com dois aliados improváveis, recorrendo a uma política de alianças pragmáticas: a Síria e Israel. Para o regime de Damasco, a ajuda ao Irão representava uma forma de combater a presença norte-americana, enquanto para Teerão, a Síria representava uma fonte de armas importante, bem como um sinal de divisão na solidariedade árabe, que poderia trazer dividendos para Teerão (Takeyh, 2009: 74-79). O apoio de Israel é ainda mais inesperado, tendo em conta as declarações dos novos líderes revolucionários contra o "Pequeno Satã» e a sua denúncia da criação do estado de Israel, como uma imposição das potências imperialistas, que deveria ser terminada. No entanto, para ambos os estados as exigências da guerra e os cálculos de longo prazo sobrepuseram-se ao fervor religioso ou ideológico. Com efeito, Teerão necessitava urgentemente de apoio militar israelita que colmatasse a falta de acesso a novas armas ou a meios de reparar o arsenal iraniano de fabrico ocidental. Para Israel, o apoio a Teerão era uma escolha táctica com vista a garantir que Saddam Hussein não consolidasse o seu domínio no Médio Oriente (Takeyh, 2009: 61-69). A 
dada altura, os próprios EUA recorreram a contactos com os iranianos, para que fossem libertados reféns no Líbano, em troca de armas (Parsi, 2007). O que ficou conhecido como o escândalo Irão-Contras foi, porventura, o evento mais demonstrativo do grande pragmatismo e oportunismo nas relações externas do Irão, mas também de Israel e dos EUA.

O fervor ideológico dos anos da revolução e da liderança de Khomeini marcaram as relações externas iranianas na década de 1980, promovendo a exportação da revolução, principalmente para o Golfo Pérsico e o Médio Oriente e consolidando uma aliança islâmica que pudesse ser um contraponto à bipolaridade. No entanto, e como vimos, o pragmatismo foi uma constante, exigindo cálculos ocasionais que contrariavam os ensinamentos religiosos e ideológicos. Os traços centrais deste período, marcado pelo isolamento internacional do Irão e pela consolidação das suas políticas de intervenção e destabilização regional, permaneceram nas décadas seguintes. Foi, no entanto, a RII a cortar laços com a comunidade internacional, profundamente desiludida com as suas políticas da acomodação face à utilização de armas químicas pelo Iraque de Saddam Hussein. Para os iranianos e os seus líderes tornou-se claro que, só dependendo de si mesmo, o Irão poderia sobreviver num contexto hostil. Estas tendências foram suavizadas durante a liderança de Rafsanjani, mas permanecem até hoje uma parte central da política externa iraniana.

\section{Abertura ao mundo: o período pragmático liderado por Rafsanjani}

O ano de 1989 representa um marco histórico também na vida política da RII. Nesse ano, Khomeini, procurando dar um novo impulso à revolução, anunciou uma fatwa contra Salman Rushdie, devido à publicação de Versículos Satânicos. ${ }^{6}$ Pouco tempo depois, o Líder Supremo e arquitecto ideológico da revolução falecia, dando início a um processo de luta interna pelo poder,

\footnotetext{
${ }^{6}$ Uma fatwa, é um edital religioso sobre a aplicação da lei islâmica em qualquer situação da vida de uma comunidade e é emitida por um clérigo ou autoridade religiosa. No caso de Salman Rushdie, foi lançada pelo Aiatola Khomeini, devido à alegada blasfémia e apostasia do seu romance Versículos Satânicos e continha uma sentença de morte por violação da lei islâmica.
} 
entre as diferentes facções da vida política, económica, social e militar iranianas (Moslem, 2002; Siavoshi, 1992). Os apoiantes da revolução islâmica procuraram consolidar um status quo que lhes fosse favorável, com acesso a benefícios políticos e socioeconómicos. Segundo Alamdari (2005: 1290-1291), nesta fase consolidaram-se diversos centros de poder verticais e autónomos que facilitaram o desenvolvimento de relações de clientelismo, com profundas implicações para as reformas económicas e políticas que o novo Presidente, Akbar Hashemi Rafsanjani, procurou implementar depois de 1989.

Neste novo contexto, a nomeação de um novo Líder Supremo era uma prioridade. Presidente da República entre 1981 e 1989, Ali Khamenei, foi então elevado à categoria de Aiatola e nomeado Líder Supremo pela Assembleia de Peritos. Com a revisão constitucional de 1989, foi abolido o cargo de Primeiro-ministro, criando um regime presidencialista, de liderança dupla, e foi estabelecido o poderoso Conselho de Segurança Nacional, com poderes reforçados em matéria de política externa. Uma vez resolvido o dilema imediato da sucessão a Khomeini, a RII precisava agora encontrar soluções para o avolumar de desafios que o contexto interno, regional e internacional colocava. Rafsanjani procurou iniciar uma era de reconstrução (Takeyh, 2009: 113), que permitisse reparar os danos causados pela devastadora guerra com o Iraque e legitimar o novo governo, com base em políticas sociais. Para isso, contudo, era necessário alterar as relações com os vizinhos do Golfo Pérsico e abrir novas possibilidades de relações comerciais com os países europeus e a União Soviética/Rússia, que permitissem ao Irão aceder a importantes créditos internacionais e reverter o estado de dependência absoluta da sua economia (Taremi, 2003: 388; Tarock, 1999). Embora as exigências práticas da reconstrução fossem um aspecto central da nova política de acomodação, a tensão entre pragmatismo e ideologia manteve-se visível, dando origem a acesso debates internos, sobre os perigos e as vantagens da cooperação com os EUA. Perante a existência de uma só superpotência, o Irão viu-se obrigado, também, a melhorar relações com diversos novos parceiros, não necessariamente muçulmanos, bem como a tentar forjar a sua presença em organizações regionais não dominadas pelo Ocidente (Herzig, 2004: 505; Ramazani, 1992: 401-403).

Com efeito, no novo contexto pós-Guerra Fria, Teerão viu-se obrigado a alterar a sua política externa, abandonando o princípio de «nem Ocidente, 
nem Oriente» e estabelecendo o princípio de "Norte e Sul» (Ramazani, 1992). Isto significava, abertura aos novos estados independentes do Cáucaso do Sul e da Ásia Central (Arjomand, 2009: 141-143; Herzig, 2004; Ramazani, 1992) e à Rússia. Apesar dos momentos de tensão entre Teerão e Moscovo, nomeadamente durante a invasão Soviética no Afeganistão (Milan, 2006: 235-246) e durante a guerra na Chechénia, os dois estados viram benefícios numa cooperação estratégica. Um dos objectivos centrais era limitar a presença norte americana no Golfo Pérsico e no Mar Cáspio (Lowe and Spencer, 2006: 40-43) e, desde o final da década de 1990, a cooperação nuclear passou a ser um aspecto central das suas relações. Teerão, com o apoio de Moscovo, desempenhou também o papel de mediador no conflito de Nagorno Karabakh, entre a Arménia e o Azerbaijão, e na guerra civil que deflagrou no Tajiquistão. Perante a abertura do espaço da Eurásia, quer o Irão, quer a Turquia procuraram reforçar a sua presença, tendo por base uma abordagem pragmática e funcionalista. Com efeito, no inicio da década de 1990, os dois estados entraram em competição por influência nesta região, principalmente através da promoção de integração regional baseada em afinidades culturais e linguísticas (Calabrese, 1998; Herzig, 2004: 507).

No contexto do Golfo Pérsico, a nova liderança iraniana procurou alcançar dois objectivos centrais: conter o Iraque e reconciliar-se com os estados do CCG. O fim da guerra com o Iraque não resolveu as disputas territoriais entre os dois estados. Com efeito, a invasão iraquiana do Kuwait, em 1990, confirmou o entendimento de Teerão de que a liderança iraquiana representava o principal elemento destabilizador na região. O Irão usou esta oportunidade para demonstrar o seu apoio ao pequeno estado árabe e exigir que o CCG denunciasse a invasão iraquiana (Ramazani, 1992: 396; Takeyh, 2009: 134). A subsequente primeira guerra do Golfo representou uma oportunidade para Teerão se afirmar como um actor empenhado na estabilidade regional, mas também trouxe ameaças claras. A primeira delas era a presença de tropas internacionais e principalmente norte-americanas, no Golfo Pérsico. Para as facções radicais no Irão, o dever da república islâmica era denunciar e combater essa presença. Contudo, numa fase em que o Irão procurava normalizar a suas relações externas e integrar-se na economia mundial, as exigências ideológicas teriam de ser calibradas por 
interesses económicos e políticos. Um outro desafio foi a permanência de Saddam no poder e o perigo de desmembramento do estado iraquiano, especialmente nos territórios curdos e de maioria Shi'ita. Perante a oportunidade de apoiar a rebelião Shi'ita no Iraque, Teerão limitou o seu apoio a questões logísticas (Ramazani, 1992: 398; Takeyh, 2009: 136; Taremi, 2003: 390) e não investiu em destabilizar o país vizinho.

A melhoria de relações com os estados do CCG tinha como objectivos centrais reforçar a política de contenção do Iraque, melhorar o contexto económico iraniano e alterar favoravelmente os arranjos de segurança regionais. Para isso, as relações problemáticas de Teerão com a Arábia Saudita tinham de ser revistas. Em 1988, após a morte de mais de 400 peregrinos, entre eles perto de 300 iranianos, aquando das peregrinações anuais a Meca, as relações diplomáticas entre os dois países foram cortadas (Caryl, 2009). Durante a guerra com o Iraque, o Irão viu os preços do crude descerem após o aumento da produção saudita, num apoio claro de Riade a Saddam Hussein. No entanto, a questão que mais separa os dois estados é a parceria estratégica da Arábia Saudita com os EUA e, embora as relações diplomáticas tenham sido restabelecidas depois da primeira guerra do Golfo, as diferentes visões relativamente ao papel os EUA não foram reconciliadas. Efectivamente, para a RII o estabelecimento de um acordo de segurança no Golfo, que exclua ao EUA e que inclua Teerão é um objectivo central, mas irreconciliável com a percepção dos estados árabes do Golfo que vêem os EUA como um aliado e uma garantia de segurança (Taremi, 2003: 390). Embora o resultado das políticas de aproximação e acomodação regionais de Rafsanjani tenha sido limitado, o contexto regional após a guerra do Golfo e com o fim da União Soviética era profundamente diferente, confirmando a RII como um actor regional incontornável.

Para Israel, este novo contexto regional tinha algumas desvantagens, nomeadamente a falta de um inimigo comum com os EUA. Após a derrota de Saddam, a Administração Bush lançou imediatamente o processo de paz israelo-árabe, que culminaria com os Acordos de Oslo. É neste contexto que a rivalidade com Teerão irá escalar para novos níveis. Segundo Parsi (2005: 261), Israel e o Irão acabaram por competir pelo mesmo vácuo de poder deixado com a derrota do Iraque. Após os acordos de paz com os estados árabes, ambos se 
encontravam em posição de se tornarem actores económicos centrais na região. Para além disso, o Irão, com a sua retórica anti-ocidental e anti-israelita, representava a ameaça necessária para manter a aliança com os EUA e para garantir apoio doméstico ao processo de paz, em Israel. Para Teerão, a sua exclusão dos arranjos de segurança regionais e a política de isolamento seguida por Israel e os EUA exigiu uma presença mais visível que confirmasse o seu papel central na segurança regional. Nesse sentido, o Irão denunciou o processo de paz e renovou o seu apoio aos grupos militantes palestinianos e no Líbano, reforçando o seu objectivo de travar o processo de paz israelo-árabe. Embora eventualmente esta política tenha rendido os seus frutos e Israel tenha alterado a sua posição face a Teerão, os danos nas relações externas do Irão com os países europeus e com os EUA foram devastadores. A denúncia de Teerão como um instigador de terrorismo islâmico fundamentalista e as notícias preocupantes sobre o seu programa nuclear pareciam reverter os resultados positivos da abertura inicial conseguida por Rafsanjani. Quando o Presidente Khatami chegou ao poder em 1997, o Irão encontrava-se num processo de mudança acelerada, exigindo reformas mais profundas do que Rafsanjani tinha sido capaz de fazer. A RII tinha também consolidado o seu programa nuclear com apoio russo e chinês e sofria, desde 1996, sanções norte-americanas, estabelecidas depois da adopção do Acto de Sanções Irão-Líbia.

\section{Diálogo civilizacional: o período reformista liderado por Khatami}

As eleições de 1997 marcaram um período fascinante na política doméstica do Irão, que teve também impacto na sua política externa. A chegada surpreendente do movimento reformista ao poder iniciou um processo de reforma que traduzia, em parte, uma nova realidade social do Irão, mas também uma ruptura com a ideologia totalitária da revolução islâmica (Arjomand, 2009: 92). O processo de liberalização da sociedade iraniana iniciou-se, pois, com esta vitória: o número de jornais, de associações e Organizações Não Governamentais (ONGs) registadas aumentou de forma exponencial; o respeito pelo estado de direito passou a ser uma prioridade assumida pelo novo Presidente (Arjomand, 2009: 93-94); e, no seu conjunto, o movimento 
procurou «re-conceptualizar as relações entre os cidadãos e o estado, bem como entre a religião e a democracia» (Takeyh, 2009: 184). Embora o movimento reformista tenha sido em grande parte restringido nos resultados da sua acção, pela estrutura institucional que garantia aos órgãos religiosos a supervisão e direito de veto de todas as iniciativas legislativas do Presidente e do Parlamento, a imagem externa de RII alterou-se de forma positiva.

Durante a campanha eleitoral, a reintegração do Irão na comunidade internacional e a reconciliação com os seus vizinhos figuraram proeminentemente nos discursos de Khatami. Uma das suas prioridades foi promover um diálogo civilizacional, apoiado na coexistência, em vez da rivalidade. Foi uma mudança de discurso radical, em comparação com os candidatos conservadores, apoiados pelas estruturas religiosas, que apostavam na denúncia do ocidente como fonte de decadência e imperialismo (Takeyh, 2009: 182-187). Khatami procurou também estabelecer diálogo com os EUA e, logo em Janeiro de 1998, após a sua eleição, deu uma entrevista exclusiva à cadeia televisiva CNN, sublinhando os interesses partilhados entre o Irão e os EUA, embora reconhecendo que se mantinham graves desentendimentos. O seu desejo de mostrar uma nova face da RII tinha sido já demonstrado aquando da sua participação no encontro da Organização da Conferência Islâmica (OCI), em Dezembro de 1997, quando afirmou "O verdadeiro diálogo só será possível quando os dois lados tiverem consciência das suas raízes e da sua identidade» (citado em Ansari, 2006: 160).

Podemos, pois, afirmar que o movimento reformador, liderado por Khatami, procurou ao nível interno transformar a RII num estado democrático, preocupado não apenas com a missão universal da revolução islâmica, mas com a reforma das estruturas domésticas. Por outro lado, o novo discurso conciliador e os gestos de boa vontade do novo Presidente procuraram mostrar ao mundo outra face do RII, facilitando o diálogo e, porventura, criando novas oportunidades de desenvolvimento económico e político. No entanto, esta abordagem teve dois problemas centrais, que ilustram a ligação próxima entre as dinâmicas internas e as opções de política externa (e vice-versa). Por um lado, a reacção norte-americana às aberturas do Presidente Khatami foi confusa, demonstrando falta de preparação e entrou em choque com a sua mensagem de diálogo, numa altura em que a Administração Clinton 
mantinha uma política de "contenção dupla» (do Irão e do Iraque), no Médio Oriente. Apenas a Secretária de Estado, Madeleine Albright, emitiu um pedido formal de desculpas, em Março de 1998, pelo envolvimento norteamericano no golpe de estado que retirou o Primeiro-ministro Mosaddeq do poder em 1951 (Ansari, 2006: 161).

A política de "dissuasão, respeito mútuo e diálogo» de Kahtami (Takeyh, 2009: 198), apoiada inicialmente pelo Líder Supremo, Khamenei, traduziu-se na melhoria de relações principalmente com a Arábia Saudita e os vizinhos do Golfo, e, em 1999, Khatami tornou-se o primeiro Presidente iraniano a visitar Riade. A esta visita seguiram-se uma série de acordos bilaterais e uma colaboração próxima com a Arábia Saudita dentro da OPEC. Khatami anunciou também que o Irão estaria disposto a respeitar um acordo de paz que os palestinianos aceitassem (neste caso, uma solução de dois estados) o que preconizava um reconhecimento implícito do estado de Israel. Na Europa, a eleição de Khatami foi vista como uma possibilidade real de liberalização das políticas domésticas, a que a União Europeia respondeu, instituindo uma nova política de «envolvimento construtivo» em vez de um «diálogo crítico». Houve uma série de visitas bilaterais sem precedente, com o Presidente Khatami a ser recebido em diversas capitais europeias. No entanto, embora a nova abordagem de Khatami fosse vista com bons olhos pelos europeus, isso não se traduziu em benefícios concretos, nomeadamente na área económica, trazendo descrédito à agenda do Presidente. As forças reaccionárias rapidamente se organizaram para minar a sua autoridade e, por sua vez, isso teve um impacto visível na imagem externa de Khatami e da RII.

Os acontecimentos de 11 de Setembro de 2001 marcaram a política externa iraniana de forma radical. A reacção inicial dos líderes iranianos foi de apoio aos EUA, disponibilizando assistência no combate ao regime Talibã, no Afeganistão. Este alinhar de interesses foi visto com desconfiança pelas diferentes forças nos dois países, principalmente entre os grupos mais radicais (os reaccionários no Irão e os neo-conservadores nos EUA) (Ansari, 2006: 164-165). Efectivamente, o Irão tinha tentado criar, desde a revolução islâmica, uma esfera de influência ideológica no Afeganistão, procurando mobilizar as populações Shi'itas, durante os anos de ocupação soviética (Milan, 2006: 236-239). Procurou inclusivamente influenciar os processos políticos neste 
país vizinho, criando uma alternativa política que lhe fosse próxima. Por isso, o interesse norte-americano em derrubar o regime Talibã foi visto de forma positiva em Teerão e as ligações iranianas à Aliança do Norte foram essenciais para que a coligação internacional, liderada pelos EUA, conseguisse alguns resultados positivos (Milan, 2006: 246-251). Às oportunidades de cooperação com os EUA no Afeganistão, os iranianos contrapuseram também os perigos de uma presença militar norte-americana no país vizinho, que viria a ser reforçada, em 2003, com a invasão do Iraque. Um sentimento de cerco (Ehteshami, 2004: 187; Milan, 2006: 248) e a percepção de que um arco de instabilidade estava em desenvolvimento nas suas fronteiras fez com que, durante a Administração Bush, não houvesse melhorias nas relações bilaterais.

Perante os desafios da guerra global contra o terrorismo e o novo contexto no Médio Oriente, a política de dissuasão, promovida pelo Presidente Khatami, tinha ser agora cuidadosamente calibrada com uma cooperação pragmática com Washington. No entanto, o discurso do Estado da Nação, do Presidente George W. Bush, em Janeiro de 2002, contrariou as aspirações de uma relação mais próxima, ao incluir o Irão no «eixo do mal». Até 2005, quando o Irão elegeu Mahmoud Ahmadinejad como novo Presidente, as preocupações iranianas centraram-se em três grandes questões: manter uma política de envolvimento construtivo na estabilização e reconstrução do Afeganistão; procurar que os seus interesses estivessem representados na nova estrutura política iraquiana; e assegurar que os dois princípios basilares da sua política externa (garantir segurança interna e estabilidade regional) eram salvaguardados. É nesta óptica que o desenvolvimento do programa nuclear iraniano deve ser entendido, como uma forma de compensar o isolamento internacional e regional e de assegurar que a sua política de independência e auto-suficiência são mantidas.

\section{Liderança regional: o período reaccionário liderado por Ahmadinejad}

Apesar das importantes aberturas de Khatami ao mundo, no final dos seus dois mandatos, o Irão encontrava-se numa situação de grande fragilidade. A sobrevivência do regime estava sob ameaça directa da super-potência 
norte-americana, agora dedicada a combater a proliferação de armamentos nucleares através da promoção da democracia, e o seu papel regional estava gravemente debilitado com a presença reforçada do exército norte-americano no Iraque e no Afeganistão. A chegada de uma nova elite ao poder serviu para rever as prioridades da política externa iraniana. Os representantes da Nova Direita, conservadores reaccionários liderados por Ahmadinejad, subiram ao poder com as eleições parlamentares de 2004 e presidenciais de 2005, apoiados pelas franjas mais conservadoras da elite clerical, pelos Guardiães da Revolução, em especial pela milícia paramilitar Basij, e, em última análise, pelo Líder Supremo Khamenei.

Esta era a geração dos veteranos da guerra Irão-Iraque, devotos do Islão e dos ideais da revolução, promovidos por Khomeini. Na sua mensagem doméstica enalteceram a redistribuição de riqueza e a justiça social e prometeram uma era de prosperidade e equidade. Prometeram também o regresso às origens da revolução, denunciando os anteriores Presidentes como tendo corrompido o ideal de Khomeini e a presença de «inimigos internos» ao regime, que serviram de legitimação às suas políticas de terrorismo e violência contra os opositores políticos (Arjomand, 2009: 149-156; Takeyh, 2009: 223-227). Inaugurava-se assim um novo período, de delapidação do carácter democrático dos processos políticos no Irão, com o recurso às milícias Basij, para cometer fraude eleitoral, nas eleições presidenciais de 2005 e, como ficou claro, depois novamente em 2009 (Arjomand, 2009: 151; 165-171). Em termos da sua política externa, os novos líderes promoveram uma política baseada nos ideais islâmicos, de forte vertente nacionalista, que identificava os EUA como a potência opressora do mundo islâmico. Esta identificação entre muçulmanos permitiu que Ahmadinejad conseguisse, com algum sucesso, ligar a segurança iraniana, incluindo o desenvolvimento do seu programa nuclear, à segurança regional (Barzegar, 2010: 184). Para isso, manteve activa a tradicional política de alianças, reforçando os laços com a Síria, o Hezbollah e o Hamas, promoveu uma retórica anti-Israelita feroz e fez do programa nuclear iraniano o símbolo da opressão dos EUA ao mundo islâmico.

O programa nuclear tem sido a principal questão na política externa da RII, durante os mandatos de Ahmadinejad, embora as origens do sonho nuclear iraniano remontem ao período do Xá, com apoio directo dos EUA 
e das potências europeias (Kibaroglu, 2006). A decisão de reactivar o programa nuclear prendeu-se, principalmente, com a experiência trágica dos iranianos durante a guerra com o Iraque. Nesse período consolidou-se a noção de auto-suficiência em termos de segurança (que a opção nuclear assegura) e a percepção de que o uso indiscriminado de agentes químicos e bacteriológicos, pelo regime de Saddam, tinha sido aceite pela comunidade internacional e, em última instância, tinha forçado o Irão a assinar o armistício (Takeyh, 2009: 244-245). Durante o final da década de 1980, Rafsanjani conduziu uma série de contactos, no Paquistão, Argentina e com A. Q. Khan do Paquistão, com vista a adquirir tecnologia nuclear, que os EUA e os parceiros europeus recusavam fornecer. Khatami continuou essa política e abordou a China e a Rússia, tendo conseguido um acordo com Moscovo para construir o reactor nuclear de Bushehr. ${ }^{7}$ No final de década de 1990, verificava-se um novo ímpeto no desenvolvimento do programa nuclear, em parte apoiado em sectores da elite iraniana com interesses directos nesta área. O resultado deste novo impulso tornou-se público, em 2002, quando foi denunciada a existência de instalações secretas em Natanz e Arak, que não tinham sido divulgadas à Agência Internacional de Energia Atómica (AIEA). Iniciou-se então o processo de negociações entre os líderes iranianos, a AIEA, os EUA e os parceiros europeus.

Relativamente ao programa nuclear e ao seu impacto na política externa iraniana, iremos centrar-nos em duas questões: a importância dos arranjos internos de poder na postura da RII nas negociações com os parceiros internacionais; e os potenciais impactos que um Irão nuclear terá no contexto regional do Médio Oriente e nas relações com os EUA. A subida ao poder dos reaccionários, em 2005, veio alterar a estratégia que Kahatami e Khamenei tinham delineado e cujo principal objectivo era manter o programa nuclear, evitando sanções do Conselho de Segurança das Nações Unidas (CSNU) (Arjomand, 2009: 202). Esta estratégia tinha trazido alguns resultados positivos, nomeadamente a assinatura do Acordo de Paris, em 2004, embora a falta de apoio dos EUA à iniciativa franco-anglo-germânica

\footnotetext{
7 Para uma perspectiva completa das ambições nucleares iranianas ver Chubin (2006).
} 
acabasse por se traduzir num triunfo para os reaccionários, que viam o acordo como uma humilhação para a RII. Efectivamente, Ahmadinejad usou o programa nuclear iraniano como arma de propaganda e de promoção de orgulho nacional e do mundo Islâmico (Ehteshami and Zweiri, 2007: 98). Por seu lado, o Líder Supremo, tentou manter a via do diálogo aberta com os europeus e, em 2006, os cinco membros permanentes do CSNU, mais a Alemanha (5+1) voltaram à mesa das negociações com o Irão. Embora o acordo proposto não tenha sido rejeitado pelo Presidente iraniano, a RII falhou os prazos estabelecidos e acabou por sofrer novas sanções. Durante 2007 e 2008, Ahmadinejad continuou o seu processo de afirmação interna, por vezes desafiando directamente a autoridade do Líder Supremo. Em 2008, Khamenei procurou novamente persuadir o CSNU da sua posição central na definição da política externa da RII e do desejo do país de continuar negociações (Arjomand, 2009: 202-203). No entanto, com o aproximar das eleições presidenciais de 2009 e a contestação que se seguiu, foi o cartel liderado pelos Guardiães da Revolução que beneficiou da fragilização da posição do Presidente Ahmadinejad e do Líder Supremo, pondo fim a qualquer esperança de negociações. Finalmente, em Junho de 2010, o CSNU aprovou um novo pacote de sanções ao Irão.

A segunda questão prende-se com as relações de um possível Irão nuclear com o Médio Oriente e os EUA. Com a saída do poder dos Talibã, no Afeganistão e de Saddam Hussein, no Iraque, o Irão é hoje um actor central no Médio Oriente. Outras potências regionais como a Arábia Saudita, o Egipto ou mesmo a Turquia poderão sentir-se tentadas a iniciar a uma corrida aos armamentos, incluindo armas nucleares, para travar a hegemonia regional iraniana. Sem dúvida, os equilíbrios de poder na região seriam profundamente afectados por essa possibilidade (Kaye and Wehrey, 2007: 111). Para o estado de Israel, a possibilidade de o Irão adquirir armas nucleares, aliada à retórica anti-semita e anti-israelita do Presidente Ahmadinejad, é um risco sem precedentes à sua segurança (Ehteshami and Zweiri, 2007: 109). Daí que os líderes israelitas mantenham a possibilidade de um ataque preventivo sobre o Irão, caso a diplomacia não produza resultados. Para os países do Golfo Pérsico, um confronto nuclear na região teria consequências catastróficas. Independentemente da forma como a região se adapta à possibilidade 
nuclear, a presença incontornável do Irão na política regional, incluindo a sua presença reforçada no Iraque, na Palestina, por via do Hamas, e no Líbano, após a vitória do Hezbollah sobre Israel, em 2006, deixa adivinhar um processo de afirmação internacional que os EUA terão de reconhecer. A abertura do Presidente Obama à normalização de relações deverá, pois, ser entendida como um passo importante nesse reconhecimento, embora se adivinhem muitas dificuldades.

\section{Conclusões}

A política externa iraniana tem sido construída com base em dois pilares essenciais: pragmatismo e ideologia. Isso traduziu-se, inicialmente, numa tensão estruturante entre a Monarquia e o Islão, que a revolução de 1979 fez pender em favor do último. Tal como a maior parte dos estados, o Irão procura salvaguardar o que considera serem os seus interesses nacionais, tendo em conta um forte sentimento nacionalista persa. Isto tem-se traduzido numa política externa flexível e em constante refluxo. A percepção de estar inserido num contexto regional e internacional desfavorável, tem favorecido uma política de alianças e acomodação, quer com os vizinhos do Golfo Pérsico, quer com os EUA. No entanto, as estruturas internas de poder e a clara dimensão ideológica trazida pela revolução islâmica têm permitido que uma visão conservadora e reaccionária tenha tido uma presença constante na política externa iraniana, antagonizando os EUA e Israel. As forças pragmáticas e reformadoras têm encontrado grandes dificuldades para justificar uma abordagem diferente, tendo em conta a profunda idealização do papel da RII no mundo. 


\section{Questões para análise}

Quais as principais razões que conduziram à Revolução Islâmica de 1979, no Irão?

Que linhas centrais guiam a política externa iraniana no período pós-revolucionário?

De que forma as dinâmicas de política interna afectam as opções de política externa no Irão? Dê exemplos ilustrativos.

Quais os motivos que levaram a RII a iniciar o seu programa nuclear? E de que forma isso afectou as suas relações com os EUA?

Qual a abordagem da RII para a segurança no Golfo Pérsico e Médio Oriente? E de que forma é ilustrativa dos princípios basilares da sua política externa?

\section{Fontes na internet}

Council on Foreign Relations, http://www.cfr.org/region/404/iran.html

World Savvy Monitor, https://monitor.worldsavvy.org/index.php?option=com content $\&$ view $=$ article $\&$ id $=508 \&$ Itemid $=923$

Presidente da República Islâmica do Irão, http://www.president.ir/en/

Líder Supremo do Irão, http://www.leader.ir/langs/en/

Fundador da revolução islâmica, Imã Khomeini, http://www.imam-khomeini. com/DefaultN.aspx?lang=en

Agência noticiosa iraniana (IRNA), http://www.irna.ir/En/default. aspx?IdLanguage $=3$

\section{Leituras recomendadas}

Takeyh Ray (2009) Guardians of the Revolution. Iran and the world in the age of the Ayatollahs. Oxford: Oxford University Press.

Pollack, K. (2004) The Persian Puzzle: The Conflict between Iran and America. Nova Iorque: Random House.

Shirin Hunter (1992) Iran After Khomeini. Nova Iorque: Praeger.

Ehteshami, A. and Zweiri, M. (2007) Iran and the rise of Its neoconservatives: The Politics of Tehran's Silent Revolution. London: Tauris.

Chubin, S. (2006) Iran's Nuclear Ambitions. Washington D.C.: Carnegie Endowment for International Peace. 


\section{Bibliografia}

Alamdari, Kazem (2005) "The Power Structure of the Islamic republic of Iran: transition from populism to clientelism, and militarization of the government", Third World Quarterly, 26(8), 1285-1301.

Algar, Hamid (2010) "Imam Khomeini: A Short Biography». [http://www.al-islam.org/imambiography/].

Ansari, Ali M. (2006) "Iran and the US in the Shadow of 9/11: Persia and the Persian Question Revisited", Iranian Studies, 39(2), 155-170.

Arjomand, Saïd. A. (2009) After Khomeini. Iran under his successors. Nova Iorque: Oxford University Press.

Barzegar, Kayhan (2010) "Iran's Foreign Policy Strategy after Saddam», The Washington Quarterly, 33(1), 173-189.

Bill, James A. (1978) "Iran and the Crisis of '78», Foreign Affairs, 57(2), 323-342.

Calabrese, John (1998) "Turkey and Iran: Limits of a Stable Relationship», British Journal of Middle Eastern Studies, 25(1), 75-94.

Caryl, Christian (2009) "The Hajj», Foreign Policy, 20 de Novembro. [http://www.foreignpolicy. com/articles/2009/11/20/reality_check_the_hajj].

Chehabi, Houchang E. (1998) "The Pahlavi period», Iranian Studies, 31(3), 495-502.

Chubin, Shaharam (2006) Iran's Nuclear Ambitions. Washington D.C.: Carnegie Endowment for International Peace.

Ehteshami, Anoushiravan (2004) "Iran's International Posture after the Fall of Baghdad", The Middle East Journal, 58(2), 179-194.

Ehteshami, Anoushiravan e Zweiri, Mahjoob (2007) Iran and the rise of its neoconservatIves: The Politics of Tehran's Silent Revolution. Londres /Nova Iorque: I.B.Tauris.

Eshraghi, F. (1984) "Anglo-Soviet Occupation of Iran in August 1941», Middle Eastern Studies, 20(1), 27-52.

Frye, Richard N. (1996) The Golden Age of Persia: The Arabs in the East. Nova Iorque: Barnes \& Noble.

Gasiorowski, Mark (1991) US Foreign Policy and the Shab: Building a Client State in Iran. Ithaca: Cornell University Press.

Ghaneabassiri, Kamyar (2002) "U.S. foreign policy and Persia, 1856-1921", Iranian Studies, 35(1), 145-175.

Gregory Gause III, F. (2002) "Iraq's Decision to Go to War, 1980-1990", Middle East Journal, 56(1), 47-70

Herzing, Edmund (2004) «Regionalism, Iran and Central Asia», International Affairs, 80(3), 503-517.

Hickey, Dennis V. (1990) «New Directions in China's Arms for Export Policy: An Analysis of China's Military Ties with Iran", Asian Affairs, 17(1), 15-29.

Hooglund, Eric (1987) "Iran and the Gulf War», MERIP Middle East Report, Re-Flagging the Gulf 148 (Setembro-Outubro), 12-18.

Katouzian, Homa (2009) "The Iranian Revolution of February 1979», Viewpoints: The Iranian Revolution at 30, The Middle East Institute.

Kaye, Dalia. D. and Wehrey, Frederic. M. (2007) "A Nuclear Iran: The Reactions of Neighbours", Survival, 49(2), 111-128. 
Kibaroglu, Mustafa (2006) "Good for the Shah, Banned for the Mullahs: The West and Iran's Quest for Nuclear Power», Middle East Journal, 60(2), 207-232.

Lenczowski, George (1972) «United States' Support for Iran's Independence and Integrity, 1945-1959", Annals of the American Academy of Political and Social Science, 401, America and the Middle East, 45-55.

Lowe, Robert e Spencer, Claire (org) (2006) Iran, Its Neighbours and the Regional Crisis. A Middle East Programme Report. London: The Royal Institute of International Affairs.

Milan, Mohsen M. (2006) "Iran's Policy towards Afghanistan», Middle East Journal, 60(2), 235-256.

Milani, Abbas (2009) "The Three Paradoxes of the Islamic Revolution in Iran», Viewpoints: The Iranian Revolution at 30, The Middle East Institute.

Moslem, Mehdi (2002) Factional Politics in Post-Khomeini Iran. Syracuse, Nova Iorque: Syracuse University Press.

Parsi, Trita (2005) "Israel-Iranian relations assessed: Strategic competition from the power cycle perspective», Iranian Studies, 38(2), 247-269.

Parsi, Trita (2007) Treacherous Alliance: The Secret Dealings of Israel, Iran, and the United States. New Heaven, Conn: Yale University Press.

Pollack, Kenneth (2004) The Persian Puzzle: The Conflict between Iran and America. Nova Iorque: Random House.

Rajacc, Farhang (1983) Islamic Values and World View: Khomeini on Man, the State and International Politics. New York: University Press of America (American Values Projected Abroad, Vol. 13).

Ramazani, R. K. (1989) «Iran's Foreign Policy: contending orientations», The Middle East Journal, 43(2), 202-217.

Ramazani, R. K. (1992) "Iran's Foreign Policy: Both North and South», The Middle East Journal, 46(3), 393-412.

Ramazani, R. K. (2004) "Ideology and Pragmatism in Iran's Foreign Policy», The Middle East Journal, 58(4), 549-559.

Siavoshi, Susan (1992) "Factionalism and Iranian Politics: The Post-Khomeini Experience», Iranian Studies, 25(3/4), 27-49.

Summitt, April R. (2004) "For a White Revolution: John F. Kennedy and the Shah of Iran", Middle East Journal, 58(4), 560-575.

Takeyh, Ray (2009) Guardians of the Revolution. Iran and the World in the Age of the Ayatollabs. Nova Iorque: Oxford University Press.

Taremi, Kamran (2003) "Iranian perspectives on Security in the Persian Gulf», Iranian Studies, 36(3), 381-391.

Tarock, Adam (1999) "Iran-Western Europe Relations on the Mend", British Journal of Middle Eastern Studies, 26(1), 41-61. 
(Página deixada propositadamente em branco) 


\section{CAPÍTULO 14}

\section{REPÚBLICA POPULAR DA CHINA}

Este capítulo traça as principais linhas de política externa da República Popular da China (RPC). Após um breve enquadramento cultural, o texto segue um alinhamento histórico desde a fundação da RPC em 1949 à actualidade, reflectindo sobre as alterações provocadas por factores endógenos e exógenos no processo de tomada de decisão. A análise dos factores endógenos descodifica a concepção tradicional de Relações Internacionais do Império do Meio, os antecedentes históricos com impacto na formulação da política externa contemporânea, o papel desempenhado nesta formulação pelas quatro gerações de líderes desde a fundação da RPC até à liderança actual, a caracterização do interesse nacional chinês e, por fim, a importância das tendências políticas do actual momento na tomada de decisão. Entre os factores exógenos com um impacto relevante na decisão destacam-se as dinâmicas de competição e cooperação e as relações de reciprocidade estabelecidas entre a China e outros actores do sistema internacional.

\footnotetext{
${ }^{1}$ Artigo elaborado no âmbito do projecto «Uma Análise da Fórmula 'Um País, Dois Sistemas': O Papel de Macau nas Relações da China com a UE e os Países de Língua Portuguesa", Financiado pela Fundação para a Ciência e a Tecnologia (FCOMP-01-0124-FEDER-009198).
} 
Factores endógenos na formulação da política externa chinesa A concepção tradicional de Relações Internacionais

Entre os factores endógenos que influenciam o processo de tomada de decisão em política externa, devemos destacar o contexto interno, ou seja, aspectos políticos, económicos, sociais, culturais e históricos que moldam as percepções dos líderes relativamente à situação e, consequentemente, enquadram a selecção da que é considerada a melhor abordagem. No caso chinês, a cultura e a história continuam a influenciar fortemente a postura adoptada pelos líderes na cena internacional. As concepções tradicionais chinesas da ordem internacional são fundamentais para entender a política externa da China moderna.

Como é que os chineses entendiam as Relações Internacionais antes da chegada do Ocidente? Antes do século XIX não havia caracteres em chinês para as palavras «internacional», "raça», "país» - facto que só se alterou com a entrada de potências estrangeiras na China. Os caracteres da palavra "China”, 中国 ou 中國 - consoante usarmos a escrita simplificada ou tradicional ainda usada em Taiwan, Hong Kong e Macau (lê-se "Zhongguo") - significam literalmente "centro» e «império/nação», ou seja, Império do Meio. Havia um desinteresse profundo em relação aos outros "países», ao «internacional» e às outras «raças». A percepção de supremacia, para além de estar presente nesta assunção da centralidade, reflecte-se na imposição de um sistema de vassalagem em que os países interessados no relacionamento com a China eram obrigados a pagar tributo ao Imperador chinês e os seus embaixadores e chefes militares tinham de lhe prestar homenagem através do kow-tow, uma prostração de corpo inteiro em que a testa tocava três vezes no chão, simbolizando a submissão absoluta. Esta cerimónia tornou-se o símbolo do choque entre as visões opostas que europeus e chineses tinham do mundo. Para um europeu, tal prostração significava que um embaixador (logo, o «seu» rei) seria vassalo do Imperador chinês, gerando mal-entendidos bem conhecidos na história, nomeadamente na corte britânica. Em suma, o sistema tributário, através do qual as missões apenas podiam entrar no Império do Meio nos termos definidos por Pequim, mostra, claramente, o desinteresse chinês no relacionamento com o exterior. 
Esta ideia da superioridade chinesa no plano internacional foi reforçada pelos ideais confucionistas de obediência, estratificação social, e harmonia, cujas relações uni-direccionais de poder e concepções hierárquicas são transpostas para o plano internacional. Segundo Confúcio, a sociedade chinesa está dividida em camadas: o Imperador está no topo, seguido dos académicos e funcionários da administração (cujo estatuto advém da aprovação nos exames, no ideal da meritocracia estabelecida por Confúcio), dos camponeses (a quem Confúcio atribui uma importância vital, por alimentarem a população), artesãos e, por fim, dos soldados (mal vistos por um filósofo que critica o recurso à violência) e comerciantes (percepcionados como uma classe imprópria por deter o dinheiro do povo). De forma análoga, a sociedade internacional está hierarquizada: o Império do Meio, que se considera a "única cultura», está no topo, e engloba as nações vizinhas Coreia, Vietname, Japão e restantes países asiáticos - que, estando perto, absorvem as ideias chinesas e conseguem ser mais civilizados, ao contrário dos europeus e africanos que são considerados bárbaros.

Que ilações nos permite tirar esta concepção tradicional das Relações Internacionais? Em primeiro lugar, ao contrário das ordens ocidentais actuais, que reflectem uma percepção da cena internacional como palco da competição entre Estados iguais, à imagem dos ideais de construção de sociedades igualitárias, a cultura chinesa não tem enraizadas concepções de igualdade mas sim de hierarquia, quer no plano interno - ao nível da família, da sociedade e do Estado - quer externo, no relacionamento com os restantes actores do sistema. Isto vai servir de base para, mais à frente, argumentarmos que as actuais declarações chinesas sobre a necessidade de assegurar a igualdade e democracia nas Relações Internacionais não passam de retórica que cairia por terra se Pequim conseguisse atingir a tão desejada hegemonia e voltasse a ser o Império do Meio. Esta retórica deu os primeiros passos com Mao Zedong, que refutou os princípios hierárquicos confucionistas em troca do igualitarismo, não só em termos de construção da sociedade ideal mas também no plano internacional; mas apesar de ser usado nos discursos não reflecte, na sua essência, o pensamento dos actuais líderes. 
Em segundo lugar, o sistema de vassalagem revela o desinteresse chinês na aproximação a outros povos e o sentimento de superioridade de então. Este sistema funcionou durante bastante tempo e permitiu a manutenção da paz; o que é notável, se compararmos com a situação na Europa da época. Estando longe dos seus vizinhos e vendo a sua superioridade respeitada, o Império não temia ameaças à civilização chinesa e não sofria invasões (o que explica, em parte, a sua incapacidade para responder à invasão europeia no século XIX) e não mostra interesse em recorrer à guerra. Isto é revelado nas descrições dos primeiros comentadores europeus que visitaram a China: Marco Polo, um visitante controverso (há quem diga que os seus escritos são baseados em leituras e não nos 17 anos que diz que viveu na China, no séc. XIII) caracterizava o Império do Meio como uma «ditadura, tamanho colossal, rica em comércio, altamente urbanizada, inventiva em negócios comerciais, fraca nos modos de guerra» (Spence, 1998: 3). Mesmo nos séculos XVI-XVII manteve-se a percepção de que o Império do Meio era muito fraco em termos militares, uma vez que tinha uma política de nãoagressão em relação aos seus vizinhos. Estas análises servem hoje de base aos argumentos de que a China não é um poder bélico mas sim pacifista e que os seus slogans de «ascensão pacífica» e "paz e desenvolvimento» são genuínos.

Em terceiro lugar, o facto do Império do Meio permitir aproximações externas (embora segundo as suas regras) mas não mostrar particular interesse nelas, partilhando os conhecimentos da civilização chinesa com os povos vizinhos e com os «bárbaros» sem no entanto impor esta partilha, revela a ausência de crença missionária e obsessão em espalhar a civilização. Isto contrasta fortemente com a cultura ocidental, apologista das missões, ou seja, na imposição da sua forma de pensar aos outros povos, em termos religiosos (Cristianismo), sociais (Direitos Humanos), políticos (Democracia) e económicos (Liberalismo). Mais à frente veremos que este contraste é hoje visível no choque entre o chamado "Consenso de Washington» e o "Consenso de Pequim»: a postura arrogante de que o Ocidente sabe melhor como é que as outras civilizações se devem governar é posta em causa por uma abordagem que não exige pré-condições comportamentais para o estabelecimento de relações de interesse mútuo. 


\section{Antecedentes históricos}

Em relação aos aspectos históricos que mais influenciam o contexto de tomada de decisão na política externa chinesa, destaca-se a vitória da GrãBretanha na Guerra do Ópio de 1840 e a assinatura do Tratado de Nanquim, que lhe cedeu a colónia de Hong Kong, abrindo o precedente à ocupação da China por potências estrangeiras e à imposição de direitos de extraterritorialidade (aplicação da lei dos países ocupantes a crimes cometidos pelos seus nacionais na China). Aos tratados que regem essa ocupação, naquele que o povo chinês considera ter sido o "Século de Humilhações", os líderes da China chamam «Tratados Desiguais», por eles considerados inválidos à luz do direito internacional, uma vez que foram impostos por potências ocupantes. Este período histórico, que à partida parece longínquo do contexto de tomada de decisão actual, não foi apagado da memória colectiva, avivada em momentos críticos de fragilidade chinesa perante os restantes actores do sistema internacional; ou seja, tudo o que envolva "perder a face», como foi o caso da reacção internacional à repressão chinesa das manifestações tibetanas em vésperas dos Jogos Olímpicos de 2008.

"Face» é prestígio, reputação atingida através da prosperidade, do sucesso e da ostentação. Este conceito aplica-se quer ao indivíduo em relação à sociedade civil - uma pessoa tem "face» se a sociedade confia na sua integridade moral - quer a um país em relação à sociedade internacional. Pode ganhar-se "face», escolhendo cuidadosamente o ambiente e o contexto em que se vai desenrolar a interacção, tendo cuidado com as aparências ou adoptando comportamentos específicos de forma a transmitir uma imagem positiva e um estatuto elevado durante os momentos de relacionamento com os outros. Mas também se pode perder "face», quer por culpa própria, caso se adoptem comportamentos desadequados, quer por intervenção de terceiros (ver Bond, 2008: 225 e 246). Os exemplos históricos acima referidos estão registados na memória chinesa como insultuosos e humilhantes, resultando numa perda de «face» motivada pela arrogância estrangeira. Estes sentimentos de injustiça e vitimização ainda hoje condicionam fortemente a formulação da política externa chinesa, não só em relação ao Ocidente, mas também em relação ao Japão que, ao ser uma potência asiática, ainda 
traumatizou mais a China com a sua demonstração de superioridade evidenciada na brutalidade das invasões perpetradas em território chinês durante a II Guerra Mundial: a ausência de um sinal claro de arrependimento por parte dos líderes japoneses tem contribuído fortemente para exacerbar atitudes nacionalistas no vizinho asiático.

Para além do desejo de vingança das opressões estrangeiras, a herança histórica também deixou o seu rasto na obsessão colectiva pela restauração da integridade territorial, a que a política de reunificação nacional dá voz. A preocupação, para além de manter regiões com tendências separatistas como é o caso do Tibete e do Xinjiang, passa pela recuperação dos territórios "perdidos». A forma entusiasta como o povo chinês celebrou o regresso de Hong Kong e Macau, em 1997 e 1999, e o aproveitamento feito pelas autoridades centrais que incentivaram o despertar do nacionalismo com base em sentimentos anti-coloniais, reflectem essas duas dinâmicas: por um lado, a libertação do imperialismo; por outro, o sonho de um país forte e unido. Estas dinâmicas exigem também a recuperação das pequenas ilhotas do Mar do Sul da China (Spratly) e no Pacífico (Diaoyutai), cujas águas são ricas em recursos energéticos, mas principalmente da ilha de Taiwan. Como é que Taiwan se tornou o corolário da política de reunificação nacional? Importa, mais uma vez, recordar a história.

A República da China, fundada em 1912 por Sun Yat-sen, dirigente do Partido Nacionalista (Kuomintang), que levou a que o último Imperador, Pu Yi, abdicasse, foi abanada pela já referida invasão japonesa em 1937. A partir da capitulação do Japão em 1945, a guerra civil entre comunistas e nacionalistas ganhou novo fôlego e terminou em 1949 com a vitória de Mao Zedong sobre Chiang Kai-shek, sucessor de Sun Yat-sen na liderança do Kuomintang. A 1 de Outubro desse ano, Mao proclamou a República Popular da China; Chiang fugiu com o Kuomintang e criou o governo da República da China, no exílio, em Taiwan, ilha recentemente libertada pelos invasores japoneses. Durante o início da Guerra Fria, a República da China em Taiwan foi reconhecida pela Organização das Nações Unidas (ONU) como o único governo legítimo da China mas, com os votos das novas nações independentes africanas cujos movimentos de libertação tinham sido apoiados por Pequim e a evolução dos interesses do bloco ocidental, o 
assento da China foi transferido para Pequim. O apoio norte-americano a Taipé, no entanto, manteve-se inalterável, tendo um impacto evidente nas relações bilaterais entre Washington e Pequim.

Do ponto de vista chinês, Taiwan é uma província chinesa "renegada", onde se refugiaram os derrotados na guerra civil, cujos descendentes não têm qualquer direito em ocupar um território que pertence, de forma legítima, à China continental. O facto do conflito no Estreito de Taiwan ser percepcionado como uma questão interna leva os líderes chineses a recusar qualquer interferência externa. Isto tem um impacto inegável na política externa chinesa, não só no que diz respeito às relações com os Estados Unidos da América e com o Japão, que possui um poderosíssimo lobby pró-Taiwan, mas também com o resto do mundo, particularmente com os países que mantêm relações diplomáticas com Taipé. A questão de Taiwan tem uma importância simbólica inestimável em termos de identidade nacional, pois tem sido usada pelas quatro gerações de líderes (ver quadro 1) para reforçar o sentimento nacionalista e de pertença colectiva. Assim, o seu impacto na contextualização no processo de tomada de decisão chinês não deve, jamais, ser menosprezado.

Para uma civilização em que a noção de tempo é bem diferente da ocidental, a memória histórica não é curta e a identidade do povo constrói-se com raízes num passado por vezes longínquo, como revelam as manifestações de orgulho nacionalista e a ênfase posta na política de reunificação nacional. Estes factores endógenos explicam a influência do contexto interno na percepção dos factores exógenos e nas reacções que eles provocam. As históricas palavras de Mao na praça de Tiananmen aquando da fundação da RPC, "a China levantou-se!», ecoam desde então nas cabeças de todos os chineses: o Século das Humilhações seria vingado a seu tempo.

\section{O papel dos líderes}

Ainda hoje recordado como o "Libertador» da China (a sua imagem num cartaz gigante pesa sobre a simbólica praça de Tiananmen, no coração de Pequim, e o mausoléu com o seu corpo é aí diariamente visitado), 
Mao Zedong conseguiu, de facto, unificar o país. No entanto, abriu um novo período de instabilidade, ao extravasar o ódio profundo que cultivou contra os "imperialistas", que tinham repartido o Império do Meio, a todos os "elementos contra-revolucionários", aplicando a "purificação moral» ao país inteiro, incluindo a vários dirigentes políticos que foram perseguidos. A partir de 1966, os Guardas Vermelhos da Revolução Cultural criam um clima de terror e de caos em Pequim que só termina com a morte de Mao em 1976. Após dois anos de convulsões e disputas de liderança, em 1978 Deng Xiaoping, que passara seis anos em «reeducação" condenado a trabalho manual, foi restabelecido como Chefe do Estado-Maior do Exército Popular de Libertação e abre uma nova página na história da China. Apelando à modernização do país e às reformas, o "pequeno timoneiro" autoriza os camponeses a vender uma parte da sua produção no mercado livre, inicia a descolectivização da agricultura, cria as famosas Zonas Económicas Especiais, substitui as subvenções do Estado por empréstimos bancários e autoriza as cidades costeiras a atrair investimento estrangeiro. Mas, apesar de criar um sistema económico socialista de mercado, divulgando o slogan «enriquecer é glorioso!», Deng não aceita que a modernização política preceda a económica, ao contrário de perestroika soviética. Em Junho de 1989, não se opõe a que o Primeiro Ministro Li Peng afaste os líderes mais reformistas e manda avançar os tanques do Exército contra os manifestantes que protestavam na praça de Tiananmen contra os efeitos destabilizadores das reformas económicas e contra a corrupção.

De que forma é que estes dois líderes decisivos na história da RPC marcaram a sua política externa? Mao manteve uma atitude hostil em relação ao exterior, combinando-a com o recurso ao modelo soviético; desinteressado pela política externa, delegou esta pasta no Primeiro Ministro Zhou Enlai. Deng, num contexto de equilíbrio da máquina burocrática entre tendências conservadoras e radicais, afastou os elementos das Forças Armadas das posições centrais de decisão política. Em relação ao mundo exterior, o dinamizador das reformas económicas mudou gradualmente a tradicional abordagem da China, fechada sobre si mesma, para uma abertura progressiva ao exterior. Esta postura foi intensificada pelos líderes da terceira geração 
(ver quadro 1) em que Jiang Zemin, líder menos carismático, manteve a política do seu antecessor. Nesta linha de continuidade, a política externa conduzida pelo actual Presidente Hu Jintao é formulada em função da política económica da RPC, onde a atracção de Investimento Directo Estrangeiro, o acesso a recursos naturais e a procura de mercados para escoar a produção, são as prioridades, num modelo económico assente nas exportações e, consequentemente, dependente do exterior.

\section{Quadro 1. Gerações de Líderes da República Popular da China}

\begin{tabular}{|c|l|}
\hline $1^{a}-$ Líder: & Mao Zedong. \\
& $\begin{array}{l}\text { Datas: } 1949-\text { Instaura a República Popular da China; } \\
1976-\text { Morre. }\end{array}$ \\
\hline $2^{\text {a }}-$ Líder: & Deng Xiaoping. \\
& Datas: $1978-$ Lança reformas e abertura ao exterior; \\
& $1992-$ Resigna aos cargos no Partido. \\
\hline $3^{\text {a }}-$ Líder: & Jiang Zemin. \\
& $\begin{array}{l}\text { Datas: } 1992-\text { Secretário-geral do Partido; } \\
\text { 2002 }- \text { Substituído por Hu Jintao. }\end{array}$ \\
\hline $4^{\text {a }}-$ Líder: & $\begin{array}{l}\text { Hu Jintao. } \\
\text { Datas: } 2002-\text { Secretário-geral do Partido; } \\
\\
2012-\text { Novo Secretário-geral será nomeado. }\end{array}$ \\
\hline
\end{tabular}

Neste contexto, importa analisar a importância, na formulação da política externa chinesa, da elite política, ou seja, dos vários elementos que compõem determinada geração de líderes, para além do Presidente. Numa notória promiscuidade entre Estado, Partido Comunista Chinês (PCC) e Exército, as mesmas personalidades ocupam o topo das três instituições, dominando o processo de tomada de decisão, tendencialmente vertical, salvaguardando o papel dirigente do partido e evitando o colapso do socialismo. Os indivíduos mais velhos, embora possam não estar já formalmente em funções, exercem o seu poder num círculo de decisão paralelo à burocracia estatal, geralmente através de cédulas do PCC, e são consultados pelos líderes em funções, apoiando a ascensão na hierarquia do Partido e do Estado de um sucessor. Apesar de terem sido feitas algumas tentativas para "horizontalizar» o processo de tomada de decisão, nomeadamente por Deng, ao afastar os militares de carreira 
de cargos políticos, a geração de Hu ainda segue a tradicional lógica de bastidores do politburo. Assim, podemos questionar-nos sobre o peso da personalidade do líder por oposição à burocracia ou mesmo à ideologia na orquestração da política externa chinesa. Se alguns líderes foram particularmente carismáticos, como Mao e Deng, a verdade é que foram sempre fiéis à base ideológica da decisão. Ainda hoje, não obstante a evolução visível nas acções externas chinesas, é inegável a preocupação com a formulação do discurso e dos slogans, de forma a colar argumentos marxistas a um socialismo "com características chinesas» (ver discursos e princípios do quadro 2 e citações oficiais incluídas neste capítulo).

De referir ainda a existência de três importantes grupos de pressão: militares, intelectuais e empresários procuram influenciar os líderes chineses na tomada de decisão. Os militares foram obrigados a assumir um papel mais passivo na sequência de Tiananmen e das já referidas medidas adoptadas por Deng mas, sendo a modernização militar e o reforço da capacidade defensiva e ofensiva chinesa uma prioridade nacional, esta tendência está a alterar-se. Quanto aos intelectuais, assumem tendencialmente um papel consultivo da elite política, visível no enquadramento que lhes é dado pela Academia Chinesa de Ciências Sociais, um think tank do Governo chinês encarregue de elaborar relatórios que apoiam a tomada de decisão. No entanto, à medida que o sistema se vai abrindo, alguns vão saindo da sombra da elite política e ganham autonomia e muitos dos afastados em Tiananmen começam a regressar à China. Por fim, paralelamente à emergência económica da China, o grupo de pressão dos empresários, defendendo interesses comerciais individuais e privados, tem ganho força.

\section{O interesse nacional}

Outro dos factores endógenos presente aquando da tomada de decisão em política externa é o interesse nacional, que reflecte os grandes desígnios a salvaguardar para garantir a sobrevivência da nação, justificando, por isso, o empenho de todos os recursos; esse interesse reflecte-se na formulação de objectivos vitais/permanentes e conjunturais, de acordo com as capaci- 
dades reais do Estado. Ao funcionar como o garante da unidade entre os membros de uma comunidade, o interesse nacional é, muitas vezes, distorcido por regimes ditatoriais. As autoridades chinesas, para defender um regime de partido único e evitar a fragmentação territorial, propagandeiam a ausência de alternativa ao Partido Comunista Chinês, cuja manutenção no poder continua a ser, desde 1949, um objectivo vital. A forma como este objectivo é atingido tem variado de geração para geração de líderes. Se Mao Zedong confiava no marxismo-leninismo enquanto ideologia aglutinadora, a geração de Hu Jintao recorre muito mais ao nacionalismo como fonte de legitimidade do regime. Ao explorar os sentimentos patrióticos de pertença à nação de origem, o nacionalismo tem raízes históricas. No caso chinês, estas raízes remontam ao Século das Humilhações e decorrentes sentimentos de vitimização, conforme já foi referido, e assumem uma vertente ideológica para garantir a estabilidade política que tem, então, sido um objectivo permanente da RPC, reflectindo-se, na actualidade, numa política externa assertiva relativamente ao Japão e numa inflexibilidade relativamente à política de reunificação nacional, como já foi referido.

Na conjuntura actual, o interesse nacional chinês passa também por garantir a manutenção dos níveis de crescimento económico que, por sua vez, têm ajudado a alimentar o nacionalismo e, consequentemente, a legitimar a presença do PCC no poder. Isto reflecte-se em dois grandes objectivos conjunturais: assegurar a procura de recursos naturais, objectivo esse que resulta numa política externa arrojada com presença em vários pontos do globo; e a busca de estabilidade regional, essencial à manutenção desse crescimento, reflectindo-se numa postura muito pragmática da China em relação aos seus vizinhos.

\section{O momento}

Para concluir, qualquer análise dos factores endógenos na formulação da política externa de um país deve ter em conta o momento específico em que ela é formulada. No momento actual, são várias as tendências que influenciam o processo de tomada de decisão chinês. Em primeiro lugar, 
a crise civilizacional, com início no "Século de Humilhações», agravou-se a partir de 1989 com o massacre de Tiananmen e a perda de credibilidade do comunismo. A substituição do Confucionismo pelos princípios do marxismo-leninismo enquanto factor ideológico aglutinador da sociedade revelar-se-ia dramática com a dissolução da ex-URSS (União das Repúblicas Socialistas Soviéticas). Este vazio espiritual do povo chinês tem vindo a ser preenchido pela actual geração de líderes com o recurso ao nacionalismo. Por este motivo, a questão de Taiwan assume uma importância inestimável do ponto de vista identitário, influenciando de forma constante as relações da RPC com todos os países que dalguma forma apoiam Taipé, incluindo o Japão e os EUA, e estando presente em qualquer negociação que a China faça, por exemplo com a União Europeia (qualquer actor que queira relacionar-se com Pequim deve reiterar a política da "China única», reconhecendo a RPC como a sua legítima representante). Em terceiro lugar, o fim da URSS e da luta ideológica sino-soviética alterou o relacionamento com a Rússia, com quem a China passou a estabelecer dinâmicas de rivalidade mas também de cooperação. Em quarto lugar, a relação da China com a economia mundial alterou-se radicalmente, passando de uma postura desinteressada e fechada a um crescente interesse, envolvimento e dependência. Por fim, os líderes chineses recorrem cada vez mais a uma nova diplomacia multilateral, participando em organizações regionais e internacionais.

\section{Factores exógenos na formulação da política externa chinesa}

\section{Dinâmicas de competição vs. cooperação}

Apresentados os factores endógenos, vamos agora analisar os elementos externos que influenciam o processo de decisão chinês. Em primeiro lugar, há que ter em conta as dinâmicas de competição e cooperação observáveis no palco das Relações Internacionais pois são elas que, em conjugação com os já observados factores endógenos, explicam que a política externa chinesa seja simultaneamente defensiva, pragmática e assertiva. Essas dinâmicas resultam, por um lado, dos próprios factores endógenos que condicionam os outros Estados do sistema internacional, 
ou seja, do conflito ou complementaridade entre os vários contextos e interesses nacionais; e, por outro, das normas vigentes, que definem as regras do jogo na cena internacional. Os actores que ambicionam atingir ou manter o estatuto de grande potência geralmente procuram que os outros percepcionem que estão a agir de acordo com essas normas, quando seleccionam os instrumentos diplomáticos para atingir os objectivos das suas políticas externas. No caso chinês, isto só se verifica quando as normas ocidentais servem os seus próprios interesses; quando isto não acontece, a China avança com normas "com características chinesas», mostrando que os factores endógenos têm um peso muito maior na formulação da sua política externa do que os factores exógenos.

Um dos instrumentos diplomáticos que se desenvolveu na segunda metade do século passado e está cada vez mais em voga é o multilateralismo, que privilegia o processo de consulta entre os vários actores de determinado espaço geopolítico. Vimos, na secção anterior, que o Império do Meio não tinha tradição neste processo de consulta, implementando um sistema tributário marcadamente hierárquico revelador do desinteresse no relacionamento com o exterior. Os primeiros anos da República Popular da China também não foram favoráveis ao estabelecimento de relações externas, apesar de Mao Zedong dar os primeiros passos em direcção ao multilateralismo na sequência da ligação política que desenvolveu com os países em desenvolvimento. É a aceitação da globalização e o posicionamento da China como uma nação win-win que vêm dar o grande impulso: quando o seu bem-estar interno passou a depender do exterior, devido à implementação de um modelo económico dependente das exportações, a diplomacia chinesa começou a ser mais visível, sendo hoje em dia muito activa, quer no plano bilateral quer multilateral.

A análise da história chinesa sugere-nos, então, que o multilateralismo não seria actualmente a forma preferencial de relacionamento se a China não estivesse tão agradada com a globalização e se mantivesse a posição hegemónica em que se encontrava no passado. A existência de uma única super-potência é, provavelmente, o factor exógeno que mais influencia a definição da política externa chinesa. Não podendo fazer face à hegemonia 
norte-americana, os líderes chineses optaram por tentar esbater essa hegemonia contrapondo um mundo multipolar como garante da paz mundial:

The multipolarization process may be zigzag, protracted and full of struggles, but this is a historical trend independent of human will. It is in conformity with the common aspirations and interests of the majority of countries and conducive to world peace and security. Our efforts to promote the development of the world towards multipolarization are not targeted at any particular country, nor are they aimed at re-staging the old play of contention for hegemony in history. Rather, these efforts are made to boost the democratization of international relations, help the various forces in the world, on the basis of equality and mutual benefit, enhance coordination and dialogue, refrain from confrontation and preserve jointly world peace, stability and development. (RPC 2003a)

Ora a melhor forma de chegar a esta multipolaridade é reforçando o papel das instâncias multilaterais, onde os vários actores internacionais são ouvidos e podem evitar decisões unilaterais. Assim, o recurso ao multilateralismo surge, não por haver um interesse genuíno chinês de agir de acordo com as normas em vigor mas motivado pelo interesse nacional de combater a hegemonia de uma potência mais forte. Consequentemente, parece-nos que se algum dia a RPC substituir os EUA nesse papel de super-potência, o multilateralismo e o ideal de um mundo multipolar podem progressivamente esvair-se da retórica chinesa.

Evidenciando a coerência entre discurso e prática, Pequim não se limita a apelar ao reforço das instâncias multilaterais a nível mundial, como a Organização da Nações Unidas e a Organização Mundial do Comércio, e dá um impulso significativo à criação de organismos de dimensão mais reduzida em áreas que considera de importância estratégica. É neste âmbito que se insere a dinamização chinesa de fora trans-regionais com países africanos: o Fórum China-África (Forum on China-Africa Cooperation - FOCAC), criado em 2000, já conta com 50 Estados membros que reúnem de três em três anos (FOCAC, 2010); e o Fórum para a Cooperação Económica e Comercial entre a China e os Países de Língua Portuguesa, conhecido por 
Fórum Macau por ter o seu secretariado baseado nesta região, criado em 2003 com o objectivo claro de facilitar o relacionamento com um nicho de países africanos (Fórum Macau, 2003). Na Ásia, a China participa em todas as organizações da Ásia Oriental - Asia-Pacific Economic Cooperation (APEC), Association of Southeast Asian Nations (ASEAN) Plus Three (China, Japão e Coreia), ASEAN Regional Forum (ARF), Council for Security Cooperation in Asia-Pacific (CSCAP) (Godement, 2006: 64) - e na Ásia Central criou em conjunto com a Rússia, em 2001, a Organização de Cooperação de Xangai (Shanghai Cooperation Organization - SCO), que tem ainda como membros o Cazaquistão, Quirgistão, Tadjiquistão e Uzbequistão e como observadores o Irão, a Mongólia, a Índia e o Paquistão (SCO, 2010).

Uma análise cuidada da participação chinesa nestes organismos, revela a prática de um "multilateralismo lucrativo» (Holslag, 2006: 11), ou seja, de satisfazer os interesses da realpolitik através deste instrumento de soft power - capacidade de influenciar pela persuasão e não pela coerção, ou seja, todas as actividades que ultrapassam o domínio da segurança, como sejam a ajuda humanitária, o investimento económico, a cultura e, neste caso, a diplomacia multilateral (Kurlantzick, 2006: 1). Ao enquadrar o relacionamento no âmbito multilateral, Pequim mostra que respeita o princípio da igualdade no tratamento, a tal "democracia das relações internacionais» (ver discurso oficial chinês sobre a multipolaridade supra-citado) que tanto defende - um conceito que não deixa de surpreender, vindo de um país de tradição anti-democrática e apologista das hierarquias. Mas os objectivos da China são bem mais realistas: os fora com países africanos são usados para consolidar a sua presença em África, revertendo em proveitos políticos e económicos; e, com a Organização de Cooperação de Xangai, Pequim visa conter os Estados Unidos na Ásia Central e o fortalecimento da Rússia e da Índia. Os líderes chineses têm adoptado uma política de grande pragmatismo no relacionamento com estes vizinhos desenvolvendo, por um lado, laços de cooperação na contenção da potência americana e, por outro, tentando impedir a formação de coligações entre eles, numa lógica de competição: por exemplo, a formação de um bloco indo-russo ou o reforço das relações entre a Índia e os EUA, que seriam claramente desvantajosas para a China. Isto mostra o papel que os factores exógenos - existência de uma superpo- 
tência e ressurgimento de duas grandes potências -, nas suas dinâmicas de competição e cooperação, jogam na formulação da política externa chinesa.

\section{Relações de reciprocidade}

Outro dos factores exógenos que influencia a forma de fazer política externa são as relações de reciprocidade que se estabelecem entre os vários actores. A grande preocupação dos líderes chineses em evidenciar esta reciprocidade é visível na fidelidade aos Cinco Princípios da Coexistência Pacífica (ver quadro 2) adoptados na década de 1950, de onde ressalta a ideia de relações mutuamente benéficas (win-win). Na prática, os governantes chineses exigem aos líderes das outras potências um tratamento de igual para igual e enquadram as relações com os países do dito "Sul" numa lógica de reciprocidade. Grande apologista das relações Sul-Sul, a China considera-se, enquanto maior país em desenvolvimento do mundo, disponível para ajudar países africanos e latino-americanos rumo ao desenvolvimento. Porquê este interesse chinês na reciprocidade?

\section{Quadro 2. Os Cinco Princípios da Coexistência Pacífica}

\begin{tabular}{|l|l|}
\hline 1 & Respeito mútuo pela soberania e integridade territorial; \\
\hline 2 & Não agressão mútua; \\
\hline 3 & Não ingerência nos assuntos internos dos outros Estados; \\
\hline 4 & Igualdade; \\
\hline 5 & Benefício mútuo. \\
\hline
\end{tabular}

Na verdade, esta retórica do benefício mútuo tem permitido às autoridades chinesas ganhar apoios em regiões de interesse político e estratégico. Em primeiro lugar, não devemos esquecer que a maior parte dos países que têm relações diplomáticas com Taiwan são africanos ou latino-americanos; consequentemente, Pequim tem tentado limitar a margem de manobra de Taipé nessas regiões e convencer líderes políticos a mudar o reconhecimento de uma capital para a outra, apesar de esta competição estar de certa forma a abrandar. Em segundo lugar, estas regiões são fontes importantes 
de matérias-primas, essenciais para manter o crescimento económico, que já vimos ser uma prioridade interna da China, e oferecem novos mercados para as suas exportações, facto particularmente relevante neste contexto de crise e consequente redução do consumo europeu e norte-americano. Em terceiro lugar, os líderes chineses procuram nestas regiões mais apoios para as suas posições nas Organizações Internacionais, como a ONU, e na revisão da hierarquia do sistema internacional. Ao cativar estes países com os Princípios da Coexistência Pacífica, como o benefício mútuo e a igualdade, a China consegue apoios para as "suas» normas, como o respeito pela soberania e integridade territorial e a não ingerência nos assuntos internos dos outros Estados:

The basic norms governing international relations on equality of sovereignty and non-interference in each other's internal affairs between the member states as stipulated in the Charter of the United Nations are absolutely not outdated. The history and culture, social systems and development models of various countries should be respected. (RPC, 2003a)

A este respeito há um factor exógeno importante que influencia a política externa chinesa: a postura ocidental relativamente a questões que Pequim considera do foro interno, como seja o (des)respeito pelos direitos humanos, a questão do Tibete e do Xinjiang e o conflito com Taiwan. Revelando total incompreensão pelo espírito missionário ocidental, parte da reacção da China passa por tentar que os restantes actores do sistema internacional adoptem os, já referidos, princípios que considera basilares no enquadramento das Relações Internacionais, tentando "achinesar» as normas ocidentais ditas «universais».

O princípio da não-ingerência nos assuntos internos leva a uma política de incondicionalidade (no-strings-attached) no relacionamento com os outros Estados, não exigindo o respeito de normas de boa governação ou respeito pelos direitos humanos. Assim, em troca da Ajuda Pública ao Desenvolvimento, por exemplo em África e na América Latina, a China apenas pede contrapartidas económicas ou apoio político, ao contrário do mundo ocidental que faz depender a ajuda de exigências que muitos líderes ditatoriais e corruptos não têm interesse em cumprir: 
As a member of the developing countries, China is ready to develop extensive and in-depth cooperation in economic, scientific and technological, educational and cultural fields on the basis of the principles of equality and mutual benefit, emphasis on results, varied forms and common development. China stands ready to offer assistance within its capacity to developing countries having difficulties. Although China's aid is limited, it is provided sincerely and without any conditions attached. (RPC, 2003b)

Este "Consenso de Pequim» apresenta uma fórmula para atingir o desenvolvimento radicalmente diferente da proposta pelo "Consenso de Washington", defendendo um modelo que contradiz a ideia de liberalização política ou reformas económicas como condições fundamentais para o desenvolvimento de longo prazo, privilegiando o comércio e investimento em infra-estruturas e instituições sociais (Thompson, 2008: 15). Este choque de "consensos» faznos regressar ao conceito de soft power: o poder de atracção da República Popular da China em determinadas regiões do globo tem aumentado de forma proporcional à sua emergência económica, com base nesta lógica da reciprocidade espelhada no slogan da cooperação Sul-Sul (ver citação anterior). Percepcionada como um parceiro mais conveniente, Pequim desafia os interesses norte-americanos na América Latina e europeus em África, regiões que as potências ocidentais há muito consideram os seus "pátios traseiros». Na América Latina, os Estados Unidos perderam terreno quando concentraram esforços no Médio Oriente na sequência do 11 de Setembro de 2001, negligenciando a região e permitindo a consolidação da presença chinesa, facto que muito agradou às elites locais anti-americanas. Quanto a África, tornou-se a questão mais sensível nas relações sino-europeias: apesar das exportações africanas para a China estarem a aumentar, a Europa é ainda de longe o maior parceiro comercial do continente africano (Fox; Godement, 2009: 41) e as antigas potências coloniais temem a capacidade chinesa de capitalizar a presença económica para obter influência política (Holslag, 2006: 11). Mais importante ainda, a União Europeia (UE) preocupase com o facto de a China começar a ser percepcionada como o soft power em África, apresentando-se como um parceiro e não como um guia e ofe- 
recendo um modelo mais atractivo do que o europeu, que exige o respeito das chamadas normas "universais». A confirmar-se esta tendência a UE, cuja política externa é baseada em linhas directrizes normativas, moldando o que é considerado "normal» em Relações Internacionais (Burton, 2009: 12-14), vê limitada a sua capacidade de exportar o modelo transnacional baseado nos seus valores, ou o que pode ser apelidado de «visão democrática cosmopolita» - princípios ocidentais de liberalismo, democracia e mercado livre (Coker, 2007: 30, 33).

\section{Considerações finais}

Este capítulo ofereceu um enquadramento histórico-conceptual que facilita a análise da actuação da República Popular da China no xadrez geopolítico contemporâneo, permitindo entender as diferentes linhas de decisão e actuação em contextos diferenciados, nomeadamente através da análise dos factores endógenos e exógenos com impacto no processo de tomada de decisão chinês. A conjugação do factor exógeno da imposição ocidental de normas reguladoras das políticas externas estatais com o factor endógeno da vitimização perante as humilhações provocadas pelas potências ocidentais (e Japão), num momento de reemergência chinesa, leva Pequim a questionar a hegemonia ocidental em ditar as regras de relacionamento internacional. Como as normas «universais» são, maioritariamente, uma criação dos governos ocidentais, os líderes chineses não estão particularmente interessados em segui-las, preferindo substituí-las pelas suas próprias directrizes (Coker, 2007: 33):

China unswervingly pursues an independent foreign policy of peace. The fundamental goals of this policy are to preserve China's independence, sovereignty and territorial integrity, create a favorable international environment for China's reform and opening up and modernization construction, maintain world peace and propel common development. [...] The Five Principles of Peaceful Coexistence and the universally recognized norms governing international relations should serve as the 
basis for setting up the new international political and economic order. [...] China is ready to establish and develop friendly relations of cooperation with all the countries on the basis of mutual respect for sovereignty and territorial integrity, mutual non-aggression, mutual non-interference in each other's internal affairs, equality and mutual benefit, and peaceful coexistence. (RPC, 2003c)

De forma hábil, a política externa chinesa define o sistema normativo de acordo com os seus interesses desenvolvendo, com grande pragmatismo, uma visão selectiva do multilateralismo e da incondicionalidade nas relações bilaterais. Mas fá-lo com a subtileza de quem aprendeu depressa com o discurso hipócrita ocidental: afinal, as suas normas apenas reiteram o legado dos Tratados de Vestefália (1648), um sistema baseado na afirmação formal da soberania estatal, integridade territorial e não interferência nos assuntos externos dos outros Estados, limitando-se a pôr em prática os ensinamentos ocidentais, não é verdade?

\section{Questões para análise}

De que forma o papel dos líderes tem condicionado/projectado a política externa chinesa?

Analise o binómio ideologia/pragmatismo na política externa chinesa; por exemplo, parece-lhe que a China enquadra o relacionamento com África e América Latina no âmbito da cooperação Sul-Sul por razões ideológicas ou económicas?

A ajuda chinesa ao desenvolvimento constitui uma alternativa à agenda de desenvolvimento ocidental e a exportação do modelo de desenvolvimento chinês para o Sul é viável?

Considera que a postura chinesa no plano internacional questiona as normas internacionais vigentes?

A clara preferência chinesa pelo multilateralismo revela um interesse genuíno em atingir um mundo multipolar ou esconde objectivos hegemónicos? Haverá uma partilha destes objectivos (pacíficos ou hegemónicos) com outras potências, como por exemplo a Rússia e a Índia no quadro da Organização de Cooperação de Xangai ou ainda com o Brasil, visível nas posições conjuntas dos BRIC no âmbito do G20? 


\section{Fontes na internet}

Agência (oficial) Noticiosa Nova China - Xinhua, http://www.xinhuanet.com/ Internet Guide for Chinese Studies, http://sun.sino.uni-heidelberg.de/igcs/

Jornal (oficial) Chinês - China Daily, http://www.chinadaily.com.cn/

Ministério da Defesa da República Popular da China, http://eng.mod.gov.cn/

Ministério dos Negócios Estrangeiros da República Popular da China, http:// www.fmprc.gov.cn/eng/

\section{Leituras recomendadas}

Dillon, Michael (2009) Contemporary China - An Introduction. New York: Routledge.

Rios, Xulio (org) (2005) Politica Exterior de China - La diplomacia de una potencia emergente. Barcelona: Bellaterra.

Robinson, Thomas; Shambaugh, David (1998) (eds) Chinese Foreign Policy Theory and Practice. Oxford: Oxford University Press.

Sanjuan, Thierry (org.) (2009) Compreender a China Contemporânea - um dicionário. Lisboa: Edições 70.

Shirk, Susan (2008) China - Fragile Superpower. Oxford: Oxford University Press. Wang, Gungwu; Zheng, Yongnian (2008) (eds) China and the New International Order. New York: Routledge.

\section{Bibliografia}

Bond, Michael H. (org) (2008) The Psychology of the Chinese People. Hong Kong: The Chinese University Press.

Burton, Benjamin (2009) «EU-China-Africa Trichotomy: The EU, China and the Normative Power Concept on the African Continent, EU-China Observer, Issue 3, College of Europe, 12-17.

Coker, Christopher (2007) «Strangers at the Gate: Africa, the Challenge of China and the Eclipse of the West", in Franco, Manuela (org), Estratégia e Segurança na África Austral. Lisboa: Fundação Luso-Americana e Instituto Português de Relações Internacionais.

FOCAC (2010) «Forum on China-Africa Cooperation». [http://www.focac.org/eng/].

Fórum Macau (2003) «Fórum para a Cooperação Económica e Comercial entre a China e os Países de Língua Portuguesa (Macau)». [http://www.forumchinaplp.org.mo].

Fox, John; Godement, François (2009) A Power Audit of EU-China Relations. London: European Council on Foreign Relations.

Godement, François (2006) «Neither hegemon nor soft power: China's rise at the gates of the West, in Zaborowski (org), Facing China's rise: Guidelines for an EU strategy. Chaillot Paper, 94. Paris: Institute for Security Studies, 51-70. 
Holslag, Jonathan (2006) "The EU and China: The Great Disillusion", Asia Paper, Brussels Institute of Contemporary China Studies, 1(3), 5 de Novembro.

Kurlantzick, Joshua (2006) "China's Charm: Implications of Chinese Soft Power», Policy Brief 47, Carnegie Endowment for International Peace, Junho, 1-8.

RPC (2003a) “China's Views on the Development of Multipolarization», Ministério dos Negócios Estrangeiros, República Popular da China (RPC), 18 de Agosto. [http://www.fmprc.gov.cn/ eng/wjdt/wjzc/t24880.htm].

RPC (2003b) "China's Stand on South-South Cooperation», Ministério dos Negócios Estrangeiros, República Popular da China (RPC), 18 de Agosto. [http://www.fmprc.gov.cn/eng/wjdt/ wjzc/t24884.htm].

RPC (2003c) "China's Independent Foreign Policy of Peace», Ministério dos Negócios Estrangeiros, República Popular da China (RPC), 18 de Agosto. [http://www.fmprc.gov.cn/eng/ wjdt/wjzc/t24881.htm].

Thompson, Drew (2008) "Economic growth and soft power: China's Africa strategy", in Waldron, Andrew (org), China in Africa. Washington: The Jamestown Foundation.

SCO (2010) «Shanghai Cooperation Organization». [http://www.sectsco.org].

Spence, Jonathan (1998) The Chan's Great Continent-China in Western Minds, W.W. Nova Iorque: Norton \& Company, Inc. 
André Barrinha

\section{CAPÍTULO 15}

\section{TURQUIA}

Pretende-se com este capítulo analisar a evolução da política externa turca desde o fim da II Guerra Mundial. Pelo seu peso económico, militar e demográfico, pelo posicionamento geográfico, pela sua história e pela complexidade da sua sociedade, a Turquia é um actor de grande importância no sistema internacional; contudo, até há bem pouco tempo conduzia a sua política externa de forma "minimalista», limitando-se em larga medida a resolver os problemas impostos (e criados) pelas dinâmicas regionais em que está inserida. Este capítulo começará por explorar as principais linhas de acção da política externa turca, assim como o papel dos principais actores na formulação dessa mesma política. Seguirse-á a análise da evolução histórica da política externa turca, onde serão exploradas as razões do comportamento externo limitado por parte da Turquia durante grande parte da Guerra Fria. As mudanças resultantes do fim do conflito bipolar e a necessária redefinição das prioridades da política externa turca serão tidas em consideração na terceira parte deste capítulo. Por fim, a quarta parte do capítulo mostrará como a Turquia tem, desde a chegada ao poder do Partido da Justiça e Desenvolvimento (AKP-Adalet ve Kalkinma Partisi) em Novembro de 2002, vindo a mudar a sua orientação em matéria de política externa no sentido de um papel mais assertivo na esfera internacional. 


\section{Actores e dinâmicas da política externa da Turquia}

Em oposição à instabilidade interna verificada durante grande parte da Guerra Fria, ${ }^{1}$ a política externa turca manteve uma linha de acção estável durante esse mesmo período, focada na limitação das externalidades provenientes da instável vizinhança de Leste e na manutenção de um bom relacionamento transatlântico. Houve obviamente excepções e períodos de maior acção a nível externo (como teremos oportunidade de constatar mais à frente no capítulo) mas, por regra, Ancara manteve um comportamento discreto. Para tal, muito contribuiu a existência de uma estrutura de política externa visivelmente resistente a atribulações internas. Esta estrutura era composta por três vértices - o vértice político-ideológico, o vértice militar e o vértice burocrático.

O vértice político-militar diz respeito ao consensual entendimento de política externa derivado da ideologia kemalista, por sua vez baseada nas ideias e políticas do 'pai fundador' da Turquia, Mustafa Kemal 'Atatürk'. Tal como aprendem os cadetes na Academia militar, "Ataturkismo [ou Kemalismo] é o conjunto realista de ideias e linhas de acção relacionadas com o estado, com a vida económica e intelectual, e com as instituições sociais de maior relevância, cujos princípios básicos foram definidos por Atatürk» (apud Birand, 1991: 69).

Apesar desta lógica kemalista se aplicar igualmente aos dois outros vértices, a sua importância é acrescida no quadro político pois faz contrastar as profundas divisões existentes ao nível da política interna com o relativo consenso existente em matéria de política externa. Assim, independentemente das orientações políticas, os governos de Ancara mantiveram, durante a Guerra Fria, a progressiva aceitação da Turquia como parte do mundo ocidental como principal objectivo de política externa, ao mesmo tempo que tentavam garantir um relacionamento estável com a sua vizinhança. Estas duas orientações políticas seguiam os dois grandes objectivos de política externa tal como definidos por Atatürk: por um lado, a modernização

\footnotetext{
1 A Turquia assistiu durante este período a três golpes militares, em 1960, 1971 e 1980 que de certa forma serviram para pôr fim a diversos episódios de instabilidade política que, particularmente nos anos 1970, levaram este país à beira da guerra civil.
} 
ocidentalizada da Turquia; por outro, a concretização do seu lema paz em casa, "paz no mundo" (Cem, 2001: 2). Como veremos mais adiante, esta lógica só muito pontualmente foi posta em causa pelos sucessivos governos turcos e, sempre que tal aconteceu, houve igualmente a preocupação de salientar a compatibilidade com estes mesmos princípios.

Em segundo lugar, há a destacar o papel do aparelho burocrático do Ministério dos Negócios Estrangeiros (MNE). Um dos pilares kemalistas do estado turco, o aparelho diplomático turco sempre possuiu um estatuto especial no quadro dos restantes ministérios: os seus concursos de admissão eram mais exigentes do que os dos outros, os seus funcionários provinham exclusivamente das universidades de elite turcas e havia uma lógica subjacente de rigor na execução das suas políticas (Robins, 2003: 72-73). A solidez do MNE fez, assim, com que as sucessivas crises políticas passassem um pouco à margem da política externa turca, na medida em que existia uma autonomia do MNE que o isolava dessas mesmas crises. Fez também com que a Turquia adoptasse uma presença internacional constante, mas moderada, pouco dada a mudanças radicais de discurso ou comportamento, focada na reprodução das práticas diplomático-burocráticas vigentes.

Finalmente, é preciso salientar o papel dos militares, igualmente importante na estabilização da política externa turca do pós-II Guerra Mundial. Apesar da sua importância política datar dos tempos do Império Otomano (Drorian, 2005: 263), as Forças Armadas turcas consolidaram o seu prestígio e legitimidade depois de Mustafa Kemal 'Atatürk' ter comandado o seu exército na libertação do que é a actual Turquia das mãos das potências vencedoras da I Guerra Mundial. O seu envolvimento directo na esfera política, ${ }^{2}$ contudo, apenas se começou a fazer sentir em finais dos anos 1950. A morte de Atatürk em 1938 abriu um espaço para a contestação da liderança política que levaria à realização de eleições multi-partidárias regulares a partir de 1946. Após uma vitória inicial em 1946, o Partido Republicano do Povo (CHP - Cumburiyet Halk Partisi) perderia o seu lugar

\footnotetext{
${ }^{2}$ Indirectamente, muitos dos líderes políticos da jovem República eram provenientes do aparelho militar (Jenkins, 2001:10).
} 
no poder para o Partido Democrático (DP - Demokrat Parti) de Adnan Menderes em 1950. O DP trouxe consigo uma nova agenda política defendendo, entre outras medidas, uma maior liberdade religiosa na esfera pública, o que preocupou as Forças Armadas turcas, guardiãs do espírito kemalista. De acordo com Armağan Kuloglu e Mustafa Şahin, este factor, juntamente com a imposição de políticas cada vez mais opressivas e de uma inflação galopante, levaram ao golpe militar de 1960, que tinha por objectivo "restaurar a democracia e a ordem kemalista»(2006: 94).

A nível externo, esse intervencionismo começou-se a fazer sentir ainda mais tarde, sendo a sua visibilidade enquanto actor político autónomo somente manifesta a partir de meados dos anos 1990, período no qual a instabilidade política turca afectou de forma directa o seu aparelho de política externa: a forte instabilidade interna levaria a que a Turquia tivesse nove Ministros dos Negócios Estrangeiros entre Julho de 1994 e Junho de 1997 (Robins, 2003: 65). Nesse período foram os militares que definiram alguns dos momentos mais marcantes da política externa turca, primeiro através do desenvolvimento de fortes relações com Israel e, posteriormente, com o ultimato lançado à Síria em 1998, quando Ancara exigia que Damasco expulsasse o líder do Partido dos Trabalhadores do Curdistão (PKK - Partiya Karkerên Kurdistan), Abdullah Öcalan (Robins, 2003: 77). No entanto, até aos anos 1990 o papel dos militares tinha essencialmente sido um papel de estabilização da política externa através da garantia do seu poder, isto é, a sua existência servia de efeito dissuasor relativamente a eventuais tentações de envolver a Turquia na conflitualidade do Médio Oriente.

O crescente intervencionismo militar, associado à instabilidade vivida dentro do MNE turco e à eleição de líderes políticos como Necmettin Erbakan, cuja agenda política fugia claramente a vários dos princípios kemalistas, vieram colocar a nu o progressivo desmembramento do triângulo da política externa turca que durante várias décadas tinha permitido que o país tivesse mantido um registo externo bastante sóbrio, apesar da enorme complexidade do seu contexto geopolítico. A partir de então a política externa turca fragmentou-se e flexibilizou-se, o que de certa forma fez com que a Turquia passasse a ter um papel mais activo na esfera política internacional. 


\section{A Turquia e a Guerra Fria}

Ao contrário do desastre da participação otomana na I Guerra Mundial, que levaria à desintegração do Império, a neutralidade do jovem Estado turco durante a II Guerra Mundial acabou por ser muito benéfica para o país. Desde logo, porque a Turquia não sofreu as destrutivas consequências da guerra, nem teve de investir no esforço militar para esse efeito. A principal vantagem para a Turquia proveio, no entanto, da reestruturação do sistema internacional do pós-guerra, com o posicionamento geoestratégico turco (na intersecção entre o espaço Soviético e o Médio Oriente, mais o controlo sobre o estreito do Bósforo) a revelar-se central para os interesses do bloco ocidental. No seguimento da doutrina Truman de $1947,{ }^{3}$ Grécia e Turquia aderem à Organização do Tratado do Atlântico Norte (OTAN) em 1952, garantindo Ancara, dessa forma, o seu lugar enquanto membro do bloco ocidental. Dois anos mais tarde, o governo de Adnan Menderes, juntamente com o Reino Unido, encetou esforços no sentido de elaborar um acordo de segurança no quadro do Médio Oriente, propondo a criação do chamado Pacto de Bagdade. Este viria, no entanto, a revelar-se um desastre, pois a maior parte dos Estados convidados - ex-colónias do tempo do Império Otomano - rejeitaram a adesão (Hale, 2007: 21). O acordo viria a ser assinado em 1955, envolvendo apenas a Turquia, o Iraque, o Irão, o Paquistão e o Reino Unido. De todos os Estados árabes convidados a participar, só o Iraque aceitou o convite.

Contrariamente à ideia comum da Turquia como ponto entre o Ocidente e o Oriente, durante a maior parte da Guerra Fria, esta foi uma ponte inexistente: para a Turquia, o Médio Oriente e Norte de África eram uma fonte de instabilidade, de problemas e de subdesenvolvimento; para os países árabes, a Turquia ainda era a metrópole colonial contra a qual tinham lutado (Karaosmanoğlu, 2004: 17). Assim, a adesão à Aliança Atlântica, juntamente com o falhanço do Pacto de Bagdade vieram confirmar a Ancara que a sua política externa tinha de estar alinhada com a do Ocidente e que o seu passado Otomano era mais um peso do que uma mais-valia.

\footnotetext{
3 Em que o Presidente norte-americano defendia a necessidade de ajudar a Grécia e a Turquia a manterem-se fora da esfera de influência soviética.
} 


\section{Desilusão e reajustamento: a Turquia e o Ocidente}

Até à crise dos mísseis de Cuba de 1962, a Turquia tinha sido um 'bom' aliado no quadro transatlântico, tendo tido um papel de relevo na Guerra da Coreia, ao enviar 4.500 militares para o conflito, o terceiro maior contingente militar, depois de norte-americanos e coreanos (Robins, 2003: 129). Um envio revestido de simbolismo por ter sido a primeira vez que as Forças Armadas turcas, enquanto tal, foram destacadas para um cenário de guerra num quadro multilateral. Era assim claro o empenho de Ancara neste relacionamento transatlântico. O desfecho da crise de Cuba viria, contudo, a trazer dúvidas sobre a forma como os restantes membros da Aliança, particularmente os EUA entendiam o papel da Turquia. No sentido de resolver a crise, Washington prometeu a Moscovo a retirada dos mísseis Júpiter da Turquia. Essa retirada já estava prevista, no entanto, esta medida viria a ser tomada por parte dos EUA sem que Ancara tivesse sido consultada, aumentando assim a suspeita em vários sectores da sociedade turca de que a Turquia estava mais empenhada no relacionamento com Washington do que vice-versa (Eralp, 2003: 110). A esta questão veio juntar-se, em 1964, a crise da carta de Johnson, em que o Presidente norte-americano Lyndon Johnson, em face dos problemas que então se viviam no Chipre, ${ }^{4}$ aconselhou a Turquia a não intervir, pois caso o fizesse isso poderia originar a intervenção da União Soviética (URSS) e nada garantia que a OTAN pudesse intervir em defesa da Turquia. Esta carta viria a ser vista com desilusão e revolta em Ancara, contribuindo para o renascer do síndroma de Sèvres.

O síndroma de Sèvres resulta da relação ambivalente que a Turquia tem com o Ocidente: por um lado, a matriz do seu desenvolvimento enquanto estado moderno esteve, durante várias décadas, directamente associada a uma modernidade ocidental; por outro, existe a suspeita de que esse mundo ocidental não só não deseja que a Turquia faça parte dele, como pretende o seu controlo ou desintegração. Este sentimento ambivalente é algo que advém dos tempos otomanos, o «homem doente da Europa» do século XIX.

\footnotetext{
${ }^{4}$ Ver mais à frente, em A aposta Europeia e a questão cipriota.
} 
O tratado de Sèvres, assinado após o fim da I Guerra Mundial, é, contudo, o marco definidor da conspiração Ocidental. Tal como a Alemanha, também o Império Otomano foi obrigado a assinar um tratado humilhante em que grande parte do território que constitui a actual Turquia foi dividido entre vários países, incluindo a Grécia, a Rússia e o Reino Unido. A aceitação forçada do Tratado levaria ao movimento independentista desencadeado por Atatürk que culminaria, três anos mais tarde, na assinatura do Tratado de Lausanne. Desde então, criou-se na matriz identitária turca esta ideia do síndroma de Sèvres, particularmente visível em vários momentos no seu relacionamento com o Ocidente.

Após a crise da Carta de Johnson, a Turquia continuou a ser uma pontade-lança da OTAN entre o espaço Soviético e o Médio Oriente, mas a política externa turca deixou de estar tão virada para o Ocidente, adoptando uma visão mais independente dos seus interesses. Em boa verdade, a crise cipriota ocupou boa parte das preocupações externas turcas, culminando na intervenção armada em 1974, dividindo em definitivo a ilha entre cipriotas gregos e cipriotas turcos. Este período coincidiria com uma moderada expansão dos horizontes da política externa turca. Bülent Ecevit, líder do CHP e primeiro-ministro da Turquia de 1972 até 1979, defendia uma política externa turca que fosse para lá do relacionamento com Washington. Nesse sentido, tomou uma série de medidas no sentido de autonomizar a Turquia da Aliança Atlântica. De entre tais medidas, há a destacar o 'Documento Político relativo aos Princípios de Cooperação Amigável', assinado entre Ancara e Moscovo, símbolo de uma breve aproximação entre estes dois países (Fuller, 2008: 154).

Para lá do relacionamento com os EUA, o síndroma de Sèvres tem servido para enquadrar o relacionamento da Turquia com a Europa, em particular com a União Europeia. Ancara e Bruxelas assinaram em 1963 o Protocolo de Ancara, que dava à Turquia o acesso a privilégios que nenhum outro estado fora das então Comunidades Europeias possuía. Entre outras medidas, este documento previa a possibilidade de a Turquia vir, no futuro, a aderir à actual União Europeia. Este aspecto foi visto como extraordinariamente relevante por parte de Ancara pois correspondia à constatação por Bruxelas de que a Turquia fazia parte do espaço europeu e, assim, consagrava-a como parte integrante do mundo Ocidental. 
Não houve desenvolvimentos significativos relativamente à eventual adesão da Turquia às, então, Comunidades Europeias até 1987, altura em que a Turquia, apesar de aconselhada a não se candidatar, fê-lo por intermédio de Turgut Özal. A resposta seria negativa e a Turquia teria de esperar uma década para poder finalmente ver aberta a possibilidade de se candidatar à União Europeia. Em vários momentos (como aquando da resposta da Comissão Europeia em 1989 ou após a Cimeira do Luxemburgo em 1997) a Turquia entendeu a mensagem por parte da UE como sendo a materialização da ideia de que Bruxelas nunca aceitaria a sua entrada na UE por preconceito e falta de entendimento da realidade turca (Robins, 2003: 110).

Em suma, o período da Guerra Fria foi essencialmente um período de enquadramento da Turquia no mundo ocidental, com algumas excepções de autonomização de política externa adoptadas durante a liderança de Ecevit. Um enquadramento com aspectos mais e menos positivos, com momentos de grande tensão (como a crise cipriota) e outros de confirmação do seu estatuto enquanto membro do mundo ocidental (como a entrada na OTAN e a assinatura do Protocolo de Ancara).

\section{O fim da Guerra Fria e a transformação do posicionamento turco}

O período relativo ao fim da Guerra Fria trouxe consequências para a Turquia, tanto de forma directa como de forma indirecta. De forma directa, no sentido em que a Turquia teve o seu papel de fronteira da OTAN questionado num contexto em que a fronteira Soviética já não representava a ameaça existencial de até então. ${ }^{5}$ Indirectamente, uma vez que com a desintegração do Bloco de Leste, todo o seu contexto regional se viu transformado. No Médio Oriente, deixou de haver a influência Soviética como contra-ponto à presença norte-americana e, na Ásia Central, Cáu-

\footnotetext{
5 Como afirma Philip Robins, essa questão só afectou a Turquia relativamente ao seu relacionamento com os membros da Aliança, mas não com a Rússia. Para Ancara, Moscovo continuava a ser vista com grande suspeição (2003: 23).
} 
caso, Balcãs e Europa de Leste, houve um completo redimensionamento do espaço geopolítico com a criação e desintegração de vários Estados, sendo de destacar pelas suas consequências particularmente nefastas, o fim da República Jugoslava. A Turquia necessitava assim de um novo rumo para a sua política externa que tivesse em consideração todas estas mudanças em seu redor, assim como a transformação do papel da OTAN a nível internacional.

No caminho para essa redefinição de política externa, a Turquia viria a assumir um papel central na Guerra do Golfo, desencadeada pelos EUA e aliados após a invasão do Kuwait por Saddam Hussein em Agosto de 1990. Devido ao enorme cepticismo interno relativamente ao envolvimento do país num conflito contra um Estado vizinho, Turgut Özal decidiu não enviar tropas para o Iraque. Permitiu, contudo, o uso das bases aéreas conjuntas (Turquia-EUA) do Sudeste turco para o ataque norte-americano às forças iraquianas (Robins, 2003: 16-17). Isto, para além de ter encerrado os oleodutos provenientes do Iraque para seu próprio prejuízo ${ }^{6}$ - decisivo para convencer a Arábia Saudita a deixar os EUA intervir no Kuwait a partir do seu território (idem). A Turquia teve igualmente um papel central na coordenação da missão humanitária no Norte do Iraque onde a população curda era alvo da perseguição de Saddam Hussein. É de realçar que o problema curdo iraquiano do pós-Guerra do Golfo levou a um aumento exponencial da visibilidade da questão curda na própria Turquia. Nessa matéria, o envolvimento turco na Guerra do Golfo acabaria por trazer mais dores de cabeça do que benefícios para a elite de Ancara (Fuller, 2008: 98-99). O conflito que opunha a Turquia ao PKK, liderado por Abdullah Öcalan desde o início da década de 1980, agudizou-se consideravelmente a partir desta altura, atingindo proporções de uma quase-guerra civil. A questão curda tornou-se estrutural na política externa turca, passando a ser um dos cinco principais eixos de acção da política externa turca do pós-Guerra Fria que iremos agora brevemente analisar.

\footnotetext{
${ }^{6}$ Um enorme prejuízo calculado em mais de oito mil milhões de dólares (Robins, 2003: 322).
} 


\section{Questão Curda}

Como acima mencionado, as proporções do conflito no Sudeste da Turquia tornaram a questão curda uma questão central não só da política interna turca, mas também da sua política externa. Internamente, o conflito curdo levou, ao longo dos últimos 30 anos, a uma radicalização do discurso político turco, centrado na necessidade de garantir o carácter unitário do estado e a integralidade do seu território (cf. Barrinha, 2008). Nesse contexto, as Forças Armadas e os serviços de segurança assumiram um papel central na condução da questão curda. O Sudeste do país, maioritariamente curdo, passou a viver num Estado de excepção, em que as regras de funcionamento democrático estiveram suspensas durante quase duas décadas (cf. Jacoby, 2005). O conflito curdo foi-se tornando igualmente central na política externa turca - Grécia, Síria, Irão, URSS e o próprio Iraque foram, em diferentes períodos, acusados por parte de Ancara de ajudar o movimento de Abdullah Öcalan. Tal como referido anteriormente, em 1998, a Turquia chegou ao ponto de ameaçar invadir a Síria caso esta não deixasse de colaborar com o líder curdo, tendo a ameaça resultado na expulsão do líder do $\mathrm{PKK}^{7}$

A questão tornou-se também central no relacionamento com a Europa, em particular com a União Europeia. Pelo lado turco, Ancara considerava que vários países Europeus, como a Suécia, Bélgica e França não faziam o suficiente para acabar com as actividades da diáspora curda ligada ao PKK nos seus países. Pelo lado da União Europeia, a questão curda afectava de forma negativa a adopção dos critérios de Copenhaga por parte de Ancara, tanto ao nível do respeito pelos direitos das minorias, como ao nível do respeito pelas liberdades civis e políticas na Turquia. Mesmo após a aceitação da Turquia como candidato a Estado membro em 1999, esta era uma questão que permanecia por resolver.

\footnotetext{
7 Seria o início da última viagem de Öcalan em liberdade, com paragem em Moscovo, Roma e Nairobi, cidade onde finalmente seria preso pelos serviços secretos turcos em colaboração com os serviços secretos norte-americanos.
} 


\section{A aposta Europeia e a questão cipriota}

Apesar da questão curda e do ocasional síndroma de Sèvres, a Turquia apostou claramente na adesão à União Europeia como aspecto central da sua política externa. Essa aposta parecia ter ficado irremediavelmente perdida em 1997 quando, na Cimeira do Luxemburgo, os Chefes de Estado e de Governo da União declararam que a Turquia não reunia as condições necessárias para poder ser considerada candidata a membro. Ancara reagiu de forma extremamente negativa a esta decisão, cortando relações com Bruxelas e acusando os líderes europeus de, entre outras coisas, quererem ser um clube cristão (cf. Robins, 2003; Dismorr, 2008). Dois anos mais tarde, numa prova de que os receios turcos eram (pelo menos parcialmente) infundados, a União Europeia considerava a Turquia como estando no caminho da integração, o que levou Ancara a finalmente entrar no processo que conduziria em 2005 ao início das negociações para a adesão. Um aspecto que, entretanto, se tornou central no relacionamento entre Ancara e Bruxelas foi a questão cipriota.

Em 1963, poucos anos após a independência do Chipre relativamente ao Reino Unido, dá-se o colapso do acordo que existia entre cipriotas turcos e cipriotas gregos relativamente à partilha do poder na ilha. Esta situação levou a um contexto de instabilidade e violência que culminaria com a ocupação militar turca da parte norte da ilha em 1974 sob o argumento de salvaguardar a sobrevivência dos cipriotas turcos. Deste então, a ilha encontra-se dividida entre cipriotas gregos e cipriotas turcos. As Nações Unidas tentaram por várias vezes encontrar uma solução para o problema. Em 2004, o então Secretário-Geral, Kofi Annan, propôs um plano que visava a unificação da ilha e progressiva resolução do conflito. Este plano foi a referendo, tendo os cipriotas gregos rejeitado a proposta, contrariamente aos cipriotas turcos, que se mostraram maioritariamente a favor do plano Annan. Nesse mesmo ano o Chipre aderia à UE tornando o relacionamento entre Ancara e Bruxelas ainda mais complexo.

Em 2006, a UE decidiu punir a Turquia por esta não abrir os seus portos marítimos ao Chipre através do congelamento de oito dos 35 dossiers de adesão (Baryusch, 2010: 3), isto para além de cinco outros dossiers bloque- 
ados unilateralmente pela França (Alessandri, 2010: 12). A intransigência de Ancara levou Bruxelas a renovar as sanções e espera-se que agora em 2011 tome novas medidas relativamente a esta questão. Muito depende da forma como os dois lados do Chipre conseguirem chegar a algum tipo de acordo relativo ao futuro da ilha.

Um aspecto central na eventual resolução do problema diz respeito à relação entre Ancara e Atenas. Antagonismos históricos e disputas territoriais levaram à securitização do relacionamento entre estes dois Estados, ao ponto de, apesar da imensa disparidade demográfica, geográfica e territorial, haver um forte equilíbrio ao nível do investimento militar entre a Turquia e a Grécia. Disputas relativas a ilhas no Mar Egeu levaram estes dois países à beira do conflito armado em 1996 (Nachmani, 2002: 99). Contudo, desde 1999 que o relacionamento entre os dois países melhorou substancialmente. Num episódio que ficaria conhecido pela 'diplomacia do tremor de terra' (earthquake diplomacy), os dois países conheceram um período de forte aproximação depois de terem sofrido tremores de terra num curto espaço de tempo, na Turquia em Agosto e na Grécia em Setembro, nos quais equipas gregas de salvamento no primeiro caso e turcas no segundo foram em pronto socorro das vítimas destes desastres naturais (Nachmani, 2002: 100). As imagens de gregos a ajudar turcos e vice-versa gerou um forte sentimento de empatia entre as populações dos dois países, permitindo, em certa medida, dissipar a noção do 'outro' enquanto ameaçador e diferente. Será igualmente importante mencionar que, desta aproximação, resultou a aceitação da Turquia como candidato a Estado membro da União Europeia na Cimeira de Helsínquia desse mesmo ano. O facto de a Grécia ter contribuído positivamente para este desfecho serviu como um factor adicional na aproximação entre os dois países (Nachmani, 2002: 113).

\section{Relações com os EUA}

Com o fim da Guerra Fria, houve uma necessária reavaliação do relacionamento turco com os EUA. Para o presidente Turgut Özal, a guerra do Golfo serviria para mostrar aos EUA a centralidade da Turquia numa nova 
ordem mundial. Contudo, como salienta Stephen Larrabee, as expectativas nunca se concretizaram (2009: 100). Pior, o fim da guerra do Golfo veio de certa forma agudizar as diferenças entre EUA e Turquia. Ancara sentia que Washington não tinha tido em suficiente consideração os prejuízos causados à Turquia pelo seu envolvimento no conflito que, além de tudo o mais, veio exacerbar o problema curdo, assunto muito sensível para as autoridades turcas (idem: 101).

Apesar disso, Ancara continuou a colaborar activamente com os EUA, tendo inclusive participado dois anos mais tarde, e por pressão de Washington, na Unified Task Force (Unitaf), missão liderada pelos EUA com o objectivo de resolver a crise humanitária que se agudizava na Somália através do envio de 300 soldados turcos. Esta era a primeira vez desde a Guerra da Coreia que a Turquia enviava forças militares para uma operação num quadro multilateral (Robins, 2003: 45). O sucesso da Unitaf levou à criação da Unitaf-2 e a um crescente envolvimento turco na missão. ${ }^{8}$ A Turquia terminaria a sua participação na Somália em Março de 1994, juntamente com os EUA, depois da desastrosa tentativa de prender Muhammad Farah Aideed que resultou na morte de 18 soldados norte-americanos. A Turquia viria ainda a contribuir para as missões das Nações Unidas e OTAN na Bósnia no início dos anos 1990, assim como no Kosovo em 1999 (próxima secção). Os anos 1990 não foram, contudo, anos de grande proximidade entre os EUA e a Turquia. A questão cipriota e a questão curda levaram a um relativo esfriamento no relacionamento entre Washington e Ancara, algo que só seria ultrapassado de forma mais consistente com a visita de Bill Clinton à Turquia em 1999 pouco antes da decisão do Conselho Europeu de Copenhaga em aceitar a Turquia como Estado candidato à adesão à UE. Para além do forte apoio dos EUA à adesão da Turquia à UE, foram os próprios EUA que apoiaram a adesão da Turquia ao G-20, grupo dos mais influentes países em desenvolvimento e desenvolvidos, fórum que entretanto se tornou central nas relações internacionais contemporâneas.

\footnotetext{
8 O Comando desta segunda missão seria inclusive atribuído a um general turco, o Gen. Cevik Bir.
} 
Apesar de não terem sido anos de grande proximidade, foram anos de convergência de interesses em várias áreas, a começar pela estabilização dos Balcãs, mas a passar igualmente por questões como: a expansão da NATO, a prevenção da proliferação de Armas de Destruição Maciça (ADM) e a abertura de novos gasodutos através da bacia do Cáspio (Kirişçi, 2002: 174). Essa sobreposição da comunhão de interesses sobre uma eventual comunhão de valores, veio de certa forma animar a relação entre Washington e Ancara numa base mais realista daquela que tinha predominado durante a Guerra Fria e que, por mais do que uma vez, levou Ancara a sentir-se traída pela falta de um empenho equitativo por parte de Washington no relacionamento entre ambos os países.

\section{O regresso à vizinhança}

Uma das principais consequências do fim da Guerra Fria para a política externa turca, diz respeito ao redimensionamento das suas relações, por um lado, com o ex-espaço Soviético de raízes culturais turcas e, por outro, com o Médio Oriento. Com a desintegração da URSS e a consequente formação de várias repúblicas na Ásia Central com ligações culturais à raiz asiática turca, vários políticos viram na independência destes Estados uma oportunidade de a Turquia reforçar a sua presença numa zona estratégica fundamental. Contudo, apesar de alguma euforia inicial, o interesse por parte de Ancara relativamente a esta região foi-se tornado mais limitado, chegando ao ponto de hoje em dia ser uma questão secundária na agenda externa turca (Robins, 2003: 270-272).

A partir de meados da década, a Turquia evoluiu também no sentido de uma mais activa política externa em relação ao Médio Oriente. Esta política desenvolveu-se a partir de duas linhas distintas: por um lado, através do desenvolvimento de relações político-militares com Israel; por outro, através do estabelecimento de laços político-religiosos com os países árabes da região. Em relação ao primeiro caso, o relacionamento com Israel focou-se fortemente na cooperação militar. No seguimento dos acordos de Oslo, falcões políticos como a primeira-ministra Tansu Çiller e o Presidente Suleyman Demirel, assim 
como as chefias das Forças Armadas conduziram, a partir de 1994, um processo de aproximação que culminou na assinatura de um acordo de cooperação militar entre Ancara e Telavive em 1996. Na mesma altura, subia ao poder um governo de coligação liderado pelo islamista Necmettin Erbakan, líder do Partido Refah, que considerava vital a Turquia retomar os seus laços com o mundo islâmico. Nesse sentido, desencadeou toda uma série de contactos com os mais diversos países muçulmanos, do Paquistão à Líbia, passando por vários países do Médio Oriente. Essa intensa aproximação ao mundo muçulmano (Erbakan chegou a sugerir a criação de uma OTAN muçulmana) não era do agrado das Forças Armadas e, em 1997, o governo liderado pelo Partido pró-islamista Refah era obrigado a demitir-se por pressão dos militares, terminando aí a política externa de cariz religioso encetada por Erbakan.

Primeiro no quadro da ONU e depois no quadro da OTAN, a Turquia viria igualmente a ter um papel importante no conflito bósnio, com uma presença de cerca de 1500 militares e a responsabilidade de patrulhamento de uma das zonas de separação definidas no pós-cessar fogo. Apesar de ter uma posição algo ambígua relativamente à independência kosovar (a minoria turca nunca esteve claramente ao lado dos albaneses na luta pela independência e a Turquia não queria, por razões de política interna, estar a favor de um movimento independentista), a Turquia decidiu seguir o consenso dos seus aliados da OTAN e participou, mesmo que de forma discreta, nas operações de bombardeamento à Sérvia (através do envio de onze F-16 de reconhecimento) e posteriormente através do envio de cerca de mil soldados para as zonas dominadas pela minoria turca (Uzgel, 2002: 83).

Em suma, os anos 1990 foram anos de adaptação a uma nova realidade internacional, em que a OTAN já não servia como eixo principal da actuação externa turca e em que a desintegração do bloco soviético fazia reemergir toda uma série de estados e regiões com laços culturais e/ou estratégicos com a Turquia que esta necessitava de ter em consideração no seu relacionamento externo. Com a excepção da adesão à UE, a Turquia, em boa parte devido à instabilidade política interna, careceu durante os anos 1990 e primeiros anos do século XXI de uma visão estratégica de fundo que lhe permitisse enquadrar todas as dimensões (novas e velhas) da sua política externa num enquadramento lógico e coerente. 


\section{A eleição do Partido da Justiça e do Desenvolvimento (AKP) e o neo-otomanismo}

A vitória do AKP nas legislativas de Novembro de 2002 não só significou a ascensão ao poder de uma nova força política, como correspondeu ao início de um processo de transformação da política, economia e sociedade turca. Apesar de mais moderado do que o antigo partido Refah, vários dos seus principais membros eram, com efeito, ex-membros do partido de Erbakan, o que deixou o aparelho kemalista extremamente preocupado. Essa preocupação revelou-se sem fundamento, pois o governo AKP dedicou boa parte do seu primeiro mandato a seguir as linhas previamente estabelecidas em matéria de política externa, principalmente na questão do seu empenho no sentido da integração europeia. Houve, contudo, uma questão que não só afectou o relacionamento com Washington, como obrigou Ancara a envolver-se de forma mais activa nas questões do Médio Oriente: a intervenção norte-americana no Iraque em 2003.

No início de 2003, os EUA começaram a negociar com o governo de Recep Tayyip Erdoğan a possibilidade de abrirem uma linha de ataque a partir do Sudeste turco. O acordo foi obtido sendo, contudo, necessária a aprovação no Parlamento. Para espanto dos norte-americanos, a proposta não seria aprovada, tendo-se mais de 100 deputados do AKP aliado à oposição no sentido de bloquearem a proposta. A invasão do Iraque era vista como contrária aos interesses turcos na região (estabilidade) e contrária à imagem da Turquia nas sociedades muçulmanas (Alessandri, 2010: 3-4). Um dos efeitos da recusa de Ancara foi a necessidade de os EUA recorrerem ao Norte do Iraque (isto é, aos curdos iraquianos) como base de apoio à sua incursão militar. Tal contribuiu para a atribuição de uma importância estratégica aos curdos iraquianos que na prática passaram a contar com o apoio dos EUA na definição de uma entidade política curda no Norte do Iraque, aspecto que desagradou a Ancara. O PKK voltou às armas em Junho de 2004 num contexto de grande autonomia curda no Norte do Iraque e de falta de poder efectivo do estado iraquiano (Larrabee, 2010: 101). O relacionamento entre os EUA e a Turquia começou a deteriorar-se de forma significativa chegando ao ponto de em 2004 a população turca 
considerar os EUA como a maior ameaça à paz internacional e à própria Turquia (Fuller, 2008: 5). Nos anos que se seguiram, Ancara manteve uma constante pressão sobre Washington no sentido de os EUA tomarem medidas efectivas que ajudassem a por termos às incursões do PKK (Barrinha, 2008), sem grande sucesso.

Gradualmente, a Turquia foi reconsiderando a sua política no Norte do Iraque, concluindo que a recusa em falar com os líderes da região era mais perniciosa que benéfica para os seus interesses. Num gesto simbólico de reaproximação, o Ministro dos Negócios Estrangeiros Ahmet Davutoğlu visitou a região em Outubro de 2009, chegando mesmo a anunciar a abertura de um consulado em Erbil, capital da região. Durante vários anos os líderes políticos curdos foram vistos como personas non gratas em Ancara; contudo, para além da constatação das limitações associadas a uma abordagem confrontacional com o governo regional curdo, Ancara chegou à conclusão que podia controlar melhor as incursões do PKK na Turquia a partir do Norte do Iraque se conseguisse a cooperação de Massoud Barzani. Além do mais, a Turquia necessitava igualmente de uma estratégia coerente para lidar com o 'novo' Iraque e o apoio dos líderes curdos podia ser essencial para estabilizar a transição política que o Iraque tem vindo a sofrer desde 2003. Em Outubro desse mesmo ano, Erdoğan tomou a ousada iniciativa de fazer deslocar uma enorme comitiva de ministros, empresários e jornalistas a Bagdade onde foram assinados 48 acordos nas mais diversas áreas, desde a segurança à gestão da água (Barysch, 2010: 5). Este foi um gesto que indicou que a Turquia estava decidida a ajudar o vizinho Iraque a retomar o seu caminho (Alessandri, 2010).

Em Abril de 2009, na sua primeira visita a um país muçulmano enquanto Presidente dos EUA, Barack Obama deu sinais claros de tentar reparar os danos causados durante a Administração Bush (Onar, 2009: 1). Isto, apesar das críticas deixadas relativamente à necessidade de Ancara confrontar o seu passado, numa clara alusão à questão do genocídio arménio (idem). Devido aos grupos de pressão da diáspora arménia em França e nos EUA, esta tem sido uma questão que tem contribuído para o dificultar das relações com o Ocidente. Os arménios reclamam que nos últimos anos do Império Otomano, durante a I Guerra Mundial, houve, por parte dos turcos, uma 
política concertada de eliminação da população arménia no que hoje é a Turquia, o que esta rejeita em parte, pois admite a morte de milhares de arménios, mas num contexto de conflito aberto entre as duas partes (Onar, 2009: 6). Esta é uma questão de estabelecimento da verdade histórica que atingiu fortes proporções políticas devido ao choque entre a intransigência turca e a pressão da diáspora arménia sobre os governos dos EUA e da Europa Ocidental. Contudo, os problemas entre a Arménia e a Turquia não se limitavam a questões históricas. Apesar de a Turquia não se ter envolvido militarmente no conflito, a guerra entre o Azerbaijão e a Arménia relativa a Nagorno-Karabagh levou ao encerramento da fronteira com a Arménia e ao fim das relações diplomáticas entre os dois países. Esta situação só mudaria em Outubro de 2009, quando os dois países assinaram um acordo no sentido de reatar as relações diplomáticas (Grigoriadis, 2010: 7). Este gesto faz parte de uma tentativa de reaproximação ${ }^{9}$ entre Ancara e Ierevan indicadora da possibilidade da normalização das relações entre os dois países no médio-prazo. Esta reaproximação está contudo dependente de uma eventual melhoria nas relações entre Ierevan e Baku, que por enquanto permanecem bastante tensas.

Em paralelo a estas abordagens conciliadoras, o governo do AKP retomou a ideia de reforçar os laços com outros países e movimentos muçulmanos, sobretudo depois da crise política de 2007-2008 que levaria à reeleição do AKP e à nomeação de Abdullah Gül como presidente da Turquia. O AKP passou a adoptar uma política externa mais agressiva e de contornos mais distintos da levada a cabo até então. Vários factores contribuíram para essa mudança: o contexto político interno, a passagem de Ahmet Davutoğlu para Ministro dos Negócios Estrangeiros, o rápido crescimento da economia turca e a atomização do sistema internacional.

O AKP saiu da crise política de 2007-08 com legitimidade política reforçada e com um presidente do mesmo partido. É de lembrar que o anterior

\footnotetext{
9 Entre outras medidas, o Presidente turco Abdullah Gül foi convidado pelo Presidente Arménio, Serzh Sarkisiyan em Abril de 2008 a assistir ao encontro de futebol entre as selecções dos dois países na qualificação para o Campeonato do Mundo de futebol de 2010. Esta medida inseriu-se numa série de passos no sentido da reaproximação dos dois países, ficando conhecida como a 'diplomacia do futebol' (Onar, 2009: 7-8).
} 
presidente, Ahmet Necdet Sezer, tinha tido uma co-habitação difícil com o AKP, sendo muitas vezes visto como o representante da ala kemalista na política turca. A sua retirada e consequente substituição por Abdullah Gül permitiu ao AKP ganhar um controlo acrescido sobre o processo de decisão política.

Em segundo lugar, há a salientar a mudança de Ministro dos Negócios Estrangeiros. Davutoğlu era o assessor político de Erdoğan no primeiro mandato, pelo que a sua passagem para a frente da diplomacia turca não pode ser considerada como uma mudança radical; contudo, passou a ser possível a Davutoğlu implementar um conjunto de ideias que desenvolveu durante a sua carreira académica e que passava pela reafirmação dos laços culturais com o Oriente num quadro neo-otomano.

No seu livro 'Profundidade Estratégica' de 2001, o então professor de Relações Internacionais argumentava que a Turquia necessitava de se comportar na esfera internacional de acordo com o seu posicionamento geográfico e com o seu passado histórico, incluindo neste o Império Otomano, mas também a Aliança Atlântica forjada durante a Guerra Fria (Barysch, 2010: 4). Esta nova política externa devia igualmente distanciar-se da clássica hard politics turca, focando-se nos aspectos culturais e económicos no sentido de promover a estabilidade e prosperidade da Turquia (Barysch, 2010: 5), a "política dos problemas-zero" (Barysch, 2010: 6). De acordo com Davutoğlu, a Turquia devia ter uma diplomacia activa, focada na inter-ligação entre o bilateral e o multilateral que visasse a prossecução dos objectivos turcos, devendo estes passar pela estabilidade regional e promoção dos interesses políticos e económicos da Turquia (Onar, 2009: 11-12). Relativamente a este ponto, Davutoğlu avança ainda com a ideia da geo-economia, isto é, o desenvolvimento de relações comerciais com uma lógica estratégica, privilegiando mercados e fornecedores até então pouco explorados por Ancara (idem). Este ponto relaciona-se directamente com o terceiro factor que ajuda a explicar as mudanças ocorridas na política externa turca nos últimos oito anos - o forte crescimento económico da Turquia.

Desde 2001, ano em que a Turquia sofreu uma forte crise financeira que exigiu a intervenção do Fundo Monetário internacional (FMI) e fez o Produto Interno Bruto (PIB) encolher 5.7\%, a economia turca não tem parado 
de crescer. Entre 2002 e 2006, teve um crescimento do PIB sempre superior a 5\%, atingindo um máximo de 9,4\% em 2004. Em 2007, esse crescimento ficou-se pelos 4,6\%, atingindo um mínimo de 1,1\% em 2008, ano do início da crise financeira internacional. Contudo, como constata Mustafa Kutlay, a Turquia está hoje numa posição financeira muito mais forte do que estava noutras ocasiões de crise (como em 2001), sendo de esperar que volte rapidamente a um crescimento elevado nos próximos anos (2009: 66). Não é pois de estranhar que Ancara tenha passado a ter em muito maior consideração a dimensão económica da sua política externa, procurando novos mercados e oportunidades para o seu tecido empresarial (Barysch, 2010: 7). Esta dinâmica empresarial tem feito com que a Turquia estabeleça relações com países e regiões até então pouco exploradas, e que proceda a um entendimento do seu contexto geográfico, cada vez mais sob uma perspectiva geo-económica, como defende o seu actual Ministro dos Negócios Estrangeiros.

Apesar da importância das três dinâmicas internas acima mencionadas (política interna, mudanças no MNE e crescimento da economia turca), é preciso ter igualmente em consideração que essas mudanças tiveram lugar num contexto internacional em mudança, baseado numa lógica de atomização do poder no sistema internacional. Num quadro de ascensão de novas potências e de um mundo pós-Americano, a Turquia passou a sentir-se como parte dessa nouvelle vague, falando directamente com o Brasil, a Rússia e a China e alargando os seus horizontes para regiões até então largamente desconhecidas como a África sub-sahariana ou a América Latina.

O reforço da legitimidade interna, a existência de uma doutrina de base associada ao novo Ministro dos Negócios Estrangeiros e de um forte crescimento económico e a progressiva afirmação de novos pólos de poder no sistema internacional contribuíram assim para uma mudança de atitude por parte da Turquia relativamente à sua política externa. Uma mudança no sentido de um maior envolvimento nas questões do Médio Oriente, mas com uma presença e actividade de nível global.

2009 foi, nesse aspecto, um ano exemplar, com uma Turquia activa em várias frentes em simultâneo. Em Agosto, Vladimir Putin deslocou-se a Ancara, tendo negociado a colaboração em dois projectos de construção 
de gasodutos. Nesse mesmo mês, Ancara e Ierevan assinaram, como já mencionámos, dois protocolos que previam o retomar, 16 anos depois das relações diplomáticas entre os dois países. Em Novembro, o primeiro-ministro turco visitou Teerão, onde em cima da mesa esteve o desenvolvimento das relações económicas entre os dois países. Finalmente, em Dezembro, Erdoğan visitou a Síria no sentido de resolver uma velha disputa territorial com Damasco. Entre outras medidas resultantes dessa visita, foi decidido abolir a necessidade de visto para cidadãos sírios (assim como libaneses, líbios e jordanos) entrarem na Turquia (Barysch, 2010: 5).

A melhoria no relacionamento com a Síria é algo que já se vinha a notar há mais tempo. Em boa verdade, aquando da incursão militar israelita na Faixa de Gaza no Inverno de 2008-09, que estaria na base do desentendimento entre Erdoğan e Shimon Perez no Fórum de Davos, ${ }^{10}$ a Turquia estava a mediar a aproximação entre a Síria e Israel, abruptamente interrompida devido a essa mesma incursão (Barrinha, 2009). Diplomatas, enviados especiais e membros do governo turco visitaram diversos países do Médio Oriente, no sentido de obterem algum consenso entre as várias partes do processo. Como Ahmet Davutoğlu, então enviado da Turquia ao Médio Oriente, fez questão de realçar, a Turquia era o único país que mantinha relações com todas as partes envolvidas no conflito - Hamas, Israel, Egipto, Síria e Fatah (Hurryiet, DN 15/01/09).

O relacionamento com Israel passou a ser a face mais visível da política externa turca. Contrariamente ao bom relacionamento entre Ancara e Tel-Aviv durante a última década e meia, uma série de eventos têm levado a uma crispação no relacionamento entre os dois países. Em 2004, Erdoğan recusou visitar Israel, ${ }^{11}$ optando por visitar Damasco no final desse mesmo ano. Foi ainda bastante crítico relativamente aos assassinatos dos líderes do Hamas Sheikh Ahmed Yassin e Abdul Aziz Rantisi por parte de Israel, acusando este de "terrorismo de Estado» (Kirişçi, 2006: 63). Em 2006, Erdoğan iria ainda mais longe ao receber uma delegação do Hamas em Ancara, liderada por

\footnotetext{
${ }^{10}$ De acordo com Paul Salem, director do Carnegie Middle East Center no Líbano, em entrevista ao Today's Zaman, o incidente de Davos foi simplesmente a face visível da mudança de relacionamento da Turquia com Israel (apud Dogan, 2010).

11 Erdoğan acabaria por visitar Israel em 2005.
} 
Khaled Meshaal (idem: 62). No Outono de 2009, Ancara retirou o convite a Israel para participar em manobras aéreas conjuntas (Barysch, 2010: 6).

Para além das dificuldades de relacionamento directo com Israel, a aproximação de Ancara a Teerão veio de certa forma complicar as relações com Telavive. No seguimento da visita de Erdoğan ao Irão em Novembro de 2009, Davutoğlu deslocou-se a Teerão em Fevereiro de 2010 com o objectivo de chegar a um acordo relativamente à questão do urânio enriquecido. Esse acordo seria de facto obtido ${ }^{12}$ em Maio, com o envolvimento do Brasil, envolvendo a transferência de 1200 quilos de urânio pouco enriquecido para a Turquia em troca de um reactor de pesquisa, sendo que esse urânio continua a ser propriedade iraniana.

Em termos de resultados, a Turquia conseguiu melhorar o seu relacionamento com o Médio Oriente, Ásia Central e Cáucaso. Não conseguiu, contudo, melhorar o relacionamento com a União Europeia, continuamente imergida na complexa problemática do alargamento (Barysch, 2010: 1). O seu relacionamento com os EUA também não melhorou substancialmente, apesar da mudança de Administração em Washington e de a Turquia continuar a ter uma importância estratégica para Washington. ${ }^{13}$

Tanto Bruxelas como Washington começam a ficar preocupados com o empenho orientalista de Ancara. A aproximação por parte da Turquia a países como a Síria, o Irão e o Sudão não ajudou a tranquilizar o receio de que a Turquia esteja em busca de alternativas (Barysch, 2010: 2).

Contudo, se é verdade que este empenho externo relativamente ao Médio Oriente é uma realidade, alicerçada em interesses económicos (expansão de mercados e investimento), culturais (reforço dos laços com países muçulmanos) e estratégicos (promoção de estabilidade na vizinhança), é preciso entender que este activismo político não é exclusivo a essa mesma região. A Turquia tem sido um dos principais contribuidores de tropas para a missão da OTAN no Afeganistão, assumiu em 2009 o cargo de membro não-permanente do

12 A sua implementação está contudo dependente da avaliação da situação por parte do Conselho de Segurança das Nações Unidas (BBC News, 17/05/10).

13 De acordo Stephen Larrabee o acesso permanente à base aérea de Incirlik, assim como a outras bases turcas garante que mais de $70 \%$ do carregamento militar enviado para o Iraque seja feito através da Turquia (2009: 99). 
Conselho de Segurança das Nações Unidas, foi impulsionadora de projectos como a Aliança das Civilizações, envidou esforços para criar, no rescaldo da crise na Geórgia, uma Plataforma de Estabilidade e Cooperação do Cáucaso e tem, nos últimos meses, desenvolvido relações com países como o Brasil, com quem até então mantinha um limitado relacionamento externo. A Turquia abriu sete embaixadas em 2009 e irá abrir vinte e seis em 2010, a maioria na África Subsaariana e na América Latina (Grigoriadis, 2010: 8).

Podemos, pois, concluir que há, de facto, uma mudança na política externa turca, que até certo ponto se tem focado mais no Médio Oriente, mas que é uma mudança sobretudo de atitude, mais do que de alteração de enfoque regional.

\section{Conclusão}

Foi objectivo deste capítulo mostrar a evolução da política externa turca desde o fim da II Guerra Mundial, com um claro enfoque na crescente afirmação internacional da Turquia. Como foi possível analisar ao longo do capítulo, esta maior afirmação turca na cena internacional não deve ser considerada como uma vitória do Islão sobre o laicismo turco ou sequer como um favorecimento de uma política externa turca voltada para o Médio Oriente em detrimento do 'destino' Ocidental que a Turquia parecia querer abraçar durante o pós-II Guerra Mundial. Em boa verdade, e seguindo a ideia de Omer Taspinar (2010), a Turquia pretende somente diversificar o seu relacionamento externo, apostando numa política externa que esteja mais de acordo com o seu crescente peso político, cultural, demográfico e sobretudo económico na esfera internacional. Utilizando a expressão de Fareed Zakaria (2008), esta é uma Turquia de uma era 'pós-Americana' e é pois neste contexto que a sua política externa deve ser entendida. 


\section{Questões para análise}

Analisando a evolução da política externa turca nos últimos cinquenta anos, até que ponto se pode falar na Turquia como 'ponte' entre o Ocidente e Oriente?

O que trouxe de novo o fim da Guerra Fria relativamente ao posicionamento turco face ao complexo quadro geopolítico em que se insere?

É a política externa turca do AKP essencialmente virada para o Médio Oriente? Justifique.

Comente a política externa turca para com a União Europeia e os Estados Unidos/Aliança Atlântica (OTAN).

\section{Fontes na internet}

The Turkish Economic and Social Studies Foundation (TESEV), http:// www.tesev.org.tr/default.asp?PG=ANAEN

Foreign Policy Institute, http://www.foreignpolicy.org.tr/

Ministério dos Negócios Estrangeiros da República da Turquia, http:// www.mfa.gov.tr

Today's Zaman, http://www.todayszaman.com/tz-web/

Hurriyet Daily News, http://www.hurriyetdailynews.com

\section{Leituras recomendadas}

Hale, William (2000) Turkish Foreign Policy 1774-2000. London: Frank Cass Publishers.

Fuller, Graham E. (2008) The New Turkish Republic. Turkey as a pivotal state in the muslim world. Washington D.C.: USIP.

Kirişçi, Kemal (2006) Turkey's foreign policy in turbulent times, Chaillot Paper, 92, EU-ISS.

Robins, Philip (2003) Suits and Uniforms. Turkish Foreign Policy Since the Cold War. London: Hurst\&Company.

Rubin, Barry Rubin e Kirişçi, Kemal (org) Turkey in World Politics. An Emerging Multiregional Power. Istambul: Bogaziçi University Press. 


\section{Bibliografia}

Alessandri, Emiliano (2010) The New Turkish Foreign Policy and the Future of Turkey-EU Relations, Documenti IAI 10/03, Instituto Affari Internazionali.

Barrinha, André (2009) "A Turquia e a ilusão do Médio Oriente», Relações Internacionais, 21.

Barrinha, André (2008) "The Copenhagen School in US-Turkey relations: the 'War on Terror' in Northern Iraq", Oficina do CES, 295, Centro de Estudos Sociais, Universidade de Coimbra.

Barysch, Katinka (2010) "Can Turkey combine EU accession and regional leadership?», Policy Brief, Center for European Reform.

BBC News (2010) "Iran signs nuclear fuel-swap deal with Turkey», 17 Maio. [http://news.bbc. co.uk/2/hi/middle_east/8685846.stm].

Birand, Mehmet Ali (1991) Shirts of Steel. An Anatomy of the Turkish Armed Forces. London: I.B. Tauris.

Davutoğlu, Ahmet (2009) "Turkish Foreign Policy and the EU in 2010", Turkish Policy Quarterly, 8(3), 11-17.

Dogan, Yonca Poyraz (2010) "Turkey is the only Middle Eastern country pointing toward the future», Today's Zaman, 24 Maio.

Drorian, Svegi (2005) "Turkey: Security, State and Society in Troubled Times», European Security, 14(2), 255-275.

Eralp, Yalim (2003) "An Insider's View of Turkey's Foreign Policy and Its American Connection", in Abramowitz, Morton (org), The United States and Turkey. Allies in Need. Nova Iorque: The Century Foundation Press, 109-144.

Fuller, Graham E. (2008) The New Turkish Republic. Turkey as a pivotal state in the Muslim world. Washington D.C.: USIP.

Grigoriadis, Ioannis (2010) The Davutoglu Doctrine and Turkish Foreign Policy. Working Paper, 8, Middle Eastern Studies Programme, ELIAMEP.

Hale, William (2007) Turkey, the US and Iraq. London: SAQI.

Hurriyet Daily News (2009) «Turkey ready for monitoring mission on Gaza-government official", 15 Janeiro.

Jacoby, Tim (2005) "Semi-Authoritarian Incorporation and Autocratic Militarism in Turkey", Development and Change, 36(4), 641-665.

Jenkins, Gareth (2001) "Context and Circumstance: The Turkish Military and Politics», Adelphi Paper, 337, The International Institute for Strategic Studies: London.

Karaosmanoğlu, Ali L. (2004) "Globalization and Its Impact on Turkey's Security in Karaosmanoğlu», in Ali L. and Tashan, Seyfi (org), The Europeanization of Turkey's Security Policy: Prospects and Pitfalls. Ancara: Foreign Policy Institute, 11-24.

Kirişçi, Kemal (2002) «U.S.-Turkish relations: New uncertainties in a renewed partnership», in Rubin, Barry e Kirisci, Kemal (org), Turkey in world politics. An emerging multiregional power. Istambul: Bogazici University Press, 169-196.

Kirişçi, Kemal (2006) Turkey's foreign policy in turbulent times. Chaillot Paper, 92, EU-ISS.

Kuloğlu, Armağan and Şahin, Mustafa (2006) "The Past and the Future of Civil-Military Relations in Turkey", in Faltas, Sami and Jansen, Sander (org), Governance and the Military: Perspectives for change in Turkey. Groningen: CESS, 87-104.

Kutlay, Mustafa (2009) "La economía durante la era republicana. Un terreno resbaladizo", Vanguardia Dossier, 32, Julho/Setembro, 60-66. 
Larrabee, Stephen (2009) "Revitalizar las relaciones con Estados Unidos», Vanguardia Dossier, 32, Julho/Setembro, 98-103.

Nachmani, Amikan (2002) "What says the neighbor to the West? On Turkish-Greek relations", in Rubin, Barry e Kirisci, Kemal (org), Turkey in world politics. An emerging multiregional power. Istambul: Bogazici University Press, 93-122.

Onar, Nora Fisher (2009) Neo Ottomanism, historical legacies and Turkish Foreign Policy, EDAM Discussion Paper Series, 3.

Robins, Philip (2003) Suits and Uniforms. Turkish Foreign Policy Since the Cold War. London: Hurst\&Company.

Taspinar, Omer (2009) "La compleja política turca para Oriente Médio», Vanguardia Dossier, 32, Julho/Setembro, 105-110.

Taspinar, Omer (2010) «Turkish Gaullism?», Today’s Zaman, 12 Abril.

Uzgel, Ilhan (2002) The Balkans: Turkey's stabilizing role», in Rubin, Barry e Kirisci, Kemal (org), Turkey in world politics. An emerging multiregional power. Istambul: Bogazici University Press, 65-92.

Zakaria, Fareed (2008) The Post-American World. Nova Iorque: W. W Northon \& Company Ltd. 


\section{NOTAS BIOGRÁFICAS}

Ana Santos Pinto é docente no Departamento de Estudos Políticos da Faculdade de Ciências Sociais e Humanas da Universidade Nova de Lisboa (FCSH/UNL). Doutoranda em Ciência Política e Relações Internacionais, Especialidade de Estudos Político de Área, na mesma Universidade, concluiu um Mestrado em História das Relações Internacionais, no Instituto Superior de Ciências do Trabalho e da Empresa (ISCTE), com uma dissertação subordinada ao tema «A Política Externa da União Europeia e o conflito israelo-palestiniano: Da cooperação política à estratégia comum (1985-2000)». Investigadora no Instituto Português de Relações Internacionais (IPRI-UNL) desde 2004, desempenhou funções de Research Consultant para a Organização das Nações Unidas, no Projecto Aliança das Civilizações (2008-2009) e foi Assistente de Investigação no Instituto de Estudos Estratégicos e Internacionais (2001-2003). Tem como principais áreas de interesse académico os Estudos Europeus, a geopolítica do Médio Oriente e questões de segurança e defesa.

André Barrinha é professor auxiliar convidado em Relações Internacionais na Faculdade de Economia da Universidade de Coimbra. Concluiu em 2009 o seu doutoramento em Relações Internacionais na Universidade de Kent, tendo defendido uma tese com o título Politics, Security and the Construction of Protracted Social Conflicts. Possui igualmente uma pós-graduação em Política Internacional e Resolução de Conflitos da Faculdade de Economia da Universidade de Coimbra, a mesma instituição onde em 2003 se licenciou em Relações Internacionais. Esteve entre 2004 e 2006 ligado ao Instituto de Estudos Estratégicos e Internacionais, em Lisboa. Entre outras publicações 
editou em 2008, com a Fundação Friedrich Ebert, a obra Towards a Global Dimension: EU's Conflict Management in the Neighborhood and Beyond.

Carlos Gaspar é director do Instituto Português de Relações Internacionais da Universidade Nova de Lisboa. Assessor do Conselho de Administração da Fundação Oriente. Docente convidado da Faculdade de Ciências Socais e Humanas de Relações Internacionais da Faculdade de Ciências Humanas e Sociais da Universidade Nova de Lisboa. Assessor do Instituto de Defesa Nacional. Conferencista no Instituto de Estudos Políticos da Universidade Católica Portuguesa e no Instituto de Estudos Superiores Militares. Director da revista Relações Internacionais, membro do Conselho de Redacção das revistas Nação e Defesa, Finisterra e Respublica. Entre os seus trabalhos, incluem-se "Portugal y la Union Europea", in Braulio Gomez Fortes, António Barreto, Pedro Magalhães (2003). «El sistema politico de Portugal», Madrid: Siglo XXI. "Revisitation du Dernier Homme», in Anne-Marie LeGloannec, Alexandre Smolar (2003), Melanges en Honneur de Pierre Hassner. Paris: Esprit. "A Guerra Fria acabou duas vezes», Nação e Defesa, 2(105). "Raymond Aron and the Origins of the Cold War", in Bryan-Paul Frost, Daniel Mahoney (2007) Essays in Honor of Raymond Aron. Political Reason in the Age of Ideology. New Brunswick: Transaction Publishers. "The United States and East Asia», in Luis Tomé, Robert Sutter (org) (2009) East Asia Today. Coordenador, com João Marques de Almeida e Nuno Severiano Teixeira (2007) Raymond Aron. Lisboa: IDN, Cosmos.

Carmen Amado Mendes é doutora pela School of Oriental and African Studies (SOAS), Universidade de Londres (2004). Professora auxiliar da Licenciatura e do Mestrado em Relações Internacionais da Faculdade de Economia da Universidade de Coimbra desde 2006, Coordenadora do Núcleo de Relações Internacionais e da Licenciatura e do Mestrado em Relações Internacionais desde 2009. Membro da Direcção da European Association for Chinese Studies desde 2008. Vogal da Direcção da Associação Portuguesa de Ciência Política (APCP) em 2006-2010 e Presidente da Secção de Relações Internacionais da APCP desde 2010. Co-fundadora do Observatório da China - Associação para a Investigação Multidisciplinar de Estudos Chineses, 
em 2005. Tem várias publicações na área das políticas interna e externa chinesas. Investigadora Responsável do projecto «Uma Análise da Fórmula 'Um País, Dois Sistemas': O Papel de Macau nas Relações da China com a UE e os Países de Língua Portuguesa», no Centro de Estudos Sociais (CES) da Universidade de Coimbra, financiado pela Fundação para a Ciência e a Tecnologia (FCT).

Carmen Fonseca é Mestre em Relações Internacionais pela FCSH-UNL com a dissertação «O Brasil na política externa portuguesa: entre a retórica e a concretização, 1976-2007», prepara actualmente, na mesma Universidade, uma tese de doutoramento sobre a política externa brasileira. É investigadora no IPRI-UNL e assistente convidada no Departamento de Estudos Políticos da FCSH-UNL.

Constantino Xavier é bolseiro Fulbright e doutorando em International Affairs na Paul H. Nitze School of Advanced International Studies, Johns Hopkins University, em Washington DC. Pós-graduado e mestre (M.A., M.Phil.) em International Politics pela Jawaharlal Nehru University, em Nova Deli, onde residiu, estudou e trabalhou entre 2004 e 2008. Licenciado em Ciência Política e Relações Internacionais pela Universidade Nova de Lisboa. Os seus interesses de investigação e publicações recentes incidem sobre processos de decisão na política externa indiana, segurança na Ásia do Sul, relações UE-Índia e Índia-Africa e políticas migratórias e diásporas. Em Washington DC prepara actualmente a sua tese de doutoramento sobre o não-alinhamento na política externa indiana e trabalha como Senior Research Assistant na Brookings Institution.

Daniela Nascimento é professora auxiliar de Relações Internacionais da Faculdade de Economia da Universidade de Coimbra, onde lecciona na Licenciatura, no Mestrado em Relações Internacionais e no Programa de Doutoramento em Política Internacional e Resolução de Conflitos. É, desde 2009, investigadora do Centro de Estudos Sociais (CES). É doutorada em Política Internacional e Resolução de Conflitos pela Universidade de Coimbra, mestre em Direitos Humanos e Democratização pelo Centro Europeu Inter- 
Universitário de Direitos Humanos e Democratização de Veneza e licenciada em Relações Internacionais pela Faculdade de Economia da Universidade de Coimbra. Os seus interesses de investigação centram-se nos estudos para a paz, direitos humanos, reconstrução pós-conflito, acção humanitária, com enfoque em África. Tem publicados nestas áreas capítulos em livros e artigos em revistas científicas nacionais e estrangeiras.

Licínia Simão é Doutora em Relações Internacionais pela Universidade de Coimbra, professora auxiliar convidada da Universidade da Beira Interior e especialista convidada na Universidade de Coimbra. Foi investigadora e professora convidada da Academia da OSCE, em Bisqueque, em 2010, colaboradora do Núcleo de Ciência Política e Relações Internacionais (NICPRI), Universidade do Minho até 2010 e integrou o Centre for European Policy Studies, em Bruxelas, como Investigadora convidada, em 2007. A autora trabalha sobre as relações externas da União Europeia para o Cáucaso do Sul e dinâmicas regionais na Eurásia. Publicações recentes incluem «Competing for Eurasia: Russian and European Union Perspectives» (com S. Fernandes), in M. R. Freire e R. Kanet (org) Russia in Eurasia: External Player and Regional Dynamics (Palgrave MacMillan); "Carta de Bisqueque: Da democracia na Ásia Central», Relações Internacionais, 2010; Engaging Civil Society in the Nagorno Karabakh Conflict: What Role for the EU and its Neighbourbood Policy?, MICROCON Policy Working Paper 11, Brighton: MICROCON.

Luís da Vinha é licenciado em Geografia pela Faculdade de Letras da Universidade de Coimbra. Obteve o grau de Mestre em Geografia - Ordenamento do Território e Desenvolvimento em 2006 com a dissertação «Dimensão da Inovação no Desenvolvimento Territorial: O Caso da Indústria de Defesa Nacional». Actualmente frequenta o Programa de Doutoramento em Política Internacional e Resolução de Conflitos, na Faculdade de Economia da Universidade de Coimbra, onde está a desenvolver uma tese sobre «Georeferencing the Bush Administration's Foreign Policy: The Role of Geographic Mental Maps in Foreign Policy Change». As suas principais áreas de interesse são: mapas mentais, factores cognitivos nos processos de decisão, processos de decisão de política externa, política externa dos 
EUA, state-building/nation-building. Publicações recentes incluem «Radical Reconstruction: A Critical Analogy of US Post-conflict State-building», Nação e Defesa, 2010; "Acquiring Geographic Knowledge in International Politics", Universitas: Relações Internacionais, 2010 e "Reassessing the 'Guns and Butter' Debate: The role of Military Revolutions and Defense Industry Innovation in Contemporary Spatial Development», Aurora Geography Journal, 2009.

Luís Tomé e doutorado em Relações Internacionais pela Universidade de Coimbra, Mestre em Estratégia pelo ISCSP-UTL e Licenciado em Relações Internacionais pela Universidade Autónoma de Lisboa (UAL). É Professor na UAL e Professor Convidado no Instituto de Estudos Superiores Militares (IESM) e do Curso de Defesa Nacional do IDN. Foi assessor no Parlamento Europeu e investigador da OTAN. Investigador nas áreas da geopolítica e da segurança internacional especializado nas regiões Euro-Atlântica, EurAsiática e Ásia-Pacífico é autor e co-autor de cerca de uma dezena de livros (alguns traduzidos para línguas estrangeiras) e de inúmeros ensaios e artigos publicados nas revistas da especialidade. É Director-Adjunto da JANUS. NET, e-journal of International Relations, autor do website EUROPASIA.NET, co-fundador do Centro Português de Geopolítica e membro do Conselho Editorial de várias publicações periódicas especializadas. Conferencista, em Portugal e no estrangeiro, tem participado em distintos projectos de investigação e colaborado com vários órgãos de comunicação social, analisando e comentando assuntos internacionais.

Maria Raquel Freire é investigadora do Centro de Estudos Sociais e professora auxiliar de Relações Internacionais da Faculdade de Economia da Universidade de Coimbra, onde lecciona na Licenciatura e Mestrado em Relações Internacionais e no programa de Doutoramento em Política Internacional e Resolução de Conflitos. É doutorada em Relações Internacionais pela Universidade de Kent, Reino Unido, mestre em Relações Internacionais pela mesma universidade e licenciada em Relações Internacionais pela Universidade do Minho. Os seus interesses de investigação centram-se nos estudos para a paz, teorias de Relações Internacionais, política externa, Rússia e espaço pós-soviético. Tem publicados nestas áreas vários capítulos 
em livros e artigos em revistas científicas nacionais e estrangeiras. É autora de Conflict and Security in the Former Soviet Union: The Role of the OSCE, Aldershot, Ashgate, 2003; e co-editora de Key Players and Regional Dynamics in Eurasia: The Return of the 'Great Game' com Roger Kanet, Palgrave, 2010. Os seus projectos de investigação actuais centram-se na análise da política externa russa e das políticas de segurança europeias, bem como peacekeeping e peacebuilding.

Nuno Severiano Teixeira é pró-Reitor da Universidade Nova de Lisboa e professor de Relações Internacionais no Departamento de Estudos Políticos da FCSH-UNL. Doutorado em História pelo Instituto Universitário Europeu, Florença e Agregado em Ciência Política e Relações Internacionais pela Universidade Nova de Lisboa. Foi Visiting Professor na Universidade Georgetown (2000) e Visiting Scholar no Instituto de Estudos Europeus da Universidade da Califórnia, Berkeley (2004). Foi Director do Instituto de Defesa Nacional (1996-2000) e do IPRI-UNL (2003-2006). Foi Ministro da Administração Interna (2000-2002) e Ministro da Defesa (2006-2009) do governo português. Tem obra publicada sobre história militar, história das relações internacionais, história da construção europeia e segurança e defesa.

Patrícia Daehnhardt é professora auxiliar de Relações Internacionais da Faculdade de Ciências Humanas e Sociais da Universidade Lusíada de Lisboa, nos cursos de Licenciatura, Mestrado e Doutoramento. É investigadora do Instituto Português de Relações internacionais (IPRI-UNL). É doutorada em Relações Internacionais pela London School of Economics and Political Science. Das suas últimas publicações constam "Germany in the European Union", in Reuben Wong e Christopher Hill (org) (2011) National and European Foreign Policy: Towards Europeanization, Routledge e "O Novo Conceito Estratégico da NATO: As relações com a União Europeia», Nação e Defesa, 126, 2010. Os seus interesses de investigação são a politica externa da Alemanha, as políticas de segurança europeias e as relações transatlânticas.

Paula Duarte Lopes é investigadora do Centro de Estudos Sociais e professora auxiliar do Núcleo de Relações Internacionais da Faculdade de 
Economia da Universidade de Coimbra, leccionando no $1^{\circ}$ e $2^{\circ}$ ciclos de Relações Internacionais, bem como no Programa de Doutoramento em Política Internacional e Resolução de Conflitos. Doutorada em Ciência Política e Relações Internacionais pela Universidade Johns Hopkins nos Estados Unidos da América. Mestre em Políticas da Economia Mundial pela London School of Economics and Political Science na Grã-Bretanha. Licenciada em Economia pela Faculdade de Economia da Universidade de Coimbra. Os seus interesses de investigação incidem actualmente sobre os estudos para a paz, governação ambiental, políticas hídricas internacionais e cooperação internacional para o desenvolvimento. Tem várias publicações e comunicações sobre dinâmicas de governação internacional hídrica e ambiental.

Paula Marques dos Santos é licenciada em Relações Internacionais, fez uma Pós-Graduação em Comércio Internacional, e doutorada em História das Relações Internacionais. Docente da Universidade Lusíada do Porto, na licenciatura e mestrado em Relações Internacionais e da ESTGL, onde foi também directora do curso de Secretariado de Administração em 2008-2009. É responsável pela coordenação da formação contínua e Pós-Graduações da ESTGL. Tem publicado sobre emigração portuguesa, relações externas de Portugal, comunicação política, cidadania europeia e política externa. É ainda membro da Team Europe - equipa de especialistas da Comissão Europeia e formadora do Centro de Informação Europeia Jacques Delors.

Verónica Martins, depois de uma licenciatura em Relações Internacionais Culturais e Políticas na Universidade do Minho, especializou-se em questões de integração europeia com um Master em Estudos Europeus (políticos e administrativos) no Colégio da Europa, em Bruges. Encontra-se actualmente a finalizar a sua tese de Doutoramento que realiza em co-tutela entre l'Institut d'Etudes Politiques de Paris (Centre d'Etudes Européennes) e a Universidade do Minho sobre a questão da europeização das políticas externas da França e Portugal em relação ao Magrebe central. Interessa-se particularmente pela investigação de temas ligados à política externa da União Europeia e políticas externas francesa e portuguesa, região do Mediterrâneo, questões de imigração, e segurança e defesa. Publicações recentes incluem, «Maghreb 
Challenges and EU Measures taken towards the Region" (2009) no âmbito da rede UE-CONSENT e «Portugal and the Mediterranean region: What role 394 for Civil Society in Foreign Policy?», in Schäfer I. and Henri J-B (org) (2009), Mediterranean Policies from Above and Below, Baden-Baden: Nomos. 
(Página deixada propositadamente em branco) 
Série

Ensino

Imprensa da Universidade de Coimbra

Coimbra University Press

2011

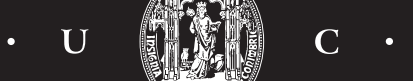

